\title{
ROSANE DE OLIVEIRA
}

\section{CARACTERIZAÇÃO DE LIPOPROTEÍNAS DE Leptospira interrogans EXPRESSAS}

\section{EM Escherichia coli}

Tese apresentada ao Programa de Pós-Graduação em Interunidades em Biotecnologia USP/Instituto Butantan/IPT, para obtenção do Título de Doutor em Biotecnologia. 


\section{ROSANE DE OLIVEIRA}

\section{CARACTERIZAÇÃO DE LIPOPROTEÍNAS DE Leptospira interrogans EXPRESSAS}

\section{EM Escherichia coli}

Tese apresentada ao Programa de Pós-Graduação em Interunidades em Biotecnologia USP/Instituto Butantan/IPT, para obtenção do Título de Doutor em Biotecnologia.

Área de Concentração: Biotecnologia

Orientador: Dra Ana Lucia Tabet Oller do Nascimento

Versão original

São Paulo

2013 
DADOS DE CATALOGAÇÃO NA PUBLICAÇÃO (CIP)

Serviço de Biblioteca e Informação Biomédica do

Instituto de Ciências Biomédicas da Universidade de São Paulo

() reprodução total

Oliveira, Rosane de.

Caracterização de lipoproteínas de Leptospira interrogans expressas em Escherichia coli / Rosane de Oliveira. -- São Paulo, 2013.

Orientador: Profa. Dra. Ana Lucia Tabet Oller do Nascimento.

Tese (Doutorado) - Universidade de São Paulo. Instituto de Ciências Biomédicas. Programa de Pós-Graduação Interunidades em Biotecnologia USP/IPT/Instituto Butantan. Área de concentração: Biotecnologia. Linha de pesquisa: Candidatos vacinais.

Versão do título para o inglês: Characterization of lipoproteins of Leptospira interrogans expressed in Escherichia coli.

1. Leptospirose 2. Leptospira interrogans 3. Proteínas recombinantes

4. Vacinas I. Nascimento, Profa. Dra. Ana Lucia Tabet Oller do

II. Universidade de São Paulo. Instituto de Ciências Biomédicas.

Programa de Pós-Graduação Interunidades em Biotecnologia

USP/IPT/Instituto Butantan III. Título. 
Candidato(a): $\quad$ Rosane de Oliveira.

Título da Tese: $\quad$ Caracterização de lipoproteinas de Leptospira interrogans expressas em Escherichia coli.

Orientador(a): $\quad$ Profa. Dra. Ana Lucia Tabet Oller do Nascimento.

A Comissão Julgadora dos trabalhos de Defesa da Tese de Doutorado, em sessão pública realizada a .................., considerou
( ) Aprovado(a)
( ) Reprovado(a)

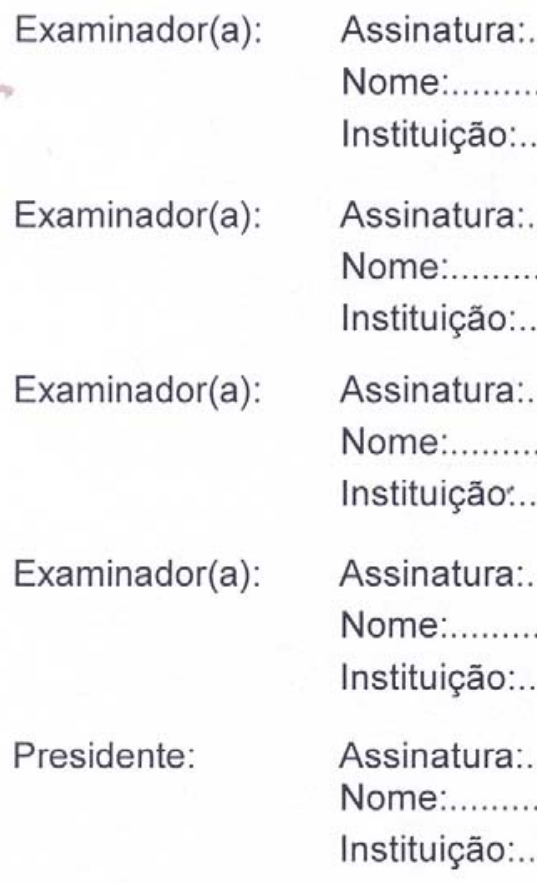




\section{CERTIFICADO}

Certificamos que o Projeto intitulado "Caracterização de lipoproteínas de Leptospira interrogans expressas em Escherichia coli" protocolo $\mathbf{n}^{\circ} 471 / 08$, sob a responsabilidade de Ana Lúcia T. O. Nascimento e Rosane de Oliveira, está de acordo com os Princípios Éticos na Experimentação Animal adotado pelo Colégio Brasileiro de Experimentação Animal (COBEA), e foi aprovado pela COMISSÃO DE ÉTICA NO USO DE ANIMAIS DO INSTITUTO BUTANTAN (CEUAIB) em reunião de $14 / 05 / 2008$

We certify that the research entitled "Characterization of lipoproteins of Leptospira interrogans expressed in Escherichia coli", protocol $\mathbf{n}^{\circ} \mathbf{4 7 1 / 0 8}$, under the responsibility of Ana Lúcia T. O. Nascimento and Rosane de Oliveira, is in agreement with the Ethical Principles in Animal Research, adopted by the Brazilian College of Animal Experimentation, and was approved by the ETHICAL COMMITTEE FOR ANIMAL RESEARCH of BUTANTAN INSTITUTE in the meeting of $\underline{05 / 14 / 2008}$ A CEUAIB autorizou a(s) mudança(s) solicitada(s) pela pesquisadora, ou seja, alteração na vigência do projeto e aditivo de animais.

\begin{tabular}{|c|c|c|}
\hline Vigência do Projeto: & $\mathbf{N}^{\circ}$ de animais/espécie & ADITIVO \\
$08 / 2008-07 / 2012$ & & 35 camundongos Balb/c \\
Centro de Biotecnologia & 35 camundongos Balb/c & 08 hamsters Golden \\
\cline { 2 - 3 }
\end{tabular}

São Paulo, 18 de junho de 2010.

De acordo:

Dr. OtáviQ Azeredo Mexcadante

Diretor do Instituto Butantan

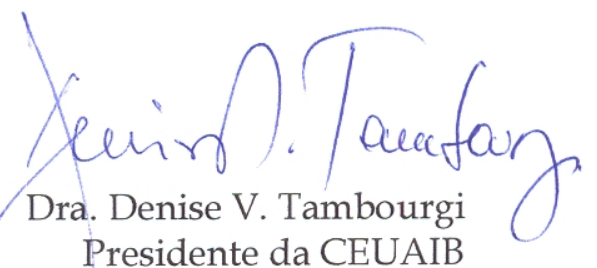


A Jurema e Edison meus queridos pais, a minha irmã Emilia e a minha Tia Luci. Obrigada por tudo... 


\section{AGRADECIMENTOS}

À Dra Ana Lucia Tabet Oller do Nascimento por me receber em seu laboratório, por sua orientação, confiança e incentivo durante a realização do meu doutorado.

Aos meus colegas do Laboratório de Biotecnologia Molecular II - Centro de Biotecnologia, do Instituto Butantan: Gabriela, Ivy, Renata, Renan, Aline de Barros, Daniel, Tatiane, Caio, Mariana, Luis Guilherme, Raquel, Marina, Guilherme, Mônica, Aline e Lucas, pela convivência, cooperação, troca de idéias e momentos de descontração.

Ao professor Dr. Sílvio A. Vasconcellos, Dra Amane P. Gonçales, Zenáide Maria de Morares e Gisele do Laboratório de Zoonoses da Faculdade de Medicina Veterinária da USP pela colaboração com as culturas de leptospiras e ensaios de imunoproteção com hamstêr.

À Dra Eliete C. Romero do Instituto Adolfo Lutz pela colaboração com os soros de pacientes.

À Dra Toshie Kawano (em memória) e Alexsander S. Souza do Departamento de Parasitologia do Instituto Butantan, pelo auxílio com o microscópio confocal.

Aos meus pais Edison e Jurema pelo apoio, incentivo e suporte durante todo o período do doutorado.

Aos meus familiares e amigos, em especial minha irmã Emilia e minha Tia Luci, pelo apoio e paciência.

À coordenação do curso de Pós-Graduação Interunidades em Biotecnologia USP/Instituto Butantan/IPT e a todos os professores que contribuíram para minha formação.

À Fundação de Amparo à Pesquisa do Estado de São Paulo (FAPESP) pela concessão da bolsa de Doutorado e financiamento do projeto, bem como ao Conselho Nacional de Desenvolvimento Científico e Tecnológico (CNPq) e à Fundação Butantan.

Obrigada a todos! 
"O sucesso nasce do querer, da determinação e persistência em se chegar a um objetivo. Mesmo não atingindo o alvo, quem busca e vence obstáculos, no mínimo fará coisas admiráveis" 


\section{RESUMO}

OLIVEIRA, R. Caracterização de lipoproteínas de Leptospira interrogans expressas em Escherichia coli. 2013. 217 f. Tese (Doutorado em Biotecnologia) Instituto de Ciências Biomédicas, Universidade de São Paulo, São Paulo, 2013.

Leptospirose é uma zoonose altamente disseminada causada por espiroquetas patogênicas do gênero Leptospira. Nos centros urbanos, os roedores são os mais importantes reservatórios da doença porque eliminam, continuamente, leptospiras vivas pela urina. Os humanos podem ser infectados pelo contato com solo ou água contaminada com urina contendo leptospiras. Desde que o controle dos roedores e medidas sanitárias não são facilmente implementadas, o desenvolvimento de uma vacina confiável é necessário para o combate da leptospirose. O sequenciamento genômico de $L$. interrogans sorovar Copenhageni e ferramentas de bioinformática permitiram a identificação de novos candidatos vacinais. Desta maneira, os genes LIC10258, LIC12880 e LIC12238 foram selecionados por análises de bioinformática e amplificados do DNA genômico de L. interrogans sorovar Copenhageni por metodologia de PCR. Os insertos de DNA foram clonados no vetor de expressão pAE e inseridos em E. coli BL21 SI para expressão das proteínas recombinantes. As proteínas rLIC10258, rLIC12880 e rLIC12238 foram purificadas por cromatografia de afinidade. A integridade estrutural das proteínas recombinantes foi avaliada por dicroismo circular que mostrou que as proteínas estavam estruturadas. Os resultados obtidos com o ensaio de imunofluorescência de fase líquida (L-IFA) e proteólise com proteinase $\mathrm{K}(\mathrm{PK})$ sugerem que as proteínas nativas correspondendo a rLIC10258, rLIC12880 e rLIC12238 estão localizadas na membrana das leptospiras. rLIC10258, rLIC12880 e rLIC12238 foram reconhecidas por soro de pacientes diagnosticados com leptospirose, sugerindo que estas proteínas são, provavelmente, expressas durante a infecção. A imunização de hamsters seguido de desafio com dose letal de leptospiras virulentas mostrou que as proteínas recombinantes rLIC10258, rLIC12880 e rLIC12238 não são capazes de conferir proteção aos animais contra leptospirose. A avaliação da capacidade de adesão das proteínas recombinantes com laminina, colágeno tipo I, colágeno tipo IV, fibronectina cellular e fibronectina plasmática mostrou que rLIC10258, proteína que possui um domínio tipo OmpA, interage com a laminina e fibronectina plasmática. A ligação foi dose dependente e saturável e portanto, esta proteína foi nomeada Lsa66 (Leptospiral surface a dhesin of $66 \mathrm{kDa}$ ). Não foi detectada interação dos componentes da matriz extracelular com rLIC12880 e rLIC12238. Todas as proteínas recombinantes foram capazes de ligar ao plasminogênio e gerar plasmina, mostrando atividade proteolítica específica. Não foi observada interação do fator $\mathrm{H} \mathrm{e}$ C4BP com as proteínas recombinantes, ao passo que apenas rLIC12238 foi capaz de ligar com o fibrinogênio. Dessa maneira, é possível que estas proteínas possam desempenhar algum papel na patogênese da doença.

Palavras-chave: Leptospirose. Leptospira interrogans. Proteínas recombinantes. Vacinas. 


\begin{abstract}
OLIVEIRA, R. Characterization of lipoproteins of Leptospira interrogans expressed in Escherichia coli. 2013. 217 p. Ph. D. thesis (Biotechnology) Instituto de Ciências Biomédicas, Universidade de São Paulo, São Paulo, 2013.

Leptospirosis is worldwide zoonosis caused by pathogenic spirochaetes of the genus Leptospira. In the urban settings, rodents are the most important reservoirs of the disease because they continuously shed live leptospires in their urine. Humans can be infected through contact with soil or water contaminated with urine containing leptospires. Since the control of the rodents and sanitation measures are not easily implemented, the development of reliable vaccine is necessary to combat the leptospirosis. The whole-genome sequences of $L$. interrogans serovar Copenhageni and bioinformatics tolls allowed the identification of novel vaccine candidates. Thus, the genes sequences of LIC10258, LIC12880 and LIC12238 were selected by bioinformatics analysis and amplified by PCR methodology from genomic DNA of $L$. interrogans serovar Copenhageni. The DNA inserts were cloned into the $E$. coli expression vector pAE and inserted in BL21 SI E. coli strain for recombinant protein expression. The proteins rLIC10258, rLIC12880 and rLIC12238 were purified by using affinity chromatography. Structural integrity of the recombinant proteins was evaluated by circular dichroism that showed well folded proteins. The results obtained with liquid-phase immunofluorescence method (L-IFA) and proteolysis with proteinase $\mathrm{K}(\mathrm{PK})$ suggest that native proteins corresponding rLIC10258, rLIC12880 and rLIC12238, are located at the leptospiral membrane. rLIC10258, rLIC12880 and rLIC12238 were recognized by antibodies present in sera from human patients diagnosed with leptospirosis, suggesting that these proteins are probably expressed during infection. The immunization of hamsters followed by challenge with lethal dose of virulent leptospires showed that the recombinant proteins rLIC10258, rLIC12880 and rLIC12238 are unable to confer protection to animals against leptospirosis. Evaluation of the adhesion capacity of the recombinant proteins with laminin, collagen type I, collagen type IV, cellular fibronectin and plasma fibronectin showed that rLIC10258 having the OmpA-like domain interacts to laminin and plasma fibronectin. The binding was dose-dependent and saturable and therefore it was named Lsa66 (Leptospiral surface adhesin of $66 \mathrm{kDa}$ ). No specific interaction to the extracellular matrix components was detected with rLIC12880 e rLIC12238. All recombinant proteins were capable to bind plasminogen and to generate plasmin, showing specific proteolytic activity. No interaction to factor $\mathrm{H}$ or C4BP was detected with recombinant proteins, whereas that only rLIC12238 was capable to bind fibrinogen. Thus, it is possible that these proteins may play a role in leptospiral pathogenesis.
\end{abstract}

Keywords: Leptospirosis. Leptospira interrogans. Recombinant proteins. Vaccines 


\section{LISTA DE ILUSTRAÇÕES}

Figura 01 - Análise in silico da similaridade dos genes LIC10258, LIC12880 e LIC12238 em diferentes espécies de Leptospira pelos programas BLAST e CLUSTAL 2.1

Figura 02 - Análise do DNA de interesse amplificado por reação de PCR em gel de agarose $1 \%$ 53

Figura 03 - Mapa do vetor de clonagem pGEM-T Easy 54

Figura 04 - Mapa do vetor de expressão pAE 54

Figura 05 - Análise dos insertos de DNA obtidos por digestão do DNA plasmidial (pAE/inserto) em gel de agarose $1 \%$. 55

Figura 06 - Análise da presença dos genes LIC10258, LIC12880, LIC12238 em diferentes espécies e sorovares de Leptospira em gel de agarose $1 \%$ 56

Figura 07 - Análise da expressão dos genes LIC10258, LIC12880 e LIC12238 em diferentes espécies e sorovares de Leptospira em gel de agarose $1 \%$ 58 Figura 08 - Análise da regulação da expressão do gene LIC10258 por fatores ambientais em gel de agarose $1 \%$ 59

Figura 09 - Análise da expressão das proteínas recombinantes em gel de SDSPAGE 60

Figura 10 - Análise das proteínas recombinantes após solubilização com $8 \mathrm{M}$ uréia e $10 \%$ glicerol em gel de SDS-PAGE.

Figura 11 - Estimativa da concentração das proteínas recombinantes em gel de SDS-PAGE.

Figura 12 - Espectros obtidos das proteínas rLIC10258, rLIC12880 e rLIC12238 por dicroísmo circular . 65

Figura 13 - Análise da presença de anticorpos IgG e IgM contra rLIC10258, rLIC12880 e rLIC12238 em soro de pacientes diagnosticados com leptospirose ... 67 Figura 14 - Detecção das proteínas recombinantes por anticorpos contra resíduos de histidina e policlonais homólogos por Western blotting 69

Figura 15 - Análise da localização celular por digetão com proteinase $\mathrm{K}$. 70

Figura 16 - Análise da localização celular das proteínas recombinantes rLIC10258, rLIC12880 e rLIC12238 por L-IFA

Figura 17 - Adesão das proteínas rLIC10258, rLIC12880 e rLIC12238 aos MECs.. 
Figura 18 - Análise da especificidade da ligação de rLIC10258 com a laminina e fibronectina plasmática.

Figura 19 - Contribuição dos resíduos de açúcar na interação de rLIC10258 com a laminina e fibronectina plasmática 76

Figura 20 - Análise da ligação das proteínas rLIC10258, rLIC12880 e rLIC12238 ao PLG humano 78

Figura 21 - Análise da especificidade da ligação de rLIC10258, rLIC12880 e rLIC12238 com o PLG humano 79

Figura 22 - Atividade enzimática da plasmina ligada as proteínas recombinantes...

Figura 23 - Análise da ligação das proteínas rLIC10258, rLIC12880 e rLIC12238 a componentes do soro e plasma humano 83

Figura 24 - Análise da especificidade da ligação de rLIC12238 com o fibrinogênio.

Figura 25 - Efeito de rLIC12238 na formação do coágulo de fibrina induzido por trombina

Figura 26 - Inibição da adesão de L. interrogans a MECs, PLG e fibrinogênio pelas proteínas rLIC10258, rLIC12880 e rLIC12238.

Figura 27 - Curva de sobrevivência dos hamsters imunizados com rLIC10258 e desafiados com leptospiras virulentas.

Figura 28 - Curva de sobrevivência dos hamsters imunizados com rLIC12880 e rLIC12238 e desafiados com leptospiras vivas

Figura 29 - Esquema de clonagem dos fragmentos do gene LIC10258. 94

Figura 30 - Análise dos fragmentos do gene LIC10258 amplificados por meio de reação de PCR em gel de agarose $1 \%$

Figura 31 - Análise dos insertos de DNA obtidos por digestão do DNA plasmidial (pGEM-T Easy/inserto) em gel de agarose 1\%

Figura 32 - Análise dos insertos de DNA obtidos por digestão do DNA plasmidial (pAE/inserto) em gel de agarose 1\%....

Figura 33 - Análise dos fragmentos recombinantes purificados em gel de SDSPAGE 97

Figura 34 - Reconhecimento dos fragmentos recombinantes por anticorpo contra resíduos de histidina e policlonais homólogos por Western blotting 98

Figura 35 - Ligação dos fragmentos recombinantes com MECs e PLG 101 
Figura 36 - Efeito da desnaturação e bloqueio dos fragmentos recombinantes na interação com MECs e PLG.

Figura 37 - Análise da especificidade da ligação dos fragmentos recombinantes com laminina, fibronectina plasmática e PLG 103

Figura 38 - Contribuição dos resíduos de açúcar na interação dos fragmentos recombinantes com a laminina e a fibronectina plasmática 105 Figura 39 - Fibronectina plasmática e PLG não competem pela ligação ao fragmento Intermediário 106 Figura 40 - Esquema demonstrando o domínio imunodomimante da proteína rLIC10258. 108 


\section{LISTA DE TABELAS}

Tabela 01 - Análise in silico dos genes LIC10258, LIC12880 e LIC12238 52

Tabela 02 - Distribuição de respondedores para anticospos lgG e lgM na fase inicial (MAT-) e convalescente (MAT+) da doença. 68

Tabela 03 - Atividade imunoprotetora e efeito esterilizante da proteína rLIC10258. 90

Tabela 04 - Atividade imunoprotetora e efeito esterilizante das proteínas rLIC12880 e rLIC12238. 92

Tabela 05 - Distribuição de respondedores para anticorpos IgG na fase inicial e convalescente da doença 100 


\section{LISTA DE QUADROS}

Quadro 01 - Sequência de oligonucleotídeos utilizados para amplificação dos genes e fragmentos de interesse 32

Quadro 02 - Títulos de anticorpos policlonais obtidos após imunização de camundongos com as proteínas recombinantes 64 Quadro 03 - Resposta humoral dos hamsters imunizados com rLIC12880 e rLIC12238 antes e depois do desafio 93 


\section{LISTA DE ABREVIATURAS E SIGLAS}

2YT/ON: meio de cultura contendo $1 \%$ de extrato de levedura e 1,6\% de peptona BSA: albumina de soro bovino

DC: dicroísmo circular

DO: densidade óptica

ELISA: ensaio imunoenzimático - enzyme linked immuno sorbent assay

EMJH: Ellinghausen-McCullough / Johson-Harris

FIOCRUZ: Fundação Oswaldo Cruz

FITC: isotiocinato de fluoresceína

IPTG: isopropil- $\beta$-galatosídeo

KD: constante de dissociação

kDa: kiloDalton

L-IFA: imunofluorescência de fase líquida

LPHS: síndrome de hemorragia pulmonar associada à leptospirose

LPS: lipopolissacarídeo

MAT: teste de microaglutinação - microscopic agglutination test

MEC: componentes da matriz extracelular

OMP: proteína de membrane externa

OMS: Organização Mundial da Saúde

OPD: o-fenilenodiamina

PBS: solução fosfato salina, $\mathrm{pH} 7,4$

PCR: reação de polimerização em cadeia

$\mathrm{PK}$ : proteinase $\mathrm{K}$

PLG: plasminogênio

PMSF: fenilmetilsulfonilflúor

SDS: sulfato dudecil de sódio

TLR: recepetor toll-like

X-gal: 5-bromo-4-cloro-3-indolil- $\beta$-D-galactopiranosideo 
1 INTRODUÇÃO

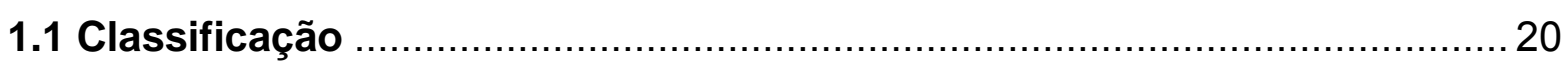

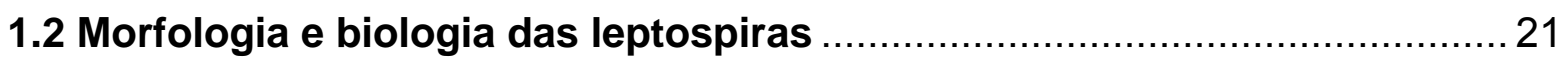

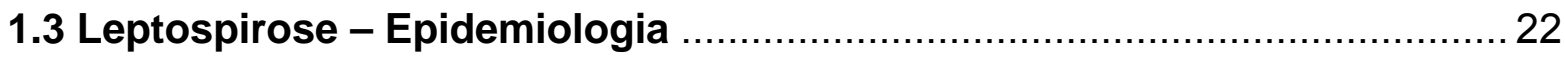

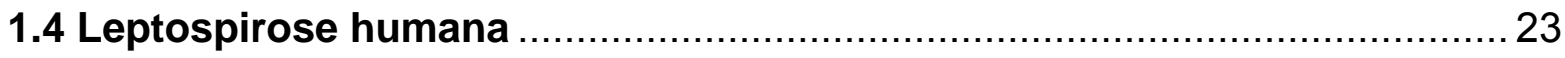

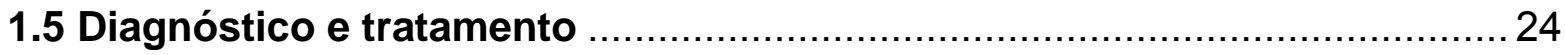

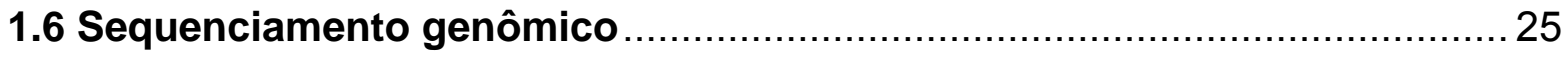

1.7 Mecanismos de patogenicidade e virulência ........................................... 26

1.8 Vacinas profiláticas e vacinologia reversa ............................................ 28

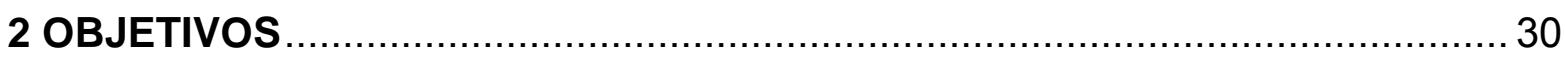

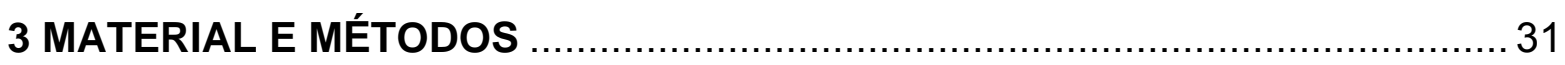

3.1 Análise por bioinformática ........................................................................ 31

3.2 Construção dos oligonucleotídeos e amplificação dos genes e fragmentos

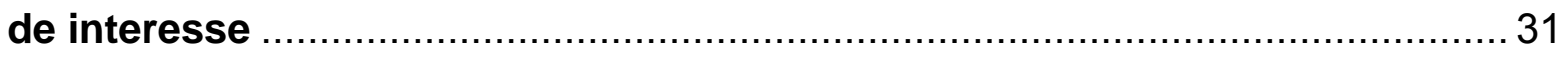

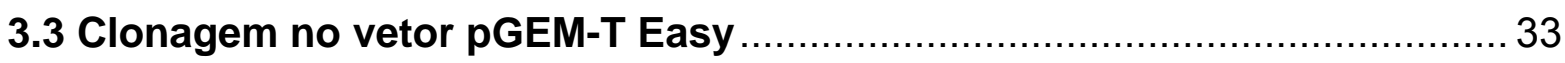

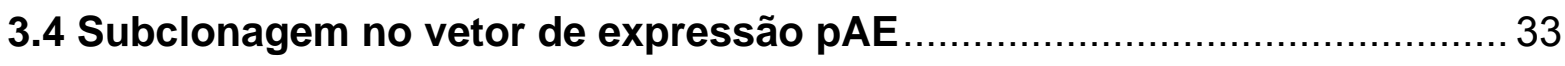

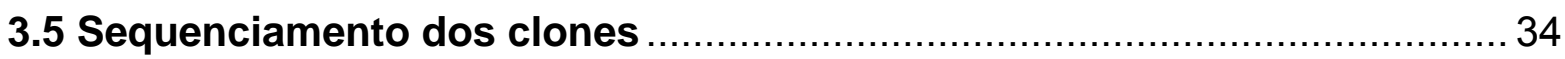

3.6 Análise da presença dos genes em diferentes cepas de Leptospira ......... 34

3.7 Extração de RNA total de diferentes espécies e sorovares de Leptospira..

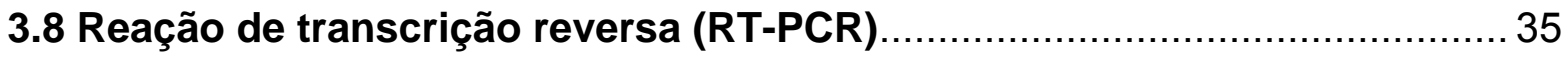

3.9 Expressão das proteínas e fragmentos recombinantes ……………….... 36

3.10 Solubilização das proteínas e fragmentos recombinantes ...................... 36

3.11 Purificação e diálise das proteínas e fragmentos recombinantes ............ 36

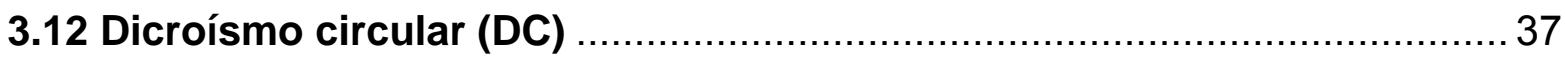

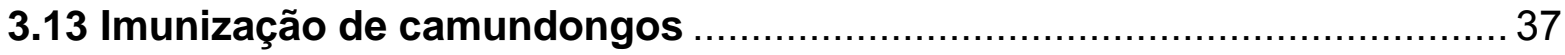

3.14 Titulação de anticorpos IgG produzidos em camundongos por ELISA ... 38

3.15 Detecção de anticorpos IgG e IgM humanos em soros de pacientes diagnosticados com leptospirose por ELISA ……......................................... 38

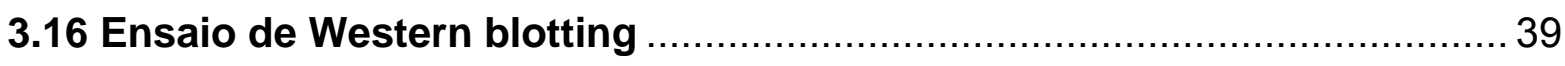

3.17 Ensaio de imunofluorescência de fase líquida (L-IFA) ……………....... 40

3.18 Ensaio de digestão com proteinase K (PK) …................................... 40 
3.19 Ensaio de adesão das proteínas e fragmentos recombinantes a componentes da matriz extracelular (MEC)

3.20 Ensaio de ligação das proteínas e fragmentos recombinantes ao PLG, fator $\mathrm{H}$, fibrinogênio, componentes do sistema complemento e C4BP.

3.21 Ensaio de atividade enzimática da plasmina

3.22 Ensaio de inibição da formação do coágulo de fibrina. 43

3.23 Curvas de dose e resposta. 44

3.24 Interação das proteínas e fragmentos recombinantes desnaturadas com MECs, PLG e fibrinogênio 44

3.25 Interação das proteínas e fragmentos recombinantes bloquedos com soro homólogo com MECs, PLG e fibrinogênio.

3.26 Ensaio de inibição da adesão de leptospiras vivas a MECs, PLG e fibrinogênio pelas proteínas recombinantes. 46

3.27 Ensaio de competição entre PLG e fibronectina plasmática pelo fragmento Intermediário. 46

3.28 Ensaio de imunização/desafio com as proteínas recombinantes 47

3.29 Culturas de Leptospiras e soros de pacientes diagnosticados com leptospirose 48

4 RESULTADOS E DISCUSSÃO 49

4.1 Análise por bioinformática 49

4.2 Amplificação dos genes LIC10258, LIC12880 e LIC12238 por PCR . 52

4.3 Clonagem no vetor pGEM-T Easy 53

4.4 Subclonagem no vetor de expressão pAE 54

4.5 Sequenciamento dos clones 55

4.6 Análise da presença dos gene LIC10258, LIC12880 e LIC12238 e de seus transcritos em diferentes cepas de Leptospira 56

4.7 Expressão das proteínas recombinantes. 59

4.8 Solubilização das proteínas rLIC10258 e rLIC12880 61

4.9 Purificação e diálise das proteínas recombinantes 62

4.10 Avaliação da atividade imunogênica das proteínas recombinantes em camundongos.

4.11 Análise da estrutura das proteínas recombinantes por DC 64

4.12 Presença de anticorpos IgG e IgM humanos contra proteínas recombinantes em soros de pacientes diagnosticados com leptospirose...... 66 
4.13 Reconhecimento de rLIC10258, rLIC12880 e rLIC12238 por anticorpos monoclonais anti-His tag e policlonais homólogos por Western blotting ....... 68 4.14 Análise da localização celular das proteínas codificadas pelos genes LIC10258, LIC12880 e LIC12238 por ensaio de digestão com PK e L-IFA

4.15 Adesão das proteínas recombinantes rLIC10258, rLIC12880 e rLIC12238 aos componentes de matriz extracelular (MEC).

4.16 Contribuição dos carboidratos da laminina e fibronectina plasmática na interação com rLIC10258

4.17 Ligação das proteínas recombinantes rLIC10258, rLIC12880 e rLIC12238 ao PLG humano. 77

4.18 Atividade enzimática da plasmina 79

4.19 Ligação das proteínas recombinantes rLIC10258, rLIC12880 e rLIC12238 ao fibrinogênio, componentes do sistema complemento, fator H e C4BP ...... 80 4.20 Inibição da formação do coágulo de fibrina pela proteína rLIC12238 ...... 84 4.21 Inibição da adesão de leptospiras vivas a MECs, PLG ou fibrinogênio pelas proteínas recombinantes rLIC10258, rLIC12880 e rLIC12238 86

4.22 Avaliação da atividade imunoprotetora das proteínas rLIC10258, rLIC12880 e rLIC12238. 88

4.23 Amplificação e clonagem dos fragmentos do gene LIC10258 94

4.24 Sequenciamento dos clones 96

4.25 Expressão e purificação dos fragmentos recombinantes 96

4.26 Reconhecimento dos fragmentos $\mathrm{N}$-terminal, Intermediário e C-terminal por anticorpos monoclonais anti-His tag e policlonais homólogos por Western blotting

4.27 Presença de anticorpos IgG e IgM humanos contra os fragmentos recombinantes da proteína rLIC10258 em soros de pacientes diagnosticados com leptospirose

4.28 Ligação dos fragmentos recombinantes de rLIC10258 a laminina, fibronectina plasmática e PLG 100

4.29 Contribuição dos carboidratos da laminina e fibronectina plasmática na interação com os fragmentos recombinantes de rLIC10258. 104

4.30 Interferência da fibronectina plasmática na ligação do PLG ao fragmento Intermediário de rLIC10258 105

4.31 Região Imunodominante da proteína rLIC10258 107 
APÊNDICE A - Identification and characterization of novel adhesins in Leptospira.

APÊNDICE B - In vitro identification of novel plasminogen-binding receptors of the pathogen Leptospira interrogans

APÊNDICE C - Characterization of novel OmpA-like protein of Leptospira interrogans that binds extracellular matrix molecules and plasminogen. 144 APÊNDICE D - Evaluation of immunoprotective activity of six leptospiral proteins in the hamsters model of leptospirosis 160 APÊNDICE E - Plasminogen binding proteins and plasmin generation on the surface of Leptospira spp: the contribution to the bacteria-host interactions..

APÊNDICE F - Adhesins of Leptospira interrogans mediate the interaction to fibrinogen and inhibit fibrina clot formation in vitro 186 APÊNDICE G - Leptospiral extracelular matrix adhesins as mediators of pathogen-host interactions 203

ANEXO A - Cromatogramas dos sequenciamentos das construções no vetor pAE contendo os insertos de DNA dos genes selecionados 214 ANEXO B - Soro de pacientes diagnosticados com leptospirose empregados nos imunoensaios com as proteínas recombinantes rLIC10258, rLIC12880 e rLIC12238

ANEXO C - Cromatogramas dos sequenciamentos das construções no vetor pAE contendo os insertos de DNA dos fragmentos do gene LIC10258 ......... 216 ANEXO D - Soro de pacientes diagnosticados com leptospirose empregados nos imunoensaios com os fragmentos recombinantes do gene LIC10258 ....217 


\section{INTRODUÇÃO}

Inicialmente conhecida como doença de Weil's, as manifestações clínicas da leptospirose foram descritas, pela primeira vez, em 1886. Em 1915, Inada e Ido isolaram o agente etiológico da leptospirose, uma nova espiroqueta denominada Spirocheta icterohaenorrhagiae japonica. Porém, em 1918, devido a características morfológicas diferenciadas, esta espiroqueta passou a integrar um novo gênero, Leptospira, pertencente a ordem Spirochaetales (KOBAYASHI, 2001).

\subsection{Classificação}

As bactérias do gênero Leptospira pertencem a família Leptospiraceae, ordem Spirochaetales, filo Spirochaetes, Reino Eubacteriaceae.

Até meados de 1989, todas as espécies de leptospiras patogênicas eram denominadas Leptospira interrogans, enquanto que L. biflexa incluía todas as espécies saprofíticas (LEVETT, 2001; EVANGELISTA; COBURN, 2010). Adicionalmente, baseando-se na expressão diferenciada de lipopolissacarídeos (LPS) de superfície, as leptospiras estão agrupadas em 24 sorogrupos e 250 sorovares. A heterogenicidade dos carboidratos que compõem a cadeia lateral dos LPS determinam a diversidade antigênica entre os sorovares, enquanto que sorovares antigenicamente relacionados estão agrupados em um sorogrupo (VINETZ, 2001; EVANGELISTA; COBURN, 2010).

Atualmente, análises de hibridização de DNA tem classificado as leptospiras em 13 espécies patogênicas (L. alexanderi, L. alstoni, L. borgpetersenii, L. inadai, $L$. interrogans, L. fainei, L. kirschneri, L. licerasiae, L. noguchii, L. santarosai, L. terpstrae, L. weilii e L. wolffi) e 6 espécies saprofíticas (L. biflexa, L. meyeri, L. yanagawae, L. kmetyi, L. vanthielii e L. wolbachii) (ADLER; DE LA PENA MOCTEZUMA, 2010; EVANGELISTA; COBURN, 2010).

Além disso, análises filogenéticas do gene constitutivo $16 S$ do RNA ribossômico sugerem a classificação das leptospiras em patogênicas ( $L$. alexanderi, L. alstoni, L. borgpetersenii, L. interrogans, L. kirschneri, L. noguchii, L. santarosai e L. weilii), intermediárias ( $L$. inadai, $L$. fainei, L. liceraciae e $L$. wolffi) e saprofíticas $(L$. biflexa, L. wolbachi, L. kmetyi, L. meyeri, L. vanthielii, L. terpstrae e L. yanagawae) (KO; GOARANT; PICARDEAU, 2009; EVANGELISTA; COBURN, 2010). 


\subsection{Morfologia e biologia das leptospiras}

As leptospiras são bactérias finas e espiraladas com aproximadamente $1 \mu \mathrm{m}$ de diâmetro por 6-20 $\mu \mathrm{m}$ de comprimento. A presença de dois flagelos no espaço periplasmático dão motilidade a estas bactérias que, diferentemente de outras espiroquetas, possuem formato característico de ponto de interrogação, devido as suas extremidades terminadas em ganchos (PLANK; DEAN, 2000; LEVETT, 2001; ADLER; DE LA PENA MOCTEZUMA, 2010).

As leptospiras são obrigatoriamente aeróbias e apresentam crescimento lento em uma temperatura ótima entre 28 e $30^{\circ} \mathrm{C}$ e pH entre 7,2 e 7,6. Estas espiroquetas crescem em meio de cultura líquido ou sólido enriquecido com vitaminas, sais de amônio e ácidos graxos de cadeia longa que são utilizados como única fonte de carbono e metabolizados por $\beta$-oxidação. O meio de cultura mais utilizado é o Ellinghausen-McCullough/Johson-Harris (EMJH) composto por ácido oléico, albumina sérica bovina e polisorbato (Tween) (LEVETT, 2001).

As leptospiras, assim como outras bactérias Gram-negativas, possuem uma estrutura de membrana dupla e a presença de LPS de superfície, porém também apresentam características semelhantes as das bactérias Gram-positivas como a associação entre a membrana citoplasmática e a camada de peptideoglicano (LEVETT, 2001; EVANGELISTA; COBURN, 2010).

$\mathrm{Na}$ membrana externa, o LPS constitui o principal antígeno das leptospiras, que apesar de ser estruturalmente semelhante ao de outras bactérias Gramnegativas, apresenta uma toxicidade 12 vezes menor para camundongos quando comparado ao LPS de Escherichia coli. A menor endotoxicidade do LPS das leptospiras pode ser atribuído a uma alteração na composição do lipídeo $A$, que possui uma unidade dissacarídica de glucosamida metilada e fosforilada. Esta característica única encontrada no LPS destas espiroquetas também contribui para uma atividade imune especifíca, com ativação do receptor Toll-like 2 (TLR2) ao invés do TLR4, o receptor clássico de LPS (HAAKE; MATSUNAGA, 2010).

Além do LPS estão presentes na superfície das leptospiras as proteínas de membrana externa (OMP), entre elas, proteínas funcionais e estruturais, hipotéticas, porinas e um grande número de lipoproteínas. Devido a sua localização, especula- 
se o envolvimento destas OMPs nas interações patogéno-hospedeiro e na patogenicidade das leptospiras (GAMBERINI et al., 2005; ATZINGEN et al., 2008).

A grande maioria das proteínas de superfície, as lipoproteínas, encontram-se ancoradas a um ácido graxo constituinte da membrana externa por uma ligação covalente com a sua porção amino-terminal (HAAKE et al., 2000; HAAKE; MATSUNAGA, 2010). Malsmstrom e colaboradores (2009) utilizando ensaios modificados de cromatografia líquida e espectrometria de massa, determinaram o número de cópias de proteínas por célula de Leptospira confirmando que as lipoproteínas são predominantes na membrana externa. Neste ensaio, a lipoproteína de membrana majoritária das leptospiras, LipL32, foi a mais abundante com 38000 cópias por célula (MALMSTROM et al., 2009). Por estarem localizadas na superfície das leptospiras, as lipoproteínas participam da adaptação e interação com o meio ambiente (HAAKE et al., 2000; HAAKE; MATSUNAGA, 2010) e como outras OMPs, provavelmente estão envolvidas na patogênese da doença.

\subsection{Leptospirose - Epidemiologia}

A leptospirose é uma zoonose causada por espiroquetas patogênicas do gênero Leptospira. Trata-se de uma doença de distribuição mundial, ocorrendo tanto em áreas rurais quanto urbanas de regiões tropicais, subtropicais e temperadas (EVANGELISTA; COBURN, 2010).

Nos países desenvolvidos, a leptospirose está geralmente associada com atividades aquáticas de lazer em ambientes contaminados, enquanto que nos países em desenvolvimento, as condições sanitárias precárias e a alta infestação de roedores infectados são fatores determinantes para a alta incidência da doença nestes países. Porém, a leptospirose também pode estar associada com atividades ocupacionais, acometendo indivíduos que trabalham em ambientes úmidos e alagadiços, como plantações de arroz, esgotos e minas (KOBAYASHI, 2001; ADLER; DE LA PENA MOCTEZUMA, 2010).

Nos centros urbanos, os roedores domésticos como Rattus norvegicus (rato de esgoto), Rattus rattus (rato preto) e Mus musculus (camundongo), são os principais reservatórios da doença, pois albergam as leptospiras nos túbulos proximais renais, eliminando-as vivas no ambiente e contaminando água, solo, 
alimentos e outros animais. Entretanto, quase todas as espécies de mamíferos podem servir de reservatório de leptospiras (FAINE et al., 1999).

No Brasil, a leptospirose é uma doença endêmica, podendo tornar-se epidêmica nas capitais e regiões metropolitanas durante os períodos chuvosos, devido a fatores como enchentes, redes de saneamento básico deficientes, condições inadequadas de habitação e a presença de grande número de roedores infectados (BRASIL, 2005).

Segundo dados do Ministério da Saúde, entre os anos de 2005 e 2011 foram confirmados 27483 casos, apresentando média anual de 3926 casos (Portal da Saúde. Disponível em: http://portal.saude.gov.br/portal/arquivos/pdf/ tab casos conf ser hist 1997 2012. pdf. Acesso em: 05 de junho de 2013). Neste mesmo período, 2674 pacientes foram a óbito, com média anual de 382 óbitos e letalidade de aproximadamente 10\% (Portal da Saúde. Disponível em: http://portal.saude.gov/portal/arquivos/pdf/tab obitos serie hietorica 2012 pdf.

Acesso em 05 de junho de 2013).

As Regiões Sudeste e Sul apresentaram as maiores porcentagens de casos confirmados, 37 e 33\%, respectivamente, seguidas das Regiões Nordeste, Norte e Centro-Oeste com 19, 10 e $1 \%$ do total de casos confirmados no Brasil, respectivamente. O Estado que reportou os maiores números de casos e óbitos foi São Paulo, com 5876 casos confirmados e 688 óbitos, correspondendo a 21,5 e $26 \%$ dos casos confirmados e óbitos totais no Brasil, respectivamente.

\subsection{Leptospirose humana}

A infecção humana ocorre pelo contato direto ou indireto com a urina de animais infectados. As leptospiras penetram ativamente por meio das mucosas (ocular, digestiva, respiratória e genital), da pele lesionada e da pele íntegra em contato por períodos prolongados com água contaminada (BRASIL, 2005). Após a penetração, as leptospiras percorrem as vias linfáticas e sanguíneas, estabelecendo-se nos túbulos renais, fígado, cérebro e olhos onde se multiplicam (FAINE et al., 1999).

O tempo de incubação da doença até o surgimento dos primeiros sintomas é variável, podendo ser de algumas horas até 28 dias (FAINE et al., 1999). 
As manifestações clínicas e o grau de severidade da leptospirose são muito variados e dependentes de fatores como: espécie da leptospira infectante e carga bacteriana, bem como idade e condição imunológica do indivíduo infectado (BRASIL, 2005).

Geralmente, os pacientes apresentam um quadro de sintomas amplo e inespecífico, o que dificulta a diferenciação da leptospirose de outras doenças febris agudas. Os sintomas mais comuns incluem: febre, calafrios, cefaleia, mal estar geral e mialgia (FAINE et al., 1999; LEVETT, 2001).

Entre 5 e 15\% dos pacientes evoluem para a forma severa da leptospirose, denominada síndrome de Weil's. Os sintomas característicos desta síndrome, que apresenta taxa de mortalidade de 4 a 50\%, são: icterícia, falência renal e hemorragias.

Recentemente, a síndrome de hemorragia pulmonar associada à leptospirose (LPHS) tem sido relatada como outra manifestação severa da doença. A LPHS apresenta sintomas inespecíficos como: dor no peito, tosse e dispneia, que geralmente aparecem entre o quarto e sexto dia da doença, podendo levar o paciente a óbito em até 72 horas (FAINE et al., 1999; TOYOKAWA; OHNISHI; KOIZUMI, 2011).

\subsection{Diagnóstico e tratamento}

Os métodos utilizados para o diagnóstico da leptospirose são usualmente sorológicos. No Brasil, os métodos mais utilizados são o teste ELISA (ensaio imunoenzimático - enzyme linked immuno sorbent assay) para pesquisa de anticorpos IgM específicos contra componentes de leptospiras patogênicas e o teste de microaglutinação (MAT - microscopic agglutination test), ambos sorológicos (BRASIL, 2005).

O MAT é o método padrão ouro recomendado pela Organização Mundial da Saúde (OMS). Apesar disso, é um método pouco sensível, de difícil padronização e execução, sendo realizado apenas por laboratórios de referência. Neste teste, amostras de soros de pacientes são submetidas à reação com suspensões de diferentes sorovares de leptospira. O MAT apresenta baixa sensibilidade na fase inicial da doença, já que anticorpos contra antígenos de superfície da leptospira não são detectados nos primeiros dias após a infecção. Além disso, por se tratar de um 
ensaio sorovar específico, os laboratórios que realizam o MAT necessitam manter culturas vivas de diferentes sorovares de Leptospira (FAINE et al., 1999; LEVETT, 2003).

Recentemente, alguns protocolos de PCR tem sido propostos, como uma alternativa ao MAT, para o diagnóstico da leptospirose. Alguns genes, como por exemplo, secY, rrs, flaB, LigA, LigB, LipL32, rrl e LA3521, tem sido utilizados como alvos e amplificados por reação de polimerase em cadeia (PCR) do liquor e urina de suspeitos de leptospirose (MERIEN et al., 1992; BROWN et al., 1995; KOIZUMI et al., 2003; FONSECA CDE et al., 2006; KOSITANONT et al., 2007).

Atualmente, foi divulgado um novo método de diagnóstico da leptospirose desenvolvido por pesquisadores da Fundação Oswaldo Cruz (FIOCRUZ). Neste método, a proteína recombinante LigA imobilizada em um cartão detecta a presença de anticorpos específicos em uma gota de sangue do paciente suspeito (FUNDAÇÃO OSWALDO CRUZ, 2010).

Quando diagnosticada, a leptospirose é tratada com antibióticos como as penicilinas e doxiciclinas. Entretanto, o tratamento é geralmente mais eficiente nos primeiros dias após a infecção. Além disso, procedimentos como diálise e terapia intensiva são necessários quando os pacientes apresentam complicações renais, respiratórias ou hemorrágicas (FAINE et al., 1999; LEVETT, 2001).

\subsection{Sequenciamento genômico}

Por ser o agente etiológico da maior parte das infecções em humanos, $L$. interrogans foi a primeira espécie a ser sequenciada (REN et al., 2003; NASCIMENTO et al., 2004a; NASCIMENTO et al., 2004b). Outra espécie patogênica, $L$. borgpetersenii também teve o seu genoma sequenciado, já que infecta rebanhos de bovinos, suínos e equinos causando grande impacto econômico na pecuária (BULACH et al., 2006). Além das espécies patogênicas, a espécie de vida livre, $L$. biflexa foi sequenciada na tentativa de desvendar os mecanismos da patogenicidade das leptospiras comparando o genoma de espécies patogênicas e saprofíticas (PICARDEAU et al., 2008).

O genoma das leptospiras é composto por dois cromossomos circulares, porém a espécie saprofítica $L$. biflexa possui, adicionalmente, um terceiro replicon denominado P74, ausente nas espécies patogênicas. Acredita-se que este replicon 
seja essencial a espécie saprofítica, já que possui genes constitutivos do metabolismo basal que são encontrados no cromossomo I das leptospiras patogênicas. Além disso, a comparação dos genomas permitiu a identificação de 1431 genes exclusivos das espécies patogênicas, sem ortológos em L. biflexa (PICARDEAU et al., 2008).

O genoma de $L$. interrogans é maior em tamanho $(4,6 \mathrm{Mb})$ do que os genomas de L. borgpetersenii e L. biflexa (3,9 Mb). Enquanto, L. borgpetersenii não é capaz de sobreviver fora do hospedeiro (BULACH et al., 2006), tem sido relatada a capacidade de $L$. interrogans sobreviver em ambientes úmidos ou água fresca por períodos de até 110 dias (TRUEBA et al., 2004). A comparação destes genomas indica que a perda de genes relacionados com a sobrevivência fora do hospedeiro limitam a transmissão de $L$. borgpetersenii apenas pelo contato direto com indivíduos infectados. Em contrapartida, o maior genoma de L. interrogans provavelmente é devido a presença de genes relacionados a sobrevivência desta espiroqueta tanto no meio ambiente quanto em mamíferos hospedeiros.

Recentemente, a espécie patogênica L. santarosai (CHOU et al., 2012) e a espécie intermediária L. licerasiae (RICALDI et al., 2012) tiveram o seu genoma totalmente sequenciado.

\subsection{Mecanismos de patogenicidade e virulência}

Os mecanismos moleculares de patogenicidade e virulência das leptospiras são, ainda, pouco conhecidos. Sendo assim, o sequenciamento de cinco espécies de Leptospira possibilitaram que análises genômicas identificassem uma grande variedade de proteínas hipotéticas que provavelmente estão envolvidas na patogênese da leptospirose (REN et al., 2003; NASCIMENTO et al., 2004a; NASCIMENTO et al., 2004b; PICARDEAU et al., 2008; CHOU et al., 2012; RICALDI et al., 2012).

Loa22, uma lipoproteína com domínio tipo OmpA, foi o primeiro fator de virulência geneticamente identificado em Leptospira. Apesar da função de Loa22 permanecer desconhecida, leptospiras mutantes em loa22 tornaram-se avirulentas em ensaios utilizando hamsters e porquinhos da índia como modelos animais (RISTOW et al., 2007). 
Além da Loa22, a motilidade e o LPS das leptospiras também são considerados fatores de virulência. Em relação a motilidade, ensaios mostraram que leptospiras mutantes no gene fliY, que codifica a proteína FliY do motor flagelar perdem a virulência e a capacidade de infectar porquinhos da índia (LIAO et al., 2009), enquanto que estudos dirigidos por Murray e colaboradores (2010) relataram a perda da virulência de leptospiras mutantes em LPS, em modelo de hamster (MURRAY et al., 2010).

Nos últimos anos, o grupo de pesquisa deste trabalho, tem identificado proteínas de membrana hipotéticas capazes de se ligar a componentes da matriz extracelular, auxiliando na adesão das leptospiras aos tecidos dos hospedeiros. Entre elas: Lsa24 que interage com a laminina (BARBOSA et al., 2006); Lsa21 que se liga a laminina, fibronectina plasmática e colágeno IV (ATZINGEN et al., 2008), Lsa63 ligante de laminina e colágeno IV (VIEIRA et al., 2010b), entre outras. Outros grupos também demonstraram a capacidade de adesão de proteínas de leptospira a componentes da matriz extracelular do hospedeiro, como as proteínas de leptospira semelhantes à imunoglobulina, LigA e LigB (CHOY et al., 2007), e LipL32, a lipoproteína de membrana majoritária das leptospiras (HAUK et al., 2008; HOKE et al., 2008).

Recentemente, este grupo de pesquisa demonstrou a capacidade das leptospiras de utilizarem proteases do hospedeiro para a penetração tecidual e invasão (VIEIRA et al., 2009). Desde então, várias proteínas que se ligam ao plasminogênio (PLG) e são capazes de convertê-lo em plasmina tem sido identificadas (VERMA et al., 2010; VIEIRA et al., 2010a; MENDES et al., 2011; DOMINGOS et al., 2012).

Além de proteínas que se ligam aos componentes da matriz extracelular e PLG, tem sido identificadas proteínas de leptospiras que se ligam aos reguladores do sistema complemento, Fator H e C4BP (VERMA et al., 2006; BARBOSA et al., 2009; CASTIBLANCO-VALENCIA et al., 2012). A ligação destas proteínas ao Fator $\mathrm{H}$ e C4BP inibiria o ataque do sistema complemento facilitando a disseminação das leptospiras e consequente colonização dos órgãos dos hospedeiros. 


\subsection{Vacinas profiláticas e Vacinologia reversa}

As medidas de controle e prevenção da leptospirose são direcionadas ao controle da população de roedores, à melhoria das condições higiênico-sanitárias da população, ações de educação em saúde e alterações do meio ambiente (BRASIL, 2005). Entretanto, como estas são medidas de difícil implementação, o desenvolvimento de uma vacina é crítico para o controle e prevenção da doença.

As vacinas contra a leptospirose disponíveis no mercado são veterinárias e compostas de bactérias inativadas ou preparações de membrana de leptospiras patogênicas (GAMBERINI et al., 2005; KO; GOARANT; PICARDEAU, 2009; ADLER; DE LA PENA MOCTEZUMA, 2010). Apenas alguns países, como Japão, China e Cuba, possuem vacinas contra a leptospirose licenciadas para uso humano (KOIZUMI; WATANABE, 2005; ADLER; DE LA PENA MOCTEZUMA, 2010). Estas vacinas conferem proteção induzindo a produção de anticorpos contra LPS presentes na membrana das leptospiras. Contudo, estas vacinas falham em induzir uma proteção a longo prazo contra a infecção. Além disso, é importante ressaltar que existem variações da composição dos carboidratos do LPS das leptospiras e, baseado na expressão diferenciada destes LPS de superfície, as leptospiras patogênicas estão distribuídas em aproximadamente 250 sororaves (KOIZUMI; WATANABE, 2005; EVANGELISTA; COBURN, 2010). Sendo assim, as vacinas veterinárias e humanas disponíveis conferem imunidade sorovar-específica, não sendo capazes de proteger contra sorovares não inclusos em sua composição (GAMBERINI et al., 2005; KOIZUMI; WATANABE, 2005; ATZINGEN et al., 2010).

Devido as limitações encontradas nas vacinas contra a leptospirose disponíveis atualmente no mercado, tem sido desenvolvidas novas estratégias para a identificação de antígenos que sejam capazes de conferir proteção cruzada contra diferentes sorovares.

O sequenciamento completo do genoma de Neisseria meningitidis sorogrupo B (TETTELIN et al., 2000) propiciou o surgimento de uma nova estratégia para identificação de candidatos vacinais, denominada "vacinologia reversa". Nesta metodologia, os prováveis candidatos vacinais são selecionados após a análise in silico dos genomas sequenciados (PIZZA et al., 2000; RAPPUOLI, 2000). Esta mesma estratégia foi empregada satisfatoriamente na busca de candidatos vacinais contra infecção por Streptococcus pneumoniae (WIZEMANN et al., 2001), 
Porphyromonas gingivalis (ROSS et al., 2001), S. pyogenes (REID et al., 2002), entre outros.

Desta maneira, para a realização do presente estudo, os genes LIC10258, LIC12880 e LIC12238 foram selecionados do genoma de L. interrogans sorovar Copenhageni para serem avaliados quanto à possibilidade de serem bons candidatos vacinais. Estes genes foram selecionados após análises de bioinformática que identificaram prováveis proteínas de membrana. 


\section{OBJETIVO}

Clonar, expressar e caracterizar proteínas com potencial vacinal e/ou diagnóstico identificadas no genoma da L. interrogans sorovar Copenhageni 


\section{MATERIAL E MÉTODOS}

\subsection{Análise por bioinformática}

Os genes foram selecionados do genoma de $L$. interrogans sorovar Copenhageni disponível no servidor público, http://aeg.lbi.ic.unicamp.br/world/lic/. Esta seleção teve como base a localização celular das proteínas hipotéticas codificadas por estes genes, que foi feita por meio do programa PSORT (NAKAI e HORTON, 1999) (http://psort.nibb.ac.jp/) e CELLO (YU et al., 2006) (http://cello.life.nctu.edu.tw/). Os genes LIC12880 e LIC12238 codificam prováveis lipoproteínas, esta identificação foi realizada pelo programa LipoP (JUNCKER et al., 2003) (http://www.cbs.dtu.dk/services/LipoP/) que analisa a presença de uma sequência consenso denominada lipobox. O programa SMART (SCHULTZ et al., 1998) (http://smart.embl-heidelberg.de/) foi utilizado para identificar a presença de peptídeo sinal nos genes selecionados. Os genes ainda foram analisados pelo $\begin{array}{llll}\text { programa } & \text { BLAST } & \text { et } & \text { 1990) }\end{array}$ (http://www.ncbi.nlm.nih.gov/blast/Blast.cgi) e CLUSTAL 2.1 (LARKIN et al., 2007) (http://www.ebi.ac.uk/Tools/msa/clustalw2/). O BLAST (ALTSCHUL et al., 1990) analisa as similaridades destas sequências com a de outras espécies e sorovares de Leptospira e também com a de outros organismos presentes no banco de dados, enquanto que o programa CLUSTAL 2.1 (LARKIN et al., 2007) gera filogramas baseados nas similaridades entre as sequências analisadas pelo BLAST (ALTSCHUL et al., 1990).

\subsection{Construção dos oligonucleotídeos e amplificação dos genes e fragmentos de interesse}

Os genes LIC10258, LIC12880, LIC12238 e os fragmentos correspondentes as porções N-terminal, intermediária e C-terminal do gene LIC10258 foram obtidos por PCR a partir do DNA genômico de L. interrogans sorovar Copenhageni M20, utilizando-se nucleotídeos forward $(F)$ e reverse $(R)$ desenhados no programa Generunner (www.generunner.net/), contendo os sítios de restrição para as enzimas BamHI/Ncol; Xhol/Ncol e Xhol/HindIII para LIC10258 e seus fragmentos, LIC12880 
e LIC12238, respectivamente. A sequência dos oligonucleotídeos construídos para cada um dos genes está descrita no quadro abaixo:

Quadro 01- Sequência de oligonucleotídeos utilizados para amplificação dos genes e fragmentos de interesse

\begin{tabular}{|c|c|}
\hline Gene & Oligonucleotídeo \\
\hline & F: 5'GGATCCGAAGCCTTCTCACCCAATTG3' \\
\hline LIC10258 & R: 5'CCATGGTTAAAGTGAAAGATAAAAATCGATTC3' \\
\hline \multirow{3}{*}{ LIC10258 N-terminal } & F: 5'GGATCCGAAGCCTTCTCACCCAAT3' \\
\hline & R: 5'CCATGGTTAATCTGTTCCATCCCAAAT3' \\
\hline & F: 5'GGATCCTCCTCTCGTATCAATATTTCTCAA3' \\
\hline LIC10258 & R: 5'CCATGGTTAATGATCTTCTTCTAACACCAG3' \\
\hline \multicolumn{2}{|l|}{ Intermediário } \\
\hline \multirow{3}{*}{ LIC10258 C-terminal } & F: 5'GGATCCATCAAAACTTGGAATGGC3' \\
\hline & R: 5'CCATGGTTAAAGTGAAAGATAAAAATCGATTC3' \\
\hline & F: 5'CTCGAGGAAGTTGTCCGAGTCTAT3' \\
\hline \multirow[t]{2}{*}{ LIC12880 } & R: 5'CCATGGTTATTGATTGTTTAATTCAG3' \\
\hline & F: 5'스CGAGTGTTTTAAACCTACCGGAG3' \\
\hline LIC12238 & R: 5'AAGCTTCTACTTCATCGCTTTTTCTATATC3' \\
\hline
\end{tabular}

Notas: LIC: identificação do gene no genoma de L. interrogans sorovar Copenhageni Abreviaturas (em inglês): $\mathrm{F}$ : forward e R: reverse

As sequências que correspondem aos sítios de restrição BamHI/Ncol; Xhol/Ncol e Xhol/HindIII para LIC10258 e seus fragmentos, LIC12880 e LIC12238, respectivamente, estão sublinhadas.

As temperaturas de fusão utilizadas foram determinadas de acordo com 0 programa Generunner e subtraídas em $5^{\circ} \mathrm{C}$, foram estas $63,56,58$ e $60{ }^{\circ} \mathrm{C}$ para LIC10258, LIC12880, LIC12238 e os fragmentos do gene LIC10258, respectivamente. Os insertos foram amplificados sem a sequência do peptídeo sinal. A amplificação e o tamanho dos insertos de interesse foi verificada por meio de eletroforese em gel de agarose 1\% em tampão TBE (450 mM Tris-Borato e $10 \mathrm{mM}$ 
EDTA). Os insertos de interesse foram purificados do gel de agarose utilizando o kit GFXPCR DNA and gel band purificatio (GE Healthcare) e os produtos obtidos foram quantificados em espectofotômetro.

\subsection{Clonagem no vetor pGEM-T Easy}

Os insertos de DNA obtidos foram clonados no vetor pGEM-T Easy. A reação de ligação foi realizada segundo a reação padrão estabelecida pelo fabricante. Os produtos de ligação foram utilizados para transformar bactérias $E$. coli $\mathrm{DH} 5 \alpha$ previamente tornadas competentes pelo método descrito por Mandel e Higa (1970) (MANDEL; HIGA, 1970).

Para a transformação foram utilizados $50 \mathrm{ng}$ do produto de ligação para $50 \mu \mathrm{L}$ de bactéria competente. O produto da transformação foi semeado em meio de cultura contendo $100 \mu \mathrm{g} / \mathrm{mL}$ de ampicilina, $100 \mathrm{mM}$ de IPTG (isopropil- $\beta-D-$ tiogalactopiranosídeo) e $50 \mathrm{mg} / \mathrm{mL}$ de X-gal (5-bromo-4-cloro-3-indolil- $\beta$-Dgalactopiranosideo). Incubou-se a $37^{\circ} \mathrm{C}$ por uma noite. As colônias positivas selecionadas foram inoculadas em $5 \mathrm{~mL}$ de meio de cultura com $100 \mu \mathrm{g} / \mathrm{mL}$ de ampicilina e incubadas a $37^{\circ} \mathrm{C}$, sob agitação, por uma noite. Para obtenção do DNA plasmidial (pGEM-T Easy/inserto) destes inóculos utilizou-se o kit Plasmid prepmini spin (GE Healthcare) seguindo as orientações do fabricante. A presença dos insertos de interesse nos plasmídeos obtidos foi confirmada por meio de eletroforese em gel de agarose, após a digestão dos plasmídeos com suas respectivas enzimas de restrição.

\subsection{Subclonagem no vetor de expressão pAE}

Os insertos correspondentes aos genes LIC10258, LIC12880, LIC12238 e aos fragmentos N-terminal/LIC10258, Intermediário/LIC10258 e C-terminal/LIC10258 foram removidos dos plasmídeos recombinantes (pGEM-T Easy/inserto) por digestão com as enzimas de restrição e tampões apropriados. O vetor de expressão pAE (RAMOS et al., 2004) foi digerido separadamente com as mesmas enzimas de restrição utilizadas para obtenção dos insertos. Após digestão, tanto os insertos quanto o vetor de expressão foram submetidos à eletroforese em gel de agarose e 
posteriormente purificados pelo kit GFX PCR DNA and Gel Band Purification (GE Healthcare).

A ligação dos insertos ao vetor $\mathrm{pAE}$ foi realizada em uma reação contendo inserto:vetor em uma proporção 5:1 em massa de DNA. Bactérias competentes $E$. coli $\mathrm{DH} 5 \alpha$ foram transformadas com os produtos de ligação e semeadas em placas com meio de cultura e antibiótico apropriados e incubadas a $37^{\circ} \mathrm{C}$ por uma noite. As colônias positivas e negativas selecionadas foram inoculadas em $5 \mathrm{~mL}$ de meio de cultura com $100 \mu \mathrm{g} / \mathrm{mL}$ de ampicilina e incubadas a $37^{\circ} \mathrm{C}$, sob agitação, por uma noite. Com estes inóculos foi realizada uma seleção por fenol-clorofórmio, a fim de confirmar a presença do inserto no vetor. A obtenção do DNA plasmidial (pAE/inserto) dos inóculos com clones positivos e a confirmação da presença dos insertos neste DNA plasmidial foi feito da mesma maneira descrita para o vetor pGEM-T Easy.

\subsection{Sequenciamento dos clones}

Tanto as construções no vetor de clonagem (pGEM-T Easy/inserto) quanto as construções no vetor de expressão (pAE/inserto), foram sequenciadas pelo método da terminação de cadeia (SANGER; NICKLEN; COULSON, 1977) no sequenciador automático 3100 Genetic Analyze da Applied Biosystems.

\subsection{Análise da presença dos genes em diferentes cepas de Leptospira}

A presença dos genes LIC10258, LIC12880 e LIC12238 foi avaliada em espécies patogênicas de Leptospira e em outros sorovares patogênicos de $L$. interrogans, utilizando reação de PCR. Foram utilizados os mesmos oligonucleotídeos desenhados para a clonagem dos genes citados acima, de acordo com o genoma de L. interrogans sorovar Copenhageni. A reação de PCR foi realizada nas mesmas condições utilizadas para obtenção dos insertos para clonagem.

Os sorovares patogênicos utilizados de $L$. interrogans foram: Icterohaemorrhagiae, Hardjo, Pomona e Canicola. As espécies patogênicas avaliadas foram: L. borgpetersenii sorovar Castellonis, L. santarosai sorovar 
Shermani, L. noguchii sorovar Panama e L. kirschneri sorovar Grippotyphosa. Foi utilizada também a espécie não patogênica L. biflexa sorovar Patoc.

\subsection{Extração de RNA total de diferentes espécies e sorovares de Leptospira}

Culturas de leptospiras $(20 \mathrm{~mL})$ com 7 dias de crescimento foram centrifugadas a $6000 \mathrm{rpm}$, por 30 minutos, a $4{ }^{\circ} \mathrm{C}$. Para extração do RNA do sedimento bacteriano obtido foi utilizado o reagente TRIzol (Invitrogen) segundo as recomendações do fabricante. Foram extraídos o RNA total de culturas de $L$. interrogans sorovares Copenhageni, Icterohaemorrhagiae, Hardjo, Pomona e Canicola e das espécies patogênicas $L$. borgpetersenii sorovar Castellonis, $L$. santarosai sorovar Shermani, L. noguchii sorovar Panamá, L. kirschneri sorovar Grippotyphosa e da espécie não patogênica $L$. biflexa sorovar Patoc. Também foram extraídos o RNA total de $L$. interrogans sorovar Icterohaemorrhagiae mantidas por 16 horas nas temperaturas de 37 ou $39^{\circ} \mathrm{C}$, ou suplementadas com $120 \mathrm{mM}$ de $\mathrm{NaCl}$ e mantidas na temperatura de $28^{\circ} \mathrm{C}$.

\subsection{Reação de Transcrição Reversa (RT-PCR)}

O RNA total $(2 \mu \mathrm{g})$ obtido das culturas de leptospiras foi tratado com $1 \mathrm{U}$ de DNase I (Invitrogen) por 15 minutos a temperatura ambiente. Para inativação da DNase I, foi adicionado $1 \mu \mathrm{L}$ de solução de EDTA a $25 \mathrm{mM}$ e, em seguida, incubouse a amostra a $65^{\circ} \mathrm{C}$ por 10 minutos. A reação de transcrição reversa foi realizada com o kit SuperScript III First-Strand Synthesis System for RT-PCR (Invitrogen) conforme as recomendações do fabricante. $2 \mu \mathrm{L}$ do cDNA obtido foi empregado como molde para a reação de PCR. Foram utilizados os mesmos oligonucleotídeos desenhados para a clonagem dos genes LIC10258, LIC12880 e LIC12238, de acordo com o genoma de L. interrogans sorovar Copenhageni. Para análise da integridade dos transcritos obtidos foi realizada amplificação utilizando oligonucleotídeos elaborados para 0 16S ribossomal (16S-F 5'CAAGTCAAGCGGAGTAGCAATACTCAGC e 16S-R 5'GATGGCAACATAA GGTGAGGGTTGC). Todas as amostras foram testadas na presença e ausência da enzima transcriptase reversa para que a possibilidade de contaminação com DNA 
fosse descartada. Os produtos de RT-PCR obtidos foram analisados em gel de agarose $1 \%$.

\subsection{Expressão das proteínas e fragmentos recombinantes}

Bactérias competentes E. coli BL21 SI (Salt Induced) foram transformadas com o plasmídeo recombinante e cultivadas em meio 2YT/ON ( $1 \%$ extrato de levedura; $1,6 \%$ triptona; sem adição de $\mathrm{NaCl}$ ) contendo $100 \mu \mathrm{g} / \mathrm{mL}$ de ampicilina e incubadas a $30^{\circ} \mathrm{C}$, sob agitação, por uma noite. Após este período, as culturas saturadas foram diluídas (1:25) em um novo meio e incubadas até atingir uma densidade óptica (DO) entre 0,6 e 0,8. A indução foi realizada adicionando-se diferentes concentrações de $\mathrm{NaCl}$ e incubando as culturas, novamente, a mesma temperatura por um período de 3 horas. A seguir as bactérias foram centrifugadas (5000 rpm/15 minutos $/ 4{ }^{\circ} \mathrm{C}$ ) e os sedimentos bacterianos ressuspendidos em tampão de lise (20 mM Tris- $\mathrm{HCl} \mathrm{pH} \mathrm{8;} 200 \mathrm{mM} \mathrm{NaCl} ; 200 \mu \mathrm{g} / \mathrm{mL}$ lisozima; $2 \mathrm{mM}$ PMSF e 1\% Triton $\mathrm{X}-100$ ). As bactérias foram lisadas em banho de gelo por sonicação e centrifugadas novamente. Os sedimentos formados foram ressuspendidos em PBS (137 mM NaCl; 2,7 mM KCl; $10 \mathrm{mM} \mathrm{Na} \mathrm{HPO}_{4} ; 2 \mathrm{mM}$ $\mathrm{KH}_{2} \mathrm{PO}_{4}$ ) e $9 \mathrm{M}$ uréia, e alíquotas do sobrenadante da sonicação e do sedimento ressuspendido foram analisadas por eletroforese em gel de poliacrilamida/SDS (sulfato dodecil de sódio).

\subsection{Solubilização das proteínas e fragmentos recombinantes}

As proteínas recombinantes rLIC12880, rLIC10258 e os fragmentos rNterminal/LIC10258, rIntermediário/LIC10258 e rC-terminal/LIC10258 foram solubilizados em tampão contendo $8 \mathrm{M}$ uréia e 10\% glicerol como descrito por Saini e colaboradores (2002) por 2 horas, sob agitação, a $37^{\circ} \mathrm{C}$ (SAINI et al., 2002).

\subsection{Purificação e diálise das proteínas e fragmentos recombinantes}

A purificação das proteínas e fragmentos recombinantes obtidos foi feita em resina de afinidade a metal. Foi utilizada a resina Chelating Sepharose (GE Healthcare) carregada com $\mathrm{Ni}^{2+}$. Contaminantes foram lavados com tampões 
contendo baixas concentrações de imidazol (20, 40 e 60 mM). As proteínas rLIC10258, rLIC12880, rN-terminal/LIC10258, rlntermediário/LIC10258 e rCterminal/LIC10258 foram renaturadas durante o processo de purificação utilizandose tampões com concentrações decrescentes de uréia. As proteínas e fragmentos recombinantes foram eluídos com $1 \mathrm{M}$ de imidazol. As frações de todas as etapas da purificação foram coletadas e analisadas em gel de SDS-PAGE. As alíquotas que continham a proteína recombinante rLIC12238 foram dialisadas contra PBS e 0,1 $\mathrm{mM}$ PMSF a $4{ }^{\circ} \mathrm{C}$ durante uma noite. As alíquotas que continham as proteínas recombinantes rLIC10258, rLIC12880, N-terminal/LIC10258, Intermediário/LIC10258 e C-terminal/LIC10258 foram dialisadas contra PBS; 0,01\% glicina e 10\% glicerol a 4 ${ }^{\circ} \mathrm{C}$ durante a noite. Após diálise, a concentração das proteínas recombinantes foi avaliada em gel SDS-PAGE, utilizando-se concentrações pré-estabelecidas de albumina de soro bovino (BSA) e o programa GelQuant.

\subsection{Dicroísmo circular (DC)}

As proteínas rLIC10258, rLIC12880 e rLIC12238 foram submetidas à diálise realizada a $4{ }^{\circ} \mathrm{C}$, com tampão contendo $\mathrm{Na}_{2} \mathrm{HPO}_{4}$ e $\mathrm{NaH}_{2} \mathrm{PO}_{4}$ em concentração final de $1 \mathrm{M}$. Foram realizadas 3 trocas da solução para certificar-se que o tampão contendo as proteínas não apresentariam íons $\mathrm{Cl}^{-}$, os quais interferem na leitura do espectropolarímetro (Jasco J810). Os valores de leitura foram obtidos no intervalo de 184 a $260 \mathrm{~nm}$. Os resultados foram expressos em elipicidade molar, segundo a fórmula:

$$
[\theta] \text { molar }=100 \times \theta(\text { degrees }) / C(M) \times I(\mathrm{~cm})
$$

onde $\theta$ é elipicidade, $\mathrm{C}$ a concentração da proteína e I o caminho ótico. Os dados obtidos foram comparados com a predição teórica feita pelo servidor público PSIPRED (JONES, 1999) (http://bioinf.cs.ucl.ac.uk/psipred/).

\subsection{Imunização de camundongos}

Foram realizadas 3 imunizações com 15 dias de intervalo entre elas em grupos de 4 camundongos BALB/c, fêmeas, com idade de 6 a 8 semanas. Os animais foram imunizados, no dorso, com $10 \mu \mathrm{g}$ de proteína ou fragmento recombinante adsorvido em alúmem, por via subcutânea. O grupo controle foi 
imunizado com PBS e alúmem. Os animais foram sangrados via plexo retro-orbital 15 dias após cada dose de imunização. $\mathrm{O}$ sangue coletado foi incubado a $4{ }^{\circ} \mathrm{C}$ durante a noite e foi centrifugado por 5 minutos a $8000 \mathrm{rpm}$. O soro foi cuidadosamente coletado e armazenado a $-20^{\circ} \mathrm{C}$.

\subsection{Titulação de anticorpos IgG produzidos em camundongos por ELISA}

A detecção de anticorpos IgG anti-rLIC10258, anti-rLIC12880, anti-rLIC12238 e anti-fragmentos da proteína rLIC10258 após as imunizações foi feita por ensaio imunoenzimático ELISA conforme descrito por Sato e colaboradores (1991) (SATO, 1991). As proteínas e fragmentos recombinantes ( $50 \mathrm{ng} /$ poço) em tampão carbonato $0,05 \mathrm{M} \mathrm{pH}$ 9,6 foram adsorvidas em placas de microdiluição (High Binding, Nunc) e incubadas com soros hiperimunes em diluição seriada (previamente incubadas com $25 \%$ de extrato de E. coli para que ocorresse a adsorção dos anticorpos inespecíficos). A seguir, as placas foram incubadas com anticorpo anti-lgG de camundongo conjugado com peroxidase (Sigma) na diluição 1:5000. A reação enzimática foi revelada pela adição de $1 \mathrm{mg} / \mathrm{mL}$ de OPD (ס-phenylenediamina, Sigma) diluído em tampão fosfato-citrato $\mathrm{pH} 5$ contendo $0,03 \%$ (vol/vol) de peróxido de hidrogênio. A reação foi interrompida pela adição de solução de $\mathrm{H}_{2} \mathrm{SO}_{4} 8 \mathrm{M}$. A DO foi determinada em leitor de microplacas usando o comprimento de onda de 492 $\mathrm{nm}$. O título individual foi determinado como sendo a maior diluição do soro com valor da $\mathrm{DO}_{492}$ maior do que 0,1 .

\subsection{Detecção de anticorpos IgG e IgM humanos em soro de pacientes diagnosticados com leptospirose por ELISA}

A detecção de anticorpos $\lg$ e $\lg M$ anti-proteínas e anti-fragmentos recombinantes no soro destes indivíduos foi feita por ELISA de maneira semelhante ao experimento de detecção de anticorpos de camundongos, introduzindo-se algumas modificações tais como: a diluição única dos soros de 1:100, os anticorpos secundários utilizados foram anti-lgG e anti-lgM humanos conjugados a peroxidase (Sigma) na diluição 1:5000. A revelação da placa ocorreu de forma semelhante, assim como a leitura dos dados. Foram realizadas cinéticas de concentração de extrato bacteriano, 5 e $20 \%$, para adsorção prévia de anticorpos inespecíficos. 
Foram consideradas amostras positivas aquelas que apresentaram valores maiores do que o estabelecido pelo cutoff. Os valores de cutoff foram calculados a partir de valores obtidos para indivíduos normais. Foram utilizadas amostras de soro de 6 e 18 indivíduos saudáveis para as proteínas e fragmentos recombinantes, respectivamente. A fórmula utilizada para o cálculo do cutoff foi a média da DO dos indivíduos normais +3 vezes o desvio padrão desta média.

\subsection{Ensaio de Western blotting}

O reconhecimento das proteínas e fragmentos recombinantes por anticorpos monoclonais anti-His tag e por anticorpos policlonais homólogos foi analisado por Western blotting. Sendo assim, as proteínas e fragmentos a serem avaliados foram separados por gel de poliacrilamida/SDS e transferidos para membrana de nitrocelulose Hybond-ECL (GE Healthcare) em sistema semi-úmido (GE) por 1 hora a $0,8 \mathrm{~mA}$ por $\mathrm{cm}^{2}$ em tris-glicina acrescido de 1,85\% de SDS (tampão de transferência). A eficiência da transferência foi avaliada por coloração de Ponceau $S$ (Sigma). As proteínas e fragmentos recombinantes foram descorados com PBS/Tween $0,05 \%$ sob agitação e a membrana foi incubada com solução de bloqueio (PBS/Leite desnatado 10\%) durante uma noite a temperatura de $4{ }^{\circ} \mathrm{C}$. Lavou-se a membrana por 15 minutos com PBS/Tween 0,05\%, e logo após a mesma foi incubada com anticorpo monoclonal de camundongo anti-polihistidina (Sigma) na diluição 1:3000 ou anticorpo policlonal de camundongo anti-rLIC0258, anti-rLIC12880, anti-rLIC12238 ou anti-fragmentos nas diluições 1:800, 1:800; 1:2000 e 1:500, respectivamente, por 2 horas a temperatura ambiente, sob agitação. A membrana foi lavada por 15 minutos com PBS/Tween 0,05\%, e incubada com anticorpo anti-lgG de camundongo conjugado com peroxidase (Sigma) na diluição 1:5000, por 1 hora a temperatura ambiente, sob agitação. Lavou-se novamente a membrana por 15 minutos com PBS/Tween 0,05\%, e as proteínas e os fragmentos foram detectados utilizando kit ECL Western Blotting Detection Reagents (GE Healthcare). As membranas com as proteínas recombinantes foram reveladas após exposição a filmes de raio-X (Kodak) por curtos períodos de tempo (1 a 10 minutos), enquanto que as membranas com os fragmentos recombinantes foram reveladas com a ajuda do programa de imagem molecular Carestream (Equilab, Whitestone, Nova York) conectado ao equipamento Gel Logic 2200PRO. 


\subsection{Ensaio de imunofluorescência de fase líquida (L-IFA)}

A localização celular das proteínas recombinantes rLIC10258, rLIC12880 e rLIC12238 foi analisada por L-IFA de acordo com o protocolo descrito por Oliveira e colaboradores (2008) (OLIVEIRA et al., 2008). Para este ensaio foram utilizadas 2,5 $\mathrm{mL}$ de culturas vivas de $L$. interrogans sorovar Copenhageni M20 que foram centrifugadas a 6000 rpm por 15 minutos. O sedimento bacteriano obtido foi lavado, 3 vezes, com PBS contendo $50 \mathrm{mM}$ de $\mathrm{NaCl}$, e após a última lavagem foi ressuspendido em $200 \mu \mathrm{L}$ do mesmo PBS acrescido de $6 \mu \mathrm{g} / \mathrm{mL}$ de iodeto de propídeo e incubado por 45 minutos a $37^{\circ} \mathrm{C}$. Após a incubação, as leptospiras foram centrifugadas e gentilmente lavadas com PBS e incubadas a $4{ }^{\circ} \mathrm{C}$, por 30 minutos, com anticorpo policlonal obtido em camundongo contra cada uma das proteínas recombinantes deste estudo, na diluição de 1:50. As leptospiras também foram incubadas com anticorpo policlonal anti-LipL32 e anti-Groel, proteínas que foram utilizadas como controle positivo e negativo do ensaio, respectivamente. Após a incubação, as leptospiras foram centrifugadas, lavadas e incubadas com anticorpo anti-mouse IgG conjugado ao FITC (isotiocianato de fluoresceína) (Sigma), por 30 minutos a $4^{\circ} \mathrm{C}$, na diluição de 1:50. Após a incubação com o anticorpo secundário, as leptospiras foram centrifugas, lavadas e ressuspendidas em PBS contendo solução antifading (ProLong Gold; Molecular Probes). As leptospiras marcadas com imunofluorescência foram examinadas em microscópio de imunofluorescência confocal LSM 510 META (Zeiss, Alemanha).

\subsection{Ensaio de digestão com proteinase K (PK)}

Este ensaio foi realizado segundo protocolo descrito por Domingos e colaboradores (2012) (DOMINGOS et al., 2012). Alíquotas de $5 \mathrm{~mL}$ de L. interrogans sorovar Copenhageni $\mathrm{M} 20$, contendo $10^{8}$ bactérias por alíquota, foram centrifugadas a 6000 rpm por 10 minutos a temperatura ambiente e gentilmente lavadas com PBS contendo $50 \mathrm{mM}$ de $\mathrm{NaCl}$. As leptospiras foram ressuspendidas em tampão de proteólise (10 mM Tris- $\mathrm{HCl}$ e $5 \mathrm{mM} \mathrm{CaCl}$ ) contendo $25 \mu \mathrm{g} / \mathrm{mL}$ de PK (Sigma) e incubadas sob agitação de $70 \mathrm{rpm}$, a $37^{\circ} \mathrm{C}$ pelos períodos de 0, 30, 60, 120 e 240 minutos. Após o período de incubação, a atividade proteolítica da PK foi interrompida pela adição de $100 \mathrm{mM}$ de PMSF e as leptospiras tratadas foram 
centrifugadas por 5 minutos a 6000 rpm, lavadas com PBS (50 mM de NaCl) por duas vezes e ressuspendidas em $1 \mathrm{~mL}$ de PBS (50 mM de $\mathrm{NaCl}$ ). Policlonais contra rLIC10258 (1:1000), rLIC12880 (1:1000), rLIC12238 (1:1000), LipL32 (1:4000) e DnaK (1:2000) foram utilizados para detectar a presença destas proteínas na superfície das leptospiras tratadas com PK, em ensaio de ELISA, como já descrito anteriormente. LipL32 e DnaK foram utilizadas como controle positivo e negativo do ensaio, respectivamente. Os resultados foram analisados estatisticamente pelo Student's two-tailed t test, comparando-se a presença das proteínas na superfície das leptospiras tratadas e não tratadas com PK. $\mathrm{P}<0,05$ foi considerado estatisticamente significante.

\subsection{Ensaio de adesão das proteínas e fragmentos recombinantes a componentes da matriz extracelular (MEC)}

Os ensaios de adesão foram realizados segundo Barbosa e colaboradores (2006) com modificações (BARBOSA et al., 2006). Placas de ELISA (High binding, Nunc) foram adsorvidas com $1 \mu \mathrm{g}$ de laminina (Sigma), colágeno tipo I (Sigma), colágeno tipo IV (Sigma), fibronectina célular (Sigma), fibrobectina plasmática (Sigma) e os controles negativos BSA (proteína não-glicosilada) e fetuína (proteína glicosilada), diluídos em $100 \mu \mathrm{L}$ de PBS. As placas foram incubadas por 2 horas a $37^{\circ} \mathrm{C}$ e, após incubação foram lavadas, três vezes, com PBS-Tween $0,05 \%$. O bloqueio foi feito por 1 horas a $37^{\circ} \mathrm{C}$ com $200 \mu \mathrm{L}$ de PBS contendo $10 \%$ de leite e após as placas foram incubadas a $4{ }^{\circ} \mathrm{C}$ por 16 horas. Após incubação, a solução bloqueio foi descartada e adicionou-se $1 \mu \mathrm{g}$ de cada proteína e fragmento recombinante diluído em $100 \mu \mathrm{L}$ de PBS em cada poço. As placas foram incubadas por 90 minutos a $37^{\circ} \mathrm{C}$ e, após incubação foram lavadas, seis vezes, com PBSTween $0,05 \%$. A adesão das proteínas e fragmentos recombinantes aos componentes da matriz extracelular foi detectada pela adição de anticorpos policlonais anti-proteínas e anti-fragmentos recombinantes, produzidos em camundongos, seguida da incubação com anticorpo anti-lgG de camundongo conjugado a peroxidase. A reação foi revelada com OPD, como já descrito anteriormente e a DO foi determinada em leitor de microplacas usando o comprimento de onda de $492 \mathrm{~nm}$. Para cada proteína recombinante testada, quatro poços foram adsorvidos com cada um dos componentes de matriz extracelular 
utilizados neste ensaio. Para controle da especificidade da reação do anticorpo, em um destes poços, a proteína ou fragmento recombinante não foi adicionada. Para análises estatísticas, a ligação das proteínas ou fragmentos recombinantes aos MECs foi comparada a ligação dos controles negativos (BSA e fetuína) aos MECs pelo Student's two-tailed $t$ test. $\mathrm{O}$ valor de $\mathrm{P}<0,05$ foi considerado estatisticamente significante. Em outro ensaio, anticorpos monoclonais anti-His tag (Sigma), na diluição 1:1000, foram utilizados para detectar a ligação de rLIC10258 e seus fragmentos a laminina e fibronectina plasmática.

\subsection{Ensaio de ligação das proteínas e fragmentos recombinantes ao PLG, fator $\mathrm{H}$, fibrinogênio, componentes do sistema complemento e C4BP}

A ligação das proteínas e fragmentos recombinantes aos componentes citados foi avaliada por um ensaio de ELISA modificado. Placas de ELISA (High binding, Nunc) foram adsorvidas com $100 \mu \mathrm{L} /$ poço de $10 \mu \mathrm{g} / \mathrm{mL}$ de PLG (Calbiochem), fator $\mathrm{H}$ (Calbiochem), fibrinogênio (Sigma), complemento humano (Sigma) e C4BP (Complements Technology) diluídos em PBS por uma noite a $4{ }^{\circ} \mathrm{C}$. BSA e fetuína foram utilizados como controles negativos. Após incubação, as placas foram lavadas uma vez com PBS-Tween $0,05 \%$ e bloqueadas com PBS contendo $10 \%$ de leite desnatado por 2 horas a $37^{\circ} \mathrm{C}$. A solução de bloqueio foi descartada e adicionou-se $1 \mu \mathrm{g} /$ poço de proteína e fragmento recombinante diluído em $100 \mu \mathrm{L}$ de PBS. As placas foram incubadas por 2 horas a $37^{\circ} \mathrm{C}$ e, após incubação foram lavadas, quatro vezes, com PBS-Tween 0,05\%. A ligação das proteínas e fragmentos recombinantes foi detectada pela adição de anticorpos policlonais antiproteínas e anti-fragmentos recombinantes (1:1000), produzidos em camundongos, seguida da incubação com anticorpo anti-lgG de camundongo conjugado a peroxidase (Sigma) na diluição 1:5000. Em outro ensaio, anticorpos monoclonais anti-His tag (Sigma), na diluição 1:1000, foram utilizados para detectar a ligação das proteínas e fragmentos recombinantes ao PLG e da proteína rLIC12238 ao fibrinogênio. A reação foi revelada com OPD, como já descrito anteriormente e determinou-se a intensidade de absorção à $492 \mathrm{~nm}$ em leitor de microplacas. Para análises estatísticas, a ligação das proteínas ou fragmentos recombinantes ao PLG foi comparada a ligação das mesmas aos controles negativos (BSA e fetuína) pelo 
Student's two-tailed t test. $\mathrm{O}$ valor de $\mathrm{P}<0,05$ foi considerado estatisticamente significante.

\subsection{Ensaio de atividade enzimática da plasmina}

Para este ensaio, placas de ELISA foram adsorvidas com $1 \mu \mathrm{g}$ de proteína recombinante ou BSA por 16 horas a $4^{\circ} \mathrm{C}$. As placas foram lavadas uma vez com PBS/Tween $0,05 \%$ e bloqueadas com PBS/Leite desnatado $10 \%$ por 2 horas a 37 ${ }^{\circ} \mathrm{C}$. A solução bloqueio foi descartada e $100 \mu \mathrm{L} /$ poço de $10 \mu \mathrm{g} / \mathrm{mL}$ de PLG humano foram adicionados e incubados por 2 horas a $37{ }^{\circ} \mathrm{C}$. Após 3 lavagens com PBS/Tween 0,05\% foram adicionados $4 \mathrm{ng} /$ poço de ativador de plasminogênio tipo uroquinase (UPA - Sigma) e 0,04 mM de substrato específico para plasmina. As placas foram incubadas por aproximadamente 16 horas a $37^{\circ} \mathrm{C}$ e a degradação do substrato foi mensurada por leitura em espectrofotômetro no comprimento de onda $405 \mathrm{~nm}$. Para análises estatísticas, a atividade enzimática da plasmina foi comparada ao controle negativo (BSA) pelo Student's two-tailed t test, sendo o valor de $P<0,05$ considerado estatisticamente significante.

\subsection{Ensaio de inibição da formação do coágulo de fibrina}

Para este ensaio $0,5 \mathrm{~mL}$ de solução de PBS contendo $1 \mathrm{mg} / \mathrm{mL}$ de fibrinogênio foi incubada com 3500 nM de rLIC12238 por 2 horas a $37^{\circ} \mathrm{C}$. Após incubação, $90 \mu \mathrm{L}$ da solução contendo rLIC12238 e fibrinogênio foi transferida para placas de ELISA e a formação do coágulo de fibrina foi iniciada pela adição de 10 $\mu \mathrm{L} /$ poço de trombina (10 U/mL - Sigma) e monitorada em leitor de microplacas (Thermo - OD $=595 \mathrm{~nm}$ ) a cada 1 minuto por 10 minutos e por mais 35 minutos, a cada 5 minutos. As soluções contendo apenas fibrinogênio com ou sem adição de trombina foram utilizadas como controles positivo e negativo do ensaio, respectivamente. Para análises estatísticas, a inibição da formação do coágulo pela proteína recombinante foi comparada com o controle positivo do ensaio pelo Student's two tailed $t$ test, o valor de $\mathrm{P}<0,05$ foi considerado estatisticamente significante. 


\subsection{Curvas de dose resposta}

A especificidade da ligação das proteínas e fragmentos recombinantes com a laminina, fibronectina plasmática, PLG e fibrinogênio foi analisada em ensaio de dose-dependência e saturação por ELISA. Neste ensaio, placas de ELISA foram adsorvidas com concentrações fixas de laminina, fibronectina plasmática, PLG e fibrinogênio ( $1 \mu \mathrm{g} / \mathrm{poço}$ ) por 16 horas a $4^{\circ} \mathrm{C}$. As placas foram lavadas três vezes e bloqueadas com PBS/Leite desnatado $10 \%$ por 2 horas a $37^{\circ} \mathrm{C}$. Após o bloqueio as placas foram incubadas com as seguintes concentrações das proteínas recombinantes: laminina e rLIC10258 (0 a $1000 \mathrm{nM}$ ); fibronectina plasmática ou PLG e rLIC10258 (0 a 2000 nM); PLG e rLIC12880 (0 a 2000 nM); PLG e rLIC12238 (0 a 2000 nM), fibrinogênio e rLIC12238 (0 a 4000 nM), laminina e fragmentos Intermediário e C-terminal (0 a $2000 \mathrm{nM}$ ), fibronectina plasmática e fragmento Intermediário (0 a 3000 nM) e PLG e fragmento Intermediário (0 a $4000 \mathrm{nM}$ ). A ligação das proteínas recombinantes foi detectada pela adição de anticorpos policlonais anti-proteínas recombinantes (1:1000), produzidos em camundongos, seguido da incubação com anticorpo anti-lgG de camundongo conjugado a peroxidase (Sigma) na diluição 1:5000. A reação foi revelada com OPD, como já descrito anteriormente e determinou-se a intensidade de absorção à $492 \mathrm{~nm}$ em leitor de microplacas. Os dados do ensaio de ELISA foram utilizados para calcular a constante de dissociação (KD) de acordo com método descrito por Pathirana e colaboradores (2006) e Lin et al. (2009) (ZUERNER et al., 2000; PATHIRANA et al., 2006), com base na equação:

$$
A=\text { [proteína] Amax / ([proteína] KD+) }
$$

onde $A$ é a absorbância a uma determinada concentração de proteína; Amax é a absorbância máxima para o leitor de placas de ELISA (equilíbrio); [proteína] é a concentração de proteína e KD é a constante de dissociação do equilíbrio para uma dada absorbância em uma dada concentração de proteína.

\subsection{Interação das proteínas e fragmentos recombinantes desnaturados com MECs, PLG e fibrinogênio}

Neste ensaio, placas de ELISA foram adsorvidas com $100 \mu \mathrm{L} /$ poço de 10 $\mu \mathrm{g} / \mathrm{mL}$ de laminina, fibronectina plasmática, PLG e fibrinogênio por 2 horas a $37^{\circ} \mathrm{C}$. 
As placas foram lavadas com PBS-T e bloqueadas com $200 \mu \mathrm{L}$ de $10 \%$ (wt/vol) de leite desnatado acrescido de $1 \%$ de BSA, por 16 horas a $4^{\circ} \mathrm{C}$. Após o bloqueio, as placas foram incubadas por 90 minutos a $37{ }^{\circ} \mathrm{C}$ com as proteínas e fragmentos recombinantes previamente desnaturados por aquecimento a $96{ }^{\circ} \mathrm{C}$ durante 10 minutos. A ligação das proteínas e fragmentos recombinantes desnaturados foi detectada pela adição de anticorpos policlonais anti-proteínas recombinantes (1:1000) e anti-fragmentos recombinantes (1:500), produzidos em camundongos, seguido da incubação com anticorpo anti-lgG de camundongo conjugado a peroxidase (Sigma) na diluição 1:5000. A reação foi revelada com OPD, como já descrito anteriormente e determinou-se a intensidade de absorção à $492 \mathrm{~nm}$ em leitor de microplacas. Para análises estatísticas, a ligação das proteínas e fragmentos recombinantes desnaturados aos componentes foi comparada a ligação das proteínas e fragmentos recombinantes não desnaturados pelo Student's twotailed t test, sendo o valor de $\mathrm{P}<0,05$ considerado estatisticamente significante.

\subsection{Interação das proteínas e fragmentos recombinantes bloqueados com soro homólogo com MECs, PLG e fibrinogênio}

Para este ensaio, placas de ELISA foram adsorvidas com $100 \mu \mathrm{L} /$ poço de 10 $\mu \mathrm{g} / \mathrm{mL}$ de laminina, fibronectina plasmática, PLG e fibrinogênio por 2 horas a $37^{\circ} \mathrm{C}$. As placas foram bloqueadas com $200 \mu \mathrm{L}$ de 10\% (wt/vol) de leite desnatado acrescido de $1 \%$ de BSA, por 16 horas a $4{ }^{\circ} \mathrm{C}$. Após o bloqueio, as placas foram incubadas por 90 minutos a $37^{\circ} \mathrm{C}$ com as proteínas e fragmentos recombinantes previamente incubados com policlonais homólogos produzidos em camundongos $(1: 200)$ durante 1 hora a $37^{\circ} \mathrm{C}$. As placas foram lavadas seis vezes com PBS-T e a ligação das proteínas e fragmentos recombinantes bloqueados com soro homólogo foi detectada pela adição de anticorpos monoclonais anti-polyhistidine conjugado a peroxidase (Sigma) na diluição 1:2000. A reação foi revelada com OPD, como já descrito anteriormente e determinou-se a intensidade de absorção à $492 \mathrm{~nm}$ em leitor de microplacas. Para análises estatísticas, a ligação das proteínas e fragmentos recombinantes bloqueados aos componentes foi comparada a ligação das proteínas e fragmentos recombinantes não bloqueados pelo Student's two-tailed t test, o valor de $\mathrm{P}<0,05$ foi considerado estatisticamente significante. 


\subsection{Ensaio de inibição da adesão de leptospiras vivas a MECs, PLG e fibrinogênio pelas proteínas recombinantes}

Neste ensaio, placas de ELISA foram adsorvidas com $10 \mu \mathrm{g} / \mathrm{mL}$ de laminina, fibronectina plasmática, PLG ou fibrinogênio $\left(100 \mu \mathrm{L} /\right.$ poço) por 16 horas a $4{ }^{\circ} \mathrm{C}$. As placas foram lavadas uma vez com PBS/Tween 0,05\% e bloqueadas com PBS/Leite desnatado $10 \%$ por 2 horas a $37^{\circ} \mathrm{C}$. A solução de bloqueio foi descartada e as placas incubadas com concentrações crescentes de proteínas recombinantes ( 0 a 5 $\mu \mathrm{g}$ ) por 90 minutos a $37^{\circ} \mathrm{C}$. Após 3 lavagens, foram adicionadas $4 \times 10^{7}$ de $L$. interrogans sorovar Copenhageni cepa M20 vivas (100 $\mu \mathrm{L} /$ poço) e incubou-se por 90 minutos a $37^{\circ} \mathrm{C}$. As placas foram lavadas para retirada das leptospiras não ligadas e foram adicionados anticorpos anti-LipL32 (1:4000), produzidos em camundongos, para quantificar de forma indireta as leptospiras ligadas, já que a LipL32 é uma proteína majoritária da membrana externa de Leptospira (HAAKE et al., 2000). Em seguida, adicionou-se anticorpos anti-mouse lgG conjugado a peroxidase (Sigma) como descrito por Barbosa e colaboradores (2006) (BARBOSA et al., 2006). A reação foi revelada utilizando o substrato OPD como já descrito neste relatório. Os resultados foram analisados estatisticamente pelo Student's two-tailed $t$ test, comparando-se a adesão das Leptospiras aos MECs, PLG e fibrinogênio na ausência e presença de proteína recombinante. $\mathrm{P}<0,05$ foi considerado estatisticamente significante.

\subsection{Ensaio de competição entre PLG e fibronectina plasmática pelo fragmento Intermediário}

Para este ensaio, placas de ELISA foram adsorvidos com $10 \mu \mathrm{g} / \mathrm{ml}$ de fragmento Intermediário (100 $\mu \mathrm{l} /$ poço) por 16 horas a $4{ }^{\circ} \mathrm{C}$. As placas foram lavadas, uma vez, com PBS-T e bloqueadas com com PBS/Leite desnatado 10\% por 2 horas a $37{ }^{\circ} \mathrm{C}$. As placas foram incubadas com $1 \mu \mathrm{g}$ de PLG com concentrações crescentes de fibronectina plasmática (0 a $1 \mu \mathrm{g}$ ) por 2 horas a $37^{\circ} \mathrm{C}$. Após quatro lavagens, a ligação da fibronectina plasmática ao fragmento Intermediário foi detectada por anticorpos contra PLG (1:4000, Calbiochem) seguido da incubação com anticorpo anti-IgG de camundongo conjugado a peroxidase (Sigma) na diluição 1:5000. Experimento semelhante foi realizado para avaliar a interferência do PLG na 
ligação da fibronectina plasmática ao fragmento Intermediário. Neste ensaio, as placas adsorvidas com o fragmento Intermediário foram incubadas com $1 \mu \mathrm{g}$ de fibronectina plasmática com concentrações crescentes de PLG (0 a $1 \mu \mathrm{g})$ e a ligação foi detectada por anticorpos contra fibronectina plasmática (1:1000, Sigma). A reação foi revelada com OPD, como já descrito anteriormente e determinou-se a intensidade de absorção à 492 nm em leitor de microplacas.

\subsection{Ensaio de imunização/desafio com as proteínas recombinantes}

Neste ensaio, grupos de doze hamstêrs Golden Syrian machos (6-8 semanas) foram imunizados subcutaneamente no dorso com $50 \mu \mathrm{g}$ de proteína recombinante rLIC10258, rLIC12880 e rLIC12238, bacterina ( $10^{9}$ leptospiras inativadas) ou PBS adsorvidos no adjuvante Alhydrogel $\left(\mathrm{Al}(\mathrm{OH})_{3}\right.$ - Brenntag Biosector) na concentração de $10 \%$. Foram realizadas duas imunizações com intervalos de 15 dias. Os grupos imunizados com bacterina e PBS foram utilizados como controle positivo e negativo do experimento, respectivamente. A bacterina foi preparada a partir de cultura de $L$. interrogans sorovar Kennwicki (cepa Pomona Fromm) virulenta e recém isolada de animal infectado conforme descrito por Silva e colaboradores (2007) (SILVA et al., 2007). Para a preparação da bacterina, a densidade celular da cultura utilizada foi estimada por meio da contagem do número de células em câmara de PetroffHausser em microscópio de campo escuro e aplicação da seguinte fórmula:

número de células por $\mathrm{mL}=$ número de células contadas $\times$ diluição $\times 50000$

A seguir, a cultura foi centrifugada a $6000 \mathrm{rpm}$ por 20 minutos a temperatura ambiente. O sedimento obtido foi lavado duas vezes com tampão PBS suplementado com $5 \mathrm{mM}$ de $\mathrm{MgCl}_{2}$ e ressuspendido em PBS. As bactérias foram inativadas por aquecimento a $56{ }^{\circ} \mathrm{C}$ por 20 minutos. A bacterina foi armazenada a $20^{\circ} \mathrm{C}$. No ensaio de desafio com a proteína rLIC10258, dois animais de cada grupo foram sangrados, via punção cardíaca, 15 dias após a segunda imunização (antes do desafio), enquanto que no ensaio com as proteínas rLIC12880 e rLIC12238, seis animais de cada grupo foram sangrados, via retro orbital, 15 dias após cada imunização. Os soros obtidos foram analisados por ELISA para determinação do título de anticorpos. Duas semanas após a segunda imunização, os hamsters foram inoculados intraperitoneamente com L. interrogans sorovar Kennwicki (cepa Pomona Fromm) virulenta e isolada recentemente de hamstêrs Golden Syrian infectados. A 
dose de bactérias para o ensaio com a proteínas rLIC10258 foi $2 \times 10^{5}$ leptospiras/animal, enquanto que no ensaio com as proteínas rLIC12880 e rLIC12238 a dose foi de $2,5 \times 10^{3}$ leptospiras/animal. Os animais desafiados foram monitorados por 21 dias e os sobreviventes foram sangrados, via punção cardíaca, e sacrificados. Para análise da presença de leptospiras, os rins dos animais sobreviventes foram coletados, macerados e ressuspendidos em solução salina nas diluições 1:10 e 1:100 e cultivadas em meio EMJH semi-sólido modificado a $28^{\circ} \mathrm{C}$. Os ensaios de imunoproteção foram realizados no Laboratório de Zoonoses da Faculdade de Medicina Veterinária da USP.

\subsection{Culturas de Leptospiras e soros de pacientes diagnosticados com leptospirose}

As diferentes cepas e sorovares de Leptospira spp utilizadas neste trabalho foram cedidas pela Faculdade de Medicina Veterinária da Universidade de São Paulo. Estas cepas foram cultivadas em meio EMJH modificado (RODRIGUEZ et al., 2002) enriquecido com $10 \%$ de soro de coelho a temperatura de $28^{\circ} \mathrm{C}$.

Os soros de pacientes diagnosticados com leptospirose utilizados neste estudo fazem parte de uma soroteca e foram cedidos pela Dra Eliete C. Romero do Instituto Adolfo Lutz. 


\section{RESULTADOS E DISCUSSÃO}

\subsection{Análise por bioinformática}

Os genes LIC10258, LIC12880 e LIC12238 foram selecionados do genoma de $L$. interrogans sorovar Copenhageni (NASCIMENTO et al., 2004b), a partir da análise in silico feita em programas disponíveis em servidores públicos.

De acordo com o programa SMART (SCHULTZ et al., 1998) todos os genes deste estudo codificam proteínas com peptídeo sinal de exportação entre os aminoácidos 1 e 28 e baseado nos programas de localização celular PSORT (NAKAI e HORTON, 1999) e CELLO (YU et al., 2006), os genes LIC10258, LIC12880 e LIC12238 codificam proteínas com provável localização na membrana externa das leptospiras.

Segundo o programa LipoP (JUNCKER et al., 2003), os genes LIC12880 e LIC12238 codificam prováveis lipoproteínas. O programa LipoP (JUNCKER et al., 2003) identifica genes que codificam lipoproteínas baseado na presença de uma sequência consenso denominada lipobox, na qual a presença de um resíduo de cisteína indica que a proteína será lipidada. Comparando as sequências do peptídeo sinal de bactérias gram-negativas, foi proposto por Wu, em 1996, o lipobox em $E$. coli (WU, 1996). Nas espiroquetas, o lipobox está representado segundo a sequência consenso Leu(Ala,Ser)-4-Leu(Val,Phe,Ile)--Ile(Val,Gly)-2-Ala(Ser,Gly)-1Cys $_{+1}$ que foi proposta por Haake (2000) após comparação e análise de 26 sequências conhecidas de lipoproteínas de espécies de Treponema spp, Borrelia spp e Leptospira spp (HAAKE, 2000).

O programa BLAST (ALTSCHUL et al., 1990) analisou a presença destes genes em outros organismos e identificou domínios conservados. A análise revelou que LIC10258 apresenta domínio tipo OmpA em sua porção C-terminal. Este domínio tem sido identificado em proteínas envolvidas na patogenicidade de bactérias gram-negativas (TORRES et al., 2006; RISTOW et al., 2007; ZHANG et al., 2010), como por exemplo: PAL (peptidoglycan-associated lipoprotein) de E. coli (CASCALES et al., 2002); OprF, uma proteína de membrana externa majoritária de Pseudomonas aeruginosa (BRINKMAN; BAINS; HANCOCK, 2000) e a Sal-OmpA de Salmonella typhimurium, uma proteína com potencial vacinal contra a salmonelose (SINGH et al., 2003). Nas leptospiras, é importante ressaltar que a primeira proteína 
descrita como fator de virulência, Loa22, possui domínio tipo OmpA (RISTOW et al., 2007). Além disso, proteínas identificadas com este domínio tem sido testadas como possíveis candidatos vacinais contra a leptospirose (YAN et al., 2010).

Todos os genes selecionados para este estudo apresentaram identidade com genes presentes em espécies de leptospiras com o genoma totalmente sequenciado. Atualmente, cinco espécies de Leptospira já foram sequenciadas: $L$. interrogans sorovar Lai cepas 56601 e IPAV (REN et al., 2003; ZHONG et al., 2011), L. interrogans sorovar Copenhageni cepa Fiocruz L1-130 (NASCIMENTO et al., 2004a; NASCIMENTO et al., 2004b), L. borgpetersenii sorovar Hardjo-bovis cepas L550 e JB197 (BULACH et al., 2006), L. biflexa sorovar Patoc cepa Patoc1 (Paris e Ames) (PICARDEAU et al., 2008), L. santarosai sorovar Shermani cepa LT821 (CHOU et al., 2012) e L. liceraciae cepas VAR010 e MMD0835 (RICALDI et al., 2012). A similaridade dos genes LIC10258, LIC12880 e LIC12238 com sequências presentes nas espécies de leptospiras citadas acima e em outras espécies que ainda não foram totalmente sequenciadas pode ser visualizada nos filogramas gerados pelo programa CLUSTAL 2.1 (LARKIN et al., 2007). A distância menor ou maior entre os ramos do filograma demonstra maior ou menor identidade entre as sequências. Como pode ser observado na figura 01 , todos os genes possuem alta identidade com sequências presentes em L. interrogans sorovar Lai. Além disso todos os genes estão presentes em L. borgpetersenii sorovar Hardjo-bovis com menor identidade. Os genes LIC12880 e LIC12238 possuem 73 e 82\% de similaridade com a espécie patogênica $L$. santarosai sorovar Shermani, enquanto que os genes LIC10258 e LIC12238 possuem pequena similaridade com a espécie de patogenicidade intermediária L. licerasiae. Além disso, apenas LIC12238 apresentou $39 \%$ de similaridade com uma sequência identificada na espécie saprofítica L. biflexa sorovar Patoc. A tabela 01 apresenta um resumo dos dados obtidos após análise in silico dos genes LIC10258, LIC12880 e LIC12238. 
Figura 01 - Análise in silico da similaridade dos genes LIC10258, LIC12880 e LIC12238 em diferentes espécies de Leptospira pelos programas BLAST e CLUSTAL 2.1
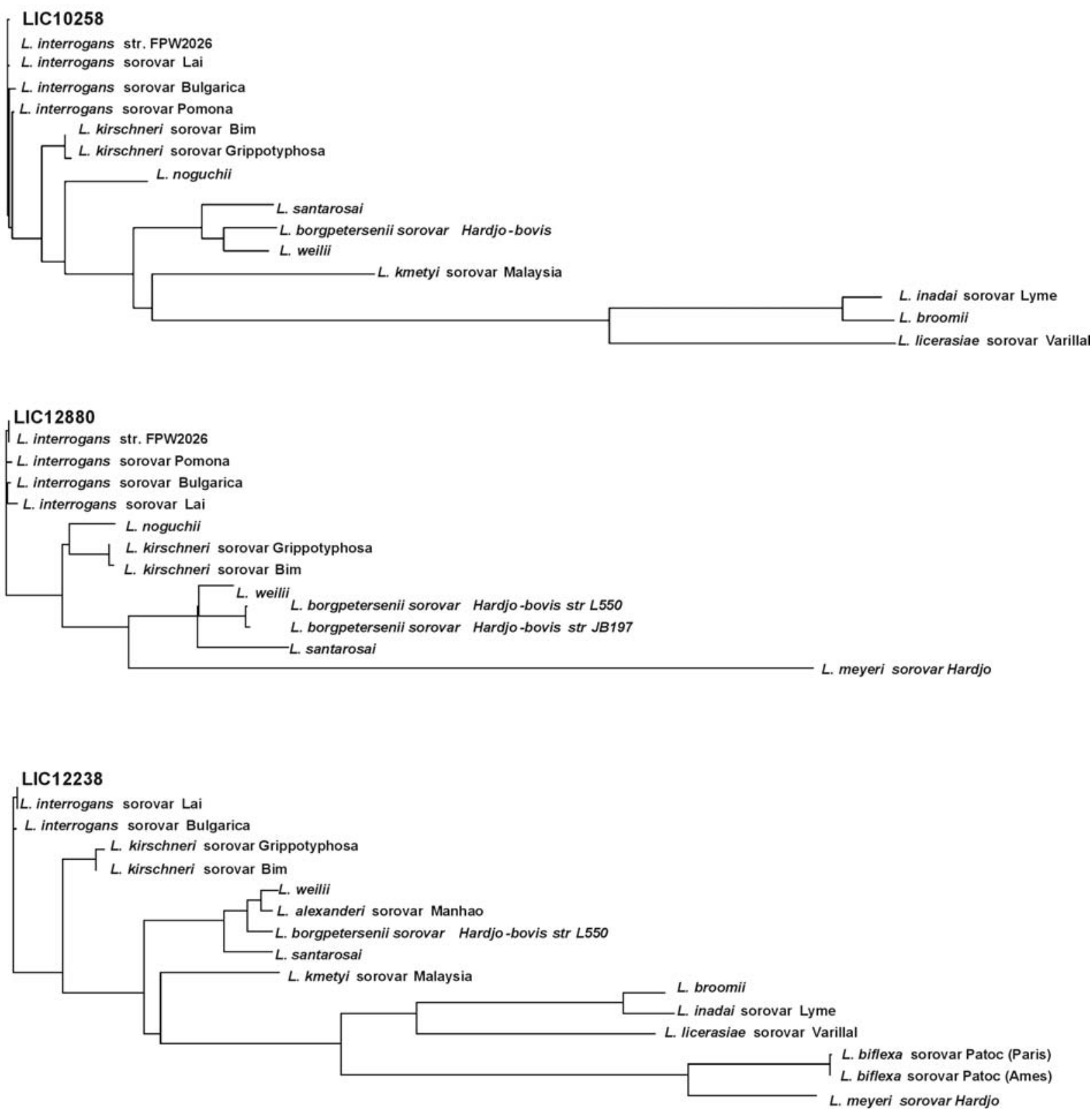
Tabela 01 - Análise in silico dos genes LIC10258, LIC12880 e LIC12238

\begin{tabular}{|c|c|c|c|c|c|c|}
\hline \multirow[t]{2}{*}{ Gene } & \multirow{2}{*}{$\begin{array}{l}\text { Descrição da } \\
\text { Função }\end{array}$} & \multirow{2}{*}{$\begin{array}{l}\text { Conservação } \\
\text { (identidade) }\end{array}$} & \multicolumn{2}{|c|}{$\begin{array}{l}\text { Localização Celular } \\
\text { (Probabilidade) }\end{array}$} & \multirow{2}{*}{$\begin{array}{c}\text { Peptídeo } \\
\text { Sinal } \\
\end{array}$} & \multirow{2}{*}{$\begin{array}{c}\text { Sítio de } \\
\text { Lipidação } \\
\end{array}$} \\
\hline & & & PSORT & CELLO & & \\
\hline LIC10258 & $\begin{array}{c}\text { Proteína } \\
\text { hipotética } \\
\text { com domínio } \\
\text { OmpA }\end{array}$ & $\begin{array}{c}\text { 99\% (Lai) } \\
79 \% \text { (LBH) } \\
44 \% \text { (LlicsVM) }\end{array}$ & $40 \%$ & $70 \%$ & $\operatorname{sim}$ & não \\
\hline LIC12880 & $\begin{array}{l}\text { Lipoproteína } \\
\text { hipotética } \\
\text { sem domínio } \\
\text { conhecido }\end{array}$ & $\begin{array}{l}99 \% \text { (Lai) } \\
76 \% \text { (LBH) } \\
73 \% \text { (LSS) }\end{array}$ & $50 \%$ & $45 \%$ & $\operatorname{sim}$ & $\operatorname{sim}$ \\
\hline LIC12238 & $\begin{array}{c}\text { Proteína } \\
\text { hipotética } \\
\text { sem domínio } \\
\text { conhecido }\end{array}$ & $\begin{array}{c}\text { 99\% (Lai) } \\
77 \% \text { (LBH) } \\
82 \% \text { (LSS) } \\
50 \% \text { (LlicsVM) } \\
\text { 39\% (LBP) }\end{array}$ & $50 \%$ & $40 \%$ & $\operatorname{sim}$ & $\operatorname{sim}$ \\
\hline
\end{tabular}

Notas: LIC: identificação do gene no genoma de $L$. interrogans sorovar Copenhageni Abreviaturas: Lai: L. interrogans sorovar Lai; LBH: L. borgpetersenii sorovar Hardjo-bovis; LBP : L. biflexa sorovar Patoc; LlicsVM: L. licerasiae serovar Varillal;

LSS: L. santarosai serovar Shermani

\subsection{Amplificação dos genes LIC10258, LIC12880 e LIC12238 por PCR}

Os genes LIC10258, LIC12880 e LIC12238 foram obtidos por amplificação (PCR) do DNA genômico extraído da cultura de $L$. interrogans sorovar Copenhageni. As bandas de DNA obtidas através da amplificação foram analisadas em gel de agarose e apresentaram o tamanho esperado de 1695, 792 e 444 pb para os clones referentes a LIC10258, LIC12880 e LIC12238, respectivamente. A figura 02 apresenta os produtos obtidos da reação de PCR purificados a partir do gel de agarose. 
Figura 02 - Análise do DNA de interesse amplificado por reação de PCR em gel de agarose $1 \%$

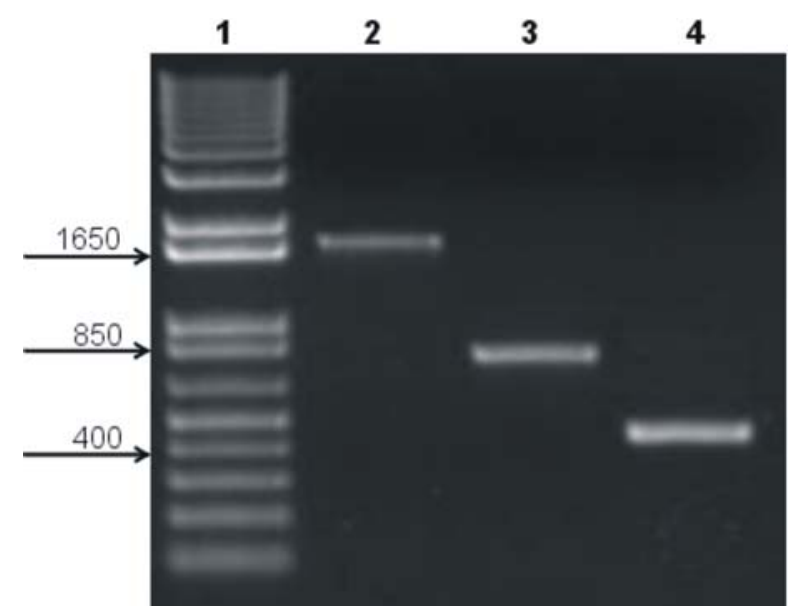

As bandas obtidas apresentaram os tamanhos esperados de $1695 \mathrm{pb}$ para LIC10258 (linha 2), $792 \mathrm{pb}$ para LIC12880 (linha 3) e 444 pb para LIC12238 (linha 4). Linha 1: Kb Plus DNA Ladder (marcador molecular).

\subsection{Clonagem no vetor pGEM-T Easy}

Este vetor foi utilizado para otimizar as reações de digestão com as enzimas específicas de cada clonagem. O pGEM-T Easy (Figura 03) é um vetor linearizado, com uma timidina 3 '-terminal em ambas extremidades, o que evita a recircularização do vetor e possibilita a ligação de produtos de PCR pois estes possuem, normalmente, uma adenosina em cada extremidade 3', adicionada pela atividade transferase terminal da Taq polimerase. O pGEM-T Easy contém os promotores T7 e SP6 e sítio de múltipla clonagem interrompendo a região codificadora da enzima $\beta$ galactosidase, o que permite a identificação dos clones recombinantes positivos e negativos por seleção das colônias bacterianas de cor branca e azul, respectivamente, em placas de meio LB, contendo ampicilina, IPTG e X-Gal. Sendo assim, os insertos de DNA obtidos por meio da reação de PCR foram clonados em vetor pGEM-T Easy e utilizados para transformar bactérias competentes DH5a. Após extração do DNA plasmidial das bactérias competentes, os plasmídeos contendo os genes LIC10258, LIC12880 e LIC12238 foram digeridos com as enzimas de restrição correspondentes para certificação da presença de insertos (dados não mostrados). 
Figura 03 - Mapa do vetor de clonagem pGEM-T Easy

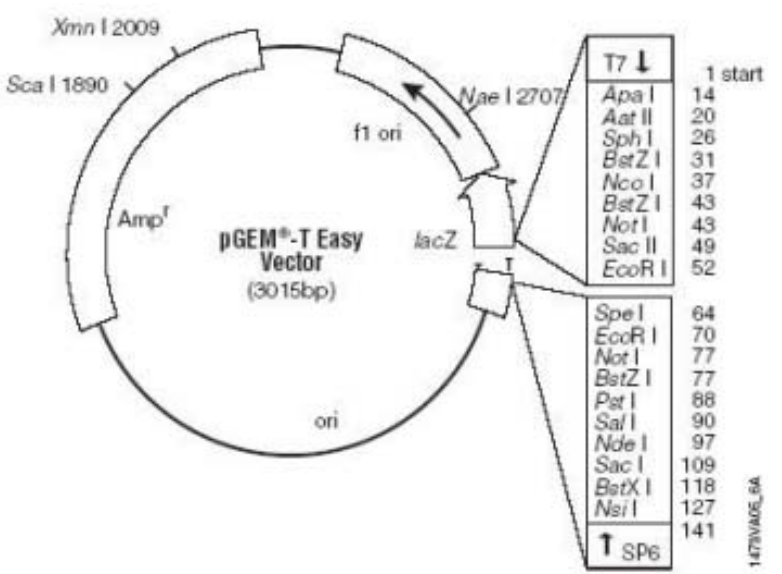

O vetor comercial pGEM-T Easy possui origem de replicação (f1ori), gene de resistência a ampicilina (Ampr) e o gene $\beta$-galactosidase para metabolismo de lactose (lacZ).

Fonte: Promega (2010).

\subsection{Subclonagem no vetor de expressão pAE}

Este vetor foi desenvolvido para expressar proteínas recombinantes contendo 6 resíduos de histidina na região N-terminal, o que permite a purificação das mesmas em coluna de cromatografia carregada com níquel. Desta maneira, os insertos correspondentes aos genes LIC10258, LIC12880 e LIC12238 foram removidos dos plasmídios recombinantes (pGEM-T Easy/inserto) e subclonados no vetor de expressão pAE (Figura 04) (RAMOS et al., 2004).

Figura 04 - Mapa do vetor de expressão pAE

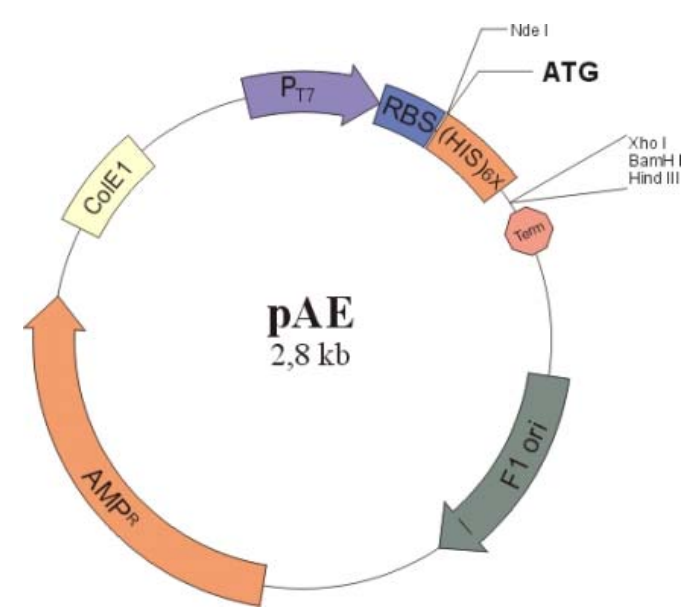

O vetor de expressão pAE possui o promotor T7 (PT7), sítio de ligação ao ribossomo (RBS), códons para expressão de seis resíduos de histidina (6xHis), códon de início da transcrição (ATG), região de terminação de transcrição (T7term), origem de replicação (F1ori) e gene de resistência à ampicilina (AmpR). 
Os clones positivos foram selecionados por meio da extração rápida por fenolclorofórmio e após a obtenção do DNA plasmidial (pAE/inserto) os clones foram digeridos com as enzimas de restrição correspondentes para confirmação da presença de inserto (Figura 05).

Figura 05 - Análise dos insertos de DNA obtidos por digestão do DNA plasmidial (pAE/inserto) em gel de agarose 1\%

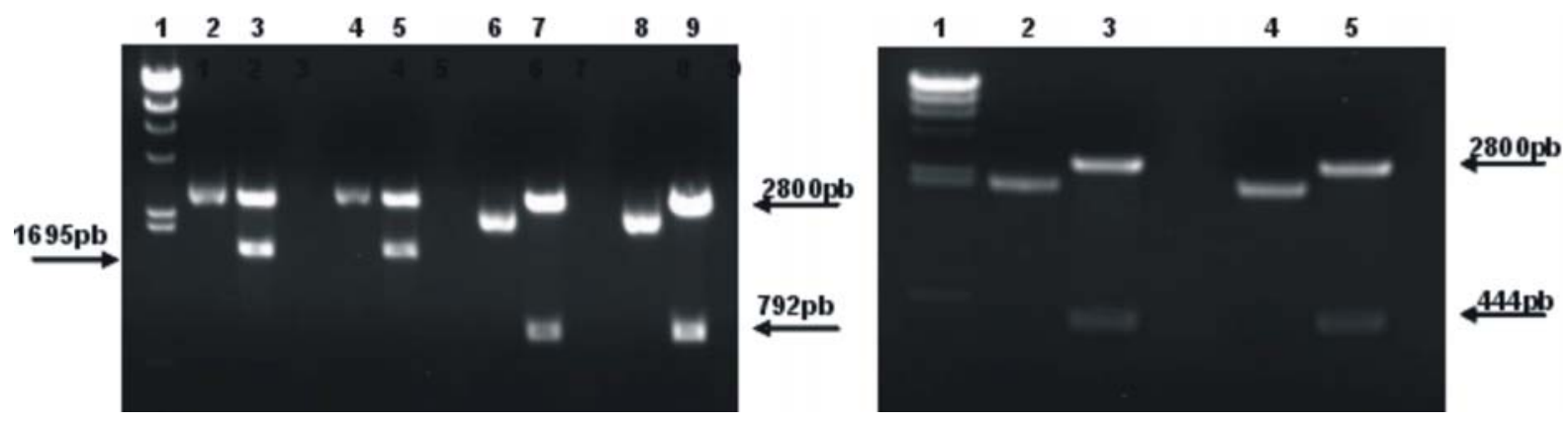

Após seleção por fenol-clorofórmio os clones positivos foram purificados e os plasmídeos obtidos digeridos com as enzimas apropriadas. A) 2-5 (LIC10258), onde 2 e 4 - pAE contendo inserto, 3 e 5 pAE digerido com as enzimas BamHI/Ncol. 6-9 (LIC12880), onde 6 e 8 - pAE contendo inserto, 7 e 9 - pAE digerido com as enzimas Xhol/Ncol. B) LIC12238, onde 2 e 4 - pAE contendo inserto, 3 e 5 pAE digerido com as enzimas Xhol/HindIII. 1. marcador molecular ( $\lambda$ hind III).

\subsection{Sequenciamento dos clones}

O sequenciamento confirmou a presença dos insertos de DNA referentes aos genes LIC10258, LIC12880 e LIC12238, tanto no vetor de clonagem pGEM-T Easy quanto no vetor de expressão pAE. No vetor de expressão pAE, apenas o clone referente a LIC10258 não foi totalmente sequenciado, porém o mesmo já havia sido completamente sequenciado no vetor pGEM-T Easy. Todas as sequências dos clones apresentaram identidade quando comparadas as sequências de bases nitrogenadas do gene original. A sequência codificadora foi confirmada pelo programa BLAST (ALTSCHUL et al., 1990) mostrando 99, 98 e 100\% de identidade com as sequências dos clones referentes a LIC10258, LIC12880 e LIC12238, respectivamente, tanto no vetor pGEM-T Easy quanto no vetor pAE. No cromatograma resultante do sequenciamento dos clones no vetor $\mathrm{pAE}$, foi possível identificar a presença do códon de iniciação (ATG), seguido das bases nitrogenadas (CAT/CAC) que codificam os resíduos de histidina e o inicio da região codificadora dos genes LIC10258, LIC12880 e LIC12238 (Anexo A). Os resultados obtidos 
confirmam que as sequências clonadas foram introduzidas na fase correta de leitura do vetor de expressão pAE.

\subsection{Análise da presença dos genes LIC10258, LIC12880 e LIC12238 e de seus transcritos em diferentes cepas de Leptospira}

As leptospiras são classificadas em sorovares devido à diversidade antigênica resultante da composição heterogênea dos carboidratos presentes nos lipopolissacarídeos da sua membrana (FAINE et al., 1999; LEVETT, 2001; BHARTI et al., 2003). Em consequência, um amplo número de espécies de mamíferos serve como hospedeiro reservatório de Leptospira e mais de 250 sorovares já foram descritos (HAAKE; MATSUNAGA, 2010). Portanto, a busca por proteínas presentes em diversas espécies e sorovares de Leptospira é um fator importante para obtenção de bons antígenos vacinais. Sendo assim, a presença dos genes LIC10258, LIC12880 e LIC12238 foi analisada em sorovares patogênicos de L. interrogans e em espécies patogênicas de Leptospira. A espécie não patogênica, $L$. biflexa sorovar Patoc também foi avaliada (Figura 06).

Figura 06 - Análise da presença dos genes LIC10258, LIC12880 e LIC12238 em diferentes espécies e sorovares de Leptospira em gel de agarose $1 \%$

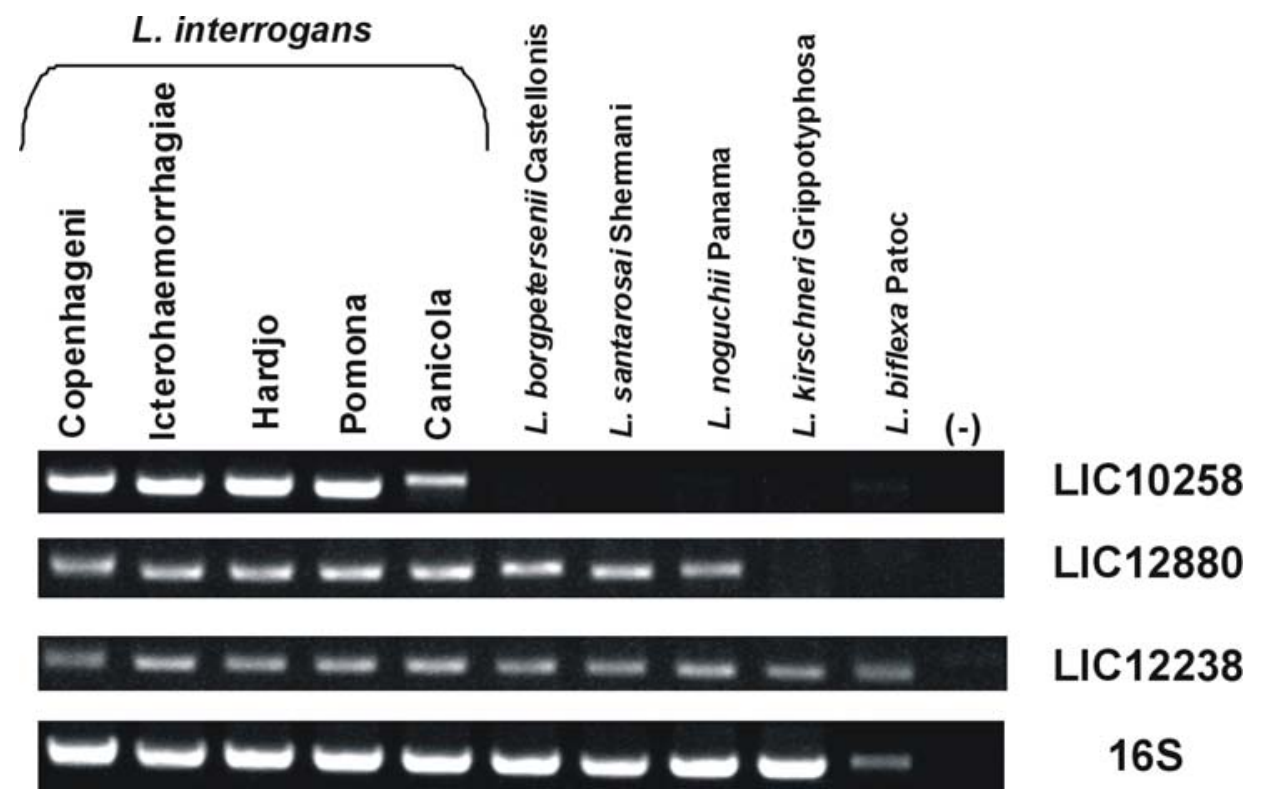

A expressão do gene 16S rRNA foi utilizado como controle da integridade dos DNAs obtidos. Não foi adicionado DNA no controle nagativo (-). 
O gene LIC12238 foi detectado em todas as espécies e sorovares testados, incluindo na espécie saprofítica $L$. biflexa. Este resultado está em concordância com análise in silico feita através do programa BLAST (ALTSCHUL et al., 1990), que mostra uma sequência presente em $L$. biflexa com $39 \%$ de similaridade com o gene LIC12238 de L. interrogans sorovar Copenhageni.

Os genes LIC10258 e LIC12880 foram detectados em todos os sorovares de L. interrogans. O gene LIC12880, por sua vez, também foi detectado nas espécies patogênicas $L$. borgpetersenii sorovar Castellonis, $L$. santarosai sorovar Shermanii e L. noguchii sorovar Panama. A expressão do gene 16S rRNA foi utilizado como controle da integridade das amostras de DNA obtidas.

Com o intuito de analisar se estes genes estão sendo transcritos nos sorovares e espécies de Leptospira em que estão presentes, foi realizada a análise da expressão dos genes LIC10258, LIC12880 e LIC12238 nos sorovares e espécies de Leptospira citados acima. Para este ensaio foi extraído o RNA total dos sorovares e espécies de Leptospira utilizados para análise genômica e a presença dos transcritos nas amostras obtidas foi analisada por RT-PCR, empregando os mesmos oligonucleotídeos utilizados para a amplificação dos genes LIC10258, LIC12880 e LIC12238. A expressão do gene 16S rRNA foi usada como controle da integridade dos transcritos obtidos e a contaminação das amostras com DNA genômico foi descartada, uma vez que não foi observada amplificação nas amostras não tratadas com a enzima transcriptase reversa. Apenas o cDNA de LIC12238 foi amplificado em todas as amostras em que este gene foi detectado. Não houve amplificação do transcrito do gene LIC10258 no sorovar Icterohaemorrhagiae de $L$. interrogans e o cDNA do gene LIC12880 não foi detectado nas espécies $L$. borgpetersenii, $L$. santarosai e L. noguchii (Figura 07). 
Figura 07 - Análise da expressão dos genes LIC10258, LIC12880 e LIC12238 em diferentes espécies e sorovares de Leptospira em gel de agarose $1 \%$

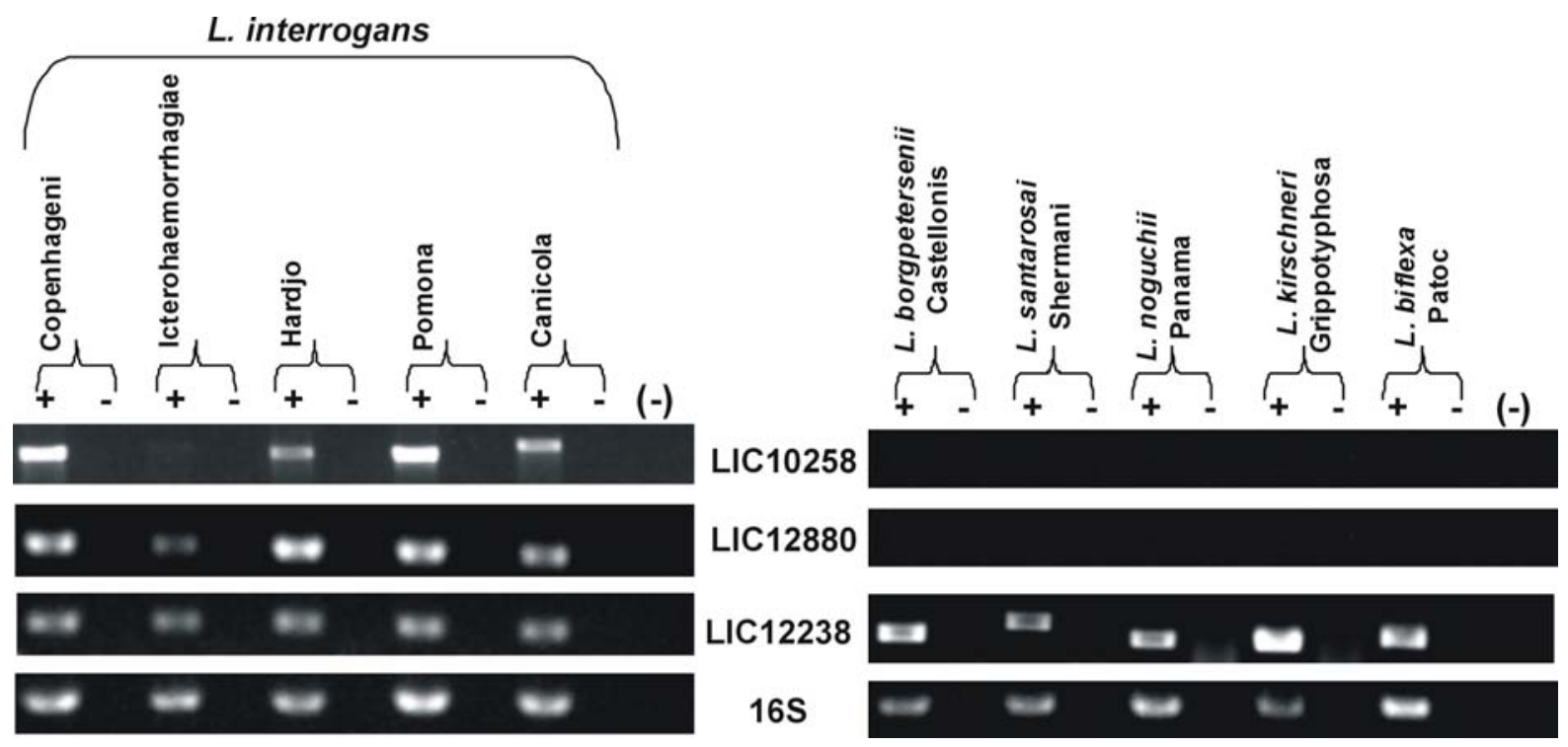

A expressão do gene 16S rRNA foi utilizado como controle da integridade dos transcritos obtidos.

$(+)$ : Enzima transcriptase reversa presente e (-): Enzima transcriptase reversa ausente.

Muitos patógenos bacterianos adaptam-se ao ambiente em que se encontram regulando a expressão de alguns de seus genes. Tem sido demonstrado que a expressão de alguns genes de Leptospira são regulados por mudanças de temperatura, $\mathrm{pH}$ ou osmolaridade (NALLY; TIMONEY; STEVENSON, 2001; LO et al., 2006; OLIVEIRA et al., 2010). Portanto, para verificar se a expressão dos genes LIC10258 e LIC12880 estaria sendo regulada por alguma das condições descritas acima foi extraído o RNA total de cultura de L. interrogans sorovar Icterohaemorrhagiae, L. borgpetersenii sorovar Castellonis, L. santarosai sorovar Shermani e L. noguchii sorovar Panama suplementada com $120 \mathrm{mM}$ de $\mathrm{NaCl}$. A adição de sal ao meio de cultura das leptospiras mimetiza as condições fisiológicas encontradas por este organismo no hospedeiro. Também foram extraídos o RNA total destas culturas mantidas, por uma noite, a 37 ou $39{ }^{\circ} \mathrm{C}$ para simular as condições encontradas pelas leptospiras durante os estágios inicial e febril da infecção.

Não foi detectada a expressão do gene LIC12880 em nenhuma das condições testadas (dados não mostrados). Por outro lado, a figura 08 mostra que, apesar da transcrição do gene LIC10258 não estar sendo regulado pela temperatura, uma vez que não houve amplificação do cDNA obtido das culturas de L. interrogans sorovar Icterohaemorrhagiae mantidas a 37 e $39^{\circ} \mathrm{C}$, foi possível 
detectar a amplificação do cDNA obtido da cultura suplementada com $120 \mathrm{mM}$ de $\mathrm{NaCl}$, sugerindo que a transcrição deste gene pode estar sendo regulada por condições fisiológicas de osmolaridade encontradas no hospedeiro.

Figura 08 - Análise da regulação da expressão do gene LIC10258 por fatores ambientais em gel de agarose $1 \%$

\section{L. interrogans Icterohaemorrhagiae}

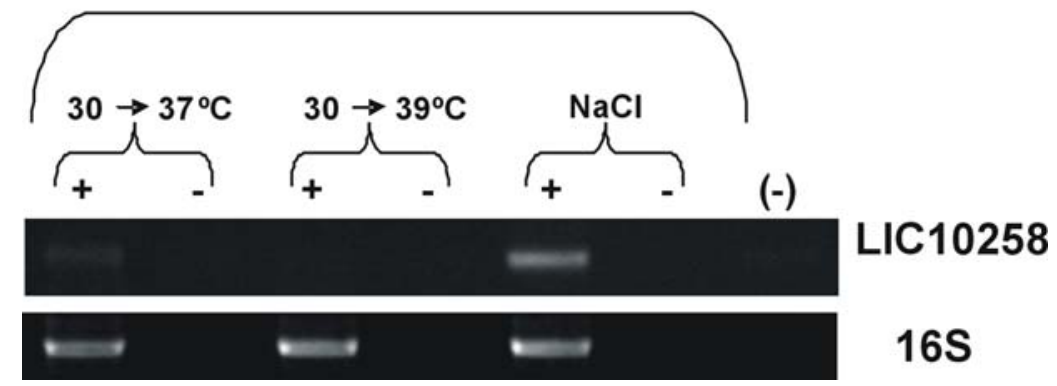

A expressão do gene $16 \mathrm{~S}$ rRNA foi utilizado como controle da integridade dos transcritos obtidos.

$(+)$ : Enzima transcriptase reversa presente e $(-)$ : Enzima transcriptase reversa ausente.

\subsection{Expressão das proteínas recombinantes}

Para obtenção das proteínas recombinantes desta tese foi realizado um estudo cinético de indução com $\mathrm{NaCl}$ em diferentes concentrações. Para este estudo foi utilizada a cepa E. coli BL21 SI (Salt Induced), que possui o gene T7 RNA polimerase integrado ao genoma sob o controle do promotor proU indutível por $\mathrm{NaCl}$ (BHANDARI; GOWRISHANKAR, 1997). Sendo assim, bactérias E. coli BL21 SI foram transformadas e induzidas em diferentes concentrações de indutor. As concentrações utilizadas foram 3, 30 e 300 mM de NaCl. Após indução, as bactérias foram lisadas e as frações protéicas obtidas (sobrenadante e sedimento) analisadas em gel de SDS-PAGE. A proteína recombinante rLIC12238 foi expressa na forma solúvel enquanto rLIC10258 e rLIC12880 foram expressas na forma insolúvel como corpúsculos de inclusão.

A massa molecular de cada proteína foi previamente analisada in silico, a partir da composição de aminoácidos utilizando o programa Generunner. A figura 09 apresenta a expressão das proteínas recombinantes na cepa E. coli BL21 SI, sendo possível observar rLIC12238 com a massa molecular esperada de 17,6 kDa presente no sobrenadante do lisado bacteriano após indução com $300 \mathrm{mM}$ de $\mathrm{NaCl}$. rLIC10258 e rLIC12880 foram observadas com massa molecular esperada de 65,7 e 
30,68 kDa, no sedimento bacteriano após indução com 30 e 300 mM de $\mathrm{NaCl}$, respectivamente.

Figura 09 - Análise da expressão das proteínas recombinantes em gel de SDSPAGE

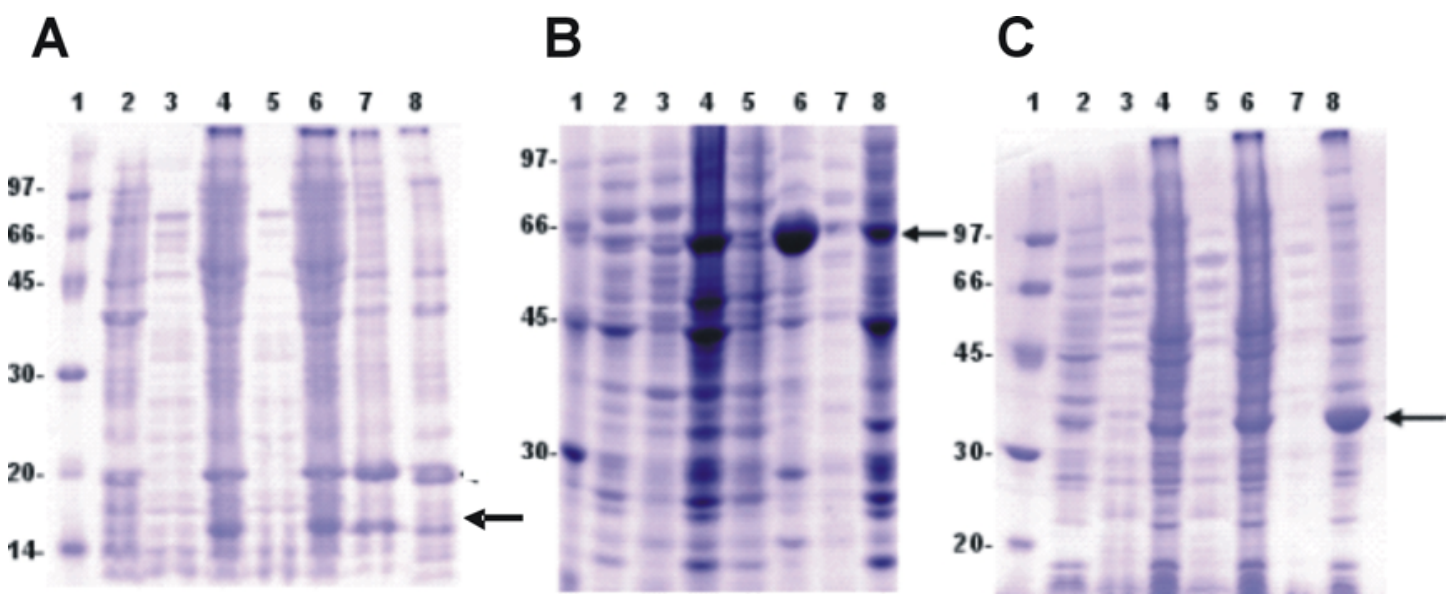

As bandas de proteínas com os tamanhos esperados de aproximadamente 17,6; 65,7 e 30,6 kDa, correspondendo a rLIC12238 (A), rLIC10258 (B) e rLIC12880 (C), respectivamente, foram visualizadas por Comassie blue. A expressão das proteínas foi analisada em diferentes concentrações de $\mathrm{NaCl}: 3 \mathrm{mM}$ (linhas 3 e 4); 30 mM (linhas 5 e 6)e 300 mM (linhas 7 e 8). rLIC12238 foi expressa na forma solúvel (A - linha 7) enquanto rLIC10258 e rLIC12880 (B e C - linhas 4, 6 e 8) foram expressas na forma insolúvel como corpúsculos de inclusão. Linha 1: massa molecular em kDa. Linha 2: extrato não induzido.

O acúmulo de proteínas sob a forma de corpúsculos de inclusão é uma característica importante do sistema de expressão em E. coli que ocorre devido um desequilíbrio entre a agregação e solubilização das proteínas recombinantes in vivo durante o processo de dobramento de sua estrutura. As proteínas recombinantes presentes nos corpúsculos de inclusão apresentam a vantagem de estarem protegidas contra a ação de proteases. Em contrapartida, durante o processo de solubilização destes corpúsculos de inclusão podem ocorrer perdas da proteína de interesse. Além disso, é necessário que a conformação estrutural destas proteínas seja recuperada, porém a renaturação da proteína recombinante, através da remoção do agente desnaturante utilizado no processo de solubilização, pode não ser bem sucedida (SORENSEN et al., 2004).

Sendo assim, na tentativa de obter as proteínas recombinantes rLIC10258 e rLIC12880 sob a forma solúvel, repetiu-se o estudo de cinética de indução de proteínas utilizando bactérias competentes E. coli BL21 DE3, BL21 Star (DE3) pLys e C43 (DE3). As diferentes cepas de E. coli DE3 também possuem o gene da T7 
RNA polimerase, porém dirigido pelo promotor lac UV5, o qual é induzido por IPTG (STUDIER et al., 1990). A cepa E. coli BL21 Star (DE3) pLys, por sua vez, carrega o plasmídeo pLys que produz pequenas quantidades de T7 lisozima, um inibidor natural da T7 RNA polimerase. A redução da expressão basal da T7 RNA polimerase permite a expressão de proteínas recombinantes mais estáveis, particularmente para proteínas tóxicas (STUDIER, 1991). A cepa E. coli C43 (DE3) contém mutações genéticas selecionadas fenotipicamente para conferir tolerância a toxicidade. Esta cepa tem sido usada para produzir proteínas que são pouco expressas em E. coli BL21 DE3 (MIROUX; WALKER, 1996). As cepas de E. coli acima citadas foram transformadas e induzidas com IPTG nas concentrações de 0,01; 0,1 e $1 \mathrm{mM}$. Porém, como em todas as condições testadas rLIC10258 e rLIC12880 foram expressas sob a forma insolúvel, optou-se então por expressar estas proteínas recombinantes em E. coli BL21 SI.

\subsection{Solubilização das proteínas rLIC10258 e rLIC12880}

Foram testados dois protocolos de solubilização de proteínas recombinantes descritos na literatura (PATRA et al., 2000; SAINI et al., 2002). Inicialmente, testouse a solubilização das proteínas em condições desnaturantes na presença de $1 \mathrm{M}$ de uréia em tampão aquoso com diferentes pHs, como o descrito por Patra e colaboradores (2000) (PATRA et al., 2000). Os diferentes pHs testados para rLIC10258 foram 6,8; 8; 9 e 12, e para rLIC12880 foram 6,8; 9 e 12. Os resultados mostraram que houve pequena solubilização da proteína rLIC10258 no tampão com $\mathrm{pH} 12$, enquanto que rLIC12880 não foi solubilizada em nenhuma das condições testadas (dados não mostrados).

Em paralelo, foi testado a solubilização das proteínas rLIC10258 e rLIC12880 em 8 M de uréia na presença de 10\% de glicerol (SAINI et al., 2002). Esta metodologia permite a renaturação da proteína durante a etapa de purificação através da remoção gradativa da uréia na presença de glicerol que evita a agregação protéica. Tanto a proteína recombinante rLIC10258, quanto rLIC12880 foram satisfatoriamente solubilizadas (Figura 10). 
Figura 10 - Análise das proteínas recombinantes após solubilização com 8 M uréia e $10 \%$ glicerol em gel de SDS-PAGE

A

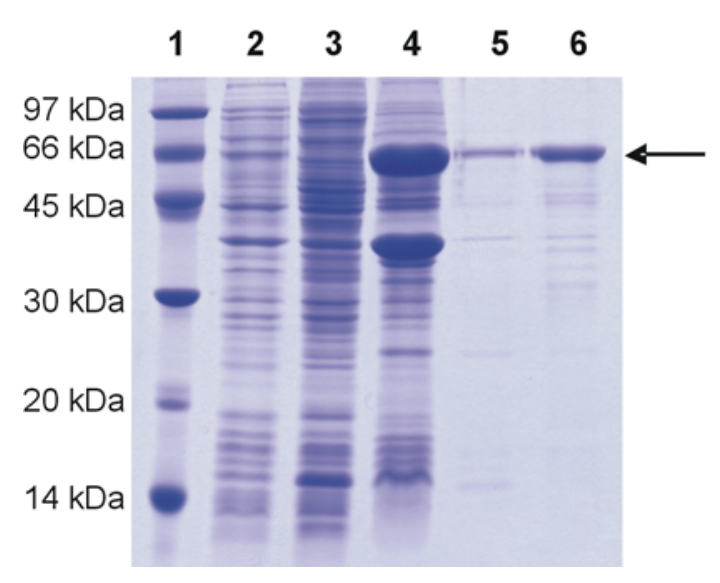

B

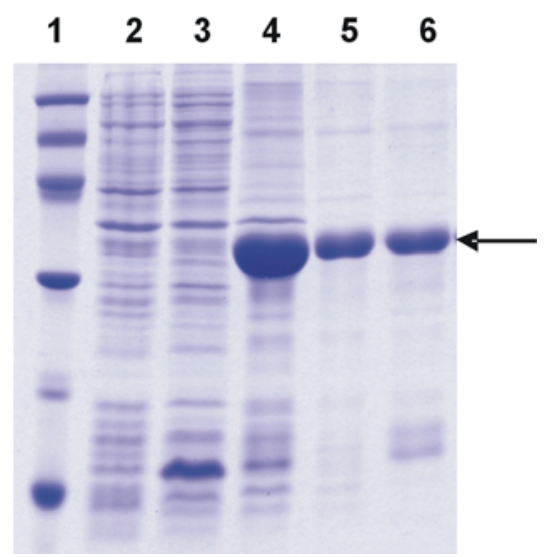

As setas indicam as bandas correspondentes as proteínas rLIC10258 (A) e rLIC12880 (B). Linha 1: massa molecular. Linha 2: extrato não induzido. Linha 3: sobrenadante da sonicação. Linha 4: sedimento da sonicação. Linha 5: sobrenadante da solubilização e linha 6: sedimento da solubilização.

\subsection{Purificação e diálise das proteínas recombinantes}

Como o sistema de expressão de proteínas utilizado neste projeto adiciona uma sequência de 6 resíduos de histidina (6xHis) na extremidade $\mathrm{N}$-terminal da proteína recombinante, as proteínas rLIC10258, rLIC12880 e rLIC12238 foram purificadas por cromatografia de afinidade utilizando resina carregada com níquel. Durante o processo de purificação, a proteína recombinante se liga ao níquel via resíduos de histidinas, os contaminantes são lavados com tampão contendo baixa concentração de imidazol e a proteína de interesse é eluída com alta concentração de imidazol. rLIC12238 foi purificada a partir do sobrenadante obtido após lise bacteriana, já que esta proteína foi expressa de maneira solúvel, enquanto que rLIC10258 e rLIC12880, expressas de maneira insolúvel, foram purificadas após a solubilização das mesmas em tampão contendo 10\% de glicerol e $8 \mathrm{M}$ uréia.

As alíquotas que continham as proteínas recombinantes foram dialisadas contra tampões apropriados. No caso das proteínas rLIC10258 e rLIC12880 foram realizadas diversas trocas do tampão de diálise para diluir a concentração de glicerol, até que a última troca eliminasse por completo o glicerol da amostra. Porém, não foi possível a retirada do glicerol das amostras contendo as proteínas 
recombinantes rLIC10258 e rLIC12880, uma vez que a retirada do mesmo ocasionou a precipitação destas proteínas.

Após diálise, a concentração das proteínas recombinantes foi estimada em gel de SDS-PAGE com concentrações pré-estabelecidas de BSA e análise densitométrica do programa GelQuant (Figura 11).

Figura 11 - Estimativa da concentração das proteínas recombinantes em gel de SDS-PAGE

69-

Linhas 1 a 5: BSA nas concentrações 4, 3, 2, 1 e 0,5 $\mu$ g, respectivamente. Linha 6: rLIC10258. Linha 7: rLIC12880 e Linha 8: rLIC12238.

\subsection{Avaliação da atividade imunogênica das proteínas recombinantes em camundongos}

Os animais foram imunizados com 3 doses de proteínas recombinantes e sangrados via plexo retro-orbital após cada dose. Os soros obtidos foram avaliados quanto à presença de anticorpos anti-rLiC10258, anti-rLIC12880 e anti-rLIC12238. Os títulos de anticorpos policlonais presentes no soro dos animais de cada grupo foram avaliados por ELISA.

O grupo imunizado com a proteína rLIC10258 só apresentou altos títulos de anticorpos após a terceira dose, enquanto que os grupos imunizados com rLIC12880 e rLIC12238 já apresentavam altos títulos após a segunda dose. O grupo controle, por sua vez, não apresentou quaisquer títulos. A média dos títulos de anticorpos obtidos por cada grupo após cada imunização está apresentada no quadro 02. 
Quadro 02 - Títulos de anticorpos policlonais obtidos após imunização de camundongos com as proteínas recombinantes

\begin{tabular}{|cccc|}
\hline $\begin{array}{c}\text { Proteína } \\
\text { Recombinante }\end{array}$ & $\mathbf{1}^{\text {a }}$ Sangria & $\mathbf{2}^{\text {a }}$ Sangria & $\mathbf{3}^{\text {a }}$ Sangria \\
\hline rLIC10258 & 25 & 5333 & 255000 \\
rLIC12880 & 8200 & 229400 & 508000 \\
rLIC12238 & 6400 & 179200 & 1014000 \\
\hline
\end{tabular}

\subsection{Análise da estrutura das proteínas recombinantes por DC}

O DC é uma técnica para o estudo dos elementos de estrutura secundária das proteínas, tais como, $\alpha$-hélice, estrutura $\beta$ e estrutura randômica, as quais contribuem na formação de sua estrutura terciária. Esta técnica utiliza a interação diferencial de moléculas com centros assimétricos (quirais) com a luz circularmente polarizada a esquerda ou direita (elipticidade), que é medida pelo polarímetro. Como as proteínas estão repletas de centros quirais distribuídos e arranjados ao longo da cadeia principal em $\alpha$-hélices, estruturas $\beta$ e outras estruturas, a estrutura secundária destas moléculas podem ser caracterizadas por espectroscopia de DC (CANTOR, 1981). Proteínas recombinantes que foram expressas na forma de corpúsculos de inclusão podem perder a estrutura no processo de renaturação, ou durante a estocagem, após purificação. Portanto, para certificar-se da integridade da conformação das proteínas recombinantes obtidas, as mesmas foram analisadas por dicroísmo circular. A figura 12 mostra a curva obtida após análise dos dados fornecidos pelo espectropolarímetro. Todas as proteínas apresentaram uma mistura de estruturas secundárias, não sendo possível identificar predominância de nenhuma estrutura. O perfil das curvas apresentadas por estas proteínas, foi condizente com a predição teórica obtida no servidor público PSIPRED (JONES, 1999) que apontou a presença de uma mistura de estruturas secundárias (a-hélice, folha $\beta$ e randômica) para estas proteínas. Além disso, é importante ressaltar que o perfil das curvas obtidas para todas as proteínas recombinantes não são semelhantes ao de proteínas sem conformação. 
Figura 12 - Espectros obtidos das proteínas rLIC10258, rLIC12880 e rLIC12238 por dicroísmo circular
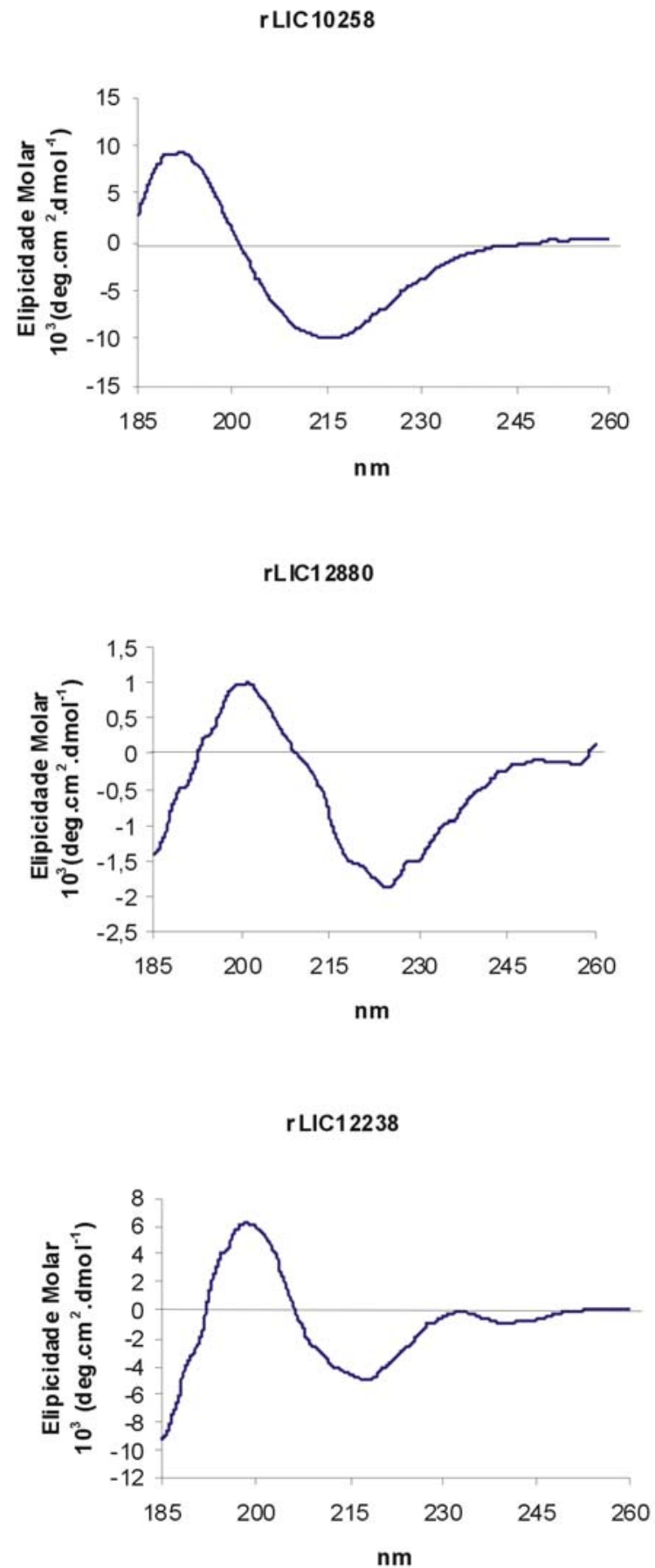


\subsection{Presença de anticorpos IgG e IgM humanos contra proteínas recombinantes em soros de pacientes diagnosticados com leptospirose}

O reconhecimento imune das proteínas recombinantes deste estudo por anticorpos IgG e IgM de amostras de soros de pacientes diagnosticados com leptospirose foi avaliada por ELISA. Inicialmente estabeleceu-se o valor de cutoff a partir de 6 amostras de soros de indivíduos normais que relataram não terem entrado em contato com a doença. Para este ensaio foram feitas incubações prévias dos soros com extrato de $E$. coli nas concentrações de 5 e $20 \%$, evitando com isso a interferência de proteínas contaminantes de E. coli presentes na amostra dos recombinantes. Porém, mesmo com a adsorção, os valores individuais de reatividade de anticorpos IgG contra as proteínas rLIC10258 e rLIC12880 foram altos. Os valores de cutoff obtidos para estas proteínas foram de 0,367 e 0,343 nm, respectivamente. Em contrapartida, para rLIC12238 a adsorção resultou na diminuição da reatividade e o valor do cutoff foi de $0,046 \mathrm{~nm}$. Em relação aos anticorpos IgM, mesmo sem a adsorção, os valores individuais de anticorpos contra as proteínas rLIC12880 e rLIC12238 foram baixos, uma vez que os valores de absorbância foram inferiores a 0,1. Apenas a proteína rLIC10258 apresentou valores maiores que foram satisfatoriamente diminuídos com a adsorção prévia. Portanto, para anticorpos lgM todos os valores de cutoff foram abaixo de $0,1 \mathrm{~nm}$.

A próxima etapa foi avaliar a antigenicidade destas proteínas através do reconhecimento por anticorpos $\lg$ e $\operatorname{lgM}$ de 20 amostras de pacientes diagnosticados com leptospirose (Anexo B). Das proteínas testadas, rLIC12880 foi a que apresentou menores percentuais de respondedores, 5\% e 15\% para IgG e $\lg \mathrm{M}$, respectivamente. O percentual de respondedores da proteína rLIC12238 foi de 35\% tanto para IgG quanto para IgM. rLIC10258 apresentou percentual de respondedores maior para $\lg$ do que para $\operatorname{lgM}, 35 \%$ e $10 \%$, respectivamente (Figura 13). Análises estatísticas revelaram que comparativamente nenhum destes valores foi significativo. 
Figura 13 - Análise da presença de anticorpos IgG e IgM contra rLIC10258, rLIC12880 e rLIC12238 em soro de pacientes diagnosticados com leptospirose

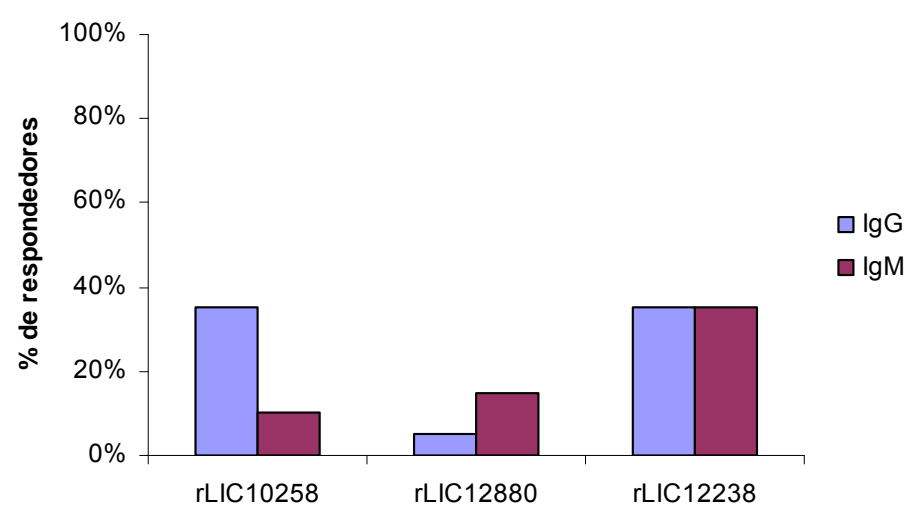

Amostras de soros de 20 indivíduos diagnosticados com leptospirose foram analisadas quanto à presença de anticorpos $\lg \mathrm{G}$ e $\operatorname{lgM}$ contra as proteínas recombinantes por ELISA.

Das 20 amostras testadas, 10 amostras eram referentes a fase convalescente da doença, com resultado MAT positivo, e as outras 10 amostras, correspondiam a fase inicial da doença, com resultado MAT negativo. O MAT é o método referência para diagnóstico da leptospirose, sendo a técnica recomendada OMS. Neste teste o soro de pacientes é submetido a reação com suspensões de antígenos de diferentes sorovares de leptospiras vivas (FAINE et al., 1999; LEVETT, 2003). Porém, como o MAT é uma técnica que apresenta baixa sensibilidade na fase inicial da doença e por se tratar de um ensaio sorovar específico, a identificação de antígenos de leptospira que possam ser reconhecidos ainda na fase inicial da leptospirose, como a proteína Lp29 (NEVES et al., 2007) e as proteínas MPL17 e MPL21 (OLIVEIRA et al., 2008), poderão facilitar o diagnóstico e tratamento precoce da doença. Além do mais, testes sorológicos baseados em proteínas recombinantes oferecem algumas vantagens como maior sensibilidade e especificidade, já que maiores concentrações de antígenos podem ser usadas (NEVES et al., 2007).

Devido aos dados apresentados, foi feita a comparação entre a frequência de respondedores que apresentaram anticorpos $\lg G$ e $\lg M$ na fase inicial $e$ convalescente da doença. A tabela 02 mostra que a proteína rLIC10258 foi a que apresentou maior frequência de respondedores, para anticorpos IgG, na fase inicial da doença (35\%). Para a proteína rLIC12238 o percentual de respondedores da fase convalescente, tanto para IgG quanto para IgM, foi significantemente maior que na 
fase inicial da doença, enquanto que para rLIC12880 não houve respondedores para fase inicial

Tabela 02 - Distribuição de respondedores para anticorpos lgG e IgM na fase inicial (MAT-) e convalescente (MAT+) da doença

\begin{tabular}{|c|c|c|c|c|c|c|}
\hline & & $\lg G$ & & & $\operatorname{Ig} M$ & \\
\hline $\begin{array}{c}\text { Fases da } \\
\text { Doença }\end{array}$ & rLIC210258 & rLIC12880 & rLIC12238 & rLIC10258 & rLIC12880 & rLIC12238 \\
\hline $\begin{array}{l}\text { Fase Inicial } \\
\text { MAT }(-) \quad n=10\end{array}$ & $3(30 \%)$ & --- & $1(10 \%)$ & --- & --- & $1(10 \%)$ \\
\hline $\begin{array}{c}\text { Fase } \\
\text { Convalescente } \\
\text { MAT }(+) n=10\end{array}$ & $4(40 \%)$ & $1(10 \%)$ & $6(60 \%)$ & $2(20 \%)$ & $3(30 \%)$ & $6(60 \%)$ \\
\hline Total $n=20$ & $7(35 \%)$ & $1(5 \%)$ & $7(35 \%)$ & $2(10 \%)$ & $3(15 \%)$ & $7(35 \%)$ \\
\hline
\end{tabular}

\subsection{Reconhecimento de rLIC10258, rLIC12880 e rLIC12238 por anticorpos monoclonais anti-His tag e policlonais homólogos por Western blotting}

Para confirmar se as proteínas recombinantes estavam sendo expressas com os resíduos de histidina na porção $\mathrm{N}$-terminal e para verificar o reconhecimento das proteínas rLIC10258, rLIC12880 e rLIC12238 por anticorpos policlonais homólogos, foi realizado um ensaio de Western blotting. Portanto, as proteínas recombinantes foram aplicadas em gel de poliacrilamida/SDS e transferidas para membranas de nitrocelulose. As membranas foram incubadas com anticorpos monoclonais anti-His tag ou com anticorpos policlonais anti-rLIC10258, ou anti-rLIC12880, ou antirLIC12238, nas diluições 1:3000, 1:800, 1:800 e 1:2000, respectivamente. A figura 14 mostra que os anticorpos monoclonais anti-His tag reconhecem as proteínas recombinantes deste estudo, da mesma forma que os soros policlonais homólogos foram capazes de reconhecer as proteínas recombinantes para as quais foram produzidos. 
Figura 14 - Detecção das proteínas recombinantes por anticorpos contra resíduos de histidina e policlonais homólogos por Western blotting

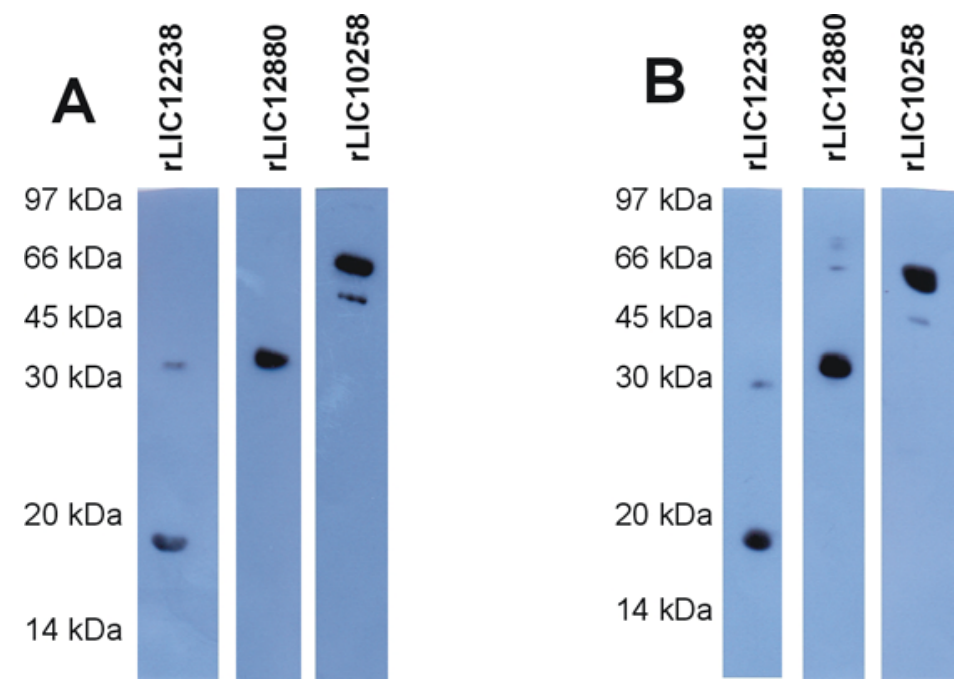

As proteínas recombinantes foram reconhecidas por anticorpo monoclonal anti-His tag $(A)$ e por policlonais contra as proteínas rLIC10258, rLIC12880 e rLIC12238 produzidos em camundongos (B).

\subsection{Análise da localização celular das proteínas codificadas pelos genes LIC10258, LIC12880 e LIC12238 por ensaio de digestão com PK e imunofluorescência de fase líquida (L-IFA)}

Devido a sua localização, proteínas associadas à membrana externa são importantes na relação patógeno-hospedeiro. Proteínas expostas à superfície servem como alvos potenciais para o sistema imunológico do hospedeiro, além de estarem envolvidas nos processos de adesão e colonização (BARBOSA et al., 2006; ATZINGEN et al., 2009). A partir do genoma de espécies patogênicas de Leptospira sequenciadas (NASCIMENTO et al., 2004a; NASCIMENTO et al., 2004b; BULACH et al., 2006), análises in silico identificaram mais de 200 proteínas com predição de estarem presentes na superfície destas leptospiras (NASCIMENTO et al., 2004a; NASCIMENTO et al., 2004b).

Os genes LIC10258, LIC12880 e LIC12238 codificam proteínas com probabilidade de estarem associadas à membrana externa, porém é necessário que a localização destas proteínas seja confirmada experimentalmente.

Um método, que vem sendo utilizado, para investigar se proteínas de leptospiras estão expostas na membrana externa é o ensaio de digestão com PK (PINNE; HAAKE, 2009; OLIVEIRA et al., 2010; MENDES et al., 2011). A PK é uma protease não específica que cliva as partes acessíveis das proteínas que estão 
expostas na superfície de leptospiras intactas. Neste ensaio, leptospiras vivas foram tratadas com PK por diferentes períodos de tempo e a presença das proteínas nativas correspondentes aos genes LIC10258, LIC12880 e LIC12238 na superfície das leptospiras foi detectada pela adição de anticorpos contra as proteínas recombinantes.

A figura 15 mostra que as proteínas codificadas pelos genes LIC10258, LIC12880 e LIC12238 foram susceptíveis ao tratamento com PK. Após 30 minutos de incubação, foi observada uma redução, estatisticamente significante, da proteínas codificada pelo gene LIC10258 e também da proteína de membrana externa, LipL32, usada como controle positivo do ensaio $(P<0,05)$. A redução das proteínas codificadas pelo genes LIC12880 e LIC12238 só foi estatisticamente significante após 1 hora de tratamento com PK $(P<0,05)$. Como esperado, não foi observada alteração na detecção da proteína citoplasmática, DnaK, usada como controle negativo do ensaio. Sendo assim, os resultados obtidos neste ensaio sugerem que as proteínas codificadas pelos genes LIC10258, LIC12880 e LIC12238 estão presentes na superfície de L. interrogans sorovar Copenhageni.

Figura 15 - Análise da localização celular por digestão com proteinase K

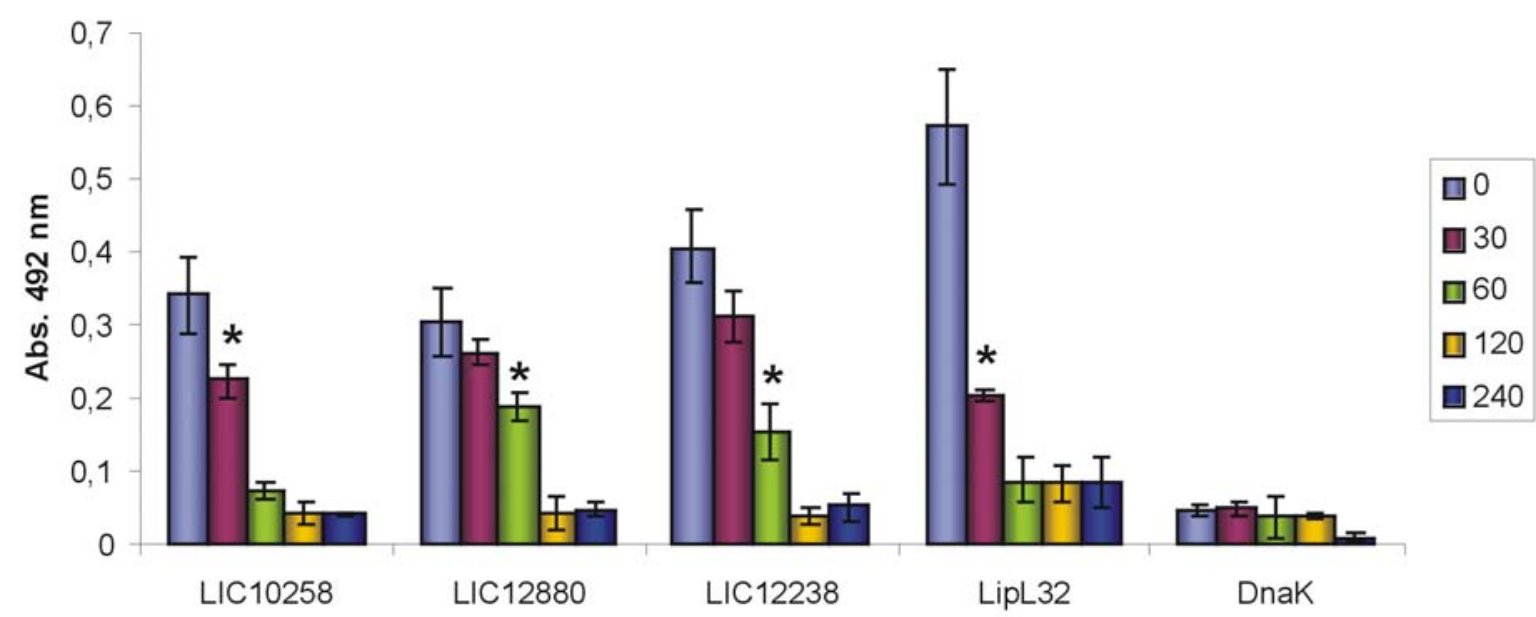

Leptospiras vivas foram incubadas com $25 \mu \mathrm{g} / \mathrm{mL}$ de PK por diferentes períodos de tempo ( 0 a 240 minutos). As leptospiras tratadas foram adsorvidas em placas de ELISA e anticorpos contra as proteínas recombinantes rLIC10258, rLIC12880 e rLIC12238 foram adicionados para detectar a presença das proteínas nativas correspondentes as recombinantes na superfície das leptospiras. A proteína de membrana externa, LipL32, e a proteína citoplasmática, DnaK, foram incluídas como controle positivo e negativo do ensaio, respectivamente. Os dados são representativos de quatro experimentos independentes. O desvio padrão representa a média de cada ponto realizado em triplicata. Significância estatística em relação as leptospiras não tratadas com PK (tempo zero) pelo Student's two tailed t test $\left({ }^{*} \mathrm{P}<0,05\right)$. 
Outro método utilizado para avaliar se as proteínas deste estudo estavam localizadas na superfície de $L$. interrogans sorovar Copenhageni foi o ensaio de LIFA utilizando leptospiras vivas. Neste método o DNA genômico das leptospiras pode ser visualizado por marcação com iodeto de propideo (Figura 16 - coluna 1) seguido da detecção com anticorpo policlonal contra cada uma das proteínas recombinantes na presença de anticorpo anti-mouse IgG conjugado ao FITC. Fluorescência verde pode ser observada, na figura 16 (coluna 2) para as proteínas rLIC10258, rLIC12880 e rLIC12238 e para o controle positivo LipL32, mas não para GroEL, uma proteína citoplasmática, utilizada como controle negativo. A localização destas proteínas na superfície de $L$. interrogans sorovar Copenhageni foi observada pela sobreposição das imagens observadas na figura 16 (coluna 3). Portanto, os dados obtidos com este ensaio indicam que rLIC10258, rLIC12880 e rLIC12238 são proteínas expostas na superfície das leptospiras. 
Figura 16 - Análise da localização celular das proteínas recombinantes rLIC10258, rLIC12880 e rLIC12238 por L-IFA
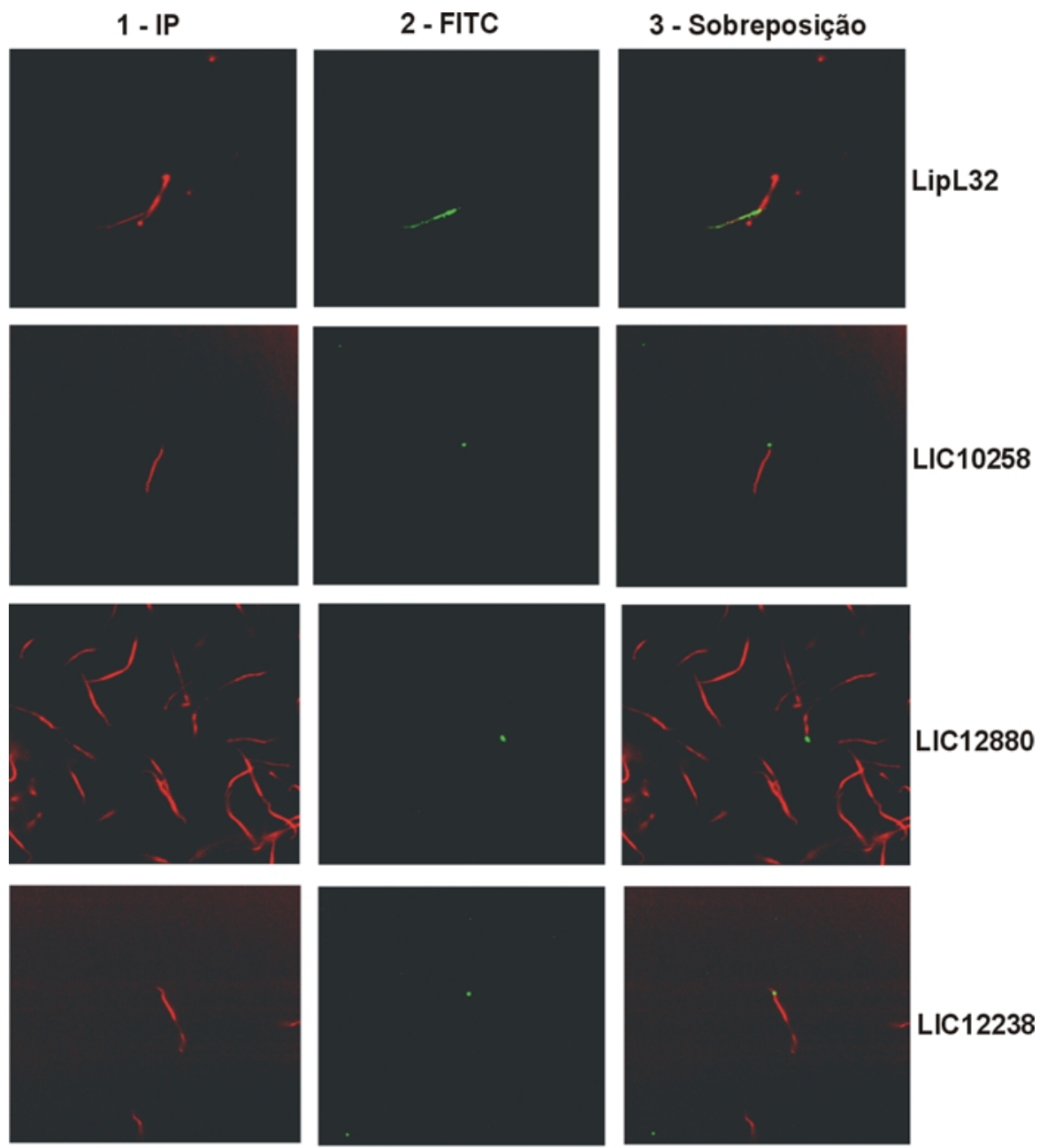

LIC12238
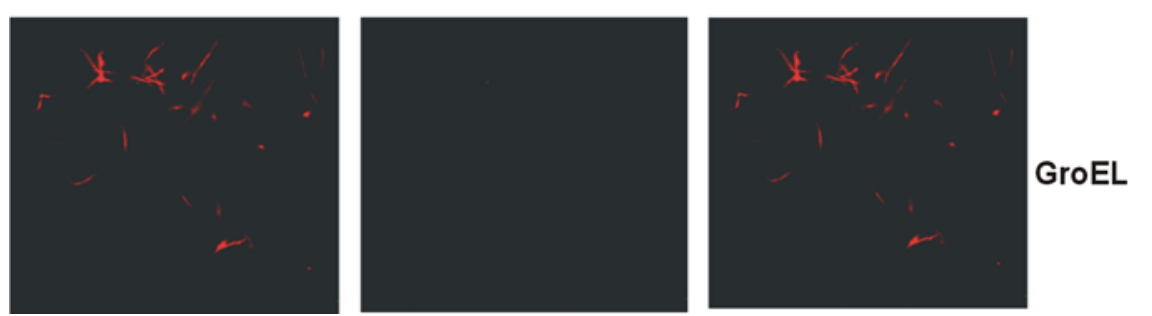

Leptospiras vivas foram marcadas com iodeto de propídeo $(1$ - IP) e as proteínas nativas na superfície das leptospiras foram detectadas pela adição de policlonais contra rLIC10258, rLIC12880 e rLIC12238 seguido da incubação com anti-mouse IgG conjugado ao FITC (2 - FITC). A presença das proteínas na superfície das leptospiras pode ser visualizada pela sobreposição das imagens (3 Sobreposição). A proteína de membrana externa, LipL32 e a proteína citoplasmática, GroEL foram usadas como controle positivo e negativo do experimento, respectivamente.

\subsection{Adesão das proteínas recombinantes rLIC10258, rLIC12880 e rLIC12238 aos MECs}

A adesão e a colonização dos tecidos do hospedeiro por patógenos é um evento crítico no processo de infecção. Já algum tempo, tem sido demonstrado que 
a interação de patógenos com componentes da matriz extracelular desempenha um papel primário na colonização dos tecidos do hospedeiro. Além disso, sabe-se que proteínas expostas na superfície dos patógenos provavelmente estariam envolvidas neste processo (BARBOSA et al., 2006; ATZINGEN et al., 2009).

Os mecanismos pelos quais espécies patogênicas de Leptospira invadem e colonizam as células hospedeiras são ainda pouco conhecidos. Porém, nos últimos anos, várias adesinas de leptospira tem sido descritas. A primeira adesina de leptospira, Lsa24 (BARBOSA et al., 2006), foi descrita pelo nosso grupo e desde então, novas adesinas tem sido relatadas, tais como Lsa21 (ATZINGEN et al., 2008), LipL32 (HAUK et al., 2008), Lp95 (ATZINGEN et al., 2009), LipL53 (OLIVEIRA et al., 2010) e Lsa63 (VIEIRA et al., 2010b).

Como os genes selecionados para este estudo codificam proteínas com probabilidade de estarem localizadas na membrana externa, especula-se a possibilidade destas proteínas interagirem com componentes da matriz extracelular. Sendo assim, para analisar a capacidade de ligação das proteínas rLIC10258, rLIC12880 e rLIC12238 aos MECs, placas de microdiluição foram adsorvidas com laminina, colágeno tipo I, colágeno tipo IV, fibronectina celular, fibronectina plasmática e os controles negativos BSA e fetuína. A adesão destas proteínas aos ECMs foi avaliada por ELISA.

Como apresentado na figura 17A, não foi observada a ligação da proteína rLIC12880 com nenhum dos MECs testados. A ligação da proteína rLIC12238 com a laminina e fibronectina plasmática não foi estatisticamente significante e portanto não foi considerada. Apenas rLIC10258 apresentou eficiente ligação a laminina e fibronectina plasmática, e por isso foi nomeada Lsa66 (LEeptospiral surface a dhesin of $\underline{66} \mathrm{kDa}$ ) (OLIVEIRA et al., 2011). A interação desta proteína com estes dois componentes da matriz foi estatisticamente significante quando comparado aos controles negativos BSA e fetuína $(P<0,005)$. A interação de rLIC10258 com a laminina e a fibronectina plasmática também foi observada quando anticorpos monoclonais anti-His foram empregados (Figura 17B) $\quad\left({ }^{*} \mathrm{P}<0,005 ; \quad{ }^{* *} \mathrm{P}<0,05\right)$. Também foi analisada a ligação da proteína rLIC10258 desnaturada e bloqueada com soro homológo com a laminina e fibronectina plasmática. Como apresentado na figura 17C, tanto a desnaturação quanto o bloqueio de rLIC10258 não foram capazes de inibir totalmente a interação desta proteína com a laminina e fibronectina 
plasmática, sugerindo a participação de epítopos não imunogênicos e não conformacionais nesta interação.

Figura 17 - Adesão das proteínas rLIC10258, rLIC12880 e rLIC12238 aos MECs
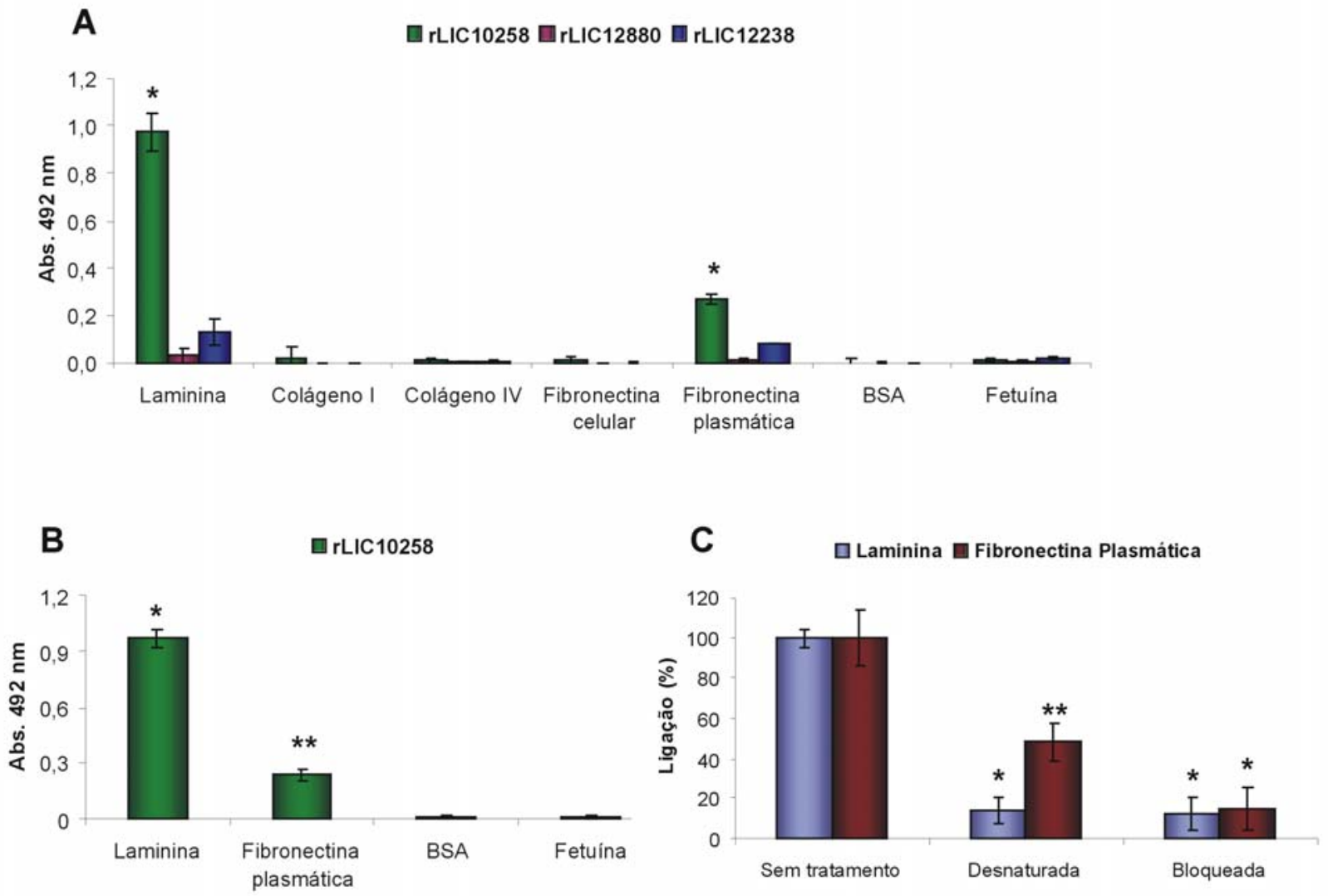

A interação das proteínas recombinantes aos MECs foi avaliada por ensaio de ELISA. Foram empregados policlonais contra as proteínas recombinantes (A) ou monoclonais anti-His tag (B) para deteç̧ão desta interação. Os dados representam uma média de três ensaios independentes. $O$ desvio padrão representa a média de cada ponto realizado em triplicata. Para análises estatísticas, a interação das proteínas recombinantes aos componentes da matriz extracelular foi comparada com a interação dos controles negativos pelo Student's two-tailed t test $\left({ }^{*} \mathrm{P}<0,005\right.$ e $\left.{ }^{* *} \mathrm{P}<0,05\right)$. (C) Análise do efeito da desnaturação e bloqueio da proteína rLIC10258 na interação com a laminina e fibronectina plasmática. Neste ensaio, rLIC10258 foi desnaturada por aquecimento a $96{ }^{\circ} \mathrm{C}$ durante 10 minutos ou bloqueada com policlonais homólogos produzidos por camundongos por 90 minutos a $37^{\circ} \mathrm{C}$. Os dados são representativos de dois experimentos independentes. Significância estatística em relação a rLIC10258 não tratada pelo Student's two-tailed t test ( ${ }^{*} P<0,005$ e $\left.{ }^{* *} P<0,05\right)$.

A especificidade da adesão de rLIC10258 a laminina e a fibronectina plasmática foi avaliada por meio de ensaios de dose-dependência e saturação variando a concentração da proteína recombinante (0 a $2000 \mathrm{nM}$ ) na presença fixa

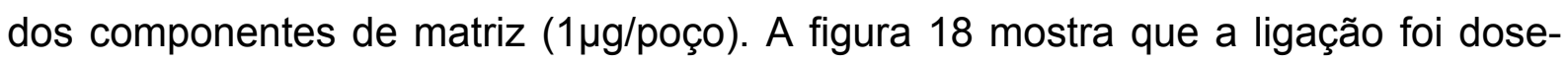
dependente e alcançou a saturação com aproximadamente 500 e 1500 nM de proteína recombinante na ligação com laminina e fibronectina plasmática, 
respectivamente. Baseado nos dados de ELISA, a constante de dissociação (KD) calculada para rLIC10258 com a laminina foi de 55,4 $\pm 15,9 \mathrm{nM}$, enquanto que para rLIC10258 com fibronectina plasmática foi de 290,83 $\pm 11,82$ nM.

Figura 18 - Análise da especificidade da ligação de rLIC10258 com a laminina e fibronectina plasmática
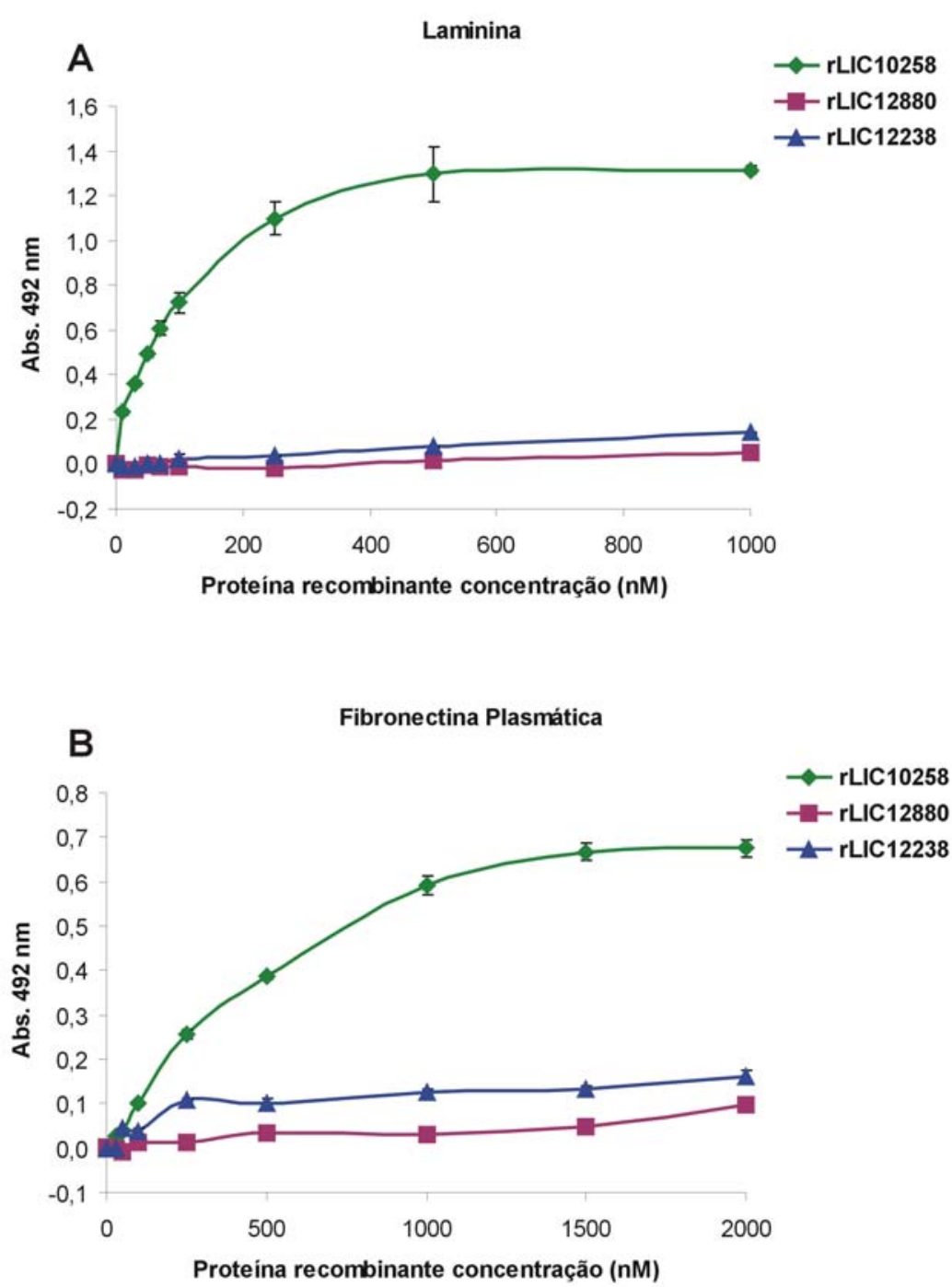

A interação da laminina (A) e fibronectina plasmática (B) foi avaliada com concentrações crescentes de rLIC10258 (0 a $2000 \mathrm{nM}$ ). O desvio padrão representa a média de cada ponto realizado em triplicata. As proteínas rLIC12880 e rLIC12238 foram incluídas como controle negativo. 


\subsection{Contribuição dos carboidratos da laminina e fibronectina plasmática na interação com rLIC10258}

O metaperiodato de sódio é um reagente que oxida os grupamentos hidroxil dos carboidratos mantendo a estrutura da cadeia polipeptídica intacta (WOODWARD; YOUNG; BLOODGOOD, 1985). Portanto, o envolvimento dos carboidratos da laminina e fibronectina plasmática na interação com a proteína recombinante rLIC10258 foi investigada através do tratamento desses MECs com metaperiodato de sódio. Sendo assim, tanto a laminina quanto a fibronectina plasmática foram oxidadas com concentrações crescentes desse reagente $(0$ a 100 mM) durante 15 minutos a $4{ }^{\circ} \mathrm{C}$, no escuro.

Como pode ser observado na figura 19 , não houve redução da ligação da proteína rLIC10258 com a laminina oxidada. Por outro lado, foi observada diminuição da ligação desta proteína com a fibronectina plasmática oxidada. $O$ efeito da oxidação na interação entre o componente e rLIC10258 foi dose-dependente e estatisticamente significante quando comparada a fibronectina não tratada $\left({ }^{*} P<0,01\right.$; ${ }^{* *} P<0,005$ e $\left.{ }^{* * *} P<0,001\right)$. Esses resultados sugerem que os resíduos de açúcar presentes na fibronectina plasmática são importantes na interação com a proteína rLIC10258.

Figura 19 - Contribuição dos resíduos de açúcar na interação de rLIC10258 com a laminina e a fibronectina plasmática

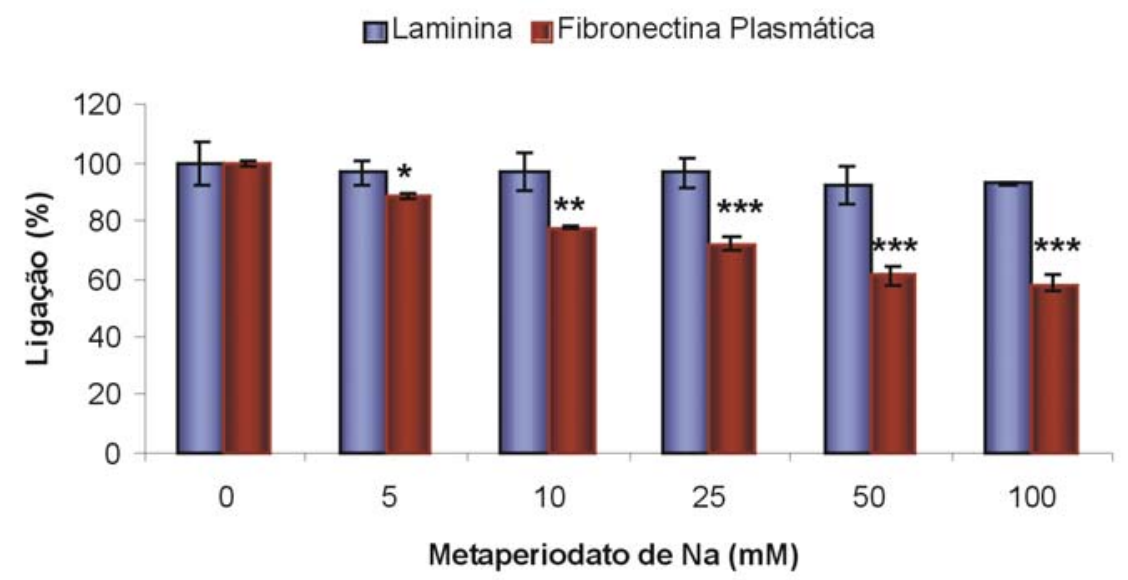

Laminina e fibronectina plasmática foram imobilizadas e tratadas com metaperiodato $(0$ a $100 \mathrm{mM})$ por 15 minutos, no escuro, a $4^{\circ} \mathrm{C}$. Barras representam a média dos valores de absorbância a $492 \mathrm{~nm}$ \pm o desvio padrão de três replicatas para cada grupo experimental. Os dados são representativos de três experimentos independentes. Significância estatística em relação a fibronectina plasmática não oxidada pelo Sudent's two-tailed t test $\left({ }^{*} \mathrm{P}<0,01 ;{ }^{* *} \mathrm{P}<0,005 \mathrm{e}{ }^{* * *} \mathrm{P}<0,001\right)$. 


\subsection{Ligação das proteínas recombinantes rLIC10258, rLIC12880 e rLIC12238 ao PLG humano}

Tem sido demonstrado que explorar as proteases do hospedeiro é uma estratégia comum dos patógenos para superar as barreiras impostas pelos componentes da matriz extracelular e tecidos epiteliais. Vários patógenos tornam-se organismos proteolíticos após capturar o PLG do hospedeiro e convertê-lo em plasmina, uma serino protease de amplo espectro, capaz de degradar constituintes da matriz extracelular e membrana basal (LAHTEENMAKI; KUKKONEN; KORHONEN, 2001; LAHTEENMAKI; KUUSELA; KORHONEN, 2001).

Já foram identificadas e caracterizadas lipoproteínas de membrana externa de espiroquetas que se ligam ao PLG, incluindo $B$. burgdorferi (BRISSETTE et al., 2009) e B. hermsii (ROSSMANN et al., 2007). Recentemente, foi demonstrado por nosso grupo, a capacidade das leptospiras de se ligarem ao PLG e convertê-lo em plasmina utilizando-se de ativadores presentes no plasma do hospedeiro (VIEIRA et al., 2009). Desde então, receptores do PLG tem sido identificados em $L$. interrogans (VERMA et al., 2010; VIEIRA et al., 2010a; MENDES et al., 2011; DOMINGOS et al., 2012).

Portanto, a capacidade de ligação das proteínas recombinantes deste estudo com o PLG foi avaliada por ELISA. O PLG humano e os controles negativos BSA e fetuína imobilizados em placas de microdiluição foram incubados com as proteínas rLIC10258, rLIC12880 e rLIC12238 e a interação foi quantificada utilizando-se anticorpos policlonais homólogos ou monoclonais anti-His tag. Todas as proteínas recombinantes deste estudo foram capazes de se ligar ao PLG humano, como pode ser observado nas figuras $20 \mathrm{~A}$ e $20 \mathrm{~B}$. A interação foi estatisticamente significante quando comparada aos controles negativos BSA e fetuína $\left({ }^{*} P<0,005 ;{ }^{* *} P<0,0005\right.$ e $\left.{ }^{* * *} P<0,00005\right)$. Também foi investigado o efeito da desnaturação e bloqueio com anticorpos homólogos das proteínas rLIC10258, rLIC12880 e rLIC12238 na ligação com o PLG. Como apresentado na figura 20C, apenas a ligação de rLIC10258 ao PLG não foi totalmente abolida quando esta proteína foi desnaturada ou bloqueada com policlonais anti-rLIC10258. Esses resultados sugerem o envolvimento de sítios de ligação lineares e não imunogênicos na ligação entre rLIC10258 e PLG. 
Figura 20 - Análise da ligação das proteínas rLIC10258, rLIC12880 e rLIC12238 ao PLG humano
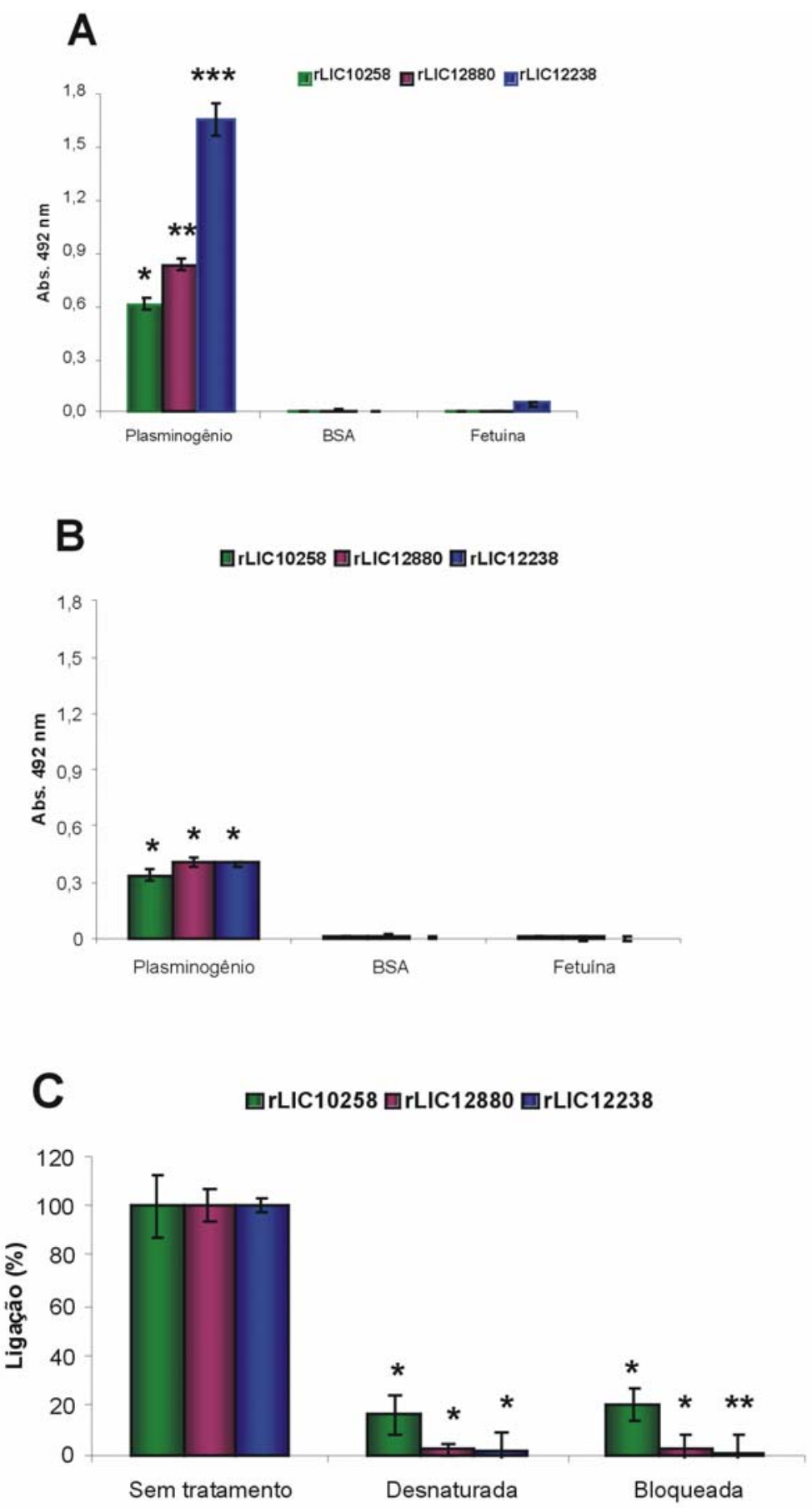

A ligação das proteínas recombinantes ao PLG foi avaliada por ensaio de ELISA utilizando anticorpos policlonais anti-proteínas recombinantes (A) ou anticorpos monoclonais anti-His tag (B). Os dados representam uma média de três ensaios independentes e o desvio padrão representa a média de cada ponto realizado em triplicata Para análises estatísticas, a interação das recombinantes com o PLG foi comparada com a interação dos controles negativos pelo Student's two-tailed test: (A) ${ }^{*} \mathrm{P}<0,005$; ${ }^{* *} \mathrm{P}<0,0005$; ${ }^{* * *} \mathrm{P}<0,00005$; (B) ${ }^{*} \mathrm{P}<0,005$. (C) Influência da desnaturação e bloqueio das proteínas recombinantes na interação com o PLG. Neste ensaio, as proteínas recombinantes foram desnaturada por aquecimento a $96^{\circ} \mathrm{C}$ durante 10 minutos ou bloqueadas com anticorpos homólogos produzidos por camundongos por 90 minutos a $37^{\circ} \mathrm{C}$. Os dados são representativos de dois experimentos independentes. Significância estatística em relação as proteínas não tratada pelo Student's two-tailed t test: ${ }^{*} \mathrm{P}<0,005 ;{ }^{* *} \mathrm{P}<0,0005$. 
A especificidade da ligação das proteínas rLIC10258, rLIC12880 e rLIC12238 com o PLG foi analisada por meio de ensaios de dose-dependência e saturação. $A$ figura 21 mostra que quando houve variação crescente da concentração das proteínas recombinantes (0 a 2000 nM) na presença de concentração fixa de PLG

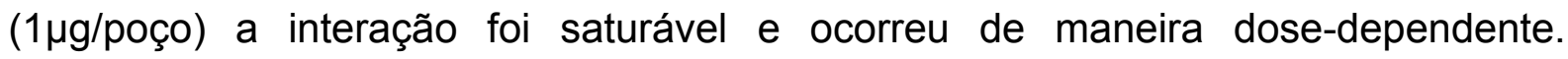
Baseado nos dados de ELISA, as constantes de dissociação (KD) das proteínas recombinantes com o PLG foram de 68,82 \pm 25,25; 167,39 \pm 60,14 e 11,97 \pm 1,06 nM para rLIC10258, rLIC12880 e rLIC12238, respectivamente.

Figura 21 - Análise da especificidade da ligação de rLIC10258, rLIC12880 e rLIC12238 com o PLG humano

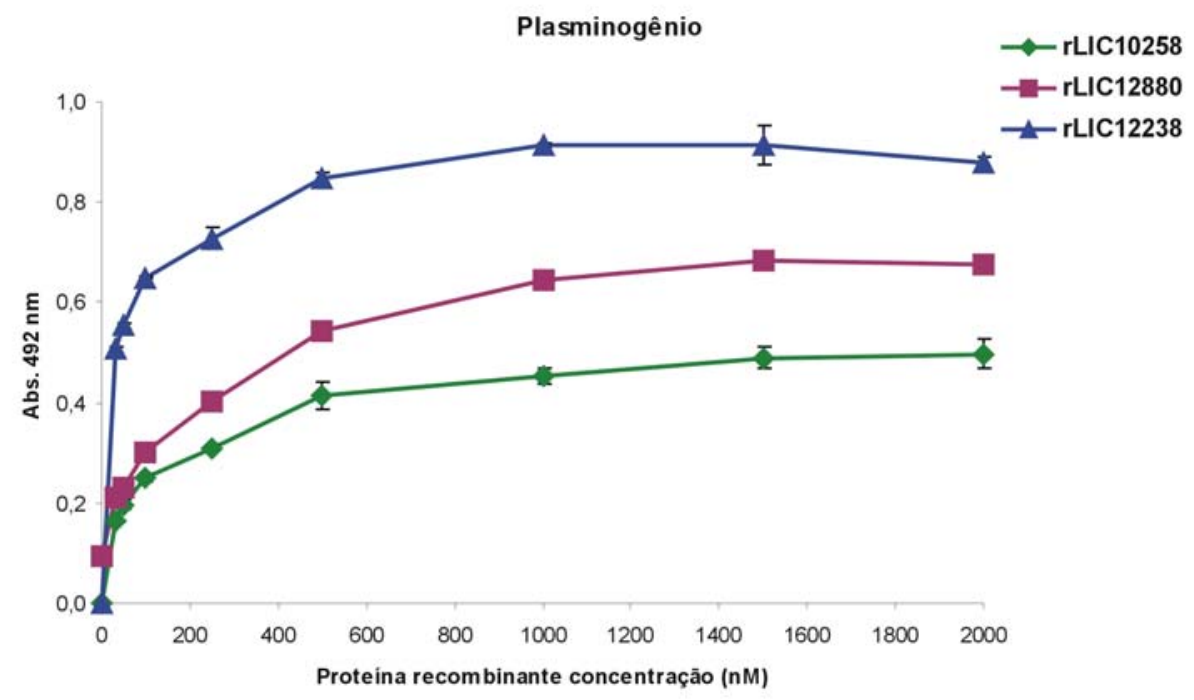

A interação de $1 \mu \mathrm{g}$ de PLG foi avaliada com concentrações crescentes das proteínas recombinantes (0 a $2000 \mathrm{nM}$ ). Os dados são representativos de dois experimentos independentes. O desvio padrão representa a média de cada ponto realizado em triplicata.

\subsection{Atividade enzimática da plasmina}

Tem sido demonstrado que plasmina pode ser gerada tanto pelo PLG ligado à superfície de $L$. interrogans quanto pelo PLG ligado a proteínas recombinantes na presença de ativador exogéno (VIEIRA et al., 2010a; MENDES et al., 2011; DOMINGOS et al., 2012). Portanto para determinar se o PLG ligado às proteínas recombinantes deste estudo pode adquirir atividade proteolítica, foi realizado um ensaio de ELISA modificado. As proteínas recombinantes rLIC10258, rLIC12880 e rLIC12238 foram imobilizadas em placas de microdiluição e, após bloqueio e 
incubação com PLG, adicionou-se o ativador de PLG tipo uroquinase (UPA) juntamente com o substrato cromogênico específico para plasmina. A reação ocorreu por 16 horas e a atividade da plasmina foi quantificada através da clivagem do substrato por absorbância a $405 \mathrm{~nm}$. O PLG capturado pelas proteínas recombinantes pode ser convertido a plasmina, como demonstrado indiretamente pela atividade proteolítica da plasmina gerada. Não foi observada atividade proteolítica para o controle negativo BSA, assim como para os controles em que não foi adicionado PLG, uPA ou substrato cromogênico (Figura 22).

Figura 22 - Atividade enzimática da plasmina ligada as proteínas recombinantes

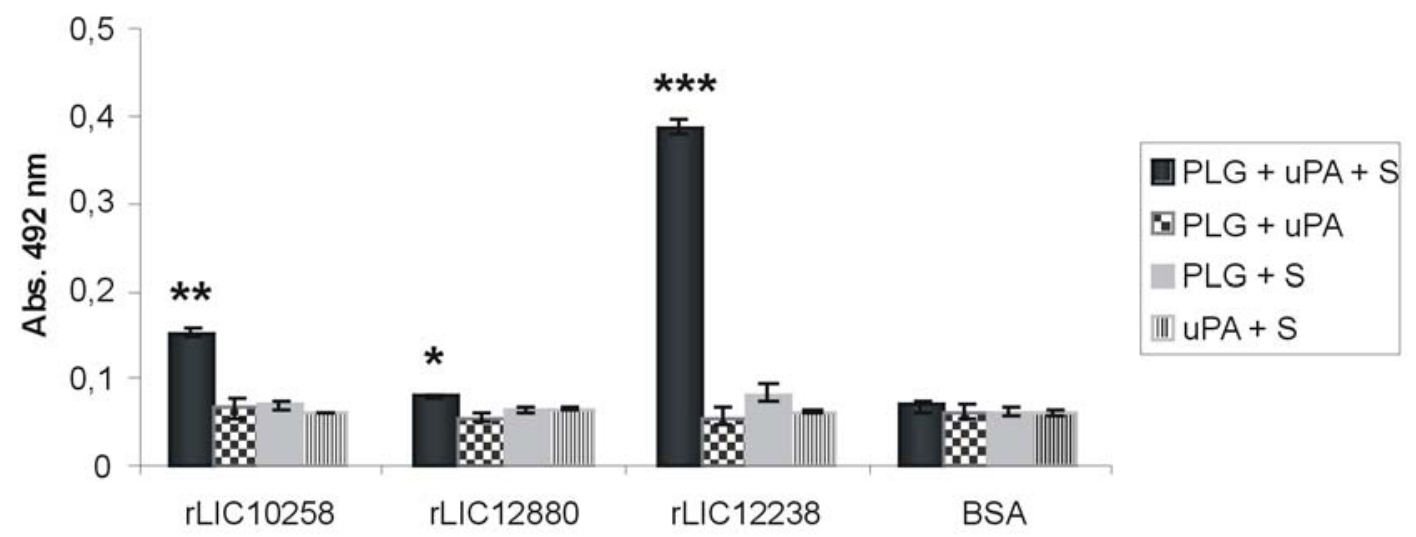

A clivagem de substrato específico para plasmina após ativação do PLG ligado as proteínas recombinantes foi avaliado através de ELISA modificado. As proteínas imobilizadas receberam os seguintes tratamentos: PLG + uPA + substrato para plasmina (PLG + uPA + S), ou controles com a ausência de um dos três componentes (PLG + uPA; PLG + S; uPA + S). BSA foi empregado como controle negativo. As barras representam as médias das absorbâncias a $405 \mathrm{~nm}$ como medida da clivagem do substrato \pm desvio padrão de quatro replicatas para cada grupo, sendo representativo de dois experimentos independentes. Diferenças estatisticamente significantes estão evidenciadas por ${ }^{*} \mathrm{P}<0,02 ;{ }^{* *} \mathrm{P}<0,001 \mathrm{e}{ }^{* * *} \mathrm{P}<0,00001$.

\subsection{Ligação das proteínas recombinantes rLIC10258, rLIC12880 e rLIC12238 ao fibrinogênio, componentes do sistema complemento humano, fator $\mathrm{H} \mathrm{e}$ C4BP}

O fibrinogênio, uma glicoproteína plasmática de $340 \mathrm{kDa}$ composta de dois pares dos peptídeos $A \alpha, B \beta$ e $Y$ ligados por meio de pontes de sulfeto, é uma das principais proteínas envolvidas nos processos de coagulação sanguínea, sendo essencial para a cicatrização de feridas e consequente reparação dos tecidos (BAMFORD et al., 2007; CHOY et al., 2011; LIN et al., 2011). A virulência de alguns patógenos, como por exemplo, Staphylococcus aureus (MOREILLON et al., 1995), 
cepas do grupo A de estreptococos (MEEHAN et al., 2001) e da espiroqueta $T$. denticola (BAMFORD et al., 2007) tem sido relacionada com a interação com o fibrinogênio. Além disso, recentemente, foi relatada a capacidade da proteína LigB de leptospiras de interagir com o fibrinogênio (CHOY et al., 2011; LIN et al., 2011).

O sistema complemento constitui a primeira linha de defesa do sistema imune inato e sua ativação direciona a uma cascata de reações que resulta na formação do complexo lítico de ataque à membrana e opsonização do microrganismo invasor (JANEWAY; FLAVELL, 1999).

Uma estratégia utilizada por diversos patógenos para evitar os efeitos destrutivos causados pela ativação do sistema complemento é sequestrar do hospedeiro, proteínas reguladoras deste sistema, como o Fator $\mathrm{H}$ e a C4BP (VERMA et al., 2006; BARBOSA et al., 2009; FRAGA; BARBOSA; ISAAC, 2011; CASTIBLANCO-VALENCIA et al., 2012).

$\mathrm{O}$ fator $\mathrm{H}$ e a C4BP são as principais proteínas reguladoras da via alternativa e clássica do sistema complemento, respectivamente. O fator $\mathrm{H}$ é uma proteína plasmática de 150 kDa composta por 20 domínios nomeados de short consensus repeat (SCRs) que inibe a via alternativa do complemento ligando-se ao C3b e deslocando o $\mathrm{Bb}$ da $\mathrm{C} 3$ convertase, além de atuar como um cofator para o Fator I que cliva o C3b em sua forma inativa, o iC3b (RIPOCHE et al., 1988). A C4BP é uma glicoproteína plasmática de 570 kDa composta de 7 cadeias a e uma única cadeia $\beta$ ligadas por um núcleo central que inibe a via clássica do complemento acelerando a diminuição e evitando a formação da C4b2a convertase e atuando como cofator para o fator I na inativação do C4b (GIGLI; FUJITA; NUSSENZWEIG, 1979).

Vários patógenos de interesse médico e veterinário, incluindo as espiroquetas B. burgdorferi (ALITALO et al., 2002; STEVENSON et al., 2002), B. hermsii (HOVIS et al., 2004) e T. denticola (MCDOWELL et al., 2005) são capazes de se ligar ao fator $\mathrm{H}$ e a proteína similar ao fator $\mathrm{H}-1$ (FHL-1). Além disso, tem sido relatado que B. recurrentis e B. duttonii são capazes de se ligar a C4BP (MERI et al., 2006).

Há várias décadas tem sido demonstrada a habilidade das leptospiras patogênicas de resistirem ao sistema complemento, apesar de não serem conhecidos os mecanismos que possibilitavam esta resistência (CINCO; BANFI, 1983). Porém, nos últimos anos tem sido descrito que as leptospiras são capazes de interagir com o fator $\mathrm{H}$ e C4BP, o que inibiria o ataque do sistema complemento e explicaria a resistência ao soro humano apresentada por este patógeno (VERMA et 
al., 2006; BARBOSA et al., 2009). As proteínas LfhA/Lsa24 (VERMA et al., 2006), LenB (STEVENSON et al., 2007), LigA e LigB (CASTIBLANCO-VALENCIA et al., 2012) foram identificadas como ligantes de fator $H$ nas leptospiras, enquanto que as proteínas LcpA (BARBOSA et al., 2010), LigA e LigB (CASTIBLANCO-VALENCIA et al., 2012) são receptores para o C4BP. Recentemente, as proteínas Lsa25, Lsa33, Lsa30 e Lsa23 foram identificadas e caracterizadas por nosso grupo como receptores de C4BP nas leptospiras (DOMINGOS et al., 2012; SOUZA et al., 2012).

Todas as proteínas recombinantes desse estudo são receptores de PLG (VIEIRA et al., 2010a; OLIVEIRA et al., 2011). Além disso, a proteína rLIC10258 interage com a laminina e fibronectina plasmática (OLIVEIRA et al., 2011). Portanto, as proteínas rLIC10258, rLIC12880 e rLIC12238 provavelmente estão envolvidas nos processos de adesão e penetração nos tecidos do hospedeiro. Sendo assim, especula-se a possibilidade destas proteínas participarem de outros mecanismos de patogenicidade e virulência das leptospiras, como por exemplo, evasão imune. Sendo assim, a capacidade de ligação das proteínas recombinantes deste estudo com o fibrinogênio, os componentes do sistema complemento humano, o fator $\mathrm{H} \mathrm{e}$ C4BP foi avaliada por ELISA. Os componentes e os controles negativos BSA e fetuína imobilizados em placas de microdiluição foram incubados com as proteínas rLIC10258, rLIC12880 e rLIC12238 e a interação foi quantificada utilizando-se anticorpos policlonais anti-proteínas recombinantes.

Como mostra a figura 23A, não foi detectada a ligação das proteínas recombinantes deste estudo com os componentes do complemento humano, fator $\mathrm{H}$ e C4BP. Em relação ao fibrinogênio, apenas rLIC12238 foi capaz de se ligar a este componente (Figura 23A). A interação desta proteína com o fibrinogênio foi estatisticamente significante quando comparado aos controles negativos BSA e fetuína. A ligação de rLIC12238 com o fibrinogênio também foi observada quando anticorpos monoclonais anti-His foram empregados (Figura 23B). Além disso, também foi analisada a influência da desnaturação e bloqueio com soro homólogo da proteína rLIC12238 na ligação com o fibrinogênio. Como apresentado na figura 23C, apenas a desnaturação de rLIC12238 foi capaz de inibir totalmente a interação desta proteína com o fibrinogênio, sugerindo a participação de epítopos não imunogênicos nesta interação. 
Figura 23 - Análise da ligação das proteínas rLIC10258, rLIC12880 e rLIC12238 a componentes do soro e plasma humano
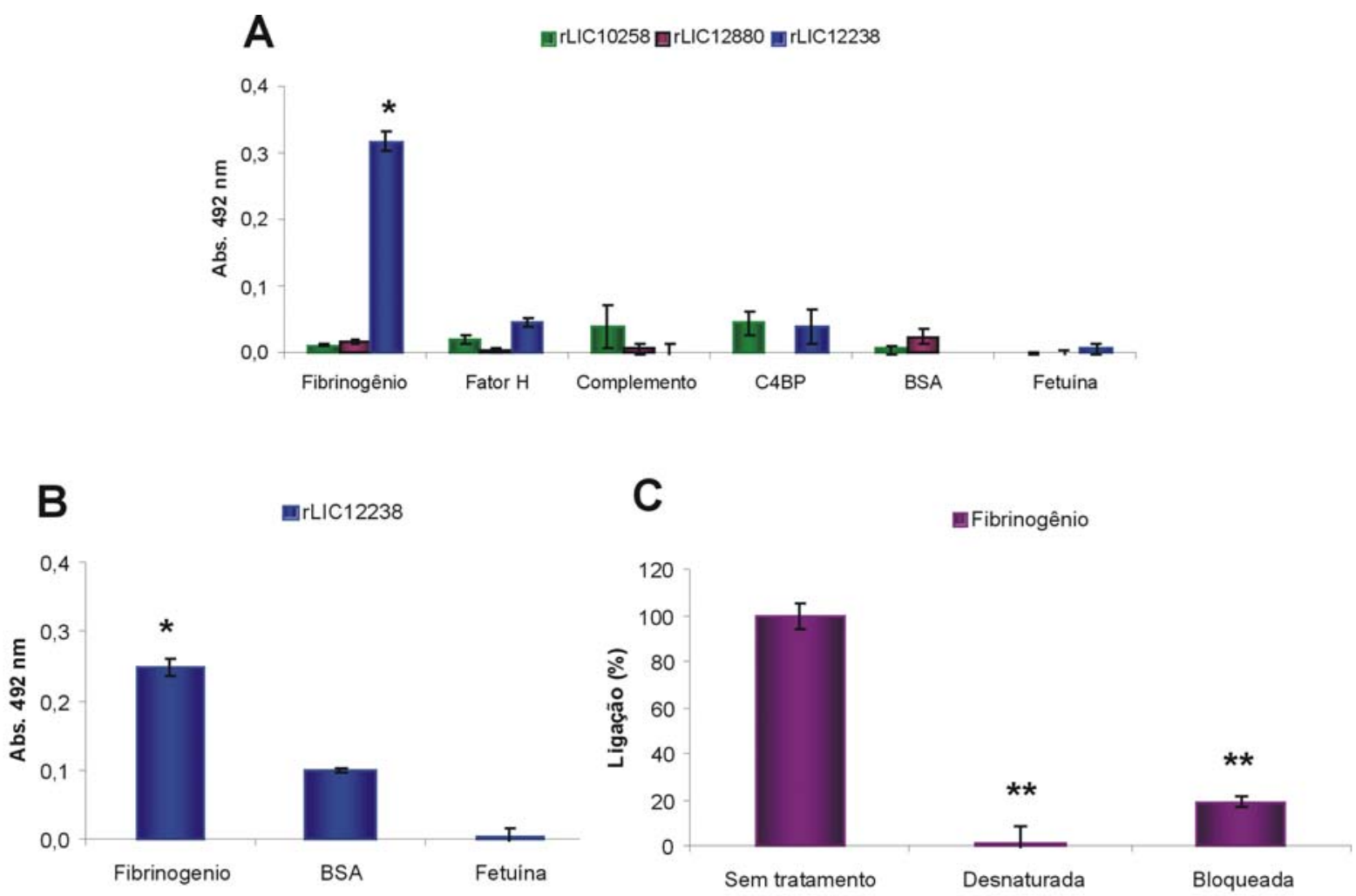

A interação das proteínas recombinantes com o fibrinogênio, fator $\mathrm{H}$, complemento humano e C4BP foi analisada por ensaio de ELISA, utilizando anticorpos policlonais anti-proteínas recombinantes (A) ou anticorpos monoclonais anti-His tag (B). Os dados representam uma média de três ensaios independentes. $O$ desvio padrão representa a média de cada ponto realizado em triplicata. Para análises estatísticas, a ligação de rLIC12238 ao fibrinogênio foi comparada com a ligação dos controles negativos pelo Student's two-tailed t test: ${ }^{*} P<0,001$. (C) Análise do efeito da desnaturação e bloqueio da proteína rLIC12238 na interação com o fibrinogênio. Neste ensaio, rLIC12238 foi desnaturada por aquecimento a $96{ }^{\circ} \mathrm{C}$ durante 10 minutos e bloqueada com policlonais homólogos produzidos por camundongos por 90 minutos a $37{ }^{\circ} \mathrm{C}$. Os dados são representativos de dois experimentos independentes. Significância estatística em relação a rLIC12238 não tratada pelo Student's two-tailed t test: ${ }^{* *} \mathrm{P}<0,0001$.

A especificidade da ligação de rLIC12238 com o fibrinogênio foi analisada por ensaio de dose-dependência e saturação. A figura 24 mostra que quando houve variação crescente da concentração da proteína $(0-4000 \mathrm{nM})$ na presença de concentração fixa de fibrinogênio ( $1 \mu \mathrm{g} /$ poço) a interação ocorreu de maneira dosedependente. A saturação desta ligação foi alcançada com aproximadamente 3500 nM de proteína recombinante. Baseado nos dados de ELISA, a constante de dissociação (KD) calculada para a interação entre rLIC12238 e o fibrinogênio foi de $733,27 \pm 276,79$ nM. Como controle negativo desta ligação foi utilizada a proteína rLIC12880 que não interage com o fibrinogênio. 
Figura 24 - Análise da especificidade da ligação de rLIC12238 com o fibrinogênio

Fibrinogênio

$\leadsto$ rLIC12238

$\rightarrow-r$ rLIC12880

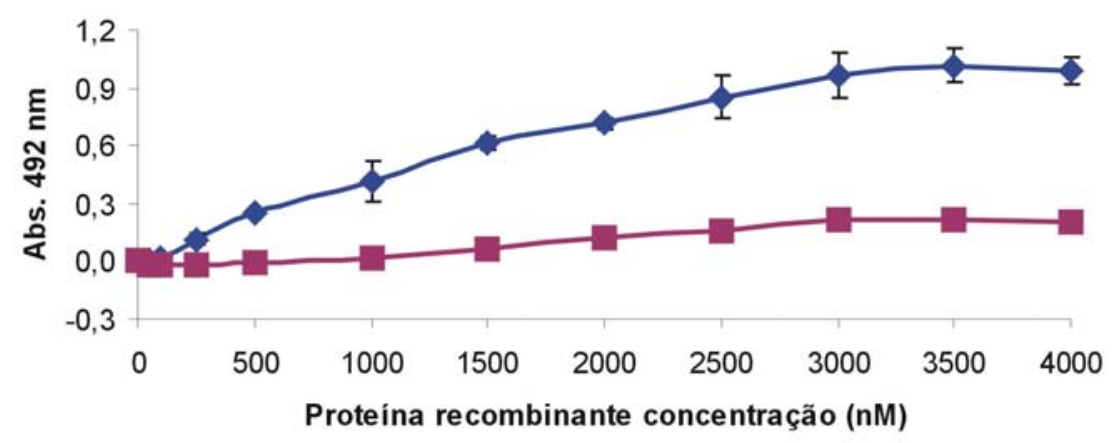

A interação de $1 \mu \mathrm{g}$ de fibrinogênio foi avaliada com concentrações crescentes de rLIC12238 (0 a $4000 \mathrm{nM}$ ). Os dados são representativos de dois experimentos independentes. $O$ desvio padrão representa a média de cada ponto realizado em triplicata. A proteína rLIC12880 foi incluída como controle negativo.

\subsection{Inibição da formação do coágulo de fibrina pela proteína rLIC12238}

O fibrinogênio é uma das principais proteínas envolvidas nos processos de coagulação sanguínea (BAMFORD et al., 2007; CHOY et al., 2011; LIN et al., 2011) e a virulência de alguns patógenos (MOREILLON et al., 1995; MEEHAN et al., 2001; BAMFORD et al., 2007) tem sido relacionada com a sua interação com o fibrinogênio.

Recentemente, foi demonstrado por Lin e colaboradores (2011) que a proteína LigB de leptospiras é capaz de ligar ao fibrinogênio e inibir a adesão e agregação plaquetária, além da formação do coágulo de fibrina. Estes resultados sugerem a presença, nas leptospiras, de um mecanismo de regulação da coagulação sanguínea do hospedeiro, o que poderia explicar os quadros hemorrágicos observados em casos clínicos de leptospirose (LIN et al., 2011). Choy et al. (2011) também relataram a inibição da formação do coágulo de fibrina pela interação de LigB com o fibrinogênio e sugerem que esta inibição, possivelmente, prejudicaria a cicatrização de feridas facilitando a entrada das leptospiras na circulação, sua disseminação e consequente estabelecimento da infecção (CHOY et al., 2011). 
A proteína rLIC12238 foi capaz de interagir com o fibrinogênio e, portanto, para analisar se esta interação poderia interferir na formação do coágulo de fibrina, foi realizado um ensaio onde o fibrinogênio foi pré-incubado com rLIC12238 e a conversão do fibrinogênio solúvel em fibrina insolúvel foi induzida pela presença de trombina. A formação do coágulo foi detectada pelo aumento da densidade ótica por um período de 45 minutos. Como relatado para a proteína LigB (CHOY et al., 2011; LIN et al., 2011), os dados apresentados na figura 25 mostram que a proteína rLIC12238 foi capaz de inibir a formação do coágulo de fibrina. Esta inibição foi estatisticamente significante ( $\left.{ }^{*} \mathrm{P}<0,01\right)$, reduzindo em $33 \%$ a formação do coágulo após 45 minutos de ensaio. Os resultados obtidos sugerem que por meio da ligação de rLIC12238 ao fibrinogênio e consequente inibição da conversão deste fibrinogênio em fibrina, esta proteína pode estar envolvida na patogenicidade das leptospiras, interferindo no processo de coagulação do hospedeiro.

Figura 25 - Efeito de rLIC12238 na formação do coágulo de fibrina induzido por trombina
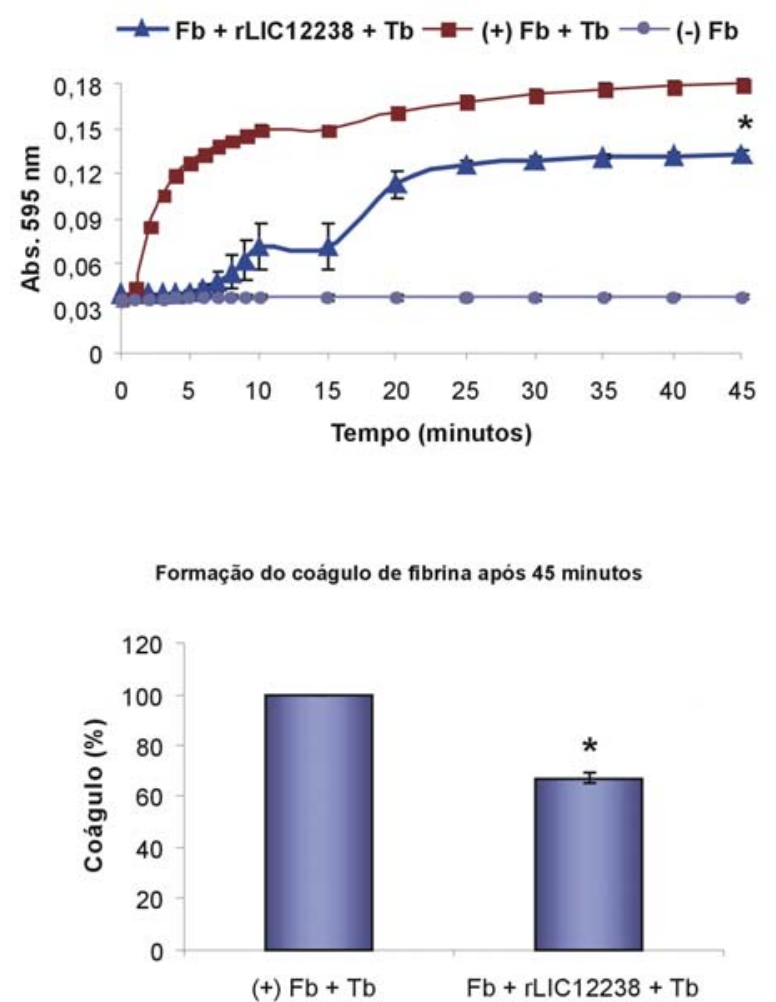

Fibrinogênio $(1 \mathrm{mg} / \mathrm{mL})$ foi pré-incubado com a proteína rLIC12238 $(3500 \mathrm{nM})$ por 2 horas a $37^{\circ} \mathrm{C}$. A formação do coágulo foi desencadeada pela adição de trombina $(10 \mathrm{U} / \mathrm{mL})$ e foi quantificada pelo aumento da densidade ótica $(595 \mathrm{~nm})$ durante 45 minutos. Os dados são representativos de dois experimentos independentes. O desvio padrão representa a média de cada ponto realizado em triplicata. Significância estatística em relação ao controle positivo pelos Student's two tailed t test: ${ }^{*} \mathrm{P}<0$,01. (+) Fb $+\mathrm{Tb}$ : controle positivo. (-) Fb: controle negativo. Fb: fibrinogênio. Tb: trombina. 


\subsection{Inibição da adesão de leptospiras vivas a MECs, PLG ou Fibrinogênio pelas proteínas recombinantes rLIC10258, rLIC12880 e rLIC12238}

Tem sido demonstrado que as proteínas recombinantes Lsa24/Lfha/LenA (BARBOSA et al., 2006), Lsa63 (VIEIRA et al., 2010b), Lsa20 (MENDES et al., 2011), Lsa25 e Lsa33 (DOMINGOS et al., 2012; OLIVEIRA et al., 2013 - manuscrito submetido) promovem um efeito inibitório na adesão das leptospiras a componentes da matriz extracelular, PLG e fibrinogênio. Devido a este fato foi avaliado o efeito de concentrações crescentes das proteínas recombinantes deste estudo ( 0 a $5 \mu \mathrm{g})$ na inibição da ligação de leptospiras a laminina, fibronectina plasmática, PLG e fibrinogênio.

Os resultados mostram que rLIC10258 foi capaz de inibir a adesão de leptospiras a laminina, a fibronectina plasmática e ao PLG (figura 26A). Da mesma forma, rLIC12880 inibiu a ligação das leptospiras ao PLG (figura 26B), enquanto rLIC12238 inibiu a interação das leptospiras ao PLG e fibrinogênio (figura 26C).

A inibição promovida pelas proteínas recombinantes deste estudo foi parcial, porém estatisticamente significante $\left({ }^{*} P<0,05\right)$. Resultados semelhantes foram obtidos com as proteínas Lsa24/Lfha/LenA (BARBOSA et al., 2006), Lsa63 (VIEIRA et al., 2010b), Lsa20 (MENDES et al., 2011), Lsa25 e Lsa33 (DOMINGOS et al., 2012; OLIVEIRA et al., 2013 - manuscrito submetido) que também inibiram parcialmente a adesão das leptospiras aos MECs, PLG e fibrinogênio. Esta inibição parcial é esperada e pode ser explicada pela presença de outros receptores em $L$. interrogans que se ligam a laminina, fibronectina, PLG e fibrinogênio. 
Figura 26 - Inibição da adesão de L. interrogans a MECs, PLG e fibrinogênio pelas proteínas rLIC10258, rLIC12880 e rLIC12238
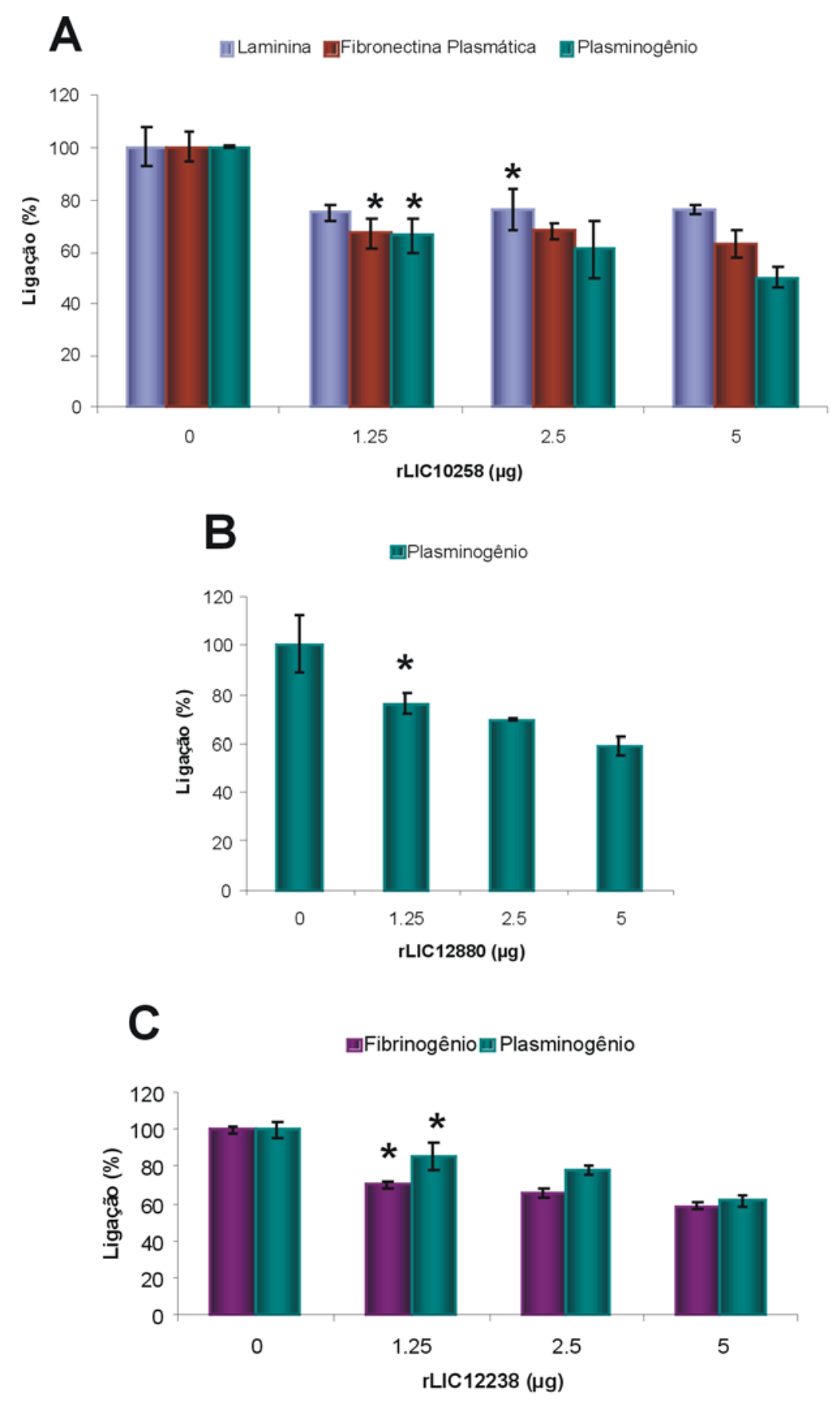

Laminina, fibronectina plasmática e PLG imobilizadas foram incubadas com concentrações crescentes de rLIC10258 (A) ou PLG imobilizado foi incubado com concentrações crescentes de rLIC12880 (B) ou PLG e fibrinogênio foram incubados com concentrações crescentes de rLIC12238 (C), seguido da adição de $4 \times 10^{7}$ de leptospiras vivas. A detecção da adesão das leptospiras ligadas aos MECs e PLG foi realizada indiretamente utilizando-se anticorpos policlonais anti-LipL32. As barras representam a média de absorbâncias a $492 \mathrm{~nm} \pm$ desvio padrão de três replicatas de dois experimentos independentes. Diferenças estatisticamente significantes estão evidenciadas: ${ }^{*} P<0,05$. 


\subsection{Avaliação da atividade imunoprotetora das proteínas rLIC10258, rLIC12880 e rLIC12238}

Devido a sua localização, proteínas associadas à membrana externa são importantes na relação patógeno-hospedeiro por estarem envolvidas nos processos de adesão e colonização, além de serem alvos potenciais para o sistema imunológico (GAMBERINI et al., 2005; KOIZUMI; WATANABE, 2005; ATZINGEN et al., 2010; CAO et al., 2011).

Vários grupos de pesquisa tem testado a atividade imunoprotetora de proteínas associadas à membrana externa, como por exemplo, OmpL1 e LipL41 (HAAKE et al., 1999), LipL32 (BRANGER et al., 2001; SEIXAS et al., 2007), LigA e LigB (KOIZUMI; WATANABE, 2004; PALANIAPPAN et al., 2006; SILVA et al., 2007; BRISSETTE et al., 2009; YAN et al., 2009; CAO et al., 2011) e proteínas OmpA-like (YAN et al., 2010).

Nosso grupo também tem demonstrado que proteínas, com probabilidade de serem expostas à superfície, produzidas em nosso laboratório (rLIC12730, rLIC10494 e rLIC12922) são capazes de conferir proteção parcial de animais desafiados com dose letal de leptospiras (ATZINGEN et al., 2010).

Portanto para avaliar a atividade imunoprotetora das proteínas rLIC10258, rLIC12880 e rLIC12238, hamsters foram imunizados com duas doses destas proteínas recombinantes e desafiados com dose letal de L. interrogans sorovar Kennewicki (cepa Pomona Fromm) virulenta. Os hamsters foram utilizados como modelo animal deste ensaio por serem altamente suscetíveis a infecção por leptospiras, e por exibirem características que mimetizam a infecção severa em humanos (HAAKE, 2006).

Foram realizados quatro ensaios independentes, dois com a proteína rLIC10258 e dois com as proteínas rLIC12880 e rLIC12238. Nestes ensaios foi empregada como controle positivo de proteção uma vacina composta de leptospiras inativadas pelo calor - L. interrogans sorovar Kennewicki (cepa Pomona Fromm).

A figura 27 mostra a curva de sobrevivência dos hamsters imunizados com rLIC10258, bacterina e PBS e desafiados com $2 \times 10^{5}$ de L. interrogans sorovar Kennewicki (cepa Pomona Fromm) virulenta.

Os resultados obtidos no primeiro experimento, mostram que a proteína rLIC10258 conferiu $20 \%$ de proteção aos animais desafiados com dose letal de 
leptospiras virulentas. A bacterina foi capaz de conferir $100 \%$ de proteção, enquanto que no grupo PBS não houve sobreviventes (Figura 27A e Tabela 03). No segundo experimento, $30 \%$ dos animais imunizados com rLIC10258 sobreviveram. A bacterina novamente conferiu $100 \%$ de proteção, enquanto que $20 \%$ dos animais imunizados com PBS sobreviveram (Figura 27B e Tabela 03). A análise da cinética das curvas de sobrevivência pelo método de Kaplan-Meyer (KAPLAN e MEIER, 1958) revelou que apesar da proteção conferida por rLIC10258 ter sido maior no segundo experimento, apenas a proteção obtida por rLIC10258 no primeiro experimento foi estatisticamente significante $(P<0,0092)$.

Figura 27 - Curva de sobrevivência dos hamsters imunizados com rLIC10258 e desafiados com leptospiras virulentas
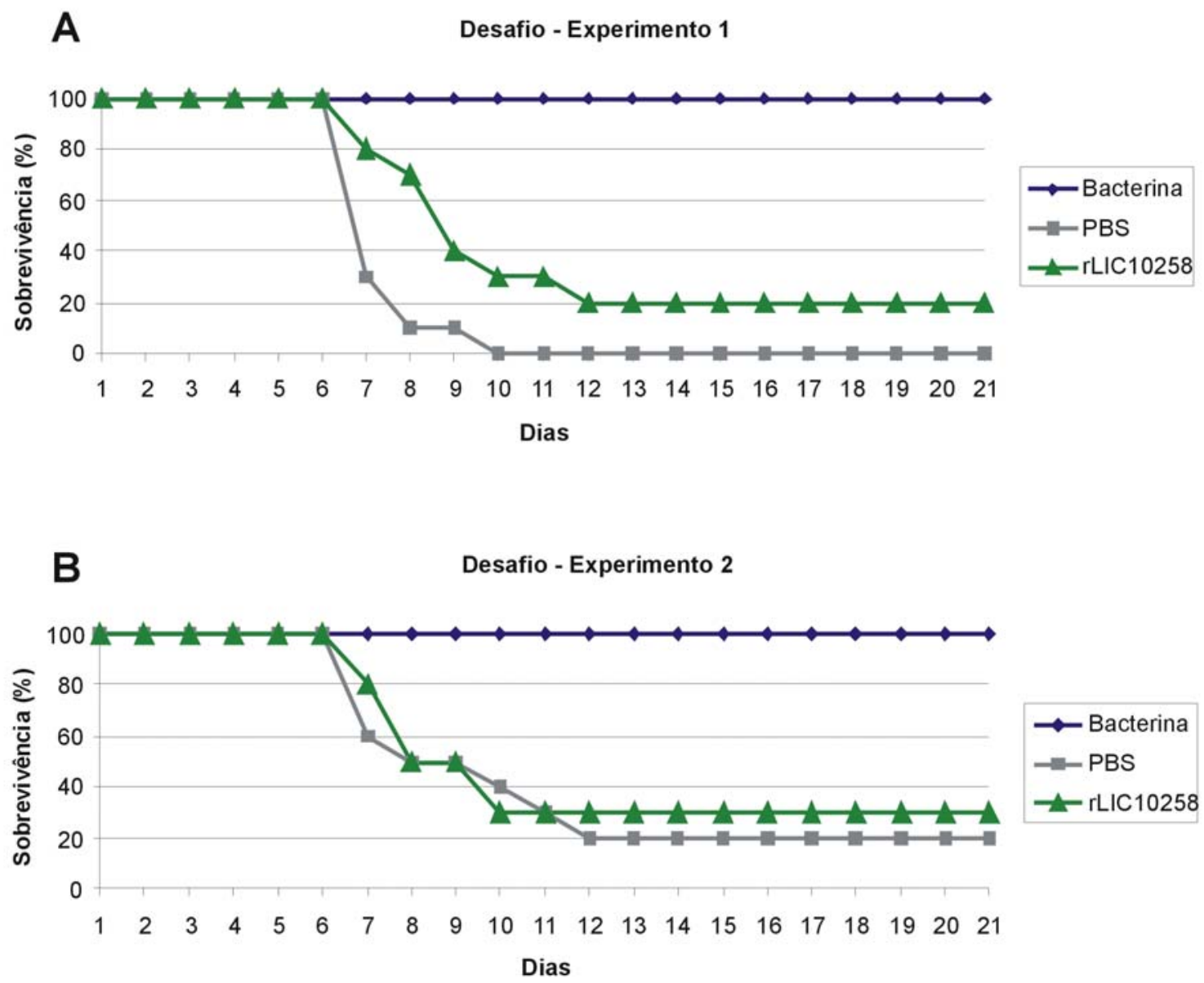

Após duas imunizações com rLIC10258, bacterina e PBS, os animais foram desafiados com $2 \times 10^{5}$ de $L$. interrogans sorovar Kennewicki (cepa Pomona Fromm) virulenta. Os animais foram monitorados quanto à morbidade por 21 dias. A) Experimento 1. B) Experimento 2. 
Tabela 03 - Atividade imunoprotetora e efeito esterilizante da proteína rLIC10258

\begin{tabular}{ccccccc}
\hline & \multicolumn{2}{c}{ Experimento 1 } & \multicolumn{3}{c}{ Experimento 2 } \\
\hline $\begin{array}{c}\text { Antígenos } \\
+\end{array}$ & \% Proteção & P value & $\begin{array}{c}\text { Presença de } \\
\text { leptospiras } \\
\text { nos rins dos } \\
\text { sobreviventes } \\
\text { (positivo/total) }\end{array}$ & \% Proteção & P value & $\begin{array}{c}\text { Presença de } \\
\text { leptospiras } \\
\text { nos rins dos } \\
\text { sobreviventes } \\
\text { (positivo/total) }\end{array}$ \\
\hline Bacterina & $\begin{array}{c}100 \% \\
(10 / 10)\end{array}$ & 0,0001 & $0 / 10$ & $\begin{array}{c}100 \% \\
(10 / 10)\end{array}$ & 0,0002 & $0 / 10$ \\
PBS & $0 \%(0 / 10)$ & ---- & ---- & $20 \%(2 / 10)$ & ---- & $0 / 2$ \\
rLIC10258 & $20 \%(2 / 10)$ & 0,0092 & $1 / 2$ & $30 \%(3 / 10)$ & 0,6768 & $2 / 3$ \\
\hline
\end{tabular}

Para analisar a resposta humoral dos animais imunizados com a proteína rLIC10258 e PBS, dois hamsters de cada grupo foram sangrados, via punção cardíaca, 15 dias após a segunda imunização (antes do desfio). Também foram analisados os soros obtidos dos animais que sobreviveram ao desafio. A média dos títulos de anticorpos obtidos após imunização com rLIC10258 foram de 200 e 400 no primeiro e segundo experimento, respectivamente. Um aumento dos títulos de anticorpos foi observado nos hamsters que sobreviveram ao desafio com leptospiras virulentas. No primeiro experimento, a média dos títulos de anticorpos obtidos após o desafio foi de 800 , enquanto que no segundo experimento foi de 1600 . Não foi detectada a produção de anticorpos nos animais imunizados com PBS em nenhum dos experimentos realizados.

A atividade imunoprotetora das proteínas rLIC12880 e rLIC12238 também foi avaliada. A figura 28 mostra a curva de sobrevivência dos hamsters imunizados com rLIC12880, rLIC12238, bacterina e PBS e desafiados com 2,5 $\times 10^{3}$ de $L$. interrogans sorovar Kennewicki (cepa Pomona Fromm).

Os resultados obtidos mostram que, no primeiro experimento, as proteínas recombinantes rLIC12880 e rLIC12238 foram capazes de proteger 33 e $50 \%$ dos hamsters desafiados com dose letal de leptospiras virulentas, respectivamente. A bacterina conferiu $100 \%$ de proteção, enquanto que $8 \%$ dos animais imunizados com PBS sobreviveram (Figura 28A e Tabela 04). No segundo experimento, não houve sobreviventes no grupo imunizado com rLIC12880 e apenas $16,5 \%$ dos 
animais imunizados com rLIC12238 sobreviveram (Figura 28B e Tabela 04). A bacterina, por sua vez, conferiu $100 \%$ de proteção, enquanto que $25 \%$ dos animais não vacinados sobreviveram. De acordo com a análise da cinética das curvas de sobrevivência pelo método de Kaplan-Meyer (KAPLAN e MEIER, 1958), a proteção conferida pelas proteínas rLIC12880 e rLIC12238 não foi estatisticamente significante em nenhum dos experimentos (Tabela 04).

Figura 28 - Curva de sobrevivência dos hamsters imunizados com rLIC12880 e rLIC12238 e desafiados com leptospiras virulentas

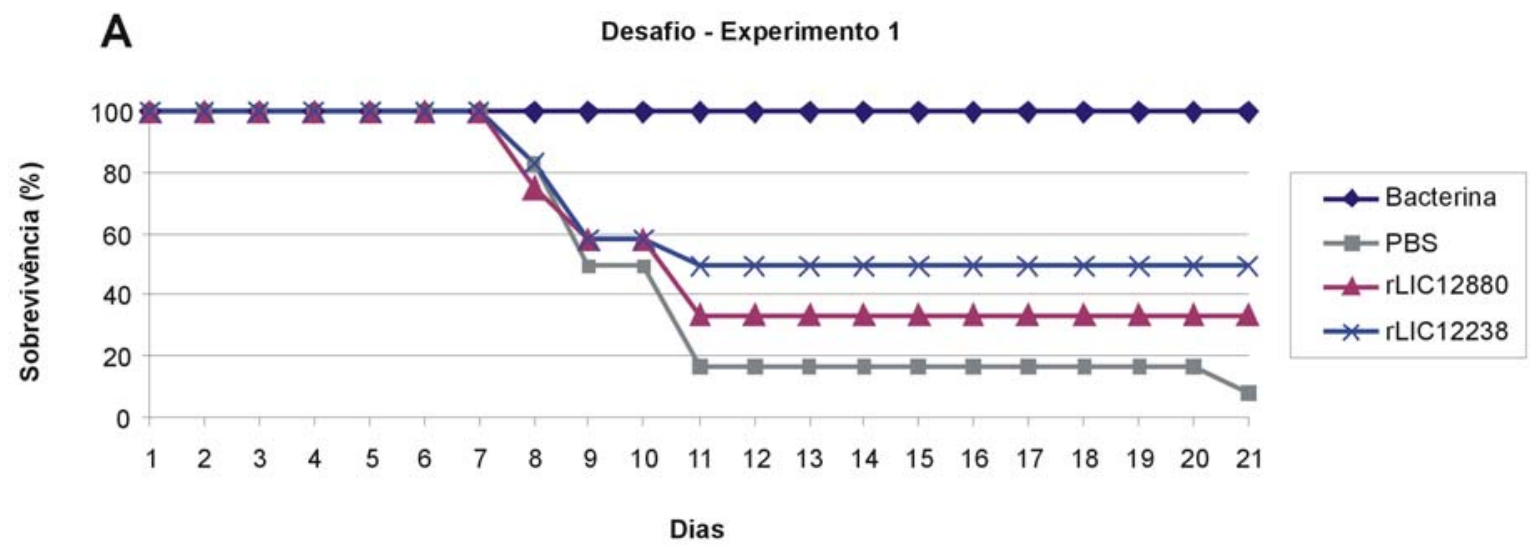

B Desafio - Experimento 2

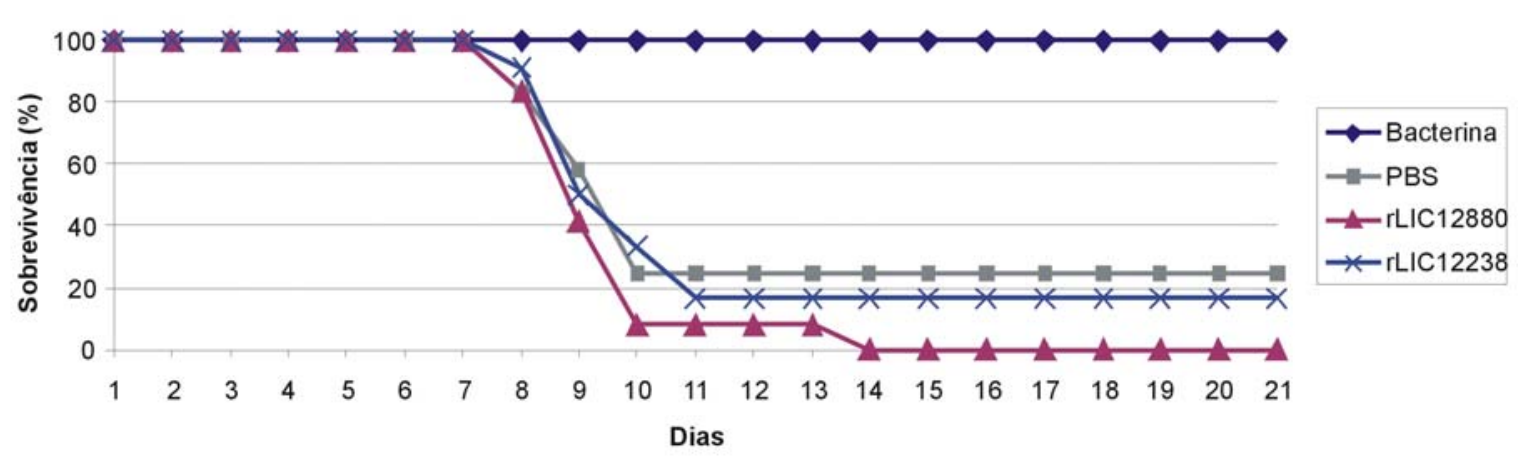

Após duas imunizações com rLIC12880, rLIC12238, bacterina e PBS, os animais foram desafiados com $2 \times 10^{3}$ de $L$. interrogans sorovar Kennewicki (cepa Pomona Fromm) virulenta. Os animais foram monitorados quanto à morbidade por 21 dias. A) Experimento 1. B) Experimento 2. 
Tabela 04 - Atividade imunoprotetora e efeito esterilizante das proteínas rLIC12880 e rLIC12238

\begin{tabular}{|c|c|c|c|c|c|c|}
\hline \multicolumn{4}{|c|}{ Experimento 1} & \multicolumn{3}{|c|}{ Experimento 2} \\
\hline $\begin{array}{c}\text { Antígenos } \\
+ \\
\text { Adjuvante }\end{array}$ & \% Proteção & $P$ value & $\begin{array}{c}\text { Presença de } \\
\text { leptospiras } \\
\text { nos rins dos } \\
\text { sobreviventes } \\
\text { (positivo/total) } \\
\end{array}$ & \% Proteção & $\mathrm{P}$ value & $\begin{array}{c}\text { Presença de } \\
\text { leptospiras } \\
\text { nos rins dos } \\
\text { sobreviventes } \\
\text { (positivo/total) } \\
\end{array}$ \\
\hline Bacterina & $\begin{array}{c}100 \% \\
(12 / 12)\end{array}$ & 0,0001 & $0 / 12$ & $\begin{array}{c}100 \% \\
(11 / 11)\end{array}$ & 0,0003 & $0 / 11$ \\
\hline PBS & $8,3 \%(1 / 12)$ & ---- & ---- & $25 \%(3 / 12)$ & ---- & $2 / 3$ \\
\hline rLIC12880 & $\begin{array}{l}33,3 \% \\
(4 / 12)\end{array}$ & 0,3206 & $4 / 4$ & $0 \%(0 / 12)$ & 0,1648 & ND \\
\hline rLIC12238 & $50 \%(6 / 12)$ & 0,0938 & $6 / 6$ & $\begin{array}{l}16,5 \% \\
(2 / 12)\end{array}$ & 0,8258 & $1 / 2$ \\
\hline
\end{tabular}

Para analisar a resposta humoral dos animais imunizados com as proteínas rLIC12880, rLIC12238 e PBS, seis hamsters de cada grupo foram sangrados, via retro-orbital, 15 dias após cada imunização. Também foram analisados os soros obtidos dos animais que sobreviveram ao desafio. $\mathrm{O}$ quadro 03 mostra que, tanto no primeiro quanto no segundo experimento, houve aumento da média dos títulos de anticorpos produzidos pelos hamsters após a segunda imunização (dia 30 - antes do desafio) com as proteínas rLIC12880 e rLIC12238. Nos dois experimentos realizados, também foi observado um aumento dos títulos de anticorpos dos hamsters que sobreviveram ao desafio com leptospiras virulentas. Não foi detectada a produção de anticorpos nos animais imunizados com PBS em nenhum dos desafios realizados (Quadro 03). 
Quadro 03 - Resposta humoral dos hamsters imunizados com rLIC12880 e rLIC12238 antes e depois do desafio

\begin{tabular}{|ccccccc|}
\hline & \multicolumn{2}{c}{ Experimento1 } & \multicolumn{3}{c|}{ Experimento2 } \\
\hline $\begin{array}{c}\text { Hamster } \\
\text { vacinados } \\
\text { com: }\end{array}$ & $\begin{array}{c}\text { Após 1 } \\
\text { imunização } \\
\text { Dia 15 }\end{array}$ & $\begin{array}{c}\text { Após 2 } \\
\text { imunização } \\
\text { Dia 30 }\end{array}$ & $\begin{array}{c}\text { Após } \\
\text { desafio } \\
\text { Dia 51 }\end{array}$ & $\begin{array}{c}\text { Após 1 } \\
\text { imunização } \\
\text { Dia 15 }\end{array}$ & $\begin{array}{c}\text { Após 2a } \\
\text { imunização } \\
\text { Dia 30 }\end{array}$ & $\begin{array}{c}\text { Após } \\
\text { desafio } \\
\text { Dia 51 }\end{array}$ \\
\hline rLIC12880 & 70 & 1375 & 1665 & 150 & 2500 & - \\
rLIC12238 & 60 & 325 & 550 & 100 & 200 & 600 \\
PBS & --- & --- & --- & --- & -- \\
\hline
\end{tabular}

Os hamsters que sobreviveram foram sacrificados e tiveram seus rins coletados para cultura e isolamento de leptospiras. As tabelas 03 e 04 mostram que o efeito da bacterina foi esterilizante em todos os experimentos realizados, uma vez que não foi detectada a presença de leptospiras nos rins dos sobreviventes. Em contrapartida, as proteínas rLIC10258, rLIC12880 e rLIC12238 não podem ser consideradas esterilizantes, já que foram detectadas leptospiras nos rins de alguns sobreviventes.

É importante ressaltar que a existência de sobreviventes no grupo de animais não vacinados e a dificuldade de reproduzir os resultados em ensaios de desafio, tem sido descrita pelo nosso grupo e por outros grupos de pesquisa (BRANGER et al., 2001; PALANIAPPAN et al., 2006; ATZINGEN et al., 2010). Em ensaios de desafio realizados por Branger e colaboradores (2001) e Palaniappan et al. (2006) foram observadas taxas de $50 \%$ e $80 \%$ de sobrevivência do grupo de animais não vacinados, respectivamente. Atzingen e colaboradores (2010) também relataram $20 \%$ de sobrevivência do grupo controle e significância estatística de apenas um de dois experimentos realizados.

Sendo assim, os resultados obtidos com estes ensaios sugerem que as proteínas rLIC10258, rLIC12880 e rLIC12238 não possuem atividade imunoprotetora e portanto não podem ser consideradas boas candidatas vacinais contra a leptospirose. 


\subsection{Amplificação e clonagem dos fragmentos do gene LIC10258}

A proteína recombinante rLIC10258 é capaz de interagir com laminina, fibronectina plasmática e PLG (OLIVEIRA et al., 2011). Sendo assim, para analisar qual parte da proteína rLIC10258 é responsável pela ligação aos componentes acima citados, as sequências de DNA correspondentes as porções $\mathrm{N}$-terminal, intermediária e C-terminal do gene LIC10258 foram obtidas por amplificação (PCR) do DNA genômico extraído da cultura de $L$. interrogans sorovar Copenhageni. Os produtos de PCR obtidos foram analisados por eletroforese em gel de agarose $1 \% \mathrm{e}$ apresentaram o tamanho esperado de 570,952 e 513 pb para os clones referentes as porções N-terminal, Intermediária e C-terminal do gene LIC10258, respectivamente. A figura 29 esquematiza os fragmentos clonados da proteína codificada pelo gene LIC10258, enquanto que a figura 30 apresenta os fragmentos de DNA obtidos após amplificação por PCR.

Figura 29 - Esquema da clonagem dos fragmentos do gene LIC10258

\section{Proteína rLIC10258}
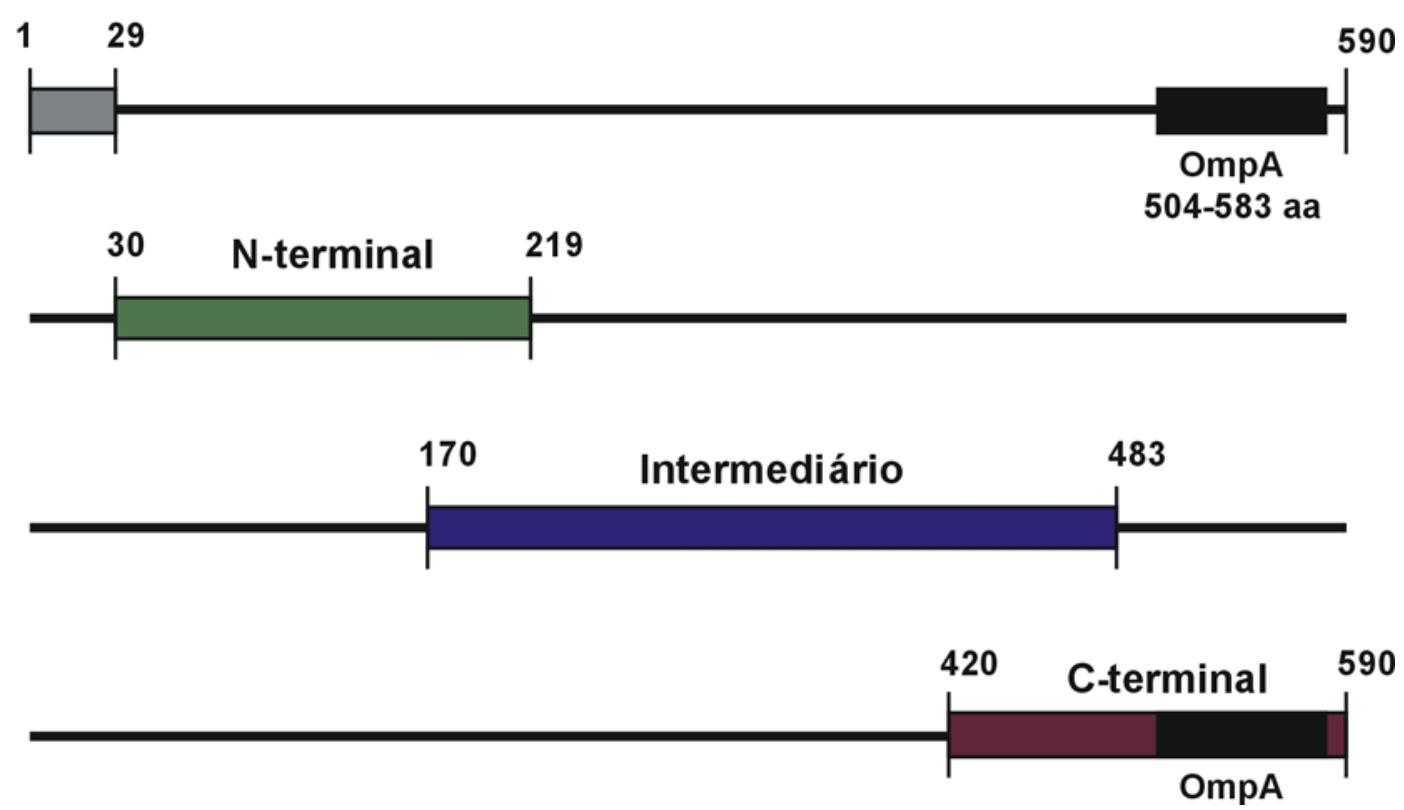

Foram clonadas as porções N-terminal (aminoácidos 30 ao 219), Intermediária (aminoácidos 170 ao 483) e C-terminal (aminoácidos 420 ao 590) da proteína codificada pelo gene LIC10258. O fragmento $\mathrm{N}$-terminal foi clonado sem o peptídeo sinal (aminoácidos 1 ao 29). 
Figura 30 - Análise dos fragmentos do gene LIC10258 amplificados por meio de reação de PCR em gel de agarose $1 \%$

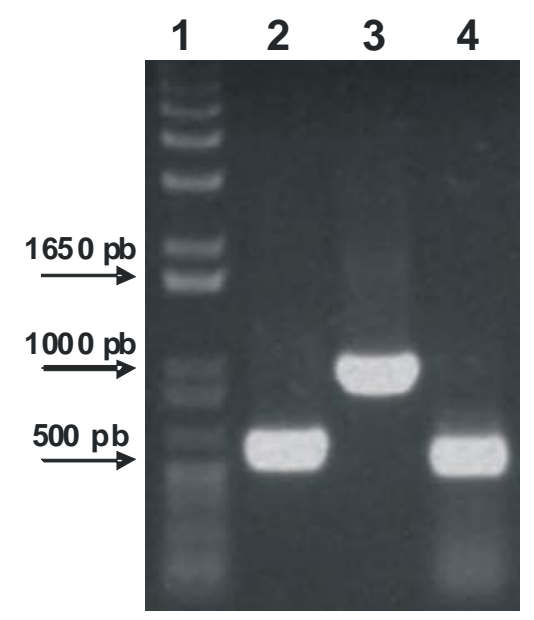

As bandas obtidas apresentaram o tamanho esperado de $570 \mathrm{pb}$ para N-terminal/LIC10258 (linha 2), 952 pb para Intermediária/LIC10258 (linha 3) e 513 pb para C-terminal/LIC10258 (linha 4). Kb Plus DNA Ladder: marcador molecular (linha 1).

Os insertos de DNA obtidos por meio de PCR foram clonados no vetor pGEMT Easy e utilizados para transformar bactérias competentes DH5a. Após extração do DNA plasmidial das bactérias competentes, os plasmídeos contendo os fragmentos do gene LIC10258 foram digeridos com as enzimas de restrição BamHI e Ncol para certificação da presença dos insertos (figura 31).

Figura 31 - Análise dos insertos de DNA obtidos por digestão do DNA plasmidial (pGEM-T Easy/inserto) em gel de agarose 1\%
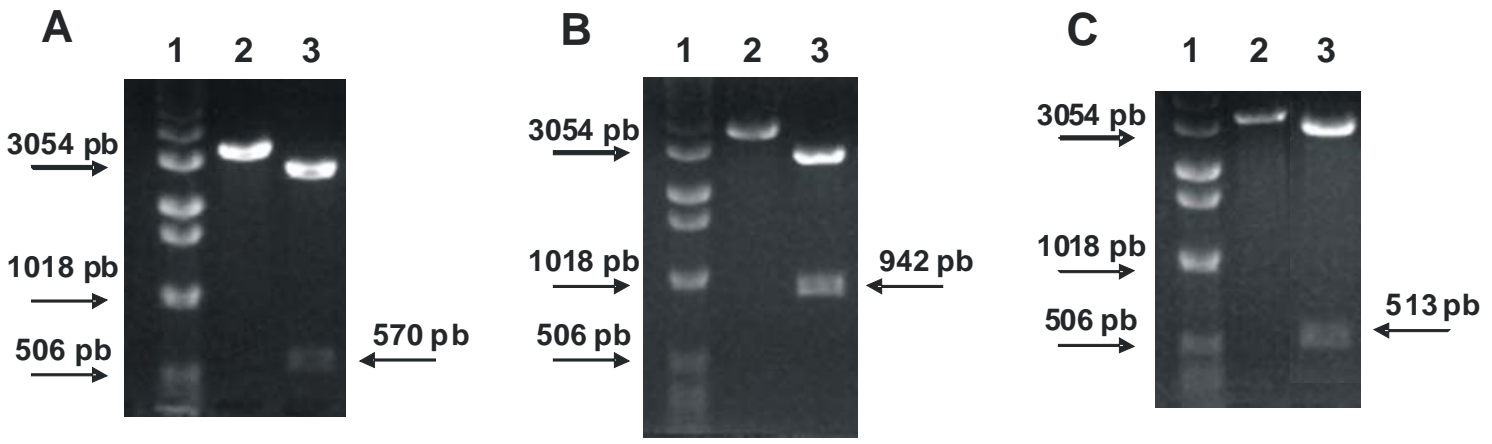

Os plasmídeos recombinantes obtidos foram digeridos com as enzimas $\mathrm{BamHI}$ e $\mathrm{Ncol}$ para confirmação da presença do inserto de interesse. A) N-terminal/LIC10258; B) Intermediário/LIC10258 e C) C-terminal/LIC10258, onde 1: Kb DNA Ladder (marcador molecular). 2: plasmídeo contendo inserto e 3: plasmídeo digerido + inserto liberado.

Os insertos correspondentes as porções N-terminal, Intermediária e Cterminal do gene LIC10258 foram removidos dos plasmídeos recombinantes (pGEM- 
T/inserto) e subclonados no vetor de expressão pAE (RAMOS et al., 2004). Os clones positivos foram selecionados por meio da extração rápida por fenolclorofórmio e após obtenção do DNA plasmidial (pAE/inserto) os clones foram digeridos com as enzimas BamHI e Ncol para confirmação da presença dos insertos (figura 32).

Figura 32 - Análise dos insertos de DNA obtidos por digestão do DNA plasmidial (pAE/inserto) em gel de agarose 1\%

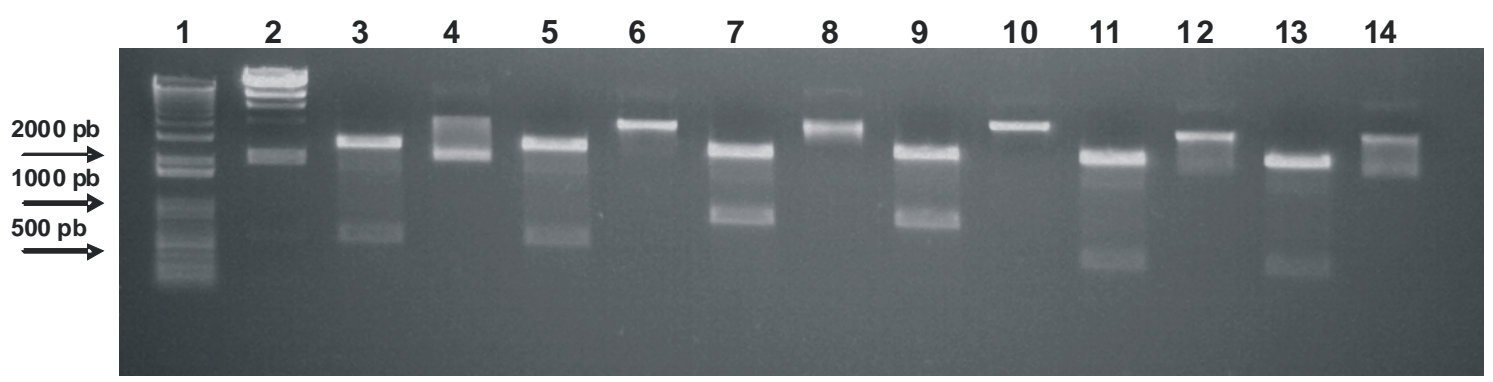

Após seleção por fenol-clorofórmio, os clones positivos foram purificados e os plasmídeos obtidos digeridos com as enzimas apropriadas. Linhas 3 a 6 : $\mathrm{N}$-terminal/LIC10258, onde linhas 3 e 5 : plasmídeo digerido + inserto liberado e linhas 4 e 6: plasmídeo contendo inserto. Linhas 7 a 10: Intermediário/LIC10258, onde linhas 7 e 9: plasmídeo digerido + inserto liberado e linhas 8 e 10: plasmídeo contendo inserto. Linhas 11 a 14: C-terminal/LIC10258, onde linhas 11 e 13: plasmídeo digerido + inserto liberado e linhas 12 e 14: plasmídeo contendo inserto. Linha 1: Kb Plus DNA Ladder e linha 2: $\lambda$ hind III (Marcadores moleculares).

\subsection{Sequenciamento dos clones}

O sequenciamento confirmou a presença dos insertos de DNA correspondentes as porções $\mathrm{N}$-terminal, Intermediária e C-terminal do gene LIC10258, tanto no vetor de clonagem pGEM-T Easy quanto no vetor de expressão pAE. Todas as sequências codificadoras foram confirmadas pelo programa BLAST (ALTSCHUL et al., 1990) mostrando $100 \%$ de identidade quando comparadas com a sequência de bases nitrogenadas do gene LIC10258, tanto no vetor pGEM-T Easy quanto no vetor pAE (Anexo C).

\subsection{Expressão e purificação dos fragmentos recombinantes}

Os fragmentos correspondentes as porções N-terminal, Intermediária e Cterminal do gene LIC10258 foram expressos, solubilizados e purificados sob as mesmas condições que a proteína rLIC10258. Sendo assim, bactérias E. coli BL21 
SI transformadas com o vetor de expressão pAE foram induzidas a expressar os fragmentos recombinantes. Após indução com $30 \mathrm{mM}$ de $\mathrm{NaCl}$, os fragmentos recombinantes foram expressos na forma insolúvel como corpúsculos de inclusão e solubilizados com $8 \mathrm{M}$ uréia e 10\% glicerol de acordo com o protocolo descrito por Saini e colaboradores (2002) (SAINI et al., 2002). Após solubilização, os fragmentos recombinantes foram purificados por cromatografia de afinidade utilizando resina carregada com níquel. Os fragmentos purificados foram analisados em gel de SDSPAGE e apresentaram a massa molecular esperada de 25,5; 36,9 e 23,3 kDa para os fragmentos $\mathrm{N}$-terminal, Intermediário e C-terminal, respectivamente (Figura 33).

Figura 33 - Análise dos fragmentos recombinantes purificados em gel de SDS-PAGE

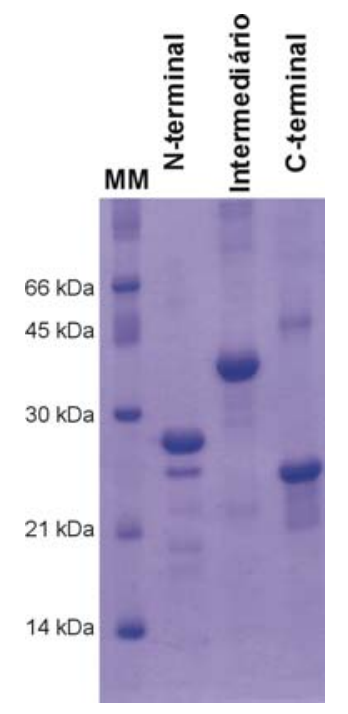

Os fragmentos recombinantes correspondentes as porções $\mathrm{N}$-terminal, Intermediária e C-terminal da proteína rLIC10258 foram purificados por cromatografia de afinidade a metal. As bandas de proteínas com os tamanhos esperados de aproximadamente 25,5; 36,9 e 23,3 kDa, correspondendo aos fragmentos $\mathrm{N}$-terminal, Intermediário e C-terminal respectivamente, foram visualizadas por Comassie blue. MM: marcador molecular.

\subsection{Reconhecimento dos fragmentos $\mathrm{N}$-terminal, Intermediário e C-terminal por anticorpos monoclonais anti-His tag e policlonais homólogos por Western blotting}

Neste ensaio, os fragmentos recombinantes foram aplicados em gel SDS/PAGE e transferidos para membrana de nitrocelulose. As membranas foram incubadas com anticorpos monoclonais anti-His tag (1:2000) e também com anticorpos policlonais contra os fragmentos $\mathrm{N}$-terminal, Intermediário e C-terminal na diluição 1:500. A figura 34A mostra que os soros policlonais homólogos foram 
capazes de reconhecer tanto a proteína rLIC10258 quanto os fragmentos recombinantes originados desta proteína. Além disso, os fragmentos recombinantes também foram reconhecidos por anticorpos monoclonais anti-His tag (Figura 34B).

Figura 34 - Reconhecimento dos fragmentos recombinantes por anticorpos contra resíduos de histidina e policlonais homólogos por Western blotting
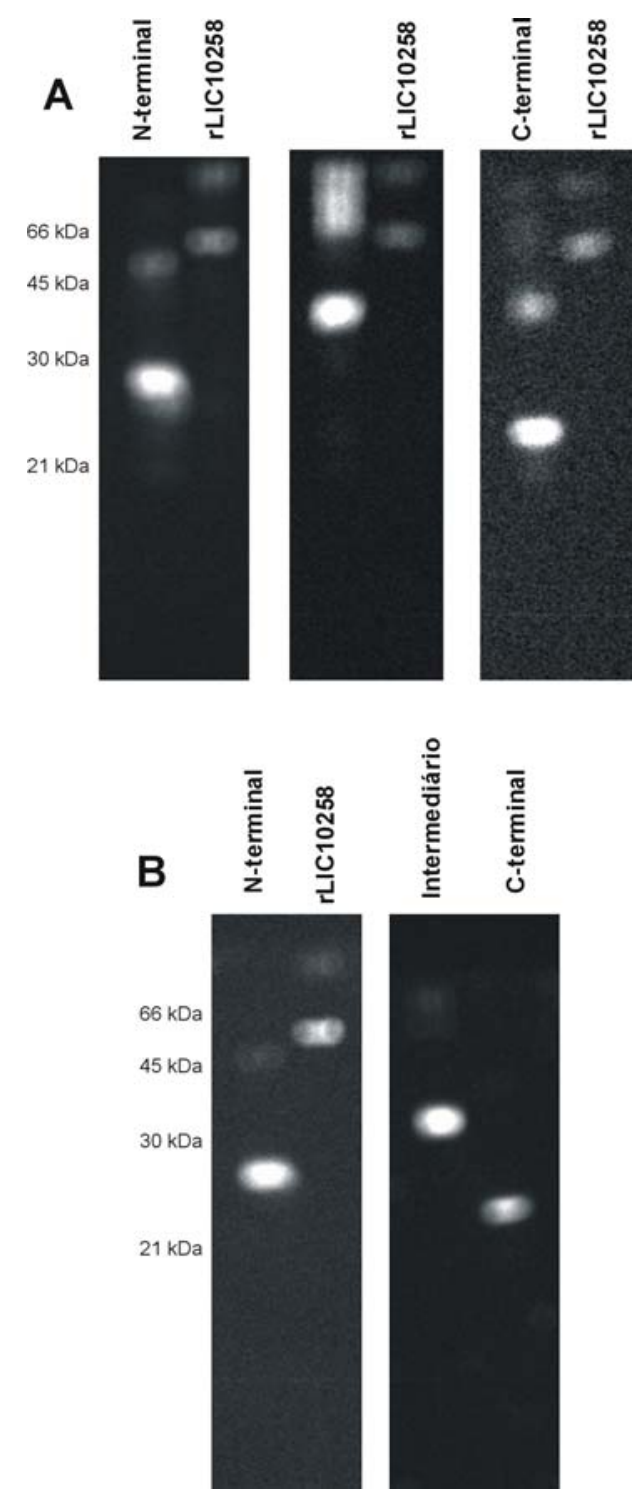

Os fragmentos recombinantes foram detectados por anticorpo monoclonal anti-His tag (A) e por policlonais contra os fragmentos recombinantes do gene LIC10258 produzidos em camundongos (B). 


\subsection{Presença de anticorpos IgG e IgM humanos contra os fragmentos recombinantes da proteína rLIC10258 em soros de pacientes diagnosticados com leptospirose}

A proteína recombinante rLIC10258 é reconhecida por anticorpos presentes nos soros de pacientes diagnosticados com leptospirose, apresentando 35 e $10 \%$ de respondedores para anticorpos IgG e IgM humanos, respectivamente. Além disso, rLIC10258 foi reconhecida por 35\% de anticorpos IgG de pacientes na fase inicial da doença, quando o MAT ainda é negativo. Sendo assim, 36 amostras de soros de 18 pacientes diagnosticados com leptospirose foram analisadas quanto a presença de anticorpos $\lg \mathrm{G}$ e $\lg \mathrm{M}$ contra os fragmentos recombinantes da proteína rLIC10258 (Anexo D). O valor de cutoff foi estabelecido a partir de 18 amostras de soros de indíviduos normais que relataram não terem entrado em contato com a doença. Os valores de cutoff, contra anticorpos IgG, obtidos para os fragmentos recombinantes $\mathrm{N}$-terminal, Intermediário e C-terminal foram de 0,105; 0,150 e 0,155 nm, respectivamente, enquanto que contra anticorpos IgM todos os valores de cutoff foram abaixo de $0,1 \mathrm{~nm}$.

Como não foram detectados anticorpos IgM humanos contra os fragmentos recombinantes em nenhuma das amostras testadas, a tabela 05 apresenta apenas o percental de respondedores que apresentaram anticorpos IgG contra os fragmentos recombinantes de rLIC10258. Como pode ser observado, não foram detectados anticorpos $\lg$ contra o fragmento C-terminal em nenhuma das amostras testadas. Por outro lado, tanto o fragmento recombinante $\mathrm{N}$-terminal quanto o Intermediário foram reconhecidos por anticorpos $\lg$ de pacientes diagnosticados com leptospirose. Para ambos fragmentos recombinantes, 0 percentual de respondedores foi maior na fase convalescente da doença. Porém, é importante ressaltar que estes fragmentos apresentaram $27,7 \%$ de respondedores na fase inicial da doença. Este resultado foi semelhante ao da proteína rLIC10258 que foi reconhecida por $35 \%$ de amostras de pacientes na fase inicial da doença, quando o MAT ainda é negativo. 
Tabela 05 - Distribuição de respondedores para anticorpos IgG na fase inicial (MAT-) e convalescente (MAT+) da doença

\begin{tabular}{cccc}
\hline Fases da Doença & N-terminal & Intermediário & C-terminal \\
\hline $\begin{array}{c}\text { Fase Inicial } \\
\text { MAT }(-) n=18\end{array}$ & $5(27,7 \%)$ & $5(27,7 \%)$ & ---- \\
$\begin{array}{c}\text { Fase } \\
\text { Convalescente } \\
\text { MAT }(+) n=18\end{array}$ & $7(38,8 \%)$ & $12(66,6 \%)$ & ---- \\
Total $n=36$ & $12(33,3 \%)$ & $17(47,2 \%)$ & --- \\
\hline
\end{tabular}

\subsection{Ligação dos fragmentos recombinantes de rLIC10258 a laminina, fibronectina plasmática e PLG}

Como a proteína recombinante rLIC10258 é capaz de ligar a laminina, fibronectina plasmática e PLG (OLIVEIRA et al., 2011), foram obtidos fragmentos recombinantes correspondentes as porções $\mathrm{N}$-terminal, Intermediária e C-terminal desta proteína com o intuito de identificar qual o fragmento responsável pela interação de rLIC10258 com os componentes acima citados. Sendo assim, placas de microdiluição foram adsorvidas com laminina, fibronectina plasmática, PLG e BSA (controle negativo) e a interação destes componentes com os fragmentos recombinantes $\mathrm{N}$-terminal, Intermediário e C-terminal foi avaliada por ELISA.

Como mostra a figura 35A, não foi observada a ligação do fragmento $\mathrm{N}$ terminal a nenhum dos componentes testados. Em contrapartida, o fragmento Intermediário foi capaz de se ligar a todos os componentes, enquanto o fragmento C-terminal interagiu apenas com a laminina. Resultados semelhantes foram obtidos quando anticorpos monoclonais anti-His foram utilizados (Figura 35B). As interações foram estatisticamente significantes quando comparadas com o controle negativo BSA $\left({ }^{*} P<0,0005 ;{ }^{* *} P<0,005\right)$.

Também foi analisado o efeito da desnaturação ou bloqueio com soro homológo dos fragmentos recombinantes na ligação com a laminina, fibronectina 
plasmática e PLG. A figura 36A mostra que tanto a desnaturação quanto o bloqueio do fragmento Intermediário não foram capazes de inibir totalmente a ligação deste fragmento a laminina, fibronectina plasmática e PLG. Da mesma forma, a desnaturação e o bloqueio do fragmento C-terminal também não foram capazes de abolir totalmente a adesão do fragmento C-terminal a laminina (Figura 36B). Esses resultados sugerem a participação de sítios de ligação lineares e não imunogênicos na interação entre os fragmentos recombinantes e laminina, fibronectina plasmática e PLG. É importante ressaltar que resultados semelhantes foram obtidos com a proteína rLIC10258 (Figura 17C).

Figura 35 - Ligação dos fragmentos recombinantes com MECs e PLG
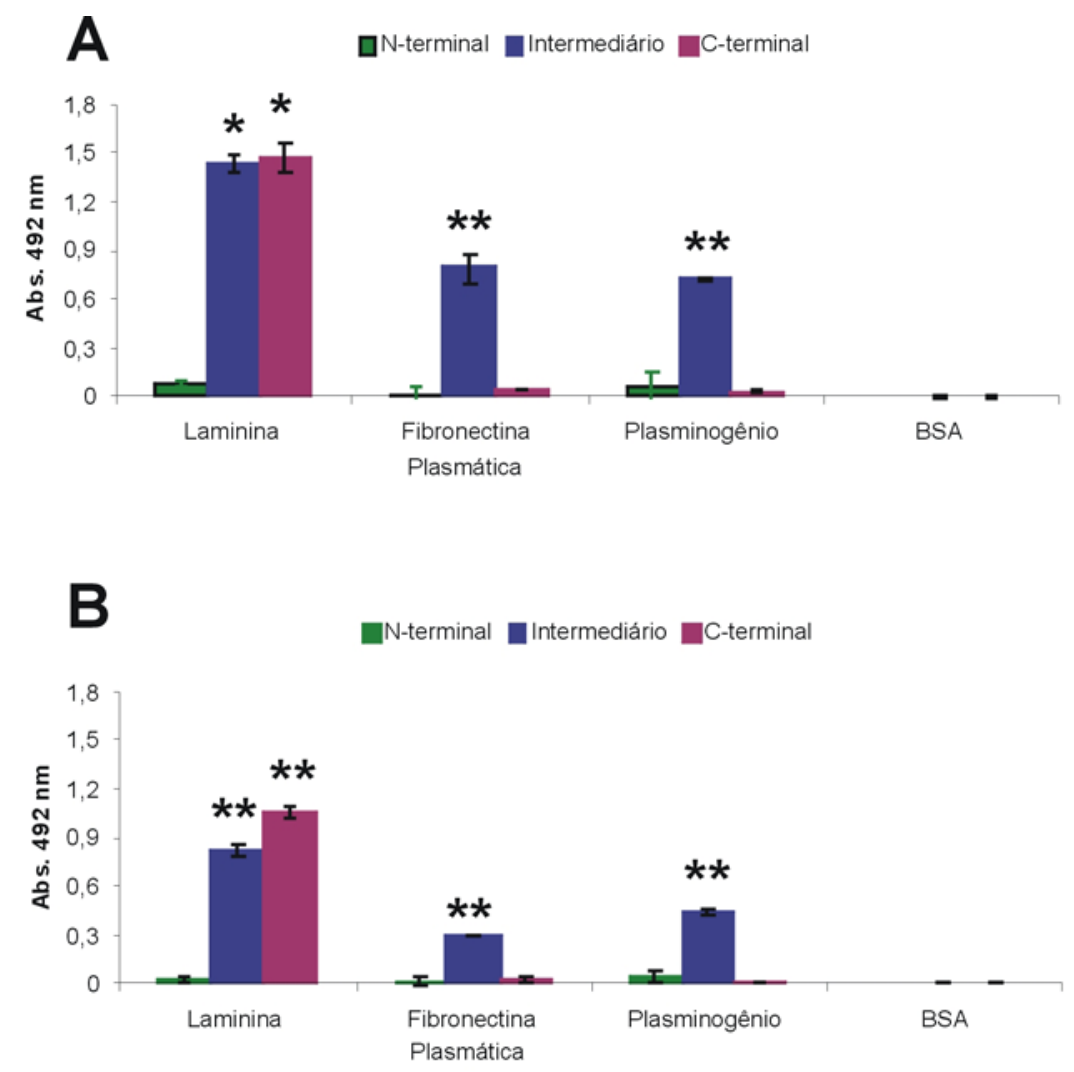

A ligação dos fragmentos recombinantes a laminina, fibronectina plasmática e PLG foi avaliada por ensaio de ELISA utilizando anticorpos policlonais anti-fragmentos recombinantes (A) ou anticorpos monoclonais anti-His tag (B). Os dados representam uma média de três ensaios independentes. Para análises estatísticas, a interação dos fragmentos recombinantes aos componentes foi comparada com a interação dos controles negativos pelo Student's two-tailed t test $\left({ }^{*} P<0,0005 ;{ }^{* *} P<0,005\right)$. 
Figura 36 - Efeito da desnaturação e bloqueio dos fragmentos recombinantes na interação com MECs e PLG
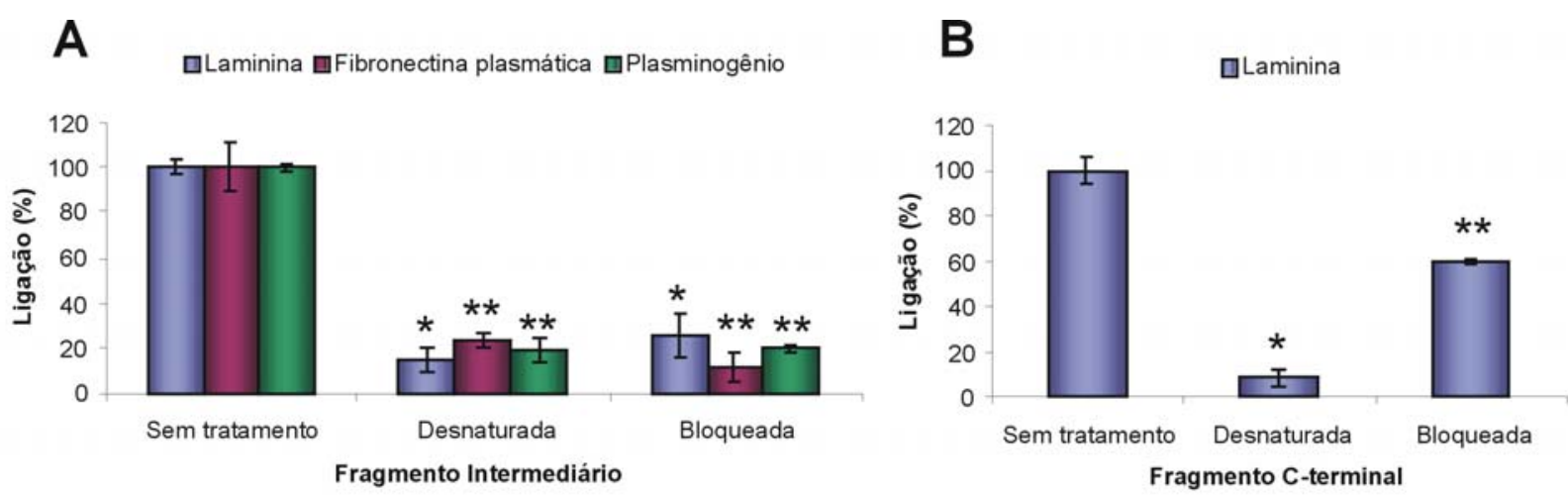

Laminina, fibronectina plasmática e plasminogênio foram incubados com o fragmento Intermediário desnaturado a $96{ }^{\circ} \mathrm{C}$ por 10 minutos ou bloqueado com policlonais homólogos (A). Da mesma maneira, o fragmento $C$-terminal desnaturado ou bloqueado foi incubado com laminina (B). Os dados são representativos de dois experimentos independentes. Significância estatística em relação aos fragmentos recombinantes não tratados pelo Student's two-tailed t test $\left({ }^{*} P<0,005 ;{ }^{* \star} P<0,05\right)$.

A especificidade da adesão dos fragmentos Intermediário e C-terminal a laminina foi avaliada em ensaio de dose-dependência e saturação. A figura 37A mostra que quando houve variação crescente da concentração dos fragmentos recombinantes (0 a $2000 \mathrm{nM}$ ) na presença fixa de laminina (1 $\mu \mathrm{g} / \mathrm{poço}$ ) a interação foi saturável e dose-dependente. A saturação desta ligação foi alcançada com aproximadamente $1000 \mathrm{nM}$ de fragmentos recombinantes. Baseado nos dados de ELISA, as constantes de dissociação (KD) dos fragmentos recombinantes com a laminina foram de $51,10 \pm 5,50 \mathrm{nM}$ e 75,32 \pm 14,50 nM para os fragmentos Intermediário e C-terminal, respectivamente. O fragmento N-terminal foi incluído como controle negativo da adesão.

Da mesma maneira, a especificidade da interação do fragmento Intermediário com a fibronectina plasmática e o PLG foi analisada em ensaio de dosedependência e saturação variando a concentração do fragmento Intermediário (0 a $4000 \mathrm{nM}$ ) na presença fixa dos componentes (1 $\mu \mathrm{g} / \mathrm{poço})$. A figura 37B e 37C mostra que a ligação foi dose-dependente e alcançou a saturação com aproximadamente 2000 e 3000 nM de fragmento Intermediário para fibronectina plasmática e PLG, respectivamente. Baseado nos dados de ELISA, a constante de dissociação calculada para o fragmento Intermediário com a fibronectina plasmática foi de $166,03 \pm 41,50 \mathrm{nM}$, enquanto que para o fragmento Intermediário com o PLG foi de 
$744,70 \pm 177,50 \mathrm{nM}$. Os fragmentos N-terminal e C-terminal foram incluídos como controles negativos da interação.

Figura 37 - Análise da especificidade da ligação dos fragmentos recombinantes com laminina, fibronectina plasmática e PLG
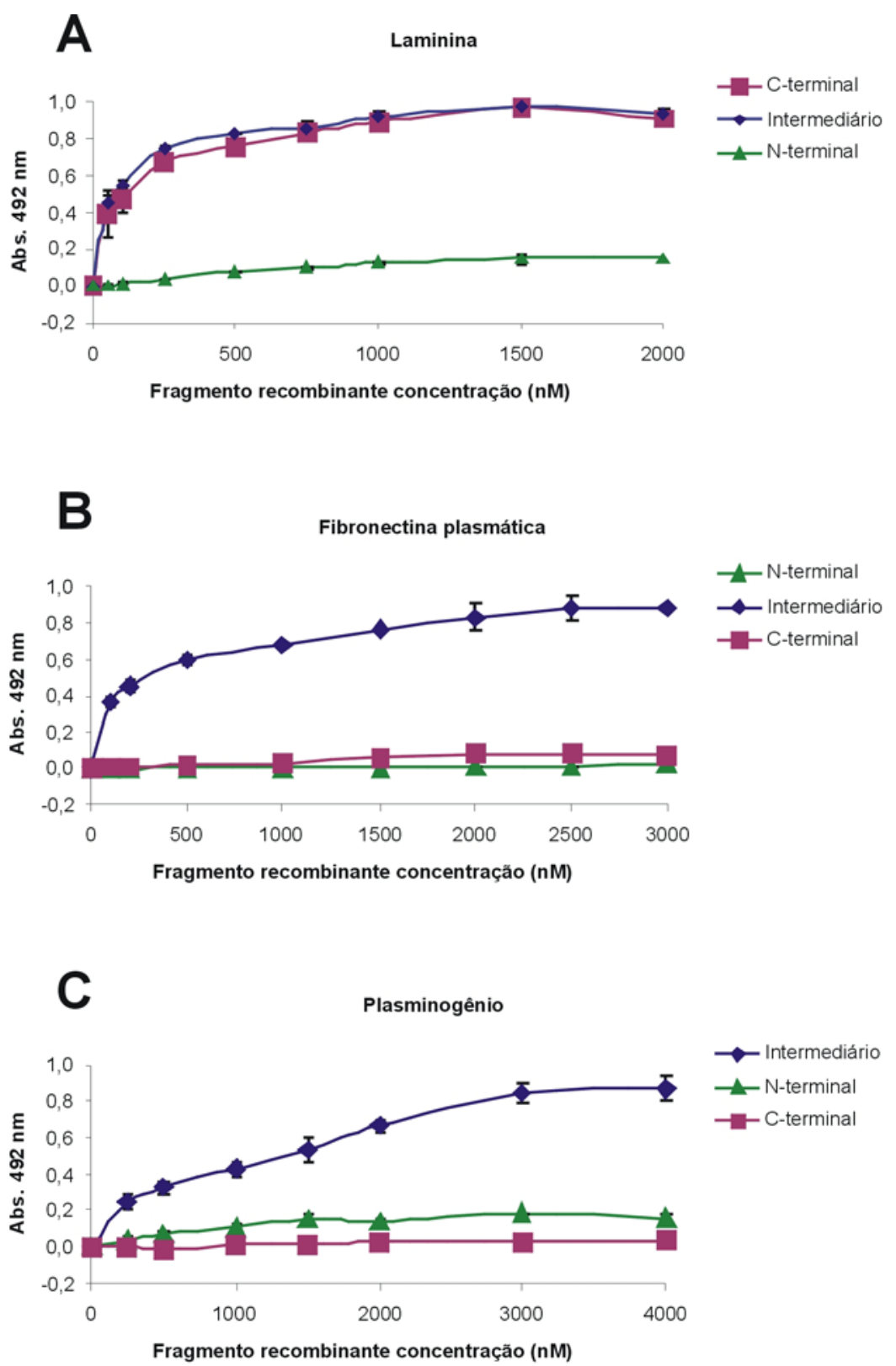

Para avaliar a capacidade dos fragmentos Intermediário e C-terminal aderirem a laminina e do fragmento Intermediário interagir com a fibronectina plasmática e PLG, placas de ELISA foram adsorvidas com laminina (A), fibronectina plasmática (B) e PLG (C) e incubadas com concentrações crescentes dos fragmentos recombinantes (0 a $4000 \mathrm{nM}$ ). A ligação foi detectada com policlonais anti-fragmentos recombinantes $(1: 1000)$ seguido da incubação com anti-lgG mouse peroxidade (1:5000). Os dados são representativos de três experimentos independentes. O desvio padrão representa a média de cada ponto realizado em triplicata. 


\subsection{Contribuição dos carboidratos da laminina e fibronectina plasmática na interação com os fragmentos recombinantes de rLIC10258}

Para analisar a participação dos carboidratos da laminina na interação com os fragmentos Intermediário e C-terminal de rLIC10258, este componente foi oxidado com concentrações crescentes de metaperiodato de sódio (0 a $100 \mathrm{mM}$ ). A figura 38A mostra que não foi observada diminuição da ligação destes fragmentos com a laminina oxidada.

A fibronectina plasmática também foi tratada com metaperiodato de sódio para investigar o envolvimento de seus açúcares na ligação com a porção Intermediária da proteína rLIC10258. Como pode ser observado na figura 38B, houve diminuição da interação deste fragmento com a fibronectina plasmática oxidada. O efeito da oxidação na interação entre este componente e o fragmento Intermediário foi dose-dependente e estatisticamente significante quando comparado a fibronectina não tratada $\left({ }^{*} P<0,01\right)$. Resultados semelhantes foram obtidos na análise da interação da proteína rLIC10258 com a laminina e fibronectina plasmática oxidada. Sendo assim, esses resultados corroboram que apenas os resíduos de açúcares da fibronectina plasmática estão envolvidos na interação com a proteína rLIC10258. 
Figura 38 - Contribuição dos resíduos de açúcar na interação dos fragmentos recombinantes com a laminina e a fibronectina plasmática
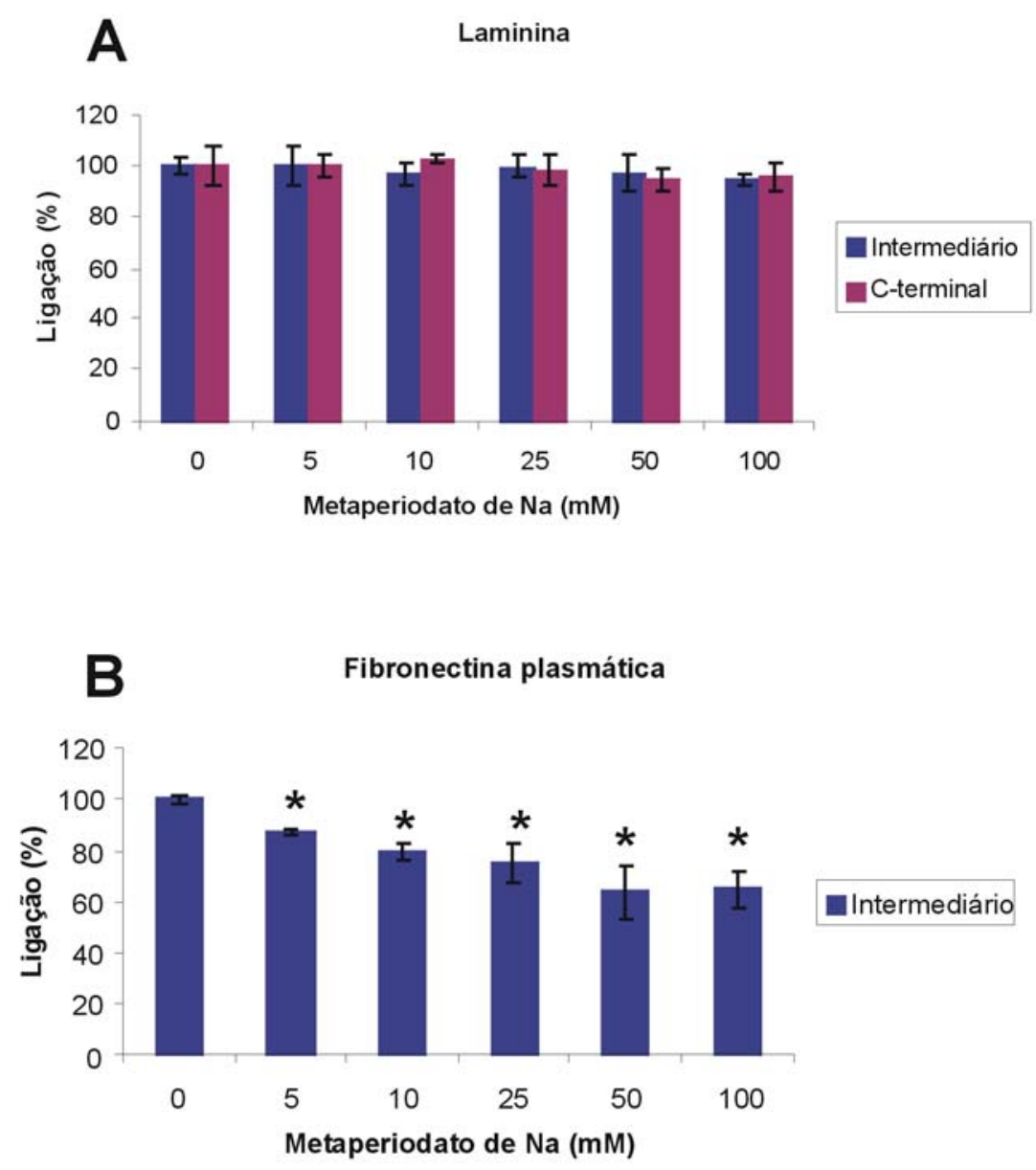

Laminina (A) e fibronectina plasmática (B) foram imobilizadas e tratadas com metaperiodato $(0$ a 100 $\mathrm{mM})$ por 15 minutos, no escuro, a $4{ }^{\circ} \mathrm{C}$. Barras representam a média dos valores de absorbância a $492 \mathrm{~nm} \pm$ o desvio padrão de três replicatas para cada grupo experimental. Os dados são representativos de dois experimentos independentes. Significância estatística em relação a fibronectina plasmática não oxidada pelo Sudent's two-tailed t test $\left({ }^{*} \mathrm{P}<0,01\right)$.

\subsection{Interferência da fibronectina plasmática na ligação do PLG ao fragmento Intermediário de rLIC10258}

Tanto a fibronectina plasmática quanto o PLG são capazes de interagir com o fragmento Intermediário. Devido a esse fato foi analisado se estes componentes competem pelo mesmo sítio de ligação na porção Intermediária da proteína rLIC10258. Portanto foram realizados ensaios para avaliar a ligação do fragmento Intermediário ao PLG na presença de concentrações crescentes de fibronectina plasmática (0 a $1 \mu \mathrm{g}$ ) e da ligação do fragmento Intermediário a fibronectina plasmática na presença de concentrações crescentes de PLG ( 0 a $1 \mu \mathrm{\mu g})$. Os 
resultados mostram que a presença de fibronectina plasmática não interfere na ligação do PLG ao fragmento Intermediário (Figura 39A). Da mesma forma, a presença de PLG também não interfere na ligação da fibronectina plasmática a porção Intermediária de rLIC10258 (Figura 39B), sugerindo que estes componentes não competem pelo mesmo sítio de ligação no fragmento Intermediário.

Figura 39 - Fibronectina plasmática e PLG não competem pela ligação ao fragmento Intermediário
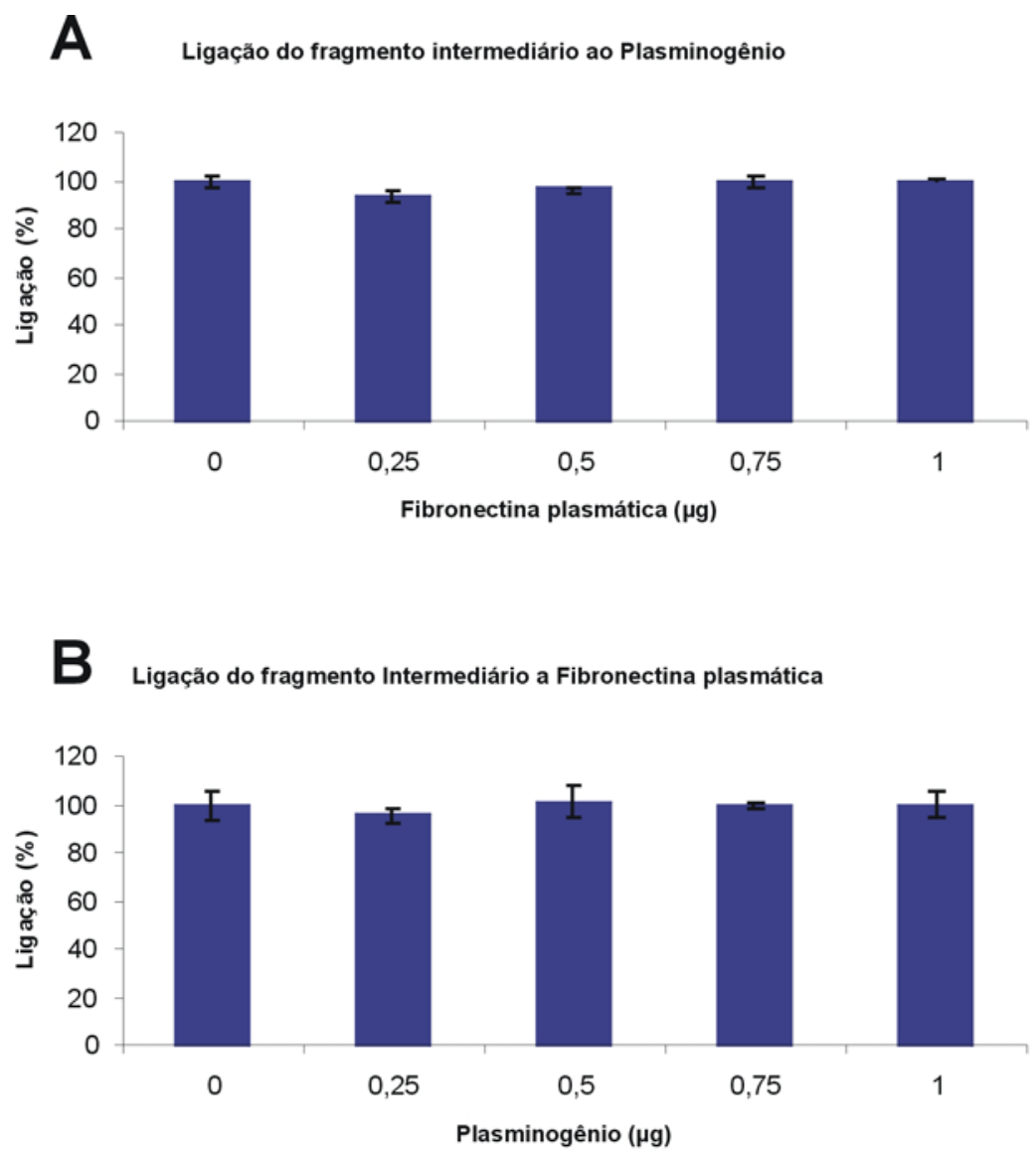

(A) O efeito da fibronectina plasmática na ligação do PLG $(10 \mu \mathrm{g} / \mathrm{ml})$ ao fragmento Intermediário imobilizado $(10 \mu \mathrm{g} / \mathrm{ml})$ foi analisado pela adição de concentrações crescentes de fibronectina plasmática (0 to $1 \mu \mathrm{g}$ ). (B) Da mesma forma, o efeito do PLG na ligação da fibronectina plasmática $(10 \mu \mathrm{g} / \mathrm{ml})$ ao fragmento Intermediário imobilizado $(10 \mu \mathrm{g} / \mathrm{ml})$ foi investigado pela adição de concentrações crescentes de PLG $(0$ to $1 \mu \mathrm{g})$. A detecção da ligação do fragmento intermediário com o PLG (A) ou fibronectina plasmática (B) foi realizado utilizando-se anticorpos específicos contra os componentes. Os dados são representativos de dois experimentos independentes. $\mathrm{O}$ desvio padrão representa a média de cada ponto realizado em triplicata. 


\subsection{Região imunodominante da proteína rLIC10258}

Para analisar qual a porção imunodominante da proteína rLIC10258 foram obtidos fragmentos recombinantes correspondentes as porções N-terminal, Intermediária e C-terminal desta proteína. O fragmento Intermediário foi construído com regiões de sobreposição tanto no fragmento N-terminal, entre os aminoácidos 170 e 219, quanto no C-terminal, entre os aminoácidos 420 e 483 (Figura 29).

Os resultados mostraram que tanto o fragmento Intermediário quanto o Cterminal foram capazes de interagir com a laminina. O perfil da ligação destes fragmentos com a laminina e os valores de KD obtidos foram semelhantes aos apresentados pela proteína rLIC10258 (Figura 18A). Portanto, como o fragmento Intermediário e C-terminal possuem uma região de sobreposição entre os aminoácidos 420 e 483, os resultados obtidos sugerem que a interação entre estes fragmentos e a laminina ocorra nesta região comum.

Em relação a fibronectina plasmática e o PLG, apenas o fragmento Intermediário foi capaz de interagir com estes componentes, sugerindo que estas interações não ocorrem nas regiões que o fragmento Intermediário possui em comum com os fragmentos $\mathrm{N}$-terminal e $\mathrm{C}$-terminal. $\mathrm{O}$ perfil da ligação do fragmento Intermediário com a fibronectina plasmática e o valor de KD obtidos foram semelhantes ao apresentado pela proteína rLIC10258 (Figura 18B), por outro lado a afinidade da ligação entre o fragmento Intermediário e PLG foi menor do que o obtido para rLIC10258 (Figura 21). Além disso, o ensaio de competição revelou que a fibronectina plasmática e o PLG não competem pelo mesmo sítio de ligação no fragmento Intermediário.

Sendo assim, os resultados indicam que a região imunodominante da proteína rLIC10258, responsável pela ligação a laminina, fibronectina plasmática e PLG está localizada entre os aminoácidos 220 e 483. A interação com a laminina possivelmente ocorre entre os aminoácidos 420 e 483, enquanto que entre os aminoácidos 220 e 419 possivelmente estão localizados os sítios de ligação a fibronectina plasmática e PLG (Figura 40). Além disso, os resultados obtidos sugerem que o domínio OmpA-like na porção C-terminal da proteína rLIC10258 não está envolvido na interação desta proteína com a laminina, fibronectina plasmática e PLG. 
Figura 40 - Esquema demonstrando o domínio imunodominante da proteína rLIC10258

\section{Proteína rLIC10258}

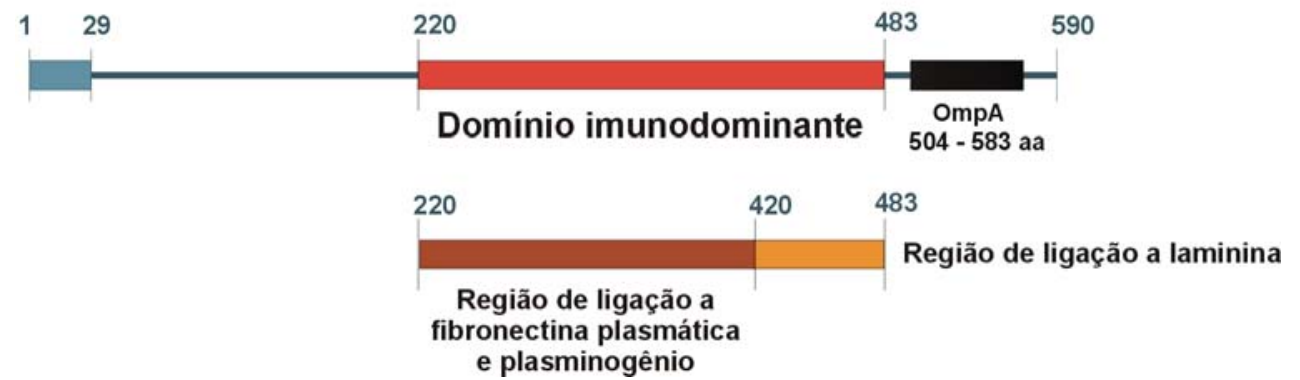

A região imunodominante da proteína rLIC10258 está situada entre os aminoácidos 220 e 483 . Entre os aminoácidos 220 e 419 estão localizados os sítios de ligação da fibronectina plasmática e PLG, enquanto que a ligação da laminina ocorre entre os aminoácidos 420 e 483. 


\section{CONCLUSÃO}

Todas as proteínas recombinantes deste estudo ligam-se ao PLG. Além disso, a proteína rLIC10258 é capaz de aderir a laminina e fibronectina plasmática e a proteína rLIC12238 interage com o fibrinogênio. Portanto, as proteínas deste estudo podem auxiliar tanto na adesão ao hospedeiro quanto na penetração dos tecidos por meio da conversão do PLG em plasmina. Além disso, os resultados obtidos sugerem que estas proteínas estão localizadas na superfície de $L$. interrogans sorovar Copenhageni e estão sendo expressas durante a infecção no hospedeiro. Portanto, as proteínas codificadas pelos genes LIC10258, LIC12880 e LIC12238, apesar de não possuírem atividade imunoprotetora, provavelmente estão envolvidas na patogenicidade das leptospiras. 


\section{REFERÊNCIAS}

ADLER, B.; DE LA PENA MOCTEZUMA, A. Leptospira and leptospirosis. Vet. Microbiol., v. 140, n. 3-4, p. 287-296, 2010.

ALITALO, A. et al. Complement inhibitor factor $\mathrm{H}$ binding to Lyme disease spirochetes is mediated by inducible expression of multiple plasmid-encoded outer surface protein E paralogs. J. Immunol., v. 169, n. 7, p. 3847-3853, 2002.

ALTSCHUL, S. F. et al. Basic local alignment search tool. J. Mol. Biol., v. 215, n. 3, p. 403-410, 1990.

ATZINGEN, M. V. et al. Lsa21, a novel leptospiral protein binding adhesive matrix molecules and present during human infection. BMC Microbiol., v. 8, p. 70, 2008.

. Lp95, a novel leptospiral protein that binds extracellular matrix components and activates e-selectin on endothelial cells. J. Infect., v. 59, n. 4, p. 264-276, 2009.

Characterization of leptospiral proteins that afford partial protection in hamsters against lethal challenge with Leptospira interrogans. J. Med. Microbiol., v. 59, Pt 9, p. 1005-1015, 2010.

BAMFORD, C. V. et al. The chymotrypsin-like protease complex of Treponema denticola ATCC 35405 mediates fibrinogen adherence and degradation. Infect. Immun., v. 75, n. 9, p. 4364-4372, 2007.

BARBOSA, A. S. et al. A newly identified leptospiral adhesin mediates attachment to laminin. Infect. Immun., v. 74, n. 11, p. 6356-6364, 2006.

Immune evasion of leptospira species by acquisition of human complement regulator C4BP. Infect. Immun., v. 77, n. 3, p. 1137-1143, 2009.

. Functional characterization of LcpA, a surface-exposed protein of Leptospira spp. that binds the human complement regulator C4BP. Infect. Immun., v. 78, n. 7, p. 3207-3216, 2010.

BHANDARI, P.; GOWRISHANKAR, J. An Escherichia coli host strain useful for efficient overproduction of cloned gene products with $\mathrm{NaCl}$ as the inducer. $\mathbf{J}$. Bacteriol., v. 179, n. 13, p. 4403-4406, 1997.

BHARTI, A. R. et al. Leptospirosis: a zoonotic disease of global importance. Lancet. Infect. Dis., v. 3, n. 12, p. 757-771, 2003.

\footnotetext{
*De acordo com: ASSOCIAÇÃO BRASILEIRA DE NORMAS TÉCNICAS. NBR 6023: informação e documentação: referências: elaboração. Rio de Janeiro, 2002.
} 
BRANGER, C. et al. Identification of the hemolysis-associated protein 1 as a crossprotective immunogen of Leptospira interrogans by adenovirus-mediated vaccination. Infect. Immun., v. 69, n. 11, p. 6831-6838, 2001.

BRASIL. Ministério da Saúde. Secretaria de Vigilância em Saúde. Guia de Vigilância Epidemiológica. 6 ed. Brasília, 2005

BRINKMAN, F. S.; BAINS, M.; HANCOCK, R. E. The amino terminus of Pseudomonas aeruginosa outer membrane protein OprF forms channels in lipid bilayer membranes: correlation with a three-dimensional model. J. Bacteriol., v. 182, n. 18, p. 5251-5255, 2000.

BRISSETTE, C. A. et al. Borrelia burgdorferi infection-associated surface proteins ErpP, ErpA, and ErpC bind human plasminogen. Infect. Immun., v. 77, n. 1, p. 300306, 2009.

BROWN, P. D. et al. Evaluation of the polymerase chain reaction for early diagnosis of leptospirosis. J. Med. Microbiol., v. 43, n. 2, p. 110-114, 1995.

BULACH, D. M. et al. Genome reduction in Leptospira borgpetersenii reflects limited transmission potential. Proc. Natl. Acad. Sci. U. S. A., v. 103, n. 39, p. $14560-$ 14565, 2006.

CANTOR, C. R. DNA choreography. Cell, v. 25, n. 2, p. 293-295, 1981.

$\mathrm{CAO}, \mathrm{Y}$. et al. Evaluation of novel fusion proteins derived from extracellular matrix binding domains of LigB as vaccine candidates against leptospirosis in a hamster model. Vaccine, v. 29, n. 43, p. 7379-7386, 2011.

CASCALES, E. et al. Pal lipoprotein of Escherichia coli plays a major role in outer membrane integrity. J. Bacteriol., v. 184, n. 3, p. 754-759, 2002.

CASTIBLANCO-VALENCIA, M. M. et al. Leptospiral Immunoglobulin-like Proteins Interact With Human Complement Regulators Factor H, FHL-1, FHR-1, and C4BP. J. Infect. Dis., v. 205, n. 6, p. 995-1004, 2012.

CHOU, L. F. et al. Sequence of Leptospira santarosai serovar Shermani genome and prediction of virulence-associated genes. Gene, v. 511, n. 2, p. 364-370, 2012.

CHOY, H. A. et al. Physiological osmotic induction of Leptospira interrogans adhesion: LigA and LigB bind extracellular matrix proteins and fibrinogen. Infect. Immun., v. 75, n. 5, p. 2441-2450, 2007.

. The multifunctional LigB adhesin binds homeostatic proteins with potential roles in cutaneous infection by pathogenic Leptospira interrogans. PLoS One, v. 6, n. 2, p. e16879, 2011.

CINCO, M.; BANFI, E. Activation of complement by leptospires and its bactericidal activity. Zentralbl. Bakteriol. Mikrobiol. Hyg. A., v. 254, n. 2, p. 261-265, 1983. 
DOMINGOS, R. F. et al. Features of two proteins of Leptospira interrogans with potential role in host-pathogen interactions. BMC. Microbiol., v. 12, p. 50, 2012.

EVANGELISTA, K. V.; COBURN, J. Leptospira as an emerging pathogen: a review of its biology, pathogenesis and host immune responses. Future Microbiol., v. 5, n. 9, p. 1413-1425, 2010.

FAINE, S. et al. Leptospira and Leptospirosis. Melbourne, Australia MediSci, 1999.

FONSECA CDE, A. et al. Leptospira DNA detection for the diagnosis of human leptospirosis. J. Infect., v. 52, n. 1, p. 15-22, 2006.

FRAGA, T. R.; BARBOSA, A. S.; ISAAC, L. Leptospirosis: aspects of innate immunity, immunopathogenesis and immune evasion from the complement system. Scand. J. Immunol., v. 73, n. 5, p. 408-419, 2011.

FIOCRUZ. Fundação Oswaldo Cruz. Ministério da Saúde. Teste rápido para leptospirose deverá ser fabricado ainda este ano. Disponível em: $<$ http://www.fiocruz.br/ccs/cgi/cgilua.exe/sys/start.htm?infoid=1110\&sid=9 $>$. Acesso em: 05 de junho de 2013.

GAMBERINI, M. et al. Whole-genome analysis of Leptospira interrogans to identify potential vaccine candidates against leptospirosis. FEMS. Microbiol. Lett., v. 244, n. 2, p. 305-313, 2005.

GIGLI, I.; FUJITA, T.; NUSSENZWEIG, V. Modulation of the classical pathway C3 convertase by plasma proteins $\mathrm{C} 4$ binding protein and $\mathrm{C} 3 \mathrm{~b}$ inactivator. Proc. Natl. Acad. Sci. U. S. A., v. 76, n. 12, p. 6596-6600, 1979.

HAAKE, D. A. Spirochaetal lipoproteins and pathogenesis. Microbiology, v. 146 ( Pt 7), p. 1491-1504, 2000.

2006.

Hamsters model of leptospirosis. Currents Protocols in Microbiology,

HAAKE, D. A. et al. The leptospiral major outer membrane protein LipL32 is a lipoprotein expressed during mammalian infection. Infect. Immun., v. 68, n. 4, p. 2276-2285, 2000.

HAAKE, D. A.; MATSUNAGA, J. Leptospira: a spirochaete with a hybrid outer membrane. Mol. Microbiol., 2010.

HAAKE, D. A. et al. Leptospiral outer membrane proteins OmpL1 and LipL41 exhibit synergistic immunoprotection. Infect. Immun., v. 67, n. 12, p. 6572-6582, 1999.

HAUK, P. et al. In LipL32, the major leptospiral lipoprotein, the C terminus is the primary immunogenic domain and mediates interaction with collagen IV and plasma fibronectin. Infect. Immun., v. 76, n. 6, p. 2642-2650, 2008. 
HOKE, D. E. et al. LipL32 is an extracellular matrix-interacting protein of Leptospira spp. and Pseudoalteromonas tunicata. Infect. Immun,. v. 76, n. 5, p. 2063-2069, 2008.

HOVIS, K. M. et al. Identification and characterization of a linear-plasmid-encoded factor $\mathrm{H}$-binding protein (FhbA) of the relapsing fever spirochete Borrelia hermsii. J. Bacteriol., v. 186, n. 9, p. 2612-2618, 2004.

JANEWAY, C. A., JR.; FLAVELL, R. A. Immunology at Yale. Immunol. Res., v. 19, n. 2-3, p. 105-106, 1999.

JONES, D. T. Protein secondary structure prediction based on position-specific scoring matrices. J. Mol. Biol., v. 292, n. 2, p. 195-202, 1999.

JUNCKER, A. S. et al. Prediction of lipoprotein signal peptides in Gram-negative bacteria. Protein Sci., v. 12, n. 8, p. 1652-1662, 2003.

KAPLAN, E. L.; MEIER, P. Nonparametric estimation from incomplete observations. J. Am. Stat. Assoc., v. 53, p. 457-481, 1958.

KO, A. I.; GOARANT, C.; PICARDEAU, M. Leptospira: the dawn of the molecular genetics era for an emerging zoonotic pathogen. Nat. Rev. Microbiol., v. 7, n. 10, p. 736-747, 2009.

KOBAYASHI, Y. Discovery of the causative organism of Weil's disease: historical view. J. Infect. Chemother., v. 7, n. 1, p. 10-15, 2001.

KOIZUMI, N.; WATANABE, $H$. Leptospiral immunoglobulin-like proteins elicit protective immunity. Vaccine, v. 22, n. 11-12, p. 1545-52, 2004.

. Leptospirosis vaccines: past, present, and future. J. Postgrad. Med., v. 51, n. 3, p. 210-214, 2005.

KOIZUMI, N. et al. [A case of leptospirosis diagnosed early by flaB-PCR]. Kansenshogaku Zasshi, v. 77, n. 8, p. 627-630, 2003.

KOSITANONT, $U$. et al. Detection and differentiation between pathogenic and saprophytic Leptospira spp. by multiplex polymerase chain reaction. Diagn. Microbiol. Infect. Dis., v. 57, n. 2, p. 117-122, 2007.

LAHTEENMAKI, K.; KUKKONEN, M.; KORHONEN, T. K. The Pla surface protease/adhesin of Yersinia pestis mediates bacterial invasion into human endothelial cells. FEBS. Lett., v. 504, n. 1-2, p. 69-72, 2001.

LAHTEENMAKI, K.; KUUSELA, P.; KORHONEN, T. K. Bacterial plasminogen activators and receptors. FEMS. Microbiol. Rev., v. 25, n. 5, p. 531-552, 2001.

LARKIN, M. A. et al. Clustal $W$ and Clustal $X$ version 2.0. Bioinformatics, v. 23, n. 21, p. 2947-2948, 2007. 
LEVETT, P. N. Leptospirosis. Clin. Microbiol. Rev., v. 14, n. 2, p. 296-326, 2001.

. Usefulness of serologic analysis as a predictor of the infecting serovar in

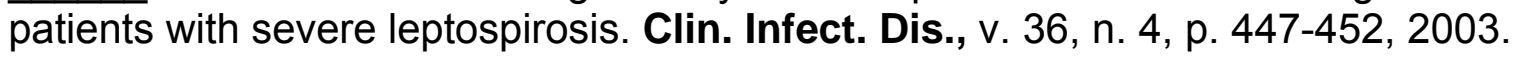

LIAO, S. et al. Inactivation of the fliY gene encoding a flagellar motor switch protein attenuates mobility and virulence of Leptospira interrogans strain Lai. BMC Microbiol., v. 9, p. 253, 2009.

LIN, Y. P. et al. Leptospira immunoglobulin-like protein B (LigB) binding to the Cterminal fibrinogen alphaC domain inhibits fibrin clot formation, platelet adhesion and aggregation. Mol. Microbio.I, v. 79, n. 4, p. 1063-1076, 2011.

LO, M. et al. Effects of temperature on gene expression patterns in Leptospira interrogans serovar Lai as assessed by whole-genome microarrays. Infect. Immun., v. 74, n. 10, p. 5848-5859, 2006.

MALMSTROM, J. et al. Proteome-wide cellular protein concentrations of the human pathogen Leptospira interrogans. Nature, v. 460, n. 7256, p. 762-765, 2009.

MANDEL, M.; HIGA, A. Calcium-dependent bacteriophage DNA infection. J. Mol. Biol., v. 53, n. 1, p. 159-162, 1970.

MCDOWELL, J. V. et al. Demonstration of factor $\mathrm{H}$-like protein 1 binding to Treponema denticola, a pathogen associated with periodontal disease in humans. Infect. Immun., v. 73, n. 11, p. 7126-7132, 2005.

MEEHAN, M. et al. The fibrinogen-binding protein (FgBP) of Streptococcus equi subsp. equi additionally binds IgG and contributes to virulence in a mouse model. Microbiology, v. 147, n. Pt 12, p. 3311-3322, 2001.

MENDES, R. S. et al. The novel leptospiral surface adhesin Lsa20 binds laminin and human plasminogen and is probably expressed during infection. Infect. Immun., v. 79, n. 11, p. 4657-4667, 2011.

MERI, T. et al. Relapsing fever spirochetes Borrelia recurrentis and B. duttonii acquire complement regulators $\mathrm{C} 4 \mathrm{~b}$-binding protein and factor $\mathrm{H}$. Infect. Immun., v. 74, n. 7, p. 4157-4163, 2006.

MERIEN, F. et al. Polymerase chain reaction for detection of Leptospira spp. in clinical samples. J. Clin. Microbiol., v. 30, n. 9, p. 2219-2224, 1992.

MIROUX, B.; WALKER, J. E. Over-production of proteins in Escherichia coli: mutant hosts that allow synthesis of some membrane proteins and globular proteins at high levels. J. Mol. Biol., v. 260, n. 3, p. 289-298, 1996.

MOREILLON, P. et al. Role of Staphylococcus aureus coagulase and clumping factor in pathogenesis of experimental endocarditis. Infect. Immun., v. 63, n. 12, p. 4738-4743, 1995. 
MURRAY, G. L. et al. Mutations affecting Leptospira interrogans lipopolysaccharide attenuate virulence. Mol. Microbiol., v. 78, n. 3, p. 701-709, 2010.

NAKAI, K.; HORTON, P. PSORT: a program for detecting sorting signals in proteins and predicting their subcellular localization. Trends. Biochem. Sci., v. 24, n. 1, p. 34-36, 1999.

NALLY, J. E.; TIMONEY, J. F.; STEVENSON, B. Temperature-regulated protein synthesis by Leptospira interrogans. Infect. Immun., v. 69, n. 1, p. 400-404, 2001.

NASCIMENTO, A. L. et al. Comparative genomics of two Leptospira interrogans serovars reveals novel insights into physiology and pathogenesis. J. Bacteriol., v. 186, n. 7 , p. 2164-2172, 2004a.

Genome features of Leptospira interrogans serovar Copenhageni. Braz. J. Med. Biol. Res., v. 37, n. 4, p. 459-477, 2004b.

NEVES, F. O. et al. Identification of a novel potential antigen for early-phase serodiagnosis of leptospirosis. Arch. Microbiol., v. 188, n. 5, p. 523-532, 2007.

OLIVEIRA, R. et al. Characterization of novel OmpA-like protein of Leptospira interrogans that binds extracellular matrix molecules and plasminogen. PLoS One, v. 6, n. 7, p. e21962, 2011.

OLIVEIRA, T. R. et al. Evaluation of leptospiral recombinant antigens MPL17 and MPL21 for serological diagnosis of leptospirosis by enzyme-linked immunosorbent assays. Clin. Vaccine Immunol., v. 15, n. 11, p. 1715-1722, 2008.

LipL53, a temperature regulated protein from Leptospira interrogans that binds to extracellular matrix molecules. Microbes Infect., v. 12, n. 3, p. 207-217, 2010.

PALANIAPPAN, $R$. $U$. et al. Immunoprotection of recombinant leptospiral immunoglobulin-like protein $A$ against Leptospira interrogans serovar Pomona infection. Infect. Immun., v. 74, n. 3, p. 1745-1750, 2006.

PATHIRANA, R. D. et al. Characterization of proteinase-adhesin complexes of Porphyromonas gingivalis. Microbiology, v. 152, n. Pt 8, p. 2381-2394, 2006.

PATRA, A. K. et al. Refolding, structural transition and spermatozoa-binding of recombinant bonnet monkey (Macaca radiata) zona pellucida glycoprotein-C expressed in Escherichia coli. Eur. J. Biochem., v. 267, n. 24, p. 7075-7081, 2000.

PICARDEAU, M. et al. Genome sequence of the saprophyte Leptospira biflexa provides insights into the evolution of Leptospira and the pathogenesis of leptospirosis. PLoS One, v. 3, n. 2, p. e1607, 2008.

PINNE, M.; HAAKE, D. A. A comprehensive approach to identification of surfaceexposed, outer membrane-spanning proteins of Leptospira interrogans. PLoS One, v. 4, n. 6, p. e6071, 2009. 
PIZZA, M. et al. Identification of vaccine candidates against serogroup $B$ meningococcus by whole-genome sequencing. Science, v. 287 , n. 5459 , p. 18161820, 2000.

PLANK, R.; DEAN, D. Overview of the epidemiology, microbiology, and pathogenesis of Leptospira spp. in humans. Microbes Infect., v. 2, n. 10, p. 1265-1276, 2000.

Portal da Saúde. Tabela de casos confirmados de Leptospirose. Brasil, Grandes Regiões e Unidades Federadas. 1997 a 2012. Disponível em: <http://portal.saude.gov.br/portal/arquivos/pdf/ tab casos conf ser hist 19972012. pdf>. Acesso em: 05 de junho de 2013.

Portal da Saúde. Tabela de óbitos por Leptospirose. Brasil. Grandes regiões e Unidades Federadas. 1997 a 2012. Disponível em: <http://portal.saude.gov/portal/arquivos/pdf/tab obitos serie hietorica 2012 pdf>.

Acesso em: 05 de junho de 2013.

RAMOS, C. R. et al. A high-copy T7 Escherichia coli expression vector for the production of recombinant proteins with a minimal $\mathrm{N}$-terminal His-tagged fusion peptide. Braz. J. Med. Biol. Res., v. 37, n. 8, p. 1103-1109, 2004.

RAPPUOLI, R. Reverse vaccinology. Curr. Opin. Microbiol., v. 3, n. 5, p. 445-450, 2000.

REID, S. D. et al. Postgenomic analysis of four novel antigens of group a streptococcus: growth phase-dependent gene transcription and human serologic response. J. Bacteriol., v. 184, n. 22, p. 6316-6324, 2002.

REN, S. X. et al. Unique physiological and pathogenic features of Leptospira interrogans revealed by whole-genome sequencing. Nature, v. 422, n. 6934, p. 888893, 2003.

RICALDI, J. N. et al. Whole genome analysis of Leptospira licerasiae provides insight into leptospiral evolution and pathogenicity. PLoS Negl. Trop. Dis., v. 6, n. 10, p. e1853, 2012.

RIPOCHE, J. et al. Two populations of complement factor $\mathrm{H}$ differ in their ability to bind to cell surfaces. Biochem. J., v. 253, n. 2, p. 475-480, 1988.

RISTOW, P. et al. The OmpA-like protein Loa22 is essential for leptospiral virulence. PLoS Pathog., v. 3, n. 7, p. e97, 2007.

RODRIGUEZ, A. G. et al. [Growth, virulence and antigenecity of Leptospira interrogans serovar mozdok in modified EMJH medium]. Rev. Cubana Med. Trop., v. 54, n. 1, p. 32-36, 2002.

ROSS, B. C. et al. Identification of vaccine candidate antigens from a genomic analysis of Porphyromonas gingivalis. Vaccine, v. 19, n. 30, p. 4135-4142, 2001. 
ROSSMANN, E. et al. Dual binding specificity of a Borrelia hermsii-associated complement regulator-acquiring surface protein for factor $\mathrm{H}$ and plasminogen discloses a putative virulence factor of relapsing fever spirochetes. J. Immunol., v. 178, n. 11, p. 7292-7301, 2007.

SAINI, D. K. et al. Cloning, overexpression, purification, and matrix-assisted refolding of DevS (Rv 3132c) histidine protein kinase of Mycobacterium tuberculosis. Protein Expr. Purif., v. 25, n. 1, p. 203-208, 2002.

SANGER, F.; NICKLEN, S.; COULSON, A. R. DNA sequencing with chainterminating inhibitors. Proc. Natl. Acad. Sci. U. S. A., v. 74, n. 12, p. 5463-5467, 1977.

SATO, K. Enzyme-linked immunosorbent assay of SlgA in whole saliva of healthy subjects and patients with oral diseases. Bull. Tokyo Med. Dent. Univ., v. 38, n. 2, p. 9-18, 1991.

SCHULTZ, J. et al. SMART, a simple modular architecture research tool: identification of signaling domains. Proc. Natl. Acad. Sci. U. S. A., v. 95, n. 11, p. 5857-5864, 1998.

SEIXAS, F. K. et al. Evaluation of different ways of presenting LipL32 to the immune system with the aim of developing a recombinant vaccine against leptospirosis. Can. J. Microbiol., v. 53, n. 4, p. 472-479, 2007.

SILVA, E. F. et al. The terminal portion of leptospiral immunoglobulin-like protein LigA confers protective immunity against lethal infection in the hamster model of leptospirosis. Vaccine, v. 25, n. 33, p. 6277-6286, 2007.

SINGH, S. P. et al. The C-terminal domain of Salmonella enterica serovar typhimurium OmpA is an immunodominant antigen in mice but appears to be only partially exposed on the bacterial cell surface. Infect. Immun., v. 71, n. 7, p. 39373946, 2003.

SORENSEN, H. P. et al. Soluble expression of aggregating proteins by covalent coupling to the ribosome. Biochem. Biophys. Res. Commun., v. 319, n. 3, p. 715719, 2004.

SOUZA, N. M. et al. Lsa30, a novel adhesin of Leptospira interrogans binds human plasminogen and the complement regulator C4bp. Microb. Pathog., v. 53, n. 3-4, p. 125-134, 2012.

STEVENSON, B. et al. Leptospira interrogans endostatin-like outer membrane proteins bind host fibronectin, laminin and regulators of complement. PLoS One, v. 2, n. 11, p. e1188, 2007.

Differential binding of host complement inhibitor factor $\mathrm{H}$ by Borrelia burgdorferi Erp surface proteins: a possible mechanism underlying the expansive host range of Lyme disease spirochetes. Infect. Immun., v. 70, n. 2, p. 491-497, 2002. 
STUDIER, F. W. Use of bacteriophage T7 lysozyme to improve an inducible T7 expression system. J. Mol. Biol., v. 219, n. 1, p. 37-44, 1991.

STUDIER, F. W. et al. Use of T7 RNA polymerase to direct expression of cloned genes. Methods Enzymol., v. 185, p. 60-89, 1990.

TETTELIN, $\mathrm{H}$. et al. Complete genome sequence of Neisseria meningitidis serogroup B strain MC58. Science, v. 287, n. 5459, p. 1809-1815, 2000.

TORRES, A. G. et al. Outer membrane protein A of Escherichia coli O157:H7 stimulates dendritic cell activation. Infec.t Immun., v. 74, n. 5, p. 2676-2685, 2006.

TOYOKAWA, T.; OHNISHI, M.; KOIZUMI, N. Diagnosis of acute leptospirosis. Expert Rev. Anti Infect. Ther., v. 9, n. 1, p. 111-121, 2011.

TRUEBA, G. et al. Cell aggregation: a mechanism of pathogenic Leptospira to survive in fresh water. Int. Microbiol., v. 7, n. 1, p. 35-40, 2004.

VERMA, A. et al. Leptospiral endostatin-like protein $A$ is a bacterial cell surface receptor for human plasminogen. Infect. Immun., v. 78, n. 5, p. 2053-2059, 2010.

. LfhA, a novel factor H-binding protein of Leptospira interrogans. Infect. Immun., v. 74, n. 5, p. 2659-2666, 2006.

VIEIRA, M. L. et al. In vitro identification of novel plasminogen-binding receptors of the pathogen Leptospira interrogans. PLoS One, v. 5, n. 6, p. e11259, 2010a.

. Lsa63, a newly identified surface protein of Leptospira interrogans binds laminin and collagen IV. J. Infect., v. 60, n. 1, p. 52-64, 2010 b.

Plasminogen acquisition and activation at the surface of leptospira species lead to fibronectin degradation. Infect. Immun., v. 77, n. 9, p. 4092-40101, 2009.

VINETZ, J. M. Leptospirosis. Curr. Opin. Infect. Dis., v. 14, n. 5, p. 527-538, 2001.

WIZEMANN, T. M. et al. Use of a whole genome approach to identify vaccine molecules affording protection against Streptococcus pneumoniae infection. Infect. Immun., v. 69, n. 3, p. 1593-1598, 2001.

WOODWARD, M. P.; YOUNG, W. W., JR.; BLOODGOOD, R. A. Detection of monoclonal antibodies specific for carbohydrate epitopes using periodate oxidation. J. Immunol. Methods, v. 78, n. 1, p. 143-153, 1985.

WU, H. C. Biosynthesis of lipoproteins. Escherichia coli and Salmonella: Cellular and Molecular Biology, v. 2, p. 1005-1014, 1996.

YAN, W. et al. Identification and characterization of OmpA-like proteins as novel vaccine candidates for Leptospirosis. Vaccine, v. 28, n. 11, p. 2277-2283, 2010. 
- Immunogenicity and protective efficacy of recombinant Leptospira immunoglobulin-like protein $B$ (rLigB) in a hamster challenge model. Microbes Infec.t, v. 11, n. 2, p. 230-237, 2009.

YU, C. S. et al. Prediction of protein subcellular localization. Proteins, v. 64, n. 3, p. 643-651, 2006.

ZHANG, Y. et al. OmpA-like protein Loa22 from Leptospira interrogans serovar Lai is cytotoxic to cultured rat renal cells and promotes inflammatory responses. Acta Biochim. Biophys. Sin. (Shanghai), v. 42, n. 1, p. 70-79, 2010.

ZHONG, Y. et al. Comparative proteogenomic analysis of the Leptospira interrogans virulence-attenuated strain IPAV against the pathogenic strain 56601. Cell Res., v. 21, n. 8, p. 1210-1229, 2011.

ZUERNER, R. et al. Technological advances in the molecular biology of Leptospira. J. Mol. Microbiol. Biotechnol., v. 2, n. 4, p. 455-462, 2000. 


\section{APÊNDICES - ARTIGOS CIENTÍFICOS PUBLICADOS EM PERIÓDICOS, CAPÍTULO DE LIVRO E MANUSCRITOS SUBMETIDOS}

APÊNDICE A - ATZINGEN, M. V., et al. Identification and characterization of novel adhesins in Leptospira. Current Research, Technology and Education Topics in Applied Microbiology and Microbial Biotechnology, p. 704-713, 2010.

APÊNDICE B - VIEIRA, M. L., et al. In vitro identification of novel plasminogenbinding receptors of the pathogen Leptospira interrogans. PloS One, v. 5, p. e11259, 2010.

APÊNDICE C - OLIVEIRA, R., et al. Characterization of novel OmpA-like protein of Leptospira interrogans that binds extracellular matrix molecules and plasminogen. Plos One, v. 6, p. e21962, 2011.

APÊNDICE D - ATZINGEN, M. V., et al. Evaluation of immunoprotective activity of six leptospiral proteins in the hamsters model of leptospirosis. Open Microbiol J, v. 6, p. 79-87, 2012.

APÊNDICE E - VIEIRA, M. L., et al. Plasminogen binding proteins and plasmin generation on the surface of Leptospira spp: the contribution to the bacteria-host interactions. J Biomed Biotechnol, p. 758513, 2012.

APÊNDICE F - OLIVEIRA, R., et al. Adhesins of Leptospira interrogans mediate the interaction to fibrinogen and inhibit fibrina clot formation in vitro. Manuscrito submetido.

APÊNDICE G - VIEIRA, M. L., et al. Leptospiral extracelular matrix adhesins as mediators of pathogen-host interactions. Manuscrito submetido. 


\title{
Identification and Characterization of Novel Adhesins in Leptospira
}

\author{
M. V. Atzingen ${ }^{1}$, G. M. Cerqueira ${ }^{1}$, M. L. Vieira ${ }^{1,2}$, R. Oliveira ${ }^{1,2}$, T. R. Oliveira ${ }^{1}$, R. F. Domingos ${ }^{1,2}$, A. $^{1}$ \\ T. Barros ${ }^{1}$, R. S. Mendes ${ }^{1,2}$ and Ana L. T. O. Nascimento ${ }^{1,2^{*}}$ \\ ${ }^{1}$ Centro de Biotecnologia, Instituto Butantan, Avenida Vital Brazil, 1500, 05503-900, Sao Paulo, SP, Brazil; \\ ${ }^{2}$ Interunidades em Biotecnologia, Instituto de Ciências Biomédicas, USP, Sao Paulo, Brazil; \\ * corresponding author
}

\begin{abstract}
Leptospirosis is a worldwide zoonosis of human and veterinary concern, caused by pathogenic spirochetes of the genus Leptospira. This work reviews the ability of six putative leptospiral outer membrane proteins to interact with extracellular matrix (ECM) molecules. The chosen the genes, LIC10314, LIC10368, LIC12099, LIC12895, LIC12906 and LIC12690, were selected from the genome sequences of L. interrogans serovar Copenhageni mostly based on their cellular localization. The purified proteins were evaluated for their binding capacity by ELISA, except for LIC12690 coding sequence that was tested under denaturing conditions by Western blotting. Binding characterization and specificity of the proteins to ECM components were also studied. Our data show that the attachment of the recombinant proteins to ECM molecules was specific, dose-dependent and saturable, fulfilling the properties of a typical receptor-ligand interaction. These novel identified membrane proteins may play a role in mediating adhesion of $L$. interrogans to the hosts and therefore in bacterial pathogenesis.
\end{abstract}

Keywords: Leptospira, recombinant proteins, adhesins

\section{Introduction}

Spirochetes are motile, helically shaped bacteria including the genera Leptospira, Leptonema, Borrelia and Treponema. Borrelia and Treponema are the causative agents of Lyme disease, relapsing fever and syphilis, respectively. Leptospira consists of a genetically diverse group of pathogenic and non-pathogenic or saprophytic species [1-3]. Leptospirosis is a widespread zoonotic disease: transmission to humans occurs through contact with domestic or wild animal reservoirs or an environment contaminated by their urine. Infection produces a wide spectrum of clinical manifestations. The early-phase of illness is characterized by fever, chills, headache and severe myalgias. Disease progresses in 5 to $15 \%$ of the clinical infections to produce severe multisystem complications such as jaundice, renal failure and hemorrhagic manifestations [3, 4]. In developed countries, leptospirosis is associated with recreational activities [1] while in developing countries it produces large urban epidemics with mortality mainly during the rainy season [5]. Leptospirosis also represents a major economic problem producing abortions, stillbirths, infertility, failure to thrive, reduced milk production and death in animals such as cows, pigs, sheep, goats, horses and dogs [3]. Environmental control measures are difficult to implement because of the long-term survival of pathogenic leptospires in soil and water and the abundance of wild and domestic animal reservoirs [1,3]. Leptospira are classified according to serovar status - more than 250 pathogenic serovars have been identified. Structural heterogeneity in lipopolysaccharide moieties appears to be the basis for the large degree of antigenic variation observed among serovars [1].

Currently available veterinarian vaccines are based on inactivated whole cell or membrane preparations of pathogenic leptospires. These types of vaccine confer protective responses through, but not exclusively, the induction of antibodies against leptospiral lipopolysaccharide [6,7]. However, these vaccines do not induce long-term protection against infection and do not provide cross-protective immunity against leptospiral serovars not included in the vaccine preparation. The large number of pathogenic serovars imposes a major limitation to the production of a multi-serovar vaccine and to the development of immunization protocols based on whole cell or membrane preparations.

Leptospira invasiveness is attributed to its ability to disseminate widely within the host during the early stage of infection but, the mechanisms associated with this invasion are poorly understood [8]. Due to their location, surfaceassociated proteins are likely to be relevant in host-pathogen interactions, hence their potential to elicit several activities, including adhesion. The interaction of pathogens with the extracellular matrix (ECM) has been well documented [9]. The extracellular matrix of mammals is composed of two main classes of macromolecules: glycosaminoglycans (GAGs), usually found covalently linked to proteins in the form of proteoglycans, and fibrous proteins with both structural and adhesive functions such as collagens, elastin, fibronectin and laminin. Besides serving as a scaffold to stabilize the physical structure of tissues, the ECM plays an important role in regulating eukaryotic cell adhesion, differentiation, migration, proliferation, shape and function. Under normal conditions, ECM is not exposed to bacteria. Pathogens may gain access to the ECM components after a tissue trauma following a mechanical or chemical injury or as a consequence of bacterial infection through the activity of toxins and lytic enzymes [9]. Long-lasting infections may occur if microorganisms reach the subepithelial tissues.

Among spirochetes, Borrelia species has been shown to express a 47-kDa outer membrane protein named BBK32 that confers attachment to fibronectin $[10,11]$ and another GAG-binding adhesin termed Bgp [12, 13]. Treponema 
pallidum, the causative agent of syphilis, also interacts with ECM through outer-surface proteins: Tp0155 and Tp0483 showed specific attachment to fibronectin [14] and Tp0751 bound to a variety of laminin isoforms [15, 16]. When we have started these investigations, the only putative leptospiral adhesin identified was a 36-kDa fibronectin-binding protein isolated from the outer sheath of a virulent variant of pathogenic leptospires [17].

Whole-genome sequencing of four pathogenic strains of Leptospira have been accomplished; two serovars of $L$. interrogans, Lai [18] and Copenhageni [19, 20] and two strains of L. borgpetersenii [21]. To date, only one saprophytic strain L. biflexa serovar Patoc, has been sequenced [22]. Genome analysis of L. interrogans serovar Copenhageni allowed identification of a repertoire of putative leptospiral surface proteins categorized as nonspecific porins, specific channels for nutrient acquisition, efflux channels, adhesins, S-layer glycoproteins, peripheral membrane proteins, or surface-maintenance proteins [20]. Of the 263 predicted genes encoding potential surface-exposed integral membrane proteins, 250 were previously unknown [19]. Besides serving as targets for the host's immune system, it is possible that a number of proteins encoded by those genes mediate the initial adhesion to host cells.

This work reviews the date of six putative leptospiral outer membrane proteins and their ability to interact with the ECM molecules, laminin, collagen Type I, collagen Type IV, cellular fibronectin and plasma fibronectin. The genes were selected from the genome sequences of L. interrogans serovar Copenhageni mostly based on their predicted cellular localization. The chosen the genes, LIC10314, LIC10368, LIC12099, LIC12895, LIC12906 and LIC12690, were cloned and proteins expressed in Escherichia coli host system. The proteins were named Lsa63 (LIC10314) [23], Lsa21 (LIC10368) [24], Lsa27 (LIC12895) [25], Lsa24 (LIC12906) [26], LipL53 (LIC12099) [27] and Lp95 (LIC12690) [28], where Lsa stands for Leptospiral surface adhesin, LipL for lipoprotein of Leptospira and Lp for Leptospiral protein. The interaction of the recombinant proteins with ECM components and the binding characterization are presented. Our data suggest a possible involvement of these proteins in the cell adhesion interaction.

\section{Materials and Methods}

\subsection{ECM components.}

All macromolecules, including the control protein fetuin, BSA and ovalbumin, were purchased from Sigma Chemical Co. (St. Louis, Mo.). Laminin-1 and collagen Type IV were derived from the basement membrane of Engelbreth-HolmSwarm mouse sarcoma, cellular fibronectin was derived from human foreskin fibroblasts, plasma fibronectin was isolated from human plasma and collagen Type I was isolated from rat tail. Antibodies used to detect ECM components were from Sigma Chemical Co. (St. Louis, Mo.), produced in rabbits against the ECM components described above.

\subsection{Bioinformatics characterization of the proteins.}

Predicted coding sequences (CDSs) were selected from the L. interrogans serovar Copenhageni genome sequences [20] based on their cellular localization predictions by PSORT program, http://psort.nibb.ac.jp [29, 30] and CELLO programs, http://cello.life.nctu.edu.tw/ [31, 32]. The SMART, http://smart.embl-heidelbergde/ [33, 34] and PFAM, http://www.sanger.ac.uk/Software/Pfam/ [35] web servers were used to search for predicted functional and structural domains within the amino acid sequences of the CDSs. The predicted lipobox sequence was evaluated by LipoP, http://www.cbs.dtu.dk/services/LipoP/ [36] and SpLip [37] programs. Sequence analysis was performed with ClustalX [38] and a tree displayed program by the Neighbour-Joining method [39].

\subsection{DNA recombinant techniques.}

Amplification of the CDSs was performed by PCR from total L. interrogans serovar Copenhageni strain Fiocruz L1130 genomic DNA using complementary primer pairs listed on Table 1. The gene sequences were amplified without the signal peptide tag, predicted by SignalP (http://www.cbs.dtu.dk/services/SignalP/). The sequences coding for Lsa21, LipL53 and Lp95 were cloned into pENTR-TOPO vector (Invitrogen) followed by transfer/recombination of DNA insert into the E. coli expression vector pDEST17 (Invitrogen) using the LR Clonase (Invitrogen). The sequences coding for Lsa63, Lsa27 and Lsa24 were cloned into pGEM-T easy vector (Promega) and subcloned into the pAE expression vector [40]. Both vector pDEST17 and pAE allow the expression of recombinant proteins with a minimal $6 \mathrm{x}$ His-tag at the N-terminus. All cloned sequences were confirmed by DNA sequencing with an ABI 3100 automatic sequencer (PE Applied Biosystems, Foster city, CA).

\subsection{Expression and purification of recombinant protein.}

Protein expression was achieved in E. coli BL21 (SI) strain by the action of T7 DNA polymerase under control of the osmotically induced promoter proU [41]. E. coli BL21 SI containing recombinant plasmids (except for Lsa27) was grown at $30{ }^{\circ} \mathrm{C}$ in Luria-Bertani (LB) broth without $\mathrm{NaCl}$ and with $100 \mu \mathrm{g} / \mathrm{ml}$ ampicillin with continuous shaking until an optical density at $600 \mathrm{~nm}$ of 0.6 to 0.8 was reached. Recombinant protein synthesis was induced by the addition of 
$300 \mathrm{mM} \mathrm{NaCl}$ for three hours. The recombinant protein Lsa27 was obtained from E. coli BL21 Star (DE3) pLys. Bacteria were grown at $37^{\circ} \mathrm{C}$ in LB broth with $100 \mu \mathrm{g} / \mathrm{ml}$ ampicillin and $50 \mu \mathrm{g} / \mathrm{ml}$ chloramphenicol until the log-phase was reach, and induced by the addition of $0.1 \mathrm{mM}$ isopropyl- $\beta$-D-thiogalactopyranoside (IPTG) for three hours. The cells were harvested by centrifugation, the bacterial pellets were resuspended in sonication buffer $(20 \mathrm{mM} \mathrm{Tris-HCl}$, $\mathrm{pH}$ 8.0, $200 \mathrm{mM} \mathrm{NaCl}, 200 \mu \mathrm{g} / \mathrm{ml}$ of lysozyme, $2 \mathrm{mM}$ phenylmethylsulfonyl fluoride (PMSF) and $1 \%$ Triton X-100) and lysed on ice with the aid of a sonicator (Ultrasonic Processor; GE Healthcare). The bacteria cell lysates were cleared by centrifugation at 3,000 $\mathrm{x}$ for $15 \mathrm{~min}$ at $4{ }^{\circ} \mathrm{C}$. The recombinant proteins Lsa63 and Lsa27 were purified from the supernatant fraction loaded onto $\mathrm{Ni}^{2+-}$ charged Sepharose beads. The proteins were extensively washed with buffer containing $20 \mathrm{mM}$ Tris- $\mathrm{HCl}, \mathrm{pH} 8.0,200 \mathrm{mM} \mathrm{NaCl}$ and increasing concentrations of imidazole (5 to $60 \mathrm{mM})$, except for Lsa27, which was washed with $5 \mathrm{mM}$ imidazol and eluted with wash buffer containing $1 \mathrm{M}$ imidazol. The rLsa27 protein was purified twice to remove contaminating E. coli proteins. The recombinant proteins Lsa21, LipL53, Lsa24 and Lp95 were purified from insoluble fraction after solubilization with $8 \mathrm{M}$ urea, $20 \mathrm{mM}$ Tris- $\mathrm{HCl}, \mathrm{pH} 8.0,500 \mathrm{mM}$ $\mathrm{NaCl}$ and addition of $10 \%$ glycerol for protein LipL53. Proteins refolding were achieved by $500 \times$ dilution with $50 \mathrm{mM}$ Tris- $\mathrm{HCl}, \mathrm{pH} 8.0$, and $500 \mathrm{mM} \mathrm{NaCl}$, except for LipL53, which was refolded by decreasing concentrations of urea during the purification through metal chelating chromatography. All recombinant proteins were extensively dialyzed against phosphate-buffered saline (PBS), $\mathrm{pH} 7.4,0.1 \%$ (wt/vol) glycine solution (at the proportion of $10 \mathrm{ml}$ of protein per $1,000 \mathrm{ml}$ of buffer) with at least five changes of buffer every $4 \mathrm{~h}$ for $48 \mathrm{~h}$.

\subsection{Binding of recombinant proteins to ECM by ELISA.}

Protein attachment to individual macromolecules of the extracellular matrix was analyzed according to a previously published protocol [15] with some modifications. Briefly, ELISA plate wells (Nunc-Immuno plate, MaxiSorp surface) were coated with $1 \mu \mathrm{g}$ of laminin, collagen type I, collagen type IV, cellular fibronectin, plasma fibronectin, BSA (nonglycosylated attachment-negative control protein), and fetuin (highly glycosylated attachment-negative control protein) in $100 \mu \mathrm{l}$ of PBS for $2 \mathrm{~h}$ at $37^{\circ} \mathrm{C}$. The wells were washed three times with PBS- $0.05 \%$ Tween 20 (PBST) and then blocked with $200 \mu \mathrm{l}$ of $1 \% \mathrm{BSA}$ for $1 \mathrm{~h}$ at $37 \mathrm{C}$, followed by an overnight incubation at $4 \mathrm{C}$. One microgram of recombinant protein was added per well in $100 \mu \mathrm{l}$ of PBS, and protein was allowed to attach to the different substrates for $1 \mathrm{~h} 30 \mathrm{~min}$ at $37{ }^{\circ} \mathrm{C}$. After washing six times with PBST, bound proteins were detected by adding an appropriate dilution of mouse antiserum in $100 \mu \mathrm{l}$ of PBS. Dilution of mouse antiserum against each recombinant protein was: Lsa24, 1:2,000; Lsa63, 1:750; Lsa21, 1:5,000; LipL53, 1:25,600 Lsa27, 1:200. Incubation proceeded for 1 h, and after three washes with PBST, $100 \mu$ of a 1:5,000 dilution of horseradish peroxidase-conjugated goat anti-mouse immunoglobulin G in PBS was added per well for $1 \mathrm{~h}$. All incubations took place at $37{ }^{\circ} \mathrm{C}$. The wells were washed three times, and $o$-phenylenediamine $(0.04 \%)$ in citrate phosphate buffer $(\mathrm{pH} 5.0)$ plus $0.01 \% \mathrm{H}_{2} \mathrm{O}_{2}$ was added. The reaction was allowed to proceed for $15 \mathrm{~min}$ and was then interrupted by the addition of $50 \mu \mathrm{l}$ of $4 \mathrm{~N} \mathrm{H}_{2} \mathrm{SO}_{4}$. The absorbance at $492 \mathrm{~nm}$ was taken in a microplate reader (Multiskan EX; Labsystems Uniscience). For determination of dose-dependent attachment of recombinant proteins to ECM components, protein concentrations varying from 0 to 2,000 $\mathrm{nM}$ in PBS were used.

\subsection{Metaperiodate treatment of laminin.}

Microtiter wells were coated with $1 \mu \mathrm{g}$ of laminin in $50 \mathrm{mM}$ sodium acetate buffer, $\mathrm{pH} 5.0$, and incubated for $16 \mathrm{~h}$ at $4{ }^{\circ} \mathrm{C}$. Wells were washed three times with $50 \mathrm{mM}$ sodium acetate buffer, $\mathrm{pH}$ 5.0, and immobilized laminin was treated with different sodium metaperiodate concentrations (5 to $100 \mathrm{mM})$ in the same buffer for 15 min at $4{ }^{\circ} \mathrm{C}$ in the dark. After three washes with $50 \mathrm{mM}$ sodium acetate buffer, wells were blocked with $200 \mu \mathrm{l}$ of $1 \% \mathrm{BSA}$ for $1 \mathrm{~h}$ at $37{ }^{\circ} \mathrm{C}$. Binding of recombinant protein $(1 \mu \mathrm{g}$ in PBS per well) to periodate-treated laminin was assessed as outlined above.

\subsection{ECM ligand-binding assays by Western blot.}

Aliquots $(1 \mu \mathrm{g})$ of each recombinant protein and negative control protein BSA were subjected to SDS-PAGE and then transferred to nitrocellulose membranes. Membranes were blocked with $5 \%$ BSA in PBS-T $(0.05 \%$ Tween 20), then incubated for $1 \mathrm{~h}$ at room temperature with either murine laminin, human fibronectin (plasma, $70 \mathrm{kDa}$ proteolytic fragment and cellular), calf collagen type I or human collagen type IV at different concentrations in PBS-T. Following extensive washing with PBS-T, membranes were incubated for $1 \mathrm{~h}$ with rabbit polyclonal antibodies specific for either ECM component (diluted 1:1,000). Finally, the membranes were washed with PBS-T and incubated for $1 \mathrm{~h}$ with antirabbit horseradish peroxide-conjugated (diluted 1:5,000, Sigma). Bound antibodies were detected using ECL reagent kit chemiluminescence substrate (GE Healthcare). Metaperiodate treatment was performed by diluting $1 \mu \mathrm{g} / \mathrm{ml}$ of laminin in $50 \mathrm{mM}$ sodium acetate buffer, $\mathrm{pH} 5.0$, with $200 \mathrm{mM}$ sodium metaperiodate just before the use on ligand-binding assay. 


\subsection{Statistical analysis.}

All results are expressed as means \pm SEM. Student's paired t test was used to determine the significance of differences between means, and $P$ lower than 0.05 was considered as statistically significant.

\subsection{Protein Data Bank accession numbers.}

The public database accession numbers for each protein sequence analyzed in this work are listed in Table 1 . Proteins can also be accessed by their genome nomenclature for the gene locus and LIC numbers (Leptospira interrogans serovar Copenhageni).

\section{Results and Discussion}

Our rationale for protein selection was mostly based on cellular localization, since surface proteins are potential targets for mediating adhesion to host. We focused on six proteins: LIC10368, LIC12895, LIC12906 and LIC12690 are putative lipoproteins with SpII lipoprotein signal peptide (signal peptidase II), consistent with LipoP program [36], LIC10314 is a conserved hypothetical protein with P83 domain [23, 42] and LIC12099 is a putative outer membrane protein with a Beta propeller repeat [27]. All predicted coding sequences are membrane proteins according to PSORT [30] and CELLO [31, 32] programs. P83 domain, Beta propeller repeats and a Domain of Unknown Function - DUF1554 were identified by BLAST analysis [43] in LIC10314, LIC12099 and LIC12906, LIC12690, respectively. Table 1 summarizes gene locus identification, protein given name, protein accession number, genome annotation feature and the sequence of primers used for cloning.

Table 1. Gene locus, protein name, NCBI reference sequence, features, sequence of the primers employed for DNA amplification.

\begin{tabular}{|c|c|c|c|c|}
\hline $\begin{array}{l}\text { Gene } \\
\text { locus }\end{array}$ & $\begin{array}{l}\text { Recombinant } \\
\text { protein given } \\
\text { name }\end{array}$ & $\begin{array}{l}\text { NCBI reference } \\
\text { sequence } \\
\text { number }^{2}\end{array}$ & $\begin{array}{l}\text { Genome annotation } \\
\text { features }\end{array}$ & Sequence of primers for PCR amplification ${ }^{3}$ \\
\hline LIC10314 & Lsa63 [23] & YP_000304 & $\begin{array}{l}\text { Conserved hypothetical } \\
\text { protein with Borrelia_P83 } \\
\text { domain }\end{array}$ & $\begin{array}{l}\text { F: } 5 \text { GGATCCTTATTTTCTCAGGAAAG (BamH I) } \\
\text { R: } 5 \text { GGTACCCTAAGGTTTAATTTTTTT (Kpn I) }\end{array}$ \\
\hline LIC10368 & Lsa21 [24] & YP_000355 & Putative lipoprotein & $\begin{array}{l}\text { F: 5’ CACCGATGAAAAAAAAGAAAATGAATTGAG } \\
\text { R: 5' AACGCGATTCATAGAGAGCG }\end{array}$ \\
\hline LIC12099 & LipL53 [27] & YP_002033 & $\begin{array}{l}\text { Outer membrane protein } \\
\text { with Beta-propeller repeat }\end{array}$ & $\begin{array}{l}\text { F: 5' CACCACCAATGTGTTTGGTATAGCG } \\
\text { R: 5' CAGCGTTTTGTGATAAAATTAAC }\end{array}$ \\
\hline LIC12895 & Lsa27 [44] & YP_002811 & Putative lipoprotein & $\begin{array}{l}\text { F: } 5 \text { GGATCCCTGAAATATACGAA (EcoRI) } \\
\text { R: } 5 \text { GAATTCTTACTGTTCTCCTTC (BamHI) }\end{array}$ \\
\hline LIC12906 & Lsa24 [26] & YP_002822 & $\begin{array}{l}\text { Probable Lipoprotein with } \\
\text { a domain of unknown } \\
\text { function (DUF1554) }\end{array}$ & $\begin{array}{l}\text { F: } 5 \text { CGCGCTCGAGAAAAAGGAAGAA (Xho I) } \\
\text { R: } 5 \text { AAGCTTTTATTGAAGAATAATTCC (Nco I) }\end{array}$ \\
\hline LIC12690 & Lp95 [28] & YP_002611 & $\begin{array}{l}\text { Probable Lipoprotein with } \\
\text { a domain of unknown } \\
\text { function (DUF1554) }\end{array}$ & $\begin{array}{l}\text { F: 5' CACCTTTTCTAACTTCGCGGACTC } \\
\text { R: 5' CTATTGTTCCACACAAAGAATGC }\end{array}$ \\
\hline
\end{tabular}

The amplified coding sequences were cloned and expressed as full-length proteins in E. coli. Recombinant proteins were purified by metal chelating chromatography and an aliquot of each protein was analyzed through SDS-PAGE: lane 1, Lsa63; lane 2, Lsa21; lane 3, LipL53; lane 4, Lsa27 and lane 5, Lsa24 (Fig. 1A). As we can see from this figure, most of the contaminants were washed away and all proteins are represented as single major bands. Due to difficulties associated with Lp95 solubility, we decided to generate three fragments corresponding to the N-terminal, C-terminal and overlap portions of the LIC12690 gene (Fig. 1B). The DNA fragments were amplified and the inserts cloned into $E$. coli expression vector, pAE [40]. Recombinant proteins were expressed with $6 \mathrm{x}$ His-tag at the N-terminal, purified by metal chelating chromatography. The recombinant protein fragments were consistently recovered from the column as single major band indicating that most of the contaminants had been removed (Fig. 1C) but, the three portions, as the whole protein, presented poor solubility in PBS. The proteins were employed to immunize mice and the antiserum raised was used to characterize the proteins.

Live immunofluorescence assay using the immuno serum against each protein confirmed the exposed cellular localization of Lsa63 [23], Lsa21[24], Lsa27 [25] and LipL53 [27]. The localization of LipL53 protein was strengthened by proteolysis assessment studies on intact leptospires. In the case of Lsa24, Triton X-100 assay confirmed its membrane localization because the protein remained in the detergent phase [26]. No conclusive experimental data was obtained with the Lp95 protein. 


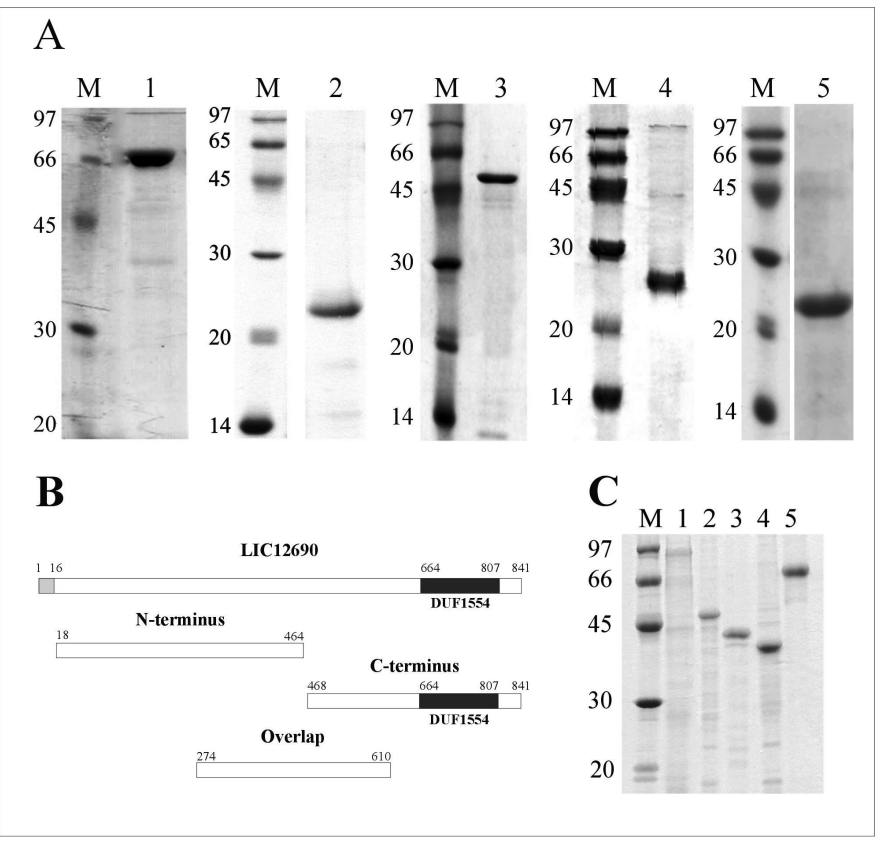

Fig. 1. (A) Analysis of recombinant protein purification: SDS - PAGE of purified protein eluted from $\mathrm{Ni}^{+2}$ charged chelating Sepharose column with $1 \mathrm{M}$ imidazole. Lane M, molecular mass protein marker, positions of standards are indicated to the left (in $\mathrm{kDa})$; lane 1, Lsa63 (63.0 $\mathrm{kDa})$; lane 2, Lsa21 (20.9 kDa); lane 3, LipL53 (54.0 kDa); lane 4, Lsa27 $(27.0 \mathrm{kDa})$; lane 5, Lsa24 (26.5 kDa). (B) Schematic representation of Lp95. Shows the signal peptide (amino acids 1 to 16), the DUF1554 domain (amino acids 664 to 807), N-terminal domain (amino acids 18 to 464), Cterminal domain (amino acids 468 to 841), and the overlap domain (amino acids 274 to 610). (C) SDS PAGE of purified Lp95 and fractions. Lane 1, Lp95 full lenght $(94.5 \mathrm{kDa})$; lane 2, N-terminal fragment (51.9 $\mathrm{kDa})$; lane 3, C-terminal fragment $(43.5 \mathrm{kDa})$; lane 4, overlap fragment $(39.7 \mathrm{kDa})$. Protein bands were visualized by Coomassie blue staining.

Lsa63 protein expression and conservation among Leptospira strains were assessed with total protein extracts from $L$. interrogans pathogenic serovars Canicola, Copenhageni, Icterohaemorrhagiae, Pomona, L borgpetersenii serovars Castelonis and Whitcombi, L. kirshneri serovars Cynoptery and Grippotyphosa, L. santarosai serovar Shermani and the non-pathogenic strain L. biflexa serovar Patoc. The data depicted in Fig. 2 shows that Lsa63 protein is conserved in all pathogenic strains and absent in the saprophytic non-pathogenic strain [23]. On the other hand, Lsa27 was only conserved in L. interrogans serovar Copenhageni and Icterohaemorrhagiae [25]. Lp95 transcript was identified serovar Canicola, Copenhageni, Icterohaemorrhagiae and Hardjo of L.interrogans inetrrogans [28]. Lsa21 and LipL53 were present only in low passage, virulent strain of L. interrogans at the normal growth temperatures $\left(28{ }^{\circ} \mathrm{C}\right)[24,27$. However, upon shifted of attenuated cultures of pathogenic strains from $28{ }^{\circ} \mathrm{C}$ to $37{ }^{\circ} \mathrm{C}$ and to $39{ }^{\circ} \mathrm{C}$, LipL53 transcript was observed, suggesting that this protein is up regulated by normal body core temperature and fever conditions [27]. The gene encoded for Lsa24 was conserved among serovars of L. interrogans (Neves, F. O., unpublished results).
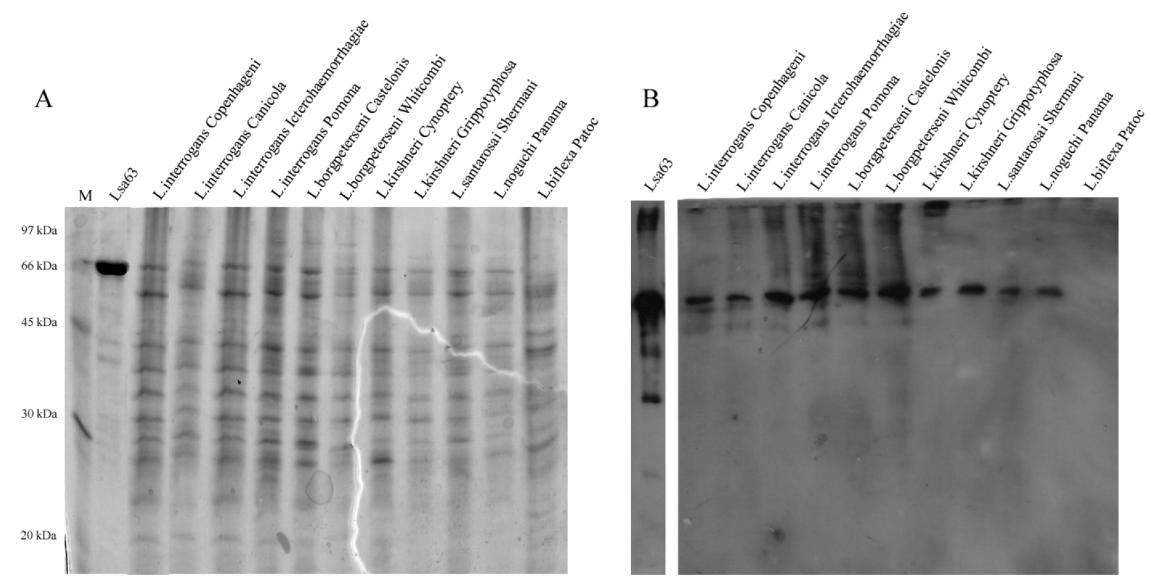

Fig. 2 Conservation of Lsa63 among leptospira strains. Whole cell lysates and Lsa63 were separated by SDS-PAGE, transferred to membranes and probed with recombinant protein antiserum followed by anti-mouse IgG conjugated to peroxidase. Reactivity was detected by ECL kit and X-ray films exposition. (A) Coomassie blue stained gel and (B) western blot of duplicate gel transferred to membrane. M: protein molecular mass marker (positions shown on the left).

To evaluate the adhesion of recombinant proteins to ECM molecules, laminin, collagen Type I, collagen Type IV, cellular fibronectin, plasma fibronectin, and the control proteins BSA and fetuin were immobilized on microdilution wells and recombinant protein attachment was assessed by an ELISA-based assay. The protein Lsa24 exhibited a significant level of attachment to laminin; the binding of Lsa24 to laminin was also significant compared to its binding to collagen IV $(P<0.05)$ and cellular fibronectin $(P<0.05)$ (Fig. 3A). No binding was observed when wells were 
coated with collagen Type I or with the highly glycosylated control protein fetuin (Fig. 3A) [26]. Similar to Lsa24, Lsa27 is also laminin-binding protein (Fig. 3B) [25]. The other proteins show a broader range binding activity. Lsa63 binded laminin and collagen IV [23], Lsa21 interacted with laminin, collagen IV and plasma fibronectin [24] and LipL53 showed adhesion to laminin, collagen IV, plasma and cellular fibronectin [27]. The behavior of Lsa63, Lsa21 and LipL53 proteins is similar to other reported adhesins, namely Len family protein [45], LigA and LigB proteins [46], LipL32 [47, 48] and TlyC [49] that have been shown to attach to more than one ECM macromolecules. In fact, attachment of Leptospira to several ECM macromolecules, including laminin, collagen I, collagen IV, cellular fibronectin, and plasma fibronectin was previously shown [26]. Emp, a cell surface protein of Staphylococcus aureus, strongly interacts with fibronectin, fibrinogen, collagen, and vitronectin [50]. The outer membrane protein YadA of Yersinia enterocolitica has been shown to bind to laminin, fibronectin, and several types of collagens [51-53]. Enterococcus faecalis adhesin Ace mediates attachment to laminin, and to collagens I and IV [54]. Finally, the Haemophilus influenzae Hap autotransporter protein exhibits the same binding profile of Lsa21 protein: it interacts with laminin, fibronectin and collagen IV [55].
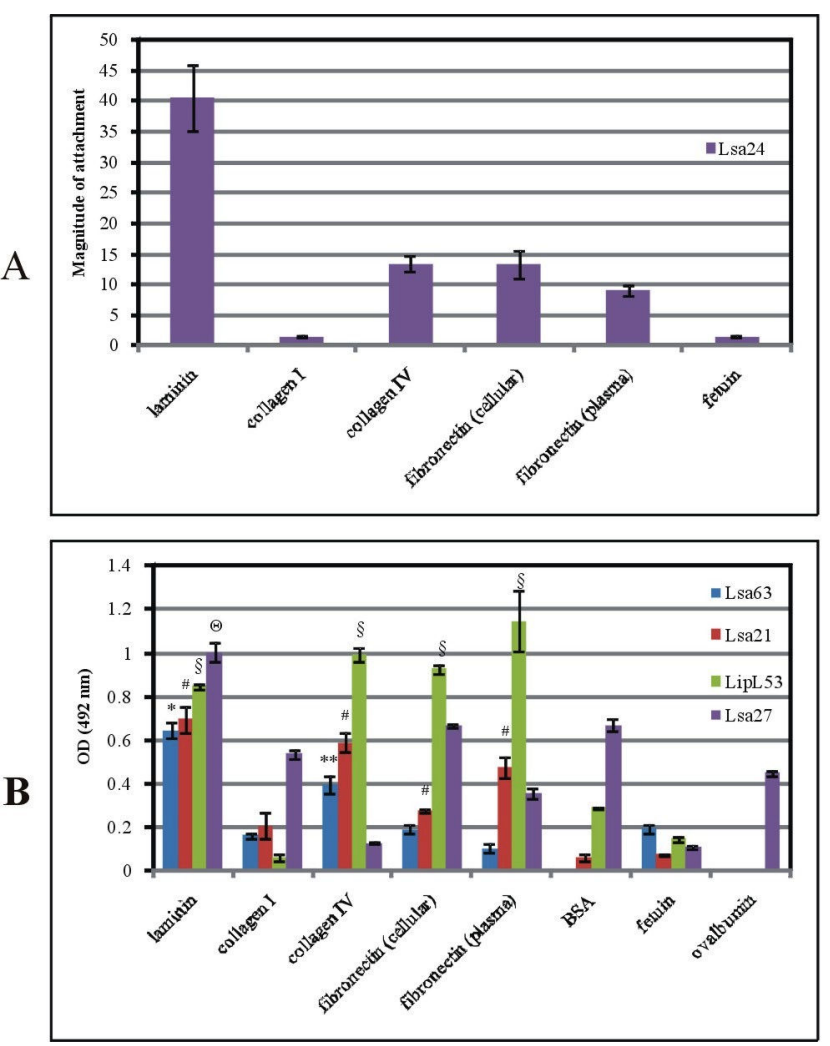

Fig. 3. Binding characteristics of recombinant proteins to ECM components. One microgram of laminin, collagen Type I, collagen Type IV, cellular fibronectin, plasma fibronectin, and the control protein fetuin were adsorbed to microtiter plates and incubated with $1 \mu \mathrm{g}$ of each recombinant protein for $2 \mathrm{~h}$ at $37^{\circ} \mathrm{C}$. After washing, the attachments to ECM components were detected with mouse serum. (A) Specific profiles of adhesion of Lsa24 to the ECM macromolecules are shown as magnitude of attachment (fold) over the negative control protein BSA, arbitrarily set equal to 1. (B) Lsa63, Lsa21, LipL53 and Lsa27 attachments to ECM components. Optical densities were obtained at $492 \mathrm{~nm}$ and the magnitude of the binding represented by bars corresponding to the mean absorbance value of three replicates \pm the standard deviation. All statistical analyses were by Student's two-tailed t-test, and the attachment of Lsa63 to ECM was compared to its binding to fetuin $(*, P<0.00005 ; * *, P<$ 0.0005); and the attachment of Lsa21, LipL53 and Lsa27 were compared to its binding to BSA (\#, $P<0.01 ; \S, P<0.05 ; \Theta, P<0.05$, respectively).

A previous study indicated that all Len proteins, but Len A, bind laminin and fibronectin [45]. We thus examined whether the DUF1554 (len-motif) contribute to the adhesion of the Lp95 and which fragments were involved in the binding. We have employed blotting instead of ELISA based assay due to the poor solubility of the protein. The Lp95 and each protein fragment were mixed up with SDS buffer, subjected onto SDS-PAGE and transferred to nitrocellulose membranes. Blotted proteins were stained Ponceau S (Fig. 4A and 4C) then examined for their ability to bind soluble laminin, fibronectin (plasma and cellular), collagen type I and IV.

Our data with affinity blotting shows that Lp95 (Fig. 4, lane 2), C-terminal fragment (Fig. 4, lane 4), overlap fragment (Fig. 4, lane 5) bind laminin (I), plasma fibronectin (II) fibronectin proteolytic fragment of $70 \mathrm{kDa}$ (III) and cellular fibronectin (IV); the N-terminal fragment (Fig. 4, lane 3) binds laminin (I) and cellular fibronectin (IV). The binding with all the fragments was dependent on ECM concentration ranging from 0.5 to $2.0 \mu \mathrm{g}$. ECM-binding protein Lsa21 [24] was used as positive control (Fig. 4D, lane 8) while rLIC10494, previously shown to be non reactive with ECM components [26] was added as a negative control (Fig. 4D, lane 9). The assays with proteolytic fragments of fibronectin indicated that the $70 \mathrm{kDa}$ fragment could account for part of the binding by the Lp95 and its fragments observed with intact fibronectin (Fig. 4II and 4III, lanes 2-5). No ECM binding was detected with BSA protein (Fig. 4, lane 6), employed as nonspecific binding control, although a weak band appeared when the highest laminin concentration $(2.0 \mu \mathrm{M})$ was employed. No significant binding of Lp95 and fragments to collagen type I or type IV were detected (data not shown). It was suggested that leptospiral attachment to ECM correlates with virulence, since virulent lines of $L$. interrogans attached to ECM more effectively than intermediate virulent and avirulent lines of the same strains [56]. 


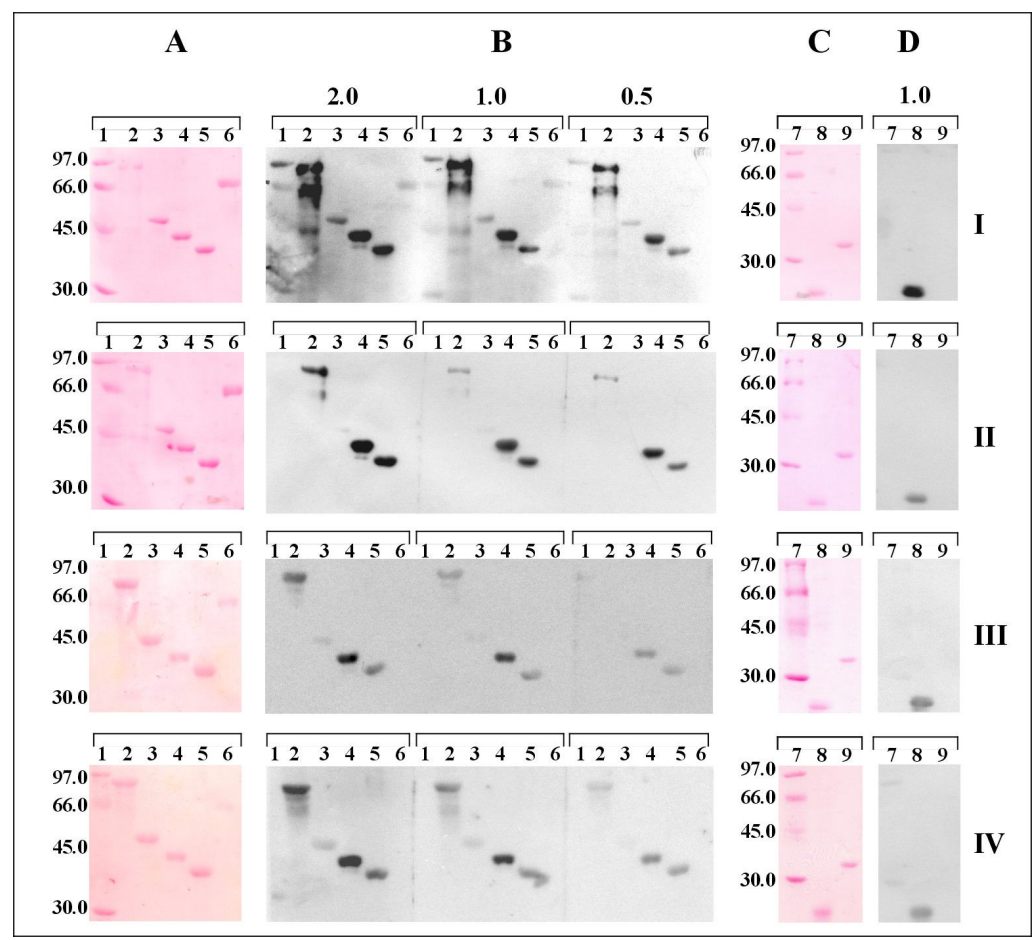

Fig. 4. Ligand affinity blot analyses of Lp95 with purified extracellular matrix components. In (A and $\mathrm{C}$ ), protein bands were visualized by Ponceau staining. In (B and D) nitrocellulose membranes containing immobilized recombinant protein were incubated with ECM components and the binding was revealed with specific antibodies. (I) laminin, (II) plasma fibronectin, (III) $70 \mathrm{kDa}$ proteolytic fragment of plasma fibronectin, (IV) cellular fibronectin. ECM concentrations ranged from $2 \mu \mathrm{g}$ to $0.5 \mu \mathrm{g}$. Lane 1 and 7 , molecular weight protein marker (in $\mathrm{kDa}$ ); lane 2, Lp95 full lenght (94.5 kDa); lane 3, $\mathrm{N}$-terminal fragment $(51.9 \mathrm{kDa})$; lane $4, \mathrm{C}$ terminal fragment $(43.5 \mathrm{kDa})$; lane 5 , overlap fragment $(39.7 \mathrm{kDa})$; lane 6 , BSA (negative control), lane 8, Lsa21, lane 9, rLIC10494. Positions of molecular mass standards are indicated to the left (in $\mathrm{kDa}$ ).

The interaction between the Lsa63, Lsa27, Lsa21, Lsa24 and LipL53 recombinant proteins and ECM molecules was also assessed on a quantitative basis as illustrated in Fig. 5. A dose-dependent and saturable binding was observed when increasing concentrations of the recombinant protein $(0-2,000 \mathrm{nM})$ were allowed to adhere to a fixed laminin concentration $(1 \mu \mathrm{g})$, fulfilling the properties of a typical receptor-ligand interaction. Saturation level was reached at a protein concentration of $700 \mathrm{nM}-800 \mathrm{nM}$ for the proteins Lsa27 and Lsa24, respectively (Fig. 5), but for the other proteins, no saturation was reached up to $1,000 \mathrm{nM}$.
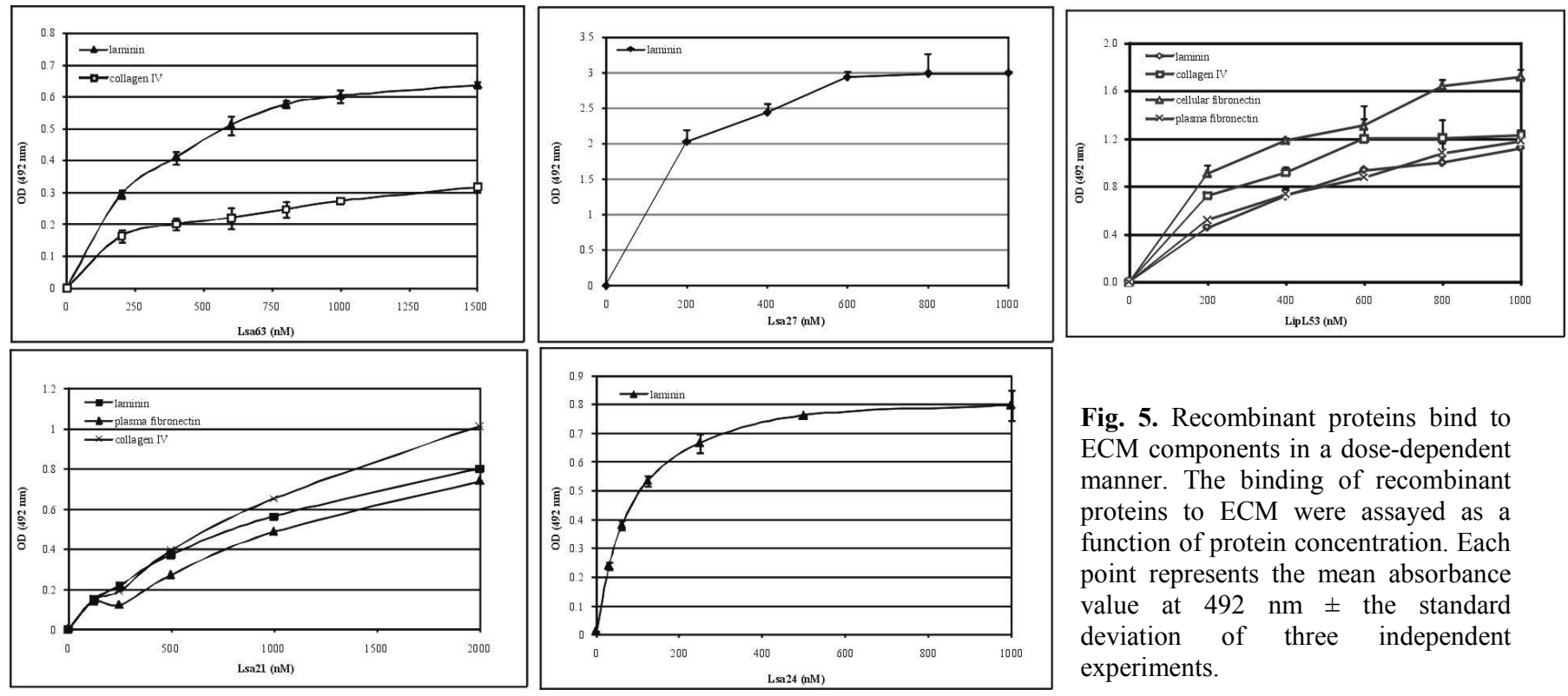

Fig. 5. Recombinant proteins bind to ECM components in a dose-dependent manner. The binding of recombinant proteins to ECM were assayed as a function of protein concentration. Each point represents the mean absorbance value at $492 \mathrm{~nm} \pm$ the standard deviation of three independent experiments.

Metaperiodate oxidation of laminin caused significant reduction in the binding activity, strongly suggesting the involvement of laminin carbohydrate moieties in the interaction. All the proteins in this study, but Lsa63, showed a decrease in laminin-binding when the reaction was performed with metaperiodate (data not shown). This finding is in agreement with the previously published data pointing to a crucial role of laminin carbohydrate groups in the interaction with pathogens $[15,57-61]$. 
To investigate whether the identified proteins presented sequence similarity with other published spirochetal ECMbinding proteins [62-66], we carried out sequence alignment analysis using Clustal X program and a tree-display NJ plot $[38,39]$. The calculated dendrogram derived from sequence alignments is pictured in Fig. 6 and shows that ECMbinding leptospiral proteins do not share either sequence similarity or conserved domains with other reported spirochetal adhesins.

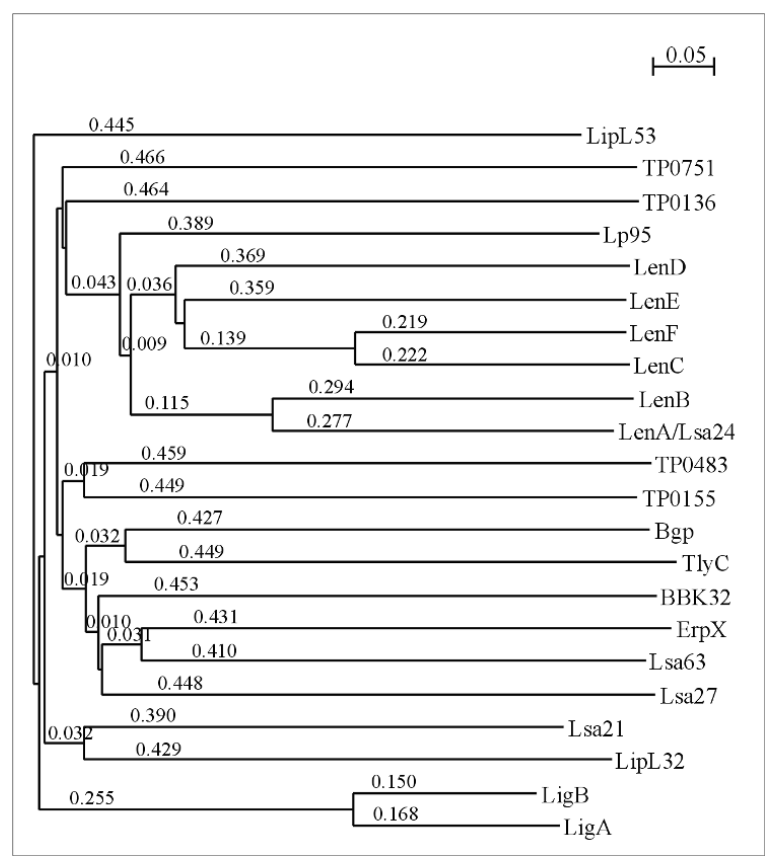

Fig. 6. Sequence comparison between spirochetal ECM binding proteins. Unrooted phylogenetic tree of predicted amino acid sequences of ECM binding proteins Lsa63 [23], Lsa21 [24], LipL53 [27], Lsa27 [25], Lp95 [28], LenA/Lsa24 [26,45], LenB-F [45], LipL32 [47,48], TlyC [49], LigA and LigB [46] of Leptospira; TP0136 [67], TP0751 [15], TP0155 and TP0483 [14] of Treponema; Bgp [12], ErpX [66] and BBK32 [10] of Borrelia. The tree was generated by Clustal X program and displayed by NJ plot. Branch lengths are depicted.

In conclusion, we have identified several leptospiral proteins in the L. interrogans serovar Copenhageni genome sequences that exhibit attachment to ECM components. Considering that leptospires are highly invasive microorganisms, there might be several other adhesins involved in the initial steps leading to infection. Studies concerning the underlying molecular mechanisms involved in adhesion are currently underway. Uncovering bacteriahost interactions at a molecular level will not only assist our understanding of the host physiology, but will facilitate the search for vaccine targets against leptospirosis.

Acknowledgements: This research was supported by FAPESP, CNPq and Fundação Butantan, Brazil. MLV, MVA, TRO, RSM, RFD, GMC, ATB and RO have fellowships from FAPESP.

\section{References}

[1] Levett PN. Leptospirosis. Clin Microbiol Rev. 2001; 14: 296-326.

[2] Farr RW. Leptospirosis. Clin Infect Dis. 1995; 21: 1-6; quiz 7-8.

[3] Faine S, Adler B, Bolin C, Perolat P. Leptospira and leptospirosis. Melbourne, Australia: MediSci. 1999.

[4] Bharti AR, Nally JE, Ricaldi JN, Matthias MA, Diaz MM, et al. Leptospirosis: a zoonotic disease of global importance. Lancet Infect Dis. 2003; 3: 757-771.

[5] Romero EC, Bernardo CC, Yasuda PH. Human leptospirosis: a twenty-nine-year serological study in Sao Paulo, Brazil. Rev Inst Med Trop Sao Paulo. 2003; 45: 245-248.

[6] de la Pena-Moctezuma A, Bulach DM, Kalambaheti T, Adler B. Comparative analysis of the LPS biosynthetic loci of the genetic subtypes of serovar Hardjo: Leptospira interrogans subtype Hardjoprajitno and Leptospira borgpetersenii subtype Hardjobovis. FEMS Microbiol Lett. 1999; 177: 319-326.

[7] Adler B, de la Pena Moctezuma A. Leptospira and leptospirosis. Vet Microbiol. 2010; 140 (3-4): 287-96.

[8] Faine S, Adler B, Bolin C, Perolat P. Leptospira and Leptospirosis. Melbourne, Australia MediSci. 1999.

[9] Ljungh A, Moran AP, Wadstrom T. Interactions of bacterial adhesins with extracellular matrix and plasma proteins: pathogenic implications and therapeutic possibilities. FEMS Immunol Med Microbiol. 1996; 16: 117-126.

[10] Probert WS, Johnson BJ. Identification of a $47 \mathrm{kDa}$ fibronectin-binding protein expressed by Borrelia burgdorferi isolate B31. Mol Microbiol. 1998; 30: 1003-1015.

[11] Probert WS, Kim JH, Hook M, Johnson BJ. Mapping the ligand-binding region of Borrelia burgdorferi fibronectin-binding protein BBK32. Infect Immun. 2001; 69: 4129-4133. 
[12] Parveen N, Leong JM. Identification of a candidate glycosaminoglycan-binding adhesin of the Lyme disease spirochete Borrelia burgdorferi. Mol Microbiol. 2000; 35: 1220-1234.

[13] Parveen N, Caimano M, Radolf JD, Leong JM. Adaptation of the Lyme disease spirochaete to the mammalian host environment results in enhanced glycosaminoglycan and host cell binding. Mol Microbiol. 2003; 47: 1433-1444.

[14] Cameron CE, Brown EL, Kuroiwa JM, Schnapp LM, Brouwer NL. Treponema pallidum fibronectin-binding proteins. $J$ Bacteriol. 2004; 186: 7019-7022.

[15] Cameron CE. Identification of a Treponema pallidum laminin-binding protein. Infect Immun. 2003; 71: 2525-2533.

[16] Cameron CE, Brouwer NL, Tisch LM, Kuroiwa JM. Defining the interaction of the Treponema pallidum adhesin Tp0751 with laminin. Infect Immun. 2005; 73: 7485-7494.

[17] Merien F, Truccolo J, Baranton G, Perolat P. Identification of a 36-kDa fibronectin-binding protein expressed by a virulent variant of Leptospira interrogans serovar icterohaemorrhagiae. FEMS Microbiol Lett. 2000; 185: 17-22.

[18] Ren SX, Fu G, Jiang XG, Zeng R, Miao YG, et al. Unique physiological and pathogenic features of Leptospira interrogans revealed by whole-genome sequencing. Nature. 2003; 422: 888-893.

[19] Nascimento AL, Ko AI, Martins EA, Monteiro-Vitorello CB, Ho PL, et al. Comparative genomics of two Leptospira interrogans serovars reveals novel insights into physiology and pathogenesis. J Bacteriol. 2004; 186: 2164-2172.

[20] Nascimento AL, Verjovski-Almeida S, Van Sluys MA, Monteiro-Vitorello CB, Camargo LE, et al. Genome features of Leptospira interrogans serovar Copenhageni. Braz J Med Biol Res. 2004; 37: 459-477.

[21] Bulach DM, Zuerner RL, Wilson P, Seemann T, McGrath A, et al. Genome reduction in Leptospira borgpetersenii reflects limited transmission potential. Proc Natl Acad Sci U S A. 2006; 103: 14560-14565.

[22] Picardeau M, Bulach DM, Bouchier C, Zuerner RL, Zidane N, et al. Genome sequence of the saprophyte Leptospira biflexa provides insights into the evolution of Leptospira and the pathogenesis of leptospirosis. PLoS One. 2008; 3: e1607.

[23] Vieira ML, de Morais ZM, Goncales AP, Romero EC, Vasconcellos SA, et al. Lsa63, a newly identified surface protein of Leptospira interrogans binds laminin and collagen IV. J Infect. 2010; 60: 52-64.

[24] Atzingen MV, Barbosa AS, De Brito T, Vasconcellos SA, de Morais ZM, et al. Lsa21, a novel leptospiral protein binding adhesive matrix molecules and present during human infection. BMC Microbiol. 2008; 8: 70.

[25] Longhi MT, Oliveira TR, Romero EC, Goncales AP, de Morais ZM, et al. A newly identified protein of Leptospira interrogans mediates binding to laminin. J Med Microbiol. 2009; 58: 1275-1282.

[26] Barbosa AS, Abreu PA, Neves FO, Atzingen MV, Watanabe MM, et al. A newly identified leptospiral adhesin mediates attachment to laminin. Infect Immun. 2006; 74: 6356-6364.

[27] Oliveira TR, Longhi MT, Goncales AP, de Morais ZM, Vasconcellos SA, et al. LipL53, a temperature regulated protein from Leptospira interrogans that binds to extracellular matrix molecules. Microbes Infect. 2010; 12: 207-217.

[28] Atzingen MV, Gomez RM, Schattner M, Pretre G, Goncales AP, et al. Lp95, a novel leptospiral protein that binds extracellular matrix components and activates e-selectin on endothelial cells. $J$ Infect. 2009; 59 (4):264-76.

[29] Nakai K, Horton P. PSORT: a program for detecting sorting signals in proteins and predicting their subcellular localization. Trends Biochem Sci. 1999; 24: 34-36.

[30] Nakai K, Kanehisa M. Expert system for predicting protein localization sites in gram-negative bacteria. Proteins. 1991; 11: 95110.

[31] Yu CS, Lin CJ, Hwang JK. Predicting subcellular localization of proteins for Gram-negative bacteria by support vector machines based on n-peptide compositions. Protein Sci. 2004; 13: 1402-1406.

[32] Yu CS, Chen YC, Lu CH, Hwang JK. Prediction of protein subcellular localization. Proteins. 2006; 64: 643-651.

[33] Letunic I, Copley RR, Pils B, Pinkert S, Schultz J, et al. SMART 5: domains in the context of genomes and networks. Nucleic Acids Res. 2006; 34: D257-260.

[34] Schultz J, Milpetz F, Bork P, Ponting CP. SMART, a simple modular architecture research tool: identification of signaling domains. Proc Natl Acad Sci U S A. 1998; 95: 5857-5864.

[35] Finn RD, Mistry J, Schuster-Bockler B, Griffiths-Jones S, Hollich V, et al. Pfam: clans, web tools and services. Nucleic Acids Res. 2006; 34: D247-251.

[36] Juncker AS, Willenbrock H, Von Heijne G, Brunak S, Nielsen H, et al. Prediction of lipoprotein signal peptides in Gramnegative bacteria. Protein Sci. 2003; 12: 1652-1662.

[37] Setubal JC, Reis M, Matsunaga J, Haake DA. Lipoprotein computational prediction in spirochaetal genomes. Microbiology. 2006; 152: 113-121.

[38] Thompson JD, Gibson TJ, Plewniak F, Jeanmougin F, Higgins DG. The CLUSTAL X windows interface: flexible strategies for multiple sequence alignment aided by quality analysis tools. Nucleic Acids Res. 1997; 25: 4876-4882.

[39] Perriere G, Gouy M. WWW-query: an on-line retrieval system for biological sequence banks. Biochimie. 1996; 78: 364-369.

[40] Ramos CR, Abreu PA, Nascimento AL, Ho PL. A high-copy T7 Escherichia coli expression vector for the production of recombinant proteins with a minimal N-terminal His-tagged fusion peptide. Braz J Med Biol Res. 2004; 37: 1103-1109.

[41] Bhandari P, Gowrishankar J. An Escherichia coli host strain useful for efficient overproduction of cloned gene products with $\mathrm{NaCl}$ as the inducer. $J$ Bacteriol. 1997; 179: 4403-4406.

[42] Rossler D, Eiffert H, Jauris-Heipke S, Lehnert G, Preac-Mursic V, et al. Molecular and immunological characterization of the p83/100 protein of various Borrelia burgdorferi sensu lato strains. Med Microbiol Immunol. 1995; 184: 23-32.

[43] Altschul SF, Gish W, Miller W, Myers EW, Lipman DJ. Basic local alignment search tool. J Mol Biol. 1990; 215: 403-410.

[44] Longhi MT, Oliveira TR, Romero EC, Goncales AP, Morais ZM, et al. A novel identified protein of Leptospira interrogans mediates binding to laminin. J Med Microbiol. 2009; 58 (10): 1275-82.

[45] Stevenson B, Choy HA, Pinne M, Rotondi ML, Miller MC, et al. Leptospira interrogans endostatin-like outer membrane proteins bind host fibronectin, laminin and regulators of complement. PLoS ONE. 2007; 2: e1188.

[46] Choy HA, Kelley MM, Chen TL, Moller AK, Matsunaga J, et al. Physiological osmotic induction of Leptospira interrogans adhesion: LigA and LigB bind extracellular matrix proteins and fibrinogen. Infect Immun. 2007; 75: 2441-2450. 
[47] Hoke DE, Egan S, Cullen PA, Adler B. LipL32 is an extracellular matrix-interacting protein of Leptospira spp. and Pseudoalteromonas tunicata. Infect Immun. 2008; 76: 2063-2069.

[48] Hauk P, Macedo F, Romero EC, Vasconcellos SA, de Morais ZM, et al. In LipL32, the major leptospiral lipoprotein, the C terminus is the primary immunogenic domain and mediates interaction with collagen IV and plasma fibronectin. Infect Immun. 2008; 76: 2642-2650.

[49] Carvalho E, Barbosa AS, Gomez RM, Cianciarullo AM, Hauk P, et al. Leptospiral TlyC is an extracellular matrix-binding protein and does not present hemolysin activity. FEBS Lett. 2009; 583 (8): 1381-5.

[50] Hussain M, Becker K, von Eiff C, Schrenzel J, Peters G, et al. Identification and characterization of a novel 38.5-kilodalton cell surface protein of Staphylococcus aureus with extended-spectrum binding activity for extracellular matrix and plasma proteins. J Bacteriol. 2001; 183: 6778-6786.

[51] Flugel A, Schulze-Koops H, Heesemann J, Kuhn K, Sorokin L, et al. Interaction of enteropathogenic Yersinia enterocolitica with complex basement membranes and the extracellular matrix proteins collagen type IV, laminin-1 and -2 , and nidogen/entactin. J Biol Chem. 1994; 269: 29732-29738.

[52] Schulze-Koops H, Burkhardt H, Heesemann J, von der Mark K, Emmrich F. Plasmid-encoded outer membrane protein YadA mediates specific binding of enteropathogenic yersiniae to various types of collagen. Infect Immun. 1992; 60: 2153-2159.

[53] Tertti R, Skurnik M, Vartio T, Kuusela P. Adhesion protein YadA of Yersinia species mediates binding of bacteria to fibronectin. Infect Immun. 1992; 60: 3021-3024.

[54] Nallapareddy SR, Qin X, Weinstock GM, Hook M, Murray BE. Enterococcus faecalis adhesin, ace, mediates attachment to extracellular matrix proteins collagen type IV and laminin as well as collagen type I. Infect Immun. 2000; 68: 5218-5224.

[55] Fink DL, Buscher AZ, Green B, Fernsten P, St Geme JW. The Haemophilus influenzae Hap autotransporter mediates microcolony formation and adherence to epithelial cells and extracellular matrix via binding regions in the $\mathrm{C}$-terminal end of the passenger domain. Cell Microbiol. 2003; 5: 175-186.

[56] Ito T, Yanagawa R. Leptospiral attachment to extracellular matrix of mouse fibroblast (L929) cells. Vet Microbiol. 1987; 15: 8996.

[57] Carneiro CR, Postol E, Boilesen C, Brentani RR. Participation of glycosylation sites in the binding of Staphylococcus aureus to laminin. Braz J Med Biol Res. 1993; 26: 689-697.

[58] Crouch ML, Alderete JF. Trichomonas vaginalis interactions with fibronectin and laminin. Microbiology. $1999 ; 145$ ( Pt 10): 2835-2843.

[59] Ghosh A, Bandyopadhyay K, Kole L, Das PK. Isolation of a laminin-binding protein from the protozoan parasite Leishmania donovani that may mediate cell adhesion. Biochem J. 1999; 337 ( Pt 3): 551-558.

[60] Tanskanen J, Saarela S, Tankka S, Kalkkinen N, Rhen M, et al. The gaf fimbrial gene cluster of Escherichia coli expresses a full-size and a truncated soluble adhesin protein. J Bacteriol. 2001; 183: 512-519.

[61] Valkonen KH, Wadstrom T, Moran AP. Identification of the N-acetylneuraminyllactose-specific laminin-binding protein of Helicobacter pylori. Infect Immun. 1997; 65: 916-923.

[62] Grosskinsky S, Schott M, Brenner C, Cutler SJ, Kraiczy P, et al. Borrelia recurrentis employs a novel multifunctional surface protein with anti-complement, anti-opsonic and invasive potential to escape innate immunity. PLoS One. 2009; 4: e4858.

[63] Fuchs H, Wallich R, Simon MM, Kramer MD. The outer surface protein A of the spirochete Borrelia burgdorferi is a plasmin(ogen) receptor. Proc Natl Acad Sci U S A. 1994; 91: 12594-12598.

[64] Lagal V, Portnoi D, Faure G, Postic D, Baranton G. Borrelia burgdorferi sensu stricto invasiveness is correlated with OspCplasminogen affinity. Microbes Infect. 2006; 8: 645-652.

[65] Rossmann E, Kraiczy P, Herzberger P, Skerka C, Kirschfink M, et al. Dual binding specificity of a Borrelia hermsii-associated complement regulator-acquiring surface protein for factor $\mathrm{H}$ and plasminogen discloses a putative virulence factor of relapsing fever spirochetes. J Immunol. 2007; 178: 7292-7301.

[66] Brissette CA, Haupt K, Barthel D, Cooley AE, Bowman A, et al. Borrelia burgdorferi infection-associated surface proteins ErpP, ErpA, and ErpC bind human plasminogen. Infect Immun. 2009; 77: 300-306.

[67] Brinkman MB, McGill MA, Pettersson J, Rogers A, Matejkova P, et al. A novel Treponema pallidum antigen, TP0136, is an outer membrane protein that binds human fibronectin. Infect Immun. 2008; 76: 1848-1857. 


\title{
In Vitro Identification of Novel Plasminogen-Binding Receptors of the Pathogen Leptospira interrogans
}

\author{
Monica L. Vieira ${ }^{1,2}$, Marina V. Atzingen ${ }^{1}$, Tatiane R. Oliveira ${ }^{1}$, Rosane Oliveira ${ }^{1,2}$, Daniel M. Andrade ${ }^{1}$, \\ Silvio A. Vasconcellos ${ }^{3}$, Ana L. T. O. Nascimento ${ }^{1,2 *}$
}

1 Centro de Biotecnologia, Instituto Butantan, São Paulo, São Paulo, Brazil, 2 Interunidades em Biotecnologia, Instituto de Ciências Biomédicas, Universidade de São Paulo, São Paulo, São Paulo, Brazil, 3 Laboratorio de Zoonoses Bacterianas do VPS, Faculdade de Medicina Veterinária e Zootecnia, Universidade de São Paulo, São Paulo, São Paulo, Brazil

\begin{abstract}
Background: Leptospirosis is a multisystem disease caused by pathogenic strains of the genus Leptospira. We have reported that Leptospira are able to bind plasminogen (PLG), to generate active plasmin in the presence of activator, and to degrade purified extracellular matrix fibronectin.

Methodology/Principal Findings: We have now cloned, expressed and purified 14 leptospiral recombinant proteins. The proteins were confirmed to be surface exposed by immunofluorescence microscopy and were evaluated for their ability to bind plasminogen (PLG). We identified eight as PLG-binding proteins, including the major outer membrane protein LipL32, the previously published rLIC12730, rLIC10494, Lp29, Lp49, LipL40 and MPL36, and one novel leptospiral protein, rLIC12238. Bound PLG could be converted to plasmin by the addition of urokinase-type PLG activator (uPA), showing specific proteolytic activity, as assessed by its reaction with the chromogenic plasmin substrate, D-Val-Leu-Lys 4-nitroanilide dihydrochloride. The addition of the lysine analog 6-aminocaproic acid (ACA) inhibited the protein-PLG interaction, thus strongly suggesting the involvement of lysine residues in plasminogen binding. The binding of leptospiral surface proteins to PLG was specific, dose-dependent and saturable. PLG and collagen type IV competed with LipL32 protein for the same binding site, whereas separate binding sites were observed for plasma fibronectin.
\end{abstract}

Conclusions/Significance: PLG-binding/activation through the proteins/receptors on the surface of Leptospira could help the bacteria to specifically overcome tissue barriers, facilitating its spread throughout the host.

Citation: Vieira ML, Atzingen MV, Oliveira TR, Oliveira R, Andrade DM, et al. (2010) In Vitro Identification of Novel Plasminogen-Binding Receptors of the Pathogen Leptospira interrogans. PLoS ONE 5(6): e11259. doi:10.1371/journal.pone.0011259

Editor: Holger Bruggemann, Max Planck Institute for Infection Biology, Germany

Received March 15, 2010; Accepted May 31, 2010; Published June 22, 2010

Copyright: (c) 2010 Vieira et al. This is an open-access article distributed under the terms of the Creative Commons Attribution License, which permits unrestricted use, distribution, and reproduction in any medium, provided the original author and source are credited.

Funding: This research was supported by FAPESP (Fundacao de Amparo a Pesquisa do Estado de Sao Paulo - www.fapesp.br), CNPq (Conselho Nacional de Desenvolvimento Cientifico e Tecnologico - www.cnpq.br) and Fundacao Butantan, Brazil. MLV, MVA, TRO and RO have fellowships from FAPESP (Brazil). The funders had no role in study design, data collection and analysis, decision to publish, or preparation of the manuscript.

Competing Interests: The authors have declared that no competing interests exist.

* E-mail: tabet@butantan.gov.br

\section{Introduction}

Leptospirosis is an emerging infectious disease with worldwide distribution and a zoonosis that is of human and veterinary concern. Pathogenic Leptospira are the etiological agents of leptospirosis, a disease with greater incidence in tropical and subtropical regions $[1,2,3,4,5]$. Leptospires cause chronic infection in domestic and wild mammalian species that harbor the bacteria in their renal tubules, shedding them through the urine into the environment, thus constituting a source of re-infection in other animals. Humans are accidental and terminal hosts in the transmission process of leptospirosis [3,6]. Leptospirosis represents a great economic burden as it affects the public health system and livestock [3].

The molecular pathogenesis of leptospirosis is poorly understood. To date, few virulence factors contributing to the pathogenesis of the disease have been identified $[7,8,9]$. It is well documented that the interaction of pathogens with the extracellular matrix (ECM) may play a primary role in the colonization of host tissues, as long-lasting infections may occur if microorganisms reach the sub-epithelial tissues [10]. Recently, the ability of the leptospires to adhere to ECM macromolecules has been shown, and some adhesins, ECM-binding proteins, have been identified $[9,11,12,13,14,15,16,17,18,19]$. However, under normal conditions, ECM is not exposed to bacteria. The proteolytic activity achieved by subversion of host proteases by pathogens, such as plasmin, has been demonstrated to be important in various bacterial infections [20]. Plasmin is a broad-spectrum serine protease component of the fibrinolytic system, which has the zymogen plasminogen (PLG) as its main component.

In our previous work, we found that Leptospira species are able to bind PLG and generate plasmin, in the presence of activator, on the outer surface in vitro [21], an activity already shown for the pathogenic spirochetes Borrelia and Treponema [22,23,24,25,26]. We have also revealed that leptospires express multiple PLG-binding proteins, as reported for other microorganisms. Recently, Verma et al. [27] have shown that the protein LenA of L. interrogans [14], formerly LfhA/Lsa24 [12,27], is a surface receptor for human plasminogen. 
In the present study, we further evaluated the ability of 14 recombinant proteins of Leptospira to mediate binding to PLG in vitro. Eight of the 14 assayed were identified as novel PLG-receptor proteins, including the major outer membrane protein LipL32 [28], the previously published rLIC12730, rLIC10494, Lp29, Lp49, LipL40 and MPL36 [29,30,31], and one novel leptospiral protein rLIC12238. Bound PLG could be converted to plasmin by the addition of urokinase-type PLG activator (uPA), showing specific proteolytic activity. We also show that PLG interaction with LipL32, also an ECM adhesin, was affected by collagen type IV but not plasma fibronectin. Our data provide an array of novel leptospiral receptors for human plasminogen, which constitutes an important step for the understanding of the molecular pathogenesis and infection process of these bacteria.

\section{Results}

\section{Selection of putative surface proteins from genome sequences}

The rationale for protein selection was mostly based on cellular localization, since surface proteins are potential receptors for PLG. Fourteen proteins available in our laboratory were selected: twelve were previously published, LipL32 [28,32], LipL40, MPL36 [29], rLIC10509 [33], Lp29, Lp49 [30], Lsa27 [11], MPL21, MPL17 [31], rLIC10494, rLIC12730 [12], and Lsa63 [19], and two are novel proteins, rLIC12922 and rLIC12238. Table 1 summarizes the features of the selected proteins and gene conservation within the sequenced genomes [34,35,36,37].

\section{Expression and purification of recombinant proteins}

The amplified coding sequences, excluding the signal peptide tags, were cloned and expressed as full-length proteins in E. coli. Gene locus, protein reference number, given name, sequences of primers used for PCR amplifications and molecular mass of recombinants are depicted in Table 1. The recombinant proteins were purified by nickel affinity chromatography, and an aliquot of each protein was analyzed by SDS-PAGE (Fig. 1). All purified proteins were represented by major bands, although in some cases such as Lsa27 and MPL21, other less intense protein bands were also observed. Structural integrity of the purified proteins not previously published, LipL40, MPL36, rLIC12922 and rLIC12238, was assessed by CD spectroscopy. The minima at 208 and $222 \mathrm{~nm}$, and the maximum at $192 \mathrm{~nm}$ in the $\mathrm{CD}$ spectrum showed the high $\alpha$-helical secondary structure content of the recombinant proteins LipL40, MPL36 and rLIC12922, while rLIC12238 showed a predominant signal of $\beta$-strands, with minimum ellipticity around $215 \mathrm{~nm}$ (data not shown).

\section{Cellular localization of the recombinant proteins}

To determine whether the proteins not previously characterized, namely Lp29, Lp49, LipL40, MPL36, rLIC10494, rLIC12730, rLIC12922 and rLIC12238, are surface-exposed proteins, we set out to analyze the corresponding protein location on the bacteria using living L. interrogans serovar Copenhageni cells and the liquid-phase immunofluorescence method. Leptospires were visualized by propidium iodide staining followed by protein detection with polyclonal mouse antiserum raised against the protein in the presence of anti-mouse IgG antibodies conjugated to FITC. The localization of the protein-green light lying on the leptospires was achieved by superimposing the two fields, and the results obtained are shown in Fig. 2. For each protein, two fields are depicted where we can see, in general, green fluorescence spots along the bacteria. An intense green fluorescence could be observed for LipL32, a well-known major outer membrane protein of Leptospira, used as a positive control [38], but not with GroEL, a protoplasmic-cylinder marker used as a negative control [39]. The PBS control showed only red fluorescence of leptospires stained with propidium iodide.

\section{Recombinant leptospiral proteins bind human plasminogen}

We have reported that $L$. interrogans binds PLG and that several proteins could act as receptors [21]. These data prompted us to investigate whether the selected surface-exposed proteins are capable of binding human PLG in vitro. We have employed Western blotting assay as a first screening to identify PLG-binding proteins. The results show that the proteins LipL32, Lp29, Lp49, LipL40, MLP36, rLIC10494, rLIC12730 and rLIC12238 were interacting with PLG, while no binding was seen with Lsa63, Lsa27, rLIC10509, MPL21, MPL17, rLIC12730 and rLIC12922 (Fig. 3A). In addition, the data clearly indicate that binding only occur with the expected molecular mass corresponding to the recombinant proteins (Fig. 3A). The binding of the proteins to PLG was also evaluated by ELISA. The fourteen recombinant leptospiral proteins, and BSA, used as negative control, were individually immobilized onto 96-wells plates, incubated with human PLG and the results obtained from three independent experiments are shown in Fig. 3B. Proteins LipL32, Lp29, Lp49, LipL40, MLP36, rLIC10494 and rLIC12238 presented statistically significant binding to PLG $(* P<0.001$ and $* * P<0.0001)$, while proteins, Lsa63, Lsa27, rLIC10509, MPL21, MPL17, rLIC12730, rLIC12922 and BSA did not show significant binding activity (Fig. 3B). The ELISA data are in agreement with the one obtained with Western blotting except for rLIC12730 and rLIC12238 that show discrepancy in binding with the two methodologies. The rLIC12730 depicted a stronger binding by Western blotting when compared to ELISA data, while rLIC12238 showed an opposite behavior (Fig. 3A, 3B).

\section{Comparison of encoding sequences of the detected leptospiral plasminogen-binding proteins and those of published plasminogen-binding proteins}

To investigate whether the identified PLG-binding proteins showed sequence similarity with other published spirochetal PLGbinding proteins $[40,41,42,43,44]$, we carried out sequence alignment analysis using the Clustal X program and a tree-display NJ plot $[45,46]$. The constructed dendrogram showed that leptospiral PLG-binding proteins do not display sequence similarity or share conserved domains with other reported spirochetal PLG-binding proteins (data not shown).

\section{Role of lysine residues in the plasminogen binding activity}

It is known that PLG kringle domains frequently mediate interactions with lysine residues of the bacterial receptors [20]. These domains participate in the binding of PLG with intact live L. interrogans serovar Copenhageni strain L1-130, since the derivative and analogue of lysine, ACA, almost totally inhibited binding [21]. Sequence analysis showed that the native PLG binding proteins, LipL32, Lp29, Lp49, LipL40, MPL36, LIC10494, LIC12238 and LIC12730, contain 9.6, 9.3, 10.7, 7.8, 10.6, 9.1, 8.8 and 5.5\% lysine residues, respectively. Based on these findings, the participation of lysine residues in the binding of the recombinant proteins was evaluated by the addition of ACA to the assay. As depicted in Fig. 4A, when $2 \mathrm{mM}$ ACA was added to the reaction, the binding of the proteins to PLG was almost completely abolished. 
Table 1. Gene locus, protein name, NCBI reference sequence, features, gene conservation, sequence of the primers employed for DNA amplification, and molecular mass of expressed recombinant proteins.

\begin{tabular}{|c|c|c|c|c|c|c|}
\hline Gene locus ${ }^{1}$ & $\begin{array}{l}\text { Recombinant } \\
\text { protein } \\
\text { given name }\end{array}$ & $\begin{array}{l}\text { NCBI } \\
\text { reference } \\
\text { sequence } \\
\text { number }\end{array}$ & $\begin{array}{l}\text { Description/ } \\
\text { Function }\end{array}$ & $\begin{array}{l}\text { Conservation } \\
\text { (identity) }^{3}\end{array}$ & $\begin{array}{l}\text { Sequence of primers } \\
\text { for PCR amplification }\end{array}$ & $\begin{array}{l}\text { Recombinant } \\
\text { protein } \\
\text { molecular } \\
\text { mass [70] }\end{array}$ \\
\hline \multirow[t]{2}{*}{ LIC11352 } & $\operatorname{LipL} 32^{\mathrm{a}}$ & YP_001316 & $\begin{array}{l}\text { Major outer membrane protein } \\
\text { (MOMP), LipL32 lipoprotein }\end{array}$ & $\begin{array}{l}\text { Lai }(100 \%) \\
\text { LBH }(98 \%)\end{array}$ & F: 5' CACCGGTGCTTTCGGTGGTCTG 3' & 30.2 \\
\hline & & & & & R: 5' ATTACTTAGTCGCGTCAGAAGC 3' & \\
\hline \multirow[t]{2}{*}{ LIC10314 } & Lsa63 $^{\text {b }}$ & YP_000304 & $\begin{array}{l}\text { Conserved hypothetical protein } \\
\text { with Borrelia_P83 domain }\end{array}$ & $\begin{array}{l}\text { Lai }(98 \%) \text {; } \\
\text { LBH }(87 \%)\end{array}$ & $\begin{array}{l}\text { F: 5' GGATCCTTATTTTCTCAGGAAAG 3' } \\
\text { (Bam } \overline{\mathrm{HI}} \text { I) }\end{array}$ & 63.0 \\
\hline & & & & LBP (39\%) & R: 5' GGTACCCTAAGGTTTAATTITITT 3' (Kpn I) & \\
\hline \multirow[t]{2}{*}{ LIC10509 } & rLIC10509 & YP_000493 & Putative lipoprotein & Lai (98\%) & $\begin{array}{l}\text { F: 5' CCGGGATCCAAAAAGAGCAAAGAAG 3' } \\
\text { (BamH I) }\end{array}$ & 22.0 \\
\hline & & & & & $\begin{array}{l}\text { R: 5' GGTACCCTACTCGAGACAGCCAGGA- } \\
\left.\text { CCTT } \overline{C 3^{\prime}(\mathrm{Kpn}} \mathrm{I}\right)\end{array}$ & \\
\hline \multirow[t]{2}{*}{ LIC12892 } & $\operatorname{Lp} 29^{d}$ & YP_002808 & Putative lipoprotein & & $\begin{array}{l}\text { F: 5' CTCGAGGCAGTACATTACAATC- } \\
\text { TTGCT } 3^{\prime} \text { (Xho I) }\end{array}$ & 29.6 \\
\hline & & & & & R: 5' CCATGGCTCTTAGGAGCCTGGAAA 3' (Nco I) & \\
\hline \multirow[t]{2}{*}{ LIC10793 } & $\operatorname{Lp} 49^{d}$ & YP_000772 & $\begin{array}{l}\text { Putative lipoprotein, } \\
\text { Surface antigen }\end{array}$ & $\begin{array}{l}\text { Lai }(99 \%) \text {; } \\
\text { LBH }(86 \%)\end{array}$ & $\begin{array}{l}\text { F: 5' CTCGAGAGCGGAGACTTTCTTTACTT 3' } \\
(X h o l)\end{array}$ & 49.1 \\
\hline & & & & & $\begin{array}{l}\text { R: } 5^{\prime} \text { CCATGGTTAAAAACCATCTCTACG- } \\
\text { ATAAAC 3' (Nco I) }\end{array}$ & \\
\hline \multirow[t]{2}{*}{ LIC12895 } & $\operatorname{Lsa} 27^{\mathrm{e}}$ & YP_002811 & Putative lipoprotein & Lai $(79 \%)$ & F: 5' GGATCCCTGAAATATACGAA 3' (EcoRI) & 27.0 \\
\hline & & & & & R: 5' GAATTCTTACTGTTCTCCTTC 3' (BamHI) & \\
\hline \multirow[t]{2}{*}{ LIC13131 } & MPL21 ${ }^{\mathrm{a}, \mathrm{f}}$ & YP_003039 & $\begin{array}{l}\text { Hypothetical protein } \\
\text { with Ycel domain }\end{array}$ & $\begin{array}{l}\text { Lai }(98 \%) \\
\text { LBP }(45 \%)\end{array}$ & F: 5' CACCACGTCTCAAAGTTACGCTTCAG 3' & 21.9 \\
\hline & & & & & R: 5' TTCTCACCATCCAGCTCGG 3' & \\
\hline \multirow[t]{2}{*}{ LIC10765 } & MPL17 $7^{\mathrm{a}, \mathrm{f}}$ & YP_000745 & $\begin{array}{l}\text { Conserved hypothetical } \\
\text { protein }\end{array}$ & $\begin{array}{l}\text { Lai }(100 \%) \\
\text { LBH }(80 \%)\end{array}$ & F: 5' CACCGAAAGTCCCGTAAGGTTCAAA 3' & 15.4 \\
\hline & & & & LBP $(41 \%)$ & R: 5' TGCAGGAGTTCCCACATTTTA 3' & \\
\hline \multirow[t]{2}{*}{ LIC10091 } & LipL40 ${ }^{a}$ & YP_000088 & Putative lipoprotein & $\begin{array}{l}\text { Lai }(100 \%) \\
\text { LBH }(84 \%)\end{array}$ & $\begin{array}{l}\text { F: 5' CCATGGGACTCGAGACGCCTCCTCC- } \\
\text { TAAAGATCC } 3^{\prime}\end{array}$ & 39.0 \\
\hline & & & & & $\begin{array}{l}\text { R: 5' CTCCATGGTCATTTCAAAACTT- } \\
\text { CTACGGGGC 3' }\end{array}$ & \\
\hline \multirow[t]{2}{*}{ LIC10054 } & MPL36 ${ }^{\mathrm{a}}$ & YP_000054 & $\begin{array}{l}\text { Putative lipoprotein with Rare } \\
\text { lipoprotein A (RpIA) like domain }\end{array}$ & $\begin{array}{l}\text { Lai }(100 \%) \\
\text { LBH }(88 \%)\end{array}$ & F: 5' CACCACGTCTTGTGCGTCGGTAGAG 3' & 35.1 \\
\hline & & & & LBP $(50 \%)$ & R: 5' CCAAGTATTCTATTTATACGTCCGAG 3' & \\
\hline \multirow[t]{2}{*}{ LIC10494 } & rLIC $10494^{g}$ & YP_000478 & Putative lipoprotein & Lai (99\%) & F: 5' CACCACTGCTAGGGCTGCAGAAA 3' & 25.8 \\
\hline & & & & & R: 5' ACTTTGAGAGCTTCGTCTCGT 3' & \\
\hline \multirow[t]{2}{*}{ LIC12730 } & rLIC $12730^{9}$ & YP_002650 & $\begin{array}{l}\text { Hypothetical protein with TPR } \\
\text { domain and } 4 \mathrm{NHL} \text { repetition }\end{array}$ & $\begin{array}{l}\text { Lai }(100 \%) \\
\text { LBH }(90 \%)\end{array}$ & F: 5' CACCAGTTCTGACGGACTTCCCAA 3' & 77.4 \\
\hline & & & & LBP $(37 \%)$ & R: 5' TCTTGCGAATGAGTTGATCC 3' & \\
\hline \multirow[t]{2}{*}{ LIC12922 } & rLIC12922 & YP_002837 & Conserved hypothetical protein & $\begin{array}{l}\text { Lai }(100 \%) \text {; } \\
\text { LBH }(89 \%)\end{array}$ & F: 5' CACCGAATCACTCAACAGAGTCATTGC 3' & 40.0 \\
\hline & & & & LBP $(48 \%)$ & R: 5' ATCAATCTAAATGAAACGTCTCTTC $3^{\prime}$ & \\
\hline \multirow[t]{2}{*}{ LIC12238 } & rLIC12238 & YP_002173 & Putative lipoprotein & $\begin{array}{l}\text { Lai }(100 \%) \\
\text { LBH }(81 \%)\end{array}$ & $\begin{array}{l}\text { F: 5' CTCGAGTGTTITAAACCTACCGGAG 3' } \\
(\text { Xho I) }\end{array}$ & 17.6 \\
\hline & & & & LBP (39\%) & $\begin{array}{l}\text { R: 5' AAGCTTCTACTTCATCGCTITTTCTATATC } \\
3^{\prime} \text { (Hind III) }\end{array}$ & \\
\hline
\end{tabular}

${ }^{1}$ http://aeg.lbi.ic.unicamp.br/world/lic/ [35].

${ }^{2}$ http://www.ncbi.nlm.nih.gov/protein/.

${ }^{3}$ Protein BLAST - http://www.ncbi.nlm.nih.gov/blast/Blast.cgi [71,72].

a Previously published by Gamberini et al. [29].

${ }^{b}$ Vieira et al. [19].

'Previously published by Gómez et al. [33].

dPreviously published by Neves et al. [30].

epreviously published by Longhi et al. [11].

fPreviously published by Oliveira et al. [31].

${ }^{9}$ Previously published by Barbosa et al. [12].

${ }^{\mathrm{h}}$ This work; Lai: L. interrogans serovar Lai [34]; LBH: L. borgpetersenii serovar Hardjo-bovis [36]; LBP: L. biflexa serovar Patoc [37].

doi:10.1371/journal.pone.0011259.t001 


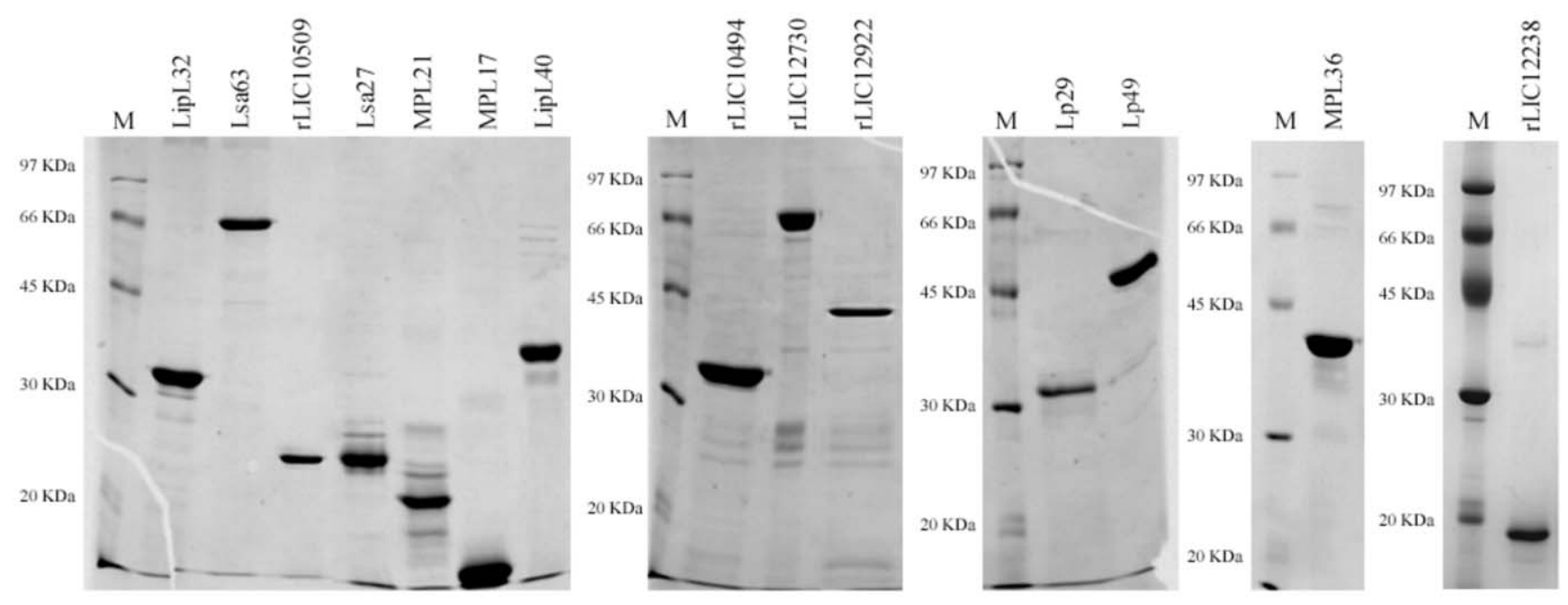

Figure 1. SDS-PAGE analysis of purified recombinant proteins. Recombinant proteins were expressed in E. coli BL21 (DE3) or SI and purified from the bacterial cell lysate using $\mathrm{Ni}^{2+}$-charged chelating Sepharose columns. M: molecular mass protein marker. doi:10.1371/journal.pone.0011259.g001

\section{Activation of plasminogen-bound proteins}

PLG bound to the surface of $L$. interrogans is converted to enzymatically active plasmin by the addition of activator [21]. To determine if PLG bound to recombinant proteins can acquire proteolytic activity, 96-well plates were coated with the test proteins, blocked, and then incubated with PLG. Unbound PLG was washed away and the uPA-type PLG activator was added together with a plasmin-specific chromogenic substrate. The reaction was carried out overnight and the plasmin activity was evaluated by measuring the cleavage of the plasmin-specific chromogenic substrate (absorbance at $405 \mathrm{~nm}$ ). As shown in Fig. 4B, the PLG captured by the proteins could be converted into plasmin, as demonstrated indirectly by specific proteolytic activity. The negative control BSA did not bind PLG (see Fig. 4) and did not show any proteolytic activity, as with the controls lacking PLG, uPA or the chromogenic substrate.

\section{Characterization of the binding of recombinant proteins to PLG}

The interactions between the recombinant proteins and PLG were assessed on a quantitative basis as illustrated in Fig. 5A. Dose-dependent and saturable binding was observed when increasing concentrations ( 0 to $1,000 \mathrm{nM}$ ) of the recombinant proteins MPL36, LipL40, LipL32, rLIC10494 and rLIC12238 were allowed to individually adhere to a fixed PLG amount $(1 \mu \mathrm{g})$. For the proteins Lp29, Lp49 and rLIC12730, the saturation level was not reached, even at the highest concentration tested $(1,000 \mathrm{nM})$. Based on the ELISA data, the calculated dissociation equilibrium constants $\left(K_{\mathrm{D}}\right)$ for the recombinant proteins with PLG are depicted in Fig. 5B; for the ones that reached equilibrium, the highest and the lowest $K_{\mathrm{D}}$ values were for LipL32 $(25.87 \pm 5.09 \mathrm{nM})$ and MPL36 $(3.52 \pm 3.95 \mathrm{nM})$, respectively.

\section{Effects of salt and heparin on LipL32- and rLIC12238 - plasminogen interactions}

As the proteins LipL32 and rLIC12238 showed the highest PLG binding and plasmin activity (Fig. 3B and Fig. 4B), they were chosen for further studies. To verify whether binding of these recombinant proteins to PLG is affected by added $\mathrm{Cl}^{-}$[47] or negatively charged heparin [48], binding assays were performed in the presence of different concentrations of $\mathrm{NaCl}$ or heparin. As shown in Fig. 6A, the increase in $\mathrm{Cl}$ anions to physiological conditions did not affect binding, and interference was only detected at a higher salt concentration, $350 \mathrm{mM}$, for both proteins. Similarly, the addition of heparin (up to 500 IU) did not have any significant effect on the interaction of the proteins with PLG (Fig. 6B).

\section{Collagen type IV, but not plasma fibronectin, competes with LipL32 for binding to PLG}

LipL32 has been previously demonstrated to be a leptospiral adhesin capable of binding collagen type IV and plasma fibronectin $[15,16]$. To see if the extracellular matrix components compete with LipL32 for the binding site of PLG or interfere somehow in the interaction with PLG, the binding assay was performed in the presence of increasing concentrations of collagen type IV or plasma fibronectin. The results show that plasma fibronectin had no effect on the binding of LipL32 to PLG (Fig. 7). On the other hand, the addition of collagen type IV decreased LipL32 binding to PLG in a dose-dependent fashion (Fig. 7), suggesting that both molecules compete for the same binding site.

\section{Discussion}

The interaction of the human plasminogen system has been suggested to be a feature that significantly contributes to the virulence of many bacterial pathogens by facilitating the initial anchoring to the endothelium [20]. Through capturing the host PLG on its surface, followed by activation to enzymatically active plasmin, the bacteria are turned into proteolytic organisms, a characteristic that has been shown to contribute to the degradation of ECM components, tissue penetration and invasion. In our previous work, we showed that leptospires are capable of capturing PLG on its outer surface and that the addition of exogenous activator converted it into enzymatically active plasmin capable of degrading ECM fibronectin [21]. In addition, multiple PLGbinding proteins present in the L. interrogans serovar Copenhageni whole cell lysates were detected, but remained unidentified [21]. Moreover, as expected, our data suggest the involvement of outer membrane proteins in the binding. Indeed, Verma and colleagues [27] have recently demonstrated that LenA, a surface leptospiral 


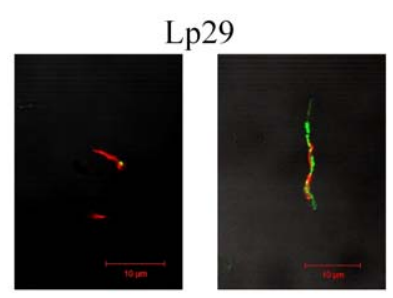

Lp49

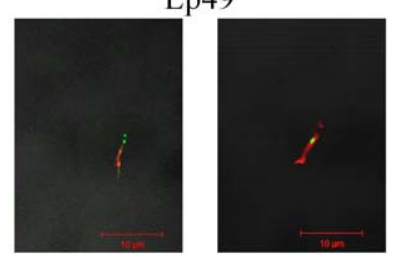

LipL40

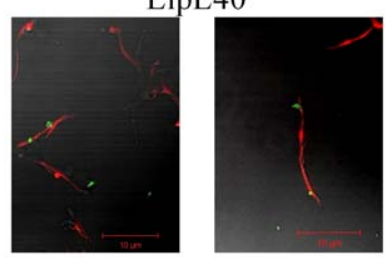

MPL36
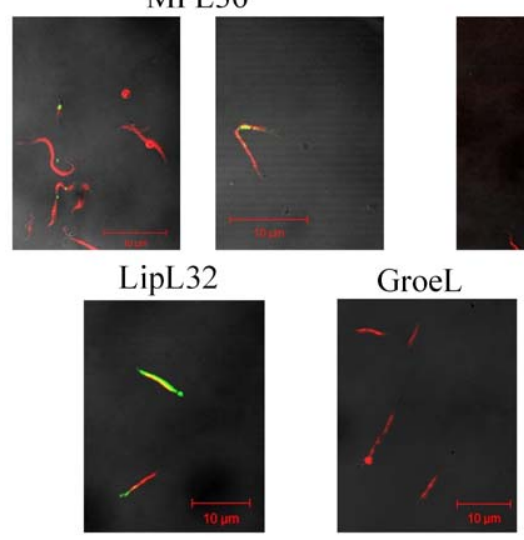

Figure 2. Cellular localization of proteins in L. interrogans by LIFA. Protein recognition by L-IFA. Proteins in live $L$. interrogans serovar Copenhageni isolates were recognized by FITC-conjugated antibodies against Lp29, Lp49, LipL40, MPL36, LIC10494, LIC12730, LIC12922, LIC12238 and LipL32 (surface-exposed lipoprotein, positive control), but not against GroEL (a protoplasmic cylinder marker) and PBS (negative control) under confocal microscopy. The leptospires were identified using the DNA counterstain propidium iodide. Panels are composite images of propidium iodide- and FITC-stained slides. Magnification, $600 \times$.

doi:10.1371/journal.pone.0011259.g002

protein [14] is a bacterial receptor for human plasminogen. The availability of several putative surface-exposed recombinant proteins of $L$. interrogans in our laboratory prompted us to investigate the ability of these proteins to interact with PLG in vitro, in order to reveal and extend the array of plasminogen receptors in Leptospira.

The fourteen proteins selected for the screening of PLG binding were cloned and expressed in E. coli as full-length recombinant proteins. The purified proteins exhibited major bands in SDSPAGE making them suitable for PLG binding assays. The structural integrity of the unpublished purified proteins was attested by CD spectroscopy revealing a mixture of $\alpha$-helix and $\beta$-strand structures. The other recombinant proteins had their CD spectra confirmed and were similar to the ones previously reported $[11,12,19,30,31,33]$. The cellular localization of the proteins Lp29, Lp49, LipL40, MPL36, rLIC10494, rLIC12730, rLIC12922 and rLIC12238, was shown to be the cell surface, similar to findings for the previously published LipL32 [28], Lsa63 [19], rLIC10509 [33], Lsa27 [11], MPL21 and MPL17 [31].

Several invasive gram-positive and gram-negative bacteria have been shown to interact with the host PLG system [20,49,50,51,52], a phenomenon that has also been observed with viruses $[53,54,55]$ and parasites [56], either by expression of PLG receptors or stimulation of host activators. In the case of spirochetes, the plasminogen activation system was studied with several species of Borrelia with Treponema denticola and suggested to have an important role during infection [22,23,24,25,26].

The human plasminogen heavy chain contains five tripledisulfide-linked peptide regions of $\sim 80$ amino acids, called kringles [57]. The process of binding to bacterial receptors on the cell surface has been shown for several pathogens to be mediated by the PLG kringle domains through the lysine-binding sites present [20]. Similarly, Borrelia [24] and Leptospira [21] also bind PLG via kringle domains. We have identified eight leptospiral plasminogenbinding proteins: LipL32 [28,32], rLIC10494, rLIC12730 [12], Lp29, Lp49 [30] and LipL40 and MPL36 [29] and one novel protein rLIC12238. The specificity of the binding of these recombinant proteins was attested by Western blotting. Interestingly, two proteins showed disparate binding intensity by Western blotting and ELISA. This could be explained by the fact that ELISA is a quantitative method but Western blotting is not. In addition, due to the denaturing condition of this latter method, it is possible that the exposure of some epitopes led to better binding for rLIC12730, while the inverse situation was seen with rLIC12238 which apparently needs a more native condition for PLG binding.

Plasminogen-binding proteins of $B$. burgdorferi, including the outer-surface lipoprotein OspA, have been identified [41]. Recently, Brissette and coworkers [44] identified three proteins of B. burgdorferi, ErpP, ErpA and ErpC, as being PLG-binding proteins. Interestingly, an evaluation of the primary sequence of spirochete PLG-binding proteins show that the proteins do not share similarity, with the exception of the Erp family protein of $B$. burgdorferi [44], BbCRASP-1 of B. hermsii [43] and HcpA of $B$. recurrentis [40].

Our data with the PLG-binding proteins point out to a primary role for lysine residues in plasminogen binding, as the lysine analog 6-aminocaproic acid (ACA) significantly inhibited binding $[21,27,58]$. However, no correlation between the number of lysine residues and PLG binding was detected. Indeed, the highest percentage of lysine residues was identified in Lsa63 [19], a protein that did not bind PLG. Moreover, lysine residue position does not seem to correlate with binding because they were distributed among all the protein sequences studied. This suggests that protein conformation and steric hindrance should be important factors in the binding of the protein/receptor to PLG. Plasminogen-binding proteins were able to generate active plasmin in the presence of urokinase-type PLG activator, as measured by the cleavage of plasmin-specific chromogenic substrate.

The recombinant proteins bind to PLG in a concentrationdependent and saturable fashion, indicating the specificity of the binding, for the proteins LipL32, LipL40, MPL36, rLIC12238 and rLIC10494. The calculated dissociation equilibrium constants $\left(K_{\mathrm{D}}\right)$ for the recombinant proteins with PLG varied from 25.87 $\pm 5.09 \mathrm{nM}$ for LipL32 to $3.52 \pm 3.95 \mathrm{nM}$ for MPL36. The plasminogen interaction/activation has been shown to be suppressed by the presence of $\mathrm{Cl}$ anions [47], while there is 

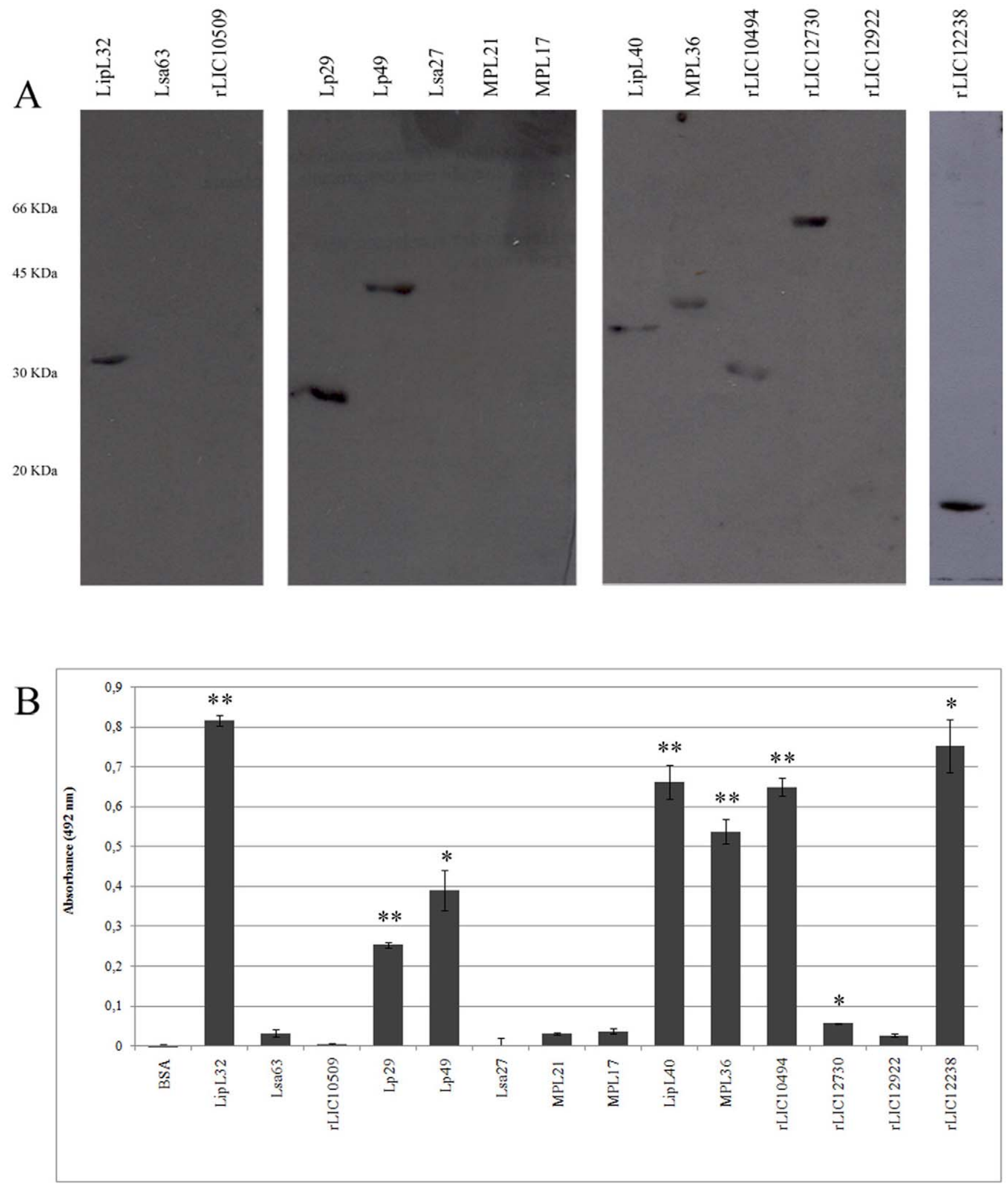

Figure 3. Binding of leptospiral recombinant proteins to human plasminogen. A. The proteins were electrophoresed in $12 \%$ SDS-PAGE gels and transferred to nitrocellulose membranes, followed by overnight incubation with $3 \mu \mathrm{g} / \mathrm{mL}$ PLG; after washing, the membrane was incubated with mouse anti-human PLG (1:750), followed by incubation with anti-mouse lgG $(1: 5,000)$. Protein reactivity was revealed by ECL reagent/exposure to $X$-ray films. B. The recombinant proteins LipL32, Lsa63, rLIC10509, Lp29, Lp49, Lsa27, MPL21, MPL17, LipL40, MPL36, rLIC10494, rLIC12730, rLIC12922 and rLIC12238 were coated onto 96-well ELISA plates $(10 \mu \mathrm{g} / \mathrm{ml})$ and allowed to interact with purified human PLG (10 $\mu \mathrm{g} / \mathrm{ml})$. BSA was used as a negative control for nonspecific binding. Binding was detected and quantified by specific antibodies. Bars represent the mean absorbance values at $492 \mathrm{~nm} \pm$ the standard deviation of four replicates for each protein and are representative of three independent experiments. ${ }^{*} P<0.001 ;{ }^{* *} P<0.0001$. doi:10.1371/journal.pone.0011259.g003 
A

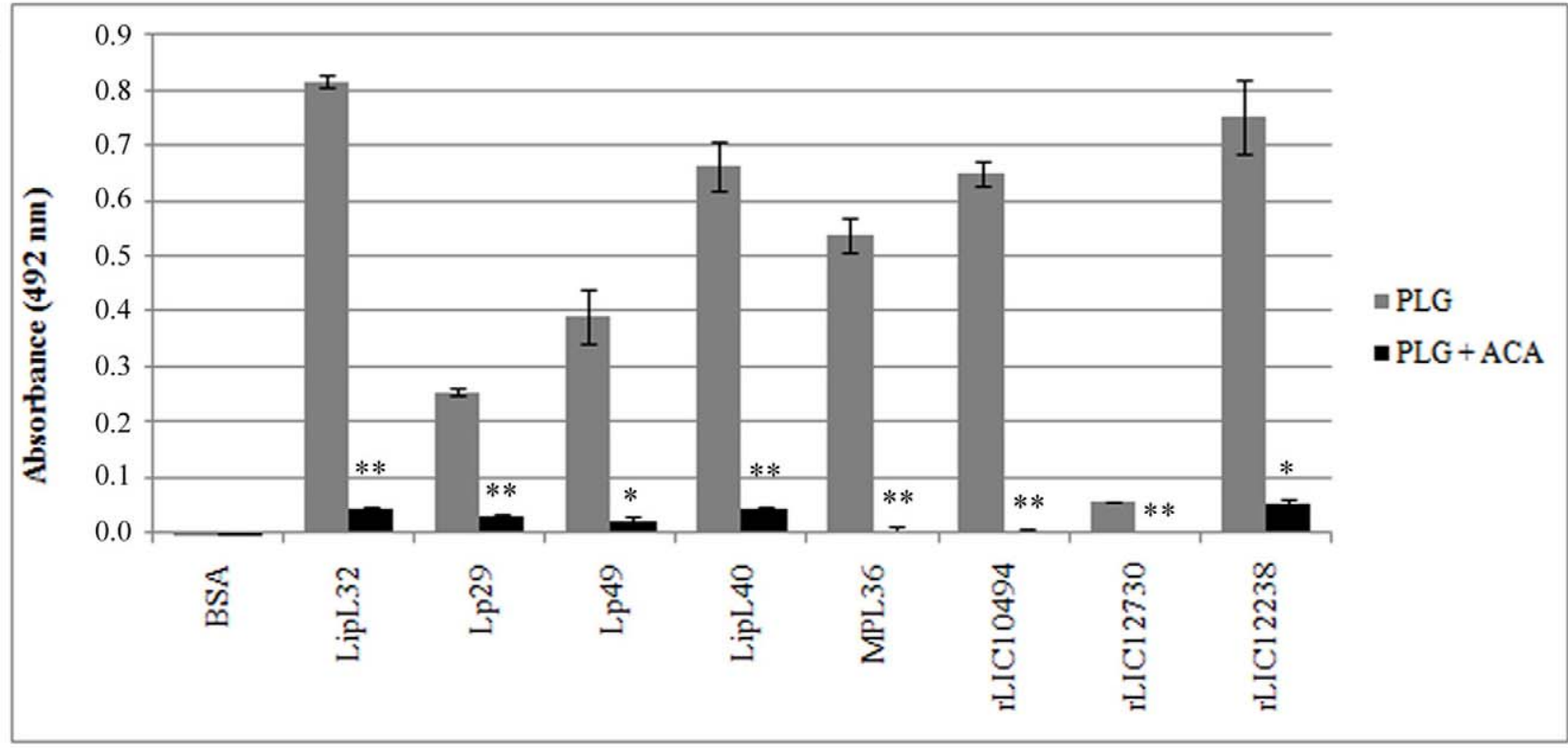

B

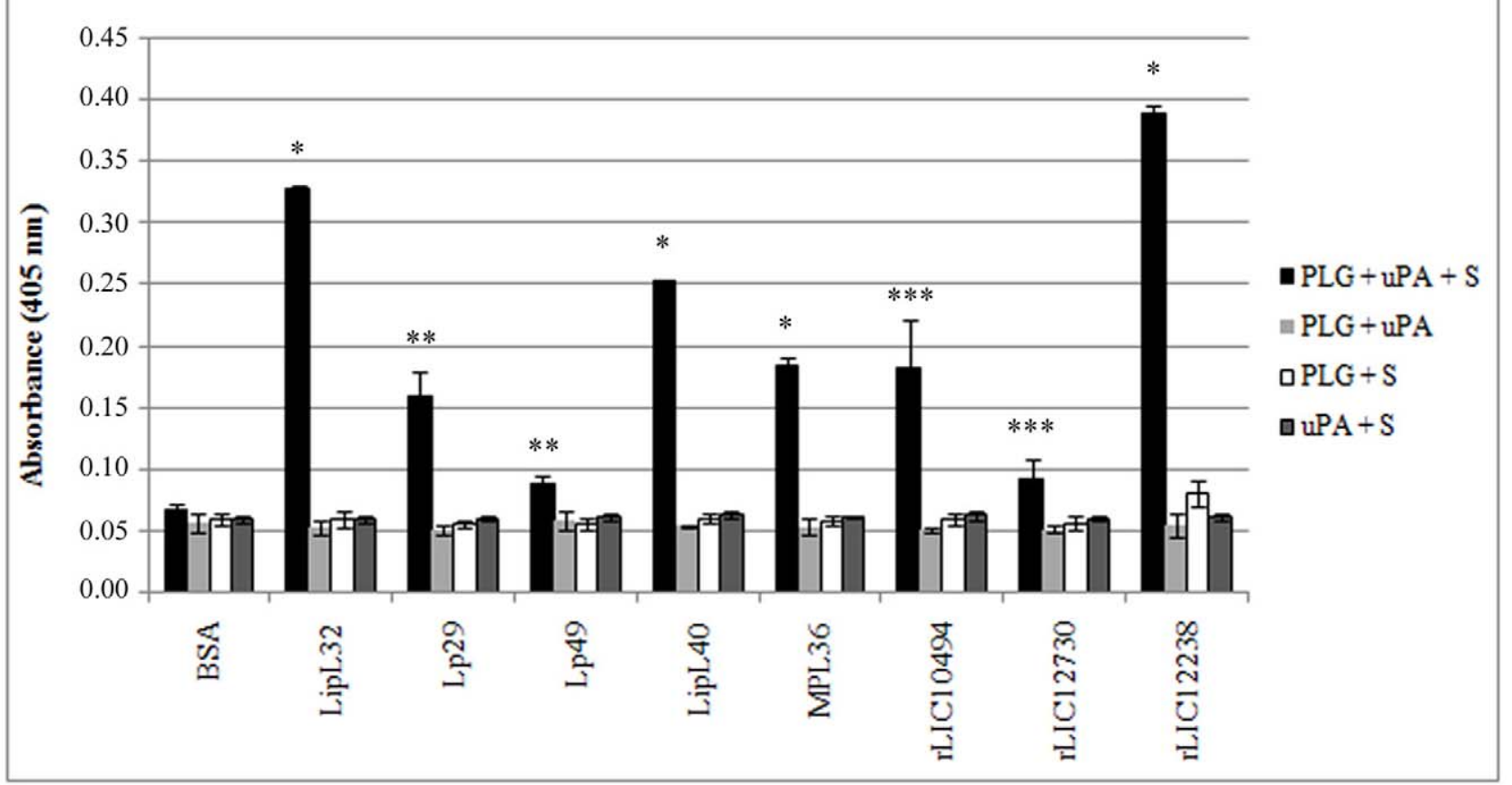

Figure 4. Role of lysine residues in recombinant protein-PLG interaction and activation to enzymatically active plasmin. A: Binding of the immobilized proteins LipL32, Lp29, Lp49, LipL40, MPL36, rLIC10494, rLIC12730 and rLIC12238 (10 $\mu \mathrm{g} / \mathrm{ml})$ to PLG (10 $\mu \mathrm{g} / \mathrm{ml}) \mathrm{was}$ carried out in the presence (PLG+ACA) or absence (PLG) of the lysine analogue 6-aminocaproic acid. BSA was used as a negative control for nonspecific binding. The bound PLG was detected and quantified by specific antibodies. Bars represent the mean absorbance at $492 \mathrm{~nm} \pm$ the standard deviation of four replicates for each sample and are representative of two independent experiments. Statistically significant differences are shown by $*(P<0.001)$ and ** $(P<0.0001)$. B: Cleavage of specific plasmin substrate by PLG bound to recombinant proteins was assayed by modified ELISA as immobilized proteins received the following treatment: PLG+uPA+specific plasmin substrate (PLG+UPA+S), or controls lacking one of the three components (PLG+uPA; PLG+S; uPA+S). BSA was employed as a negative control. Bars represent the mean absorbance values at $405 \mathrm{~nm}$, as a measure of relative substrate cleavage, \pm the standard deviation of four replicates for each experimental group and are representative of two independent experiments. Statistically significant differences are shown by ${ }^{*}(P<0.00001),{ }^{* *}(P<0.005)$ and ${ }^{* * *}(P<0.05)$.

doi:10.1371/journal.pone.0011259.g004

evidence that heparin dextran derivatives could contribute to the regulation of plasmin activity, not only by impeding plasmin generation, as a result of their binding to plasminogen but also by directly affecting the catalytic activity of the enzyme [48]. The addition of $\mathrm{Cl}^{-}$did not inhibit LipL32 or rLIC12238-PLG interactions, showing in fact, a positive effect with increasing sodium chloride concentration. The presence of heparin had no influence on the binding of either protein to PLG. Similar results 
A

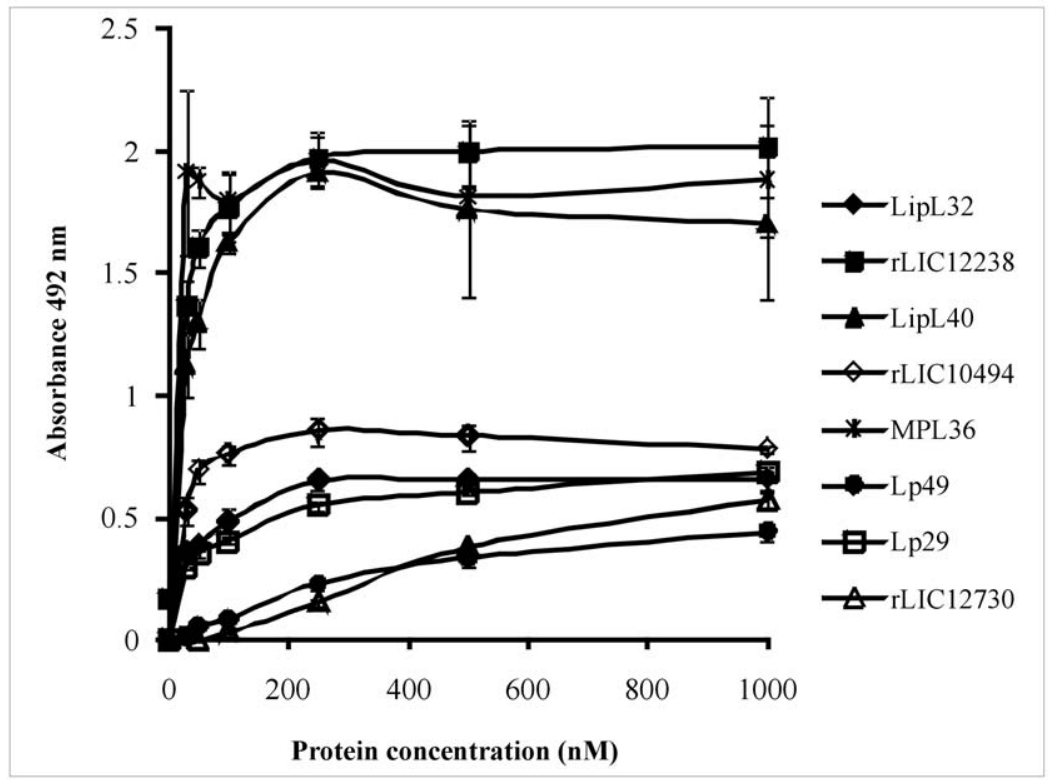

$\mathrm{B}$

\begin{tabular}{|lc|}
\hline Recombinant proteins & Dissociation constant $\left(\boldsymbol{K}_{\mathbf{p}}\right)$ \\
\hline LipL32 & $25.87 \pm 5.09 \mathrm{nM}$ \\
rLIC12238 & $11.97 \pm 1.06 \mathrm{nM}$ \\
LipL40 & $18.24 \pm 2.45 \mathrm{nM}$ \\
rLIC10494 & $10.98 \pm 2.33 \mathrm{nM}$ \\
MPL36 & $3.52 \pm 3.95 \mathrm{nM}$ \\
Lp49 & ND * \\
Lp29 & ND * \\
rLIC12730 & ND * \\
\hline & \\
\hline
\end{tabular}

Figure 5. Characterization of recombinant proteins binding to PLG. A. PLG $(10 \mu \mathrm{g} / \mathrm{ml})$ was immobilized in $96-w e l l$ ELISA plates, and each recombinant protein at 0 to $1,000 \mathrm{nM}$ was added for interaction. The binding was detected using antiserum raised in mice against each protein at appropriate dilutions (1:4,000 for LipL32; 1:5,000 for rLIC12238, LipL40 and MPL36; 1:1,000 for Lp29 and Lp49; 1:500 for rLIC12730), followed by horseradish peroxidase-conjugated anti-mouse lgG. Data represent the mean absorbance values \pm the standard deviation of six replicates for each experimental group. The results are representative of two independent experiments. B. The dissociation constant $\left(K_{\mathrm{D}}\right)$ was calculated based on ELISA data for the recombinant proteins that reached equilibrium up to a concentration of 1,000 nM. doi:10.1371/journal.pone.0011259.g005

were obtained by Brissette and coworkers [44] studying the effect of both compounds on the interactions of ErpP recombinant protein of B. burgdorferi and plasminogen. Furthermore, Verma et al. [27] showed that heparin had no effect on LenA-PLG interactions but that the addition of salt led to an increase in binding.

The identified PLG-binding proteins Lp29, Lp49, LipL40 and MPL36 have been previously reported to be reactive with sera from leptospirosis patients [29,30] while rLIC12238 and rLIC10494 react with sera from hamsters infected with Leptospira (Nascimento, $\mathrm{AL}$ et al., unpublished results). These data suggest that the proteins are expressed and exposed during the course of infection. We confirmed here the localization of these four proteins and presented their PLG-binding properties. Taken together, our results implicate that these proteins play a possible role in virulence.

The protein LipL32 is a major outer membrane antigen expressed during mammalian infection $[16,28]$. It has been shown that LipL32 is recognized by patients' sera $[15,59]$ and has the ability to bind to ECM macromolecules [15], activities that suggest a role in the pathogenesis of leptospires. Intriguingly, it has also been demonstrated that LipL32 is not essential for either acute or chronic infection with $L$. interrogans [60]. Here, we provide another activity for LipL32, as a PLG-binding protein, giving further support to its importance during infection. Additionally, our results suggest that collagen type IV and PLG interact with the same site of LipL32, a situation that does not occur with plasma fibronectin. The dual activity of LipL32 in binding PLG and ECM macromolecules together with our previous findings of fibronectin degradation by plasmin-coated leptospires [21], may have implications on the mechanisms of the invasion process.

In conclusion, we have identified and characterized eight proteins as being PLG-binding proteins of Leptospira. There is evidence that at least five of them (LipL32, Lp29, Lp49, LipL40 
A

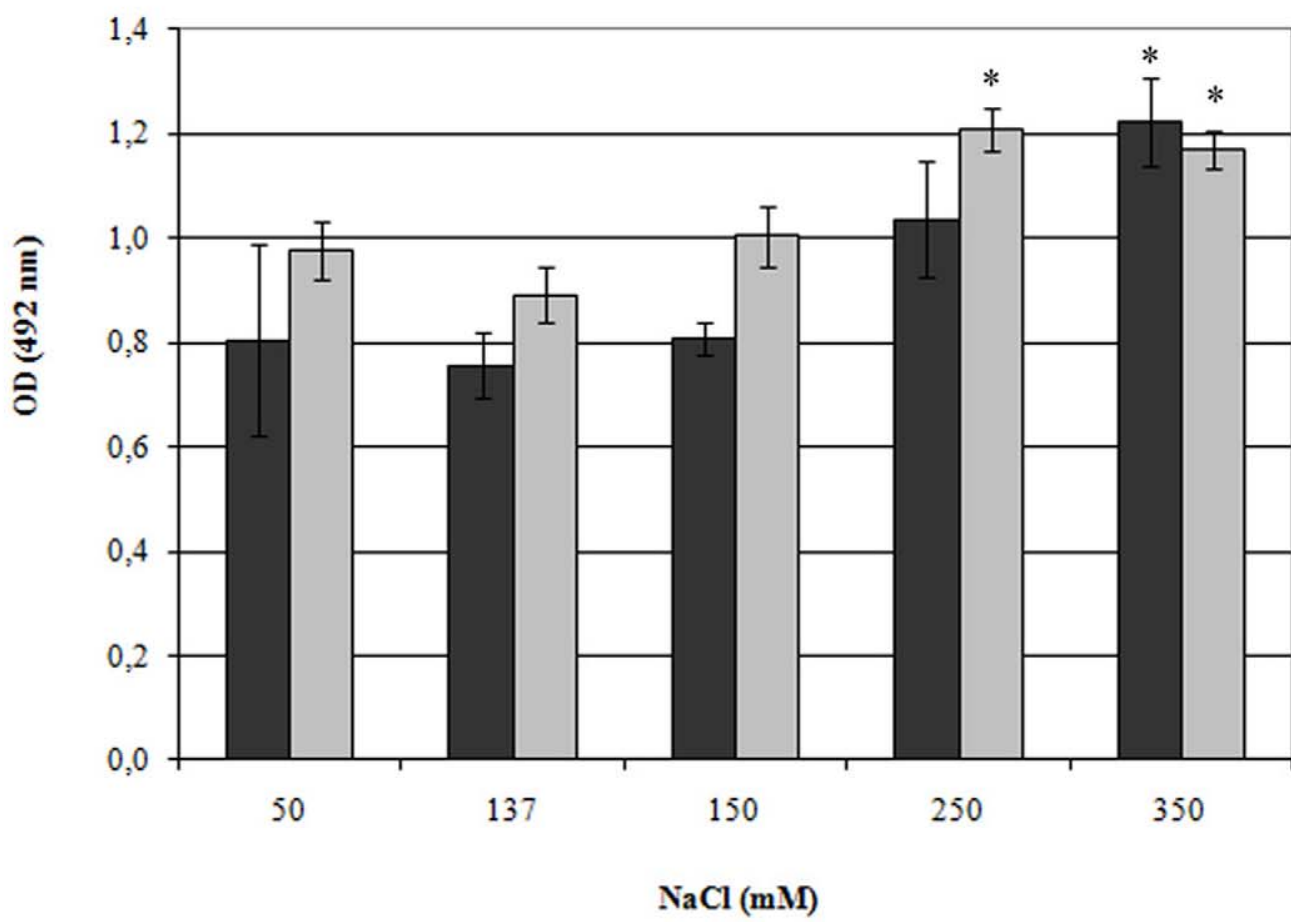

$\square \operatorname{LipL32}$

口rLIC 12238

B

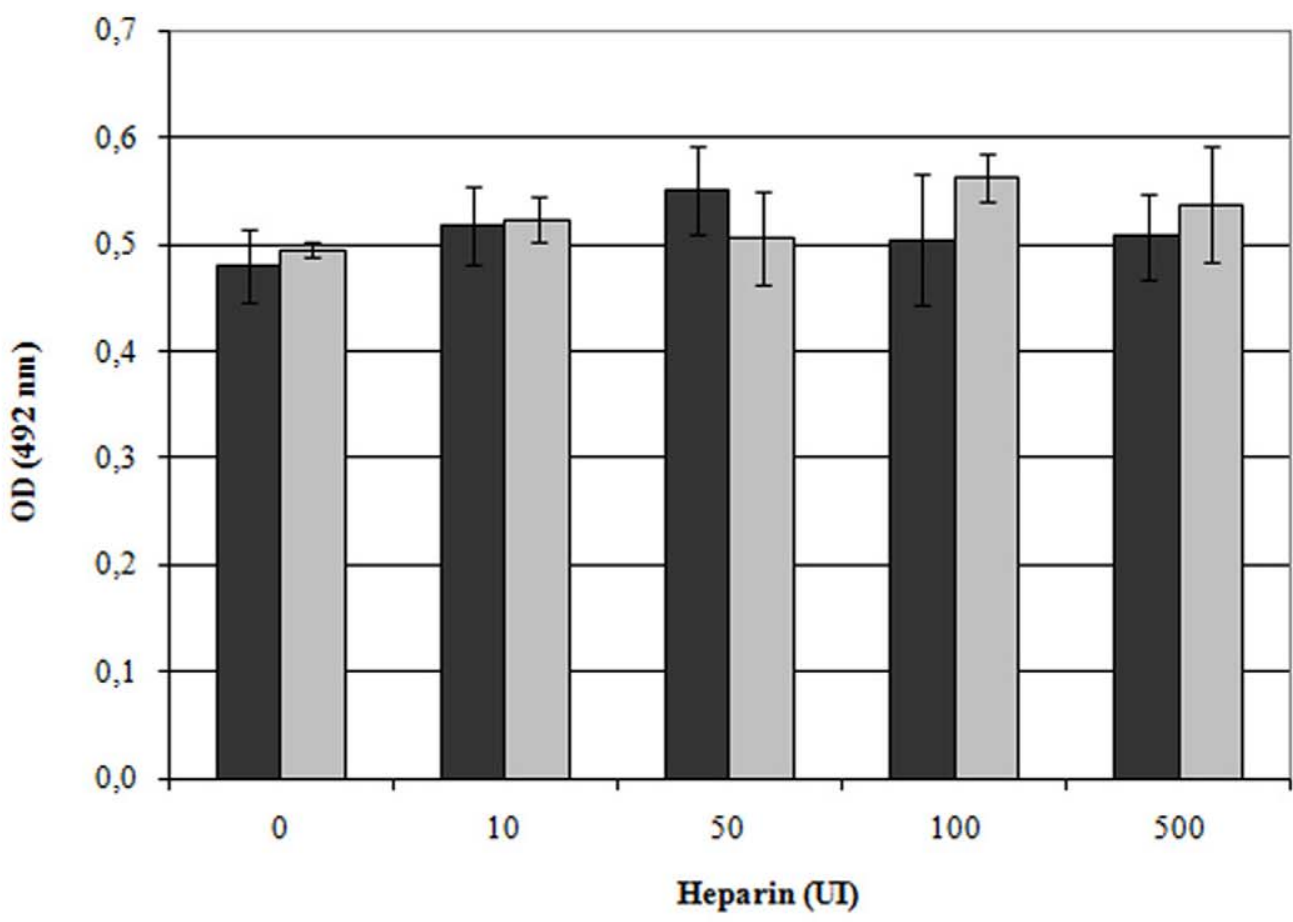

QLipL32

口LIC12238 
Figure 6. Effects of ionic strength and heparin in PLG binding by LipL32 and rLIC12238. Binding of LipL32 and rLIC12238 (10 $\mu$ g/ml) to immobilized PLG $(10 \mu \mathrm{g} / \mathrm{ml})$ was performed with the addition of increasing concentrations of $\mathrm{NaCl}(0$ to $350 \mathrm{mM})$ (A) or heparin (0 to 500 IU) (B). The detection of bound-PLG was assayed by specific antibodies. Bars represent the mean absorbance values \pm the standard deviation of four replicates for each experimental group and are representative of two independent experiments. The data show statistically significant differences in $\mathbf{A}$, shown by * $(P<0.05)$, but not in $\mathbf{B}$.

doi:10.1371/journal.pone.0011259.g006

and MPL36) are expressed during natural infection [28,29,30]. PLG-binding/activation through the proteins/receptors on the surface of Leptospira could help the bacteria to specifically overcome tissue barriers, facilitate invasion and colonize mammalian tissues. We believe that these studies provide new insights into leptospiral pathogenesis and infection.

\section{Materials and Methods}

Bioinformatics characterization of the proteins

Predicted coding sequences (CDSs ) were analyzed as their cellular localization predictions by PSORT program, http://psort. nibb.ac.jp [61,62]. The web servers SMART, http://smart. embl-heidelbergde/ [63,64], PFAM, http://www.sanger.ac.uk/ Software/Pfam/ [65], and LipoP, http://www.cbs.dtu.dk/services/ LipoP/ [66] were used to search for predicted functional and structural domains within the amino acid sequences of the CDSs.

\section{Cloning, expression and purification of recombinant proteins}

Amplification of the CDSs was performed by PCR from $L$. interrogans serovar Copenhageni genomic DNA using complementary primer pairs. The gene sequences were amplified without the signal peptide tag, predicted by SignalP (http://www.cbs.dtu.dk/ services/SignalP/ ). The final constructs were verified by DNA sequencing on an ABI Prism 3730_L sequencer (Seq- Wright,

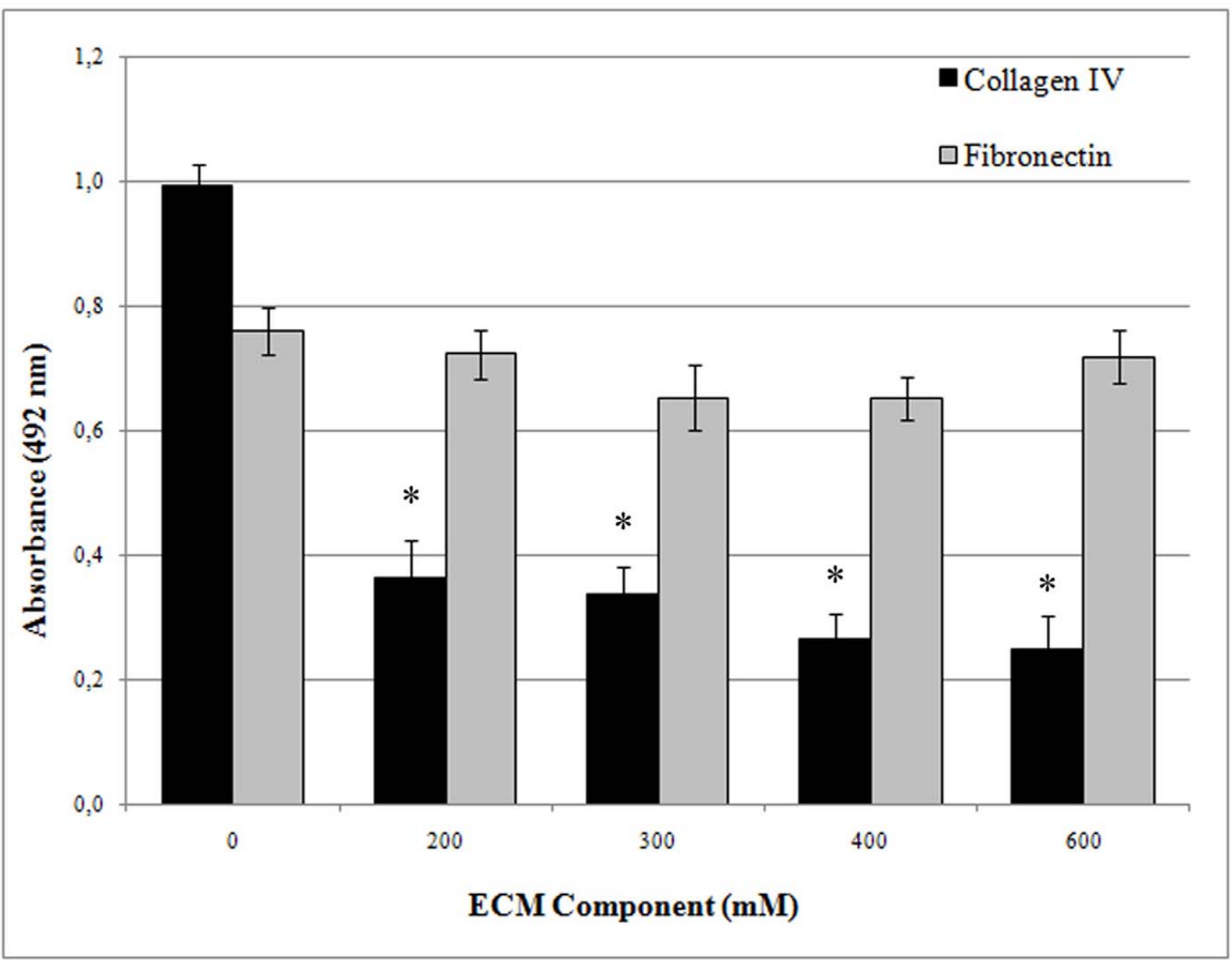

Figure 7. Effect of extracellular matrix macromolecules on PLG binding by LipL32. Binding of LipL32 (10 $\mu \mathrm{g} / \mathrm{ml})$ to immobilized PLG $(10 \mu \mathrm{g} / \mathrm{ml})$ was performed with the addition of increasing concentrations of plasma fibronectin or collagen type IV (0 to $600 \mathrm{mM})$. The detection of bound-PLG was assayed by specific antibodies. Bars represent the mean absorbance values \pm the standard deviation of four replicates for each condition and are representative of two independent experiments. Results of statistically significant interference with binding in comparison with the positive control (no addition of purified ECM macromolecules) are shown: $P<0.0003(*)$. doi:10.1371/journal.pone.0011259.g007 
Houston, TX) with appropriate vector-specific T7 (F: TAATACGACTCACTATAGGG) and pAE (R:CAGCAGCGAACTCAGTTCCT) primers. Cloning, expression and purification of the recombinant proteins Lsa63, LIC10509, Lp29, Lp49 and Lsa27 have been previously described [11,19,30,33]. The sequences coding for MPL21, MPL17, MPL36, LipL40, LipL32, LIC10494, LIC12730 and LIC12922 were cloned into the $E$. coli Gateway cloning (pENTR) and expression (pDEST17) system (Invitrogen), according to the protocol described elsewhere [29]. The expression and purification of MPL21 and MPL17 were performed as reported elsewhere [31], and rLIC10494 and rLIC12730, as previously described [12]. The recombinant proteins MPL36 and LipL40 were purified from E. coli BL21 (DE3) and E. coli BL21-SI, respectively. Bacteria were grown in Luria-Bertani (LB) broth with or without $\mathrm{NaCl}$, at $37^{\circ}$ or $30^{\circ} \mathrm{C}$, and at $\log$-phase they were induced by $1 \mathrm{mM}$ isopropyl- $\beta-\mathrm{D}$ thiogalactopyranoside (IPTG) or $3 \mathrm{mM} \mathrm{NaCl}$ for $3 \mathrm{~h}$ at $37^{\circ} \mathrm{C}$ or $30^{\circ} \mathrm{C}$, respectively. The bacteria cell lysates were cleared by centrifugation at $3,000 \times \mathrm{g}$ for $15 \mathrm{~min}$, and the supernatants were loaded onto $\mathrm{Ni}^{2+-}$ charged Sepharose beads. The beads were washed with increasing concentrations of imidazole (20 to $60 \mathrm{mM}$ ) and the proteins eluted with $0.5 \mathrm{M}$ imidazole. The proteins LipL32 and rLIC12922 were expressed in E. coli BL21-SI for $3 \mathrm{~h}$ at $30^{\circ} \mathrm{C}$ with the addition of $150 \mathrm{mM} \mathrm{NaCl}$ to the log-phase culture grown in $\mathrm{LB}$ broth without $\mathrm{NaCl}$. The proteins were expressed in the soluble form, as the above protocol described for the proteins MPL36 and LipL40. The LIC12238 CDS was cloned into the pGEM-T-Easy vector (Promega), and transferred into the pAE expression vector [67]. The construct was transformed into E. coli BL21-SI, and the log-phase culture, grown at $30^{\circ} \mathrm{C}$, was induced by incubation in the presence of $300 \mathrm{mM} \mathrm{NaCl}$ for $3 \mathrm{~h}$. The protein rLIC12238 was expressed in the soluble form and purified as described above.

\section{Circular dichroism spectroscopy}

Purified recombinant proteins were dialyzed against sodium phosphate buffer (pH 7.4). Circular dichroism (CD) spectroscopy measurements were performed at $20^{\circ} \mathrm{C}$ using a Jasco J-810 spectropolarimeter (Japan Spectroscopic, Tokyo) equipped with a Peltier unit for temperature control. Far-UV CD spectra were measured using a $1 \mathrm{~mm}$-path length cell at $0.5 \mathrm{~nm}$ intervals. The spectra were presented as an average of five scans recorded from 180 to $260 \mathrm{~nm}$. The molar ellipticity $(\Phi)$ is expressed in deg. $\mathrm{cm}^{2} \cdot \mathrm{dmol}^{-1}$.

\section{Antisera production against recombinant proteins}

The recombinant proteins were adsorbed onto $10 \%$ ( $\mathrm{vol} / \mathrm{vol}$ ) of Alhydrogel (2\% $\mathrm{Al}(\mathrm{OH})_{3}$, Brenntag Biosector, Denmark), used as adjuvant. Each recombinant protein $(10 \mu \mathrm{g})$ was subcutaneously injected in female BALB/c mice (4-6 weeks old). Two subsequent booster injections were given at two-week intervals with the same protein preparations. Negative-control mice were injected with PBS/Alhydrogel. Two weeks after each immunization, the mice were bled from the retro-orbital plexus, and the pooled sera were analyzed by enzyme-linked immunosorbent assay for the determination of antibody titers. All animal studies were approved by the Ethics Committee of Instituto Butantan, under protocol 506/ 08, São Paulo, SP, Brazil.

\section{Liquid-phase immunofluorescence assay (L-IFA)}

The localization of the recombinant proteins by L-IFA was performed as previously described [31]. In brief, 2.5-ml suspensions of live leptospires (L. interrogans serovar Copenhageni strain M 20 , routinely cultured as described elsewhere [21] were harvested at 10,000 rpm for $15 \mathrm{~min}$, washed twice with PBS (with $50 \mathrm{mM}$ $\mathrm{NaCl}$ ), resuspended in $200 \mu \mathrm{l}$ of $\mathrm{PBS}$ with $6 \mu \mathrm{g} / \mathrm{ml}$ propidium iodide to stain the nuclei, and incubated for $45 \mathrm{~min}$ at $37^{\circ} \mathrm{C}$. After incubation, the leptospires were gently washed with PBS and incubated for $30 \mathrm{~min}$ at $4^{\circ} \mathrm{C}$ with polyclonal mouse antiserum against each recombinant protein or GroEL at a 1:50 dilution. The leptospires were washed and incubated with goat anti-mouse $\mathrm{IgG}$ antibodies conjugated to fluorescein isothiocyanate (FITC, Sigma) at a dilution 1:50 for $30 \mathrm{~min}$ at $4^{\circ} \mathrm{C}$. After incubation with secondary antibody, the leptospires were washed and resuspended in PBS-antifading solution (ProLong Gold, Molecular Probes). The immunofluorescently labeled leptospires were examined with the use of a confocal LSM 510 META immunofluorescence microscope (Zeiss, Germany).

\section{Plasminogen binding}

The binding of the recombinant proteins to PLG was evaluated by a modified ELISA as follows: 96-well plates (Costar High Binding, Corning) were coated overnight in PBS at $4^{\circ} \mathrm{C}$ with $100 \mu \mathrm{l}$ of $10 \mu \mathrm{g} / \mathrm{ml}$ of the recombinant proteins or bovine serum albumin (BSA) as negative control. Plates were washed once with PBS supplemented with $0.05 \%$ (vol/vol) Tween 20 (PBS-T) and blocked for $2 \mathrm{~h}$ at $37^{\circ} \mathrm{C}$ with PBS with $10 \%$ (wt/vol) non-fat dry milk. The blocking solution was discarded and $100 \mu \mathrm{l}$ of $10 \mu \mathrm{g} / \mathrm{ml}$ human plasminogen in PBS was incubated for $2 \mathrm{~h}$ at $37^{\circ} \mathrm{C}$. Wells were washed four times with PBS-T and incubated for $1 \mathrm{~h}$ at $37^{\circ} \mathrm{C}$ with mouse anti-human plasminogen (Sigma-Aldrich) (1:4,000 in PBS). Plates were washed again and incubated with horseradish peroxidase-conjugated anti-mouse immunoglobulin $\mathrm{G}(\mathrm{IgG})$, diluted 1:5,000 in PBS. After three washings, $100 \mu \mathrm{l} /$ well of $1 \mathrm{mg} / \mathrm{ml}$ o-phenylenediamine (OPD) plus $1 \mu \mathrm{l} / \mathrm{ml} \mathrm{H}_{2} \mathrm{O}_{2}$ in citrate phosphate buffer ( $\mathrm{pH} 5.0$ ) were added. The reactions were carried out for $5 \mathrm{~min}$ and stopped by the addition of $50 \mu \mathrm{l}$ /well of $\mathrm{H}_{2} \mathrm{SO}_{4}$ (2 N). Readings were taken at $492 \mathrm{~nm}$.

\section{Effects of salt and heparin on recombinant proteins- plasminogen interactions}

To assess the role of ionic interactions or of heparin-binding domains in LipL32 or rLIC12238 binding to plasminogen, increasing concentrations of $\mathrm{NaCl}(0-350 \mathrm{mM})$ or heparin $(0-$ $500 \mathrm{IU})$ (Roche) were added to the PBS-based buffer with plasminogen to the recombinant protein-coated wells. In both experiments, the detection of bound-plasminogen was performed as described above.

\section{SDS-PAGE and affinity blotting}

The purified recombinant proteins were electrophoresed in $12 \%$ SDS-PAGE gels and transferred to nitrocellulose membranes (Hybond-ECL, GE Healthcare) in semi-dry equipment. The membranes were blocked with $5 \% \mathrm{BSA}$ for $2 \mathrm{~h}$ at $37^{\circ} \mathrm{C}$, washed three times (10 min for each wash) with PBS- $0.5 \%$ Tween-20 solution and incubated overnight with $3 \mu \mathrm{g} / \mathrm{mL}$ PLG $4^{\circ} \mathrm{C}$, followed by $2 \mathrm{~h}$ incubation at room temperature. The membranes were then washed three times and incubated with mouse antihuman PLG (1:750) for $3 \mathrm{~h}$ at room temperature, followed by three more washings and $1 \mathrm{~h}$ incubation at room temperature with anti-mouse $\operatorname{IgG}(1: 5,000)$. The membranes were washed and the protein's reactivity was revealed using the ECL reagent (GE Healthcare) with subsequent exposure to X-ray films.

\section{Characterization of the binding}

To determine the role of lysines in plasminogen-recombinant protein interactions, the lysine analog 6-aminocaproic acid (ACA) 
(Sigma-Aldrich) was added together with plasminogen at a final concentration of $2 \mathrm{mM}$ to the recombinant protein-coated wells. To assess the role of ionic interactions or of heparin-binding domains in LipL32 or rLIC12238 binding to plasminogen, increasing concentrations of $\mathrm{NaCl}(0-350 \mathrm{mM})$ or heparin $(0-$ $500 \mathrm{IU})$ (Roche) were added to the PBS-based buffer with plasminogen which was then added to the recombinant proteincoated wells. In both experiments, the detection of boundplasminogen was performed as described above.

\section{Plasmin enzymatic activity assay}

First, 96-well ELISA plates were coated overnight with $10 \mu \mathrm{g}$ / $\mathrm{ml}$ recombinant proteins or BSA in PBS at $4{ }^{\circ} \mathrm{C}$. Plates were then washed once with PBS-T and blocked with PBS with $10 \%$ (wt/vol) non-fat dry milk for $2 \mathrm{~h}$ at $37^{\circ} \mathrm{C}$. The blocking solution was discarded and $100 \mu \mathrm{l} /$ well of $10 \mu \mathrm{g} / \mathrm{ml}$ human plasminogen was added, followed by incubation for $2 \mathrm{~h}$ at $37^{\circ} \mathrm{C}$. Wells were washed three times with PBS-T, and then $4 \mathrm{ng} /$ well of human uPA (Sigma-Aldrich) were added. Subsequently, $100 \mu \mathrm{l} /$ well of the plasmin-specific substrate D-valyl-leucyl-lysine- $p$-nitroanilide dihydrochloride (Sigma-Aldrich) was added at a final concentration of $0.4 \mathrm{mM}$ in PBS. Plates were incubated overnight at $37^{\circ} \mathrm{C}$ and substrate was measured by taking readings at $405 \mathrm{~nm}$.

\section{Dose-response curves}

First, 96-well ELISA plates were coated overnight in PBS at $4^{\circ} \mathrm{C}$ with $100 \mu \mathrm{l}$ of $10 \mu \mathrm{g} / \mathrm{ml}$ plasminogen. Plates were then blocked and increasing concentrations of the purified recombinant proteins $(0-1 \mu \mathrm{M})$ were added $(100 \mu \mathrm{l} /$ well in PBS $)$. The assessment of bound proteins was performed by incubation for $1 \mathrm{~h}$ at $37^{\circ} \mathrm{C}$ with the antiserum raised against each protein at appropriate dilutions (1:4,000 for LipL32; 1:5,000 for rLIC12238, LipL40 and MPL36; 1:1,000 for Lp29 and Lp49; 1:500 for rLIC12730), followed by horseradish peroxidase-conjugated anti-mouse IgG (Sigma) $(1: 10,000$ in PBS). The binding was evaluated by the peroxidase

\section{References}

1. Haake DA, Dundoo M, Cader R, Kubak BM, Hartskeerl RA, et al. (2002) Leptospirosis, water sports, and chemoprophylaxis. Clin Infect Dis 34: e40-43.

2. Bharti AR, Nally JE, Ricaldi JN, Matthias MA, Diaz MM, et al. (2003) Leptospirosis: a zoonotic disease of global importance. Lancet Infect Dis 3: $757-771$.

3. Faine S, Adler B, Bolin C, Perolat P (1999) Leptospira and Leptospirosis. Second ed. Melbourne, Australia: MediSci. 259 p.

4. Levett PN (2001) Leptospirosis. Clin Microbiol Rev 14: 296-326.

5. Vinetz JM (2001) Leptospirosis. Curr Opin Infect Dis 14: 527-538.

6. Plank R, Dean D (2000) Overview of the epidemiology, microbiology, and pathogenesis of Leptospira spp. in humans. Microbes Infect 2: 1265-1276.

7. Matsunaga J, Barocchi MA, Croda J, Young TA, Sanchez Y, et al. (2003) Pathogenic Leptospira species express surface-exposed proteins belonging to the bacterial immunoglobulin superfamily. Mol Microbiol 49: 929-945.

8. Ristow P, Bourhy P, da Cruz McBride FW, Figueira CP, Huerre M, et al. (2007) The OmpA-like protein Loa22 is essential for leptospiral virulence. PLoS Pathog 3: e97.

9. Atzingen MV, Barbosa AS, De Brito T, Vasconcellos SA, de Morais ZM, et al. (2008) Lsa21, a novel leptospiral protein binding adhesive matrix molecules and present during human infection. BMC Microbiol 8: 70.

10. Patti JM, Allen BL, McGavin MJ, Hook M (1994) MSCRAMM-mediated adherence of microorganisms to host tissues. Annu Rev Microbiol 48: 585617.

11. Longhi MT, Oliveira TR, Romero EC, Goncales AP, Morais ZM, et al. (2009) A novel identified protein of Leptospira interrogans mediates binding to laminin. J Med Microbiol.

12. Barbosa AS, Abreu PA, Neves FO, Atzingen MV, Watanabe MM, et al. (2006) A newly identified leptospiral adhesin mediates attachment to laminin. Infect Immun 74: 6356-6364.

13. Choy HA, Kelley MM, Chen TL, Moller AK, Matsunaga J, et al. (2007) Physiological osmotic induction of Leptospira interrogans adhesion: LigA and LigB bind extracellular matrix proteins and fibrinogen. Infect Immun 75: 2441-2450. substrate OPD and readings were taken at $492 \mathrm{~nm}$. The ELISA data were used to calculate the dissociation constant $\left(K_{\mathrm{D}}\right)$ according to the method described by Pathirana et al. [68] and Lin et al. [69], based on the equation: $A=A m a x$ [protein]/ $\left(K_{\mathrm{D}}+[\right.$ protein] $)$, where $\mathrm{A}$ is the absorbance at a given protein concentration, Amax is the maximum absorbance for the ELISA plate reader (equilibrium), [protein] is the protein concentration and $K_{\mathrm{D}}$ is the dissociation equilibrium constant for a given absorbance at a given protein concentration (ELISA data point).

\section{Interference of collagen type IV and plasma fibronectin with PLG binding by LipL32}

First, 96-well plates were coated overnight at $4^{\circ} \mathrm{C}$ with $100 \mu \mathrm{l}$ of $10 \mu \mathrm{g} / \mathrm{ml}$ recombinant LipL32 in PBS, washed once and blocked with $10 \%(\mathrm{w} / \mathrm{v})$ non-fat dry milk for $2 \mathrm{~h}$ at $37^{\circ} \mathrm{C}$. The plates were then incubated for $2 \mathrm{~h}$ at $37^{\circ} \mathrm{C}$ with $200 \mathrm{nM}$ PLG together with increasing concentrations of collagen type IV (Sigma-Aldrich) or plasma fibronectin (Sigma-Aldrich) (both from 0 to $600 \mathrm{nM}$ ). After four washings, PLG binding was quantified by specific antibodies as described above.

\section{Acknowledgments}

We are deeply indebted to Dr. Toshie Kawano and Alexsander Seixas de Souza (Departamento de Parasitologia, Instituto Butantan, São Paulo, Brazil) for use of the confocal microscope facilities and helpful discussion. We thank Dr. Gustavo M. Cerqueira for a critical reading of the manuscript and Dr. A. Leyva for help with English editing.

\section{Author Contributions}

Conceived and designed the experiments: MV ALTON. Performed the experiments: MV MA TO RO DA. Analyzed the data: MV MA TO RO DA SV ALTON. Contributed reagents/materials/analysis tools: MV MA TO RO DA SV ALTON. Wrote the paper: MV ALTON.

14. Stevenson B, Choy HA, Pinne M, Rotondi ML, Miller MC, et al. (2007) Leptospira interrogans endostatin-like outer membrane proteins bind host fibronectin, laminin and regulators of complement. PLoS ONE 2: e1188.

15. Hauk P, Macedo F, Romero EC, Vasconcellos SA, de Morais ZM, et al. (2008) In LipL32, the major leptospiral lipoprotein, the $\mathrm{C}$ terminus is the primary immunogenic domain and mediates interaction with collagen IV and plasma fibronectin. Infect Immun 76: 2642-2650.

16. Hoke DE, Egan S, Cullen PA, Adler B (2008) LipL32 is an extracellular matrixinteracting protein of Leptospira spp. and Pseudoalteromonas tunicata. Infect Immun 76: 2063-2069.

17. Atzingen MV, Gomez RM, Schattner M, Pretre G, Goncales AP, et al. (2009) Lp95, a novel leptospiral protein that binds extracellular matrix components and activates e-selectin on endothelial cells. J Infect.

18. Carvalho E, Barbosa AS, Gomez RM, Cianciarullo AM, Hauk P, et al. (2009) Leptospiral TlyC is an extracellular matrix-binding protein and does not present hemolysin activity. FEBS Lett 583: 1381-1385.

19. Vieira ML, de Morais ZM, Goncales AP, Romero EC, Vasconcellos SA, et al. Lsa63, a newly identified surface protein of Leptospira interrogans binds laminin and collagen IV. J Infect 60: 52-64.

20. Lahteenmaki K, Kuusela P, Korhonen TK (2001) Bacterial plasminogen activators and receptors. FEMS Microbiol Rev 25: 531-552.

21. Vieira ML, Vasconcellos SA, Goncales AP, de Morais ZM, Nascimento AL (2009) Plasminogen acquisition and activation at the surface of leptospira species lead to fibronectin degradation. Infect Immun 77: 4092-4101.

22. Nordstrand A, Shamaei-Tousi A, Ny A, Bergstrom S (2001) Delayed invasion of the kidney and brain by Borrelia crocidurae in plasminogen-deficient mice. Infect Immun 69: 5832-5839.

23. Coleman JL, Gebbia JA, Piesman J, Degen JL, Bugge TH, et al. (1997) Plasminogen is required for efficient dissemination of $\mathrm{B}$. burgdorferi in ticks and for enhancement of spirochetemia in mice. Cell 89: 1111-1119.

24. Coleman JL, Sellati TJ, Testa JE, Kew RR, Furie MB, et al. (1995) Borrelia burgdorferi binds plasminogen, resulting in enhanced penetration of endothelial monolayers. Infect Immun 63: 2478-2484. 
25. Fenno JC, Tamura M, Hannam PM, Wong GW, Chan RA, et al. (2000) Identification of a Treponema denticola OppA homologue that binds host proteins present in the subgingival environment. Infect Immun 68: 1884-1892.

26. Klempner MS, Noring R, Epstein MP, McCloud B, Rogers RA (1996) Binding of human urokinase type plasminogen activator and plasminogen to Borrelia species. J Infect Dis 174: 97-104.

27. Verma A, Brissette CA, Bowman AA, Shah ST, Zipfel PF, et al. Leptospiral endostatin-like protein A (LenA) is a bacterial cell-surface receptor for human plasminogen. Infect Immun.

28. Haake DA, Chao G, Zuerner RL, Barnett JK, Barnett D, et al. (2000) The leptospiral major outer membrane protein LipL32 is a lipoprotein expressed during mammalian infection. Infect Immun 68: 2276-2285.

29. Gamberini M, Gomez RM, Atzingen MV, Martins EA, Vasconcellos SA, et al. (2005) Whole-genome analysis of Leptospira interrogans to identify potential vaccine candidates against leptospirosis. FEMS Microbiol Lett 244: 305-313.

30. Neves FO, Abreu PA, Vasconcellos SA, de Morais ZM, Romero EC, et al. (2007) Identification of a novel potential antigen for early-phase serodiagnosis of leptospirosis. Arch Microbiol 188: 523-532.

31. Oliveira TR, Longhi MT, de Morais ZM, Romero EC, Blanco RM, et al. (2008) Evaluation of leptospiral recombinant antigens MPL17 and MPL21 for serological diagnosis of leptospirosis by enzyme-linked immunosorbent assays. Clin Vaccine Immunol 15: 1715-1722.

32. Branger C, Sonrier C, Chatrenet B, Klonjkowski B, Ruvoen-Clouet N, et al. (2001) Identification of the hemolysis-associated protein 1 as a cross-protective immunogen of Leptospira interrogans by adenovirus-mediated vaccination. Infect Immun 69: 6831-6838.

33. Gomez RM, Vieira ML, Schattner M, Malaver E, Watanabe MM, et al. (2008) Putative outer membrane proteins of Leptospira interrogans stimulate human umbilical vein endothelial cells (HUVECS) and express during infection. Microb Pathog 45: 315-322.

34. Ren SX, Fu G, Jiang XG, Zeng R, Miao YG, et al. (2003) Unique physiological and pathogenic features of Leptospira interrogans revealed by whole-genome sequencing. Nature 422: 888-893.

35. Nascimento AL, Verjovski-Almeida S, Van Sluys MA, Monteiro-Vitorello CB, Camargo LE, et al. (2004) Genome features of Leptospira interrogans serovar Copenhageni. Braz J Med Biol Res 37: 459-477.

36. Bulach DM, Zuerner RL, Wilson P, Seemann T, McGrath A, et al. (2006) Genome reduction in Leptospira borgpetersenii reflects limited transmission potential. Proc Natl Acad Sci U S A 103: 14560-14565.

37. Picardeau M, Bulach DM, Bouchier C, Zuerner RL, Zidane N, et al. (2008) Genome sequence of the saprophyte Leptospira biflexa provides insights into the evolution of Leptospira and the pathogenesis of leptospirosis. PLoS ONE 3: e1607.

38. Nally JE, Whitelegge JP, Bassilian S, Blanco DR, Lovett MA (2007) Characterization of the outer membrane proteome of Leptospira interrogans expressed during acute lethal infection. Infect Immun 75: 766-773.

39. Haake DA, Matsunaga J (2002) Characterization of the leptospiral outer membrane and description of three novel leptospiral membrane proteins. Infect Immun 70: 4936-4945.

40. Grosskinsky S, Schott M, Brenner C, Cutler SJ, Kraiczy P, et al. (2009) Borrelia recurrentis employs a novel multifunctional surface protein with anticomplement, anti-opsonic and invasive potential to escape innate immunity. PLoS One 4: e4858.

41. Fuchs H, Wallich R, Simon MM, Kramer MD (1994) The outer surface protein A of the spirochete Borrelia burgdorferi is a plasmin(ogen) receptor. Proc Natl Acad Sci U S A 91: 12594-12598.

42. Lagal V, Portnoi D, Faure G, Postic D, Baranton G (2006) Borrelia burgdorferi sensu stricto invasiveness is correlated with OspC-plasminogen affinity. Microbes Infect 8: 645-652.

43. Rossmann E, Kraiczy P, Herzberger P, Skerka C, Kirschfink M, et al. (2007) Dual binding specificity of a Borrelia hermsii-associated complement regulatoracquiring surface protein for factor $\mathrm{H}$ and plasminogen discloses a putative virulence factor of relapsing fever spirochetes. J Immunol 178: 7292-7301.

44. Brissette CA, Haupt K, Barthel D, Cooley AE, Bowman A, et al. (2009) Borrelia burgdorferi infection-associated surface proteins ErpP, ErpA, and ErpC bind human plasminogen. Infect Immun 77: 300-306.

45. Perriere G, Gouy M (1996) WWW-query: an on-line retrieval system for biological sequence banks. Biochimie 78: 364-369.

46. Thompson JD, Gibson TJ, Plewniak F, Jeanmougin F, Higgins DG (1997) The CLUSTAL X windows interface: flexible strategies for multiple sequence alignment aided by quality analysis tools. Nucleic Acids Res 25: 4876-4882.
47. Urano T, Sator de Serrano V, Chibber BA, Castellino FJ (1987) The control of the urokinase-catalyzed activation of human glutamic acid 1-plasminogen by positive and negative effectors. J Biol Chem 262: 15959-15964.

48. Ledoux D, Papy-Garcia D, Escartin Q, Sagot MA, Cao Y, et al. (2000) Human plasmin enzymatic activity is inhibited by chemically modified dextrans. J Biol Chem 275: 29383-29390.

49. Degen JL, Bugge TH, Goguen JD (2007) Fibrin and fibrinolysis in infection and host defense. J Thromb Haemost 5 Suppl 1: 24-31.

50. Bergmann S, Hammerschmidt S (2007) Fibrinolysis and host response in bacterial infections. Thromb Haemost 98: 512-520.

51. Coleman JL, Benach JL (1999) Use of the plasminogen activation system by microorganisms. J Lab Clin Med 134: 567-576.

52. Sun $H$ (2006) The interaction between pathogens and the host coagulation system. Physiology (Bethesda) 21: 281-288.

53. Goto H, Kawaoka Y (1998) A novel mechanism for the acquisition of virulence by a human influenza A virus. Proc Natl Acad Sci U S A 95: 10224-10228.

54. Okumura Y, Yano M, Murakami M, Mori S, Towatari T, et al. (1999) The extracellular processing of HIV-1 envelope glycoprotein gp160 by human plasmin. FEBS Lett 442: 39-42.

55. LeBouder F, Morello E, Rimmelzwaan GF, Bosse F, Pechoux C, et al. (2008) Annexin II incorporated into influenza virus particles supports virus replication by converting plasminogen into plasmin. J Virol 82: 6820-6828.

56. Rojas M, Labrador I, Concepcion JL, Aldana E, Avilan L (2008) Characteristics of plasminogen binding to Trypanosoma cruzi epimastigotes. Acta Trop 107: 54-58.

57. Castellino FJaP, A.V (2003) Plasminogen: structure, activation, and regulation Waisman D, ed. New York: Kluwer Academic/Plenum Publishers.

58. Crowe SD, Sievwright JK, Auld GC, Hoore NR, Gow NA, et al. (2003) Candida albicans binds human plasminogen identification of eight plasminogen-binding proteins. Mol Microbiol 47: 1637-1651.

59. Flannery B, Costa D, Carvalho FP, Guerreiro H, Matsunaga J, et al. (2001) Evaluation of recombinant Leptospira antigen-based enzyme-linked immunosorbent assays for the serodiagnosis of leptospirosis. J Clin Microbiol 39: 3303-3310.

60. Murray GL, Srikram A, Hoke DE, Wunder EA, Jr., Henry R, et al. (2009) Major surface protein LipL32 is not required for either acute or chronic infection with Leptospira interrogans. Infect Immun 77: 952-958.

61. Nakai K, Horton P (1999) PSORT: a program for detecting sorting signals in proteins and predicting their subcellular localization. Trends Biochem Sci 24: $34-36$.

62. Nakai K, Kanehisa M (1991) Expert system for predicting protein localization sites in gram-negative bacteria. Proteins 11: 95-110.

63. Letunic I, Copley RR, Pils B, Pinkert S, Schultz J, et al. (2006) SMART 5: domains in the context of genomes and networks. Nucleic Acids Res 34: D257-260.

64. Schultz J, Milpetz F, Bork P, Ponting CP (1998) SMART, a simple modular architecture research tool: identification of signaling domains. Proc Natl Acad Sci U S A 95: 5857-5864.

65. Finn RD, Mistry J, Schuster-Bockler B, Griffiths-Jones S, Hollich V, et al. (2006) Pfam: clans, web tools and services. Nucleic Acids Res 34: D247-251.

66. Juncker AS, Willenbrock H, Von Heijne G, Brunak S, Nielsen H, et al. (2003) Prediction of lipoprotein signal peptides in Gram-negative bacteria. Protein Sci 12: $1652-1662$

67. Ramos CR, Abreu PA, Nascimento AL, Ho PL (2004) A high-copy T7 Escherichia coli expression vector for the production of recombinant proteins with a minimal N-terminal His-tagged fusion peptide. Braz J Med Biol Res 37: $1103-1109$

68. Pathirana RD, O'Brien-Simpson NM, Veith PD, Riley PF, Reynolds EC (2006) Characterization of proteinase-adhesin complexes of Porphyromonas gingivalis. Microbiology 152: 2381-2394.

69. Lin YP, Lee DW, McDonough SP, Nicholson LK, Sharma Y, et al. (2009) Repeated domains of leptospira immunoglobulin-like proteins interact with elastin and tropoelastin. J Biol Chem 284: 19380-19391.

70. Viratyosin W, Ingsriswang S, Pacharawongsakda E, Palittapongarnpim P (2008) Genome-wide subcellular localization of putative outer membrane and extracellular proteins in Leptospira interrogans serovar Lai genome using bioinformatics approaches. BMC Genomics 9: 181

71. Altschul SF, Madden TL, Schaffer AA, Zhang J, Zhang Z, et al. (1997) Gapped BLAST and PSI-BLAST: a new generation of protein database search programs. Nucleic Acids Res 25: 3389-3402.

72. Altschul SF, Gish W, Miller W, Myers EW, Lipman DJ (1990) Basic local alignment search tool. J Mol Biol 215: 403-410. 


\title{
Characterization of Novel OmpA-Like Protein of Leptospira interrogans That Binds Extracellular Matrix Molecules and Plasminogen
}

\author{
Rosane Oliveira ${ }^{1,2}$, Zenaide Maria de Morais ${ }^{3}$, Amane Paldes Gonçales ${ }^{3}$, Eliete Caló Romero ${ }^{4}$, Silvio \\ Arruda Vasconcellos ${ }^{3}$, Ana L. T. O. Nascimento ${ }^{1,2 *}$
}

1 Centro de Biotecnologia, Instituto Butantan, São Paulo, Brazil, 2 Interunidades em Biotecnologia, Instituto de Ciências Biomédicas, Universidade de São Paulo, São Paulo, Brazil, 3 Laboratório de Zoonoses Bacterianas do VPS, Faculdade de Medicina Veterinária e Zootecnia, Universidade de São Paulo, São Paulo, Brazil, 4 Centro de Bacteriologia, Instituto Adolfo Lutz, São Paulo, Brazil

\begin{abstract}
Leptospira interrogans is the etiological agent of leptospirosis, a zoonotic disease of human and veterinary concern. The identification of novel proteins that mediate host-pathogen interactions is important for understanding the bacterial pathogenesis as well as to identify protective antigens that would help fight the disease. We describe in this work the cloning, expression, purification and characterization of three predicted leptospiral membrane proteins, LIC10258, LIC12880 (Lp30) and LIC12238. We have employed Escherichia coli BL21 (SI) strain as a host expression system. Recently, we have identified LIC12238 as a plasminogen (PLG)-binding receptor. We show now that Lp30 and rLIC10258 are also PLG-receptors of Leptospira, both exhibiting dose-dependent and saturating binding $\left(K_{\mathrm{D}}, 68.8 \pm 25.2 \mathrm{nM}\right.$ and $167.39 \pm 60.1 \mathrm{nM}$, for rLIC10258 and rLIC12880, respectively). In addition, LIC10258, which is a novel OmpA-like protein, binds laminin and plasma fibronectin ECM molecules and hence, it was named Lsa66 (Leptospiral surface adhesin of $66 \mathrm{kDa}$ ). Binding of Lsa66 to ECM components was determined to be specific, dose-dependent and saturable, with a $K_{\mathrm{D}}$ of $55.4 \pm 15.9 \mathrm{nM}$ to laminin and of $290.8 \pm 11.8 \mathrm{nM}$ to plasma fibronectin. Binding of the recombinant proteins to PLG or ECM components was assessed by using antibodies against each of the recombinant proteins obtained in mice and confirmed by monoclonal antipolyhistidine antibodies. Lsa66 caused partial inhibition on leptospiral adherence to immobilized ECM and PLG. Moreover, this adhesin and rLIC12238 are recognized by antibodies in serum samples of confirmed leptospirosis cases. Thus, Lsa66 is a novel OmpA-like protein with dual activity that may promote the attachment of Leptospira to host tissues and may contribute to the leptospiral invasion. To our knowledge, this is the first leptospiral protein with ECM and PLG binding properties reported to date.
\end{abstract}

Citation: Oliveira R, de Morais ZM, Gonçales AP, Romero EC, Vasconcellos SA, et al. (2011) Characterization of Novel OmpA-Like Protein of Leptospira interrogans That Binds Extracellular Matrix Molecules and Plasminogen. PLoS ONE 6(7): e21962. doi:10.1371/journal.pone.0021962

Editor: Sergio Costa Oliveira, Federal University of Minas Gerais, Brazil

Received January 13, 2011; Accepted June 15, 2011; Published July 6, 2011

Copyright: (c) 2011 Oliveira et al. This is an open-access article distributed under the terms of the Creative Commons Attribution License, which permits unrestricted use, distribution, and reproduction in any medium, provided the original author and source are credited.

Funding: This work was supported by FAPESP, CNPq and Fundação Butantan, Brazil. The funders had no role in study design, data collection and analysis, decision to publish, or preparation of the manuscript.

Competing Interests: The authors have declared that no competing interests exist.

*E-mail: tabet@butantan.gov.br

\section{Introduction}

Leptospirosis is a febrile disease caused by pathogenic spirochaetes of the genus Leptospira. The disease is been considered an important re-emerging infectious disease [1]. The transmission of leptospirosis has been associated with exposure of individuals in close proximity to wild or farm animals. Lately, the disease became prevalent in cities with sanitation problems and large population of urban rodent reservoirs, which contaminate the environment through their urine $[1,2]$. Due to the broad spectrum of symptoms, such as, fever, chills, headache, and myalgias, and similarity with other tropical illness, leptospirosis often remains largely under diagnosed. Progression to multi-organ system complications occurs in $5-15 \%$ of cases, with mortality rates of $5-40 \%[1,2]$. The disease also has a great economic impact in the agricultural industry since it affects livestock inducing abortions, stillbirths, infertility, reduced milk production and death $[1,2]$. Commercially available vaccines, consisting of heat or chemically inactivated leptospires, named bacterins, provide serovar-specific protection against infection. The lack of serovar cross-protection in addition to the need for annual revaccination imposes a major limitation of whole-cell Leptospira vaccines [3]. The search for novel protein antigens that could elicit a broad protective and long-term immunity is currently under investigation.

Surface-associated proteins, as a result of their location, are likely to be important in host-pathogen interactions, hence their potential to promote several activities, including adhesion. The interaction of pathogens with the extracellular matrix (ECM) has been well documented [4]. In the case of leptospires, some adhesion ECM-binding molecules have been characterized thus far. These include the Lsa24/Len protein family [5,6], LigA/LigB [7], Lsa21 [8], LipL32 [9], TlyC [10], Lp95 [11], Lsa63 [12] and OmpL37 [13]. We were the first group to describe that Leptospira species are able to bind PLG and generate plasmin, in the presence of activator, on the outer surface in vitro [14]. More recently, we have shown that eight out of fourteen recombinant 
proteins available in our laboratory are PLG-binding proteins [15]. We believe that understanding the molecular mechanism of pathogenesis of Leptospira should help in the identification of novel vaccine candidates.

In the present study, we describe the cloning, expression, purification and characterization of three predicted membrane proteins, LIC10258, LIC12880 and LIC12238, identified in the genome sequences of $L$. interrogans serovar Copenhageni [16]. One of them, LIC12238, was previously described as a plasminogenbinding protein [15]. We now show that rLIC12880, previously named Lp30 [17] and rLIC10258 are also plasminogen-receptors of Leptospira. In addition, rLIC10258, which is a novel OmpA-like protein, is also capable to bind laminin and plasma fibronectin ECM molecules and hence it was named Lsa66 (Leptospiral surface adhesin of $66 \mathrm{kDa}$ ). The recombinant proteins are recognized by antibodies in serum samples of individuals in convalescent phase of the disease. Furthermore, the coding sequences for LIC10258, LIC12880 and LIC12238 may be expressed on the surface of bacteria because they are detected by immunofluorescence assay with intact living leptospires. Thus, it is possible that Lsa66 and LIC12238 proteins are expressed during infection and may play a role in pathogenesis.

\section{Methods}

\section{Leptospira strains and sera}

The non-virulent Leptospira strains used were: L. interrogans serovar Canicola strain Hound Utrech IV, L. interrogans serovar Copenhageni strain M 20, L. interrogans serovar Icterohaemorrhagiae strain RGA, L. interrogans serovar Pomona strain Pomona, L. interrogans serovar Hardjo strain Hardjoprajitno, L. borgpetersenï serovar Castellonis strain Castellon 3, L. kirshneri serovar Grippotyphosa strain Moskva V, L. santarosai serovar Shermani strain 1342 K, L. noguchii serovar Panama strain CZ 214 and $L$. biflexa serovar Patoc strain Patoc, were cultured at $28^{\circ} \mathrm{C}$ under aerobic conditions in liquid EMJH medium (Difco ${ }^{\circledR}$ ) with $10 \%$ rabbit serum, enriched with L-asparagine (wt/vol: 0.015\%), sodium pyruvate (wt/vol: $0.001 \%$ ), calcium chloride (wt/vol: 0,001\%), magnesium chloride (wt/vol: $0.001 \%$ ), peptone (wt/ vol:0.03\%) and meat extract (wt/vol: 0.02\%) [18]. Leptospira cultures are maintained in Faculdade de Medicina Veterinária e Zootecnia, USP, São Paulo, SP, Brazil. Confirmed- leptospirosis serum samples were from Instituto Adolfo Lutz collection, São Paulo, Brazil.

\section{Characterization of the protein in silico}

Predicted coding sequence (CDS) LIC10258, LIC12880 and LIC12238 were identified using non redundant protein and $L$. interrogans serovar Copenhageni databases the $L$. interrogans serovar Copenhageni [16]; cellular localization prediction was performed by PSORT, http://psort.nibb.ac.jp [19] and CELLO, http:// cello.life.nctu.edu.tw/ [20] programs. The SMART, http:// smart.embl-heidelbergde/ [21], PFAM, http://www.sanger.ac.uk/ Software/Pfam/ [22], and LipoP, http://www.cbs.dtu.dk/services/ LipoP/ [23] web servers were used to search for predicted functional and structural domains. Sequence analysis was performed by BLAST [24] using Conserved Domain Database [25].

\section{DNA isolation and PCR analysis}

Leptospira cultures were harvested by centrifugation at 11,500 $\mathrm{g}$ for 30 min and gently washed in sterile PBS twice. Genomic DNA was isolated from the pellets by guanidine-detergent lysing method using DNAzol ${ }^{\circledR}$ Reagent (Invitrogen), according to the manufacturer's instructions. Primers were designed according to $L$. interrogans serovar Copenhageni genome sequences (GenBank accession AE016823) and are listed in Table 1. PCR was performed in a reaction volume of $25 \mu \mathrm{l}$ containing $100 \mathrm{ng}$ of genomic DNA, $1 \times$ PCR buffer $(20 \mathrm{mM}$ Tris-HCl, $\mathrm{pH} 8.4$, $50 \mathrm{mM} \mathrm{KCl}$ ), $2 \mathrm{mM} \mathrm{MgCl}_{2}, 20 \mathrm{pmol}$ of each specific primer, $200 \mu \mathrm{M}$ of each dNTP, and $2.5 \mathrm{U}$ Taq DNA Polymerase (Invitrogen). Cycling conditions were: $94^{\circ} \mathrm{C}-4 \mathrm{~min}$, followed by 40 cycles at $94^{\circ} \mathrm{C}-50 \mathrm{sec}, 64^{\circ} \mathrm{C}(\mathrm{LIC} 10258)$ or $56^{\circ} \mathrm{C}$ (LIC12880) or $58^{\circ} \mathrm{C}$ (LIC12238) - $50 \mathrm{sec}, 72^{\circ} \mathrm{C}-90 \mathrm{sec}$, and a final extension cycle of $7 \mathrm{~min}$ at $72^{\circ} \mathrm{C}$. PCR amplified products were loaded on a $1 \%$ agarose gel for electrophoresis and visualization with ethidium bromide.

\section{RNA extraction and RT-PCR analysis}

For reverse transcription (RT)-PGR, total RNA was isolated by the acid guanidinium thiocyanate phenol-chloroform method using TRIzol ${ }^{\circledR}$ Reagent (Invitrogen) according to the manufacturer's recommendations. One microgram of RNA from each sample was treated with $1 \mathrm{U}$ of DNAse I Amplification Grade (Invitrogen) for $15 \mathrm{~min}$ at room temperature. DNAse I was inactivated by the addition of $1 \mu \mathrm{l}$ of $25 \mathrm{mM}$ EDTA solution followed by an incubation at $65^{\circ} \mathrm{C}$ for $10 \mathrm{~min}$. DNAse-treated RNAs were reversely transcribed using the SuperScript ${ }^{\text {TM }}$ III First-Strand Synthesis System for RT-PCR (Invitrogen). One tenth of RT products were amplified in a $25 \mu \mathrm{l}$ reaction mix using oligonucleotides LIC10258-F/LIC10258-R or LIC12880-F/ LIC12880-R or LIC12238-F/LIC12238-R as described above. Samples quantity and integrity were verified by amplification of a 1,042 bp 16 S ribosomal cDNA fragment using oligomers:

16F 5'CAAGTCAAGCGGAGTAGCAATACTCAGC $3{ }^{\prime}$ and 16S-R 5' GATGGCAACATAAGGTGAGGGTTGC 3'.

The effect of temperature on LIC10258 transcript levels within the $L$. interrogans serovar Icterohaemorrhagiae strain was assessed by culturing leptospires at $37^{\circ} \mathrm{C}$ and $39^{\circ} \mathrm{C}$. Additional cultures grown at $30^{\circ} \mathrm{C}$ were shifted overnight to $37^{\circ} \mathrm{C}$ and to $39^{\circ} \mathrm{C}$, to simulate conditions encountered by bacteria upon entry into the host and in a febrile stage. Induction of LIC10258 expression by osmolarity was examined by centrifugation of cultures grown at $30^{\circ} \mathrm{C}$ in $\mathrm{EMJH}$ supplemented with $1 \%$ rabbit serum followed by resuspension in fresh EMJH medium or in EMJH containing $120 \mathrm{mM} \mathrm{NaCl}$. Cultures were incubated for $24 \mathrm{~h}$ before being harvested for RNA isolation. The same procedures were performed with LIC12880 in the L. borgpetersenii serovar Castellonis, L. santarosai serovar Shermani and L. noguchii serovar Panama strains.

\section{DNA recombinant techniques}

Predicted CDS LIC10258, LIC12880 and LIC12238, without signal peptides, were amplified by the PCR from $L$. interrogans serovar Copenhageni strain Fiocruz L1-130 genomic DNA using the primer pairs listed in Table 1. The PCR products obtained for each corresponding gene were cloned into pGEM-T easy vector (Promega) and subcloned into the pAE expression vector [26] at the restriction sites depicted in Table 1 . The $\mathrm{pAE}$ vector allows the expression of recombinant proteins with a minimal $6 \mathrm{x}$ His-tag at the N-terminus. All cloned sequences were confirmed by DNA sequencing with an ABI 3100 automatic sequencer (PE Applied Biosystems, Foster city, CA).

\section{Expression and purification of recombinant protein}

Expression and purification of the recombinant proteins Lp30 and rLIC12238 have been previously described by Neves et al (2007) [17] and Vieira et al (2010) [15], respectively. Protein expression of the Lsa66 was achieved in E. coli BL21 (SI) strain by the action of T7 DNA polymerase under control of the osmotically 
Table 1. Gene locus, protein name, gene bank reference sequence, features, gene conservation, sequence of the primers employed for DNA amplification, and molecular mass of expressed recombinant proteins.

\begin{tabular}{|c|c|c|c|c|c|c|}
\hline $\begin{array}{l}\text { Gene } \\
\text { locus }\end{array}$ & $\begin{array}{l}\text { Recombinant } \\
\text { protein given } \\
\text { name }\end{array}$ & $\begin{array}{l}\text { NCBI reference } \\
\text { sequence } \\
\text { number }^{2}\end{array}$ & $\begin{array}{l}\text { Description/ } \\
\text { Function }\end{array}$ & $\begin{array}{l}\text { Conservation } \\
\text { (identity) }^{3}\end{array}$ & $\begin{array}{l}\text { Sequence of primers } \\
\text { for PCR amplification }\end{array}$ & $\begin{array}{l}\text { Recombinant } \\
\text { protein } \\
\text { molecular mass }\end{array}$ \\
\hline \multirow[t]{2}{*}{ LIC10258 } & rLIC10258 & YP_000249 & $\begin{array}{l}\text { Hypothetical protein } \\
\text { with ompA domain }\end{array}$ & $\begin{array}{l}\text { Lai }(99 \%) ; \\
\text { LBH }(79 \%)\end{array}$ & $\begin{array}{l}\text { F:5' GGATCCGAAGCCTTCT- } \\
\text { CAC } \overline{C C A A T T G} 3^{\prime} \text { (BamH I) }\end{array}$ & $65.74 \mathrm{kDa}$ \\
\hline & & & & & $\begin{array}{l}\text { R:5' CCATGGTTAAAGTGAAAG- } \\
\text { ATAAAAATCGATTC 3' (NCO I) }\end{array}$ & \\
\hline \multirow[t]{2}{*}{ LIC12880 } & Lp30 & YP_002796 & Putative lipoprotein & $\begin{array}{l}\text { Lai }(99 \%) ; \\
\text { LBH }(76 \%)\end{array}$ & $\begin{array}{l}\text { F: } 5^{\prime} \text { CTCGAGGAAGTTGT- } \\
\text { CCGAGTCTAT } 3^{\prime} \text { (Xho I) }\end{array}$ & $30.68 \mathrm{kDa}$ \\
\hline & & & & & $\begin{array}{l}\text { R: 5' CCATGGTTATTGATT- } \\
\text { GTTTAATCAG 3' (NCO I) }\end{array}$ & \\
\hline \multirow[t]{2}{*}{ LIC12238 } & rLIC12238 & YP_002173 & Hypothetical protein & $\begin{array}{l}\text { Lai }(99 \%) ; \\
\text { LBH }(77 \%) \text {; }\end{array}$ & $\begin{array}{l}\text { F: 5' CTCGAGTGTTTTAA- } \\
\text { ACCTACCGGAG 3' (Xho I) }\end{array}$ & $17.635 \mathrm{kDa}$ \\
\hline & & & & LBP (39\%) & $\begin{array}{l}\text { R:5'AAGCTTCTACTTCATCG- } \\
\text { CTIITCTATATC 3' (Hind III) }\end{array}$ & \\
\hline
\end{tabular}

${ }^{1}$ http://aeg.lbi.ic.unicamp.br/world/lic/;

${ }^{2}$ http://www.ncbi.nlm.nih.gov/protein/;

${ }^{3}$ http://www.ncbi.nlm.nih.gov/blast/Blast.cgi/. This work, Lai: L. interrogans serovar Lai; LBH: L. borgpetersenii serovar Hardjo-bovis; LBP: L. biflexa serovar Patoc. doi:10.1371/journal.pone.0021962.t001

induced promoter proU. E. coli BL21 (SI) containing recombinant plasmids were grown at $30^{\circ} \mathrm{C}$ in Luria-Bertani broth without $\mathrm{NaCl}$ and with $100 \mu \mathrm{g} / \mathrm{ml}$ ampicillin with continuous shaking until an optical density at $600 \mathrm{~nm}$ of 0.6 to 0.8 was reached. Recombinant protein synthesis was induced by the addition of $30 \mathrm{mM} \mathrm{NaCl}$. After three hours, the cells were harvested by centrifugation, the bacterial pellets resuspended in lysis buffer $(10 \mathrm{mM}$ Tris-HCl, pH 8.0, $150 \mathrm{mM} \mathrm{NaCl}, 100 \mu \mathrm{g} / \mathrm{ml}$ of lysozyme, $1 \%$ Triton X-100, $2 \mathrm{mM}$ phenylmethylsulfonyl fluoride [PMSF]). The bacterial cell pellets were lysed on ice with the aid of a sonicator (Ultrasonic Processor; GE Healthcare). The insoluble fraction was washed with $20 \mathrm{ml}$ of buffer (20 mM Tris-HCl, pH 8.0, $500 \mathrm{mM} \mathrm{NaCl}, 1 \mathrm{M}$ urea and $0,1 \%$ Triton $\mathrm{X}-100)$ and resuspended in a buffer containing $20 \mathrm{mM}$ Tris-HCl, pH 8.0, $500 \mathrm{mM} \mathrm{NaCl}, 10 \%$ (vol/ vol) glycerol and $8 \mathrm{M}$ urea. The protein was then purified through metal chelating chromatography in a Sepharose fast flow column (GE Healthcare) and fractions were analyzed in 12\% SDS-PAGE. The protein was extensively dialyzed against phosphate-buffered saline (PBS), pH 7.4, 0.1\% (wt/vol) glycine solution (at the proportion of $10 \mathrm{ml}$ of protein per $1000 \mathrm{ml}$ of buffer) containing decreasing gradient of glycerol $(10-0 \%)$, pooled and stored at $4{ }^{\circ} \mathrm{C}$.

\section{Circular dichroism spectroscopy}

Purified recombinant proteins were dialyzed against sodium phosphate buffer ( $\mathrm{pH}$ 7.4). Circular dichroism (CD) spectroscopy measurements were performed at $20^{\circ} \mathrm{C}$ using a Jasco J-810 spectropolarimeter (Japan Spectroscopic, Tokyo) equipped with a Peltier unit for temperature control. Far-UV CD spectra were measured using a $1 \mathrm{~mm}$-path-length cell at $0.5 \mathrm{~nm}$ intervals. The spectra were presented as an average of five scans recorded from 180 to $260 \mathrm{~nm}$. The molar ellipticity $(\Phi)$ is expressed in deg.cm. $\mathrm{dmol}^{-1}$. Spectra data was submitted to DICROPROT web server, http://dicroprot-pbil.ibcp.fr/, using the method that calculated the secondary structure content from the ellipticity experimental data [27].

\section{Antiserum}

Five female BALB/c mice ( $4-6$ weeks old) were immunized subcutaneously with $10 \mu \mathrm{g}$ of the recombinant proteins. The recombinant protein was adsorbed in 10\% (vol/vol) of Alhydrogel $\left(2 \% \mathrm{Al}(\mathrm{OH})_{3}\right.$, Brenntag Biosector, Denmark), used as adjuvant. Two subsequent booster injections were given at two-week intervals with the same preparation of $10 \mu \mathrm{g}$ of the proteins. Negative-control mice were injected with PBS. One week after each immunization, the mice were bled from the retro-orbital plexus and the pooled sera were analyzed by enzyme-linked immunosorbent assay (ELISA) for determination of antibody titers. All animal studies were approved by the Ethics Committee of the Instituto Butantan, São Paulo, SP, Brazil under protocol $n^{\circ}$ 471/08. The Committee in Animal Research in Instituto Butantan adopts the guidelines of the Brazilian College of Animal Experimentation.

\section{Immunoblotting assay}

The purified recombinant proteins were loaded into 15\% SDSPAGE and transferred to nitrocellulose membranes (Hybond ECL; GE Healthcare) in semi-dry equipment. Membranes were blocked with 5\% non-fat dried milk and 2.5\% BSA in PBS containing $0.05 \%$ Tween 20 (PBS-T) and then incubated with anti-Lsa66 (1:800), anti-Lp30 (1:800), anti-rLIC12238 (1:2,000) mouse serum or anti-his antibody (1:3,000) (GE Healthcare) for $2 \mathrm{~h}$ at room temperature. After washing, the membrane was incubated with horseradish peroxidase (HRP)-conjugated antimouse IgG (1:5,000; Sigma) in PBS-T for $1 \mathrm{~h}$. The proteins reactivity was revealed by ECL reagent kit chemiluminescence substrate (GE Healthcare) with subsequent exposition to X-Ray film.

\section{Microscopic agglutination test (MAT)}

The microscopic agglutination test was performed according to Faine et al. (1999) [1]. In brief, an array of serovars of Leptospira spp. as antigens were employed: Australis, Autumnalis, Bataviae, Canicola, Castellonis, Celledoni, Copenhageni, Cynopteri, Djasiman, Grippotyphosa, Hardjo, Hebdomadis, Icterohaemorrhagiae, Javanica, Panama, Patoc, Pomona, Pyrogenes, Sejroe, Shermani, Tarassovi and Wolffi. All the strains were maintained in EMJH liquid medium (Difco, USA) at $29^{\circ} \mathrm{C}$. A laboratory-confirmed case of leptospirosis was defined by the demonstration of a four-fold 
microagglutination titer rise between paired serum samples. The probable predominant serovar was considered to be the one with the highest dilution that could cause $50 \%$ of agglutination. MAT was considered negative when the titer was below 100 .

\section{ELISA for detection of human antibodies}

Human IgG and IgM antibodies against Lsa66, Lp30 and rLIC12238 were evaluated by ELISA. In brief, samples (negative and positive MAT sera from 10 confirmed leptospirosis patients) were diluted 1:100 and evaluated for total IgG and IgM using peroxidase-conjugated anti-human IgG and IgM antibodies, 1:5,000 (Sigma, USA). Cutoff values were set at three standard deviations above the mean $\mathrm{OD}_{492}$ of sera from 6 individuals, unexposed to leptospirosis, from the city of São Paulo, Brazil.

\section{Plasminogen binding assay}

The binding of the recombinant proteins to PLG was evaluated by a modified ELISA as follows: 96-well plates (Costar High Binding, Corning) were coated overnight in PBS at $4^{\circ} \mathrm{C}$ with $100 \mu \mathrm{l}$ of $10 \mu \mathrm{g} / \mathrm{ml}$ of the human plasminogen; fetuin and bovine serum albumin (BSA) were employed, as negative control. Plates were washed once with PBS supplemented with $0.05 \%$ (vol/vol) Tween 20 (PBS-T) and blocked for $2 \mathrm{~h}$ at $37^{\circ} \mathrm{C}$ with PBS with $10 \%$ (wt/vol) non-fat dry milk. The blocking solution was discarded and $100 \mu \mathrm{l}$ of $10 \mu \mathrm{g} / \mathrm{ml}$ recombinant proteins in PBS was incubated for $2 \mathrm{~h}$ at $37^{\circ} \mathrm{C}$. Wells were washed four times with PBS-T and incubated for $1 \mathrm{~h}$ at $37^{\circ} \mathrm{C}$ with polyclonal mouse antirecombinant proteins (1:1,000 in PBS). In another assay, anti- His tag monoclonal antibodies (Sigma) were employed to detect protein binding at 1:1000 dilution. Plates were washed again and incubated with horseradish peroxidase-conjugated anti-mouse immunoglobulin $\mathrm{G}(\mathrm{IgG})$, diluted $1: 5,000$ in PBS. After three washings, $100 \mu \mathrm{l} /$ well of $1 \mathrm{mg} / \mathrm{ml} \quad o$-phenylenediamine (OPD) plus $1 \mu \mathrm{l} / \mathrm{ml} \mathrm{H}_{2} \mathrm{O}_{2}$ in citrate phosphate buffer ( $\mathrm{pH} 5.0$ ) were added. The reactions were carried out for $5 \mathrm{~min}$ and stopped by the addition of $50 \mu \mathrm{l} /$ well of $\mathrm{H}_{2} \mathrm{SO}_{4}(2 \mathrm{~N})$. Readings were taken at $492 \mathrm{~nm}$.

\section{Plasmin enzymatic activity assay}

96-well ELISA plates were coated overnight with $10 \mu \mathrm{g} / \mathrm{ml}$ recombinant proteins (or BSA for negative control) in PBS at $4^{\circ} \mathrm{C}$. Plates were washed once with PBS-T and blocked for $2 \mathrm{~h}$ at $37^{\circ} \mathrm{C}$ with PBS with $10 \%$ (wt/vol) non-fat dry milk. The blocking solution was discarded and $100 \mu \mathrm{l} /$ well of $10 \mu \mathrm{g} / \mathrm{ml}$ human plasminogen was added, followed by incubation for $2 \mathrm{~h}$ at $37^{\circ} \mathrm{C}$. Wells were washed three times with PBS-T, and then $4 \mathrm{ng} /$ well of human uPA (Sigma-Aldrich) was added. Subsequently, $100 \mu \mathrm{l} /$ well of plasminspecific substrate $\mathrm{D}^{\text {-valyl-leucyl-lysine- } p \text {-nitroanilide dihydrochlo- }}$ ride (Sigma- Aldrich) was added at a final concentration of $0.4 \mathrm{mM}$ in PBS. Plates were incubated overnight at $37^{\circ} \mathrm{C}$ and substrate degradation was measured by taken the readings at $405 \mathrm{~nm}$.

\section{Binding of recombinant proteins to ECM}

Protein attachment to individual macromolecules of the extracellular matrix was analyzed according to a previously published protocol [6] with some modifications. Briefly, ELISA plate wells were coated with $1 \mu \mathrm{g}$ of laminin, collagen type I, collagen type IV, cellular fibronectin, plasmatic fibronectin, BSA (nonglycosylated attachment-negative control protein) and fetuin (highly glycosylated attachment-negative control protein) in $100 \mu \mathrm{L}$ of PBS for $2 \mathrm{~h}$ at $37^{\circ} \mathrm{C}$. The wells were washed three times with PBS containing $0.05 \%$ Tween 20 and then blocked with $200 \mu \mathrm{L}$ of $1 \%$ BSA (overnight at $4^{\circ} \mathrm{C}$ ). One microgram of each protein (Lsa66 152 nM, Lp30 326 nM and rLIC12238 $\sim 567 \mathrm{nM}$ ) was added per well in $100 \mu \mathrm{L}$ of PBS, and proteins were allowed to attach to the different substrates for $2 \mathrm{~h}$ at $37^{\circ} \mathrm{C}$. After washing six times with PBS-T, bound proteins were detected by adding an appropriate dilution of mouse antiserum in $100 \mu \mathrm{L}$ of PBS. Dilutions of mouse antiserum against each recombinant protein were equalized as to give an $\mathrm{OD}_{492 \mathrm{~nm}}$ value of 1.0, as follows: Lsa66 (LIC10258) 1:800; Lp30 (LIC12880) 1:10,000 and rLIC12238 (LIC12238) 1:10,000. In addition, anti-polyhistidine monoclonal antibodies were employed as protein-binding probes at 1:1000 dilution. Incubation proceeded for $1 \mathrm{~h}$ at $37^{\circ} \mathrm{C}$, and after three washings with PBS-T, $100 \mu \mathrm{L}$ of a 1:5,000 dilution of horseradish peroxidase-conjugated goat anti-mouse IgG in PBS was added per well for $1 \mathrm{~h}$ at $37^{\circ} \mathrm{C}$. The wells were washed three times, and 0 -phenylenediamine $(1 \mathrm{mg} / \mathrm{mL})$ in citrate phosphate buffer $(\mathrm{pH} 5.0)$ plus $1 \mu \mathrm{L} / \mathrm{mL} \mathrm{H}_{2} \mathrm{O}_{2}$ was added $(100 \mu \mathrm{L}$ per well). The reaction was allowed to proceed for $10 \mathrm{~min}$ and was then interrupted by the addition of $50 \mu \mathrm{L}$ of $8 \mathrm{M} \mathrm{H}_{2} \mathrm{SO}_{4}$. The absorbance at $492 \mathrm{~nm}$ was determined in a microplate reader (Multiskan EX; Labsystems Uniscience). For determination of dose-dependent attachment of Lsa66 to laminin and plasma fibronectin, protein concentrations varying from 0 to $1,500 \mathrm{nM}$ in PBS were used. For statistical analyses, the binding of Lsa66 to ECM macromolecules was compared to its binding to BSA and fetuin by Students two-tailed $t$ test.

\section{Dissociation constant $\left(K_{\mathrm{D}}\right)$ for the recombinant proteins binding to ECM and PLG}

The ELISA data were used to calculate the dissociation constant $\left(K_{\mathrm{D}}\right)$ according to the method previously described [28] based on the equation: $\mathrm{A}=\mathrm{Amax}$ [protein] $/\left(K_{\mathrm{D}}+\right.$ [protein] $)$, where $\mathrm{A}$ is the absorbance at a given protein concentration, Amax is the maximum absorbance for the ELISA plate reader (equilibrium), [protein] is the protein concentration and $K_{\mathrm{D}}$ is the dissociation equilibrium constant for a given absorbance at a given protein concentration (ELISA data point).

\section{Inhibition of live leptospires binding to laminin, plasma} fibronectin and plasminogen by Lsa66 and Lp30

ELISA plates were coated with laminin or plasma fibronectin or plasminogen $(1 \mu \mathrm{g} /$ well $)$. The plates were washed and blocked with $10 \%$ non-fat dry milk in PBS-T for $2 \mathrm{~h}$ at $37^{\circ} \mathrm{C}$. The blocking solution was discarded, and the wells were incubated for $90 \mathrm{~min}$ at $37^{\circ} \mathrm{C}$ with increasing concentrations of recombinant proteins $(0$ to $5.0 \mu \mathrm{g})$. After three washings, $100 \mu \mathrm{L} /$ well of $4 \times 10^{7}$ live $L$. interrogans serovar Copenhageni strain M20 were added for $90 \mathrm{~min}$ at $37^{\circ} \mathrm{C}$. The unbound leptospires were washed and the quantification of bound leptospires was performed indirectly by anti-LipL32 antibodies produced in mice $(1: 4,000)$, based on the fact that LipL32 is a major outer membrane leptospiral protein [29]; the procedure was followed by horseradish peroxidaseconjugated anti-mouse IgG antibodies, essentially as described in Barbosa et al. (2006) [6]. The detection was performed by OPD as above described.

\section{Liquid-phase immunofluorescence assay (L-IFA)}

The localization of LIC10258, LIC12880 and LIC12238 encoded proteins by L-IFA was performed as described Oliveira et al (2010) [30]. In brief, suspensions of $2.5 \mathrm{ml}$ live leptospires $\left(\sim 10^{9}\right.$ cells $\left./ \mathrm{ml}\right)$ were harvested at $10,000 \mathrm{rpm}$ for $15 \mathrm{~min}$, washed twice with PBS (with $50 \mathrm{mM} \mathrm{NaCl}$ ), resuspended in $200 \mu \mathrm{l}$ of PBS with $6 \mu \mathrm{g} / \mathrm{ml}$ propidium iodide to stain the nuclei, and incubated 
for $45 \mathrm{~min}$ at $37^{\circ} \mathrm{C}$. After incubation, the leptospires were washed gently with PBS and incubated for $30 \mathrm{~min}$ at $4^{\circ} \mathrm{C}$ with polyclonal mouse anti-serum against Lsa63, rLipL32 or rGroEL at a 1:50 dilution. The leptospires were washed and incubated with goat anti-mouse IgG antibodies conjugated to fluorescein isothiocyante (FITC, Sigma) at a dilution 1:50 for $30 \mathrm{~min}$ at $4^{\circ} \mathrm{C}$. After incubation with secondary antibody, the leptospires were washed and resuspended in PBS-antifading solution (ProLong Gold, Molecular Probes). The immunofluorescence-labeled leptospires were examined by use of a confocal LSM 510 META immunofluorescence microscope (Zeiss, Germany).

\section{Statistical analysis}

All results are expressed as means \pm SEM. Student's paired $t$ test was used to determine the significance of differences between means, and $\mathrm{P}$ lower than 0.05 was considered as statistically significant.

\section{ECM components and plasminogen}

All macromolecules, including the control proteins fetuin and BSA, were purchased from Sigma Chemical Co. (St. Louis, Mo.). Laminin-1 and collagen Type IV were derived from the basement membrane of Engelbreth-Holm-Swarm mouse sarcoma, cellular fibronectin was derived from human foreskin fibroblasts, plasma fibronectin was isolated from human plasma and collagen Type I was isolated from rat tail. Plasminogen native, purified from human plasma, was purchased from Merck.

\section{Nucleotide sequence accession numbers}

Gene bank accession number for protein sequences LIC10258, LIC12880 and LIC12238 is AAS68886, AAS71433 and ASS70810, respectively (see Table 1). The protein can also be accessed by the genome nomenclature for the gene locus, LIC number (Leptospira interrogans Copenhageni).

\section{Results}

\section{Bioinformatic analysis}

The genes encoding LIC10258, LIC12880 and LIC12238 were identified by analysis of the genome sequences of the chromosome I of L. interrogans serovar Copenhageni and each one is present as a single copy [16]. The CDSs LIC10258, LIC12880 and LIC12238 have signal peptide ranging from amino acid 1 to 28, according to SMART web server, and are predicted to be outer membrane proteins based PSORT [19] and CELLO [20] web servers. The LIC12280 and LIC12238 are putative lipoproteins, with a

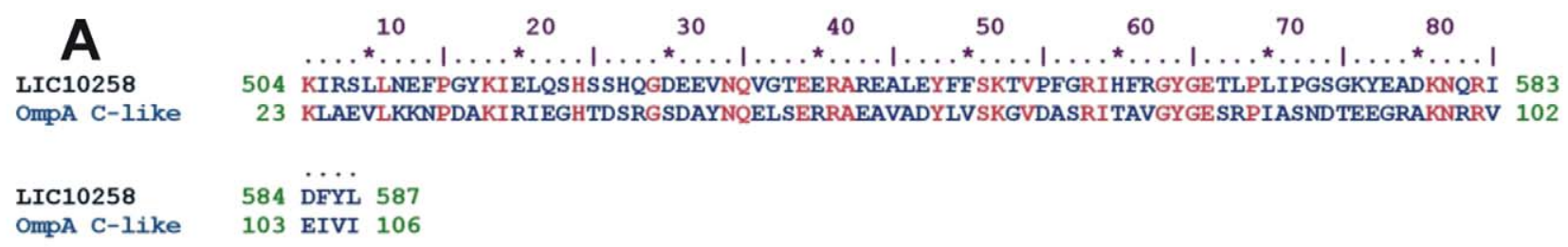

B

1 - 2 HQS H

2 - $2 \mathrm{AIZ}^{-} \mathrm{P}$

$3-3 C Y Q-K$

4 - 3 CYP $B$

5-1R $1 M A$

$6-2 \mathrm{ZF}^{-} \mathrm{A}$

7 - $2 \mathrm{~K}^{-} \mathrm{S}^{-} \mathrm{A}$

8-gi $1 \overline{7} 1912007$

9-gi 162450138

18. gi 50084798

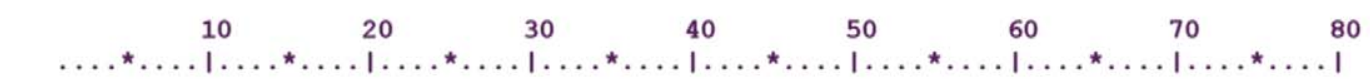

5 NNIVY

29 YNTVY

2 IDPFT

2 IDPFT

. [4] . FGFD

160 AFTIL. [1] . YERQ

29 ILNMP . [4] . FDSS

997 WLTLR FDSN

94 HEEVQ FETN

154 IINLS . [4] . FKFN
FDLD KYDIR, [ 2] FAOMIDAHANFIRSN [ 4], VTVEGHADE, [1], GTPEYNISLGERRAN 64 FGFD KYDIT. [ 2]. YVQILDAHAAYLNAT. [ 4] . VLVEGNTDE. [1] . GTPEYNIALGQRRAD 88 ENA. [1] . SDAIN. [ 2] MMLYIERIAKIIQKL . [ 5] . INVRGFTDD . [5] . TRFKSHYELAANRAY 67 SDAIN. [ 2].MMLYIERIAKIIQKL. [ 5]. INVRGFTDD. [5]. TRFKSHYELAANRAY 67 KDSLR. [ 2] .AQDNLKVLAQRLSRT . [ 4] . VRVEGHTDF. [1] . GSDKYNQALSERRAY 73 GDQLT. [ 2] .SKKRLSQIADYIRHN. [ 4]. LVLVATYTD. [2] .DGKSASQSLSERRAE 221 SATLK. [ 2] .GANTLTGVAMVLKEY . [ 4] . VNVIGYTDS. [1] . GGHDLNMRLSQQRAD 92 DGNLN. [12] . GAPTLDDEEKRIDRK. [10] . FVLEGHADS . [1] . GTEASNMRLSERRAR 1072 SDVIR. [ 6]. LEASLQKISEVVAKT. [ 7]. LFIVGHTDT. [1] . GSAEHNLALSRKRAR 160 GSGLN. [ 5] . GHEELERLSNDIRNH. [ 6]. IHLVGHTDR. [1] . GSDSYNYNLGLKRAQ 222

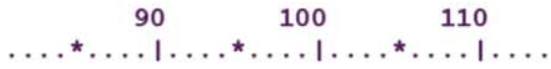

\begin{tabular}{|c|c|c|c|}
\hline 2S_H & 6 & KMYLQGKGVS. [3] . ISIVS. [1] . GKEKPA. [ 8] .YS & \\
\hline $\mathrm{AIZ} \mathrm{P}$ & & [1]. GEEKPA. [ 8].YSK & 13 \\
\hline CYQ_K & 68 & .LSFSS. [1] . GSTNPI. [ 8].RMI & 3 \\
\hline YP_B & 6 & . GSTNPI. [ 8], RI & 113 \\
\hline M_A & & VVA & 39 \\
\hline ZF8_A & 22 & i. [1].C & 267 \\
\hline K1S_A & & TL & 3 \\
\hline gi $1 \overline{7} 19$ & 1073 & [1] . GESLPV. [ 8] .RY] & \\
\hline & & L & \\
\hline & & .ISFSS. [1] . GKSQPI . [] & \\
\hline
\end{tabular}

Figure 1. Sequence analysis. (A) Sequence alignment of the OmpA C-like domain with the C-terminal region of CDS LIC10258. (B) Sequence alignments comparison of C-terminal region of CDS LIC10258 with proteins having OmpA-like domain from diverse pathogens: 1 . Escherichia coli (chain H); 2. PAL of Haemophilus influenza; 3. Helicobacter pylori (chain K); 4. Helicobacter pylori (chain B); 5. Neisseria meningitides; 6. Vibrio alginolyticus; 7. Escherichia coli (chain A); 8. Verrucomicrobium spinosum DSM 4136; 9. Sorangium cellulosum; 10. Acinetobacter sp. ADP1 (putative antigen).

doi:10.1371/journal.pone.0021962.g001 
A

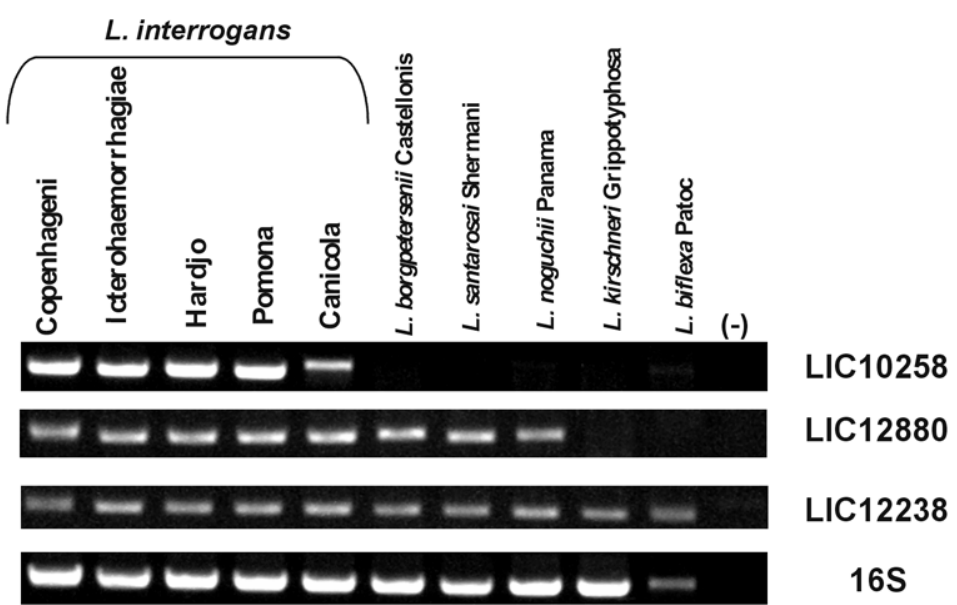

B
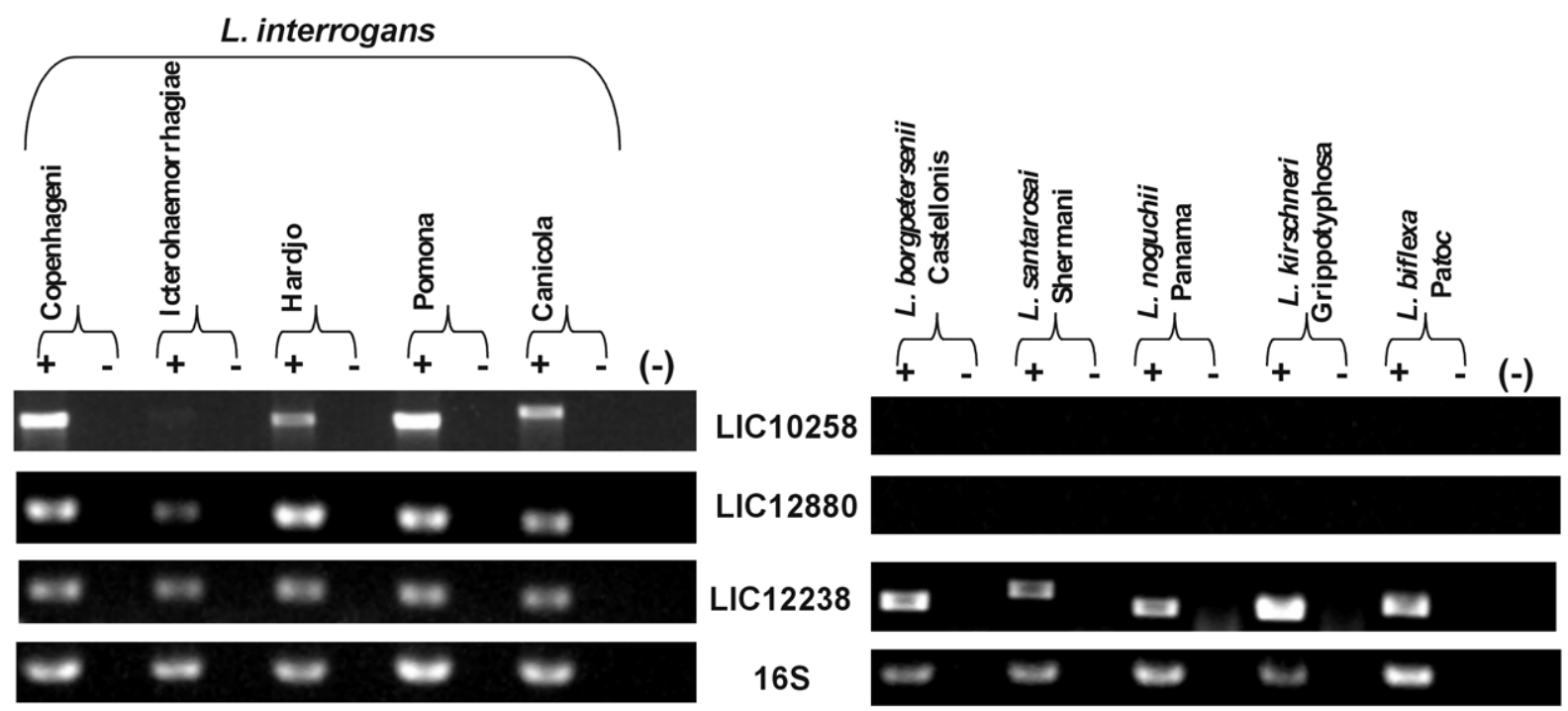

C

L. interrogans Icterohaemorrhagiae

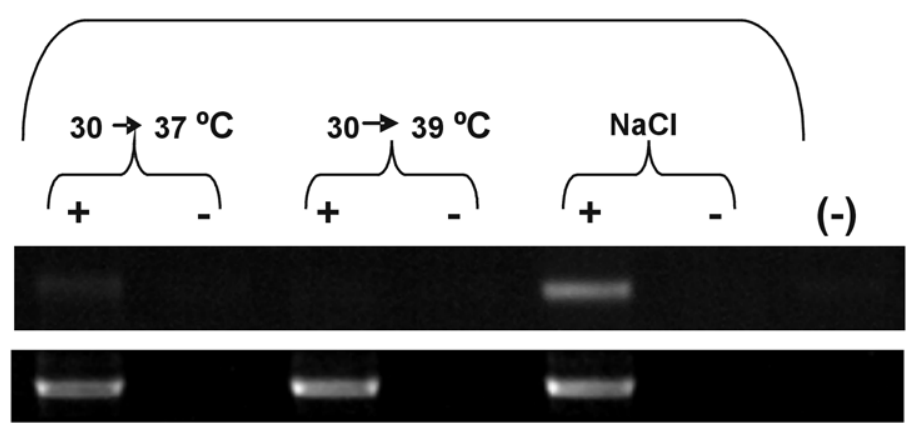

LIC10258

Figure 2. Distribution and expression of LIC10258, LIC12880 and LIC12238 genes in saprophytic and pathogenic leptospires. (A) Genomic DNA from L. biflexa Patoc and from nine serovars belonging to the pathogenic species of Leptospira were subjected to PCR analysis with specific primers designed according to $L$. interrogans serovar Copenhageni genome sequences. Amplification of $16 S$ DNA shows template integrity. No DNA was added to the negative control reaction (-). (B) RT-PCR analysis of LIC10258, LIC12880 and LIC12238 transcripts in high-passage Leptospira strains. Reactions were performed with specific primers designed according L. interrogans serovar Copenhageni. Samples quantity and integrity were 
verified by amplification of $16 \mathrm{~S}$ ribosomal CDNA fragment. +: reverse transcriptase present. -: reverse transcriptase omitted. No CDNA was added to the negative control reaction (-). (C) Transcript analysis of LIC10258 in L. interrogans serovar Icterohaemorrhagiae after submission of bacterial culture to temperature upshift from 30 to $37^{\circ} \mathrm{C}, 30$ to $39^{\circ} \mathrm{C}$ and to physiological osmmolarity. doi:10.1371/journal.pone.0021962.g002

cleavage site for signal peptidase II, according to LipoP program [23]. Blast analysis showed that the CDS LIC10258 has a putative OmpA- like domain at the C-terminal, from amino acid 504 to 583. Sequence alignment of the OmpA C-like domain with the Cterminal region of LIC10258 is depicted in Fig. 1A. Sequence alignments of OmpA-like conserved domain from diverse pathogens [25] are depicted in fig. 1B. The LIC10258 is present in the genome sequences of $L$. interrogans serovar Lai (99\% identity) [31], of L. borgpetersenii serovar Hardjo-bovis (79\% identity) [32], but is absent in L. biflexa serovar Patoc [33]. Similar putative coding sequence of LIC12880 was found in L. interrogans serovar Lai $(99 \%$ identity), in L. borgpetersenii serovar Hardjo-bovis $(76 \%$ identity), but is absent in L. biflexa serovar Patoc. The CDS LIC1 2238 was identified in L. interrogans serovar Lai (99\% identity), in $L$. borgpetersenii serovar Hardjo-bovis $(77 \%$ identity) and in $L$. biflexa serovar Patoc (39\% identity). Table 1 summarizes the main features of the selected proteins and gene conservation within the sequenced genomes $[31,32,33]$.

\section{Distribution and expression of LIC10258, LIC12880 and LIC12238 genes among Leptospira strains}

The LIC10258 gene is present in the main serovars of $L$. interrogans, Copenhageni, Icterohaemorrhagiae, Hardjo, Pomona and Canicola but no DNA amplification was detected in $L$. borgpertesenii serovar Castellonis, L. santarosai serovar Shermani, L. noguchii serovar Panama, L. kirschneri serovar Grippotyphosa and in L. biflexa serovar Patoc (Fig.2A). Gene LIC12880 was found in all serovars tested of $L$. interrogans and in L. borgpertesenii serovar Castellonis, L. santarosai serovar Shermani, L. noguchii serovar Panama, but absent in L. kirschneri serovar Grippotyphosa and in L. biflexa serovar Patoc (Fig. 2A). Also shown in this figure is the DNA conservation of LIC12238 that was identified in all tested strains. 16S DNA amplification was performed to attest template integrity (Fig. 2A). The expression of LIC10258, LIC12880 and LIC12238 by in vitro cultured leptospires was evaluated by PCR amplification of reversely transcribed total RNA. The results obtained revealed the presence of LIC10258 transcripts in four L. interrogans strains mentioned above but no amplification was detected with serovar Icterohaemorrhagiae (Fig. 2B). In the case of LIC12880, transcripts were observed only in serovars of $L$. interrogans, although the gene was found in other pathogenic strains (Fig. 2A e 2B). Transcripts of LIC12238 were identified in all analyzed strains (Fig. 2B). DNA contamination was discarded as no amplification was observed in the absence of reverse transcriptase. The integrity of total RNA used in RT-PCR experiment was assured by the presence of a 1,042-bp $16 \mathrm{~S}$ ribosomal cDNA fragment in all samples (Figure 2B). We set out to examine whether environmental factors, such as osmolarity and temperature could influence LIC10258 and LIC12880 regulation at the transcriptional level. Induction of LIC10258 and LIC12880 expression by osmolarity was assessed by growing cultures at $30^{\circ} \mathrm{C}$ in EMJH supplemented with $1 \%$ rabbit serum and resuspending them in fresh EMJH medium or in EMJH containing $120 \mathrm{mM}$ $\mathrm{NaCl}$. The addition of $120 \mathrm{mM} \mathrm{NaCl}$ to the medium mimics physiological conditions ( 300 mosmol per liter) encountered by leptospires upon entry into the host [34]. We also evaluated gene expression of both genes from cultures subjected to temperature upshifts from $30^{\circ} \mathrm{C}$ to $37^{\circ} \mathrm{C}$ and from $30^{\circ} \mathrm{C}$ to $39^{\circ} \mathrm{C}$ during an overnight period to simulate conditions experienced by leptospires in the early stages of infection and during febrile stage. The results obtained show that cultures of L. interrogans serovar Icterohaemorrhagiae submitted to temperature upshift from $37^{\circ} \mathrm{C}$ to $39^{\circ} \mathrm{C}$ had no effect on the level of LIC10258 transcript (Fig. 2C). However, LIC10258 transcription (Fig. 2C) could be detected when the same culture strain was shifted to physiological osmolarity, at $30^{\circ} \mathrm{C}$. In the case of LIC12880, no transcripts were observed in $L$. borgpertesenii serovar Castellonis, L. santarosai serovar Shermani and L. noguchii serovar Panama culture strains submitted to the same temperature and osmolarity conditions above described (data not shown).

\section{Expression and purification of recombinant proteins}

The amplified coding sequences, excluding the signal peptide tags, were cloned and expressed as full-length proteins in E. coli. Gene locus, protein reference number, given name, sequences of primers used for PCR amplifications and molecular mass of recombinants are illustrated in Table 1 . The recombinant proteins were purified by nickel affinity chromatography, and an aliquot of each protein was analyzed by SDS-PAGE (Fig. 3AC). All purified proteins were represented by major bands (Fig. 3D). To further confirm that these proteins are indeed histag recombinants we carried out immunoblotting technique and probed them with his-tag antibodies. The data is shown in figure $3 \mathrm{E}$ and, as we can see, anti-His tag antibodies recognized the 3 recombinant proteins. However, in the case of rLIC12238 and Lsa66 preparation, other protein bands were also detected, being in the first case probably due to non-specific reaction and in the second, possibly caused by some protein degradation. Similar data were obtained when blotted recombinant proteins were probed with the respective homolog antiserum raised in mice (Fig. 3F).

\section{Structural integrity of the purified proteins was assessed by circular dichroism (CD) spectroscopy}

As depicted in Fig. 4, the maximum at $192 \mathrm{~nm}$ of $\alpha$-helix with a broad minimum ellipticity around $215 \mathrm{~nm}$, probably of $\beta$-strands, in the CD spectrum show that Lsa66 has both secondary structures; maximum ellipticity of $198 \mathrm{~nm}$ of $\beta$-strands was detected with rLIC12238, while maximum ellipticity around $200 \mathrm{~nm}$ was observed with the protein Lp30. According to DICROPROT web server, the $\alpha$-helix percentage of the proteins was higher in Lsa66 followed by rLIC12238, being the lower value for Lp30. These results are consistent with a mixture of $\alpha$-helices and $\beta$-strands and are in agreement with the in silico analysis that showed both secondary structures (http://bioinf.cs.ucl.ac.uk/ psipred/).

\section{Detection of the LIC10258, LIC12880 and LIC12238 coding sequences by immunofluorescence confocal microscopy}

To evaluate whether the selected CDSs are located at the bacterial membrane, we set out to analyze the protein position by using living organisms and the liquid-phase immunofluorescence method. Leptospires were visualized by propidium iodide staining (Fig. 5, column A) followed by protein detection with polyclonal 

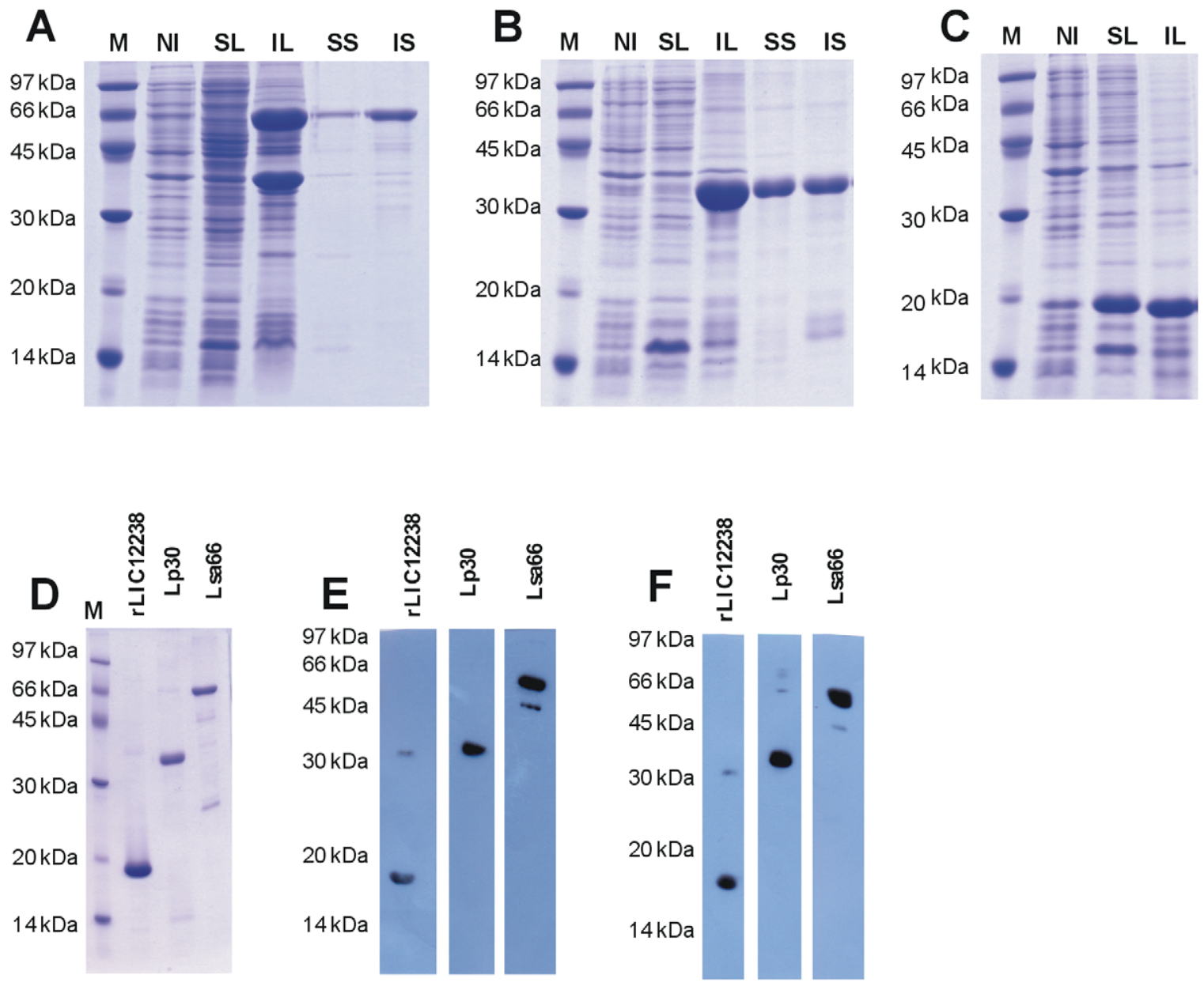

Figure 3. Protein analysis by SDS-PAGE and Western blotting. (A) Lsa66, (B) Lp30 and (C) rLIC12238 expression from NaCl-induced E. coli BI21-SI. M: molecular mass protein marker; NI: non-induced total bacterial extract; SL: supernatant after bacterial cell lysis and centrifugation; IL: inclusion body pellet after bacterial lysis and centrifugation; SS: soluble fraction of the induced culture in the presence of $8 \mathrm{M}$ urea; IS: insoluble fraction of the induced culture in the presence of $8 \mathrm{M}$ urea. (D) Comassie blue stained purified recombinant proteins. (E) and (F) are western blotting analysis of the recombinant proteins probed with anti-His tag antibodies and the respective homolog antiserum, respectively. doi:10.1371/journal.pone.0021962.g003

mouse antiserum raised against the protein in the presence of antimouse IgG antibodies conjugated to FITC. Green fluorescence could be observed in figure 5 column B, for Lsa66, Lp30,
rLIC12238 and LipL32, an outer membrane protein used as a positive control [29], but not with GroEL, a protoplasmic-cylinder marker, used as a negative control [35]. The localization of the
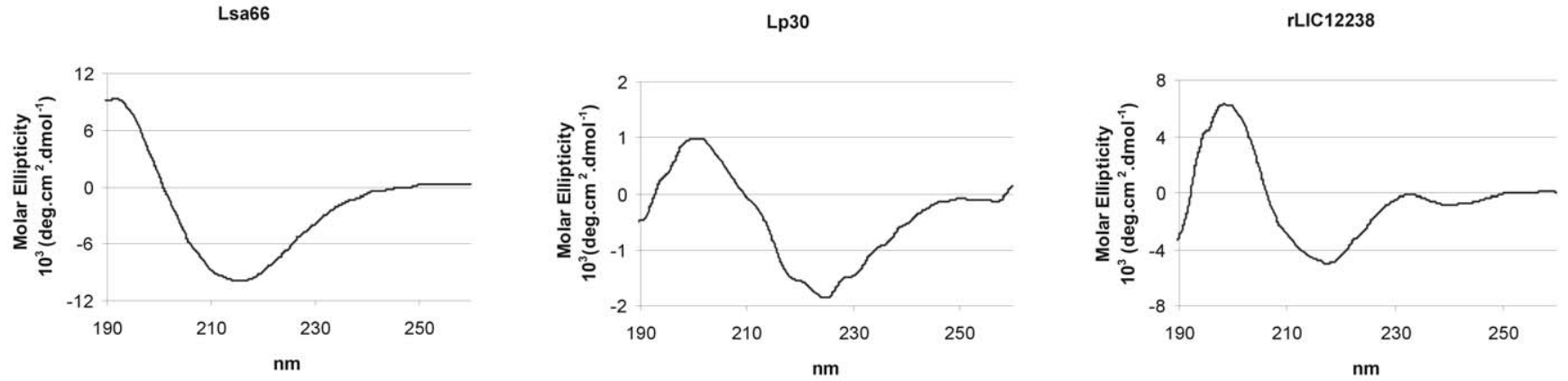

Figure 4. Circular dichroism spectra of the recombinant proteins. CD spectra of recombinant proteins Lsa66, Lp30 and rLIC12238. Far-UV CD spectra are presented as an average of five scans recorded from 190 to $260 \mathrm{~nm}$. Experimental conditions, as described in M\&M. doi:10.1371/journal.pone.0021962.g004 


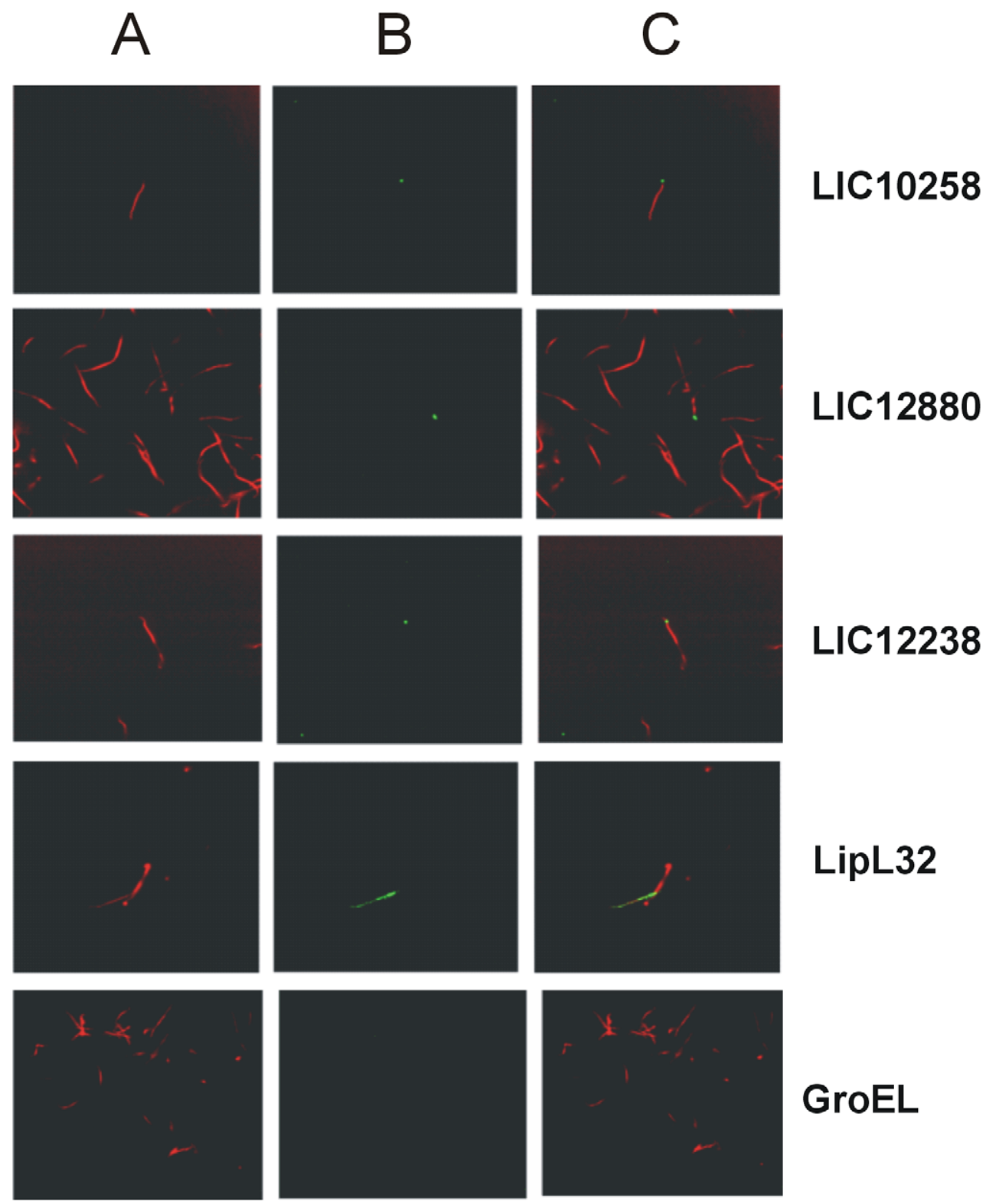

Figure 5. Localization of proteins in L. interrogans by L-IFA. Confocal microscopy was performed with live L. interrogans using antisera specific for LIC10258, LIC12880, LIC12238, LipL32 (surface-exposed lipoprotein) and GroEL (protoplasmic cylinder marker). FITC-conjugated secondary antibodies were used to detect the surface-bound antibodies (B). Leptospires were identified by propidium iodide (A) staining of the DNA. Colocalization is shown in the merged images (C).

doi:10.1371/journal.pone.0021962.g005

protein-green light lying on the leptospires was achieved by merging both fields and the results obtained are shown in figure 5, column C.

\section{Recombinant leptospiral proteins bind human plasminogen}

We have reported that leptospires bind PLG and that several proteins could act as receptors, including the recombinant protein rLIC12238 of this work $[14,15]$. We then decided to investigate whether the selected surface-exposed proteins, Lp30 and Lsa66, were also capable of binding human PLG in vitro. Human purified plasminogen was coated to ELISA plates, allowed to interact with the recombinant proteins Lsa66 and Lp30 and the results obtained from three independent experiments using antibodies against the recombinant proteins are shown in Fig. 6A. The binding of the proteins were also evaluated with anti-polyHis monoclonal antibodies (Fig. 6B). The interactions between the recombinant proteins and PLG were assessed on a quantitative basis as illustrated in Fig. 6C. Dose-dependent and saturable binding was observed when increasing concentrations ( 0 to $2,000 \mathrm{nM}$ ) of the recombinant proteins Lsa66 and Lp30 were allowed to individually adhere to a fixed PLG amount $(1 \mu \mathrm{g})$. Based on the ELISA data, the calculated dissociation equilibrium constants $\left(K_{\mathrm{D}}\right)$ for the recombinant proteins with PLG is $68.8 \pm 25.2 \mathrm{nM}$ and $167.39 \pm 60.1 \mathrm{nM}$, for Lsa66 and Lp30, respectively (Fig. 6C). 
A

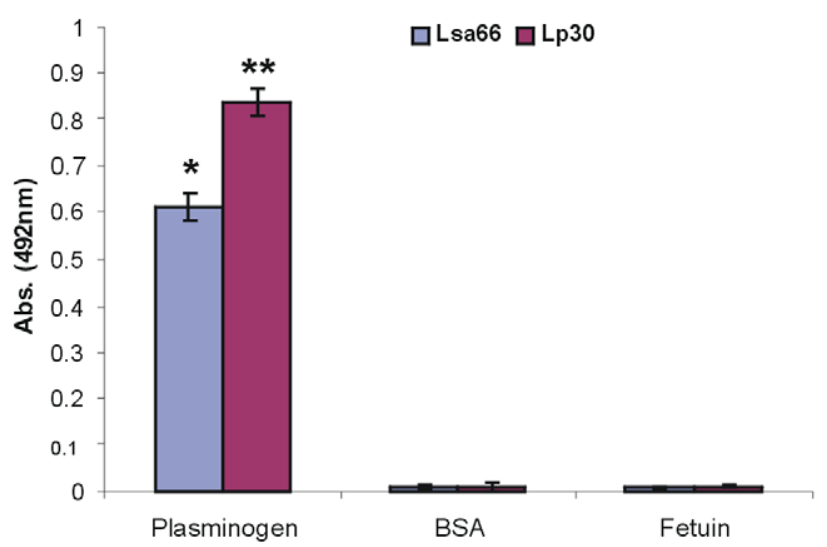

B
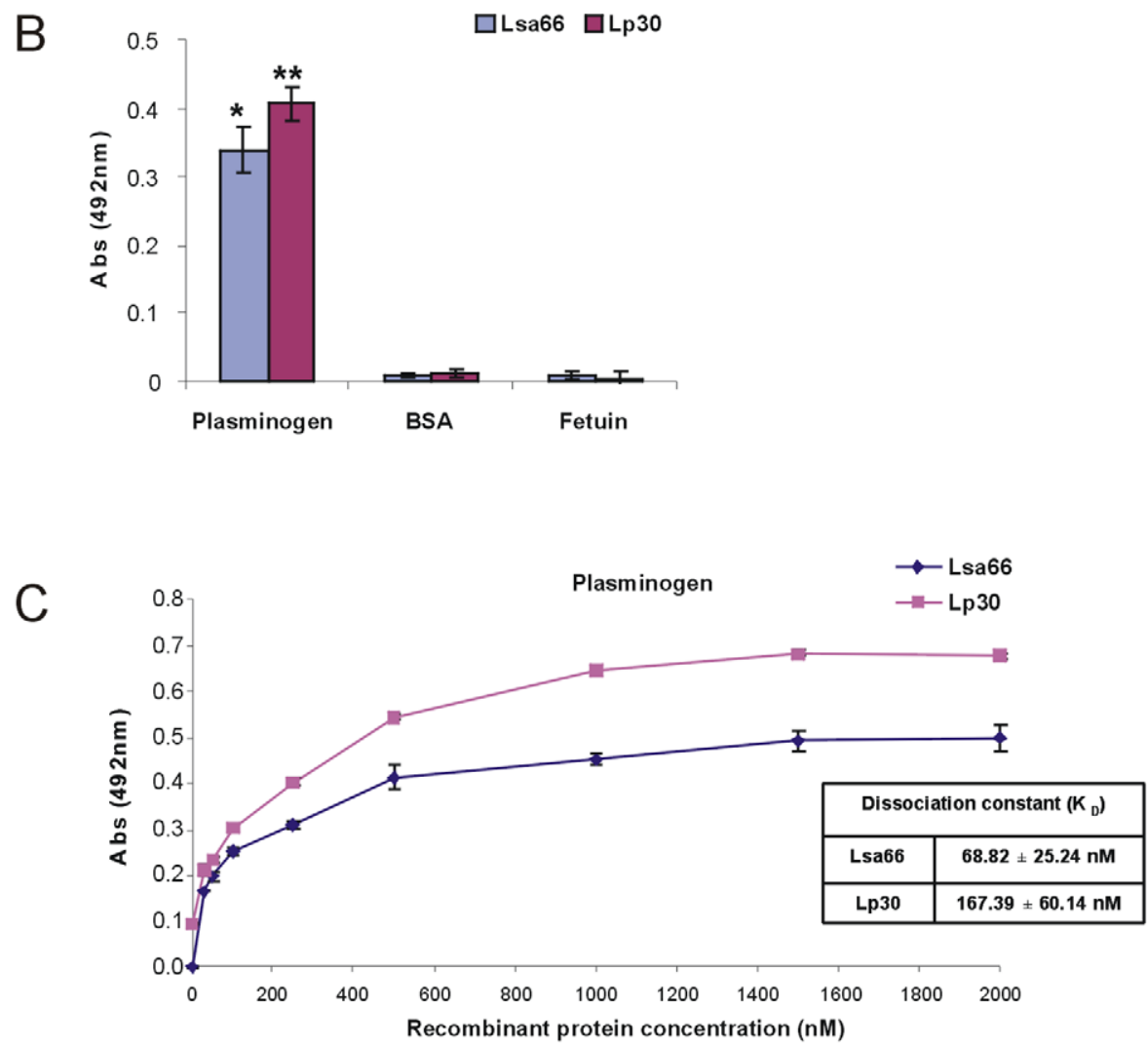

D

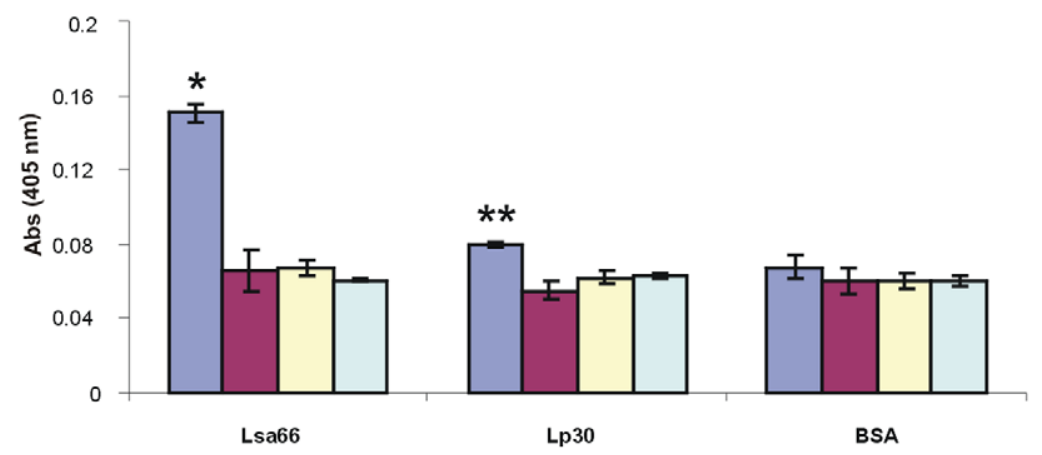

$\square P L G+U P A+S$

$\square P L G+U P A$

$\square P L G+S$

DUPA $+S$ 
Figure 6. Recombinant proteins binding to human plasminogen. (A) Binding of leptospiral recombinant proteins to human plasminogen. Human purified plasminogen $(10 \mu \mathrm{g} / \mathrm{ml})$ was coated to ELISA plates and allowed to interact with the recombinant proteins Lsa66 and Lp30 $(10 \mu \mathrm{g} / \mathrm{ml})$. BSA and fetuin were used as a negative control for nonspecific binding. The binding was detected by specific antibodies. Bars represent the mean of absorbance at $492 \mathrm{~nm} \pm$ the standard deviation of three replicates for each protein and are representative of three independent experiments. For statistical analyses, the binding of Lsa66 and Lp30 to human PLG was compared to its binding to BSA as well as fetuin by two-tailed $t$ test $\left({ }^{*} \mathrm{P}<0.005\right.$ and $\left.{ }^{*} \mathrm{P}<0.0005\right)$. (B) Similar as described in $(\mathrm{A})$ but the binding of the recombinant proteins was detected by specific antipolyhistidine monoclonal antibodies. (C)Ten $\mu \mathrm{g} / \mathrm{ml}$ pf PLG was immobilized into 96 -wells ELISA plates and 0 to $2,000 \mathrm{nM}$ of each recombinant protein was added for interaction. The binding was detected using antiserum raised in mice against each protein in appropriate dilutions (1:500 for Lsa66 and 1:500 for Lp30) followed by horseradish peroxidase-conjugated anti-mouse IgG. Data represent the mean absorbance values \pm the standard deviation of three replicates for each experimental group. The dissociation constant $\left(K_{\mathrm{D}}\right)$ was calculated based on ELISA data for the recombinant proteins that have reached the equilibrium concentration. (D) Plasmin generation by PLG bound to recombinant proteins was assayed by modified ELISA as immobilized proteins received the following treatment: PLG + UPA + specific plasmin substrate (PLG + uPA + S), or controls lacking one of the three components (PLG + uPA; PLG + S; uPA + S). BSA was employed as negative control. Bars represent mean absorbance at $405 \mathrm{~nm}$, as a measure of relative substrate degradation \pm the standard deviation of four replicates for each experimental group and are representative of two independent experiments. Statistically significant binding in comparison to the negative control (BSA) are show: ${ }^{*} \mathrm{P}<0.001$ and ${ }^{* *} \mathrm{P}<0.02$. doi:10.1371/journal.pone.0021962.g006

\section{Plasmin generation from PLG-bound proteins}

PLG bound to the surface of $L$. interrogans is converted to enzymatically active plasmin by the addition of activator [14]. To evaluate if PLG bound to recombinant proteins can acquire proteolytic activity, as reported for rLIC12238 [15], 96-well plates were coated with the test proteins, blocked, and then incubated with PLG. Unbound PLG was washed away and the uPA-type PLG activator was added together with a plasmin-specific chromogenic substrate. The reaction was carried out overnight and the plasmin activity was evaluated by measuring the cleavage of the plasmin-specific chromogenic substrate (absorbance at $405 \mathrm{~nm}$ ). As shown in Fig. 6D, PLG captured by the proteins could be converted into plasmin, as indirectly demonstrated by specific proteolytic activity. The negative control BSA did not bind PLG (see Fig. 6A) and did not show any proteolytic activity. The same situation occurred with the controls lacking PLG, uPA or the chromogenic substrate.

\section{Adhesion of recombinant proteins to ECM components}

The Lsa66, Lp30 and rLIC12238 proteins are suggested to be surface-exposed by immunofluorescence microscopy. We therefore investigated whether these proteins could mediate host colonization by adhering to extracellular matrix proteins. Thus, laminin, collagen Type I, collagen Type IV, cellular fibronectin, plasma fibronectin, and the control protein fetuin were immobilized on microdilution wells and recombinant protein attachment was assessed by an ELISA-based assay using antibodies against the proteins. As shown in Fig. 7A, Lsa66 protein exhibited efficient adhesiveness to laminin and plasma fibronectin. No statistically significant adhesiveness was observed with this protein when wells were coated with collagen Type I and IV, plasma fibronectin or with the highly glycosylated control protein fetuin. No binding was observed with the proteins Lp30 and rLIC12238 with ECM components (Fig. 7A). The Lsa66 interaction with ECM molecules was also observed when anti-polyhistidine monoclonal antibodies were employed (Fig. 7B). The interaction between Lsa66 with laminin and with plasma fibronectin was also assessed on a quantitative basis as depicted in Fig. $6 \mathrm{~B}$ and $6 \mathrm{C}$, respectively. A dose-dependent and saturable binding was observed when increasing concentrations of the recombinant protein $(0-$ $1000 \mathrm{nM}$ ) were allowed to adhere to a fixed laminin concentration $(1 \mu \mathrm{g})($ Fig. $7 \mathrm{C})$ or recombinant protein $(0-2000 \mathrm{nM})$ to plasma fibronectin $(1 \mu \mathrm{g})$ (Fig. 7D). Binding saturation level was reached by protein concentration of $\sim 500 \mathrm{nM}$, in the case of laminin, and above $1500 \mathrm{nM}$ for plasma fibronectin (Fig. 7C and 7D), respectively. Also shown in these figures are the calculated dissociation equilibrium constants $\left(K_{\mathrm{D}}\right)$ for the recombinant protein Lsa66 with laminin, $55.4 \pm 15.9 \mathrm{nM}$ and with plasma fibronectin, 290.8 $\pm 11.8 \mathrm{nM}$.

\section{Inhibition of $L$. interrogans attachment to ECM and plasminogen by Lsa66 and Lp30}

The inhibitory effect promoted by Lsa66 on leptospiral adherence to laminin, plasma fibronectin and by Lsa66 and Lp30 to plasminogen was quantified by an ELISA-like assay. ECM- and plasminogen-coated microtiter wells were incubated with increasing concentration of Lsa66 (Fig. 8A) and Lp30 (Fig. 8B) previous to the addition of $4 \times 10^{7}$ L. interrogans. Bound leptospires were probed with anti-LipL32 serum, as LipL32 is a major outer membrane leptospiral protein [29]. Lsa66 caused an inhibition of leptospires attachment to laminin $(P<0.05)$, to plasma fibronectin $(P<0.05)$ and to plasminogen $(P<0.05)$ (Fig. 8A). In the case of Lp30, inhibition of leptospiral adherence to plasminogen was achieved with $1.25 \mu \mathrm{g}(P<0.05)$ (Fig. 8B). The experiment was performed in triplicate and repeated three times with similar results.

\section{Reactivity of recombinant proteins with sera from confirmed cases of leptospirosis}

To investigate whether LIC10258, LIC12880 and LIC12238 coding sequences are capable to promote an immune response from an infected host, we evaluated the reactivity of the proteins with antibodies present in serum samples of confirmed early (MAT -) and convalescent (MAT + ) phases of leptospirosis patients. We performed an ELISA using 20 serum samples, 10 of each phase of the disease. The results depicted in fig. 9 show that although several samples presented IgM- and IgG-antibodies against the recombinant proteins in the convalescent phase, positive MAT serum samples, no or very low reactivity was achieved at the early phase of the disease where MAT was negative. The best performances were obtained with Lsa66 and rLIC12238 proteins (Fig. 9A and 9C). It is worth mentioning that $30 \%$ of ELISA IgG antibodies were detected with Lsa66 with MAT negative serum (Fig.9A).

\section{Discussion}

A number of studies have established OmpA as a multifaceted molecule with many diverse roles. OmpA outer membrane protein of Escherichia coli and other enterobacteria have been reported to act as adhesin/invasin, to participate in biofilm formation and to have role as immune target and evasin [36]. OmpA-like domains (named after the C-terminal domain of E. coli OmpA protein) have been shown to non-covalently associate with peptidoglycan [37]. 
口Lsa66 ㄴp30 rLIC12238

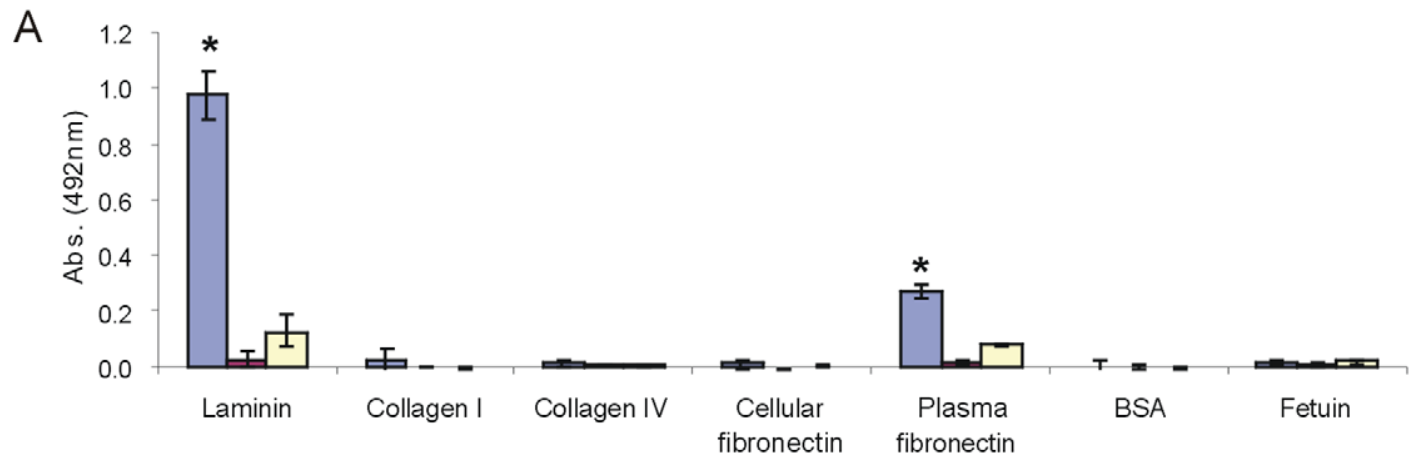

B

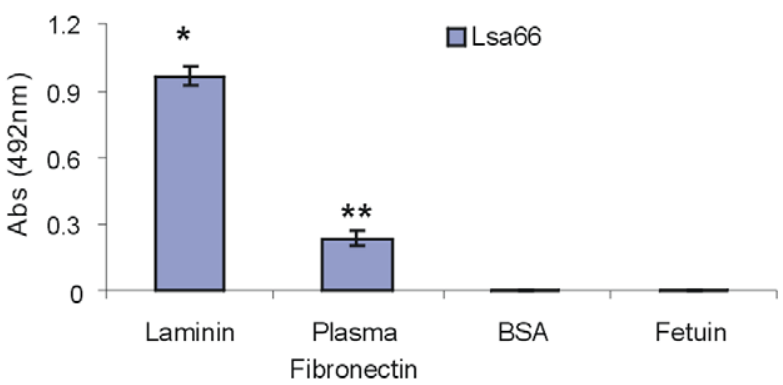

C

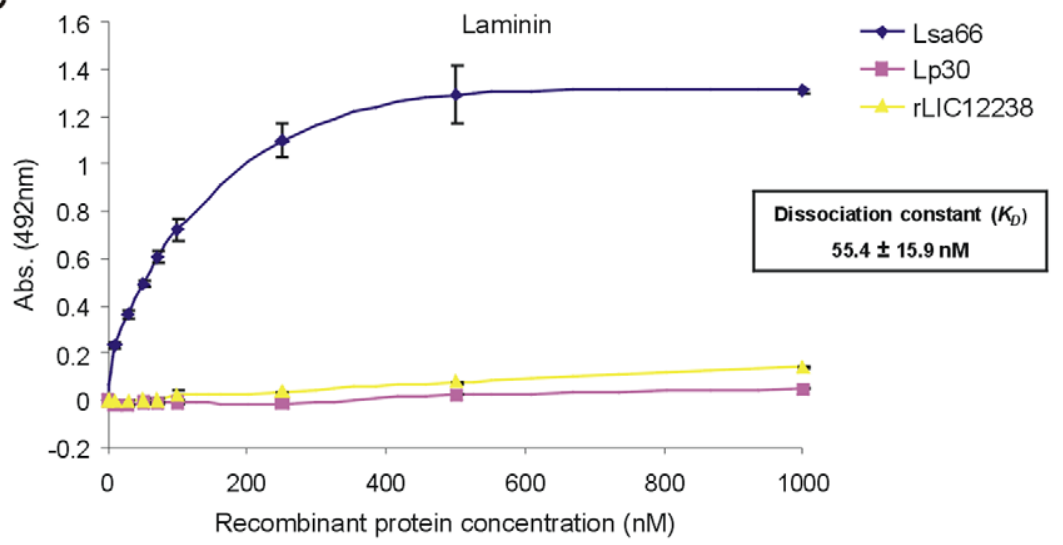

D

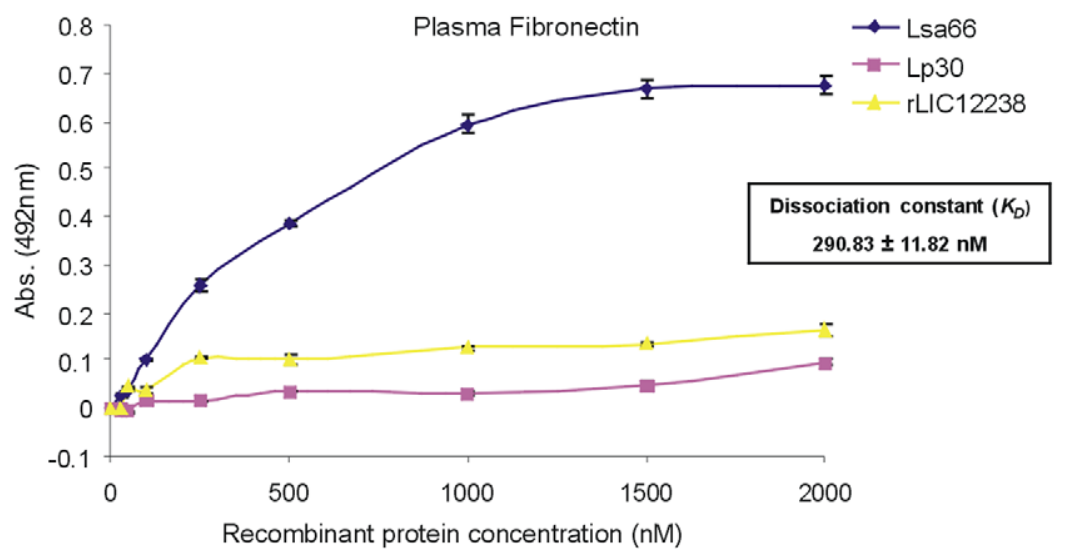


Figure 7. Binding characteristics of Lsa66, Lp30 and rLIC12238 to ECM components. (A) Wells were coated with $1 \mu \mathrm{g}$ of laminin, collagen type I, collagen type IV, cellular fibronectin, plasma fibronectin and the control proteins BSA and fetuin. $1 \mu \mathrm{g}$ of the recombinant protein was added per well and the binding was measured by an ELISA-based assay. In (A) the protein binding was detected by polyclonal antibodies against each protein, while in (B) protein binding was evaluated by anti-polyhistidine monoclonal antibodies. Data represent the mean \pm the standard deviation from three independent experiments. For statistical analyses, the attachment of recombinant proteins to the ECM components was compared to its binding to BSA as well as fetuin by the two-tailed $t$ test $\left({ }^{*} \mathrm{P}<0.005\right)$. (C) and (D) are recombinant proteins dose-dependent binding experiments with laminin (C) and plasma fibronectin (D); in both cases bindings were detected by polyclonal antibodies against each protein; each point was performed in triplicate and expressed as the mean absorbance value at $492 \mathrm{~nm} \pm$ standard error for each point. Lp30 and rLIC12238 were included as a negative control. The dissociation constants $\left(K_{\mathrm{D}}\right)$ are depicted and were calculated based on ELISA data for the recombinant proteins that reached equilibrium up to a concentration of $1,000 \mathrm{nM}$, in the case of laminin and 2,000 $\mathrm{nM}$, for the plasma fibronectin. doi:10.1371/journal.pone.0021962.g007

Members of this family include the $E$. coli outer membrane protein OmpA [36], the E. coli lipoprotein PAL (Peptidoglycan-associated lipoprotein) [38], the Neisseria meningitidis RmpM, a putative peptidoglycan binding protein, [39], the E. coli motor protein MotB [40] and the flagellar motor proteins PomB and MotY of Vibrio alginolyticus [41], which interact with the inner membrane. Moreover, peptidoglycan-associated lipoprotein (Pal) is a potential vaccine candidate against Haemophilus influenza [42]. The first protein identified in pathogenic Leptospira having a G-terminal OmpA consensus was Loa22 [43], followed by Omp52 identified in L. santarosai serovar Shermani, and shown to be reactive with sera of human patients infected with leptospires [44]. Recently, an OmpA70 was identified in L. interogans serovar Copenhageni [45]. The OmpA-like protein Loa22 was reported to be essential for the leptospiral virulence [43] and to promote inflammatory responses in cultured rat renal cells [46]. More recently, Yan and colleagues (2010) [47] have reported OmpA-like proteins as novel vaccine candidates for leptospirosis. Thus, it is possible that OmpA-like proteins have a function in leptospiral pathogenesis.

We have identified one novel putative protein with OmpA-like domain at C-teminus (OmpA C-like) encoded by the LIC10258 gene, we named Lsa66, and two putative lipoproteins, one encoded by the gene LIC12880, previously reported as Lp30 [17], and the other, LIC12238, described as a plasminogen-binding protein [15]. DNA amplification of LIC10258 was present in many serovars of $L$. interrogans but was absent in other pathogenic species tested, including $L$. borgpertensenii serovar Castellonis. Because this gene was identified in L. borgpertensenii serovar
Hardjo-bovis genome sequences [32], it is possible that the gene is absent only in the serovar evaluated. Intriguingly, expression of LIC10258 was not observed in serovar Icteroharmorrhagiae under normal growth conditions. Likewise, no LIC12880 transcripts were detected in 3 pathogenic species of Leptospira. The gene LIC10258 was expressed only under physiological osmolarity in $L$. interrogans serovar Icterohamorrhagiae, a characteristic shared with ligA and $B$ genes [48] and LIC10368 [8]. The addition of $120 \mathrm{mM}$ $\mathrm{NaCl}$ to the culture medium reproduces the hosts serum osmolarity $(\sim 300 \operatorname{mos} M)$, thus providing a more physiological environment for leptospiral growth. Indeed, this is not surprising because $6 \%$ of the $L$. interrogans genes were revealed to be susceptible to osmoregulation [49]. Osmotic control of gene expression has been reported as an environmental cue associated with virulence in a variety of pathogens [34], including Tcp pilli of $V$. cholerae [50] and invA of S. Typhimurium [51]. Nevertheless, expression of the LIC12880 gene seemed to be restricted only to serovars of $L$. interrogans because bacterial cultures shifted to physiological conditions had no effect on gene expression.

The LIC10258, LIC12880 and LIC12238 coding sequences were cloned, without the signal peptide, and the proteins expressed in E. coli with a molecular mass of 66,30 and $17 \mathrm{kDa}$, respectively. Recombinant proteins were purified by $\mathrm{Ni}^{2+}$-chelating chromatography as a major protein band and were recognized by anti-His tag monoclonal antibodies and by polyclonal antiserum obtained in mice against each of them. Assessment of secondary structure of the recombinant proteins after the purification process has been performed by CD spectroscopy and showed a mixture of $\alpha$-helices
A

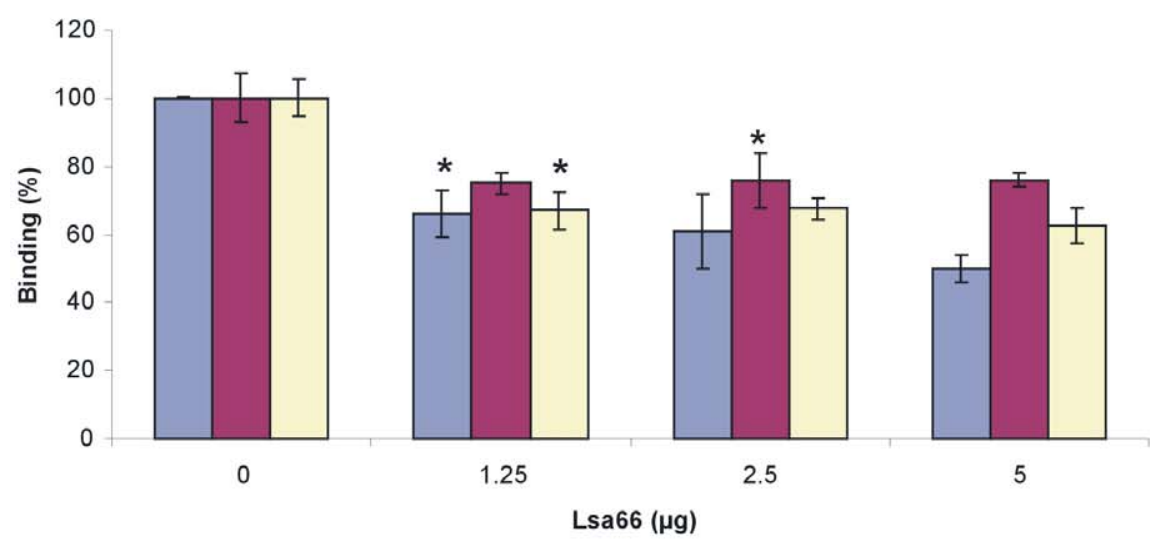

B aplasminogen

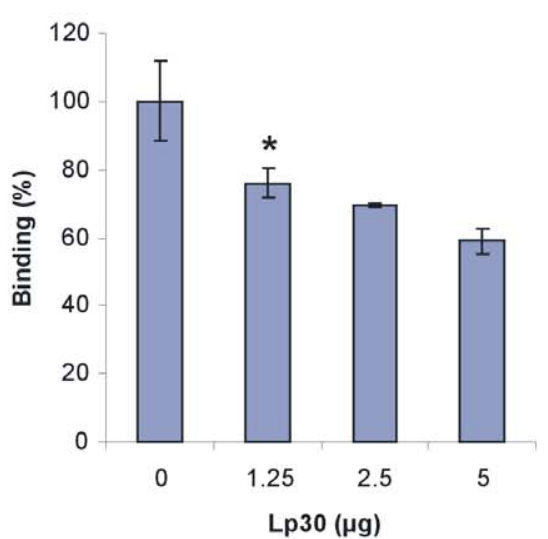

Figure 8. Inhibition of L. interrogans attachment to ECM and plasminogen by Lsa66 and Lp30. ECM- or plasminogen-coated microtiter wells were incubated with increasing concentration $(0-5.0 \mu \mathrm{g})$ of Lsa66 (A) or plasminogen-coated microtiter wells and increasing concentration (0$5.0 \mu \mathrm{g}$ ) of $\mathrm{Lp} 30$ (B) for $1 \mathrm{~h} 30$ min prior to the addition of $4 \times 10^{7}$ leptospires. Wells were probed with anti-LipL32 serum. Data are expressed as $A_{492} \mathrm{~nm}$ \pm S.E. of three independent experiments, each performed in triplicate. Significance was assessed by comparison with the "no protein" wells by Students two-tailed $t$ test $\left({ }^{*}, P<0.05\right)$.

doi:10.1371/journal.pone.0021962.g008 
A
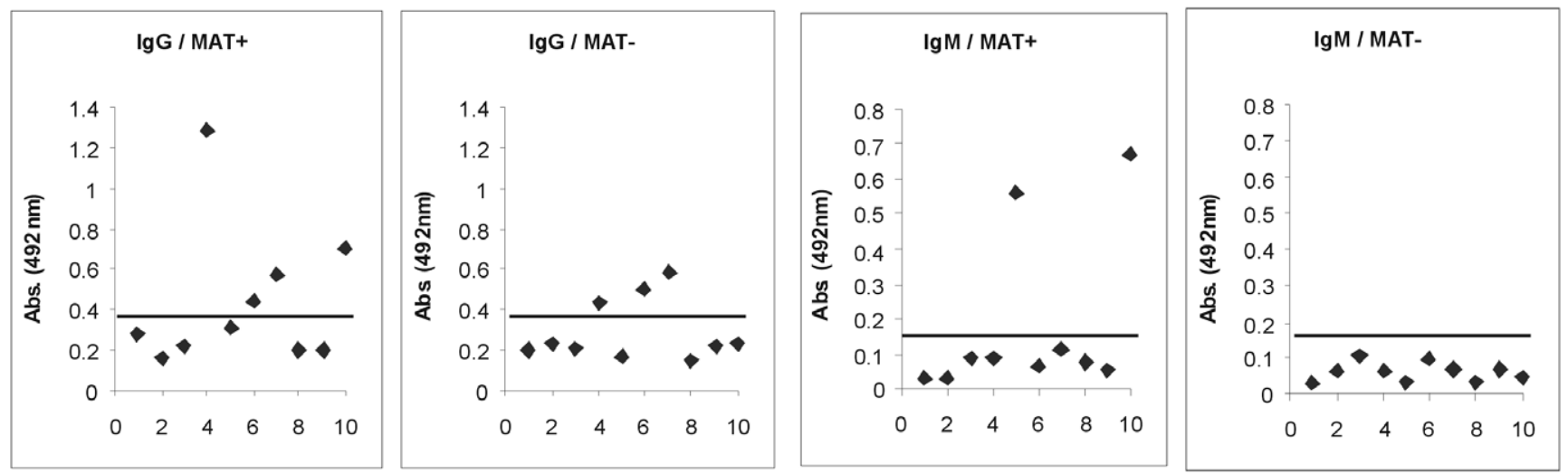

B
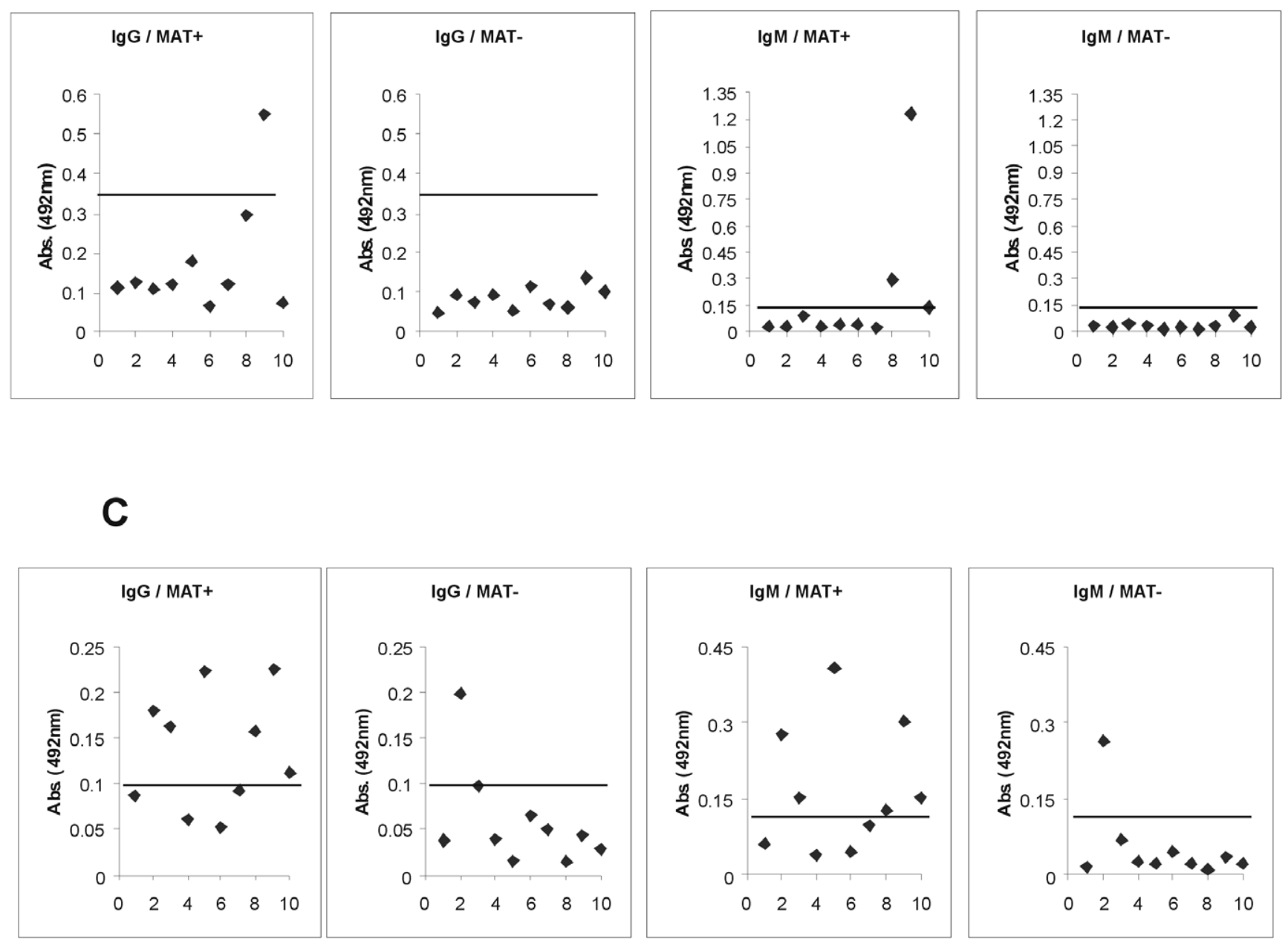

Figure 9. Reactivity of the recombinant antigens Lsa66, Lp30 and rLIC12238 with serum samples of individuals diagnosed with leptospirosis. Positive sera (responders) were determined by ELISA with the recombinant proteins and serum samples from patients in both phases of the disease. The reactivity was evaluated as IgM or IgG antibodies. Serum was considered MAT positive or MAT negative if agglutination was detected when the sera were tested for their reactivity's with isolates of the 22 serovars (see Methods). The cutoff values are depicted as horizontal bars and were defined as the mean plus 3 standard deviations obtained for sera from five healthy individuals. A, B and C show the data for Lsa66, Lp30 and rLIC12238, respectively.

doi:10.1371/journal.pone.0021962.g009 
and $\beta$-strands structures, similar to the data predicted by bioinformatics, rendering the recombinant proteins suitable for further studies.

The ability to interact with the host PLG system has been shown for several invasive gram-positive and gram-negative bacteria [52,53]. Moreover, this interaction has been described for some virus and parasites $[54,55]$. The plasminogen activation system was studied with several species of Borrelia and with Treponema denticola and suggested to have an important role during infection $[56,57]$. We have reported that Leptospira species were also capable to bind PLG and generating plasmin, in the presence of activator, on the outer surface in vitro [14]. Furthermore, we have demonstrated that plasmin-coated virulent L.interrogans bacteria were capable of degrading purified extracellular matrix fibronectin, a step that may contribute to leptospiral invasiveness [14]. Verma et al. (2010) [58] have demonstrated that the protein LenA of L. interrogans [5], formerly LfhA/Lsa24 [6,59], is a surface receptor for human plasminogen. More recently, we have shown eight novel PLG-receptor proteins of Leptospira, including rLIC12238 of this work [15]. We now identified Lsa66 and Lp30, as novel PLG-binding proteins. The highest binding affinity was achieved for $\mathrm{rLIC1} 12238\left(K_{\mathrm{D}}=11.97 \pm 1.06 \mathrm{nM}\right.$, in [15]) followed by Lsa66 $\left(K_{\mathrm{D}}=68.82 \pm 25.24 \mathrm{nM}\right)$, being the lowest value for $\operatorname{Lp} 30\left(K_{\mathrm{D}}=167.39 \pm 60.14 \mathrm{nM}\right)$. The binding affinity value obtained for Lsa66 is of the same order of magnitude of the ones calculated for other recombinant proteins reported from our laboratory [15]. Bound PLG, as demonstrated with rLIC12238, could be converted to plasmin by the addition of urokinase-type PLG activator (uPA), showing specific proteolytic activity. Thus, it is possible that this protein may contribute to leptospiral infectiveness.

Several leptospiral adhesins have been described to date. These include 36-kDa fibronectin-binding protein [60], Lsa24 [6] /LfhA [59], LigA and LigB proteins [7], Len-family proteins [5], Lsa21 [8], LipL32 [9], Lsa27 [61], Lp95 [11], TlyC [10], LipL53 [30], Lsa63 [12] and OmpL37 [13]. Lsa66 exhibits extracellular matrixbinding properties, and it is a laminin and plasma fibronectinbinding protein. Estimated binding affinity of Lsa66 was higher to laminin than with plasma fibronectin. It is thus possible that besides acting as PLG-receptor, this protein may also play a role in the attachment to host tissues.

Lsa66 inhibited adhesion of intact $L$. interrogans to immobilized plasminogen, laminin and plasma fibronectin. Comparable effect was exhibited by Lp30 upon plasminogen. The inhibitory effect promoted by the recombinant proteins was partial and in agreement with the presence of additional binding proteins contributing to the leptospiral adherence to extracellular matrix components and plasminogen. Similar results were obtained with other leptospiral adhesins, Lsa24 [6], LigA and LigB proteins [7], Lsa63 [12] and OmpL37 [13].

\section{References}

1. Faine S, Adler B, Bolin C, Perolat P (1999) Leptospira and Leptospirosis. Melbourne, Australia MediSci.

2. Levett PN (2001) Leptospirosis. Clin Microbiol Rev 14: 296-326.

3. Bolin CA, Thiermann AB, Handsaker AL, Foley JW (1989) Effect of vaccination with a pentavalent leptospiral vaccine on Leptospira interrogans serovar hardjo type hardjo-bovis infection of pregnant cattle. Am J Vet Res 50: 161-165.

4. Ljungh A, Moran AP, Wadstrom T (1996) Interactions of bacterial adhesins with extracellular matrix and plasma proteins: pathogenic implications and therapeutic possibilities. FEMS Immunol Med Microbiol 16: 117-126.

5. Stevenson B, Choy HA, Pinne M, Rotondi ML, Miller MC, et al. (2007) Leptospira interrogans endostatin-like outer membrane proteins bind host fibronectin, laminin and regulators of complement. PLoS ONE 2: e1188.

6. Barbosa AS, Abreu PA, Neves FO, Atzingen MV, Watanabe MM, et al. (2006) A newly identified leptospiral adhesin mediates attachment to laminin. Infect Immun 74: 6356-6364.
Immunofluorescence of LIC10258, LIC12880 and LIC12238 coding sequences at the surface of leptospires, as a result of antiserum recognition raised against each protein was detected as single spots. This could be explained since quantitative proteomics studies of $L$. interrogans have estimated only 75 and 11 copies per cell of LIC10258 and LIC12238, respectively, while LIC12880 did not fall in protein abundance scale to have its number of copies calculated [62]. On the other hand, 3,800 and 15,000 copies per cell were estimated of LipL32 and GroEL, respectively. These findings could explain the focal distribution and low fluorescence intensity of our coding sequences, contrasting with the fluorescence detected for LipL32. Interestingly, although present in high copy number, no green fluorescence was detected when antiGroEL was added, attesting the integrity of the bacteria.

Lsa66 and rLIC12238 share serum recognition properties with the previously described adhesins, LipL32 [63], LigA and LigB proteins [64], Lsa27 [61], Lsa63 [12] and OmpL37 [13] that have shown positive reactivity with serum samples from patients diagnosed with leptospirosis. Interestingly, the OmpA-like leptospiral lipoprotein Loa22, although reactive with convalescent mouse sera and essential for virulence of $L$. interrogans in the animal model [43], does not bind ECM molecules [6]. This suggests that the binding of Lsa66 to laminin or plasma fibronectin does not occur through the OmpA-like domain at the G-terminus. Protein recognition by serum of confirmed leptospirosis samples together with the immunofluorescence data suggest that Lsa66 and rLIC12238 may be surface exposed.

In conclusion, we present in these studies one novel OmpA-like protein, Lsa66, and two predicted lipoproteins that are PLGbinding receptors. Lsa66, in addition, is an ECM binding protein that reacts with antibodies present in both phases of the disease. Thus, it is possible that this dual activity of Lsa66 may promote the attachment to host via ECM and may help the leptospires to overcome tissue barriers by plasmin generation. Revealing bacteria-host interactions at a molecular level should elucidate our understanding of the host physiology and facilitate the search for vaccine targets against leptospirosis.

\section{Acknowledgments}

We are deeply indebted to Alexsander Seixas de Souza (Departamento de Parasitologia, Instituto Butantan, São Paulo, Brazil) for use of the confocal microscope facilities and helpful discussion.

\section{Author Contributions}

Conceived and designed the experiments: RO APG SAV ALTON. Performed the experiments: RO ZMM APG ECR. Analyzed the data: RO ECR SAV ALTON. Contributed reagents/materials/analysis tools: RO ECR SAV ALTON. Wrote the paper: RO ALTON.

7. Choy HA, Kelley MM, Chen TL, Moller AK, Matsunaga J, et al. (2007) Physiological osmotic induction of Leptospira interrogans adhesion: LigA and LigB bind extracellular matrix proteins and fibrinogen. Infect Immun 75: 2441-2450.

8. Atzingen MV, Barbosa AS, De Brito T, Vasconcellos SA, de Morais ZM, et al. (2008) Lsa21, a novel leptospiral protein binding adhesive matrix molecules and present during human infection. BMC Microbiol 8: 70 .

9. Hoke DE, Egan S, Cullen PA, Adler B (2008) LipL32 is an extracellular matrixinteracting protein of Leptospira spp. and Pseudoalteromonas tunicata. Infect Immun 76: 2063-2069.

10. Carvalho E, Barbosa AS, Gomez RM, Cianciarullo AM, Hauk P, et al. (2009) Leptospiral TlyC is an extracellular matrix-binding protein and does not present hemolysin activity. FEBS Lett.

11. Atzingen MV, Gomez RM, Schattner M, Pretre G, Goncales AP, et al. (2009) Lp95, a novel leptospiral protein that binds extracellular matrix components and activates e-selectin on endothelial cells. J Infect. 
12. Vieira ML, de Morais ZM, Goncales AP, Romero EC, Vasconcellos SA, et al. (2010) Lsa63, a newly identified surface protein of Leptospira interrogans binds laminin and collagen IV. J Infect 60: 52-64.

13. Pinne M, Choy HA, Haake DA (2010) The OmpL37 surface-exposed protein is expressed by pathogenic Leptospira during infection and binds skin and vascular elastin. PLoS Negl Trop Dis 4: e815.

14. Vieira ML, Vasconcellos SA, Goncales AP, de Morais ZM, Nascimento AL (2009) Plasminogen acquisition and activation at the surface of leptospira species lead to fibronectin degradation. Infect Immun 77: 4092-4101.

15. Vieira ML, Atzingen MV, Oliveira TR, Oliveira R, Andrade DM, et al. (2010) In vitro identification of novel plasminogen-binding receptors of the pathogen Leptospira interrogans. PLoS One 5: e11259.

16. Nascimento AL, Verjovski-Almeida S, Van Sluys MA, Monteiro-Vitorello CB, Camargo LE, et al. (2004) Genome features of Leptospira interrogans serovar Copenhageni. Braz J Med Biol Res 37: 459-477.

17. Neves FO, Abreu PA, Vasconcellos SA, de Morais ZM, Romero EC, et al. (2007) Identification of a novel potential antigen for early-phase serodiagnosis of leptospirosis. Arch Microbiol 188: 523-532.

18. Turner LH (1970) Leptospirosis. 3. Maintenance, isolation and demonstration of leptospires. Trans R Soc Trop Med Hyg 64: 623-646.

19. Nakai K, Kanehisa M (1991) Expert system for predicting protein localization sites in gram-negative bacteria. Proteins 11: 95-110.

20. Yu CS, Lin CJ, Hwang JK (2004) Predicting subcellular localization of proteins for Gram-negative bacteria by support vector machines based on n-peptide compositions. Protein Sci 13: 1402-1406.

21. Letunic I, Copley RR, Pils B, Pinkert S, Schultz J, et al. (2006) SMART 5: domains in the context of genomes and networks. Nucleic Acids Res 34: D257-260.

22. Finn RD, Mistry J, Schuster-Bockler B, Griffiths-Jones S, Hollich V, et al. (2006) Pfam: clans, web tools and services. Nucleic Acids Res 34: D247-251.

23. Juncker AS, Willenbrock H, Von Heijne G, Brunak S, Nielsen H, et al. (2003) Prediction of lipoprotein signal peptides in Gram-negative bacteria. Protein Sci 12: $1652-1662$.

24. Altschul SF, Madden TL, Schaffer AA, Zhang J, Zhang Z, et al. (1997) Gapped BLAST and PSI-BLAST: a new generation of protein database search programs. Nucleic Acids Res 25: 3389-3402.

25. Marchler-Bauer A, Anderson JB, Chitsaz F, Derbyshire MK, DeWeese-Scott C, et al. (2009) CDD: specific functional annotation with the Conserved Domain Database. Nucleic Acids Res 37: D205-210.

26. Ramos GR, Abreu PA, Nascimento AL, Ho PL (2004) A high-copy T7 Escherichia coli expression vector for the production of recombinant proteins with a minimal N-terminal His-tagged fusion peptide. Braz J Med Biol Res 37: 1103-1109.

27. Deleage G, Geourjon C (1993) An interactive graphic program for calculating the secondary structure content of proteins from circular dichroism spectrum. Comput Appl Biosci 9: 197-199.

28. Lin YP, Lee DW, McDonough SP, Nicholson LK, Sharma Y, et al. (2009) Repeated domains of leptospira immunoglobulin-like proteins interact with elastin and tropoelastin. J Biol Chem 284: 19380-19391.

29. Haake DA, Chao G, Zuerner RL, Barnett JK, Barnett D, et al. (2000) The leptospiral major outer membrane protein LipL32 is a lipoprotein expressed during mammalian infection. Infect Immun 68: 2276-2285.

30. Oliveira TR, Longhi MT, Goncales AP, de Morais ZM, Vasconcellos SA, et al. (2010) LipL53, a temperature regulated protein from Leptospira interrogans that binds to extracellular matrix molecules. Microbes Infect 12: 207-217.

31. Ren SX, Fu G, Jiang XG, Zeng R, Miao YG, et al. (2003) Unique physiological and pathogenic features of Leptospira interrogans revealed by whole-genome sequencing. Nature 422: 888-893.

32. Bulach DM, Zuerner RL, Wilson P, Seemann T, McGrath A, et al. (2006) Genome reduction in Leptospira borgpetersenii reflects limited transmission potential. Proc Natl Acad Sci U S A 103: 14560-14565.

33. Picardeau M, Bulach DM, Bouchier C, Zuerner RL, Zidane N, et al. (2008) Genome sequence of the saprophyte Leptospira biflexa provides insights into the evolution of Leptospira and the pathogenesis of leptospirosis. PLoS One 3: e1607.

34. Mekalanos JJ (1992) Environmental signals controlling expression of virulence determinants in bacteria. J Bacteriol 174: 1-7.

35. Haake DA, Matsunaga J (2002) Characterization of the leptospiral outer membrane and description of three novel leptospiral membrane proteins. Infect Immun 70: 4936-4945.

36. Smith SG, Mahon V, Lambert MA, Fagan RP (2007) A molecular Swiss army knife: OmpA structure, function and expression. FEMS Microbiol Lett 273: $1-11$.

37. Wang Y (2002) The function of OmpA in Escherichia coli. Biochem Biophys Res Commun 292: 396-401.

38. Cascales E, Bernadac A, Gavioli M, Lazzaroni JC, Lloubes R (2002) Pal lipoprotein of Escherichia coli plays a major role in outer membrane integrity. J Bacteriol 184: 754-759.
39. Grizot S, Buchanan SK (2004) Structure of the OmpA-like domain of RmpM from Neisseria meningitidis. Mol Microbiol 51: 1027-1037.

40. Kojima S, Blair DF (2004) The bacterial flagellar motor: structure and function of a complex molecular machine. Int Rev Cytol 233: 93-134.

41. Kojima S, Shinohara A, Terashima H, Yakushi T, Sakuma M, et al. (2008) Insights into the stator assembly of the Vibrio flagellar motor from the crystal structure of MotY. Proc Natl Acad Sci U S A 105: 7696-7701.

42. Parsons LM, Lin F, Orban J (2006) Peptidoglycan recognition by Pal, an outer membrane lipoprotein. Biochemistry 45: 2122-2128.

43. Ristow P, Bourhy P, da Cruz McBride FW, Figueira CP, Huerre M, et al. (2007) The OmpA-like protein Loa22 is essential for leptospiral virulence. PLoS Pathog 3: e97.

44. Hsieh WJ, Chang YF, Chen CS, Pan MJ (2005) Omp52 is a growth-phaseregulated outer membrane protein of Leptospira santarosai serovar Shermani. FEMS Microbiol Lett 243: 339-345.

45. Fraga TR, Chura-Chambi RM, Goncales AP, Morais ZM, Vasconcellos SA, et al. (2010) Refolding of the recombinant protein OmpA70 from Leptospira interrogans from inclusion bodies using high hydrostatic pressure and partial characterization of its immunological properties. J Biotechnol 148: 156-162.

46. Zhang Y, Bao L, Zhu H, Huang B, Zhang H (2010) OmpA-like protein Loa22 from Leptospira interrogans serovar Lai is cytotoxic to cultured rat renal cells and promotes inflammatory responses. Acta Biochim Biophys Sin (Shanghai) 42: 70-79.

47. Yan W, Faisal SM, McDonough SP, Chang CF, Pan MJ, et al. (2010) Identification and characterization of OmpA-like proteins as novel vaccine candidates for Leptospirosis. Vaccine 28: 2277-2283.

48. Matsunaga J, Barocchi MA, Croda J, Young TA, Sanchez Y, et al. (2003) Pathogenic Leptospira species express surface-exposed proteins belonging to the bacterial immunoglobulin superfamily. Mol Microbiol 49: 929-945.

49. Matsunaga J, Lo M, Bulach DM, Zuerner RL, Adler B, et al. (2007) Response of Leptospira interrogans to physiologic osmolarity: relevance in signaling the environment-to-host transition. Infect Immun 75: 2864-2874.

50. Miller VL, Mekalanos JJ (1988) A novel suicide vector and its use in construction of insertion mutations: osmoregulation of outer membrane proteins and virulence determinants in Vibrio cholerae requires toxR. J Bacteriol 170: 2575-2583.

51. Galan JE, Curtiss R, 3rd (1991) Distribution of the invA, -B, -C, and -D genes of Salmonella typhimurium among other Salmonella serovars: invA mutants of Salmonella typhi are deficient for entry into mammalian cells. Infect Immun 59: 2901-2908.

52. Coleman JL, Benach JL (1999) Use of the plasminogen activation system by microorganisms. J Lab Clin Med 134: 567-576.

53. Sun H (2006) The interaction between pathogens and the host coagulation system. Physiology (Bethesda) 21: 281-288.

54. LeBouder F, Morello E, Rimmelzwaan GF, Bosse F, Pechoux C, et al. (2008) Annexin II incorporated into influenza virus particles supports virus replication by converting plasminogen into plasmin. J Virol 82: 6820-6828.

55. Rojas M, Labrador I, Concepcion JL, Aldana E, Avilan L (2008) Characteristics of plasminogen binding to Trypanosoma cruzi epimastigotes. Acta Trop 107: 54-58.

56. Fenno JC, Tamura M, Hannam PM, Wong GW, Chan RA, et al. (2000) Identification of a Treponema denticola OppA homologue that binds host proteins present in the subgingival environment. Infect Immun 68: 1884-1892.

57. Klempner MS, Noring R, Epstein MP, McCloud B, Rogers RA (1996) Binding of human urokinase type plasminogen activator and plasminogen to Borrelia species. J Infect Dis 174: 97-104.

58. Verma A, Brissette CA, Bowman AA, Shah ST, Zipfel PF, et al. (2010) Leptospiral endostatin-like protein $\mathrm{A}$ is a bacterial cell surface receptor for human plasminogen. Infect Immun 78: 2053-2059.

59. Verma A, Hellwage J, Artiushin S, Zipfel PF, Kraiczy P, et al. (2006) LfhA, a novel factor $\mathrm{H}$-binding protein of Leptospira interrogans. Infect Immun 74: 2659-2666.

60. Merien F, Truccolo J, Baranton G, Perolat P (2000) Identification of a 36-kDa fibronectin-binding protein expressed by a virulent variant of Leptospira interrogans serovar icterohaemorrhagiae. FEMS Microbiol Lett 185: 17-22.

61. Longhi MT, Oliveira TR, Romero EC, Goncales AP, de Morais ZM, et al. (2009) A newly identified protein of Leptospira interrogans mediates binding to laminin. J Med Microbiol 58: 1275-1282.

62. Malmstrom J, Beck M, Schmidt A, Lange V, Deutsch EW, et al. (2009) Proteome-wide cellular protein concentrations of the human pathogen Leptospira interrogans. Nature 460: 762-765.

63. Flannery B, Costa D, Carvalho FP, Guerreiro H, Matsunaga J, et al. (2001) Evaluation of recombinant Leptospira antigen-based enzyme-linked immunosorbent assays for the serodiagnosis of leptospirosis. J Clin Microbiol 39: 3303-3310.

64. Croda J, Ramos JG, Matsunaga J, Queiroz A, Homma A, et al. (2007) Leptospira immunoglobulin-like proteins as a serodiagnostic marker for acute leptospirosis. J Clin Microbiol 45: 1528-1534. 


\title{
Evaluation of Immunoprotective Activity of Six Leptospiral Proteins in the Hamster Model of Leptospirosis
}

\author{
Marina V. Atzingen ${ }^{1}$, Mônica L. Vieira ${ }^{1,3}$, Rosane Oliveira ${ }^{1,3}$, Renan F. Domingos ${ }^{1,3}$, Renata S. \\ Mendes ${ }^{1,3}$, Aline T. Barros ${ }^{1}$, Amane P. Gonçales ${ }^{2}$, Zenaide M. de Morais ${ }^{2}$, Silvio A. Vasconcellos ${ }^{2}$ \\ and Ana L. T. O Nascimento ${ }^{1,3 \#}$. \\ ${ }^{1}$ Centro de Biotecnologia, Instituto Butantan, Avenida Vital Brazil, 1500, 05503-900, São Paulo, SP, Brazil \\ ${ }^{2}$ Laboratório de Zoonoses Bacterianas do VPS, Faculdade de Medicina Veterinária e Zootecnia, USP, Avenida Prof. \\ Dr. Orlando Marques de Paiva, 87, 05508-270, São Paulo, SP, Brazil \\ ${ }^{3}$ Interunidades em Biotecnologia, Instituto de Ciências Biomédicas, USP, Avenida Prof. Lineu Prestes, 1730, 05508- \\ 900, São Paulo, SP, Brazil
}

\begin{abstract}
Leptospirosis is a worldwide zoonosis caused by pathogenic Leptospira. The whole-genome sequence of $L$. interrogans serovar Copenhageni together with bioinformatics tools represent a great opportunity to search for novel antigen candidates that could be used as subunit vaccine against leptospirosis. We focused on six genes encoding for conserved hypothetical proteins predicted to be exported to the outer membrane. The genes were amplified by PCR from Leptospira interrogans genomic DNA and were cloned and expressed in Escherichia coli. The recombinant proteins tagged with $\mathrm{N}$-terminal hexahistidine were purified by metal-charged chromatography. The immunization of hamsters followed by challenge with lethal dose of virulent strain of Leptospira showed that the recombinant proteins Lsa21, Lsa66 and rLIC11030 elicited partial protection to animals. These proteins could be used combined or in a mixture with novel adjuvants in order to improve their effectiveness.
\end{abstract}

Keywords: Leptospira interrogans, leptospirosis, recombinant protein, vaccine.

\section{INTRODUCTION}

Leptospirosis is a highly spread zoonosis of human and veterinary concern. The disease is caused by pathogenic species of the genus Leptospira with a higher incidence in tropical and subtropical countries, where the conditions for transmission are particularly appropriate $[1,2]$. Transmission to humans occurs by direct or indirect contact to water or soil contaminated with the urine of chronically infected mammals. In the urban surroundings, due to sanitation problems and large population of urban rodent reservoirs, the disease spreads and become prevalent [3]. Flu-like symptoms, such as fever, chills, headache, and severe myalgias take place in the early phase of the disease, making clinical diagnostic very difficult. Multi-organ system complications may occur in $5-15 \%$ of the cases with $5-40 \%$ mortality rates $[1,4]$.

Presently there are veterinarian vaccines derived from inactivated whole cell preparations of pathogenic leptospires. These vaccines afford protection most probably through the induction of antibodies against leptospiral lipopolysaccharide $[2,5,6]$. Therefore, they do not confer protection against leptospiral serovars not included in the preparation

\footnotetext{
*Address correspondence to this author at the Centro de Biotecnologia, Instituto Butantan, Avenida Vital Brazil, 1500, 05503-900, São Paulo, SP, Brazil; Tel: (5511) 37220019; Fax: (5511) 37261505;

E-mail: tabet@butantan.gov.br
}

and as polysaccharide antigens, do not induce long-term protection. Human vaccines are available in Cuba [7] and China [8] with the same limitations of the veterinarian ones. The large number of pathogenic serovars $(>200)$ represents a major limitation to the production of a multi-serovar component vaccine. A cost-effective vaccine preparation against leptospirosis has long been pursued [3].

Due to their location, outer membrane proteins (OMPs) can participate of host-pathogen interactions and have become the focus of many research groups. OMPs have been shown to be surface-exposed and expressed during infection of the mammalian host $[9,10]$. Several recombinant protein have been evaluated as vaccine candidates, such as, outer membrane protein OmpL1, lipoprotein LipL41 [11], hemolysis-associated protein 1 (Hap1) / lipoprotein LipL32 [1214], immunoglobulin-like protein [15-18] and predicted outer membrane proteins [19]. Moreover, Yan et al. [20] have shown that leptospiral proteins with an OmpA-like domain conferred partial protection against lethal infection of leptospira. Recently, the evaluation of several recombinant proteins as potential antigens against leptospirosis were published but the results were not very encouraged [21]. Cellmediated immunity has also been explored [22] and pathogenic leptospires have been shown to stimulate in vivo the production of type 1 cytokines involved in cellular immunity in hamster model [23]. 
In the present work, we evaluated the immune response promoted by six recombinant proteins in hamsters. Four of them were previously characterized, LIC10368 [24], LIC11030 [25], LIC10258 [26] and LIC12253 [27], but their immune protective activity has not been tested by our research group. LIC10821 and LIC10672 are hypothetical coding sequences identified by bioinformatics tools in the genome sequences of the $L$. interrogans serovar Copenhageni. LIC10672 has also been identified by proteomics studies with virulent leptospiral strain [28]. Our results showed that the recombinant proteins elicited partial protection against lethal challenge with $L$. interrogans serovar Kennewicki strain Pomona Fromm in hamsters.

\section{MATERIALS AND METHODOLOGY}

\section{Leptospira Strains and Culture Conditions}

The non-pathogenic L. biflexa (serovar Patoc strain Patoc 1) and the pathogenic L. interrogans (serovars Copenhageni strain M-20, Canicola strain Hond Utrechet IV, Hardjo strain Hardjoprajtino, Icterohaemorrhagiae strain RGA and Pomona strain Pomona), L. borgpetersenni serovar Whitcombi strain Whitcomb, L. kirshneri (serovars Cynopteri strain 3522C and Grippotyphosa strain Moskva V), L. santarosai serovar Shermani strain $1342 \mathrm{~K}$, L. noguchi serovar Panama strain CZ214 and the virulent strain of $L$. interrogans serovar Kennewicki strain Pomona Fromm (strain LPF) and serovar Copenhageni (strain Fiocruz L1-130) were cultured at $28{ }^{\circ} \mathrm{C}$ under aerobic conditions in liquid EMJH medium (Difco ${ }^{\circledR}$ - USA) with $10 \%$ rabbit serum, enriched with L-asparagine (wt/vol: $0.015 \%$ ), sodium pyruvate (wt/vol: $0.001 \%$ ), calcium chloride (wt/vol: $0.001 \%$ ), magnesium chloride (wt/vol: $0.001 \%$ ), peptone (wt/vol:0.03\%) and meat extract (wt/vol: $0.02 \%$ ) [29]. Virulence of the $L$. interrogans serovar Kennewicki strain Pomona Fromm (strain LPF) and serovar Copenhageni (strain Fiocruz L1130) was maintained by iterative passages in Golden Syrian hamsters[1]. The animals were infected with $10^{4}$ leptospires and sacrificed after the appearance of symptoms, such as loss of weight and mobility (approximately 5 days postinfection). Kidneys were removed and macerated and the leptospires recovered through culture [1].

\section{'In silico' Identification and Characterization of the Pro- tein}

Predicted coding sequences (CDSs) were selected from the L. interrogans serovar Copenhageni genome sequences [30] based on their cellular localization prediction by CELLO program, http://cello.life.nctu.edu.tw/ [31, 32]. SMART, http://smart.embl-heidelbergde/ $[33,34]$ and PFAM, http://www.sanger.ac.uk/Software/Pfam/ [35] web servers were used to search for predicted functional and structural domains within the amino acid of the selected CDS. The predicted lipobox sequence was evaluated by LipoP, http://www.cbs.dtu.dk/services/LipoP/ [36] program.

\section{DNA Isolation and PCR Analysis}

Leptospira cultures were harvested by centrifugation at $11,500 \mathrm{X} \mathrm{g}$ for $30 \mathrm{~min}$ and gently washed in sterile PBS twice. Genomic DNA was isolated from the pellets by gua- nidine-detergent lysing method using DNAzol ${ }^{\circledR}$ Reagent (Invitrogen), according to manufacturer's instructions. The DNA fragments were amplified using oligonucleotides designed according to L. interrogans serovar Copenhageni genome sequences (GenBank accession AE016823) (Table 1). PCR was performed in a reaction volume of $25 \mu$ l containing $100 \mathrm{ng}$ of genomic DNA, 1 X PCR buffer (20 mM Tris-HCl, $\mathrm{pH} 8.4,50 \mathrm{mM} \mathrm{KCl}), 2 \mathrm{mM} \mathrm{MgCl}_{2}, 20$ pmol of each specific primer, $200 \mu \mathrm{M}$ of each dNTP, and $2.5 \mathrm{U}$ Taq DNA Polymerase (Invitrogen). Cycling conditions were: $94{ }^{\circ} \mathrm{C}, 5 \mathrm{~min}$, followed by 35 cycles at $94{ }^{\circ} \mathrm{C}, 50 \mathrm{sec}, 6{ }^{\circ} \mathrm{C}, 50 \mathrm{sec}, 72{ }^{\circ} \mathrm{C}$, $1 \mathrm{~min} 30 \mathrm{sec}$, and a final extension cycle of $7 \mathrm{~min}$ at $72{ }^{\circ} \mathrm{C}$. PCR amplified products were loaded on a $1 \%$ agarose gel for electrophoresis and visualization with ethidium bromide.

\section{Cloning, Expression and Purification of Recombinant Proteins}

Amplification of the CDSs was performed by PCR from total L. interrogans serovar Copenhageni strain Fiocruz L1130 genomic DNA using complementary primer pairs listed on Table 1. The gene sequences were amplified without the signal peptide tag, predicted by SignalP (http://www.cbs.dtu.dk/services/SignalP/) [37]. All cloned sequences were confirmed by DNA sequencing with an $\mathrm{ABI}$ 3100 automatic sequencer (PE Applied Biosystems, Foster city, CA). Cloning, expression and purification of the recombinant proteins LIC10368 (Lsa21), LIC10258 (Lsa66), LIC11030 and LIC12253 have been previously described [24-27]. The coding sequences for LIC10821 and LIC10672 were cloned into pGEM-T easy vector (Promega) and subcloned into the pAE expression vector [38] that allows the expression of recombinant proteins with a minimal $6 \times$ Histag at the N-terminus. Protein expression was achieved in $E$. coli BL21 (SI) strain by the action of T7 DNA polymerase under control of the osmotically induced promoter proU [39]. E. coli BL21 SI containing recombinant plasmids were grown at $30{ }^{\circ} \mathrm{C}$ in Luria-Bertani [37] broth without $\mathrm{NaCl}$ and with $100 \mu \mathrm{g} / \mathrm{ml}$ ampicillin with continuous shaking until an optical density at $600 \mathrm{~nm}$ of 0.6 to 0.8 was reached. Recombinant protein synthesis was induced by the addition of 300 $\mathrm{mM} \mathrm{NaCl}$. After three hours, the cells were harvested by centrifugation, the bacterial pellets resuspended in lysis buffer $(20 \mathrm{mM}$ Tris- $\mathrm{HCl}$, pH 8.0, $200 \mathrm{mM} \mathrm{NaCl}, 100 \mu \mathrm{g} / \mathrm{ml}$ of lysozyme, $2 \mathrm{mM}$ phenylmethylsulfonyl fluoride (PMSF) and $1 \%$ Triton X-100). The bacterial cell pellets were lysed on ice with the aid of an ultrasonic cell disruptor (Sonifier 450 , Branson, USA). The bacterial lysate was centrifuged at $3,000 \mathrm{X} \mathrm{g}$ for $10 \mathrm{~min}$ at $4{ }^{\circ} \mathrm{C}$. The pellets were resuspended in buffer containing $8 \mathrm{M}$ urea; $20 \mathrm{mM}$ Tris- $\mathrm{HCl}, \mathrm{pH} 8.0 ; 500$ $\mathrm{mM} \mathrm{NaCl}$. The proteins were purified through $\mathrm{Ni}^{2+}$-charged beads of chelating fast-flow chromatographic column (GE Healthcare). The rLIC10821 and rLIC10672 were refolded on-column by gradually removing urea $(8-0 \mathrm{M})$. The contaminants were washed away with low imidazole concentration and the recombinant proteins were eluted in $20 \mathrm{mM}$ Tris- $\mathrm{HCl}, \mathrm{pH} 8.0 ; 500 \mathrm{mM} \mathrm{NaCl}$ and $500 \mathrm{mM}$ imidazole. The efficiency of the purifications was evaluated by $12 \%$ SDSPAGE. The purified recombinant proteins were extensively dialyzed against PBS, $\mathrm{pH} 7.4$, glycine solution (wt/vol: 0.1 $\%$ ), at the proportion of $10 \mathrm{ml}$ of protein per $1,000 \mathrm{ml}$ of buffer, with at least five changes of buffer every $4 \mathrm{~h}$ for $48 \mathrm{~h}$. 
Table 1. Gene Locus, Protein name, NCBI Reference Sequence, Features, Gene Conservation, Sequence of the Primers Employed for DNA Amplification, and Molecular Mass of Expressed Recombinant Proteins

\begin{tabular}{|c|c|c|c|c|c|c|}
\hline $\begin{array}{l}\text { Gene } \\
\text { Locus }^{1}\end{array}$ & $\begin{array}{c}\text { Recom- } \\
\text { binant } \\
\text { Protein } \\
\text { given } \\
\text { Name }\end{array}$ & $\begin{array}{c}\text { NCBI } \\
\text { Reference } \\
\text { Sequence } \\
\text { Number }^{2}\end{array}$ & $\begin{array}{l}\text { Descrip- } \\
\text { tion/Function }\end{array}$ & $\begin{array}{l}\text { Conserva- } \\
\text { tion (Iden- } \\
\text { tity) }^{3}\end{array}$ & Sequence of primers for PCR amplification & $\begin{array}{c}\text { Recombi- } \\
\text { nant Pro- } \\
\text { tein Mo- } \\
\text { lecular } \\
\text { Mass }\end{array}$ \\
\hline LIC10368 & Lsa2 $1^{\mathrm{b}}$ & $\begin{array}{l}\text { YP_00035 } \\
5\end{array}$ & Putative lipoprotein & Lai $(100 \%)$ & $\begin{array}{c}\text { F: 5' CACCGATGAAAAAAAAGAAAATGAATTGAG } \\
3 \text { ', } \\
\text { R: 5' AACGCGATTCATAGAGAGCG 3', }\end{array}$ & $21 \mathrm{kDa}$ \\
\hline LIC10258 & $\operatorname{Lsa66}^{\mathrm{a}}$ & $\begin{array}{l}\text { YP_00024 } \\
9\end{array}$ & $\begin{array}{l}\text { Hypothetical protein } \\
\text { with ompA domain }\end{array}$ & $\begin{array}{l}\text { Lai }(99 \%) \\
\text { LBH }(83 \%)\end{array}$ & $\begin{array}{c}\text { F:5' GGATCCGAAGCCTTCTCACCCAATTG 3' } \\
\text { (BamH I) } \\
\text { R:5' CCATGGTTAAAGTGAAAGA- } \\
\text { TAAAAATCGATTC 3' (Nco I) }\end{array}$ & $65 \mathrm{kDa}$ \\
\hline LIC11030 & $\begin{array}{c}\text { rLIC110 } \\
30^{c}\end{array}$ & $\begin{array}{c}\text { YP_00100 } \\
0\end{array}$ & $\begin{array}{l}\text { Putative lipoprotein } \\
\text { with a domain of } \\
\text { unknown function } \\
\text { (DUF1565) }\end{array}$ & Lai $(99 \%)$ & 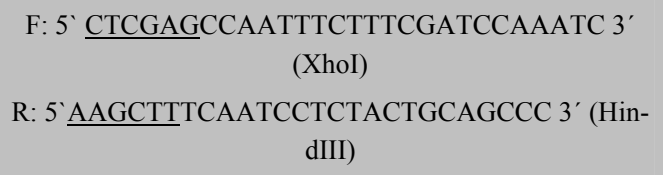 & $37 \mathrm{kDa}$ \\
\hline LIC10821 & $\begin{array}{c}\text { rLIC108 } \\
21\end{array}$ & $\begin{array}{l}\text { YP_00079 } \\
8\end{array}$ & $\begin{array}{l}\text { Putative lipoprotein } \\
\text { with a domain of } \\
\text { unknown function } \\
\text { (DUF1565) }\end{array}$ & Lai $(100 \%)$ & 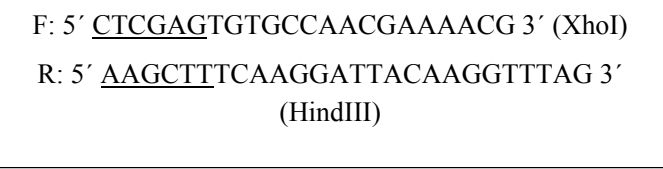 & $37 \mathrm{kDa}$ \\
\hline LIC12253 & $\mathrm{Lsa} 25^{\mathrm{d}}$ & $\begin{array}{l}\text { YP_00218 } \\
8\end{array}$ & $\begin{array}{l}\text { Putative lipoprotein } \\
\text { with a domain of } \\
\text { unknown function } \\
\text { (DUF1566) }\end{array}$ & $\begin{array}{l}\text { Lai }(100 \%) \\
\text { LBH }(77 \%) \\
\text { LBP }(39 \%)\end{array}$ & 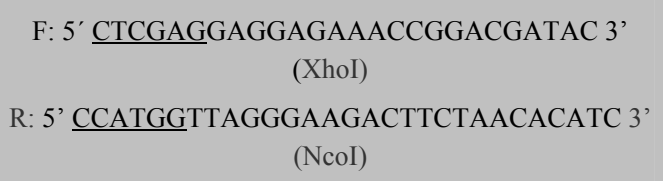 & $24 \mathrm{kDa}$ \\
\hline LIC10672 & $\begin{array}{l}\text { rLIC106 } \\
72\end{array}$ & $\begin{array}{l}\text { YP_00065 } \\
6\end{array}$ & hypothetical protein & $\begin{array}{l}\text { Lai }(100 \%) \\
\text { LBH }(95 \%)\end{array}$ & 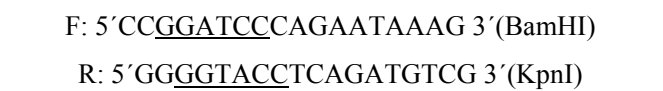 & $23 \mathrm{kDa}$ \\
\hline
\end{tabular}

http://aeg.lbi.ic.unicamp.br/world/lic/ [30, 42].

${ }^{2} \mathrm{http}: / /$ www.ncbi.nlm.nih.gov/protein/.

${ }^{3}$ Protein BLAST - http://www.ncbi.nlm.nih.gov/blast/Blast.cgi [43, 44].

${ }^{a}$ Previously published by Oliveira et al [26].

${ }^{\mathrm{b}}$ Previously published by Atzingen et al [24]

'Previously published by Mendes et al [25]

${ }^{\mathrm{d}}$ Previously published by Felix et al. [21]; Domingos et al., [27].

Lai: L. interrogans serovar Lai [45]; LBH: L. borgpetersenii serovar Hardjo-bovis [46]; LBP: L. biflexa serovar Patoc [47].

\section{ELISA for Detection of Hamster IgG Antibodies}

Hamster immunoglobulin $\mathrm{G}$ (IgG) antibodies against recombinant proteins were detected by ELISA. The plates were covered with $250 \mathrm{ng} /$ well of each protein. Total IgG was evaluated by serial dilution of hamster's sera followed by the addition of goat anti-hamster IgG peroxidase conjugated (1:5,000; KPL, Gaithersburg, MD, USA).

\section{Hamster Immunization and Challenge Studies}

Twelve male Golden Syrian hamsters (6 - 8 weeks old) were immunized subcutaneously with $50 \mu \mathrm{g}$ of recombinant protein adsorbed in $10 \%$ Alhydrogel $\left(2 \% \mathrm{Al}(\mathrm{OH})_{3}\right)$, used as adjuvant. One booster injection was given after two-weeks with the same preparation of recombinant protein $(50 \mu \mathrm{g})$. Negative-control group of hamsters were injected with PBS in $10 \%$ Alhydrogel. As a positive control, a group of hamsters was immunized with killed whole-leptospires (bacterin vaccine), prepared as described by Silva et al. [17]. In brief, washed pellets of $L$. interrogans serovar Kennewicki strain Pomona Fromm strain LPF cultures were heat-inactivated at $56{ }^{\circ} \mathrm{C}$ for $20 \mathrm{~min}$, resuspended in PBS and stored at $-20^{\circ} \mathrm{C}$ until use. Hamsters were immunized with a dose of $10^{9}$ inactivated leptospires in $10 \%$ Alhydrogel on days 0 and 14 . Two hamsters of each group were bled, before the challenge, by cardiac puncture and the sera were analyzed by ELISA for the determination of antibody titers. The ELISA titer was considered to be the last dilution of serum that registered an optical density of 0.10 . Two weeks after the second immunization, groups of 10 hamsters were challenged with an intraperitoneal inoculum of 3-5 $\times 10^{7}$ leptospires assessed in a Petroff-Hausser counting chamber (approx. 400-10,000 $\mathrm{LD}_{50}$ ) from the same L. interrogans serovar Kennewicki strain Pomona Fromm, strain LPF, but in this case freshly isolated from liver of infected Golden Syrian hamster and no culture passaged. Hamsters were monitored daily for clinical signs of leptospirosis and euthanized when clinical signs of 
terminal disease appeared. For the challenges, $\mathrm{LD}_{50}$ was calculated as follows: hamsters were infected intraperitoneally with 10 -fold serial dilutions. Inocula of $10^{5}-10^{0}$ organisms were tested. Animals were monitored daily for clinical symptoms until 28 days post-infection. We then estimated how many virulent leptospires per injected hamster led to ca. $50 \%$ mortality, a dose therefore used for our LD50 experiments. Negative control animals were injected with the same volume of sterile EMJH media [40].

\section{Ethics of Animal Experimentation}

All animal studies were approved by the Ethic Committees of the Instituto Butantan and of the Faculdade de Medicina Veterinaria e Zootecnia, USP, São Paulo, Brazil.

\section{Statistical Analysis}

The statistical analysis was performed by using GraphPad Prism 3.00 (GraphPad software Inc.) which calculates survival fractions using the product limit or Kaplan-Meier method [41]. Logrank test (equivalent to Mantel-Haenszel test) was used to compare survival curves. All $P$-values were two-tailed and a $P$ value of $<0.05$ was considered to indicate statistical significance.

\section{RESULTS}

\section{Bioinformatics Analysis}

The genes encoding LIC10368, LIC10258, LIC11030, LIC10821, LIC12253 and LIC10672 were identified by analysis of the genome sequences of the chromosome I of $L$. interrogans serovar Copenhageni and each one is presented as a single copy $[30,42]$. The CDS LIC12253 and LIC10258 are predicted to be outer membrane proteins, while CDS LIC10368, LIC11030, LIC10821 and LIC10672 are predicted to be extracellular based on CELLO web server [31, 32]. PFAM and SMART programs found no putative conserved domain within the LIC10368 and LIC10672 CDS; the LIC10821 and LIC11030 presented a DUF1565 (domain of unknown function), the LIC12253 presented a DUF1566 domain, and the LIC10258 presented an OmpA-family protein domain. Blast analysis showed that the CDS LIC10368 has no homology with other known bacterial proteins; LIC10258 has partial identity (25\%) with other spirochetal proteins; LIC12253, LIC10821 and LIC11030 present 30\% similarity with other bacterial proteins due to the presence of DUF1566 or DUF1565 domain, respectively; CDS LIC10672 has partial identity (20-30\%) with other bacterial proteins (chaperone Skp of G. lovleyi, ferredoxin of T. oceani, transposase of $C$. botulinum) $[43,44]$. The LipoP program predicted LIC10368, LIC11030 and LIC10821 CDS as putative lipoproteins, with a cleavage site for signal peptidase II at amino acids 18-19, 17-18, 17-18, respectively [36]. Similar putative coding sequences LIC10368, LIC10258, LIC11030, LIC10821, LIC12253 and LIC10672 were found in L. interrogans serovar Lai (99 - $100 \%$ identity with LA0419, LA0301, LA3064, LA3340, LA1508 and LA3522, respectively) [45]. LIC10258, LIC12253 and LIC10672 CDS were also identified in the genome sequences of $L$. borgpetersenii serovar Hardjo (77 - 95\% identity with LBL0511, LBL1929 and LBL2387, respectively) [46]. LIC10368, LIC11030 and LIC10821 CDS were not identified in L. borgpetersenii [46]. Only LIC12253 CDS were identified in the genome sequences of $L$. biflexa serovar Patoc (39\% identity with LEPBI_I0560) [47]. Table 1 summarizes the features of the selected proteins and gene conservation within the sequenced genomes.

\section{Distribution and Expression of Genes Among Leptospira Strains}

The presence of the genes LIC10368 (Lsa21), LIC10258 (Lsa66) and LIC11030 were reported previously [24-26] having DNA fragments amplified only in L. interrogans (serovars Canicola, Copenhageni, Hardjo, Icterohaemorrhagiae and Pomona). LIC12253 gene was amplified in all pathogenic strains and a less intense band was detected in the saprophytic strain [27]. The presence of the novel genes LIC10821 and LIC10672 was examined by PCR in ten pathogenic and in one saprophytic strain of Leptospira, using a pair of primers designed according to $L$. interrogans serovar Copenhageni genome sequences (Table 1). DNA fragments were amplified in all ten strains of pathogenic species of L. interrogans, except that LIC10821 was not amplified in the L. interrogans serovar Canicola and L. santarosai serovar Shermani. In the case of LIC10672 gene no significant amplification product was detected in the non pathogenic strain Patoc 1 (L. biflexa serovar Patoc) (Fig. 1). Template integrity was attested by $16 \mathrm{~S}$ DNA amplification.

\section{Cloning, Expression and Purification of Recombinant Proteins}

The genes were amplified, without the signal peptide sequence, and the DNA insert cloned and expressed as a full-

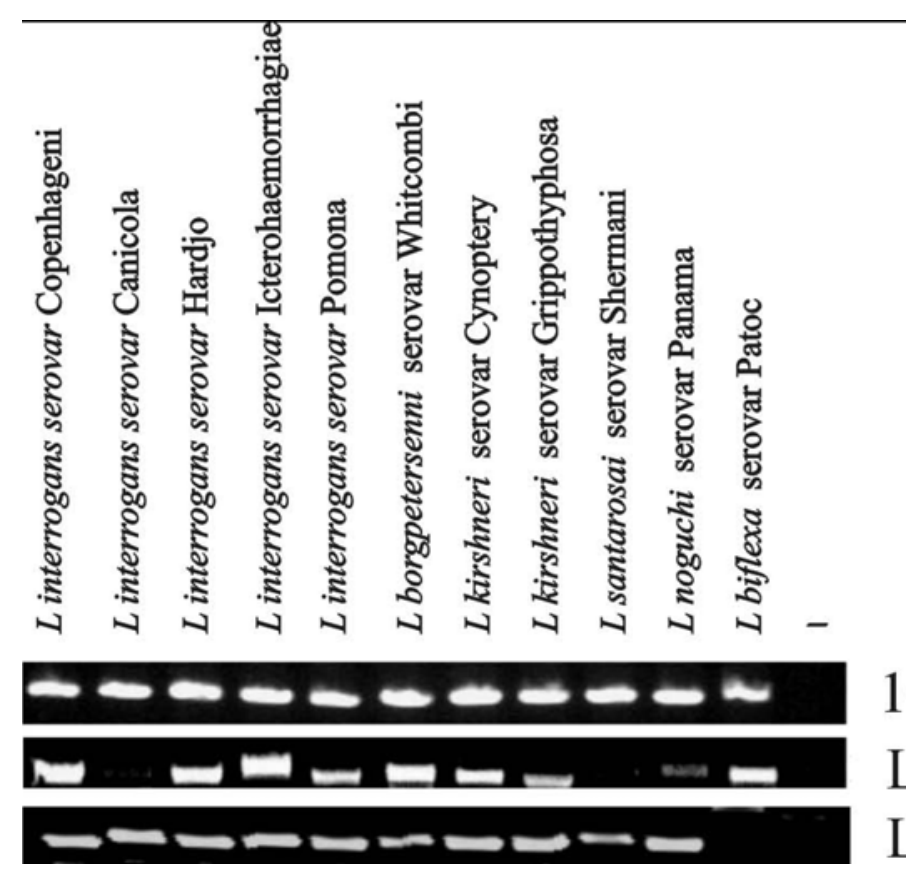

Fig. (1). Distribution of LIC10821 and LIC10672 genes among saprophytic and pathogenic leptospires. Genomic DNA from $L$. biflexa Patoc and from ten serovars belonging to the pathogenic species of Leptospira were subjected to PCR analysis with specific primers designed according to $L$. interrogans serovar Copenhageni genome sequences. Amplification of 16S DNA shows template integrity. No DNA was added to the negative control reaction (-). 
length protein in E. coli. Recombinant proteins were expressed with $6 \times$ His-tag at the N-terminus and purified by metal chelating chromatography. Purified recombinant proteins appeared as a single band by SDS-PAGE analysis with Coomassie staining (Fig. 2).

\section{Antibody Response Induced by Immunization with Re- combinant Proteins}

To assess whether hamsters immunized with the recombinant antigens (Lsa21, Lsa66, rLIC11030, rLIC10821, Lsa25 and rLIC10672) and PBS (control) promoted IgG antibody response against the antigens, sera were collected from the animals on days $30^{\text {th }}$ (prior) and $51^{\text {th }}$ (after) the challenge. Two animals were bled by cardiac puncture and euthanatized. The antibodies were analyzed by ELISA using the recombinant proteins as antigen probes. The data obtained for each protein are depicted in Fig. (3) and refer to assay 1 . Two weeks after the second immunization (day 30 ), hamsters produced an antibody response with titers equiva-

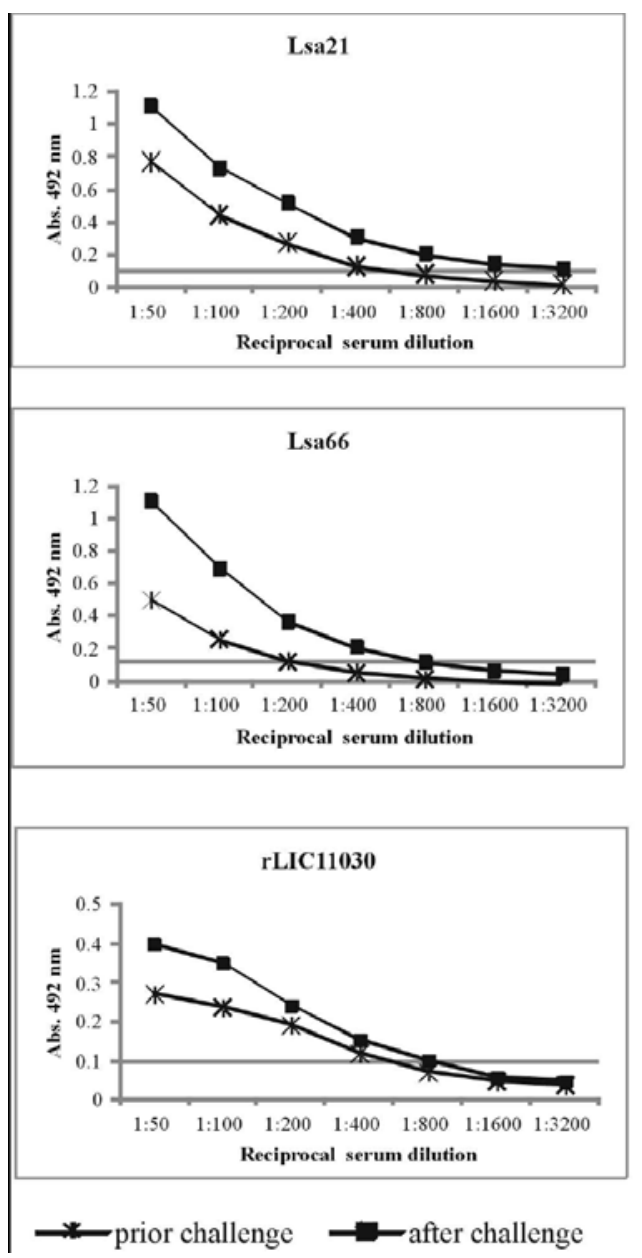

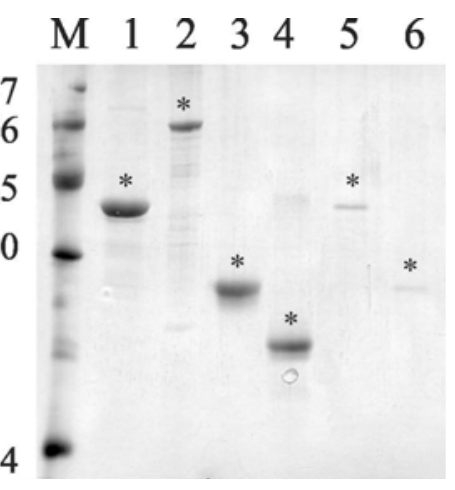

Fig. (2). Analysis of purified recombinant proteins by metal chelating chromatography through SDS-12\% PAGE. Purified protein eluted from $\mathrm{Ni}^{+2}$ - charged chelating sepharose column with $1 \mathrm{M}$ imidazole. Lane $\mathrm{M}$, molecular mass protein marker; lane 1, rLIC10821 (37 kDa); lane 2, Lsa66 (65 kDa); lane 3, Lsa25 (24 $\mathrm{kDa}$ ); lane 4, Lsa21 (21 kDa); lane 5, rLIC11030 (37 kDa); lane 6, rLIC10672 (23 kDa). Protein bands were visualized by Coomassie blue staining. Positions of molecular mass standards are indicated on the left (in $\mathrm{kDa}) .(*)$ denotes each protein band.

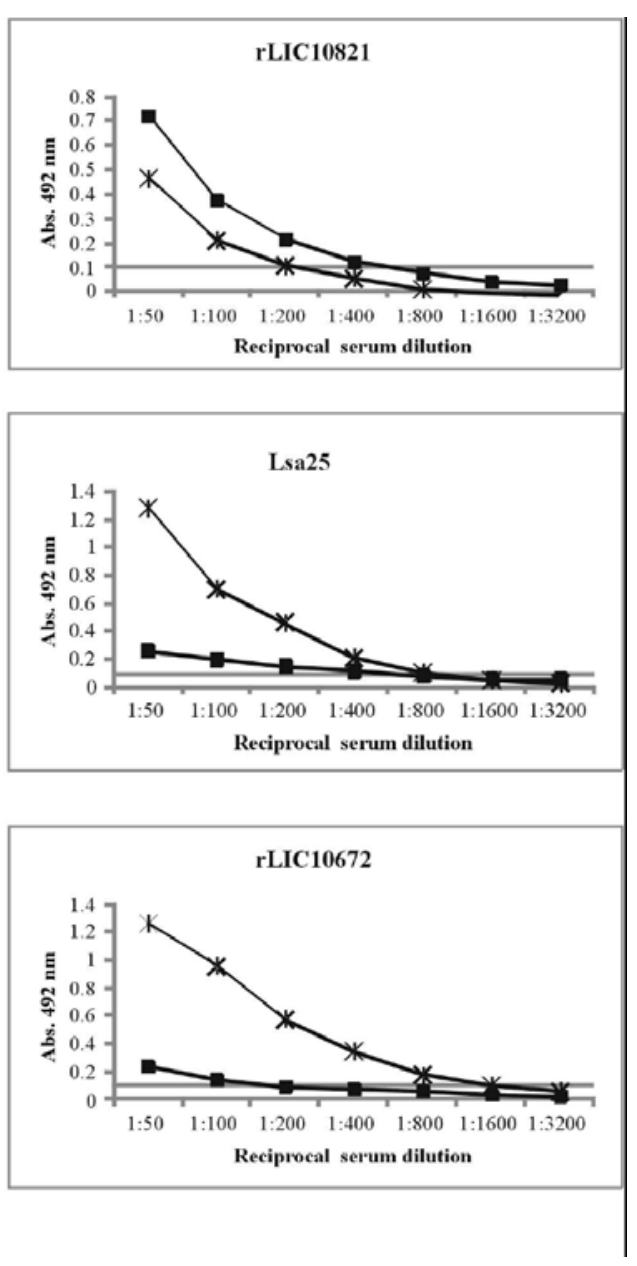

Fig. (3). Induction of humoral immune response in hamsters. The animals were immunized subcutaneously with PBS (negative control), Lsa21, Lsa66, rLIC11030, rLIC10821, Lsa25 or rLIC10672, $50 \mu \mathrm{g}$ each and boostered after two weeks. Animals were bled on day 30 (prior challenge) and 51 (after the challenge) to determine antigen specific total IgG responses in sera of immunized groups by ELISA method. Microdilution plates were coated with recombinant proteins and incubated with a serial dilution of serum from the immunized hamsters for IgG measurements. The data represent a pooled serum from two hamsters per group (days 30) or survival animals after challenge (day 51). All antibody titers refer to challenge assay 1. 
lent to 1:400 of anti-Lsa21, 1:200 of anti-Lsa66, 1:400 of anti-rLIC11030, 1:200 of anti-rLIC10821, 1:800 of antiLsa25 and 1:1,600 of anti-rLIC10672. After challenge (day 51) the titers measured were 1:3,200 of anti-Lsa21, 1:800 of anti-Lsa66, 1:800 of anti-rLIC11030, 1:400 of antirLIC10821, 1:400 of anti-Lsa25 and 1:100 of antirLIC10672. No significant level of antibody was detected in control animals immunized with PBS-adjuvant at any time point. An increment of antibody titer was observed after the bacterial challenge with all the proteins, except for Lsa25 and rLIC10672 that an opposite effect was detected (Fig. 3). Although the reason for the antibody decay is unknown, we may speculate that a shift in IgG subclass response might have occurred or that because Golden Syrian hamsters are not isogenic animals, thus immune response may be different.

\section{Protection Induced by Hamster Immunization with Re- combinant Proteins}

Evaluation of recombinant proteins protection in hamster model followed by challenge with virulent leptospires was performed in two independent assays. The surviving plots are presented in Fig. (4) and the data obtained with the statistical analysis are depicted in Table 2. Experiment 1 (Fig. 4A) shows that immunization with the Lsa21 and rLIC11030 proteins conferred partial protection of $30 \%$, followed by 20 $\%$ protection for the proteins Lsa66, rLIC10821 and Lsa25, against lethal challenge with $3-5 \times 10^{7}$ leptospires when

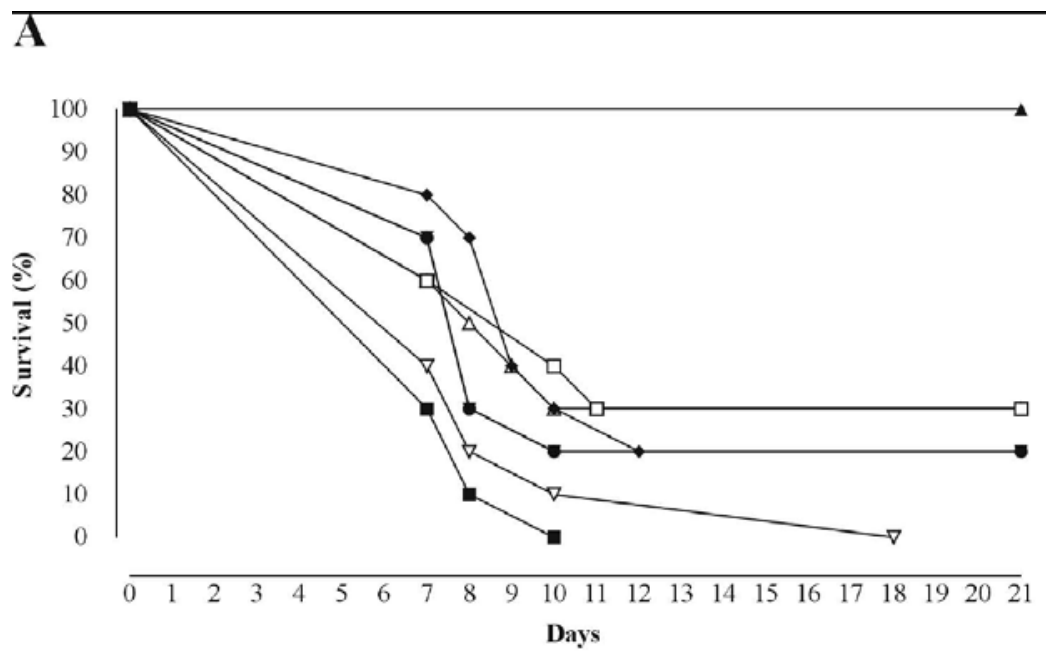

B

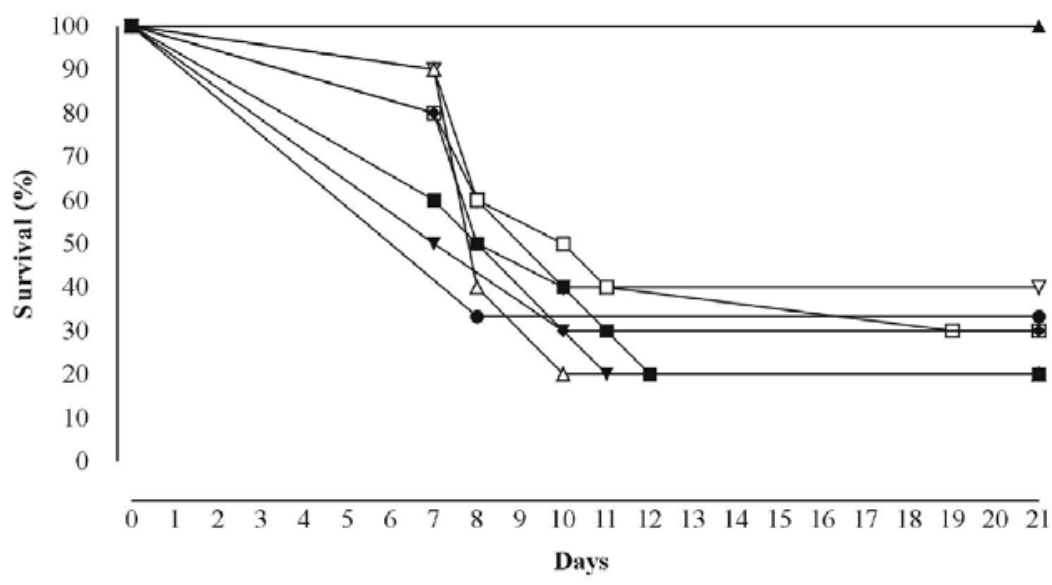

\begin{tabular}{ll|}
$\rightarrow$ killed whole-leptospires & $\rightarrow$ rLIC11030 \\
$\rightarrow$ PBS & $\rightarrow$ rLIC10821 \\
$\triangle$ Lsa21 & $\rightarrow$ Lsa25 \\
$\rightarrow-$ Lsa66 & $\rightarrow$ RLIC10672
\end{tabular}

Fig. (4). Survival curves of hamsters immunized with recombinant proteins and challenged with virulent leptospires. The animals were immunized subcutaneously with PBS (negative control), bacterin (killed whole-leptospires) (positive control), Lsa21, Lsa66, rLIC11030, rLIC10821, Lsa25 or rLIC10672. Two weeks after the second immunization (day 30) with the recombinant proteins, the animals were challenged intraperitoneally with $3-5 \times 10^{7}$ of $L$. interrogans serovar Kennewicki strain Pomona Fromm (LPF) in PBS. The animals were monitored for morbidity until day 21 post-challenge. $\mathbf{A}$ and $\mathbf{B}$ depicted the data of two independent experiments. 
Table 2. Protective Efficacy of Recombinant Proteins in a Hamster Model

\begin{tabular}{|c|c|c|c|c|c|c|}
\hline \multirow{2}{*}{ Antigen } & \multicolumn{3}{|c|}{ Experiment 1 } & \multicolumn{3}{c|}{ Experiment 2 } \\
\cline { 2 - 6 } & $\begin{array}{c}\text { \% Protection } \\
\text { (No. Surviving/Total) }\end{array}$ & P value* & $\begin{array}{c}\text { Culture } \\
\text { (Negative/Total) }\end{array}$ & $\begin{array}{c}\text { \% Protection } \\
\text { (No. Surviving/Total) }\end{array}$ & P value* & $\begin{array}{c}\text { Culture } \\
\text { (Negative/Total) }\end{array}$ \\
\hline \hline killed whole-leptospires & $100 \%(10 / 10)$ & $<0.0001$ & $10 / 10$ & $100 \%(10 / 10)$ & 0.0002 & $10 / 10$ \\
\hline PBS & $0 \%(0 / 10)$ & ----- & ND & $20 \%(2 / 10)$ & $-\cdots$ & 0.9224 \\
\hline Lsa21 & $30 \%(3 / 10)$ & $0.0470 *$ & $1 / 3$ & $20 \%(2 / 10)$ & $2 / 2$ \\
\hline Lsa66 & $20 \%(2 / 10)$ & $0.0092^{*}$ & $1 / 2$ & $30 \%(3 / 10)$ & 0.6768 & $1 / 3$ \\
\hline rLIC11030 & $30 \%(3 / 10)$ & $0.0144 *$ & $2 / 3$ & $30 \%(3 / 10)$ & 0.5102 & $2 / 3$ \\
\hline rLIC10821 & $20 \%(2 / 10)$ & 0.0640 & $2 / 2$ & $20 \%(2 / 10)$ & 0.8628 & $1 / 2$ \\
\hline Lsa25 & $20 \%(2 / 10)$ & 0.0640 & $1 / 2$ & $30 \%(3 / 10)$ & 0.3784 & $3 / 3$ \\
\hline rLIC10672 & $0 \%(0 / 10)$ & 0.4180 & ND & $40 \%(4 / 10)$ & 0.3393 & $4 / 4$ \\
\hline
\end{tabular}

** The statistical analysis was performed by Kaplan-Meier method [41] and Logrank test compared to PBS survival curves.

* $P$-values $(<0.05)$ considered to indicate statistical significance.

ND: not determined

compared to the PBS-control (Fig. 4A and Table 2). Heat inactivated whole-cell leptospires (bacterin) afforded 100\% protection while no survival animal was seen with PBScontrol group. In the second experiment (Fig. 4B), 40\% of the animals immunized with the proteins rLIC10672 survived, 30\% survived with Lsa66, rLIC11030 and Lsa25, $20 \%$ survived with Lsa21, rLIC10821 and in PBS-control group. Bacterin afforded 100\% protection (Fig. 4B, Table 2). Kaplan-Meyer evaluation [41] of the kinetics of the survival curves showed a statistically significant protective effect, for the animals immunized with Lsa21, Lsa66 and rLIC11030 proteins only with the data of experiment 1 . The survival animals at day 21 post-infection were sacrificed and their kidneys collected for culture, isolation of leptospires and the results are summarized in Table 2 . It is interesting to note that in the experiment 1 , a shift showing a delay in animal death was observed with all proteins, except with rLIC10672. Moreover, 70\% of survived animals had no leptospires in their kidneys (Table 2). The rLIC10672, however, produced inconsistent results between the experiments.

\section{DISCUSSION}

Vaccines are one of the most successful methods of preventing infectious diseases [48]. Predicted outer membrane proteins have been identified during genome annotation of pathogenic L. interrogans serovars Lai [45] and Copenhageni [30] and L. borgpetersenii [46]. Almost 50\% of these proteins were assigned as conserved or hypothetical proteins of unknown function [30]. Several of these proteins are predicted to be located at surface of leptospires and therefore we believe that they may be involved in pathogenesis and protective immunity. Chang and colleagues [19] working with putative outer membrane proteins of Leptospira that had no similarity with other organisms deposited in the NCBI database, identified novel antigens that although afforded partial protection against lethal challenge could act as a multicomponent vaccine against leptospirosis. Putative leptospiral outer membrane proteins with an OmpA-like domain have also been shown to elicit protective activity against hamster leptospirosis [20]. Moreover, our group has shown partial protection conferred in hamsters by two recombinant proteins, rLIC12730 and rLIC10494 [49]. More recently, Felix and colleagues [21] have shown the data obtained in challenge assays with hamsters immunized individually with 27 recombinant proteins, but their end results were not very promising.

In this work, we report the immune response induced by two previously identified adhesins, LIC10368 - Lsa21 [24], LIC10258 - Lsa66 [26], and four hypothetical outer membrane proteins of unknown function, encoded by the genes, LIC11030, LIC10821, LIC12253 and LIC10672. The proteins Lsa21, Lsa66 and LIC11030 have been experimentally shown to be surface exposed in leptospires by live immunofluorescence microscopy [24-26]. DNA amplification was not observed in the non pathogenic L. biflexa strain for all studied genes, except for LIC10821 and LIC12253 [27].

The effectiveness of these proteins to elicit protective immunity in hamster model using alum as an adjuvant was evaluated. Our results demonstrated that Lsa21, Lsa66 and rLIC11030 proteins afforded partial protection, as revealed by enhanced survival and reduced leptospiral isolation in kidney. Kaplan-Meyer analysis [41] of the kinetics of the survival curves confirmed partial protective, statistically significant effect, for the animals immunized with these proteins in one of the experiments. The number of surviving in control animals in one of the assays $(0 / 10$ against $2 / 10)$ could be responsible for the inconsistencies obtained. Noteworthy are the displacement of the curves when these proteins were administered. Comparable data were shown when OmpAlike domain proteins [20] and recombinant proteins, rLIC12730 and rLIC10494, were administered in hamsters [49]. The possible synergistic immunoprotection effect of these proteins, in combination or not, with other antigens merits further evaluation. In fact, protective effect of combined proteins have been previously observed with LipL41OmpL1 [11] and with rLp1454 - Lp1118 - MCEII [19]. 
Preparations using novel adjuvants can also be used to improve and maybe, modulate the immune response. Delivery systems can also be employed in order to increment the vaccine efficacy. Work performed with leptosome-entrapped leptospiral proteins, antigens entrapped with PC-liposomes and E. coli lipid liposomes [50] have shown to improve immune response. Moreover, leptospiral antigens delivered by Mycobacterium smegmatis lipids (smegmosomes) were shown an enhancement in both Th1 and Th2 immune responses [51].

Survival protection elicited in hamsters immunized with recombinant proteins could be correlated with the antibody responses for the proteins Lsa21, Lsa66, rLIC11030 and rLIC10821, suggesting the participation Th2 immune response, although Th1 contribution cannot be excluded. The recombinant proteins were able to promote sterilizing immunity in $70 \%$ of the survived animals, as bacteria could not be recovered from kidneys (see Table 2). Moreover, the fact that some of the animals immunized with these recombinant proteins were clinically normal may suggest that bacterial burden was probably lower when compared to negative PBS control group.

\section{CONCLUSION}

We introduced in this work six proteins, including two novel leptospiral proteins. Five of these proteins are potential antigens that induced partial immunoprotection activity against challenge with the virulent Kennewicki strain Pomona Fromm strain. The employment of new generation adjuvants and the combination of one or more proteins should improve the immune protective activity of these proteins and may lead to the development of a multicomponent vaccine that could generate cross-protection against a wide range of pathogenic Leptospira serovars.

\section{ACKNOWLEDGEMENTS}

This work was supported by FAPESP, CNPq and Fundacao Butantan, Brazil; MVA, MLV, RO, RFD, RSM and ATB have scholarship from FAPESP.

\section{REFERENCES}

[1] Faine S, Adler B, Bolin C, Perolat P. Leptospira and Leptospirosis. Melbourne, Australia MediSci 1999.

[2] Bharti AR, Nally JE, Ricaldi JN, et al. Leptospirosis: a zoonotic disease of global importance. Lancet Infect Dis 2003; 3: 757-71.

[3] Ko AI, Galvao Reis M, Ribeiro Dourado CM, Johnson WD Jr, Riley LW. Urban epidemic of severe leptospirosis in Brazil. Salvador Leptospirosis Study Group. Lancet 1999; 354: 820-5.

[4] Plank R, Dean D. Overview of the epidemiology, microbiology, and pathogenesis of Leptospira spp. in humans. Microbes Infect / Institut Pasteur 2000; 2: 1265-76.

[5] de la Pena-Moctezuma A, Bulach DM, Kalambaheti T, Adler B. Comparative analysis of the LPS biosynthetic loci of the genetic subtypes of serovar Hardjo: Leptospira interrogans subtype Hardjoprajitno and Leptospira borgpetersenii subtype Hardjobovis. FEMS Microbiol Lett 1999; 177: 319-26.

[6] Adler B, de la Pena Moctezuma A. Leptospira and leptospirosis. Vet Microbiol 2009.

[7] Martinez R, Perez A, Quinones Mdel C, et al. Efficacy and safety of a vaccine against human leptospirosis in Cuba. Revista panamericana de salud publica $=$ Pan. Am J Public Health 2004; 15: 249-55.
[8] Yan Y, Chen Y, Liou W, et al. An evaluation of the serological and epidemiological effects of the outer envelope vaccine to leptospira. J Chin Med Assoc 2003; 66: 224-30.

[9] McBride AJ, Athanazio DA, Reis MG, Ko AI. Leptospirosis. Curr Opin Infect Dis 2005; 18: 376-86.

[10] Cullen PA, Xu X, Matsunaga J, et al. Surfaceome of Leptospira spp. Infect Immun 2005; 73: 4853-63.

[11] Haake DA, Mazel MK, McCoy AM, et al. Leptospiral outer membrane proteins OmpL1 and LipL41 exhibit synergistic immunoprotection. Infect Immun 1999; 67: 6572-82.

[12] Branger C, Sonrier C, Chatrenet B, et al. Identification of the hemolysis-associated protein 1 as a cross-protective immunogen of Leptospira interrogans by adenovirus-mediated vaccination. Infect Immun 2001; 69: 6831-8.

[13] Seixas FK, da Silva EF, Hartwig DD, et al. Recombinant Mycobacterium bovis BCG expressing the LipL32 antigen of Leptospira interrogans protects hamsters from challenge. Vaccine 2007; 26: 8895.

[14] Seixas FK, Fernandes CH, Hartwig DD, Conceicao FR, Aleixo JA, Dellagostin OA. Evaluation of different ways of presenting LipL32 to the immune system with the aim of developing a recombinant vaccine against leptospirosis. Can J Microbiol 2007; 53: 472-9.

[15] Palaniappan RU, McDonough SP, Divers TJ, et al. Immunoprotection of recombinant leptospiral immunoglobulin-like protein A against Leptospira interrogans serovar Pomona infection. Infect Immun 2006; 74: 1745-50.

[16] Koizumi N, Watanabe H. Leptospiral immunoglobulin-like proteins elicit protective immunity. Vaccine 2004; 22: 1545-52.

[17] Silva EF, Medeiros MA, McBride AJ, et al. The terminal portion of leptospiral immunoglobulin-like protein LigA confers protective immunity against lethal infection in the hamster model of leptospirosis. Vaccine 2007; 25: 6277-86.

[18] Yan W, Faisal SM, McDonough SP, et al. Immunogenicity and protective efficacy of recombinant Leptospira immunoglobulin-like protein $\mathrm{B}(\mathrm{rLigB})$ in a hamster challenge model. Microbes Infect / Institut Pasteur 2009; 11: 230-7.

[19] Chang YF, Chen CS, Palaniappan RU, et al. Immunogenicity of the recombinant leptospiral putative outer membrane proteins as vaccine candidates. Vaccine 2007; 25: 8190-7.

[20] Yan W, Faisal SM, McDonough SP, et al. Identification and characterization of OmpA-like proteins as novel vaccine candidates for Leptospirosis. Vaccine 28: 2277-83.

[21] Felix SR, Hartwig DD, Argondizzo AP, et al. Subunit approach to evaluation of the immune protective potential of leptospiral antigens. Clin Vaccine Immunol 18: 2026-30.

[22] Koizumi N, Watanabe H. Leptospirosis vaccines: past, present, and future. J postgrad med 2005; 51: 210-4.

[23] Vernel-Pauillac F, Merien F. Proinflammatory and immunomodulatory cytokine mRNA time course profiles in hamsters infected with a virulent variant of Leptospira interrogans. Infect Immun 2006 ; 74: 4172-9.

[24] Atzingen MV, Barbosa AS, De Brito T, et al. Lsa21, a novel leptospiral protein binding adhesive matrix molecules and present during human infection. BMC Microbiol 2008; 8: 70.

[25] Mendes RS, Von Atzingen M, de Morais ZM, et al. The novel leptospiral surface adhesin Lsa20 binds laminin and human plasminogen and is probably expressed during infection. Infect Immun 79: 4657-67.

[26] Oliveira R, de Morais ZM, Goncales AP, Romero EC, Vasconcellos SA, Nascimento AL. Characterization of novel OmpA-like protein of Leptospira interrogans that binds extracellular matrix molecules and plasminogen. PLoS ONE 6 :e21962.

[27] Domingos RF, Vieira ML, Romero EC, et al. Features of two proteins of Leptospira interrogans with potential role in host-pathogen interactions. BMC Microbiol 12: 50.

[28] Vieira ML, Pimenta DC, de Morais ZM, Vasconcellos SA, Nascimento AL. Proteome Analysis of Leptospira interrogans Virulent Strain. Open Microbiol J 2009; 3: 69-74.

[29] Turner LH. Leptospirosis. 3. Maintenance, isolation and demonstration of leptospires. Transactions of the Royal Society of Tropical Medicine and Hygiene. 1970; 64: 623-46.

[30] Nascimento AL, Verjovski-Almeida S, Van Sluys MA, et al. Genome features of Leptospira interrogans serovar Copenhageni. Brazilian journal of medical and biological research = Revista brasileira de pesquisas medicas e biologicas / Sociedade Brasileira de Biofisica et al. 2004; 37:459-77. 
[31] Yu CS, Lin CJ, Hwang JK. Predicting subcellular localization of proteins for Gram-negative bacteria by support vector machines based on n-peptide compositions. Protein Sci 2004; 13: 1402-6.

[32] Yu CS, Chen YC, Lu CH, Hwang JK. Prediction of protein subcellular localization. Proteins 2006; 15; 64: 643-51.

[33] Letunic I, Copley RR, Pils B, Pinkert S, Schultz J, Bork P. SMART 5: domains in the context of genomes and networks. Nucleic Acids Res 2006; 34: D257-60.

[34] Schultz J, Milpetz F, Bork P, Ponting CP. SMART, a simple modular architecture research tool: identification of signaling domains. Proc Natl Acad Sci USA 1998; 95: 5857-64.

[35] Finn RD, Mistry J, Schuster-Bockler B, et al. Pfam: clans, web tools and services. Nucleic Acids Res 2006; 34: D247-51.

[36] Juncker AS, Willenbrock H, Von Heijne G, Brunak S, Nielsen H, Krogh A. Prediction of lipoprotein signal peptides in Gramnegative bacteria. Protein Sci 2003; 12: 1652-62.

[37] Nielsen H, Engelbrecht J, Brunak S, von Heijne G. Identification of prokaryotic and eukaryotic signal peptides and prediction of their cleavage sites. Protein engineering 1997 ; 10: 1-6.

[38] Ramos CR, Abreu PA, Nascimento AL, Ho PL. A high-copy T7 Escherichia coli expression vector for the production of recombinant proteins with a minimal N-terminal His-tagged fusion peptide. Brazilian journal of medical and biological research $=$ Revista brasileira de pesquisas medicas e biologicas / Sociedade Brasileira de Biofisica et al. 2004; 37: 1103-9.

[39] Bhandari P, Gowrishankar J. An Escherichia coli host strain useful for efficient overproduction of cloned gene products with $\mathrm{NaCl}$ as the inducer. J Bacteriol 1997; 179: 4403-6.

[40] Vernel-Pauillac F, Goarant C. Differential cytokine gene expression according to outcome in a hamster model of leptospirosis. PLoS neglected tropical diseases 4: e582.

[41] Kaplan EL, Meier P. Nonparametric estimation from incomplete data. J Am Stat Assoc 1958; 53: 457-81.
[42] Nascimento AL, Ko AI, Martins EA, et al. Comparative genomics of two Leptospira interrogans serovars reveals novel insights into physiology and pathogenesis. J bacteriol 2004; 186: 2164-72.

[43] Altschul SF, Gish W, Miller W, Myers EW, Lipman DJ. Basic local alignment search tool. J Mol Biol 1990; 215: 403-10.

[44] Altschul SF, Madden TL, Schaffer AA, et al. Gapped BLAST and PSI-BLAST: a new generation of protein database search programs. Nucleic Acids Res 1997; 25: 3389-402.

[45] Ren SX, Fu G, Jiang XG, et al. Unique physiological and pathogenic features of Leptospira interrogans revealed by whole-genome sequencing. Nature 2003; 422: 888-93.

[46] Bulach DM, Zuerner RL, Wilson P, et al. Genome reduction in Leptospira borgpetersenii reflects limited transmission potential Proc Natl Acad Sci USA 2006; 103: 14560-5.

[47] Picardeau M, Bulach DM, Bouchier C, Zuerner RL, Zidane N, Wilson PJ, et al. Genome sequence of the saprophyte Leptospira biflexa provides insights into the evolution of Leptospira and the pathogenesis of leptospirosis. PLoS ONE 2008; 3: e1607.

[48] Bagnoli F, Baudner B, Mishra RP, et al. Designing the next generation of vaccines for global public health. Omics 545-66.

[49] Atzingen MV, Goncales AP, de Morais ZM, et al. Characterization of leptospiral proteins that afford partial protection in hamsters against lethal challenge with Leptospira interrogans. J medical microbiol ; 59: 1005-15.

[50] Faisal SM, Yan W, McDonough SP, Chang CF, Pan MJ, Chang YF. Leptosome-entrapped leptospiral antigens conferred significant higher levels of protection than those entrapped with PC-liposomes in a hamster model. Vaccine 2009; 27: 6537-45.

[51] Faisal SM, Yan W, McDonough SP, Mohammed HO, Divers TJ, Chang YF. Immune response and prophylactic efficacy of smegmosomes in a hamster model of leptospirosis. Vaccine 2009; 27: 6129-36.

(C) Fontana et al.; Licensee Bentham Open.

This is an open access article licensed under the terms of the Creative Commons Attribution Non-Commercial License (http://creativecommons.org/licenses/ by-nc/3.0/) which permits unrestricted, non-commercial use, distribution and reproduction in any medium, provided the work is properly cited. 


\title{
Plasminogen Binding Proteins and Plasmin Generation on the Surface of Leptospira spp.: The Contribution to the Bacteria-Host Interactions
}

\author{
Monica L. Vieira, ${ }^{1,2}$ Marina V. Atzingen, ${ }^{1}$ Rosane Oliveira, ${ }^{1,2}$ Renata S. Mendes, ${ }^{1}$ \\ Renan F. Domingos, ${ }^{1,2}$ Silvio A. Vasconcellos, ${ }^{3}$ and Ana L. T. O. Nascimento ${ }^{1,2}$ \\ ${ }^{1}$ Centro de Biotecnologia, Instituto Butantan, Avenida Vital Brazil, 1500, 05503-900 São Paulo, SP, Brazil \\ ${ }^{2}$ Interunidades em Biotecnologia, Instituto de Ciências Biomédicas, USP, Avenida Prof. Lineu Prestes, 1730, \\ 05508-900 São Paulo SP, Brazil \\ ${ }^{3}$ Laboratorio de Zoonoses Bacterianas do VPS, Faculdade de Medicina Veterinária e Zootecnia, USP, \\ Avenida Prof. Dr. Orlando Marques de Paiva, 87, 05508-270 São Paulo, SP, Brazil
}

Correspondence should be addressed to Ana L. T. O. Nascimento, tabet@butantan.gov.br

Received 13 February 2012; Revised 11 June 2012; Accepted 25 June 2012

Academic Editor: Edward F. Plow

Copyright () 2012 Monica L. Vieira et al. This is an open access article distributed under the Creative Commons Attribution License, which permits unrestricted use, distribution, and reproduction in any medium, provided the original work is properly cited.

\begin{abstract}
Leptospirosis is considered a neglected infectious disease of human and veterinary concern. Although extensive investigations on host-pathogen interactions have been pursued by several research groups, mechanisms of infection, invasion and persistence of pathogenic Leptospira spp. remain to be elucidated. We have reported the ability of leptospires to bind human plasminogen (PLG) and to generate enzimatically active plasmin (PLA) on the bacteria surface. PLA-coated Leptospira can degrade immobilized ECM molecules, an activity with implications in host tissue penetration. Moreover, we have identified and characterized several proteins that may act as PLG-binding receptors, each of them competent to generate active plasmin. The PLA activity associated to the outer surface of Leptospira could hamper the host immune attack by conferring the bacteria some benefit during infection. The PLAcoated leptospires obstruct complement C3b and IgG depositions on the bacterial surface, most probably through degradation. The decrease of leptospiral opsonization might be an important aspect of the immune evasion strategy. We believe that the presence of PLA on the leptospiral surface may (i) facilitate host tissue penetration, (ii) help the bacteria to evade the immune system and, as a consequence, (iii) permit Leptospira to reach secondary sites of infection.
\end{abstract}

\section{Introduction}

The spirochete Leptospira interrogans is a highly invasive pathogen and the causal agent of leptospirosis, one of the most widespread zoonosis of human and veterinary concern. The disease represents a great economic burden because it has an effect on the public health system and the livestock [1-4]. The disease occurs mainly in urban regions lacking adequate sanitary conditions, associated with activities that involve direct contact with contaminated water, soil, or animals $[3,5,6]$. The leptospires chronically infect mammal species, which harbor the bacteria in their renal tubules, shedding them through the urine into the environment, thus constituting a source of reinfection to other animals. Humans are accidental and terminal hosts in the transmission process of leptospirosis $[1,7]$. The leptospires enter the body via abrasions on skin or actively through mucosa, spreading to any tissue, but specially colonizing kidneys and liver [2].

The understanding of molecular aspects of the pathogenesis, the virulence, and invasion processes by which the leptospires infect the hosts and initiate tissue colonization remains to be elucidated, despite the availability of genomic sequencing of five strains of Leptospira that have identified more than 200 putative membrane proteins that might be involved in pathogenesis [8-12]. Yet, only few virulence 
factors related to the pathogenesis of the disease have been reported [13-16].

The ability of the leptospires to adhere to extracellular matrix (ECM) proteins is assumed to be crucial during the first steps of pathogenesis [17]. Indeed, this ability has been recently and firstly described by our group [18] and a number of adhesins, ECM-binding proteins, have been identified $[15,18-26]$. After leptospiral adherence, the next fundamental step must be to overcome the barriers imposed by epithelial tissues and extracellular matrixes, to reach the bloodstream and secondary sites of infection within the hosts. Proteolytic activity has been demonstrated to be important during the penetration of several pathogenic microorganisms [27]. Because the presence of ECM degrading enzymes is limited to few bacterial pathogens, one of the strategies employed to surmount this deficiency is the interaction with protease-mediated systems of the hosts [27].

Plasmin is a broad-spectrum serine protease component of the fibrinolytic system, which has PLG as a main component. PLG is a circulating single-chain zymogen that is converted to plasmin by cleavage of the peptide bond between Arg-560 and Val-561, mediated by PLG activatorslike uPA (urokinase-type PLG activator) and tPA (tissuetype PLG activator). Once activated to plasmin the bacteria are endowed with membrane-associated proteolytic activity, a characteristic that have been demonstrated to contribute to the degradation of ECM components, tissue penetration, and invasion. It has been reported that several pathogens, including the spirochetes Borrelia spp. and Treponema spp., bind PLG on the surface and converts it to plasmin by host activators [28-30]. The binding of PLG and plasmin generation promotes ECM molecules degradation and it is essential for dissemination of the bacteria through the host tissues, thus suggesting its importance in invasiveness process [27, 31-35].

In this paper, we highlight and compile the recent studies performed by our group describing and characterizing the leptospiral binding to PLG [36], the identification of possible PLG receptors [37-40], and the aspect of the leptospiral immune escape strategy associated to plasmin proteolytic activity [41]. The disclosure of this proteolytic system on the surface of Leptospira spp. and the implications associated to bacterial infectivity are discussed.

\section{Materials and Methods}

2.1. Bacteria Isolates and Culture Conditions. Virulent L. interrogans serovar Copenhageni strain Fiocruz L1-130 is routinely cultured at Faculdade de Medicina Veterinária da Universidade de Sao Paulo by iterative passages in Golden Syrian hamsters for maintenance of virulence [1]. The organs-derived leptospires were cultured at $28^{\circ} \mathrm{C}$ in semisolid modified Elinghausen-McCullough-JohnsonHarris (EMJH) medium supplemented with $10 \%$ rabbit sera. Nonvirulent culture-attenuated $L$. interrogans serovar Copenhageni strain M20 are equally routinely cultured by maintenance in liquid-modified EMJH medium supplemented with $10 \%$ rabbit sera [42]. For the experiments of PLG binding, to exclude the PLG interference from the rabbit serum supplementing the culture medium, serumfree leptospires were obtained by three passages in liquid modified EMJH medium supplemented with $10 \%$ Leptospira enrichment EMJH (BD, Difco), cultured at $28^{\circ} \mathrm{C}$.

2.2. Labeling of Leptospires with Plasmin. The leptospires were treated with PLG and uPA based in the protocol described by Coleman et al. [43], with modifications. A total of $7.0 \times 10^{9}$ leptospires were centrifuged at $6,000 \times \mathrm{g}$ for $10 \mathrm{~min}$ at $25^{\circ} \mathrm{C}$, resuspended in $1.4 \mathrm{~mL}$ of EMJH culture medium supplemented with $10 \%$ Leptospira enrichment $\mathrm{EMJH}$, divided into 7 aliquots of $0.2 \mathrm{~mL}$ each $\left(1.0 \times 10^{9}\right.$ leptospires) in $2 \mathrm{~mL}$ microcentrifuge tubes, and recentrifuged. The 7 tubes containing the leptospires received different treatments: (a) 30\% plasma and $3 \mathrm{U}$ uPA (urokinase, Sigma) in $100 \mu \mathrm{L}$ low-salt PBS (lsPBS-with $50 \mathrm{mM} \mathrm{NaCl}$ ), (b) $5 \mu \mathrm{g}$ PLG (native PLG purified from human plasma was from Calbiochem) and $3 \mathrm{U}$ uPA in $100 \mu \mathrm{L}$ lsPBS, (c) $2 \mu \mathrm{g}$ PLG and $3 \mathrm{U}$ uPA in $100 \mu \mathrm{L}$ lsPBS, (d) $0.5 \mu \mathrm{g}$ PLG and $3 \mathrm{U}$ uPA in $100 \mu \mathrm{L}$ lsPBS, (e) $5 \mu \mathrm{g}$ PLG in $100 \mu \mathrm{L}$ lsPBS, (f) $3 \mathrm{UuPA}$ in $100 \mu \mathrm{L}$ lsPBS, and (g) $100 \mu \mathrm{L}$ lsPBS. All the preparations were incubated for $1 \mathrm{~h}$ at $37^{\circ} \mathrm{C}$, under gentle shaking, prior to the addition of the uPA, and followed by $1 \mathrm{~h}$ incubation at $37^{\circ} \mathrm{C}$. Leptospires were then centrifuged and washed three times with $0.7 \mathrm{~mL}$ lsPBS.

2.3. Measurement of Enzymatic Activity of Plasmin-Coated Leptospires. The treated leptospires $\left(1.0 \times 10^{9}\right.$ per sample $)$ were resuspended in $300 \mu \mathrm{L}$ lsPBS and divided into 3 aliquots. Each aliquot received $100 \mu \mathrm{L}$ of $0.5 \mathrm{mg} / \mathrm{mL}$ of the chromogenic substrate D-Val-Leu-Lys 4-nitroanilide dihydrochloride (Sigma) in lsPBS, to a final substrate concentration of $0.25 \mathrm{mg} / \mathrm{mL}$. The suspensions were incubated for $1.5 \mathrm{~h}$ at $37^{\circ} \mathrm{C}$, under gentle shaking, and then centrifuged at $6,000 \times \mathrm{g}$ for $10 \mathrm{~min}$ at $25^{\circ} \mathrm{C}$. The supernatants $(150 \mu \mathrm{L})$ were transferred to 96-well microplates and the cleavage of the specific plasmin substrate was quantified with a microplate reader set at a wavelength of $405 \mathrm{~nm}$.

2.4. 6-Aminocaproic Acid (ACA) Binding-Inhibition Assay. Low-passage virulent $L$. interrogans serovar Copenhageni strain Fiocruz L1-130 $\left(1.0 \times 10^{9}\right.$ leptospires/sample $)$ was treated with PLG and uPA, as described above, except for the addition of increase concentrations of ACA (Sigma) ranging from 0 to $1,000 \mathrm{mM}$, added together with the PLG. PLG quantity was set at $5 \mu \mathrm{g}$ and $\mathrm{uPA}$ at $3 \mathrm{U}$. Aliquots treated with only PLG, uPA, or ACA, and just lsPBS treated, were used as controls. The enzymatic plasmin activity was measured as described before.

2.5. Liquid-Phase Immunofluorescence Assay (L-IFA). Live bacteria suspensions $\left(2.5 \times 10^{9}\right)$ were harvested at $12,800 \times \mathrm{g}$ for $15 \mathrm{~min}$, washed twice with lsPBS, resuspended in $200 \mu \mathrm{L}$ lsPBS containing $8 \mu \mathrm{g}$ of human PLG, and incubated for $45 \mathrm{~min}$ at $37^{\circ} \mathrm{C}$. After the incubation, $6 \mu \mathrm{g} / \mathrm{mL}$ of propidium iodide (Sigma) were added to stain the nuclei, and the suspensions were incubated for more $45 \mathrm{~min}$ at $37^{\circ} \mathrm{C}$. After 
this time, the leptospires were gently washed three times with 1 sPBS and incubated for $45 \mathrm{~min}$ at $37^{\circ} \mathrm{C}$ with mouseproduced antiserum against human PLG (Sigma) at a $1: 50$ dilution. The leptospires were washed three times and incubated with goat anti-mouse IgG antibodies conjugated to fluorescein isothiocyanate (FITC; Sigma) at a dilution of $1: 50$ for $45 \mathrm{~min}$ at $37^{\circ} \mathrm{C}$. After this incubation, the leptospires were washed twice and resuspended in lsPBSantifading solution (ProLong Gold; Molecular Probes). The immunofluorescence-labeled leptospires were examined by the use of a confocal LSM 510 META immunofluorescence microscope (Zeiss, Germany). As control for cell integrity, we used antibodies against recombinant Leptospira proteins LipL32 or GroEL, produced in mice, following all the mentioned procedures for PLG.

2.6. SDS-PAGE and Affinity Blotting. Total leptospiral protein extracts for SDS-PAGE were prepared from $10 \mathrm{~mL}$ of $\sim 10^{9}$ bacteria in EMJH serum-free cultures. The cells were harvested by centrifugation, washed three times with $5 \mathrm{mM} \mathrm{MgCl}_{2}$ in lsPBS, and resuspended in $100 \mu \mathrm{L}$ PBS. The proteins were loaded into 10\% SDS-PAGE and transferred to nitrocellulose membranes (Hybond-ECL, GE Healthcare) in semidry equipment. The membranes were blocked for $2 \mathrm{~h}$ at $37^{\circ} \mathrm{C}$ with $5 \%$ BSA, washed three times $(10 \mathrm{~min}$ for each wash) with PBS-0.5\% Tween-20 solution (PBS-T), and incubated overnight with $3 \mu \mathrm{g} / \mathrm{mL}$ PLG or $3 \mu \mathrm{g} / \mathrm{mL}$ PLG + $100 \mathrm{mM}$ ACA at $4^{\circ} \mathrm{C}$, followed by a $2 \mathrm{~h}$ incubation at room temperature. Then, the membranes were washed three times and incubated with mouse anti-human PLG ( $1: 750$, Sigma) for $3 \mathrm{~h}$ at room temperature, following by more than three washings and $1 \mathrm{~h}$ incubation at room temperature with antimouse IgG-peroxidase conjugated $(1: 5,000$, Sigma). The membranes were washed and the protein's reactivity was revealed by ECL reagent (GE Healthcare) with subsequent exposition to X-Ray films (Kodak).

2.7. Assay for the Degradation of Immobilized ECM Macromolecules. 96-well plates were coated overnight at $37^{\circ} \mathrm{C}$ with $0.5 \mu \mathrm{g} /$ well of cellular fibronectin (Sigma) or laminin (Sigma), washed four times with $200 \mu \mathrm{L}$ per washing with PBS-T, and blocked with $2 \%$ BSA in PBS-T for $2 \mathrm{~h}$ at $37^{\circ} \mathrm{C}$, followed by two washings. The spirochetes $\left(1.0 \times 10^{8}\right.$ leptospires/per sample) were treated as described above with $10 \mu \mathrm{g}$ PLG and $3 \mathrm{U}$ uPA or lsPBS (untreated). Bacteria were washed, resuspended in $100 \mu \mathrm{L}$ 1sPBS, and transferred to the plate previously coated wells. The plates were centrifuged at $180 \times \mathrm{g}$ for $15 \mathrm{~min}$ to ensure the contact of the leptospires with the immobilized ECM components. The plates were incubated at $37^{\circ} \mathrm{C}$ for $20 \mathrm{~h}$ and washed 5 times to remove the bacteria. The degradation of the ECM components were detected by reduction in absorbance followed by incubation with antifibronectin or antilaminin IgG antibodies $(1: 5,000$ dilution in $100 \mu \mathrm{L}$ PBS-T for $45 \mathrm{~min}$ at $37^{\circ} \mathrm{C}$, Sigma), antiIgG peroxidase conjugated antibodies $(1: 5,000$ dilution in $100 \mu \mathrm{L}$ PBS-T for $45 \mathrm{~min}$ at $37^{\circ} \mathrm{C}$, Sigma), and $100 \mu \mathrm{L} /$ well of $1 \mathrm{mg} / \mathrm{mL} o$-phenylenediamine-OPD—in citrate phosphate buffer, pH 5.0 plus $1 \mu \mathrm{L} / \mathrm{mL} \mathrm{H}_{2} \mathrm{O}_{2}$. The reaction was stopped with $50 \mu \mathrm{L} /$ well $4 \mathrm{~N} \mathrm{H}_{2} \mathrm{SO}_{4}$, and the absorbance was measured at $492 \mathrm{~nm}$. Percentage degradation was calculated by de formula $(A-B) / A(100)$, where $A=$ the mean PBS samples absorbance (positive control group) and $B=$ the mean experimental group absorbance (untreated or plasmin).

2.8. Bioinformatics Characterization of the Proteins. Predicted coding sequences (CDSs) were analyzed as their cellular localization predictions by PSORT program, http:// psort.hgc.jp/ [44, 45]. The SMART http://smart.embl-heidelberg.de/ [46, 47], PFAM http://www.sanger.ac.uk/resour ces/software/ [48], and LipoP, http://www.cbs.dtu.dk/services/LipoP/ [49] web servers were used to search for predicted functional and structural domains within the amino acid sequences of the CDSs.

2.9. Cloning, Expression, and Purification of Recombinant Proteins. Amplification of the CDSs was performed by PCR from L. interrogans serovar Copenhageni genomic DNA using complementary primer pairs. The gene sequences were amplified without the signal peptide tag and predicted by SignalP (http://www.cbs.dtu.dk/services/SignalP/). The final constructs were verified by DNA sequencing on an ABI Prism 3730_L sequencer (Seq-Wright, Houston, TX, USA) with appropriate vector-specific T7 (F: TAATACGACTCACTATAGGG) and pAE (R: CAGCAGCCAACTCAGTTCCT) primers. Cloning, expression, and purification of the recombinant proteins have been previously described as summarized in Table 1.

2.10. Plasminogen Binding to Recombinant Proteins. The binding of the recombinant proteins to PLG was evaluated by a modified ELISA, based in the protocol described by Brissette et al. [50], as follows: 96-well plates (Costar High Binding, Corning) were coated overnight in $\mathrm{PBS}$ at $4^{\circ} \mathrm{C}$ with $100 \mu \mathrm{L}$ of $10 \mu \mathrm{g} / \mathrm{mL}$ of the recombinant proteins or bovine serum albumin (BSA, Sigma) as negative control. Plates were washed once with PBS-T and blocked for $2 \mathrm{~h}$ at $37^{\circ} \mathrm{C}$ with PBS with $10 \%$ (wt/vol) nonfat dry milk. The blocking solution was discarded and $100 \mu \mathrm{L}$ of $10 \mu \mathrm{g} / \mathrm{mL}$ human PLG (Calbiochem) in PBS was incubated for $2 \mathrm{~h}$ at $37^{\circ} \mathrm{C}$. Wells were washed four times with PBS-T and incubated for $1 \mathrm{~h}$ at $37^{\circ} \mathrm{C}$ with mouse anti-human PLG $(1: 4,000$ in PBS, Sigma). Plates were washed again and incubated with horseradish peroxidase-conjugated anti-mouse immunoglobulin G (IgG, Sigma), diluted $1: 5,000$ in PBS. After three washings, $100 \mu \mathrm{L} /$ well of $1 \mathrm{mg} / \mathrm{mL}$ OPD plus $1 \mu \mathrm{L} / \mathrm{mL} \mathrm{H}_{2} \mathrm{O}_{2}$ in citrate phosphate buffer ( $\mathrm{pH}$ 5.0) were added. The reactions were carried out for $5 \mathrm{~min}$ and stopped by the addition of $50 \mu \mathrm{L} /$ well of $\mathrm{H}_{2} \mathrm{SO}_{4}(4 \mathrm{~N})$. Readings were taken at $492 \mathrm{~nm}$.

\subsection{Enzymatic Activity Assay of Plasmin Bound to Recom-} binant Proteins. ELISA plates were coated overnight with $10 \mu \mathrm{g} / \mathrm{mL}$ recombinant proteins or BSA in PBS at $4^{\circ} \mathrm{C}$. Plates were then washed once with PBS-T and blocked with PBS with $10 \%(\mathrm{wt} / \mathrm{vol})$ nonfat dry milk for $2 \mathrm{~h}$ at $37^{\circ} \mathrm{C}$. The blocking solution was discarded and $100 \mu \mathrm{L} /$ well of $10 \mu \mathrm{g} / \mathrm{mL}$ human PLG (Calbiochem) was added, followed by 


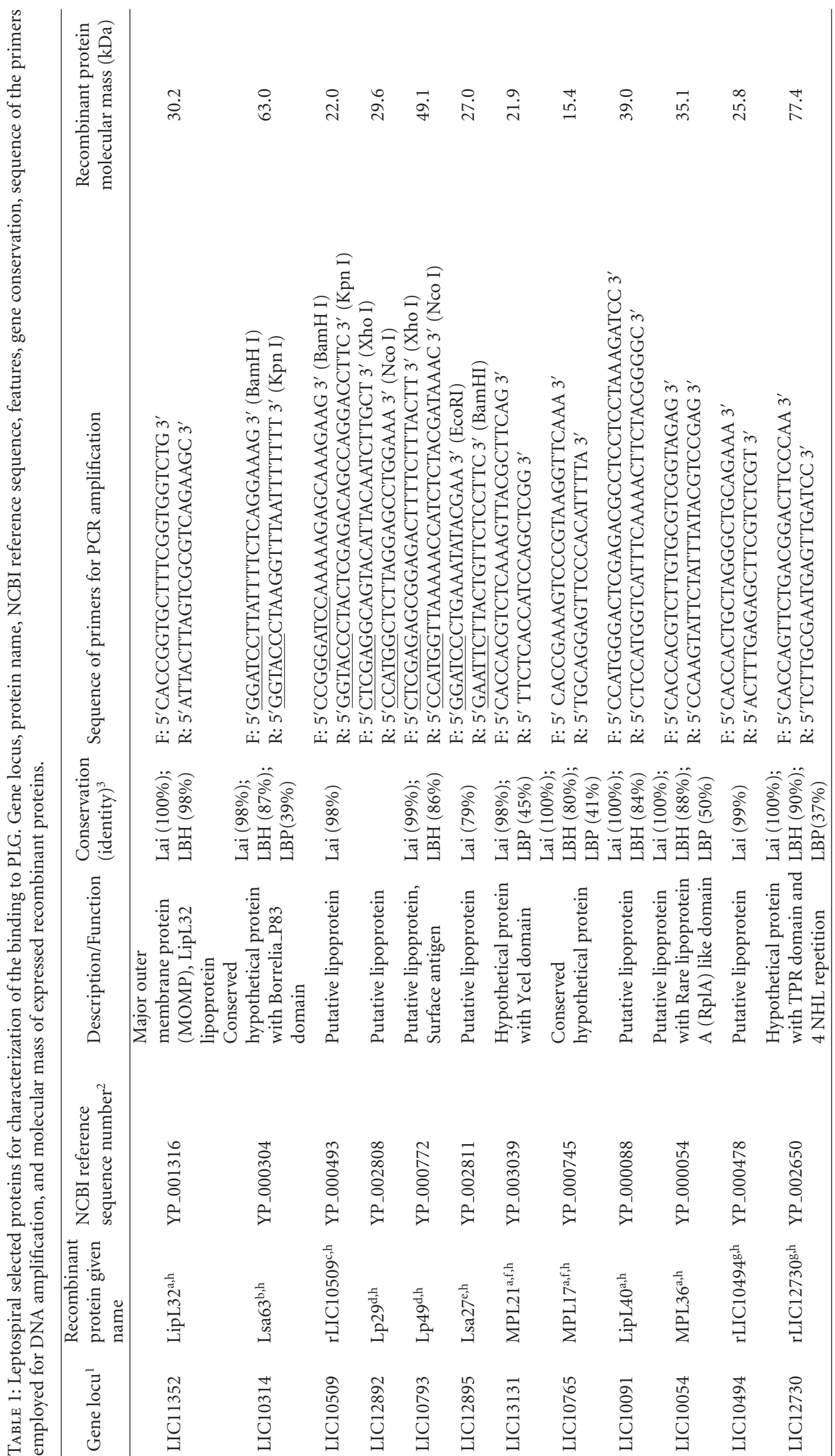




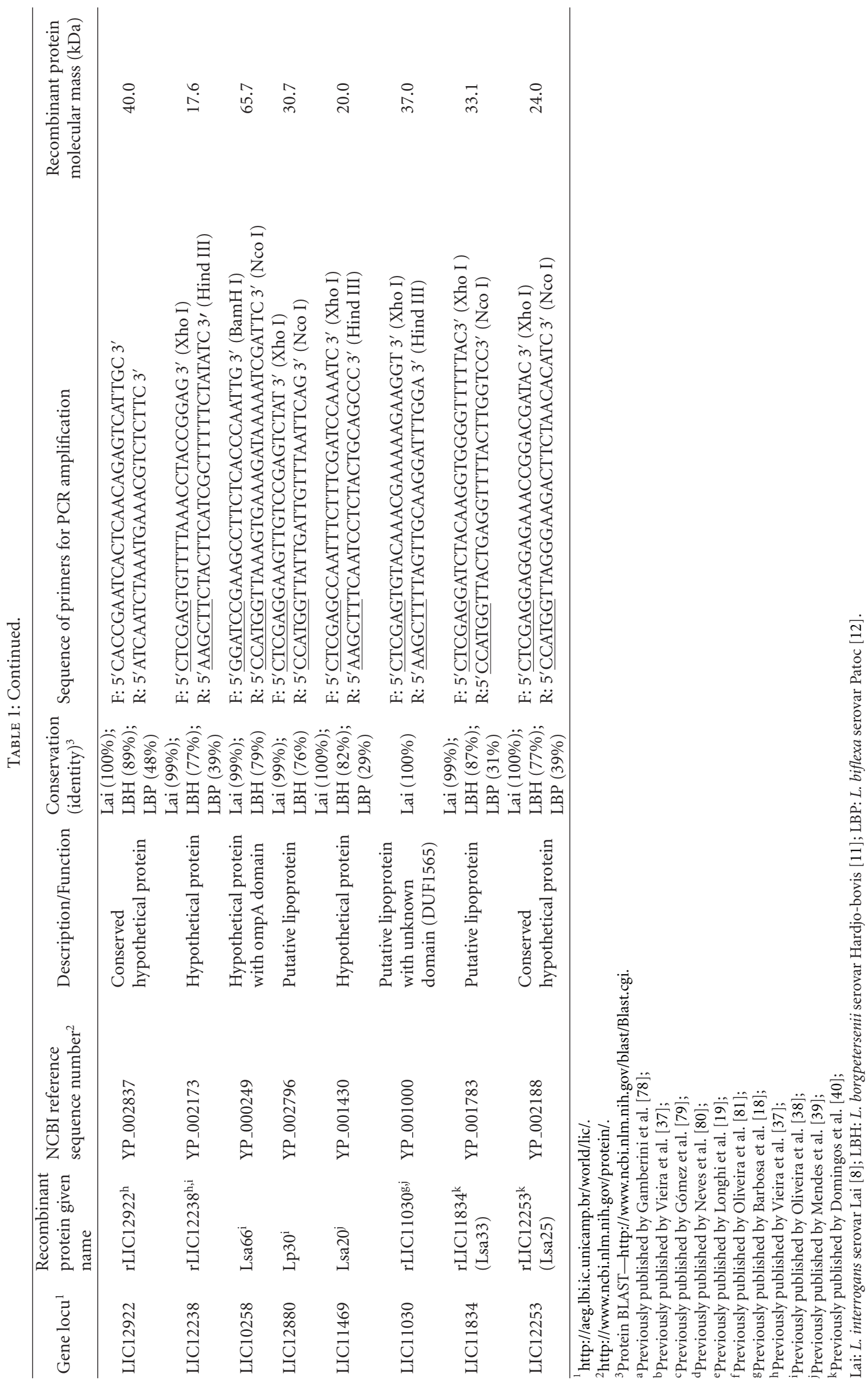


incubation for $2 \mathrm{~h}$ at $37^{\circ} \mathrm{C}$. Wells were washed three times with PBS-T, and then $4 \mathrm{ng} /$ well of human uPA (Sigma) were added. Subsequently, $100 \mu \mathrm{L} /$ well of the plasmin-specific substrate $D$-valyl-leucyl-lysine 4-p-nitroanilide dihydrochloride (Sigma) was added at a final concentration of $0.4 \mathrm{mM}$ in PBS. Plates were incubated overnight at $37^{\circ} \mathrm{C}$ and substrate was measured by taking readings at $405 \mathrm{~nm}$.

2.12. Dose-Response Curves and Dissociation Constant of the Proteins-PLG Interactions. ELISA plates were coated overnight in PBS at $4^{\circ} \mathrm{C}$ with $100 \mu \mathrm{L}$ of $10 \mu \mathrm{g} / \mathrm{mL}$ PLG. Plates were then blocked and increasing concentrations of the purified recombinant proteins $(0-1 \mu \mathrm{M})$ were added $(100 \mu \mathrm{L} /$ well in PBS). The assessment of bound proteins was performed by incubation for $1 \mathrm{~h}$ at $37^{\circ} \mathrm{C}$ with the antiserum raised against each protein at appropriate dilutions, followed by horseradish peroxidase-conjugated antimouse IgG (1:10,000 in PBS, Sigma). The binding was evaluated by the peroxidase substrate OPD and readings were taken at $492 \mathrm{~nm}$. The ELISA data were used to calculate the dissociation constant $\left(K_{\mathrm{D}}\right)$ according to the method described by Pathirana et al. [51] and Lin et al. [52], based on the equation: $A=A_{\max }$ [protein] $/\left(K_{\mathrm{D}}+\right.$ [protein] $)$, where $A$ is the absorbance at a given protein concentration, $A_{\max }$ is the maximum absorbance for the ELISA plate reader (equilibrium), [protein] is the protein concentration, and $K_{\mathrm{D}}$ is the dissociation equilibrium constant for a given absorbance at a given protein concentration (ELISA data point).

2.13. Two-Dimensional Gel Electrophoresis (2-DE Gels). Virulent low passage leptospires culture was harvested by centrifugation at $12,800 \times \mathrm{g}$ at $4^{\circ} \mathrm{C}$ for $10 \mathrm{~min}$. Pellet was washed $(\times 5)$ by resuspension in PBS containing $5 \mathrm{mM} \mathrm{MgCl}_{2}$. The pellet was resuspended in DeStreak rehydration solution(GE Healthcare, USA) and lysed by vigorous vortexing. The cellular debris was separated by centrifugation at $20,800 \times \mathrm{g}$ for $10 \mathrm{~min}$, and the supernatant was collected. Total protein content was determined according to the Bradford method (Pierce Biotechnology, USA). Samples containing $200 \mu \mathrm{g}$ of protein were adjusted to $125 \mu \mathrm{L}$ with DeStreak rehydration solution(GE Healthcare, USA), along with $0.8 \%$ (v/v) IPG buffer, with a $\mathrm{pH}$ range of 3-10 (GE Healthcare).

First-dimension isoelectric focusing was performed using the IPGphor-System (GE Healthcare, USA), and the second dimension was conducted on the Ettan DALTsix system (GE Healthcare). The IPG gel strips $(7 \mathrm{~cm})$ with a linear separation of immobilized $\mathrm{pH}$ ranging from 3 to 10 were rehydrated directly with the solubilized samples. The focusing protocol was $30 \mathrm{~V}$ for $180 \mathrm{Vh}, 150 \mathrm{~V}$ for $300 \mathrm{Vh}, 350 \mathrm{~V}$ for $350 \mathrm{Vh}, 500 \mathrm{~V}$ for $500 \mathrm{Vh}, 1000 \mathrm{~V}$ for $1,000 \mathrm{Vh}, 3,000 \mathrm{~V}$ for 3,000 Vh, and 5,000 V for 40,000 Vh, with a $50 \mu \mathrm{A} /$ strip maximum-setting at $20^{\circ} \mathrm{C}$. The strips were equilibrated twice (reduced and alkylated) for $15 \mathrm{~min}$ in $15 \mathrm{~mL}$ equilibration solution (0.05 M Tris- $\mathrm{HCl}, \mathrm{pH} 8.8,6.0 \mathrm{M}$ urea, 30\% [v/v] glycerol, and 2\% [w/v] SDS), first with the addition of $1 \%$ DTT, and finally with $2.5 \%$ iodoacetamide. After equilibration, the strips were attached to the $12 \%$
SDS-PAGE. The gels were stained by Coomassie Blue R350 (PhastGel BlueR-GE Healthcare). The gels were analyzed with Image Master-2D Platinum version 6.0 software (GE Healthcare, USA).

2.14. Mass Spectrometry and Protein Identification. The samples were analyzed by MALDI-TOF (Matrix Assisted Laser Desorption Ionization-Time of Flight) mass spectrometry, using $\alpha$-cyano-4-hydroxycinnamic acid as the matrix on an Ettan MALDI-TOF/Pro instrument (Amersham Biosciences, USA). The spots preparation, mass spectrometry, and database search for protein identification were performed according to the protocol already described in Vieira et al. [53]. Prediction for protein localization was performed by LipoP program [49].

2.15. Human Sera and Microscopic Agglutination Test. Confirmed-leptospirosis serum samples were obtained from Instituto Adolfo Lutz collection, Sao Paulo, Brazil, as previously described [41]. In brief, a laboratory-confirmed case of leptospirosis was defined by the demonstration of a four-fold microagglutination titer rise between paired serum samples. The probable predominant serovar was considered the titer that was the highest sample dilution with $50 \%$ of agglutination. MAT (microscopic agglutination test) was considered negative when the titer was below 100. In addition to the MAT-negative and MAT-positive paired samples of the same individuals with laboratory and clinic leptospirosis confirmations, we also employed sera from normal healthy donors (normal human sera-NHS), without a known history of leptospirosis, with confirmed negative MAT.

2.16. Human IgG and C3b Deposition on Leptospires. L. interrogans serovar Pomona strain LPF $\left(2.5 \times 10^{7}\right.$ cells/well $)$ were diluted in $50 \mu \mathrm{L}$ lsPBS, coated onto microplates, and allowed to stand at $37^{\circ} \mathrm{C}$ for $1 \mathrm{~h}$, followed by overnight at $4^{\circ} \mathrm{C}$. The plates were washed twice with $200 \mu \mathrm{L}$ lsPBS and blocked with 5\% nonfat dry milk and 2.5\% BSA for $2 \mathrm{~h}$ at $37^{\circ} \mathrm{C}$. After addition of $50 \mu \mathrm{L}$ of pooled sera/well (NHS, MAT-negative or MAT-positive) as a source of IgG, the plates were allowed to incubate for $30 \mathrm{~min}$ on ice, and then washed three times. The coated leptospires were treated with $50 \mu \mathrm{L} /$ well of $5 \mu \mathrm{g} / \mathrm{mL} \mathrm{uPA}$ (urokinase, Sigma) and $40 \mu \mathrm{g} / \mathrm{mL}$ PLG (Calbiochem) for $2 \mathrm{~h}$ at $37^{\circ} \mathrm{C}$, or only with uPA, only with PLG, or no additions, as negative controls. After three washings, the plates were incubated with anti-human IgG Fc region specific antibodies (Calbiochem) at a dilution of $1: 5,000$ for $1 \mathrm{~h}$ at $37^{\circ} \mathrm{C}$, and then with secondary antibodies conjugated with peroxidase at a dilution of $1: 10,000$ for $1 \mathrm{~h}$ at $37^{\circ} \mathrm{C}$. The IgG depositions on leptospires were evaluated by the peroxidase substrate OPD and readings were taken at $492 \mathrm{~nm}$. When dilutions of NHS were used, they were performed with lsPBS.

The protocol of C3b deposition on leptospires was similar to the IgG deposition described before, with exception of the incubation with NHS, placed at $37^{\circ} \mathrm{C}$ for $50 \mathrm{~min}$, and use of anti-human C3b primary antibodies $(1: 5,000)$ 

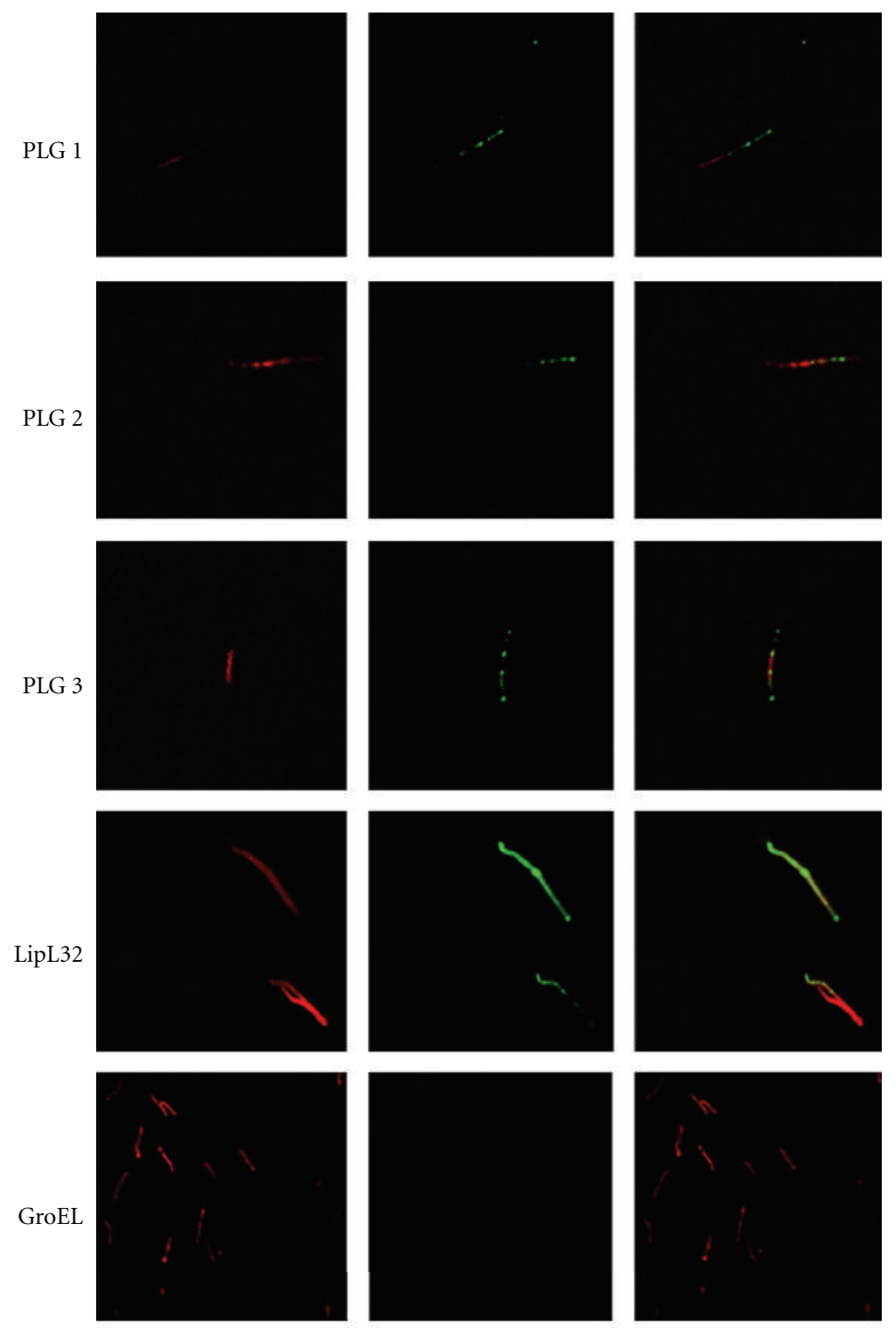

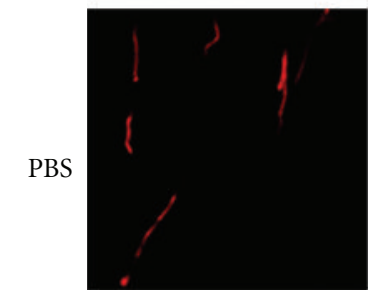

(a)

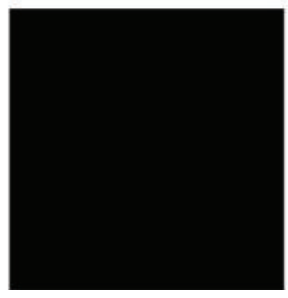

(b)

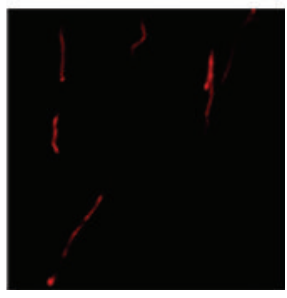

(c)

FIGURE 1: Recognition of PLG binding to Leptospira by L-IFA. Live virulent L. interrogans serovar Copenhageni isolates were treated with PLG, and the recognition was assessed through polyclonal anti-PLG antibodies under a confocal immunofluorescence microscope (PLG 1 to 3). PLG-treated leptospires stained for the proteins LipL32 (outer surface protein marker) or GroEL (a protoplasmic-cylinder marker) and untreated leptospires (PBS), are shown as controls (a) DNA propidium iodide-stained, (b) FITC-stained and (c) A+B composite images.

(Calbiochem), followed by secondary antibodies conjugated with peroxidase $(1: 5,000)$.

\subsection{Human C3b Degradation by Leptospires. L. interrogans} serovar Pomona strain LPF ( $10^{8}$ leptospires/sample) were treated in $200 \mu \mathrm{L}$ lsPBS with the addition of $10 \mu \mathrm{g}$ PLG and
$3 \mathrm{U}$ uPA (plasmin), $10 \mu \mathrm{g}$ PLG, or no additions (untreated). The cells were incubated for $1 \mathrm{~h}$ at $37^{\circ} \mathrm{C}$ with the PLG, and for one more hour after the addition of uPA. The cells were washed three times with lsPBS, and then resuspended in $100 \mu \mathrm{L}$ lsPBS containing $15 \mu \mathrm{g} / \mathrm{mL}$ human purified C3b (Calbiochem), being incubated for $20 \mathrm{~h}$ at $37^{\circ} \mathrm{C}$. The leptospires were removed by centrifugation, $20 \mu \mathrm{L}$ of the supernatants 


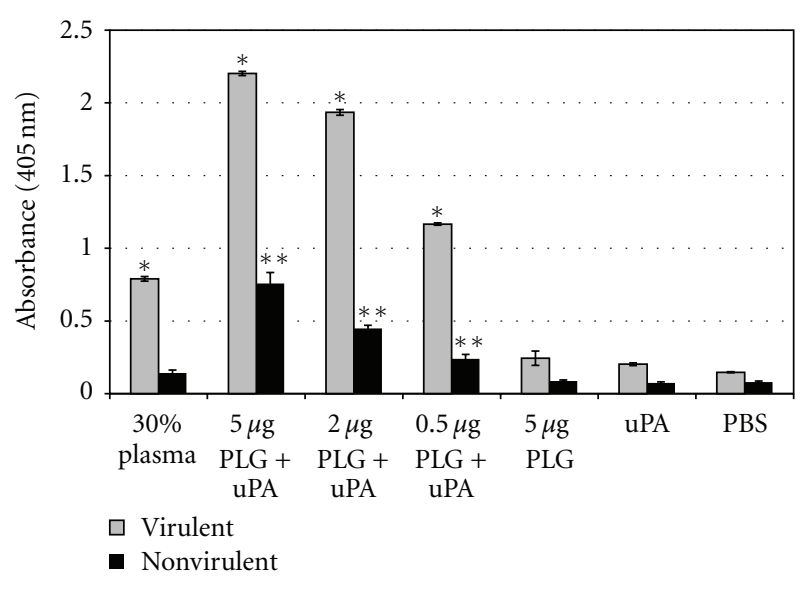

FIGURE 2: Cleavage of the plasmin-specific chromogenic substrate by plasmin-bound leptospires. Live low-passage virulent and high-passage nonvirulent $L$. interrogans serovar Copenhageni cells received the following treatments: PBS only (PBS), uPA alone (uPA), $5 \mu \mathrm{g}$ PLG alone (PLG), PLG in crescent quantities $(0.5,2$ and $5 \mu \mathrm{g}$ ) together with uPA, and 30\% human plasma together with uPA (30\% plasma). Bars represent mean absorbance as a measure of relative substrate degradation \pm the standard deviation of three replicates for each experimental group and are representative of three independent experiments. ${ }^{*}$ Virulent leptospires experiments: statistically significant $(P<0.0001)$ in comparison to the PBS control; ** nonvirulent leptospires experiments: statistically significant $(P<0.01)$ in comparison to the PBS control. The 30\% plasma, as PLG source, and all the PLG + uPA samples of the virulent leptospires were statistically significant $(P<0.001)$ in comparison to the same nonvirulent bacteria tested samples.

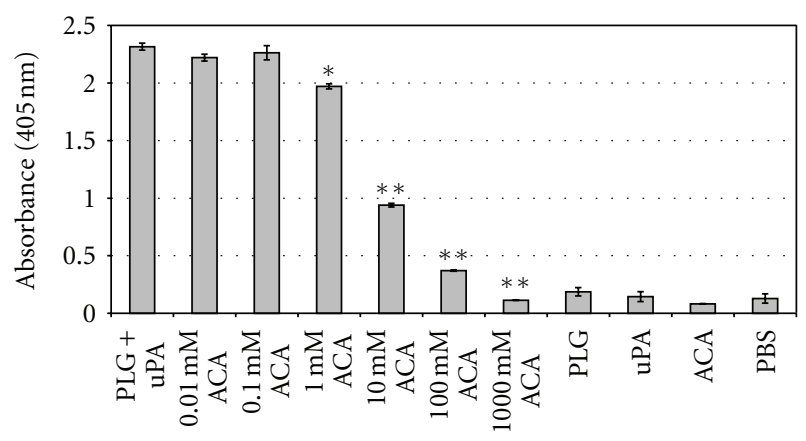

FIGURE 3: Inhibition of PLG binding to L. interrogans by ACA. Low-passage virulent $L$. interrogans serovar Copenhageni cells were treated with the following: PLG together with uPA (PLG + uPA), PLG together with uPA with the addition of crescent concentrations of ACA (0.01 to 1,000 mM ACA), PLG alone (PLG), uPA alone (uPA), ACA alone (ACA), and no additions (PBS). The cleavage of the plasmin-specific substrate D-Val-Leu-Lys 4-nitroanilide dihydrochloridein by the treated spirochetes was measured by absorbance readings at $405 \mathrm{~nm}$. Bars represent mean absorbance \pm the standard deviation of three replicates for each experimental group and are representative of three independent experiments. Statistically significant substrate degradation inhibition results in comparison to the positive control (PLG $+\mathrm{uPA}$ ) are shown: $P<$ $0.01\left(^{*}\right)$ and $P<0.0001\left(^{* *}\right)$. were separated by $10 \%$ SDS-PAGE and then transferred to nitrocellulose membranes in semi-dry equipment. The membranes were blocked by incubating overnight at $4^{\circ} \mathrm{C}$ with $5 \%$ nonfat dry milk and $1 \%$ BSA. The C3b detection was made by incubations with anti-human C3b antibodies and secondary antibodies conjugated with peroxidase, followed by ECL (GE Healthcare) development.

2.18. Serum Susceptibility Testing for Treated Leptospires. Complement-mediated killing of leptospires was evaluated after incubation with nonimmune NHS, as described by Meri et al. [54], with some modifications. Approximately $5 \times 10^{8}$ L. interrogans serovar Pomona strain LPF per sample were treated with $40 \mu \mathrm{g}$ PLG and $4 \mathrm{U}$ uPA in $200 \mu \mathrm{L}$ lsPBS for $3 \mathrm{~h}$ at $37^{\circ} \mathrm{C}$. As a control, one aliquot of L. interrogans serovar Pomona strain LPF was incubated only with PBS. Then, the samples were divided into aliquots containing $1.0 \times 10^{8}$ cells, which were added by $80 \mu \mathrm{L}$ NHS and $80 \mu \mathrm{L}$ EMJH medium supplemented with $10 \%$ Leptospira enrichment. The bacteria suspensions were incubated at $37^{\circ} \mathrm{C}$ for one hour, followed by a incubation of $5 \mathrm{~min}$ on ice for stopping complement activation. After, $20 \mu \mathrm{L}$ of each sample (four replicates) were transferred to microplates filled with $180 \mu \mathrm{L}$ of EMJH medium/well. The plates were sealed with a sterile adhesive film and incubated at $30^{\circ} \mathrm{C}$ for 4 days. Bacterial growth was determined by counting leptospires in a PetroffHausser chamber under dark-field microscopy.

2.19. Statistics. For the data that were tested for statistical significance, the student's two-tailed test was applied, considering the minimum of $P<0.05$.

\section{Results and Discussion}

3.1. Binding of Human Plasminogen by L. interrogans Cells. Live-immunofluorescence microscopy (L-IFA) was employed in order to evaluate the ability of L. interrogans cells to bind human PLG. L-IFA revealed that leptospires bind PLG in their outer surface along the entire cell, as seen when the bacteria were probed with antibodies antiPLG (Figure 1). PLG bound to leptospires does not seem to damage the bacterial membrane because no fluorescence of GroEL, a cytoplasmatic heat-shock protein [55], was achieved when serum anti-GroEL was employed (Figure 1). The leptospiral recombinant proteins LipL32, an abundant outer membrane protein of Leptospira [56], used as positive control, showed an intense surface fluorescence. We also observed that the spirochete regular movement was conserved, suggesting that the flagella remained undamaged. Taken together, these data suggest that the PLG-binding does not interfere with the membrane structure or dynamics [36].

3.2. Activation and Enzymatic Activity of Plasminogen-Bound Leptospira. The binding of PLG to leptospiral surface was further analyzed by plasmin enzymatic activity. Leptospires were incubated with purified PLG, followed by plasmin activation after addition of uPA, conferring the bacteria a surface-associated plasmin activity (Figure 2), as measured 


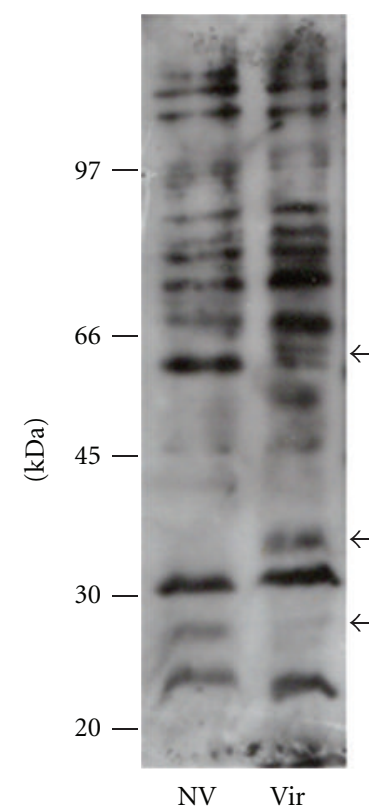

(a)

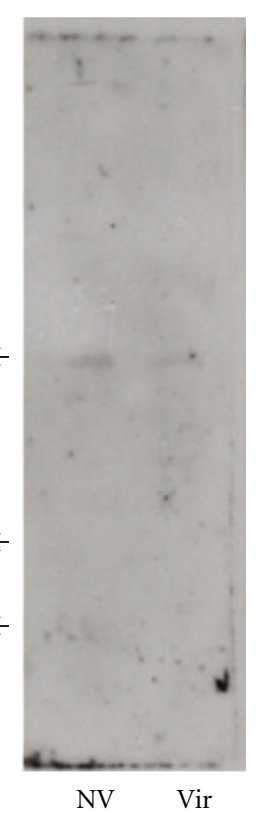

(b)
FIGURe 4: Binding of human PLG to L. interrogans proteins by affinity blotting. Total protein extracts were resolved by $10 \%$ SDS-PAGE and electroblotted into nitrocellulose membranes. The membranes were incubated with PLG (a) or PLG + ACA (b), and the binding was detected by anti-PLG antibodies and peroxidaseconjugated antibodies. The reactivity was revealed by ECL (GE Healthcare) and exposure to X-Ray films. NV: high passage, nonvirulent $L$. interrogans serovar Copenhageni strain M 20; Vir: low-passage, virulent $L$. interrogans serovar Copenhageni strain Fiocruz L1-130. The arrows indicate reactivity protein regions seen in the virulent but absent in the nonvirulent bacterial extract. Positions of protein molecular mass markers are shown on the left.

by the degradation of plasmin's chromogenic specific substrate [36].

The labeling with PLG alone did not trigger proteolytic activity suggesting that $L$. interrogans serovar Copenhageni is dependent on the host PLG activation system, probably not possessing an endogenous mechanism, as already reported for other pathogens [57-64]. In contrast, the ability of PLG activation is shown for a number of pathogenic microorganisms [57-64].

Both the virulent and nonvirulent strains of $L$. interrogans serovar Copenhageni tested were capable of capturing PLG, although the virulent strain seems to be more efficient in the PLG-binding than the nonvirulent bacteria ( 2.5 fold $)$ (Figure 2) [36]. PLG is present in plasma at a concentration of approximately $20.8 \pm 1.9 \mathrm{mg} / 100 \mathrm{~mL}$ [65]. Our data shows that virulent $L$. interrogans, but not the attenuated strain, have the ability to sequester PLG from human plasma in the conditions assayed. At any rate, once in the host, the infectious leptospires can acquire PLG when reach the blood circulation.

3.3. Inhibition by 6-Aminocaproic Acid (ACA) of Proteolytic Activity Acquired by L. Interrogans. It is well known that the

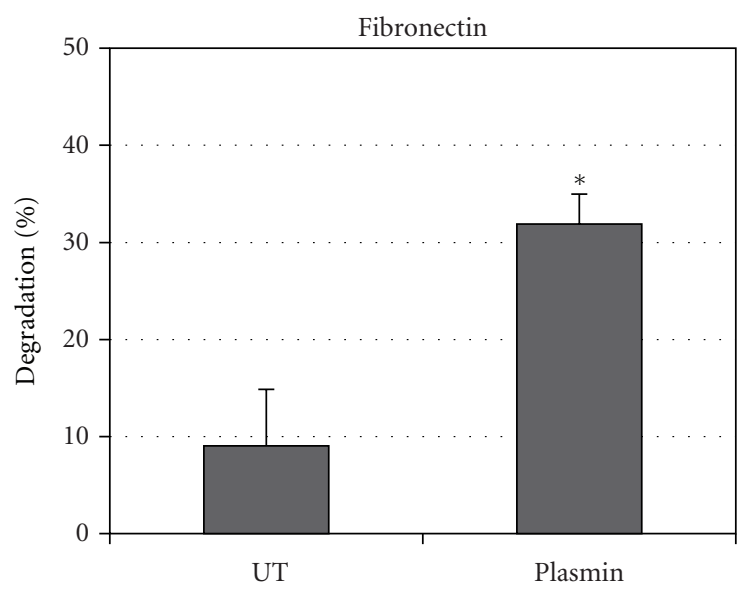

(a)

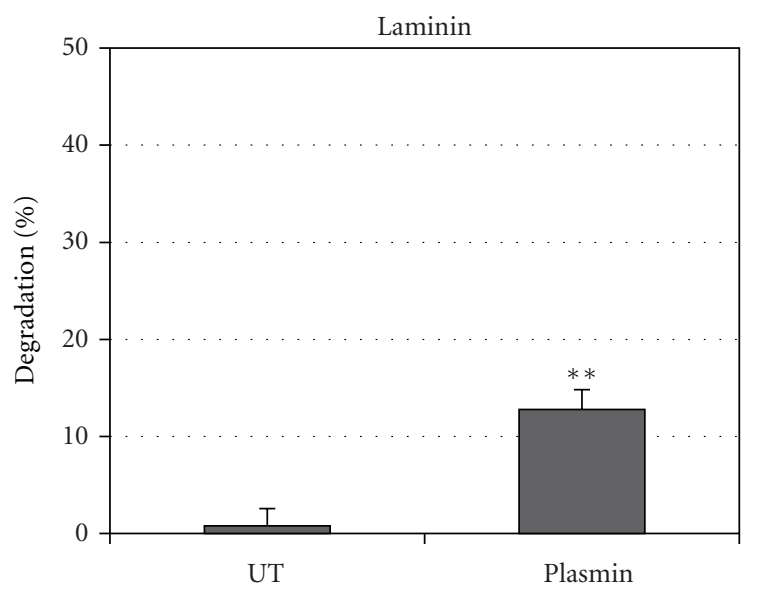

(b)

FIGURE 5: Fibronectin and laminin degradation by plasmin-coated leptospires. Spirochetes were incubated in lsPBS with no additions (UT) and with addition of PLG and UPA (plasmin). ELISA plate wells coated with $0.5 \mu \mathrm{g} /$ well fibronectin (a) or laminin (b) were incubated for $20 \mathrm{~h}$ with the spirochetes from each experimental group to allow substrate digestion. Plates were then incubated with antibodies antilaminin or antifibronectin. A reduction in absorbance was interpreted as substrate digestion, relative to controls lacking bacteria $(0.5 \mu \mathrm{g} /$ well purified laminin or cellular fibronectin, corresponding to $0 \%$ degradation). Percent degradation (a reduction in absorbance value relative to control lacking bacteria) was calculated as described in Section 2. Bars represent mean percent substrate degradation relative to the positive control $(0 \%$ degradation $) \pm$ the standard deviation of three replicates. The experiment was independently performed three times with similar results. $P<0.001\left(^{*}\right)$ and $P<0.01\left(^{* *}\right)$.

lysine-binding sites of PLG kringle domains frequently mediate interactions with lysine residues of the cellular receptors [27]. ACA, a lysine analogue, decreased the proteolytic activity of virulent $L$. interrogans serovar Copenhageni incubated with PLG, in a dose-dependent manner (Figure 3). The total inhibition (100\%) of plasmin activity achieved with the higher ACA concentrations employed shows that the PLG interaction with these spirochetes occurs trough the lysinebinding sites of the kringle domains [36]. 


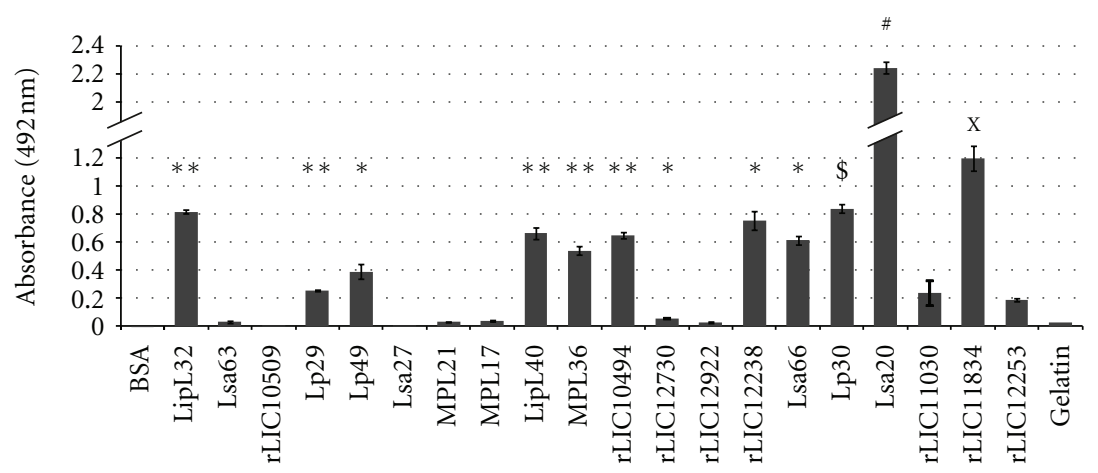

Figure 6: Binding of leptospiral recombinant proteins to human plasminogen. The recombinant proteins LipL32, Lsa63, rLIC10509, Lp29, Lp49, Lsa27, MPL21, MPL17, LipL40, MPL36, rLIC10494, rLIC12730, rLIC12922, rLIC12238, Lsa66, Lp30, Lsa20, rLIC11030, rLIC11834, and rLIC12253 were coated onto 96-well ELISA plates $(10 \mu \mathrm{g} / \mathrm{mL})$ and allowed to interact with purified human PLG (10 $\mu \mathrm{g} / \mathrm{mL})$. BSA and gelatin were used as a negative control for nonspecific binding. Binding was detected and quantified by specific antibodies. Bars represent the mean absorbance values at $492 \mathrm{~nm} \pm$ the standard deviation of four replicates for each protein and are representative of three independent experiments. Statistically significant binding in comparison to negative control BSA are shown by $*(P<0.001) ;{ }^{* *}(P<0.0001)$; ${ }^{\$}(P<0.02)$; $\#(P<0.0005)$. The binding of rLIC11834 and rLIC12253 was compared to its binding to gelatin ${ }^{X}(P<0.005)$.

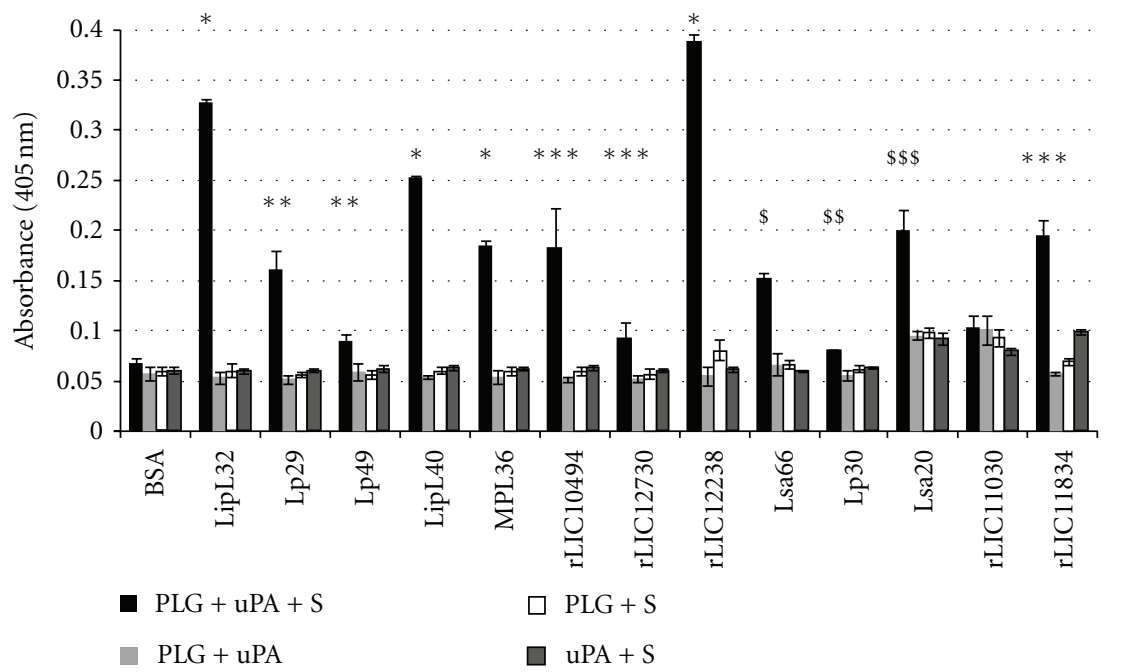

FIGURE 7: Activation of recombinant protein-PLG to enzymatically active plasmin. Cleavage of specific plasmin substrate by PLG bound to recombinant proteins was assayed by modified ELISA as immobilized proteins received the following treatment: PLG $+\mathrm{uPA}+$ specific plasmin substrate $(P L G+u P A+S)$ or controls lacking one of the three components (PLG + uPA; PLG + S; uPA + S). BSA was employed as a negative control. Bars represent the mean absorbance values at $405 \mathrm{~nm}$, as a measure of relative substrate cleavage, \pm the standard deviation of four replicates for each experimental group and are representative of two independent experiments. Statistically significant differences are shown by $*(P<0.00001),{ }^{* *}(P<0.005),{ }^{* * *}(P<0.05),{ }^{\$}(P<0.001),{ }^{\$ \$}(P<0.02)$, and $\$ \$(P<0.003)$.

3.4. Analysis of Plasminogen-Binding L. Interrogans Proteins on Cell Lysates. Assessment of leptospiral proteins binding to PLG was first visualized by affinity blotting using total whole-cell lysates (Figure 4(a)). Our results are indicative that multiple leptospiral proteins are capable of binding PLG, although these affinity blotting experiments do not simulate the protein-PLG interaction in vivo. As expected, the data also demonstrate that there are similarities between the PLGbinding proteins of the virulent and nonvirulent strains, but also revealed the presence of some reactive bands on the low-passage virulent strain that are absent in the nonvirulent one, indicating that virulent strains have more PLG binding proteins. Thus, based on the data from enzymatic activity and affinity blotting presented here we cannot discriminate whether the increased bound activity of the virulent strain is due to only differential expression of a different set of membrane receptors, an increased expression of the same receptors, or both. Comparable to the results obtained with the intact leptospires, the affinity blotting was inhibited by the presence of the lysine analog, ACA, supporting the central role of lysine residues of the proteins in the PLG interactions (Figure 4(b)) [36].

3.5. Plasmin-Coated Leptospira Degrades Immobilized ECM Molecules. Plasmin is a broad-spectrum serine protease that 


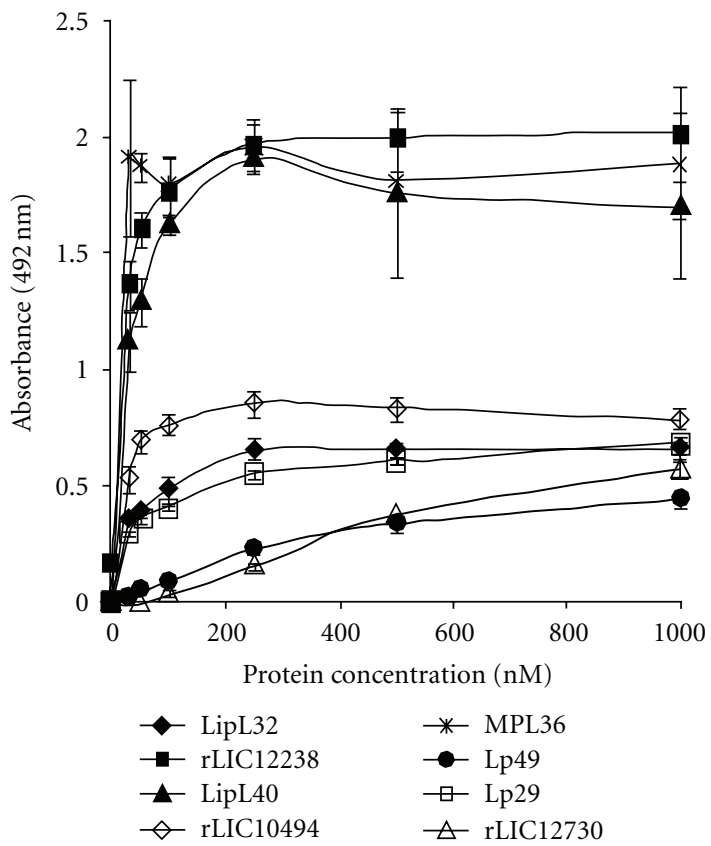

(a)

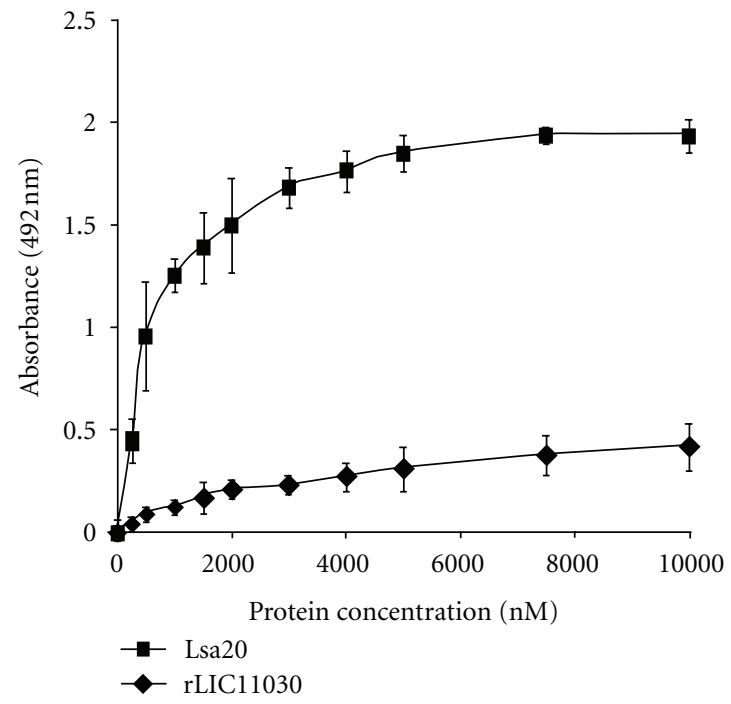

(c)

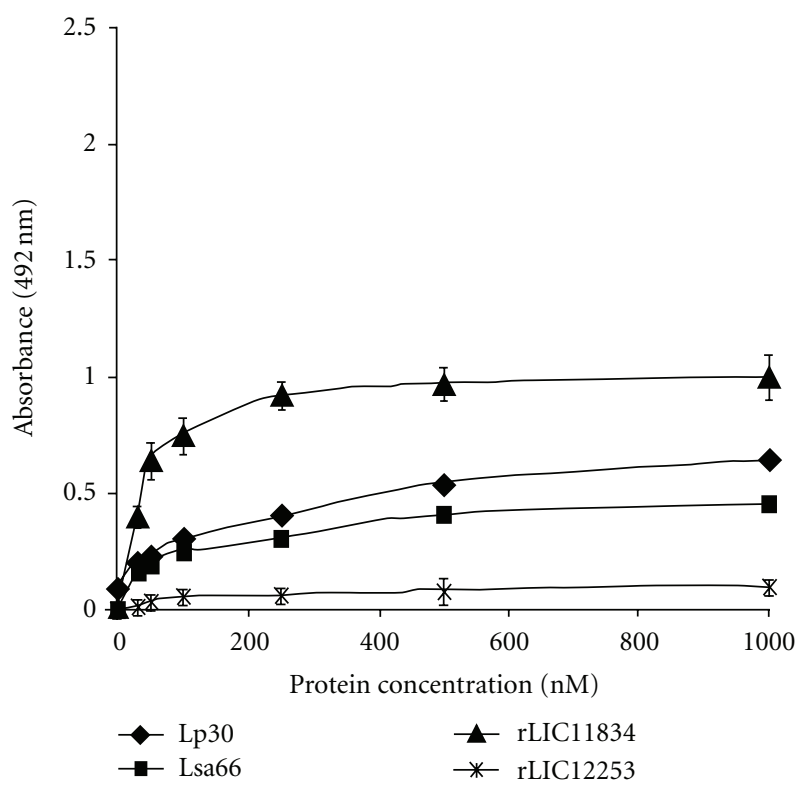

(b)

\begin{tabular}{lc}
\hline Recombinant proteins & Dissociation constant $\left(\mathrm{K}_{D}\right)$ \\
\hline LipL32 & $25.87 \pm 5.09 \mathrm{nM}$ \\
rLIC 12238 & $11.97 \pm 106 \mathrm{nM}$ \\
LipL40 & $18.24 \pm 2.45 \mathrm{nM}$ \\
rLIC 10494 & $10.98 \pm 2.33 \mathrm{nM}$ \\
MPL36 & $3.52 \pm 3.95 \mathrm{nM}$ \\
Lp49 & $\mathrm{ND}^{*}$ \\
Lp29 & $\mathrm{ND}^{*}$ \\
rLIC 12730 & $\mathrm{ND}^{*}$ \\
Lsa66 & $68.82 \pm 25.54 \mathrm{nM}$ \\
Lp30 & $167.39 \pm 60.14 \mathrm{nM}$ \\
rLIC 11834 & $23.53 \pm 4.66 \mathrm{nM}$ \\
rLIC 12253 & $\mathrm{ND}^{*}$ \\
Lsa20 & $509.13 \pm 77.47 \mathrm{nM}$ \\
rLIC 11030 & $\mathrm{ND}^{*}$ \\
* ND not determined &
\end{tabular}

(d)

FIGURE 8: Characterization of recombinant proteins binding to PLG. In (a), (b), and (c) PLG (10 $\mu$ g/mL) was immobilized in 96-well ELISA plates, and each recombinant protein at 0 to $1,000 \mathrm{nM}$ was added for interaction. The binding was detected using antiserum raised in mice against each protein at appropriate dilutions $(1: 4,000$ for LipL32; $1: 5,000$ for rLIC12238, LipL40, and MPL36; 1:1,000 for Lp29, Lp49, Lsa20, and rLIC11030; 1:500 for rLIC12730, Lsa66, and Lp30; 1:750 for rLIC11834 and rLIC12253), followed by horseradish peroxidaseconjugated anti-mouse IgG. Data represent the mean absorbance values \pm the standard deviation of six replicates for each experimental group. The results are representative of two independent experiments. In (d) The dissociation constant $\left(K_{\mathrm{D}}\right)$ was calculated based on ELISA data for the recombinant proteins that reached equilibrium up to a concentration of $1,000 \mathrm{nM}$.

is capable to degrade directly laminin and fibronectin. To evaluate whether the plasmin associated to the leptospires surface can directly break these ECM components, purified soluble human fibronectin and laminin were adhered into 96-well plates, and the reaction was evaluated by exposing the ECM proteins with low-passage virulent $L$. interrogans, pretreated with PLG/uPA. As shown in Figure 5, the plasmincoated leptospires were able to significantly cleave down the immobilized ECM macromolecules, when compared to the ones exposed to untreated bacteria [36].

Given that leptospires are highly invasive pathogens that are thought to penetrate the skin or break in the skin to initiate infection, the ability of digesting ECM macromolecules via plasmin activity might be an important step for leptospiral pathogenesis. To date, this is the first proteolytic activity detected in Leptospira that can promote 


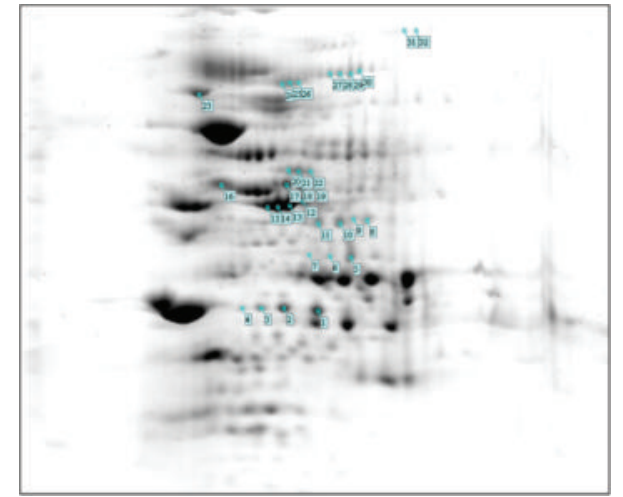

(a)

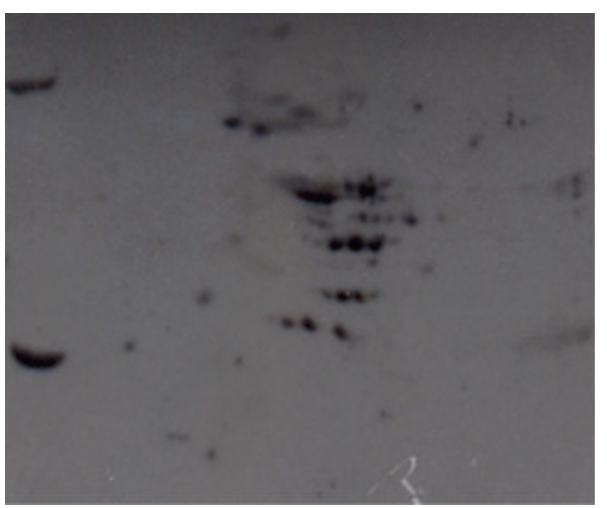

(b)

Figure 9: Two-dimensional gel analysis of L. interrogans PLG binding proteins. Leptospiral total cell lysates were separated by isoelectric point ( $\mathrm{pH} 3-10)$ and molecular mass on $12 \%$ SDSPAGE. Replicate gels were Coomassie Blue stained (a) or transferred to membranes and submitted to PLG affinity immunoblotting (b). The reactive spots are enumerated on (a). The results are representative of three independent experiments performed in duplicates.

ECM degradation and it is a plausible mechanism that can contribute to leptospiral invasiveness $[1,66]$.

3.6. Recombinant Leptospiral Proteins Bind Human Plasminogen. In order to investigate PLG binding proteins in Leptospira we benefitted from the availability of several recombinant proteins of $L$. interrogans available in our laboratory. We evaluated the ability of these proteins to interact with PLG in vitro. Table 1 summarizes the features of these proteins and gene conservation within the sequenced genomes [8-12]. The binding of these proteins to PLG was quantified by ELISA and the results are shown in Figure 6. Proteins LipL32, Lp29, Lp49, LipL40, MLP36, rLIC10494, rLIC12730, rLIC12238, Lsa66, Lp30, Lsa20, and Lsa33 (rLIC11834) presented significant binding to PLG while proteins Lsa63, Lsa27, rLIC10509, MPL21, MPL17, rLIC12922, rLIC11030, Lsa25 (rLIC12253), BSA, and gelatin did not show significant binding activity (Figure 6) [37-40].

3.7. Activation of Plasminogen-Bound Proteins. To evaluate whether purified PLG-binding proteins were independently

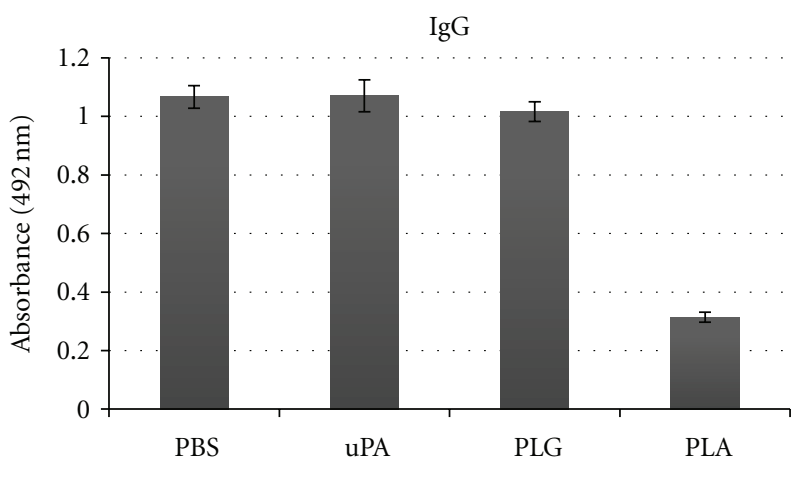

(a)

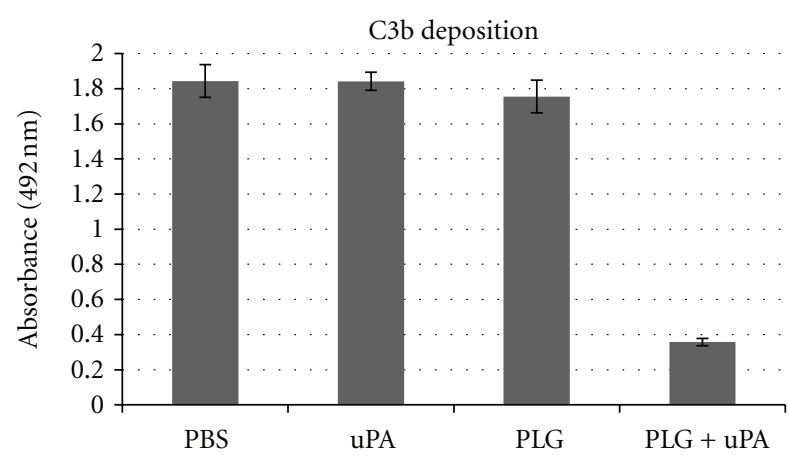

(b)

Figure 10: Human IgG and C3b binding to L. interrogans. Bacteria were coated onto microtiter plates $\left(25 \times 10^{6}\right.$ leptospires/well $)$ and IgG (a) or C3b (b)were bound by incubating bacteria with $100 \%$ NHS. Bacteria were treated with PBS, $40 \mu \mathrm{g} / \mathrm{mL}$ PLG (PLG), $5 \mu \mathrm{g} / \mathrm{mL}$ uPA (uPA), or PLG + uPA (Pla). Presence of human IgG or $\mathrm{C} 3 \mathrm{~b}$ deposited on leptospires was determined by ELISA. Bars represent the mean absorbance values at $492 \mathrm{~nm} \pm$ the standard deviation of three replicates for each experimental group and are representative of two independent experiments.

capable to generate active plasmin in the presence of uPA PLG activator, we measured the degradation of plasmin specific chromogenic substrate in a modified ELISA. The PLG captured by the proteins could be converted into plasmin, as demonstrated indirectly by specific proteolytic activity (Figure 7). The negative control BSA, that showed no PLG binding, produced no significant proteolytic activity, as well as the controls lacking PLG, uPA, or the chromogenic substrate [37-40].

3.8. Characterization of the Binding of Recombinant Proteins to PLG. The binding between each recombinant protein and PLG was assessed on a quantitative basis as illustrated in Figures 8(a), 8(b), and 8(c). Dose-dependent and saturable binding was observed when increasing concentrations ( 0 to $1,000 \mathrm{nM}$ ) of the recombinant proteins MPL36, LipL40, LipL32, rLIC10494, rLIC12238, Lsa66, Lp30, Lsa33 (rLIC11834), and Lsa20 was allowed to individually adhere to a fixed amount of PLG $(1 \mu \mathrm{g})$, indicating the specificity of the binding. For the proteins Lp29, Lp49, rLIC12730, Lsa25 (rLIC12253), and rLIC11030, the saturation level was not 
TABle 2: L. interrogans PLG-binding proteins identified by MALDI-TOF mass spectrometry. The proteins are identified as the genomic nomenclature (LIC: Leptospira interrogans serovar Copenhageni), and are listed and respective NCBI reference sequence, predicted name/function and predicted cellular localization, in theoric molecular mass and isoelectric point (pI).

\begin{tabular}{lcccr}
\hline Gene locus $^{1}$ & $\begin{array}{c}\text { NCBI reference } \\
\text { sequence number }\end{array}$ & Gene/protein function & Localization $^{3}$ & Theoric molecular mass (kDa) \\
\hline LIC12816 & YP_002733 & Hypothetical protein & Membrane & 14.7 \\
LIC10788 & YP_000767 & flaA-1 (Flagellar filament sheath protein) & Membrane & 35.0 \\
LIC11194 & YP_001164 & Putative citrate lyase & Cytoplasm & 37.2 \\
LIC12875 & YP_002791 & tuf (Elongation factor Tu) & Cytoplasm & 4.6 \\
LIC12795 & YP_002712 & Acetyl-CoA acetyltransferase & Cytoplasm & 6.1 \\
LIC12407 & YP_002339 & Glutamine synthetase protein & Cytoplasm & 5.6 \\
LIC10524 & YP_000508 & dnaK (Heat shock protein) & Cytoplasm & 55.4 \\
\hline
\end{tabular}

${ }^{1}$ http://aeg.lbi.ic.unicamp.br/world/lic/.

${ }^{2}$ http://www.ncbi.nlm.nih.gov/protein/.

${ }^{3}$ Lipo P: Juncker et al., [49].

reached, even at the highest concentration tested $(1,000 \mathrm{nM})$. Based on the ELISA data, the calculated dissociation equilibrium constants $\left(K_{\mathrm{D}}\right)$ for the recombinant proteins with PLG are depicted in Figure 8(d); for the ones that reached equilibrium, the highest and the lowest $K_{\mathrm{D}}$ values were for Lsa20 $(509.13 \pm 77.47 \mathrm{nM})$ and MPL36 $(3.52 \pm 3.95 \mathrm{nM})$, respectively, [37-40].

3.9. Proteomic Approach to Leptospiral PLG Binding Protein Identification. In order expand our knowledge on PLG binding proteins, we decided to employ two-dimensional gel electrophoresis followed by affinity immunoblotting, as an alternative strategy to identify novel leptospiral PLGbinding proteins. Total protein extracts of low passage L. interrogans were separated by isoelectric point and molecular mass (Figure 9(a)), transferred to membranes, and incubated with PLG and anti-PLG antibodies for detection of reactive spots (Figure 9(b)). The reactive spots were excised and prepared for MALDI-TOF mass spectrometry and protein identification. Under the conditions assayed, we could identify seven proteins capable of binding PLG, as depicted in Table 2. Two were annotated as membrane and five as cytoplasmatic proteins (Table 2). Along with the membrane proteins, one is hypothetical and the other is a putative flagellar filament sheath protein (FlaA-1); the cytoplasmic proteins are citrate lyase, Tuf (elongation factor), acetyl-CoA acetyltransferase, glutamine synthetase, and the heat shock protein DnaK. While the role of membrane proteins on the PLG sequestering within the host is expected, the meaning of cytoplasmatic proteins remains to be investigated. Intriguingly, none of the PLG-binding recombinant proteins was detected in these experiments. One possible explanation is that the identified proteins, except LIC12816, are expressed in high amounts per cell, while the proteins assayed in our laboratory were below the detection limit, as reported by quantitative proteomics [67]. However, LipL32 that was shown to have the highest expression level per leptospiral cell, was not detected in our proteomics studies. Although the reason for this is unknown, we might speculate that because LipL32 is always presented as isoforms in 2D gels $[53,68,69]$, it is possible that these isoforms do not bind PLG. Several cytoplasmatic proteins of other pathogenic microrganisms have been identified as PLG binding proteins, such as Bifidobacterium animalis DnaK [70], Paracoccidioides brasiliensis, Schistosoma bovis and Streptcoccus pneumoniae enolases [71] and Streptococcus pneumoniae GAPDH [72]. For some of these proteins, there is the possibility that at some moment they could be exposed in the bacterial outer membrane. Indeed, it has been recently reported that $B$. burgdorferi enolase, which is both a cytoplasmic and membrane-associated protein, is also a PLG-binding protein [73]. It is also possible that the PLG binding to these cytoplasmic proteins are not relevant for the bacteria.

3.10. Human $\operatorname{IgG}$ and C3b Deposition on Leptospires. Plasmin-generation on surface of $L$. interrogans may facilitate the bacteria to degrade opsonizing IgG and C3b molecules, and therefore contribute to immune evasion. To test this hypothesis, microtiter plates coated with virulent $L$. interrogans serovar Pomona were incubated with NHS, as a source of C3b and nonspecific IgG molecules. Bacteria were then treated with PLG and UPA, and the resulting surfaceassociated opsonins were quantified by specific antibodies. The results show that the incubation of bacteria with PLG and $\mathrm{uPA}$ resulted in a decrease in IgG $\mathrm{Fc}$ region (Figure 10(a)) and C3b depositions (Figure 10(b)) at the leptospiral surface. No effect on IgG or C3b binding to L. interrogans was observed with only PLG or uPA [41].

\subsection{IgG Binding from Human Leptospirosis Immune Serum} to L. Interrogans. To evaluate whether PLA activity observed against nonspecific human IgG bound to leptospires could also be functional to immune sera from patients diagnosed with leptospirosis, we performed the same experiment using MAT negative (preimmune phase) and MAT positive (convalescent immune phase) pools of human sera. As expected, MAT positive sera resulted in significant higher IgG depositions on bacterial surface when compared to NHS and MAT negative sera (Figure 11). When PLA was generated on leptospires, a noticeable decrease in the amount of IgG 


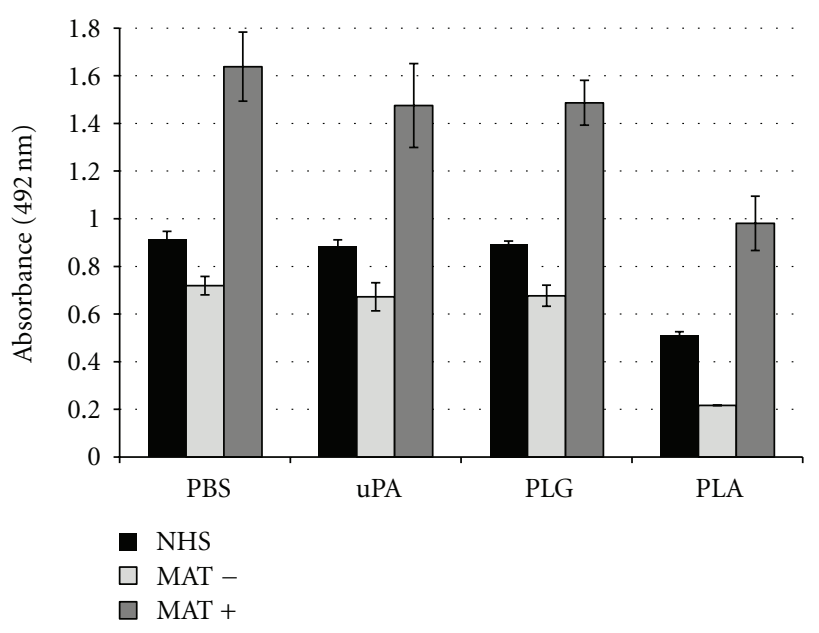

Figure 11: IgG binding from human leptospirosis immune serum to L. interrogans. Bacteria were coated onto microtiter plates $\left(25 \times 10^{6}\right.$ leptospires/well $)$ and $\operatorname{IgG}$ was bound by incubating bacteria 50\% nonimmune human sera (NHS) or confirmed paired leptospirosis patients sera: MAT negative (MAT-) or MAT positive (MAT+). Bacteria were treated with PBS, $40 \mu \mathrm{g} / \mathrm{mL}$ PLG (PLG), $5 \mu \mathrm{g} / \mathrm{mL}$ uPA (uPA), or PLG + uPA (Pla). Presence of human IgG deposited on leptospires was determined by ELISA using Fc-specific anti-human IgG antibodies. Bars represent the mean absorbance values at $492 \mathrm{~nm} \pm$ the standard deviation of three replicates for each experimental group and are representative of two independent experiments.

deposition from both negative and positive MAT sera was detected [41].

Opsonization obstruction by antibodies or complement system appears to be an interesting approach for the bacteria to evade the first line of human immune defense upon infection. In fact, the expression of proteins on the bacterial surface that sequester host complement regulators FH, FHL1 , or C4BP and therefore the inhibition of the complement cascade by the alternative or classical pathways has been employed by several pathogens [74-77]. Moreover, the proteolytic cleavage of antibodies that prevents the activation of complement classical pathway or Fc receptor-mediated phagocytosis, is another well-known strategy employed by pathogenic bacteria [74-77].

3.12. Human C3b Degradation by Leptospires. Meri and colleagues [54] reported the capability of Leptospira-bound factor $\mathrm{H}(\mathrm{FH})$ to act as a cofactor for the serum protease factor I in cleaving C3b. Thus, we decided to assess whether the decrease in C3b deposition by Leptospira-generated PLA was due to $\mathrm{C} 3 \mathrm{~b}$ cleavage. L. interrogans serovar Pomona were coated with PLA by treatment with PLG and UPA, and then incubated with human purified C3b in fluid-phase. The resulting supernatant together with anti-C3b-specific antibodies was analyzed by Western blotting (Figure 12). The data revealed the appearance of two-lower molecular mass bands of estimated 60 and $20 \mathrm{kDa}$, concurrently with the decrease in the masses of the alpha $(105 \mathrm{kDa})$ and beta $(75 \mathrm{kDa}) \mathrm{C} 3 \mathrm{~b}$ chains that took place only with PLA-coated

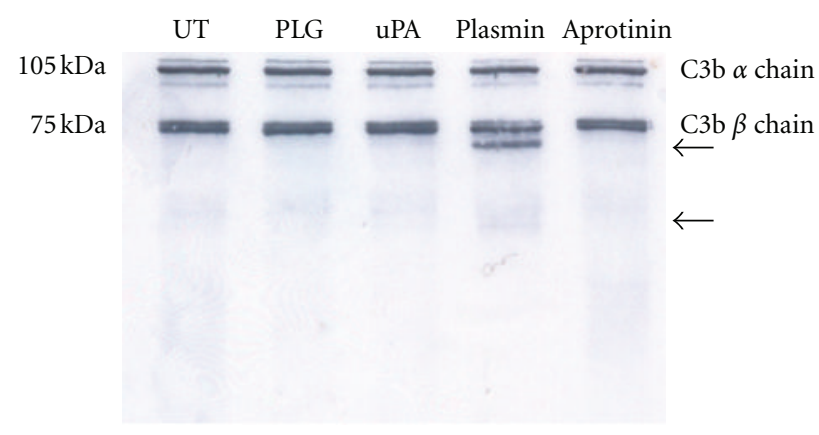

(a)

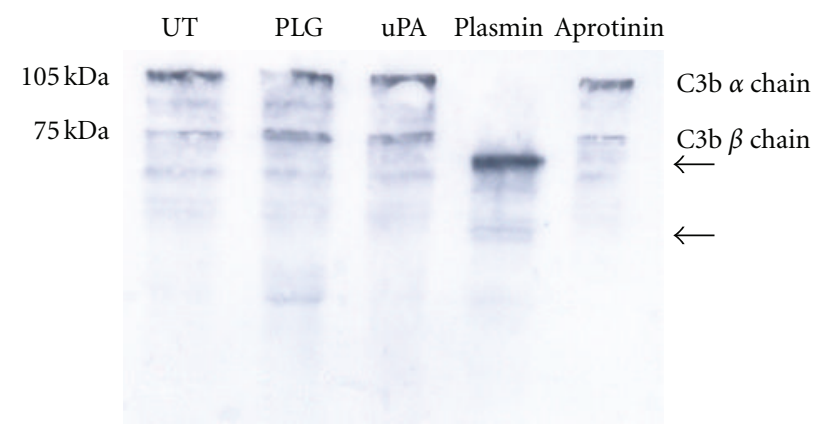

(b)

Figure 12: Detection of human C3b. Leptospires ( $10^{8} /$ sample) were treated with $10 \mu \mathrm{g}$ PLG and $3 \mathrm{U}$ uPA (Plasmin), only with PLG (PLG), or left untreated (UT). The cells were incubated with $15 \mu \mathrm{g} / \mathrm{mL}$ human purified $\mathrm{C} 3 \mathrm{~b}$ for $20 \mathrm{~h}$ at $37^{\circ} \mathrm{C}$, and the supernatants were resolved by SDS-PAGE and transferred to membranes. The C3b was detected by specific antibodies followed by ECL reagent development and exposition to X-Ray films. There are indicated the native human $\mathrm{C} 3 \mathrm{~b}$ alpha chain $(105 \mathrm{KDa})$ and beta-chain $(75 \mathrm{KDa})$, as well as the degradation products (arrows).

leptospires. Untreated or leptospires only treated with PLG showed no gradation. The results unmistakably show that the human C3b is cleaved by leptospires-coated PLA, indicating that the reduction in deposition is most probably due to degradation [41].

3.13. Serum Susceptibility Testing for Treated Leptospires. It has been described that L. interrogans serovar Pomona is partially susceptible to complement killing upon incubation with normal human sera [54]. To evaluate whether the PLG/PLA binding to leptospires confers protection on exposure to NHS, leptospires were treated with PLG+uPA (Pla) or with PBS, as negative control, and incubated for one hour with pooled NHS. The bacteria were harvested and counted in a dark-field microscopy using Petroff-Hausser chamber, at the fourth day of incubation. The number of untreated leptospires was almost four times less when compared to the plasmin-coated leptospires $\left(0.35 \times 10^{8} \pm 0.1 \times 10^{8}\right.$ versus $1.28 \times 10^{8} \pm 0.3 \times 10^{8}$ leptospires $/ \mathrm{mL}$ ), suggesting that the leptospires endowed with active plasmin are less vulnerable to components present in NHS [41]. 


\section{Conclusions}

The interaction of the human PLG system has been suggested to be a feature that significantly contributes to the virulence of many bacterial pathogens by facilitating the initial anchoring to endothelium and penetration [27]. Our group has been studying the interaction of Leptospira with PLG/plasmin generation system and the possible implications for pathogenesis. We demonstrated that leptospires interact with PLG and can acquire plasmin activity associated to the surface with no apparent damage to the surface, what occurs through multiple proteins. Although nonvirulent leptospires can interact with PLG, there seems to be a correlation between the efficiency of PLG capturing and virulence, suggesting a role in virulence and infection. Moreover, the generation of enzymatically active PLA on the leptospiral surface decreased C3b and IgG depositions that may constitute a novel mechanism by which leptospires could evade the immune system until reach immunologically safe environments. This latter assertion will also have implication to the bacterial persistence within the host. We believe that the disclosure of this enzymatically system will shed light on the molecular mechanism of leptospiral pathogenesis.

\section{Acknowledgments}

The authors are deeply indebted to Alexsander Seixas de Souza (Departamento de Parasitologia, Instituto Butantan, Sao Paulo, Brazil) for the use of the confocal microscope facilities and the helpful discussion. This work was supported by FAPESP, CNPq, and Fundação Butantan, Brazil; M.L.Vieira; M.V.Atzingen; R.Oliveira; R.S.Mendes; R.F.Domingos have scholarships from FAPESP (Brazil).

\section{References}

[1] S. Faine, B. Adler, C. Bolin, and P. Perolat, Leptospira and Leptospirosis, MediSci, Melbourne, Australia, 2nd edition, 1999.

[2] P. N. Levett, "Leptospirosis," Clinical Microbiology Reviews, vol. 14, no. 2, pp. 296-326, 2001.

[3] J. M. Vinetz, "Leptospirosis," Current Opinion in Infectious Diseases, vol. 14, no. 5, pp. 527-538, 2001.

[4] A. R. Bharti, J. E. Nally, J. N. Ricaldi et al., "Leptospirosis: a zoonotic disease of global importance," Lancet Infectious Diseases, vol. 3, no. 12, pp. 757-771, 2003.

[5] A. I. Ko, M. Galvão Reis, C. M. Ribeiro Dourado, W. D. Johnson, and L. W. Riley, "Urban epidemic of severe leptospirosis in Brazil," Lancet, vol. 354, no. 9181, pp. 820-825, 1999.

[6] D. A. Haake, M. Dundoo, R. Cader et al., "Leptospirosis, water sports, and chemoprophylaxis," Clinical Infectious Diseases, vol. 34, no. 9, pp. e40-43, 2002.

[7] R. Plank and D. Dean, "Overview of the epidemiology, microbiology, and pathogenesis of Leptospira spp. in humans," Microbes and Infection, vol. 2, no. 10, pp. 1265-1276, 2000.

[8] S. X. Ren, G. Fu, X. G. Jiang et al., "Unique physiological and pathogenic features of Leptospira interrogans revealed by whole-genome sequencing," Nature, vol. 422, no. 6934, pp. 888-893, 2003.
[9] A. L. T. O. Nascimento, S. Verjovski-Almeida, M. A. Van Sluys et al., "Genome features of Leptospira interrogans serovar Copenhageni," Brazilian Journal of Medical and Biological Research, vol. 37, no. 4, pp. 459-478, 2004.

[10] A. L. T. O. Nascimento, A. I. Ko, E. A. L. Martins et al., "Comparative Genomics of two Leptospira interrogans serovars reveals novel insights into physiology and pathogenesis," Journal of Bacteriology, vol. 186, no. 7, pp. 2164-2172, 2004.

[11] D. M. Bulach, R. L. Zuerner, P. Wilson et al., "Genome reduction in Leptospira borgpetersenii reflects limited transmission potential," Proceedings of the National Academy of Sciences of the United States of America, vol. 103, no. 39, pp. 14560-14565, 2006.

[12] M. Picardeau, D. M. Bulach, C. Bouchier et al., "Genome sequence of the saprophyte Leptospira biflexa provides insights into the evolution of Leptospira and the pathogenesis of leptospirosis," PLoS One, vol. 3, no. 2, Article ID e1607, 2008.

[13] J. Matsunaga, M. A. Barocchi, J. Croda et al., "Pathogenic Leptospira species express surface-exposed proteins belonging to the bacterial immunoglobulin superfamily," Molecular Microbiology, vol. 49, no. 4, pp. 929-945, 2003.

[14] P. Ristow, P. Bourhy, F. W. da Cruz McBride et al., "The OmpAlike protein Loa22 is essential for Leptospiral virulence," PLoS pathogens, vol. 3, no. 7, article e97, 2007.

[15] M. V. Atzingen, A. S. Barbosa, T. De Brito et al., "Lsa21, a novel leptospiral protein binding adhesive matrix molecules and present during human infection," BMC Microbiology, vol. 8, article no. 70, 2008.

[16] Y. Luo, Y. Liu, D. Sun et al., "InvA protein is a Nudix hydrolase required for infection by pathogenic Leptospira in cell lines and animals," The Journal of Biological Chemistry, vol. 286, no. 42, pp. 36852-36863, 2011.

[17] E. C. Boyle and B. B. finlay, "Bacterial pathogenesis: exploiting cellular adherence," Current Opinion in Cell Biology, vol. 15, no. 5, pp. 633-639, 2003.

[18] A. S. Barbosa, P. A. E. Abreu, F. O. Neves et al., "A newly identified leptospiral adhesin mediates attachment to laminin," Infection and Immunity, vol. 74, no. 11, pp. 6356-6364, 2006.

[19] M. T. Longhi, T. R. Oliveira, E. C. Romero et al., "A newly identified protein of Leptospira interrogans mediates binding to laminin," Journal of Medical Microbiology, vol. 58, no. 10, pp. 1275-1282, 2009.

[20] H. A. Choy, M. M. Kelley, T. L. Chen, A. K. Møller, J. Matsunaga, and D. A. Haake, "Physiological osmotic induction of Leptospira interrogans adhesion: LigA and LigB bind extracellular matrix proteins and fibrinogen," Infection and Immunity, vol. 75, no. 5, pp. 2441-2450, 2007.

[21] B. Stevenson, H. A. Choy, M. Pinne et al., "Leptospira interrogans endostatin-like outer membrane proteins bind host fibronectin, laminin and regulators of complement," PLoS One, vol. 2, no. 11, Article ID e1188, 2007.

[22] P. Hauk, F. Macedo, E. C. Romero et al., "In LipL32, the major leptospiral lipoprotein, the $\mathrm{C}$ terminus is the primary immunogenic domain and mediates interaction with collagen IV and plasma fibronectin," Infection and Immunity, vol. 76, no. 6, pp. 2642-2650, 2008.

[23] D. E. Hoke, S. Egan, P. A. Cullen, and B. Adler, "LipL32 is an extracellular matrix-interacting protein of Leptospira spp. and Pseudoalteromonas tunicata," Infection and Immunity, vol. 76, no. 5, pp. 2063-2069, 2008.

[24] M. V. Atzingen, R. M. Gómez, M. Schattner et al., "Lp95, a novel leptospiral protein that binds extracellular matrix components and activates e-selectin on endothelial cells," Journal of Infection, vol. 59, no. 4, pp. 264-276, 2009. 
[25] E. Carvalho, A. S. Barbosa, R. M. Gómez et al., "Leptospiral TlyC is an extracellular matrix-binding protein and does not present hemolysin activity," FEBS Letters, vol. 583, no. 8, pp. 1381-1385, 2009.

[26] M. L. Vieira, Z. M. de Morais, A. P. Gonçales, E. C. Romero, S. A. Vasconcellos, and A. L. T. O. Nascimento, "Lsa63, a newly identified surface protein of Leptospira interrogans binds laminin and collagen IV,' Journal of Infection, vol. 60, no. 1, pp. 52-64, 2010.

[27] K. Lähteenmäki, P. Kuusela, and T. K. Korhonen, "Bacterial plasminogen activators and receptors," FEMS Microbiology Reviews, vol. 25, no. 5, pp. 531-552, 2001.

[28] J. L. Coleman, T. J. Sellati, J. E. Testa, R. R. Kew, M. B. Furie, and J. L. Benach, "Borrelia burgdorferi binds plasminogen, resulting in enhanced penetration of endothelial monolayers," Infection and Immunity, vol. 63, no. 7, pp. 2478-2484, 1995.

[29] M. S. Klempner, R. Noring, M. P. Epstein et al., "Binding of human plasminogen and urokinase-type plasminogen activator to the Lyme disease spirochete, Borrelia burgdorferi," Journal of Infectious Diseases, vol. 171, no. 5, pp. 1258-1265, 1995.

[30] L. T. Hu, G. Perides, R. Noring, and M. S. Klempner, "Binding of human plasminogen to Borrelia burgdorferi," Infection and Immunity, vol. 63, no. 9, pp. 3491-3496, 1995.

[31] J. L. Coleman, J. A. Gebbia, J. Piesman, J. L. Degen, T. H. Bugge, and J. L. Benach, "Plasminogen is required for efficient dissemination of B. burgdorferi in ticks and for enhancement of spirochetemia in mice," Cell, vol. 89, no. 7, pp. 1111-1119, 1997.

[32] J. L. Coleman and J. L. Benach, "Use of the plasminogen activation system by microorganisms," Journal of Laboratory and Clinical Medicine, vol. 134, no. 6, pp. 567-576, 1999.

[33] J. L. Coleman and J. L. Benach, "The generation of enzymatically active plasmin on the surface of spirochetes," Methods, vol. 21, no. 2, pp. 133-141, 2000.

[34] A. Nordstrand, A. Shamaei-Tousi, A. Ny, and S. Bergström, "Delayed invasion of the kidney and brain by Borrelia crocidurae in plasminogen-deficient mice," Infection and Immunity, vol. 69, no. 9, pp. 5832-5839, 2001.

[35] W. B. Haile, J. L. Coleman, and J. L. Benach, "Reciprocal upregulation of urokinase plasminogen activator and its inhibitor, PAI-2, by Borrelia burgdorferi affects bacterial penetration and host-inflammatory response," Cellular Microbiology, vol. 8, no. 8, pp. 1349-1360, 2006.

[36] M. L. Vieira, S. A. Vasconcellos, A. P. Gonçales, Z. M. De Morais, and A. L. T. O. Nascimento, "Plasminogen acquisition and activation at the surface of Leptospira species lead to fibronectin degradation," Infection and Immunity, vol. 77, no. 9, pp. 4092-4101, 2009.

[37] M. L. Vieira, M. V. Atzingen, T. R. Oliveira et al., "In vitro identification of novel plasminogen-binding receptors of the pathogen Leptospira interrogans," PLoS One, vol. 5, no. 6, p. e11259, 2010.

[38] R. Oliveira, Z. M. de Morais, A. P. Gonçales, E. C. Romero, S. A. Vasconcellos, and A. L. T. O. Nascimento, "Characterization of novel OmpA-like protein of Leptospira interrogans that binds extracellular matrix molecules and plasminogen," PLoS One, vol. 6, no. 7, Article ID e21962, 2011.

[39] R. S. Mendes, M. Von Atzingen, Z. M. de Morais et al., "The novel leptospiral surface adhesin Lsa20 binds laminin and human plasminogen and is probably expressed during infection," Infection and Immunity, vol. 79, no. 11, pp. 46574667, 2011.
[40] R. F. Domingos, M. L. Vieira, E. C. Romero et al., "Features of two proteins of Leptospira interrogans with potential role in host-pathogen interactions," BMC Microbiology, vol. 12, article 50, 2012.

[41] M. L. Vieira, Z. M. de Morais, S. A. Vasconcellos, E. C. Romero, and A. L. T. O. Nascimento, "In vitro evidence for immune evasion activity by human plasmin associated to pathogenic Leptospira interrogans," Microbial Pathogenesis, vol. 51, no. 5, pp. 360-365, 2011.

[42] L. H. Turner, "Leptospirosis III. Maintenance, isolation and demonstration of leptospires," Transactions of the Royal Society of Tropical Medicine and Hygiene, vol. 64, no. 4, pp. 623-646, 1970.

[43] J. L. Coleman, E. J. Roemer, and J. L. Benach, "Plasmincoated Borrelia burgdorferi degrades soluble and insoluble components of the mammalian extracellular matrix," Infection and Immunity, vol. 67, no. 8, pp. 3929-3936, 1999.

[44] K. Nakai and P. Horton, "PSORT: a program for detecting sorting signals in proteins and predicting their subcellular localization," Trends in Biochemical Sciences, vol. 24, no. 1, pp. 34-35, 1999.

[45] K. Nakai and M. Kanehisa, "Expert system for predicting protein localization sites in gram-negative bacteria," Proteins: Structure, Function and Genetics, vol. 11, no. 2, pp. 95-110, 1991.

[46] I. Letunic, R. R. Copley, B. Pils, S. Pinkert, J. Schultz, and P. Bork, "SMART 5: domains in the context of genomes and networks," Nucleic Acids Research, vol. 34, pp. D257-260, 2006.

[47] J. Schultz, F. Milpetz, P. Bork, and C. P. Ponting, "SMART, a simple modular architecture research tool: identification of signaling domains," Proceedings of the National Academy of Sciences of the United States of America, vol. 95, no. 11, pp. 5857-5864, 1998.

[48] R. D. Finn, J. Mistry, B. Schuster-Böckler et al., "Pfam: clans, web tools and services," Nucleic Acids Research, vol. 34, pp. D247-251, 2006.

[49] A. S. Juncker, H. Willenbrock, G. Von Heijne, S. Brunak, H. Nielsen, and A. Krogh, "Prediction of lipoprotein signal peptides in Gram-negative bacteria," Protein Science, vol. 12, no. 8, pp. 1652-1662, 2003.

[50] C. A. Brissette, K. Haupt, D. Barthel et al., "Borrelia burgdorferi infection-associated surface proteins ErpP, ErpA, and ErpC bind human plasminogen," Infection and Immunity, vol. 77, no. 1, pp. 300-306, 2009.

[51] R. D. Pathirana, N. M. O’Brien-Simpson, P. D. Veith, P. F. Riley, and E. C. Reynolds, "Characterization of proteinaseadhesin complexes of Porphyromonas gingivalis," Microbiology, vol. 152, no. 8, pp. 2381-2394, 2006.

[52] Y. P. Lin, D. W. Lee, S. P. McDonough, L. K. Nicholson, Y. Sharma, and Y. F. Chang, "Repeated domains of Leptospira immunoglobulin-like proteins interact with elastin and tropoelastin," Journal of Biological Chemistry, vol. 284, no. 29, pp. 19380-19391, 2009.

[53] M. L. Vieira, D. C. Pimenta, Z. M. de Morais, and A. L. Nascimento, "Proteome analysis of Leptospira interrogans virulent strain," The Open Microbiology Journal, vol. 3, pp. 6974, 2009.

[54] T. Meri, R. Murgia, P. Stefanel, S. Meri, and M. Cinco, "Regulation of complement activation at the C3-level by serum resistant leptospires," Microbial Pathogenesis, vol. 39, no. 4, pp. 139-147, 2005.

[55] D. A. Haake and J. Matsunaga, "Characterization of the leptospiral outer membrane and description of three novel 
leptospiral membrane proteins," Infection and Immunity, vol. 70, no. 9, pp. 4936-4945, 2002.

[56] D. A. Haake, G. Chao, R. L. Zuerner et al., "The leptospiral major outer membrane protein LipL32 is a lipoprotein expressed during mammalian infection," Infection and Immunity, vol. 68, no. 4, pp. 2276-2285, 2000.

[57] K. C. Young, G. Y. Shi, D. H. Wu et al., "Plasminogen activation by streptokinase via a unique mechanism," Journal of Biological Chemistry, vol. 273, no. 5, pp. 3110-3116, 1998.

[58] H. E. McCoy, C. C. Broder, and R. Lottenberg, "Streptokinases produced by pathogenic group $\mathrm{C}$ streptococci demonstrate species-specific plasminogen activation," Journal of Infectious Diseases, vol. 164, no. 3, pp. 515-521, 1991.

[59] H. R. Lijnen, F. De Cock, B. Van Hoef, B. Schlott, and D. Collen, "Characterization of the interaction between plasminogen and staphylokinase," European Journal of Biochemistry, vol. 224, no. 1, pp. 143-149, 1994.

[60] B. Schlott, K. H. Gührs, M. Hartmann, A. Röcker, and D. Collen, "NH2-terminal structural motifs in staphylokinase required for plasminogen activation," Journal of Biological Chemistry, vol. 273, no. 35, pp. 22346-22350, 1998.

[61] K. Okada, S. Ueshima, T. Takaishi, H. Yuasa, H. Fukao, and O. Matsuo, "Effects of fibrin and $\alpha_{2}$-Antiplasmin on plasminogen activation by staphylokinase," American Journal of Hematology, vol. 53, no. 3, pp. 151-157, 1996.

[62] O. A. Sodeinde, Y. V. B. K. Subrahmanyam, K. Stark, T. Quan, Y. Bao, and J. D. Goguen, "A surface protease and the invasive character of plague," Science, vol. 258, no. 5084, pp. 10041007, 1992.

[63] S. P. Leytus, L. K. Bowles, J. Konisky, and W. F. Mangel, "Activation of plasminogen to plasmin by a protease associated with the outer membrane of Escherichia coli," Proceedings of the National Academy of Sciences of the United States of America, vol. 78, no. 3 I, pp. 1485-1489, 1981.

[64] Z. Li, V. A. Ploplis, E. L. French, and M. D. P. Boyle, "Interaction between group A streptococci and the plasmin(ogen) system promotes virulence in a mouse skin infection model," Journal of Infectious Diseases, vol. 179, no. 4, pp. 907-914, 1999.

[65] D. Collen, G. Tytgat, H. Claeys, M. Verstraete, and P. Wallén, "Metabolism of plasminogen in healthy subjects: effect of tranexamic acid," Journal of Clinical Investigation, vol. 51, no. 6, pp. 1310-1318, 1972.

[66] M. A. Barocchi, A. I. Ko, M. Galvão Reis, K. L. McDonald, and L. W. Riley, "Rapid translocation of polarized MDCK cell monolayers by Leptospira interrogans, an invasive but nonintracellular pathogen," Infection and Immunity, vol. 70, no. 12, pp. 6926-6932, 2002.

[67] J. Malmström, M. Beck, A. Schmidt, V. Lange, E. W. Deutsch, and R. Aebersold, "Proteome-wide cellular protein concentrations of the human pathogen Leptospira interrogans," Nature, vol. 460, no. 7256, pp. 762-765, 2009.

[68] P. A. Cullen, S. J. Cordwell, D. M. Bulach, D. A. Haake, and B. Adler, "Global analysis of outer membrane proteins from Leptospira interrogans serovar Lai," Infection and Immunity, vol. 70, no. 5, pp. 2311-2318, 2002.

[69] J. E. Nally, J. P. Whitelegge, S. Bassilian, D. R. Blanco, and M. A. Lovett, "Characterization of the outer membrane proteome of Leptospira interrogans expressed during acute lethal infection," Infection and Immunity, vol. 75, no. 2, pp. 766-773, 2007.

[70] M. Candela, M. Centanni, J. Fiori et al., "DnaK from Bifidobacterium animalis subsp. lactis is a surface-exposed human plasminogen receptor upregulated in response to bile salts," Microbiology, vol. 156, no. 6, pp. 1609-1618, 2010.

[71] S. V. Nogueira, F. L. Fonseca, M. L. Rodrigues et al., "Paracoccidioides brasiliensis enolase is a surface protein that binds plasminogen and mediates interaction of yeast forms with host cells," Infection and Immunity, vol. 78, no. 9, pp. 4040-4050, 2010.

[72] R. Lottenberg, C. C. Broder, M. D. Boyle, S. J. Kain, B. L. Schroeder, and R. 3rd. Curtiss, "Cloning, sequence analysis, and expression in Escherichia coli of a streptococcal plasmin receptor," Journal of Bacteriology, vol. 174, no. 16, pp. 52045210, 1992.

[73] A. M. Floden, J. A. Watt, and C. A. Brissette, "Borrelia burgdorferi enolase is a surface-exposed plasminogen binding protein," PLoS One, vol. 6, no. 11, Article ID e27502, 2011.

[74] A. M. Blom, T. Hallström, and K. Riesbeck, "Complement evasion strategies of pathogens-Acquisition of inhibitors and beyond," Molecular Immunology, vol. 46, no. 14, pp. 28082817, 2009.

[75] J. D. Lambris, D. Ricklin, and B. V. Geisbrecht, "Complement evasion by human pathogens," Nature Reviews Microbiology, vol. 6, no. 2, pp. 132-142, 2008.

[76] P. F. Zipfel, R. Würzner, and C. Skerka, "Complement evasion of pathogens: common strategies are shared by diverse organisms," Molecular Immunology, vol. 44, no. 16, pp. 38503857, 2007.

[77] S. H. M. Rooijakkers and J. A. G. van Strijp, "Bacterial complement evasion," Molecular Immunology, vol. 44, no. 1-3, pp. 23-32, 2007.

[78] M. Gamberini, R. M. Gómez, M. V. Atzingen et al., "Wholegenome analysis of Leptospira interrogans to identify potential vaccine candidates against leptospirosis," FEMS Microbiology Letters, vol. 244, no. 2, pp. 305-313, 2005.

[79] R. M. Gómez, M. L. Vieira, M. Schattner et al., "Putative outer membrane proteins of Leptospira interrogans stimulate human umbilical vein endothelial cells (HUVECS) and express during infection," Microbial Pathogenesis, vol. 45, no. 5-6, pp. 315-322, 2008.

[80] F. O. Neves, P. A. E. Abreu, S. A. Vasconcellos, Z. M. De Morais, E. C. Romero, and A. L. T. O. Nascimento, "Identification of a novel potential antigen for early-phase serodiagnosis of leptospirosis," Archives of Microbiology, vol. 188, no. 5, pp. 523-532, 2007.

[81] T. R. Oliveira, M. T. Longhi, Z. M. De Morais et al., "Evaluation of leptospiral recombinant antigens MPL17 and MPL21 for serological diagnosis of leptospirosis by enzyme-linked immunosorbent assays," Clinical and Vaccine Immunology, vol. 15, no. 11, pp. 1715-1722, 2008. 


\title{
MANUSCRITO SUBMETIDO- Adhesins of Leptospira interrogans mediate the
}

\section{interaction to fibrinogen and inhibit fibrin clot formation in vitro}

\author{
Rosane Oliveira $^{1,2}$, Renan F. Domingos ${ }^{1,2}$, Gabriela H. Siqueira ${ }^{1,2}$, Luis G. Fernandes ${ }^{1,2}$, Natalie M. \\ Souza $^{1,2}$, Monica L. Vieira ${ }^{1}$, Zenaide M. de Morais ${ }^{3}$, Silvio A. Vasconcellos ${ }^{3}$ and Ana L. T. O. \\ Nascimento ${ }^{1,2, *}$
}

${ }^{1}$ Centro de Biotecnologia, Instituto Butantan, Avenida Vital Brazil, 1500, 05503-900, São Paulo, SP,
Brazil; ${ }^{2}$ Programa Interunidades em Biotecnologia, Instituto de Ciências Biomédicas, USP, Avenida
Prof. Lineu Prestes, 1730, 05508-900, São Paulo, SP, Brazil; ${ }^{3}$ Laboratorio de Zoonoses Bacterianas
do VPS, Faculdade de Medicina Veterinária e Zootecnia, USP, Avenida Prof. Dr. Orlando Marques de

Paiva, 87, 05508-270, São Paulo, SP, Brazil.

\section{ABSTRACT}

We report in this work that Leptospira strains, virulent $L$. interrogans serovar Copenhageni, attenuated $L$. interrogans serovar Copenhageni and saprophytic $L$. biflexa serovar Patoc are capable of binding fibrinogen $(\mathrm{Fg})$. The interaction of leptospires with $\mathrm{Fg}$ inhibits thrombin- induced fibrin clot formation that may affect the haemostatic equilibrium. Additionally, we show that plasminogen (PLG)/plasmin ( $\mathrm{CHOU}$ et al., 2012) generation on the surface of Leptospira causes degradation of human $\mathrm{Fg}$. The data suggest that PLA-coated leptospires were capable to employ their proteolytic activity to decrease one substrate of the coagulation cascade. We also present six leptospiral adhesins and PLG- interacting proteins, rLIC12238, Lsa33, Lsa30, OmpL1, rLIC11360 and rLIC11975, as novel Fg-binding proteins. The recombinant proteins interact with $\mathrm{Fg}$ in a dose-dependent and saturable fashion when increasing protein concentration were set to react to a fix human $\mathrm{Fg}$ concentration. The calculated dissociation equilibrium constants $\left(K_{D}\right)$ of these reactions ranged from $733.3 \pm$ 276.8 to $128+89.9 \mathrm{nM}$ for rLIC12238 and Lsa33, respectively. The interaction of recombinant proteins with human $\mathrm{Fg}$ resulted in inhibition of fibrin clot by thrombin-catalyzed reaction, suggesting that these versatile proteins could mediate $\mathrm{Fg}$ interaction in Leptospira. Our data reveal for the first time possible mechanisms by which fibrinolysis occur during leptospirosis. Moreover, decreasing fibrin clot would cause an imbalance of the coagulation cascade that may facilitate bleeding and help bacteria dissemination.

\section{AUTHOR SUMMARY}

Leptospirosis is probably the most widespread zoonosis in the world. Caused by spirochaetes of the genus Leptospira, it has greater incidence in tropical and subtropical regions. The disease has become prevalent in cities with sanitation problems and a large population of urban rodent reservoirs, which contaminate the environment through their urine. The control of the disease has been hampered by the lack of prophylactic interventions. Understanding the mechanisms involved in pathogenesis of leptospirosis should contribute to new strategies that would help fight the disease. We show in this work that Leptospira strains, virulent, attenuated or saprophytic are capable of binding fibrinogen (Fg). The interaction of leptospires with $\mathrm{Fg}$ inhibits the formation of fibrin clot that may result of an imbalance in the haemostatic equilibrium. In addition, we show that plasminogen (PLG)/plasmin (PLA) generation on the surface of leptospires can lead to $\mathrm{Fg}$ degradation, showing evidence of possible route of fibrinolysis in leptospirosis. We also present six leptospiral proteins, previously shown to adhere to extracellular matrix (ECM) components and plasminogen (PLG), as novel Fg-binding proteins. These proteins were able of inhibiting fibrin clot formation by thrombincatalyzed reaction, suggesting that in Leptospira these multifunctional proteins could mediate $\mathrm{Fg}$ interaction. Our data suggest possible mechanisms that leptospires could employ to interfere with the coagulation cascade and fibrinolytic system that might lead to bacteria spreading. 


\section{INTRODUCTION}

The spirochete Leptospira interrogans is a highly invasive pathogen and the causal agent of leptospirosis, one of the most widespread zoonosis of human and veterinary concern (FAINE et al., 1999a). The transmission occurs through contact with environmental water contaminated by leptospires shed in the urine of animal carriers (SETTE; RAPPUOLI, 2010). Humans are accidental and terminal hosts in the transmission process of leptospirosis. The leptospires enter the body via abrasions on skin or actively through mucosa, spreading to any tissue, and colonizing target organs (MALMSTROM et al., 2009). Leptospira can cause damage of the endothelium of small blood vessels, leading to hemorrhage and localized ischemia in multiple organs. As a consequence, renal tubular necrosis, hepatocellular damage and development of leptospirosis-associated pulmonary hemorrhage syndrome (LPHS) may occur in the host (DALEY, PETERS;LARSEN, 2008). The mechanisms responsible for bleeding in leptospirosis are poorly understood. Hemolysins could play an important role in this toxic response and several genes coding for predicted hemolysins were identified in the genome sequencing $L$. interrogans (ALBERTS et al., 2007). Yet, when evaluated, these proteins failed to show hemolytic activity in human erythrocytes (VARKI et al., 2009).

Fg and PLG are key proteins in the coagulation cascade and fibrinolysis, respectively, and critical determinants of bacterial virulence and host defense (FRANTZ, STEWART;WEAVER, 2010). Fg is the major clotting protein present in blood plasma with an important role in blood coagulation and thrombosis. PLG under the action of its activators generates PLA, a serine-protease capable of degrading ECM components, fibrin, facilitating the pathogen penetration and invasion (LODISH et al., 2000).

We have previously shown that PLAassociated Leptospira renders the bacteria with proteolytic activity capable of degrading ECM components (LODISH et al., 2000) that in turn, may help bacterial penetration and dissemination. Furthermore, PLA-coated leptospires have also shown to degrade IgG and $\mathrm{C} 3 \mathrm{~b}$ that could facilitate the bacterial immune evasion (MUIZNIEKS, WEISS;KEELEY, 2010). The adhesion of physiological osmotically induced Leptospira with Fg was described but their effect on fibrin formation was not ascertained (HAYES et al., 2011). The leptospiral proteins LigB and OmpL37 were shown to interact with $\mathrm{Fg}$ and LigB was reported to reduce fibrin clot formation (LJUNGH; WADSTROM, 1996).

We thus decided to evaluate if $\mathrm{Fg}$ associated Leptospira was capable to inhibit the fibrin clot formation and the ability of six recombinant proteins to act as leptospiral Fgreceptors. We report that Leptospira strains and the recombinant ECM- and PLGinteracting proteins, rLIC12238 (PARVEEN; LEONG, 2000), Lsa33 (CAMERON et al., 2004), Lsa30 (MILLER, MILLER;WHITE, 1966), OmpL1 (ITO; YANAGAWA, 1987) and rLIC11360 and rLIC11975 (Siqueira et al., submitted to publication), are capable to adhere to $\mathrm{Fg}$. We also show that this interaction inhibits fibrin clot formation by thrombin-catalyzed reaction. Moreover, PLAcoated Leptospira was capable to degrade Fg. Altogether, the results suggest possible pathways that Leptospira may interfere with the coagulation/bleeding process.

\section{METHODS}

Ethics Statement. All animal studies were approved by the Ethical Committee for Animal Research of Instituto Butantan, São Paulo, SP, Brazil under protocol $\mathrm{n}^{\circ}$ 798/11. The Committee in Animal Research in Instituto Butantan adopts the guidelines of the Brazilian College of Animal Experimentation.

Leptospira strains and culture conditions. The non-pathogenic L. biflexa serovar Patoc strain Patoc 1, the pathogenic attenuated $L$. interrogans serovar Copenhageni strain M-20 and the virulent strains of $L$. interrogans serovar Kennewicki strain Pomona Fromm (LPF) and serovar Copenhageni strain Fiocruz L1-130 were cultured at $28^{\circ} \mathrm{C}$ under aerobic conditions in liquid EMJH medium (Difco $尺$ ) with $10 \%$ rabbit serum, enriched with Lasparagine (wt/vol: $0.015 \%$ ), sodium pyruvate (wt/vol: $0.001 \%$ ), calcium chloride (wt/vol: $0.001 \%$ ), magnesium chloride (wt/vol: $0.001 \%)$, peptone (wt/vol:0.03\%) and meat extract (wt/vol:0.02\%) (Turner, 1970). Leptospira cultures are maintained in Faculdade de Medicina Veterinária e Zootecnia, USP, São Paulo, SP, Brazil.

Bioinformatics characterization of the proteins. Predicted coding sequences (CDSs ) were analyzed for their cellular localization by PSORT program, http://psort.nibb.ac.jp (THOMAS; HIGBIE, 1990). The web servers SMART, $\quad$ http://smart.embl-heidelberg.de/ 
(BARBOSA et al., 2006), PFAM, http://www.sanger.ac.uk/Software/Pfam/ (BRE INER et al., 2009), and LipoP, http://www.cbs.dtu.dk/services/LipoP/ (BARBO SA et al., 2006) were used to search for predicted functional and structural domains within the amino acid sequences of the CDSs.

Cloning, expression and purification of recombinant proteins. Amplification of the CDSs was performed by PCR from $L$. interrogans serovar Copenhageni strain M-20 genomic DNA using complementary primer pairs (Table 1). The gene sequences were amplified without the signal peptide tag. The final constructs were verified by DNA sequencing on an $\mathrm{ABI}$ Prism 3730_L sequencer (Seq- Wright, Houston, TX) with appropriate vector-specific T7 (F: TAATACGACTCACTATAGGG) and pAE (R:CAGCAGCCAACTCAGTTCCT) primers. Detailed of cloning, expression and purification of the recombinant proteins Lsa33, rLIC12238, Lsa30, OmpL1, rLIC11360 and rLIC11975 has been previously described (VERMA et al., 2006) (Siqueira et al., manuscript submitted to publication).

Antiserum. Five female BALB/c mice (4-6 weeks old) were immunized subcutaneously with $10 \mu \mathrm{g}$ of each recombinant protein adsorbed in $10 \%$ ( $\mathrm{vol} / \mathrm{vol})$ of Alhydrogel ( $2 \%$ $\mathrm{Al}(\mathrm{OH})_{3}$, Brenntag Biosector, Denmark), used as adjuvant. Two subsequent booster injections were given at 2-week intervals with the same recombinant proteins preparation. Negative - control mice were injected with PBS plus Alhydrogel. Two weeks after each immunization, the mice were bled from the retro - orbital plexus and the pooled sera were analyzed by ELISA for determination of antibody titers.

Binding of soluble human Fg to Leptospira. For accessing the leptospiral binding to soluble human $\mathrm{Fg}$, ELISA plates were coated with $10^{8}$ leptospires per well, allowed to set for $3 \mathrm{~h}$ at $37^{\circ} \mathrm{C}$ and then blocked with $200 \mu \mathrm{L}$ of phosphate-buffered saline containing $0.05 \%$ Tween (PBS-T) with 10\% non-fat dry milk. After $2 \mathrm{~h}$ incubation, plates were washed with PBS-T and then $100 \mu \mathrm{L}$ of a Fg solution (FgSigma) $(10 \mu \mathrm{g} / \mathrm{mL}$ in low salt PBS - IsPBScontaining $50 \mathrm{mM} \mathrm{NaCl}$ ) were added per well and incubation proceeded for $2 \mathrm{~h}$. After extensive washing, $100 \mu \mathrm{L}$ of solution containing goat anti-Fg (1:25,000 in IsPBS) were added per well and incubation was carried out for $1 \mathrm{~h}$ at $37^{\circ} \mathrm{C}$. After three washings, $100 \mu \mathrm{L}$ of solution containing peroxidase (HRP)-conjugated rabbit anti-goat IgG (1:50,000 in IsPBS) were added per well and the reaction continued for $1 \mathrm{~h}$ at $37^{\circ} \mathrm{C}$. The wells were washed three times, and $O$ phenylenediamine (OPD) $(1 \mathrm{mg} / \mathrm{mL})$ in citrate phosphate buffer ( $\mathrm{pH} 5.0$ ) plus $1 \mu \mathrm{L} / \mathrm{mL} \mathrm{H}_{2} \mathrm{O}_{2}$ was added (100 $\mu \mathrm{L}$ per well). The reaction was allowed to proceed for $10 \mathrm{~min}$ and interrupted by the addition of $50 \mu \mathrm{L}$ of $8 \mathrm{M} \mathrm{H}_{2} \mathrm{SO}_{4}$. Readings were taken at $492 \mathrm{~nm}$ in a microplate reader (Multiskan EX; Thermo Fisher Scientific, Helsinki, Finland). The binding of $\mathrm{Fg}$ to each leptospiral strain was performed in triplicate and a negative control in which $\mathrm{Fg}$ was omitted was included. BSA was used as a negative control of binding. For statistical analyses, the binding of $\mathrm{Fg}$ to each leptospiral strain was compared to negative control using Student's two-tailed $t$ test.

Human $\mathrm{Fg}$ degradation by leptospires coated with PLA. Virulent L. interrogans serovar Kennewicki strain Pomona Fromm $\left(10^{8}\right.$ leptospires/sample) were treated in 200 $\mu \mathrm{L}$ IsPBS with the addition of: (a) $10 \mu \mathrm{g}$ PLG (b) 3U urokinase (uPA) (c) $10 \mu \mathrm{g}$ PLG and $3 \mathrm{U}$ UPA (PLA) or (d) no additions (untreated). The cells were incubated for $1 \mathrm{~h}$ at $37^{\circ} \mathrm{C}$ with the PLG, and for one more hour after the addition of UPA. The cells were washed three times with IsPBS, resuspended in $100 \mu \mathrm{L}$ IsPBS containing $15 \mathrm{mg} / \mathrm{mL}$ human purified $\mathrm{Fg}$ (Sigma, USA), and incubated for $16 \mathrm{~h}$ at $37^{\circ} \mathrm{C}$. As controls, one sample received $1 \mu \mathrm{g}$ aprotinin (Sigma, USA) to the Fg-leptospires incubation, and one sample containing only $\mathrm{Fg}$ (lacking leptospires) was employed. The leptospires were removed by centrifugation, 20 $\mu \mathrm{L}$ of the supernatants were separated by $8 \%$ SDS-PAGE and then transferred to nitrocellulose membranes in semi-dry equipment. The membranes were blocked by incubating overnight at $4^{\circ} \mathrm{C}$ with $5 \%$ non-fat dry milk and $1 \%$ BSA. The Fg detection was performed by incubations with anti-human $\mathrm{Fg}$ antibodies and secondary antibodies conjugated with HRP, followed by ECL (GE Healthcare) development.

\section{Effect of Fg-bound leptospires on fibrin clot} formation. Live leptospires $\left(10^{9}, 10^{7}, 10^{5}\right.$ cells $/ \mathrm{mL}$ ) were harvested at $6,000 \mathrm{rpm}$ for 20 $\mathrm{min}$ at room temperature, washed once with IsPBS, resuspended in $0.5 \mathrm{~mL}$ of IsPBS plus 1 $\mathrm{mg} / \mathrm{mL}$ of $\mathrm{Fg}$ (Sigma), and incubated for $2 \mathrm{~h}$ at $37^{\circ} \mathrm{C}$. ELISA plates were placed with 90 $\mu \mathrm{L} /$ well of leptospires plus $\mathrm{Fg}$ and $10 \mu \mathrm{L} /$ well of thrombin $(10 \mathrm{U} / \mathrm{mL}$ - Sigma). The fibrin clot formation was measured every $1 \mathrm{~min}$ for 10 $\min$ and then every $5 \mathrm{~min}$ for $35 \mathrm{~min}$ by an 
ELISA plate reader (Multiskan EX Thermo Fisher Scientific) at OD595 $\mathrm{nm}$. The positive control of the reaction employed $\mathrm{Fg}(1 \mathrm{mg} / \mathrm{mL})$ plus thrombin $(10 \mathrm{U} / \mathrm{mL})$ while in the negative control thrombin was omitted. For statistical analyses, inhibition of fibrin clot formation was compared with the positive control by Student's two tailed $t$ test.

Fg binding assay and dose-response curves. The binding of the recombinant proteins to $\mathrm{Fg}$ was evaluated by a modified ELISA, as follows: 96-well plates (Costar High Binding, Corning) were coated overnight in PBS at $4^{\circ} \mathrm{C}$ with $100 \mu \mathrm{L}$ of $10 \mu \mathrm{g} / \mathrm{mL}$ of the human $\mathrm{Fg}$ (Sigma); gelatin (Difco) was employed as negative control. Plates were washed three times with PBS-T and blocked for $2 \mathrm{~h}$ at $37^{\circ} \mathrm{C}$ with PBS with $10 \%$ (wt/vol) non-fat dry milk. The blocking solution was discarded and $100 \mu \mathrm{L}$ of $10 \mu \mathrm{g} / \mathrm{mL}$ recombinant proteins in PBS was incubated for $2 \mathrm{~h}$ at $37^{\circ} \mathrm{C}$. Wells were washed three times with PBS-T and incubated for $1 \mathrm{~h}$ at $37^{\circ} \mathrm{C}$ with polyclonal mouse antiserum produced against each recombinant protein. The serum dilution used was determined by titration curve with the corresponding recombinant protein and the value of 1.0 at OD492 $\mathrm{nm}$ was employed. These values are: 1:1,000 for rLIC12238; 1:750 for Lsa33; 1:500 for rLIC11975 and rLIC11360; 1:400 for Lsa30 and 1:800 for OmpL1. After incubation, plates were washed again and incubated with HRP-conjugated anti-mouse immunoglobulin $\mathrm{G}(\mathrm{lgG})$, diluted $1: 5,000$ in PBS. After three washings, $100 \mu \mathrm{L} /$ well of 1 $\mathrm{mg} / \mathrm{mL}$ OPD plus $1 \mu \mathrm{L} / \mathrm{mL} \quad \mathrm{H}_{2} \mathrm{O}_{2}$ in citrate phosphate buffer $(\mathrm{pH}$ 5.0) were added. The reactions were carried out for $15 \mathrm{~min}$ and stopped by the addition of $50 \mu \mathrm{L} /$ well of $\mathrm{H}_{2} \mathrm{SO}_{4}(8 \mathrm{M})$. Readings were taken at OD492 $\mathrm{nm}$. In another assay, the assessment of bound proteins was performed by incubation for $1 \mathrm{~h}$ at $37^{\circ} \mathrm{C}$ with monoclonal anti-polyhistidine-HRP (Sigma) at appropriate dilutions: 1:5,000 for rLIC12238; 1:10,000 for rLIC11975 and rLIC11360; 1:1,000 for Lsa30; 1:500 for Lsa33 and 1:400 for OmpL1. The reaction was developed with $1 \mathrm{mg} / \mathrm{mL}$ OPD plus $1 \mu \mathrm{L} / \mathrm{mL}$ $\mathrm{H}_{2} \mathrm{O}_{2}$, as described above. The rate of interaction of recombinant proteins to $\mathrm{Fg}$ was determined by measuring the reaction as a function of time. The OD492 $2_{\mathrm{nm}}$ value after $2 \mathrm{~h}$ interaction was considered the maximal binding $(100 \%)$ and was used for statistical analyses, using Student's two-tailed t test. For determination of dose-response curves of the binding of recombinant proteins to human $\mathrm{Fg}$, protein concentrations varying from 0 to 4,000 $\mathrm{nM}$ in PBS were used. For statistical analyses, the binding of recombinant proteins to human $\mathrm{Fg}$ was compared to its binding to gelatin by Student's two-tailed $t$ test.

Dissociation equilibrium constant $\left(K_{D}\right)$ for the binding of recombinant proteins to human Fg. The ELISA data were used to calculate the dissociation equilibrium constant $\left(\mathrm{K}_{\mathrm{D}}\right)$ according to the method previously described (MALMSTROM et al., 2009) based on the equation: $K_{D}=($ Amax. $[$ protein] $) / A)-$ [protein], where $A$ is the absorbance at a given protein concentration, Amax is the maximum absorbance for the ELISA plate reader (equilibrium), [protein] is the protein concentration and $\mathrm{K}_{D}$ is the dissociation equilibrium constant for a given absorbance at a given protein concentration (ELISA data point).

Effect of recombinant protein denaturing on the interaction with Fg. ELISA plates were coated overnight at $4^{\circ} \mathrm{C}$ with $100 \mu \mathrm{L}$ of 10 $\mu \mathrm{g} / \mathrm{mL} \mathrm{Fg}$. Plates were washed three times with PBS-T and blocked with $200 \mu \mathrm{L}$ of $10 \%$ $(\mathrm{wt} / \mathrm{vol})$ nonfat dry milk for $2 \mathrm{~h}$ at $37^{\circ} \mathrm{C}$. The recombinant proteins were denatured by incubation at $96^{\circ} \mathrm{C}$ for $10 \mathrm{~min}$; $1 \mu \mathrm{g}$ of each was added per well in $100 \mu \mathrm{L}$ of PBS. The recombinant proteins were allowed to attach to $\mathrm{Fg}$ at $37^{\circ} \mathrm{C}$ for $90 \mathrm{~min}$. After washing six times with PBS-T, bound recombinant proteins were detected by incubation with mouse serum raised against the respective protein (dilutions described above) at $37^{\circ} \mathrm{C}$ for $1 \mathrm{~h}$. After three washings with PBS-T, $100 \mu \mathrm{L}$ of a 1:5,000 dilution of HRP-conjugated rabbit anti-mouse IgG (Sigma) in PBS was added per well for $1 \mathrm{~h}$ at $37^{\circ} \mathrm{C}$. The detection was performed with OPD, as previously described. BSA or gelatin was used as negative control (data not shown). For statistical analyses, the attachment of denatured recombinant proteins to $\mathrm{Fg}$ was compared to untreated recombinants binding by the two-tailed t test $\left({ }^{*} P<0.05\right)$.

Antibody inhibition assay. 96-well plates were coated with $1 \mu \mathrm{g}$ of $\mathrm{Fg}$ in $100 \mu \mathrm{L}$ of PBS and allowed to set overnight at $4^{\circ} \mathrm{C}$. The wells were washed three times with PBS-T and then blocked with $200 \mu \mathrm{L}$ of $10 \%$ (wt/vol) nonfat dry milk for $2 \mathrm{~h}$ at $37^{\circ} \mathrm{C}$. Prior to the next step, the proteins were incubated for $1 \mathrm{~h}$ at $37^{\circ} \mathrm{C}$ with the respective antibodies diluted 1:50 in $100 \mu \mathrm{l}$ of PBS. After the incubation, each recombinant protein $(1 \mu \mathrm{g})$ was added per well in $100 \mu \mathrm{L}$ of PBS, and allowed to attach to $\mathrm{Fg}$ for $90 \mathrm{~min}$ at $37^{\circ} \mathrm{C}$. After washing six times with PBS-T, bound recombinant proteins were detected by adding monoclonal HRP-conjugated mouse anti-polyhistidine-HRP (Sigma) at dilutions 
described above. Incubation proceeded for $1 \mathrm{~h}$ at $37^{\circ} \mathrm{C}$. The detection was performed with OPD, as previously described. BSA or gelatin was used as negative control (data not shown). For statistical analyses, the attachment of blocked recombinant proteins to $\mathrm{Fg}$ was compared to the binding with the untreated proteins by the two-tailed t test $\left({ }^{*} P<0.05\right)$.

Fibrin clot formation inhibition assay in the presence of recombinant proteins. The assay of thrombin-catalyzed fibrin clot inhibition was performed in the presence of recombinant proteins. We have employed the concentration of recombinant proteins in which there was a binding saturation to $\mathrm{Fg}$. Recombinant proteins were resuspended in $0.5 \mathrm{~mL}$ of PBS plus $1 \mathrm{mg} / \mathrm{mL}$ of $\mathrm{Fg}$ and incubated for $2 \mathrm{~h}$ at $37^{\circ} \mathrm{C}$. ELISA plates were coated with $90 \mu \mathrm{L} /$ well of recombinant proteins plus $\mathrm{Fg}$ and $10 \mu \mathrm{L} /$ well of thrombin $(10 \mathrm{U} / \mathrm{mL})$. The fibrin clot formation was measured as previously described. Reduction of the fibrin clot formation was calculated by comparing the value of the last reading point, at $45 \mathrm{~min}$, with the positive control $(100 \%)$.

Metaperiodate treatment of $\mathrm{Fg}$. Microtitre wells were coated with $1 \mu \mathrm{g}$ of $\mathrm{Fg}$ in $50 \mathrm{mM}$ sodium acetate buffer, $\mathrm{pH} 5.0$, and incubated for $16 \mathrm{~h}$ at $4^{\circ} \mathrm{C}$. Wells were washed three times with the same buffer, and Fg was treated with sodium metaperiodate $(0-100 \mathrm{mM})$, in the same buffer for $15 \mathrm{~min}$ at $4^{\circ} \mathrm{C}$ in the dark. After three washes with $50 \mathrm{mM}$ sodium acetate buffer, wells were blocked with $200 \mu \mathrm{L}$ of $1 \%$ $\mathrm{BSA}$ for $1 \mathrm{~h}$ at $37^{\circ} \mathrm{C}$. Binding of recombinant proteins $(1 \mu \mathrm{g}$ in PBS per well) to metaperiodate - treated $\mathrm{Fg}$ was evaluated as described above.

Inhibition of live leptospires binding to $\mathrm{Fg}$ by recombinant proteins. ELISA plates were coated with $\mathrm{Fg}(1 \mu \mathrm{g} / \mathrm{well})$ in PBS and allowed to set overnight at $4^{\circ} \mathrm{C}$; the wells were then washed and blocked with $10 \%$ non-fat dry milk in PBS-T for $2 \mathrm{~h}$ at $37^{\circ} \mathrm{C}$. The blocking solution was discarded, and the wells were incubated for $90 \mathrm{~min}$ at $37^{\circ} \mathrm{C}$ with increasing concentrations of recombinant proteins ( 0 to $4.5 \mu \mathrm{M})$. After three washings, $100 \mu \mathrm{L} /$ well of $4 \times 10^{7}$ live $L$. interrogans serovar Copenhageni strain M-20 were added for $90 \mathrm{~min}$ at $37^{\circ} \mathrm{C}$. The unbound leptospires were washed and the quantification of bound leptospires was performed indirectly by anti-LipL32 antibodies produced in mice $(1: 4,000)$, based on the fact that LipL32 is a major expressed membrane leptospiral protein (VIEIRA, ATZINGEN et al., 2010); the procedure was followed by the addition of HRP-conjugated anti-mouse IgG antibodies, essentially as described in Atzingen et al., (2008) (LAHTEENMAKI, KUUSELA;KORHONEN, 2001). The detection was performed by OPD, as above described.

\section{RESULTS}

Adhesion of Leptospira spp. to $\mathrm{Fg}$ and inhibition of fibrin clot formation. We have evaluated the capability of soluble human $\mathrm{Fg}$ $(10 \mu \mathrm{g} / \mathrm{mL})$ to interact with immobilized strains of leptospires by ELISA. We performed the experiments using virulent $L$. interrogans serovar Copenhageni strain Fiocruz L1-130, pathogenic attenuated $L$. interrogans serovar Copenhageni strain M-20 and one saprophytic L. biflexa serovar Patoc strain Patoc 1. As a control, we have employed BSA. Figure 1A depicts one representative experiment showing that all strains tested were able of binding human $\mathrm{Fg}$, but the virulent strain was more efficient. We have assessed the effect of Leptospira-bound to $\mathrm{Fg}$ on the inhibition of thrombin-catalyzed fibrin clot formation. The reaction was analyzed with the same strains and readings were taken at OD595 $5_{\mathrm{nm}}$ every 1 min for the first $10 \mathrm{~min}$ and then every $5 \mathrm{~min}$ for $35 \mathrm{~min}$. The complete reaction, $\mathrm{Fg}$ plus thrombin, was used as a positive control while in the negative one, thrombin was missing. The determination was performed in two independent experiments and a representative assay is exposed in Figure 1B. The data show that all the strains studied promoted an inhibition of fibrin formation, although the pathogenic strains seem more competent. The results suggest that Leptospira could modulate fibrin clot formation.

PLA-associated leptospires on human Fg. The effect of PLA-coated virulent $L$. interrogans serovar Kennewicki strain Pomona Fromm on human $\mathrm{Fg}$ was evaluated by Western blotting using anti-human $\mathrm{Fg}$ antibodies (Fig. 1C). The results show that PLA generation on the surface of Leptospira cause degradation of human $\mathrm{Fg}$ (Fig. 1C, lane $5)$, which is not observed when one of the reaction components is missing (Fig. $1 \mathrm{C}$, lanes 1,2 , 3and 4) and completely prevented in the presence of a serine protease inhibitor, aprotinin (Fig. 1C, lane 6). The data suggest that PLA-coated leptospires were capable to employ their proteolytic activity to interfere with one of the coagulation cascade substrate.

Selection of putative surface proteins from genome sequences. The rationale for protein selection was mostly based on cellular localization, since surface proteins are 
potential receptors for $\mathrm{Fg}$. We have selected six proteins, all of them previously shown to be leptospiral adhesins, four were already published, rLIC12238 (LUO et al., 2000), Lsa33 (MATSUNAGA et al., 2005), Lsa30 (CONFER; AYALEW, 2013), OmpL1 (SMITH et al., 2007) and two, rLIC11360 and rLIC11975, are submitted to publication. Table 1 summarizes features of the selected proteins, gene locus, given name, gene conservation within the sequenced genomes, the sequences of primers used for cloning techniques and molecular mass.

\section{Expression and purification of recombinant} proteins. The amplified coding sequences, excluding the signal peptide tags, were cloned and expressed as full-length proteins in E. coli. The recombinant proteins were expressed with $6 \mathrm{XHis}$ tag at the $\mathrm{N}$-terminus and purified by nickel affinity chromatography, as previously described (PARSONS, LIN;ORBAN, 2006).

Interaction of leptospiral recombinant proteins with Fg. Proteins of Leptospira have been reported to bind $\mathrm{Fg}$ (BARBOSA et al., 2006). We thus decided to investigate whether the selected surface-exposed proteins were capable of binding human $\mathrm{Fg}$ in vitro. Six recombinant leptospiral proteins, expressed and purified in our laboratory, and gelatin, used as negative control, were individually immobilized onto 96-wells plates and incubated with human Fg. The binding was quantified by ELISA and the results obtained from three independent experiments are shown in Fig. 2. The protein bound to Fg was probed with the respective homolog polyclonal antiserum raised in mice (Fig. 2A) or with the monoclonal antibody anti-histidine tag (Fig. 2B). The percentage of binding for each protein with $\mathrm{Fg}$, measured as a function of time is shown in Fig. 2C. The protein rLIC11360 promptly reacted with $\mathrm{Fg}$ with $40 \%$ of binding achieved after 5 min reaction, contrasting with rLIC11975 that showed very low binding activity at this time (Fig. 2C). The binding of recombinant proteins to $\mathrm{Fg}$ was also assessed after blocking the proteins with the corresponding antibody (Fig. 2D) and after submitting them to denaturing conditions at $96^{\circ} \mathrm{C}$ for $10 \mathrm{~min}$ (Fig. 2E). The binding was totally inhibited by antibody-blocked protein in the case Lsa30, Lsa33, rLIC11975, rLIC12238 and rLIC11360, while a very low percentage of the binding remained for OmpL1 (8.4\%), suggesting the participation of nonimmunogenic epitopes on the interaction (Fig. 2D). The adhesion of heat-denatured proteins to Fg was almost totally abolished in the case of rLIC12238 and OmpL1, 24\% remained with rLIC11360, while $63-77 \%$ of the binding continued with Lsa30, Lsa33 and rLIC11975 (Fig. 2E), suggesting that with these last proteins epitopes involved in the binding were already exposed or the binding is based on linear epitopes rather than conformational ones.

Characterization of the binding of recombinant proteins to $\mathrm{Fg}$. The interactions between the recombinant proteins and $\mathrm{Fg}$ was assessed on a quantitative basis, as indicated in Fig. 3A. Dose-dependent and saturable binding was observed when increasing concentrations ( 0 to $4,000 \mathrm{nM}$ ) of recombinant proteins rLIC12238, Lsa33, OmpL1, rLIC11975 and rLIC11360, or (0 to 2,000) of Lsa30, were allowed to individually adhere to a fixed human $\mathrm{Fg}$ amount $(10 \mathrm{mg} / \mathrm{mL})$. Saturation was reached with all except Lsa30 protein, due to the impossibility to achieve this protein at higher concentrations. Based on the ELISA data, the calculated dissociation equilibrium constants $\left(K_{D}\right)$ for the recombinant proteins with Fg are depicted in Fig. 3B; the highest and the lowest $K_{D}$ values were for rLIC12238 $(733.3 \pm 276.8 \mathrm{nM})$ and Lsa33 (128 \pm 89.9 nM), respectively.

Effect of $\mathrm{Fg}$ oxidation on recombinant protein binding. In order to address the role of $\mathrm{Fg}$ sugar moieties in the interaction with recombinant proteins, $\mathrm{Fg}$ was oxidized by sodium metaperiodate, ranging from 5 to 100 $\mathrm{mM}$, at $4^{\circ} \mathrm{C}$ for $15 \mathrm{~min}$. The effect of periodate concentration on the binding with each protein is shown in Fig. 3C. This mild treatment ensures cleavage of vicinal carbohydrate hydroxyl groups, while polypeptide chain structure remains intact (MALMSTROM et al., 2009). Oxidation effect was dose-dependent and a considerable reduction $(83 \%)$ in attachment of rLIC11360 to metaperiodatetreated $\mathrm{Fg}$ was observed at a $100 \mathrm{mM}$ concentration of periodate, followed by $66 \%$ and $43 \%$ for rLIC11975 and Lsa30, respectively. Almost no reduction in the interaction of oxidized-Fg was obtained with the proteins Lsa33, OmpL1 and rLIC12238 (Fig. 3C). These results indicate that Fg sugar residues are important for the interaction of rLIC11360, rLIC11975 and Lsa30 proteins.

Inhibition of fibrin formation by recombinant proteins-bound to $\mathrm{Fg}$. Since Leptospira bound to $\mathrm{Fg}$ inhibited thrombincatalyzed fibrin formation, we decided to investigate whether the recombinant proteins bound to $\mathrm{Fg}$ were capable to mediate this interaction. Each recombinant protein was pre- 
incubated with $1 \mathrm{mg} / \mathrm{mL}$ of $\mathrm{Fg}$ at $37^{\circ} \mathrm{C}$ for $2 \mathrm{~h}$. The reaction mixtures were used to coat ELISA plates and $10 \mathrm{U} / \mathrm{mL}$ of thrombin was added per well. The fibrin clot formation was measured every $1 \mathrm{~min}$ for $10 \mathrm{~min}$ and then every $5 \mathrm{~min}$ for $35 \mathrm{~min}$. The percentage of inhibition was calculated as a function of time, taking the complete reaction at the last time-point, in the absence of proteins, as a $100 \%$ fibrin formation (positive control). In the negative control, thrombin was omitted from the reaction. The measurements were performed in triplicate and representative curves of two independent experiments are shown in Fig. 4A and the percentage of inhibition is illustrated in Fig. 4B. The proteins rLIC11360 and Lsa30 were not employed on these assays because they were kept at $\mathrm{pH} 12$ for solubility and thrombin is not active above $\mathrm{pH} 10$. The data show that the four proteins tested promoted an inhibition of $40-50 \%$ on the fibrin clot formation, suggesting a possible involvement of these proteins in the coagulation process.

Inhibition of live leptospires binding to $\mathrm{Fg}$ by recombinant proteins. The inhibitory effect exerted by recombinant proteins on leptospiral adherence to $\mathrm{Fg}$ was quantified by ELISA. Fg-coated microtiter wells were incubated with increasing concentration $(0-$ $4.5 \mu \mathrm{M})$ of rLIC12238 (A), rLIC11975 (B), Lsa23 (C), rLIC11360 (D), Lsa33 (E) and OmpL1 (F) for 90 min prior to the addition of $4 \times 10^{7} \quad$ L. interrogans serovar Copenhageni strain M-20. Wells were probed with antiLipL32 serum, given the fact that LipL32 is a major membrane leptospiral protein (PINNE, MATSUNAGA;HAAKE, 2012). The results are depicted in Figure $5 \mathrm{~A}$ to $\mathrm{F}$, and show that the proteins caused a modest, but significant reduction in the number of leptospires adhering to $\mathrm{Fg}\left({ }^{*} P<0.05\right)$ with $0.5,1.0,1.0,0.1,0.25$ and $1.0 \mu \mathrm{M}$ of rLIC12238, rLIC11975, rLIC11360, Lsa30, Lsa33 and OmpL1, respectively. We have performed three independent experiments with comparable results.

\section{DISCUSSION}

$\mathrm{Fg}$, a $340 \mathrm{kD}$ glycoprotein, is the major clotting protein present in blood plasma with an important role in coagulation and thrombosis. Activation of prothrombin to thrombin promotes the conversion of soluble $\mathrm{Fg}$ into insoluble fibrin to form a clot (BLOM, 2002). Several studies have suggested roles of PLG and Fg in host bacterial interactions (LIMA et al., 2013). The fibrinolytic system that generates PLA from PLG and its activators UPA, decomposes the fibrin clot by degrading fibrin (MEKALANOS, 1992). This system is negatively regulated by PLG activator inhibitor 1 (PAI-1). A balance between coagulation system and anticoagulation is necessary to avoid pathophysiological conditions, such as, bleeding and thrombosis (ATZINGEN et al., 2008).

Several Fg-binding proteins of important pathogens, such as, Staphylococcus aureus (VIEIRA, 2009), group B Streptococcus (VIEIRA, DE MORAIS et al., 2010), Lactobacillus salivarius (VIEIRA, DE MORAIS et al., 2010) and the spirochetes Treponema pallidum (KERR, 1999), T. denticola (ATZINGEN et al., 2009) have been reported and characterized. These Fg-binding proteins are bacterial surface or secreted adhesins that although acting through different mechanisms will ultimately lead to enhance the bacterial survival in the host (ATZINGEN et al., 2009).

The adhesion of virulent $L$. interrogans strain Fiocruz L1-130 to Fg has been shown to be induced by physiological osmolarity, but the effect of this binding on fibrin clot formation was not evaluated (PINNE, MATSUNAGA;HAAKE, 2012). The leptospiral proteins, LigA and LigB (CARVALHO et al., 2009) and OmpL37 have been described as Fg-binding proteins. In addition, the interaction of LigB with Fg was shown to inhibit thrombincatalyzed fibrin formation .

In this work, we have assessed the interaction of three leptospiral strains cultivated under normal conditions with $\mathrm{Fg}$. We have assayed virulent $L$. interrogans serovar Copenhageni Fiocruz L1-130, attenuated $L$. interrogans serovar Copenhageni $\mathrm{M}-20$ and non-pathogenic saprophytic $L$. biflexa serovar Patoc Patoc 1 and the effect of this binding on the thrombin-catalyzed fibrin formation. Moreover, we studied six leptospiral adhesinand PLG-binding proteins, rLIC12238, Lsa33 , Lsa30 , OmpL1 , rLIC11360 and rLIC11975 (Siqueira et al., manuscript submitted to publication) for their capacity to bind $\mathrm{Fg}$ and to inhibit fibrin clot formation. We show that all strains tested bind $\mathrm{Fg}$, including the saprophytic one, and that this interaction inhibits fibrin clot formation, though the virulent strain appears to be more efficient. Attachment of recombinant proteins to $\mathrm{Fg}$ was specific, dose-dependent and saturable with all proteins but Lsa30. The interaction of all six proteins with $\mathrm{Fg}$, similar to the Leptospira, promoted an inhibition on thrombin-induced fibrin clot formation. Thus, Leptospira, similar to other pathogens, express multiple Fg-binding proteins . 
The inhibitory effect observed with leptospires and with the six recombinant proteins on fibrin formation was moderate, similar to the level observed with LigB , but contrasting with the total clotting impediment promoted by the Fg-binding proteins, SdrG of $S$. epidermidis and ClfA of S. aureus. The data suggest that in Leptospira other mechanisms might be involved in fibrin formation and/or the main function of these Fgbinding proteins is not associated with the clotting.

As expected, recombinant proteins partially inhibited attachment of intact $L$. interrogans to immobilized Fg. The inhibitory effect exerted by the recombinant proteins was moderate, ranging from 0.1 to $1.0 \mu \mathrm{M}$ of protein concentration to reach significance, and could be explained by the existence of additional $L$. interrogans binding proteins contributing to the leptospiral adherence to $\mathrm{Fg}$.

We have described the interaction of Leptospira with fibrinolytic system and shown that this association renders the bacteria with proteolytic activity capable of degrading ECM components. Several membrane proteins were identified as PLG-binding receptors capable of generating PLA in the presence of activator, suggesting that the interaction with the fibrinolytic system might be important during leptospirosis. Indeed, the increased plasma levels of $\mathrm{Fg}$ degradation products detected in leptospirosis has provided evidence for fibrinolysis activity. We show now that Leptospira surface-associated PLA activity is capable to degrade $\mathrm{Fg}$ in vitro, suggesting one possible pathway to generate Fg metabolites during the disease.

$\mathrm{Fg}$ is considerably upregulated during inflammation or under exposure to stress such systemic infections. The activation of coagulation cascade with increased levels of plasma $\mathrm{Fg}$ during leptospirosis has been detected. It has been suggested that these findings are possibly associated to severe tissue damage, vascular endothelial injury or a compensating production by the liver in response to the augmented Fg utilization . Our data show that Leptospira either through their Fg-binding proteins or coated with PLA activity would increase the consumption of $\mathrm{Fg}$ molecules by sequestering or degrading them. Under these circumstances, a reduction on fibrin clot formation is expected. In addition, leptospirosis patients with clinical bleeding were reported to have lower platelet counts when compared to other patients, a condition that would help decrease thrombosis, facilitate bleeding and help bacterial dissemination.
In conclusion, we have provided molecular evidence of the mechanisms that Leptospira could employ to interact with components of the coagulation cascade and the fibrinolytic system. In addition, we have shown that six adhesins could mediate the binding of Leptospira to $\mathrm{Fg}$ and impair thrombin- induced fibrin clot formation. We believe that our results should contribute to the understanding of the complex coagulopathy observed during leptospirosis.

ACKNOWLEDGMENTS: This work was supported by FAPESP, CNPq and Fundacao Butantan, Brazil; RO, RFD, GHS, NMS, LGF and MLV have scholarships from FAPESP (Brazil). The funders had no role in study design, data collection and analysis, decision to publish, or preparation of the manuscript.

\section{REFERENCES}

1. Plank R, Dean D (2000) Overview of the epidemiology, microbiology, and pathogenesis of Leptospira spp. in humans. Microbes Infect 2: 1265-1276.

2. Faine S, Adler B, Bolin C, Perolat P (1999) Leptospira and Leptospirosis. Melbourne, Australia MediSci.

3. Bharti AR, Nally JE, Ricaldi JN, Matthias MA, Diaz MM, et al. (2003) Leptospirosis: a zoonotic disease of global importance. Lancet Infect Dis 3: 757-771.

4. Levett PN (2001) Leptospirosis. Clin Microbiol Rev 14: 296-326.

5. Marotto PC, Ko Al, Murta-Nascimento C, Seguro AC, Prado RR, et al. (2010) Early identification of leptospirosis-associated pulmonary hemorrhage syndrome by use of a validated prediction model. J Infect 60: 218-223.

6. McBride AJ, Athanazio DA, Reis MG, Ko Al (2005) Leptospirosis. Curr Opin Infect Dis 18: 376-386.

7. Zhang YX, Geng Y, Bi B, He JY, Wu CF, et al. (2005) Identification and classification of all potential hemolysin encoding genes and their products from Leptospira interrogans serogroup Icterohae-morrhagiae serovar Lai. Acta Pharmacol Sin 26: 453-461.

8. Hauk $P$, Negrotto $S$, Romero EC, Vasconcellos $S A$, Genovez ME, et al. (2005) Expression and characterization of HlyX hemolysin from Leptospira interrogans serovar Copenhageni: potentiation of hemolytic activity by LipL32. Biochem Biophys Res Commun 333: 13411347.

9. Carvalho E, Barbosa AS, Gomez RM, Cianciarullo AM, Hauk $P$, et al. (2009) Leptospiral TlyC is an extracellular matrix-binding protein and does not present hemolysin activity. FEBS Lett.

10. Degen JL, Bugge TH, Goguen JD (2007) Fibrin and fibrinolysis in infection and host defense. $J$ Thromb Haemost 5 Suppl 1: 24-31.

11. Lahteenmaki K, Kuusela P, Korhonen TK (2001) Bacterial plasminogen activators and receptors. FEMS Microbiol Rev 25: 531-552.

12. Vieira ML, Vasconcellos SA, Goncales AP, de Morais ZM, Nascimento AL (2009) Plasminogen acquisition and activation at the surface of leptospira species lead to fibronectin degradation. Infect Immun 77: 4092-4101. 
13. Vieira ML, de Morais ZM, Vasconcellos SA, Romero $E C$, Nascimento AL (2011) In vitro evidence for immune evasion activity by human plasmin associated to pathogenic Leptospira interrogans. Microb Pathog 51: 360-365.

14. Choy HA, Kelley MM, Chen TL, Moller AK, Matsunaga $\mathrm{J}$, et al. (2007) Physiological osmotic induction of Leptospira interrogans adhesion: LigA and LigB bind extracellular matrix proteins and fibrinogen. Infect Immun 75: 2441-2450.

15. Choy HA, Kelley MM, Croda J, Matsunaga J, Babbitt JT, et al. (2011) The multifunctional LigB adhesin binds homeostatic proteins with potential roles in cutaneous infection by pathogenic Leptospira interrogans. PLoS One 6: e16879.

16. Lin YP, McDonough SP, Sharma Y, Chang YF (2011) Leptospira immunoglobulin-like protein B (LigB) binding to the $\mathrm{C}$-terminal fibrinogen alphaC domain inhibits fibrin clot formation, platelet adhesion and aggregation. Mol Microbiol 79: 1063-1076.

17. Vieira $M L$, Atzingen $M V$, Oliveira TR, Oliveira $R$, Andrade DM, et al. (2010) In vitro identification of novel plasminogen-binding receptors of the pathogen Leptospira interrogans. PLOS One 5: e11259.

18. Domingos RF, Vieira ML, Romero EC, Goncales AP, de Morais ZM, et al. (2012) Features of two proteins of Leptospira interrogans with potential role in host-pathogen interactions. $B M C$ Microbiol 12: 50

19. Souza NM, Vieira ML, Alves IJ, de Morais ZM, Vasconcellos SA, et al. (2012) Lsa30, a novel adhesin of Leptospira interrogans binds human plasminogen and the complement regulator C4bp. Microb Pathog 53: 125-134.

20. Fernandes LG, Vieira ML, Kirchgatter K, Alves IJ, de Morais ZM, et al. (2012) OmpL1 is an Extracellular Matrix- and PlasminogenInteracting Protein of Leptospira spp. Infect Immun 80: 3679-3692.

21. Nakai K, Horton P (1999) PSORT: a program for detecting sorting signals in proteins and predicting their subcellular localization. Trends Biochem Sci 24: 34-36.

22. Nakai K, Kanehisa M (1991) Expert system for predicting protein localization sites in gramnegative bacteria. Proteins 11: 95-110.

23. Letunic I, Copley RR, Pils B, Pinkert S, Schultz J, et al. (2006) SMART 5: domains in the context of genomes and networks. Nucleic Acids Res 34: D257-260.

24. Schultz J, Milpetz F, Bork P, Ponting CP (1998) SMART, a simple modular architecture research tool: identification of signaling domains. Proc Natl Acad Sci U S A 95: 5857-5864.

25. Finn RD, Mistry J, Schuster-Bockler B, Griffiths-Jones S, Hollich V, et al. (2006) Pfam: clans, web tools and services. Nucleic Acids Res 34: D247-251.

26. Juncker AS, Willenbrock H, Von Heijne G, Brunak S, Nielsen $\mathrm{H}$, et al. (2003) Prediction of lipoprotein signal peptides in Gram-negative bacteria. Protein Sci 12: 1652-1662.

27. Lin YP, Lee DW, McDonough SP, Nicholson LK, Sharma Y, et al. (2009) Repeated domains of leptospira immunoglobulin-like proteins interact with elastin and tropoelastin. $\mathrm{J} \mathrm{Biol} \mathrm{Chem} \mathrm{284:}$ 19380-19391.

28. Malmstrom J, Beck M, Schmidt A, Lange V, Deutsch EW, et al. (2009) Proteome-wide cellular protein concentrations of the human pathogen Leptospira interrogans. Nature 460: 762-765.

29. Atzingen MV, Barbosa AS, De Brito T, Vasconcellos SA, de Morais ZM, et al. (2008) Lsa21, a novel leptospiral protein binding adhesive matrix molecules and present during human infection. BMC Microbiol 8: 70.

30. Oliveira R, de Morais ZM, Goncales AP, Romero EC, Vasconcellos SA, et al. (2011) Characterization of novel OmpA-like protein of Leptospira interrogans that binds extracellular matrix molecules and plasminogen. PLOS One 6: e21962.

31. Pinne M, Choy HA, Haake DA (2010) The OmpL37 surface-exposed protein is expressed by pathogenic Leptospira during infection and binds skin and vascular elastin. PLoS Negl Trop Dis 4: e815.

32. Woodward MP, Young WW, Jr., Bloodgood RA (1985) Detection of monoclonal antibodies specific for carbohydrate epitopes using periodate oxidation. $\mathrm{J}$ Immunol Methods 78: 143-153.

33. Weisel JW (2005) Fibrinogen and fibrin. Adv Protein Chem 70: 247-299.

34. Sun $\mathrm{H}$ (2006) The interaction between pathogens and the host coagulation system. Physiology (Bethesda) 21: 281-288.

35. Flick MJ, Du X, Prasad JM, Raghu H, Palumbo JS, et al. (2013) Genetic elimination of the binding motif on fibrinogen for the $\mathrm{S}$. aureus virulence factor ClfA improves host survival in septicemia. Blood 121: 1783-1794.

36. Dramsi S, Morello E, Poyart C, Trieu-Cuot P (2012) Epidemiologically and clinically relevant Group B Streptococcus isolates do not bind collagen but display enhanced binding to human fibrinogen. Microbes Infect 14: 1044-1048.

37. Collins J, van Pijkeren JP, Svensson L, Claesson MJ, Sturme M, et al. (2012) Fibrinogen-binding and platelet-aggregation activities of a Lactobacillus salivarius septicaemia isolate are mediated by a novel fibrinogen-binding protein. Mol Microbiol 85: $862-877$.

38. Houston $S$, Hof $R$, Francescutti $T$, Hawkes $A$, Boulanger MJ, et al. (2011) Bifunctional role of the Treponema pallidum extracellular matrix binding adhesin Tp0751. Infect Immun 79: 13861398.

39. Haapasalo M, Muller KH, Uitto VJ, Leung WK, McBride BC (1992) Characterization, cloning, and binding properties of the major 53-kilodalton Treponema denticola surface antigen. Infect Immun 60: 2058-2065.

40. Edwards AM, Jenkinson HF, Woodward MJ, Dymock D (2005) Binding properties and adhesionmediating regions of the major sheath protein of Treponema denticola ATCC 35405. Infect Immun 73: 2891-2898.

41. Bamford CV, Fenno JC, Jenkinson HF, Dymock D (2007) The chymotrypsin-like protease complex of Treponema denticola ATCC 35405 mediates fibrinogen adherence and degradation. Infect Immun 75: 4364-4372.

42. Rivera J, Vannakambadi G, Hook M, Speziale P (2007) Fibrinogen-binding proteins of Gram-positive bacteria. Thromb Haemost 98: 503-511.

43. Davis SL, Gurusiddappa S, McCrea KW, Perkins S, Hook M (2001) SdrG, a fibrinogen-binding bacterial adhesin of the microbial surface components recognizing adhesive matrix molecules subfamily from Staphylococcus epidermidis, targets the thrombin cleavage site in the Bbeta chain. $\mathrm{J}$ Biol Chem 276: 2779927805.

44. Liu CZ, Shih MH, Tsai PJ (2005) ClfA(221-550), a fibrinogen-binding segment of Staphylococcus aureus clumping factor $A$, disrupts fibrinogen function. Thromb Haemost 94: 286-294.

45. Verma A, Brissette CA, Bowman AA, Shah ST, Zipfel $P F$, et al. (2010) Leptospiral endostatin-like protein $\mathrm{A}$ is a bacterial cell surface receptor for 
human plasminogen. Infect Immun 78: 20532059

46. Mendes RS, Von Atzingen M, de Morais ZM, Goncales AP, Serrano SM, et al. (2011) The novel leptospiral surface adhesin Lsa20 binds laminin and human plasminogen and is probably expressed during infection. Infect Immun 79: 4657-4667

47. Wagenaar JF, Goris MG, Sakundarno MS, Gasem MH, Mairuhu AT, et al. (2007) What role do coagulation disorders play in the pathogenesis of leptospirosis? Trop Med Int Health 12: 111122.

48. Wagenaar JF, Goris MG, Partiningrum DL, Isbandrio B, Hartskeerl RA, et al. (2010) Coagulation disorders in patients with severe leptospirosis are associated with severe bleeding and mortality. Trop Med Int Health 15: 152-159.

49. Chierakul W, Tientadakul P, Suputtamongkol Y, Wuthiekanun V, Phimda K, et al. (2008) Activation of the coagulation cascade in patients with leptospirosis. Clin Infect Dis 46: 254-260.

50. De Francesco Daher E, Oliveira Neto FH, Ramirez SM (2002) Evaluation of hemostasis disorders and anticardiolipin antibody in patients with severe leptospirosis. Rev Inst Med Trop Sao Paulo 44: 85-90.

51. Higgins R, Cousineau G (1977) The pathogenesis of leptospirosis I. Hemorrhages in experimental leptospirosis in guinea pigs. Can J Comp Med 41: 174-181.

52. Ren SX, Fu G, Jiang XG, Zeng $R$, Miao $Y G$, et al. (2003) Unique physiological and pathogenic features of Leptospira interrogans revealed by whole-genome sequencing. Nature 422: 888893.

53. Bulach DM, Zuerner RL, Wilson $P$, Seemann $T$, McGrath A, et al. (2006) Genome reduction in Leptospira borgpetersenii reflects limited transmission potential. Proc Natl Acad Sci U S A 103: 14560-14565.

54. Picardeau M, Bulach DM, Bouchier C, Zuerner RL, Zidane N, et al. (2008) Genome sequence of the saprophyte Leptospira biflexa provides insights into the evolution of Leptospira and the pathogenesis of leptospirosis. PLoS One 3: e1607.

55. Ricaldi JN, Fouts DE, Selengut JD, Harkins DM, Patra $\mathrm{KP}$, et al. (2012) Whole genome analysis of Leptospira licerasiae provides insight into leptospiral evolution and pathogenicity. PLOS Negl Trop Dis 6: e1853.

56. Chou LF, Chen YT, Lu CW, Ko YC, Tang CY, et al. (2012) Sequence of Leptospira santarosai serovar Shermani genome and prediction of virulence-associated genes. Gene 511: 364-370.

\section{Legend to Figures}

Figure 1. Adhesion of leptospires to Fg. (A). The binding of soluble human $\mathrm{Fg}(10 \mu \mathrm{g} / \mathrm{mL})$ to immobilized strains of leptospires ( $L$. interrogans sorovar Copenhageni strain Fiocruz L1-130, L. interrogans serovar Copenhageni strain $\mathrm{M}-20$, and $L$. biflexa serovar Patoc strain Patoc 1 ) was accessed by ELISA. After $2 \mathrm{~h}$ interaction, plates were washed and the detection of bound Fg was verified by incubation with goat anti-Fg $(1: 25,000)$ followed by incubation with HRPconjugated rabbit anti-goat IgG (1:50,000).
Two independent experiments were performed, and the data represent the mean \pm the standard deviation from one representative experiment. For statistical analyses, the attachment of $\mathrm{Fg}$ to leptospires was compared to its binding to negative control BSA, by the two-tailed t test $\left({ }^{* * *} P<0.001\right)$. (B) Inhibition of fibrin clot formation by leptospires. $1 \mathrm{mg} / \mathrm{mL}$ of $\mathrm{Fg}$ plus live leptospires, pre-incubated for $2 \mathrm{~h}$ at $37^{\circ} \mathrm{C}$, and $10 \mathrm{U} / \mathrm{mL}$ of thrombin were placed into ELISA plates. The fibrin clot formation was measured every $1 \mathrm{~min}$ for $10 \mathrm{~min}$ and then every $5 \mathrm{~min}$ for $35 \mathrm{~min}$. Each point was performed in triplicate and expressed as the mean absorbance value at $595_{\mathrm{nm}} \pm \mathrm{SD}$ for each point. (C) Degradation of Fg by PLAcoated leptospires. L. interrogans serovar Kennewicki strain Pomona Fromm (LPF) $\left(10^{8} /\right.$ sample) were treated with the addition of $10 \mu \mathrm{g}$ PLG (3), 3U uPA (4) $10 \mu \mathrm{g}$ PLG and 3U UPA (PLA) $(5,6)$ or no additions (untreated) (2). (1) Control lacking leptospires and (6) Addition of $1 \mu \mathrm{g}$ aprotinin to the Fg-leptospires incubation. The cells were incubated with 15 $\mathrm{mg} / \mathrm{mL}$ human purified $\mathrm{Fg}$ for $16 \mathrm{~h}$ at $37^{\circ} \mathrm{C}$, and the supernatants were fractioned by SDSPAGE and transferred to membranes. The Fg was detected by specific antibodies followed by ECL reagent development. Indicated on the left are the molecular mass standards, and on the right, the masses of the intact Fg (340 kDa) and its degradation product ( $\mathrm{D}$ domains, 90 $\mathrm{kDa})$.

Figure 2. Recombinant proteins binding to human Fg. Human Fg $(10 \mu \mathrm{g} / \mathrm{mL})$ was coated to ELISA plates and allowed to interact with the recombinant proteins $(10 \mu \mathrm{g} / \mathrm{mL})$. Gelatin was used as a negative control for nonspecific binding. The reaction was detected with polyclonal antibodies raised against each proteins (M\&M) in (A), (C) and (E) while monoclonal anti-polyhistidine HRP antibodies was employed in (B) and (D). In (C) the percentage of binding for each protein with $\mathrm{Fg}$ was measured as a function of time up to 120 $\min$. The effect of denaturing the recombinant proteins by incubation for $10 \mathrm{~min}$ at $96^{\circ} \mathrm{C}$ or blocking the proteins with the respective antibodies for $1 \mathrm{~h}$ at $37^{\circ} \mathrm{C}$, previously to interaction with $\mathrm{Fg}$ are shown in (D) and (E). Bars represent the mean of absorbance at $492_{\mathrm{nm}} \pm$ the standard deviation of three replicates for each protein and are representative of three independent experiments. For statistical analyses, the binding of recombinant proteins to human $\mathrm{Fg}$ was compared to its binding to gelatin or untreated recombinant binding, in the case of (D) and (E) by two-tailed $t$ test $\left({ }^{*} P<0.05\right)$. 
Figure 3. Binding characterization of recombinant proteins to human Fg. (A) Ten $\mathrm{mg} / \mathrm{mL}$ of $\mathrm{Fg}$ was immobilized into 96-wells ELISA plates and 0 to $4,000 \mathrm{nM}$ of each recombinant protein was added for interaction. The bindings were detected using antiserum raised in mice against each protein followed by HRP-conjugated anti-mouse IgG. Data represent the mean absorbance values \pm the standard deviation of three replicates for each experimental group. (B) The dissociation constant $\left(\mathrm{K}_{D}\right)$ was calculated based on ELISA data for the recombinant proteins that have reached the equilibrium concentration. (C) Immobilized $\mathrm{Fg}$ was treated with sodium metaperiodate ( 5 to $100 \mathrm{mM}$ ) for $15 \mathrm{~min}$ at $4^{\circ} \mathrm{C}$ in the dark, prior to the binding with recombinant proteins (as described in Fig. 2). Mean absorbance values at $492_{\mathrm{nm}}$ ( \pm the standard deviations of three independent experiments) were compared to those obtained with untreated $\mathrm{Fg}(0 \mathrm{mM})$.

Figure 4. Inhibition of fibrin clot formation by recombinant proteins. ELISA plates were coated with $1 \mathrm{mg} / \mathrm{mL}$ of $\mathrm{Fg}$ plus recombinant proteins, pre-incubated for $2 \mathrm{~h}$ at $37^{\circ} \mathrm{C}$, and $10 \mathrm{U} / \mathrm{mL}$ of thrombin. (A) The fibrin clot formation was measured every $1 \mathrm{~min}$ for 10 min and then every $5 \mathrm{~min}$ for $35 \mathrm{~min}$. Each point was performed in triplicate and expressed as the mean absorbance value at $595_{n m} \pm$ SD for each point. In (B) the inhibition of fibrin clot by recombinant proteins is shown after $45 \mathrm{~min}$. Bars represent the mean absorbance values \pm standard deviation of three replicates for each condition and are representative of two independent experiments.

Figure $5 . \quad$ Inhibition of $L$. interrogans attachment to human $\mathrm{Fg}$ by recombinant proteins. Fg-coated microtiter wells were incubated with increasing concentration $(0-4.5 \mu \mathrm{M})$ of rLIC12238 (A), rLIC11975 (B), rLIC11360 (C), Lsa30 (D), Lsa33 (E) and OmpL1 (F) for 90 min prior to the addition of $4 \times 10^{7}$ leptospires. Wells were probed with anti-LipL32 serum (1:4,000). Data are expressed as OD492 $\mathrm{nm} \pm$ SD of three independent experiments, each performed in triplicate. Significance was assessed by comparison with the "no protein" wells by Students two-tailed $t$ test $\left({ }^{*} P<0.05\right)$. 
Table 1. Gene locus, protein given name, NCBI reference sequence, protein conservation, sequence of the primers employed for DNA amplification and molecular mass of expressed recombinant proteins.

\begin{tabular}{|c|c|c|c|c|c|c|}
\hline $\begin{array}{l}\text { Gene } \\
\text { locus }\end{array}$ & Given name & $\begin{array}{l}\text { NCBI reference } \\
\text { sequence } \\
\text { number }^{2}\end{array}$ & $\begin{array}{l}\text { Description/ } \\
\text { function }\end{array}$ & $\begin{array}{l}\text { Conservation } \\
\text { (identity) }^{3}\end{array}$ & Sequence of primers for PCR amplification & $\begin{array}{l}\text { Recombinant } \\
\text { protein } \\
\text { molecular mass }\end{array}$ \\
\hline \multirow[t]{2}{*}{ LIC11834 } & $\operatorname{Lsa33}^{\mathrm{a}}$ & YP_001783.1 & $\begin{array}{l}\text { Putative } \\
\text { lipoprotein }\end{array}$ & $\begin{array}{l}\text { Lai }(99 \%) \\
\text { LBH }(87 \%) \\
\text { LlicsVM }(60 \%)\end{array}$ & $\begin{array}{l}\text { F:5'CTCGAGGATCTACAAGGTGGGGTTT } \\
\text { TTAC3'(XhoI) }\end{array}$ & $33.1 \mathrm{kDa}$ \\
\hline & & & & $\begin{array}{l}\text { LSS }(34 \%) \\
\operatorname{LBP}(31 \%)\end{array}$ & $\begin{array}{l}\text { R:5'CCATGGTTACTGAGGTTTTACTTGG } \\
\text { TCC3' (NcoI) }\end{array}$ & \\
\hline \multirow[t]{2}{*}{ LIC11975 } & Lsa36 & YP_0019141 & $\begin{array}{l}\text { Outer membrane } \\
\text { protein }\end{array}$ & $\begin{array}{l}\text { Lai }(99 \%) \\
\text { LlicsVM (54\%) }\end{array}$ & 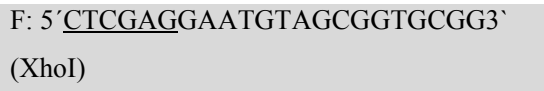 & $36.12 \mathrm{kDa}$ \\
\hline & & & & LBP $(38 \%)$ & $\begin{array}{l}\text { R: 5' } \underline{\text { AAGCTTTCATCCCAAAAGATAA }} \\
\text { TTCA 3' (HindIII) }\end{array}$ & \\
\hline \multirow[t]{2}{*}{ LIC10973 } & OmpL1 $1^{b}$ & YP_000947.1 & $\begin{array}{l}\text { Outer membrane } \\
\text { protein }\end{array}$ & $\begin{array}{l}\text { Lai }(94 \%) \\
\text { LBH }(87 \%)\end{array}$ & $\begin{array}{l}\text { F:5' GGATCCAAAACATATGCAATTGTAG } \\
\text { G3' (BamHI) }\end{array}$ & $32.4 \mathrm{kDa}$ \\
\hline & & & & $\begin{array}{l}\text { LSS }(87 \%) \\
\text { LlicsVM }(51 \%) \\
\text { LBP }(44 \%)\end{array}$ & $\begin{array}{l}\text { R: 5'GGTACCTTAGAGTTCGTGTTTA } \\
\text { TAACC3' (KpnI) }\end{array}$ & \\
\hline \multirow[t]{2}{*}{ LIC11360 } & Lsa23 & YP_0013241 & $\begin{array}{l}\text { Putative } \\
\text { lipoprotein }\end{array}$ & $\begin{array}{l}\text { Lai }(99 \%) \\
\text { LBH }(69 \%)\end{array}$ & $\begin{array}{l}\text { F: 5' GGATCCGAACTTCCTTACTTTTC } \\
\text { CCCTAAC 3' (BamHI) }\end{array}$ & $22.53 \mathrm{kDa}$ \\
\hline & & & & $\begin{array}{l}\text { LSS }(67 \%) \\
\text { LlicsVM }(44 \%)\end{array}$ & $\begin{array}{l}\text { R: 5'AAGCTTGAATGTTGACTAGAGG } \\
\text { CATTTACT 3' (HindIII) }\end{array}$ & \\
\hline \multirow[t]{2}{*}{ LIC12238 } & rLIC12238 & YP_002173 & $\begin{array}{l}\text { Hypothetical } \\
\text { protein }\end{array}$ & $\begin{array}{l}\text { Lai }(99 \%) \\
\text { LBH }(77 \%)\end{array}$ & $\begin{array}{l}\text { F: 5' CTCGAGTGTTTTAAACCTACC } \\
\text { GGAG 3' (Xho I) }\end{array}$ & $17.635 \mathrm{kDa}$ \\
\hline & & & & $\begin{array}{l}\text { LBP }(39 \%) \\
\text { LlicsVM }(50 \%)\end{array}$ & $\begin{array}{l}\text { R: 5'AAGCTTCTACTTCATCGCTTTTTC } \\
\text { TATATC 3' (Hind III) }\end{array}$ & \\
\hline \multirow[t]{2}{*}{ LIC11087 } & $\operatorname{Lsa} 30^{\mathrm{d}}$ & YP_0010571 & $\begin{array}{l}\text { Hypothetical } \\
\text { protein }\end{array}$ & $\begin{array}{l}\text { Lai }(99 \%) \\
\text { LSS }(81 \%)\end{array}$ & $\begin{array}{l}\text { F: 5' CTCGAGGGAGATTCCAGAAAG } \\
\text { AAAAC 3' (XhoI) }\end{array}$ & $30 \mathrm{kDa}$ \\
\hline & & & & $\begin{array}{l}\text { LBH }(75 \%) \\
\text { LBP }(30 \%) \\
\text { LlicsVM }(29 \%)\end{array}$ & 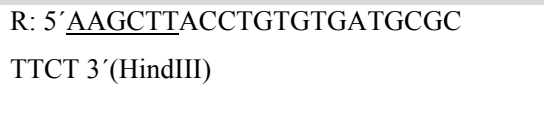 & \\
\hline
\end{tabular}

${ }^{1}$ http://aeg.lbi.ic.unicamp.br/world/lic/;

${ }^{2}$ http://www.ncbi.nlm.nih.gov/protein/;

${ }^{3}$ http://www.ncbi.nlm.nih.gov/blast/Blast.cgi/. This work, Lai: L. interrogans serovar Lai ; LBH: L. borgpetersenii serovar Hardjo-bovis ; LBP: L.

biflexa serovar Patoc ; LlicsVM: L. licerasiae serovar Varillal ; LSS: L. santarosai serovar Shermani

a Previously published by Domingos et al., 2012

${ }^{b}$ Previously published by Fernandes et al., 2012

${ }^{c}$ Previously published by Vieira et al., 2010 and Oliveira et al., 2011

${ }^{d}$ Previously published by Souza et al., 2012 
Figure 01

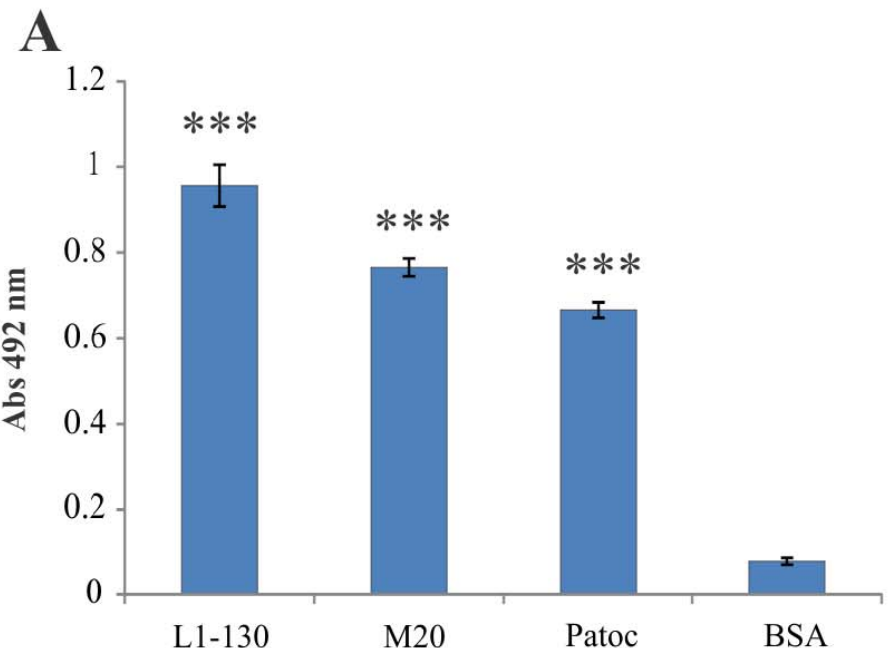

B

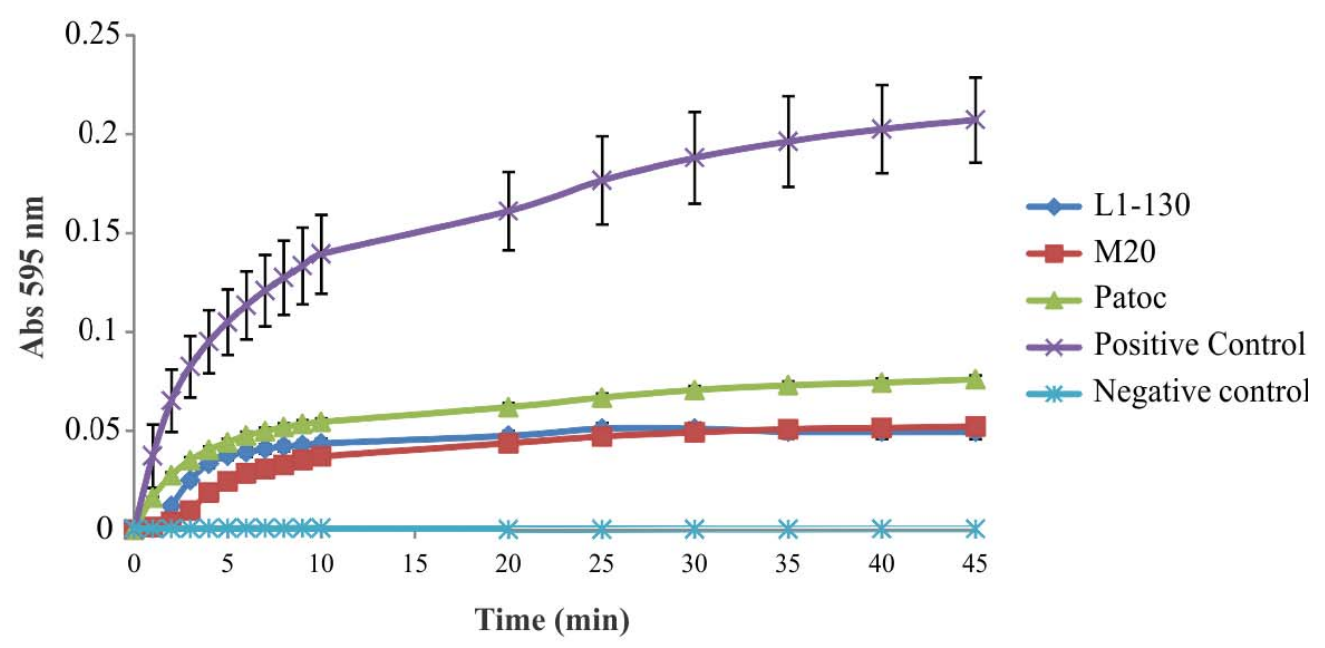

C

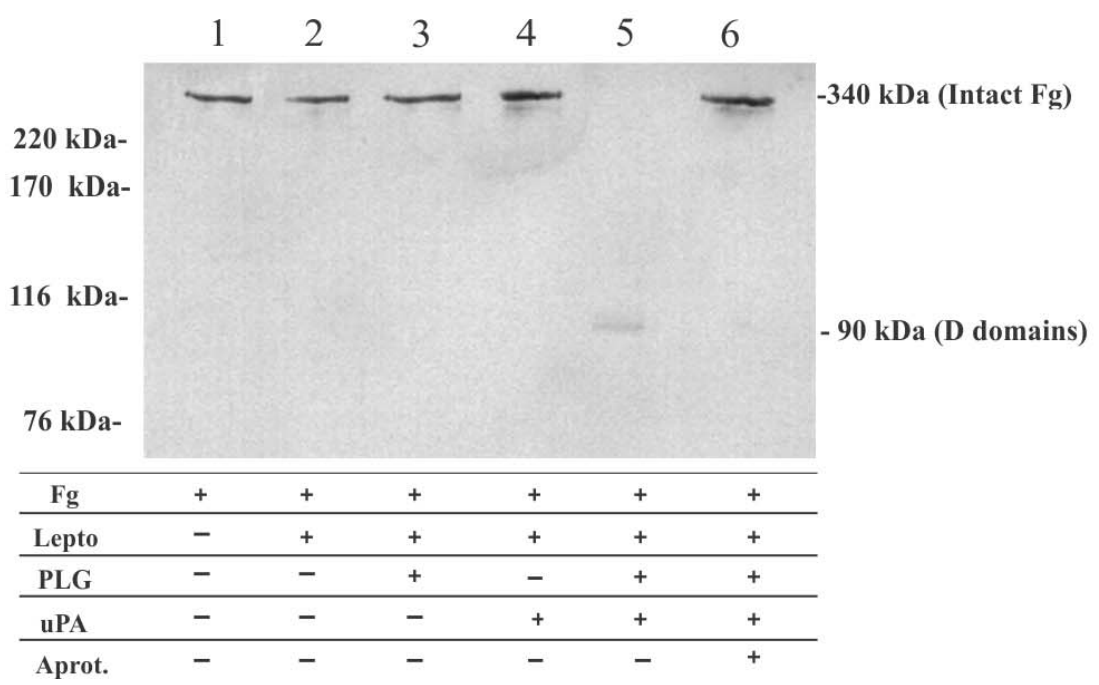


Figure 02

$\mathbf{A}$

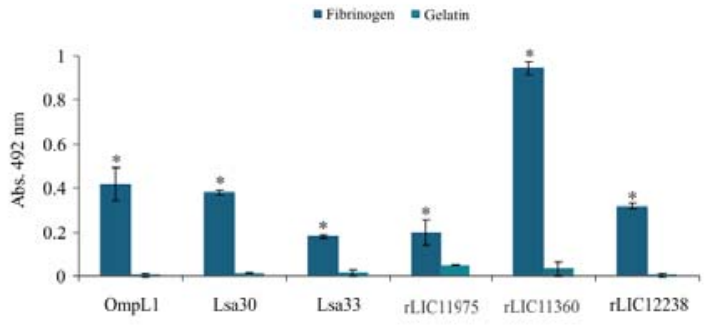

C
B

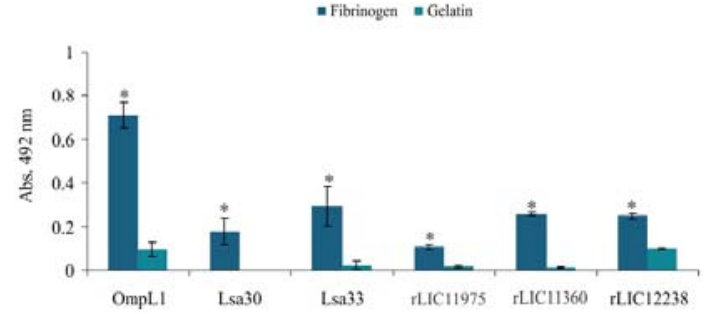

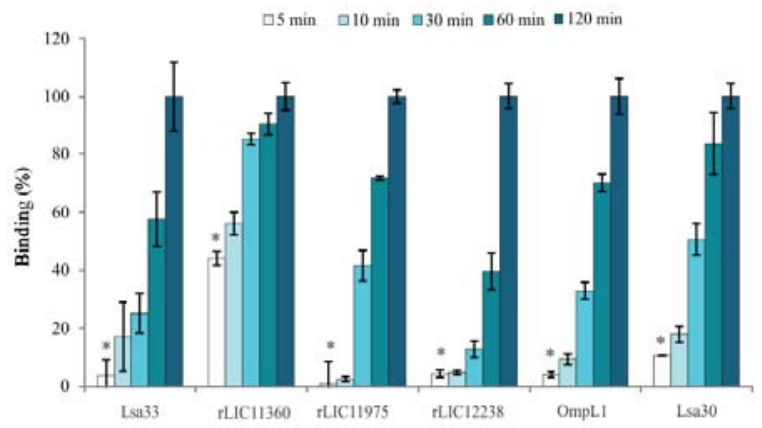

D

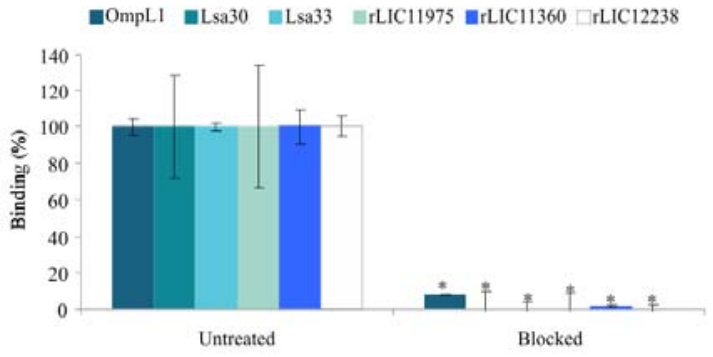

$\mathbf{E}$

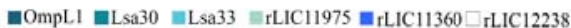

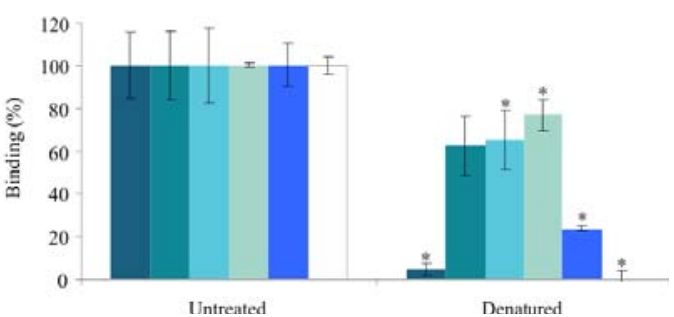


Figure 03

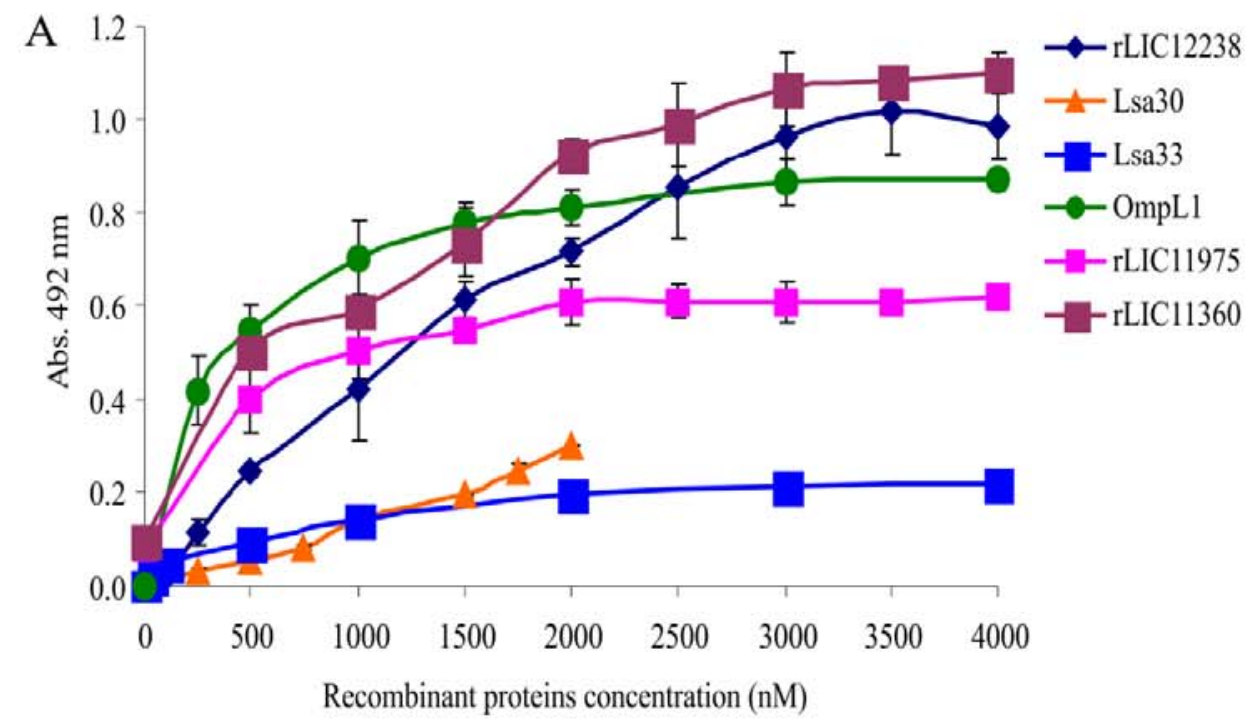

\begin{tabular}{lc} 
B & \multicolumn{2}{c}{ Dissociation constant $(\mathrm{KD}-\mathrm{nM})$} \\
\cline { 2 - 2 } Lsa33 & $128 \pm 89.91$ \\
rLIC11975 & $205.70 \pm 49.03$ \\
OmpL1 & $222.58 \pm 63.06$ \\
rLIC11360 & $506.37 \pm 0.29$ \\
rLIC12238 & $733.27 \pm 276.79$ \\
Lsa30 & ND $^{*}$
\end{tabular}

*ND: not determined

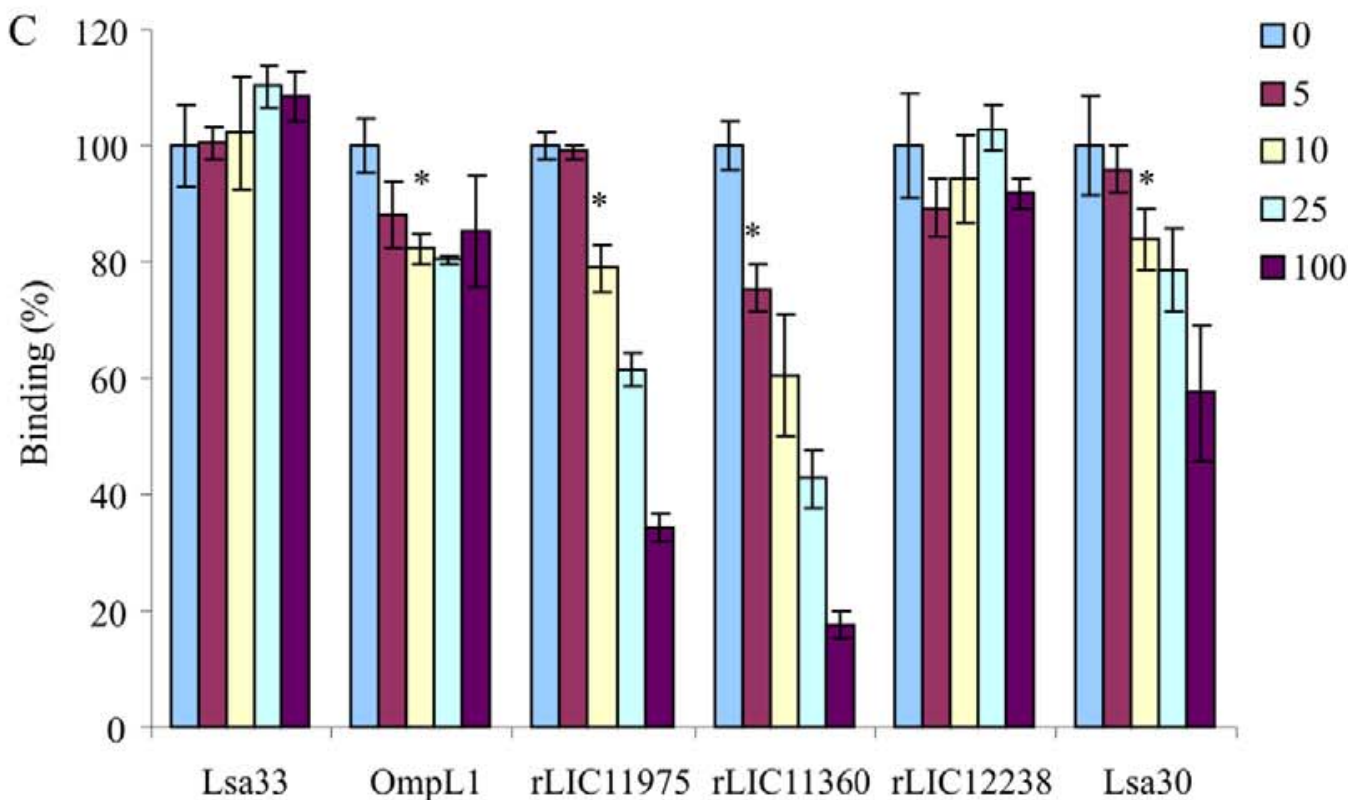


Figure 04
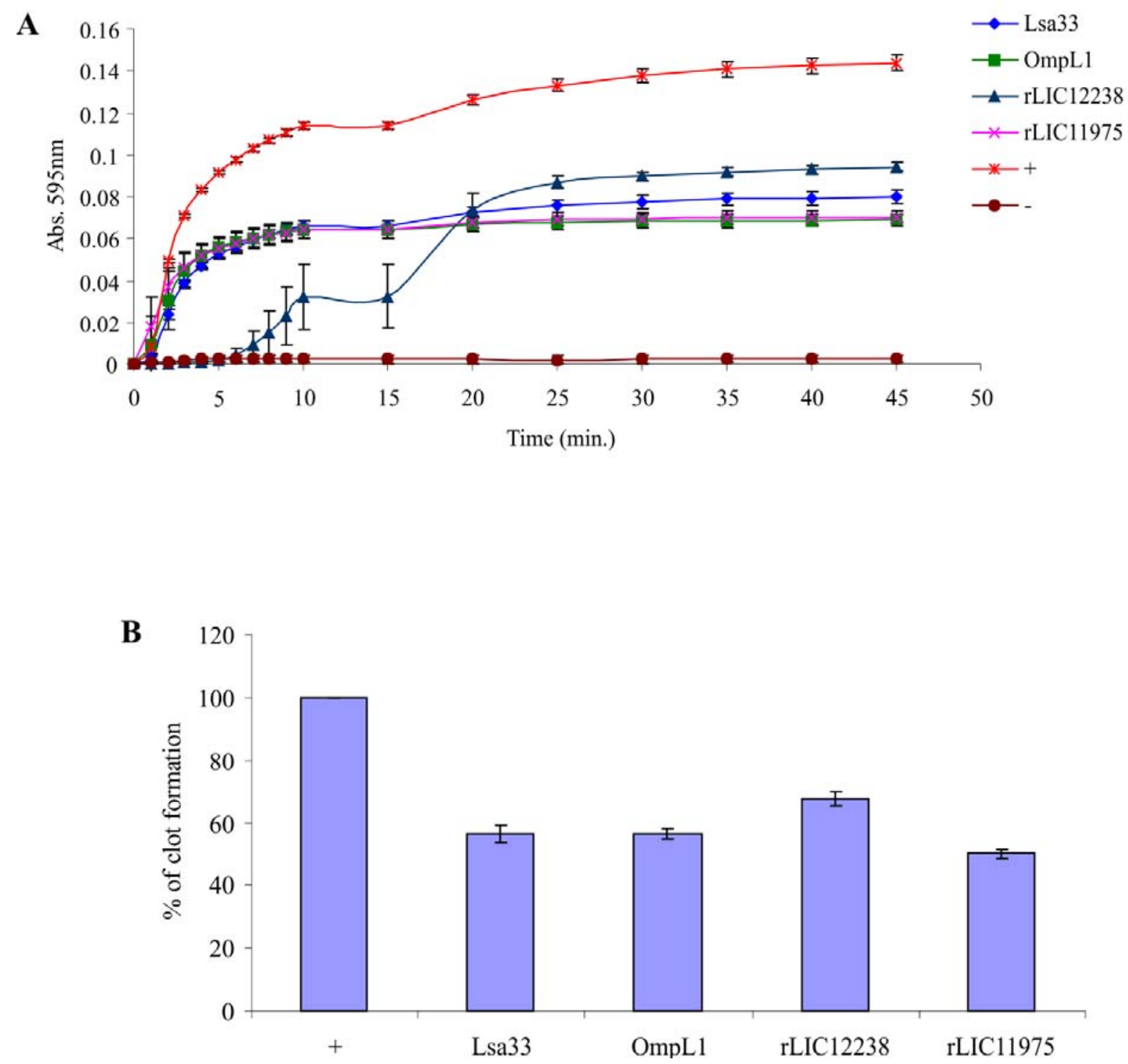
Figure 05

A

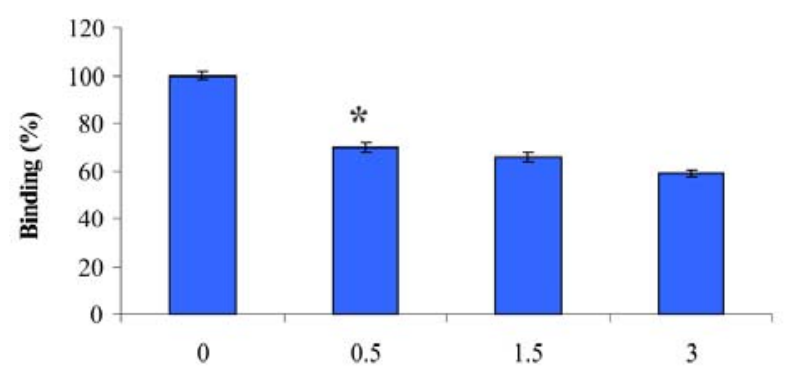

C

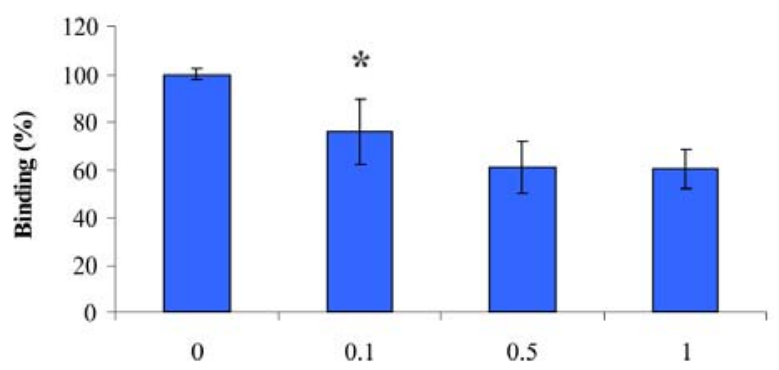

Lsa30 ( $\mu \mathrm{M})$

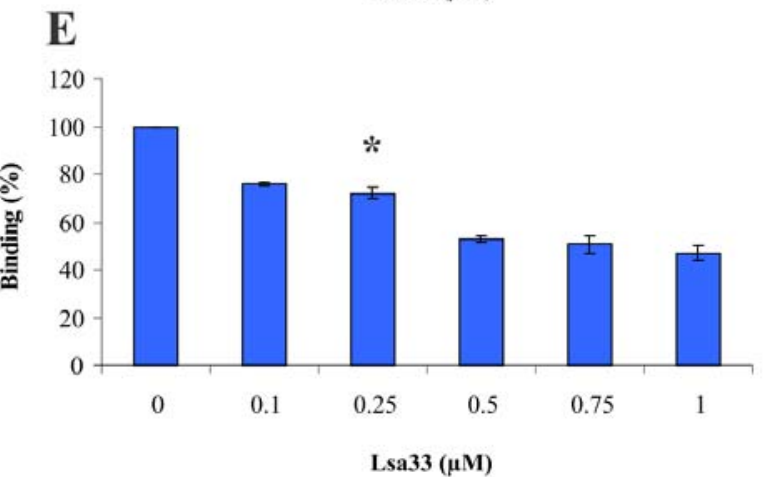

B

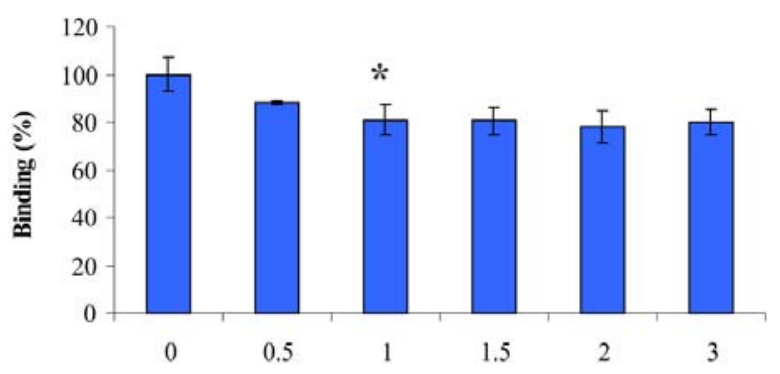

D

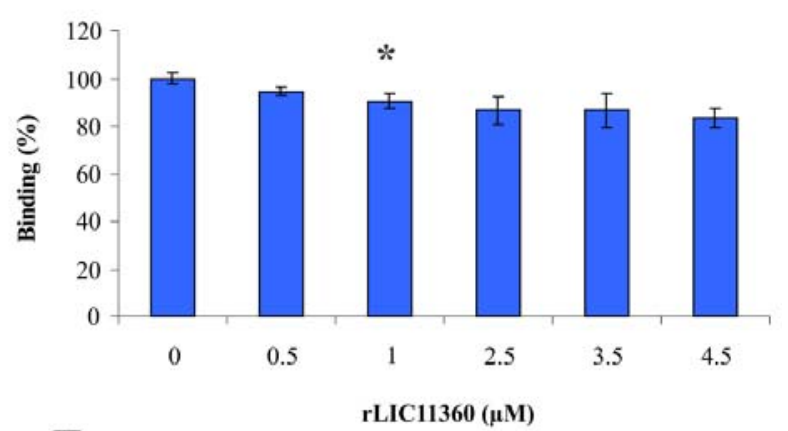

F

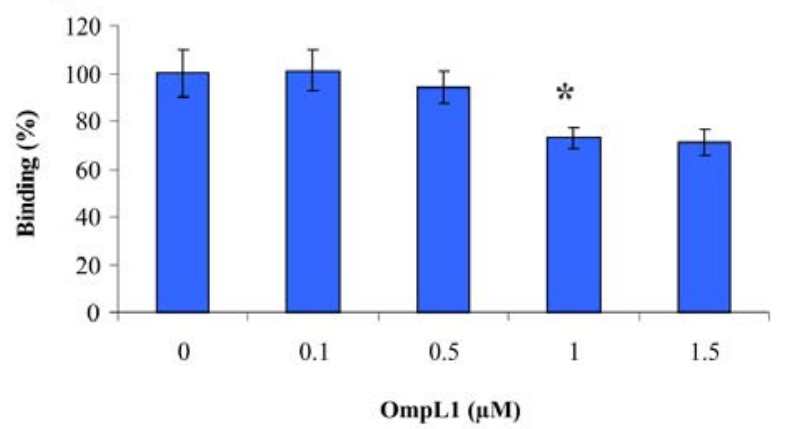




\title{
MANUSCRITO SUBMETIDO - Leptospiral extracellular matrix adhesins as mediators of pathogen-host interactions
}

\author{
Monica L. Vieira ${ }^{1}$, Luis G. Fernandes ${ }^{1,2}$, Renan F. Domingos ${ }^{1,2}$, Rosane Oliveira ${ }^{1,2}$, Gabriela H. \\ Siqueira $^{1,2}$, Natalie M. Souza ${ }^{1,2}$, Aline R. F. Teixeira ${ }^{1,2}$, Marina V. Atzingen ${ }^{1}$ and Ana L. T. O. \\ Nascimento ${ }^{1,2, *}$
}

\begin{abstract}
${ }^{1}$ Centro de Biotecnologia, Instituto Butantan, Avenida Vital Brazil, 1500, 05503-900, São Paulo, SP, Brazil; ${ }^{2}$ Programa Interunidades em Biotecnologia, Instituto de Ciências Biomédicas, USP, Avenida Prof. Lineu Prestes, 1730, 05508-900, São Paulo, SP, Brazil;
\end{abstract}

\begin{abstract}
Leptospirosis is been considered an important re-emerging infectious disease that affects people and animal worldwide. The disease is an important zoonosis caused by pathogenic Leptospira spp. Several studies in the last ten years have presented new insights into $L$. interrogans potential virulence strategies. This review summarizes our current knowledge of bacterial attachment to extracellular matrix (ECM) components and discusses the possible role of these interactions in leptospiral pathogenesis. Leptospiral proteins show different binding specificity for extracellular matrix molecules: some are exclusive lamininbinding proteins (Lsa24/LfhA/LenA, Lsa27), while others have a broader spectrum binding profiles (LigB, Lsa21, LipL53). These proteins mediate the interaction of Leptospira with ECM and may play a primary role in the colonization of host-tissues. Moreover, there are multifunctional proteins that exhibit binding activities towards a number of target proteins including plasminogen-plasmin and regulators of the complement system, and as such, may also act in bacterial dissemination and immune evasion processes. Many ECM-interacting proteins are recognized by human leptospirosis serum samples, or detected in cellular infiltrates of liver or kidney of hamsters experimentally infected or identified in liver and kidney tissues of fatal human cases of leptospirosis, indicating their expression during infection. This compilation of data should enhance our understanding of the molecular mechanisms of leptospiral pathogenesis.
\end{abstract}

\section{Introduction}

Spirochetes are motile, helically shaped bacteria that include the genera Leptospira, Leptonema, Borrelia and Treponema. Borrelia and Treponema are the causative agents of
Lyme disease, relapsing fever and syphilis. The genus Leptospira encompasses both pathogenic and saprophytic species. Pathogenic Leptospira are the etiological agent of leptospirosis while saprophytic bacteria are free-living environmental organisms. Leptospira are classified according to serovar status, where more than 250 pathogenic serovars have been identified. Structural heterogeneity in lipopolysaccharide moieties seems to be the basis for the great degree of antigenic variation observed among serovars . Some pathogenic species are transmitted through direct contact, whereas the majority is usually transmitted via contact with contaminated soil and water, such as $L$. borgpetersenii and $L$. interrogans, respectively. Leptospirosis is considered an important reemerging infectious disease that affects populations worldwide . In tropical and subtropical regions, the disease is endemic, while in temperate climates, the disease is associated with occupational and recreational activities. According to available data, it is estimated that more than 500,000 cases of leptospirosis occur annually and some studies indicate that the disease can represent 20 $40 \%$ of febrile illnesses of unknown cause . Leptospirosis also represents a major economic burden, as the disease promotes abortions, stillbirths, infertility, failure to thrive, reduced milk production and death in animals such as cows, pigs, sheep, goats, horses and dogs.

Leptospires enter the host mainly via intact sodden or damaged skin or mucosa. Infection produces a wide spectrum of clinical manifestations, varying from subclinical infection to severe manifestations. The initial phase exhibits wide-ranging and nonspecific symptoms such as fever, chills, headache and myalgia, common to other diseases such as influenza, dengue and some viral diseases. 
Leptospirosis can progress to a severe condition known as Weil's syndrome, corresponding to $5-15 \%$ of the reported cases. This manifestation is generally characterized by hemorrhage, jaundice, kidney failure, meningitis and hypotension. In the last few years, another severe manifestation of leptospirosis, the leptospirosis pulmonary hemorrhage syndrome (LPHS), has been the focus of public health concern. It was first described in North Korea and China, and has been increasingly reported worldwide. LPHS is estimated to account for up to $70 \%$ mortality rates due to pulmonary hemorrhage.

Currently available veterinary and human vaccines are based on inactivated whole cell or membrane preparations of pathogenic leptospires. These types of vaccine confer protective responses through, but not exclusively, the induction of antibodies against leptospiral lipopolysaccharide. However, these vaccines do not induce long-term protection against infection and do not provide crossprotective immunity against leptospiral serovars not included in the vaccine preparation. Several research groups have tested the protective activity of several recombinant proteins as potential vaccines. Nevertheless, only a few proteins are able to confer partial protection against challenge with virulent leptospires and it is anticipated that a multicomponent acellular vaccine will be necessary for complete protection.

In the past ten years, we have witnessed an increase in our knowledge of Leptospira and leptospirosis. Modern molecular approaches, such as genomics, proteomics and mutagenesis have produced a great amount of data. Several identified proteins have been described to interact with ECM molecules. This review aims to assemble the current knowledge of leptospiral adhesins focusing on host interactions for this pathogen and pointing out new trends for the characterization of these attachment proteins.

\section{Genomics and proteomics}

Currently, there are ten published leptospiral genome sequences: two strains of $L$. interrogans serovar Lai, 56601 and IPAV , $L$. interrogans serovar Copenhageni strain Fiocruz L1- 130 , two strains of $L$. borgpetersenii serovar Hardjo, L550 and JB197 , L. santarosai serovar Shermani strain LT821, two strains of L. licerasiae, VAR010 and MMD0835 and two strains of the saprophyte L. biflexa, Paris and Ames. Two chromosomes characterize the genomes of pathogenic strains, with a size ranging from 3.9 to $4.6 \mathrm{Mb}$. Comparative genomics between pathogenic and saprophyte strains has identified unique genes present in pathogenic species that could be important for virulence. Additionally, genome annotation has predicted several genes with a potential role in pathogenesis and virulence. Hypothetical and conserved hypothetical genes of unknown function are overrepresented in pathogenic species and their role remains to be determined.

The main mechanism in the pathogenesis of leptospirosis, as in other spirochetal diseases, is the ability of the pathogens to rapidly disseminate within the host during the early stage of infection. Putative outer membrane proteins would be available to the immune response during host infection and hence, constitute important targets for immune protection through mechanisms such as antibody-dependent phagocytosis and complement-mediated killing. In this regard, a major limitation in the field of leptospirosis has been the identification of membraneassociated proteins through conventional biochemical and molecular methods. Accordingly, whole-genome sequencing has made an impressive impact in the microbial field landscape and has helped to overcome these limitations. The available sequences combined with bioinformatics tools and DNA recombinant techniques have allowed the prediction of all proteins in silico and their production in laboratory, independently of their abundance and without the need to grow the microorganism in vitro. Among these coding sequences are the hypothetical ones, predicted to be located at the surface of Leptospira. Our group has been particularly interested in this class of proteins, and thus far we have characterized several of them as possible leptospiral adhesins that we believe may be involved in host-interactions.

Genomic tools are important for revealing general aspects of the organism and were the first strategy for high-throughput identification of proteins. However, it does not indicate which proteins are in fact being expressed under a certain condition. For instance, it has been shown that some leptospiral virulence factors are downregulated after several passages in culture medium (Lig and Lsa21 ). Additionally, several studies have reported that environmental cues affect leptospiral protein expression, at both, the transcriptional and proteomic level . Yet, most of proteomics data have revealed basically the same proteins, i.e., proteins that are abundantly expressed. One 
of the most important contributions to the leptospiral field came from the work of Malmstrom and colleagues. These authors, by using the strategy of combining three mass spectrometry based proteomic methods, provided information on the number of copies of expressed proteins per cell under a particular condition. Using L. interrogans serovar Copenhageni strain Fiocruz L1-130, they validated the expression of a significant number of hypothetical proteins and provided a complete profile of leptospiral proteins.

\section{Extracellular matrix}

The extracellular matrix $(\mathrm{ECM})$ is an intricate network of macromolecules, whose primary role includes supporting, and connecting cells and tissues. Nonetheless, the role of the ECM surpasses a structural function in relation to tissue components, since its composition and organization influences various physiological processes required for tissue morphogenesis, differentiation and homeostasis, such as cell adhesion, migration, proliferation and cell differentiation. Two main classes of macromolecules constitute the ECM: (i) polysaccharide chains of glycosaminoglycans (GAGs) and (ii) fibrous proteins, such as collagen, elastin, fibronectin, and laminin .

The GAGs are long unbranched polysaccharides constructed of repeating disaccharide units. The disaccharide units contain an amino sugar (Nacetylgalactosamine, GalNAc or Nacetylglucosamine, GIcNAc) and a uronic acid (glucuronate or iduronate) or glucose. GAGs are highly negatively charged molecules that permit high hydration, viscosity and interaction with other molecules. The most important GAGs for the ECM composition are hyaluronic acid, chondroitin sulfate, dermatan sulfate, keratin sulfate, heparan sulfate and heparin.

Collagens are the most abundant proteins found in the animal kingdom and the major protein constituents in the ECM, providing the scaffold for the attachment of other ECM components, providing tensile strength, regulating cell adhesion and supporting chemotaxis and migration. In addition to the collagens and GAGs, multi adhesive matrix proteins that interact with a variety of collagen types, other matrix proteins, polysaccharides, cell-surface receptors and signaling molecules, compose ECM. Their major function is to attach cells to the ECM . Laminin is a multiadhesive protein that binds to numerous proteoglycans, type IV collagen, and certain receptors on the cell surface, such as integrins, an important class of cell adhesion molecules.
Fibronectins are complex glycoproteins, present in plasma and in ECM, that display important multi-adhesive properties. Fibronectin provides a molecular bridge between the collagen scaffold and the other ECM components, as it contains different domains of high-affinity binding sites for collagen, heparin, gelatin and integrins (via an RGD motif), thereby attaching cells to the ECM . Plasma fibronectin circulating in the blood can bind to fibrin, activate platelets and enhance blood clotting. The elastin results in the assembly of the monomeric precursor tropoelastin . Elastin proportionally provides a degree of elasticity to the ECM, and further permits molecular interaction with ECM components such as proteoglycans, fibulin and fibrillin .

\section{ECM and pathogens}

From the pathogen point of view, the ECM represents a physical barrier that must be overcome to establish local infection or reach the circulation and preferred sites of infection. However, as an abundant constituent with multiple adhesive properties, instead of blocking the dissemination of the microorganisms, these barriers can be on the other hand exploited in a way to facilitate the interaction with the host. Bacterial adhesion to the host cells and tissues is the initial and crucial step for colonization and infection, and it also helps the long-term persistence of the pathogen within the host. Pathogens may achieve access to the ECM components after a tissue injury since in the normal state ECM is not exposed to bacteria .

Based on these assertions, it is essential to understand the mechanisms of bacterial adhesion for the purpose of preventing pathogens from initiating first binding and colonization to help fight infections. Bacterial adhesion to host ECM is initially mediated by loose associations, followed by stronger and more intimate interactions through bacterial components. Due to their privileged exposed localization, allowing environmental sensing and interactions, the adherence to ECM molecules is frequently mediated by OMPs .

It is well documented the ECM and cell-binding capacities of several pathogens, including Pneumococcus, Listeria monocytogenes, Staphylococcus aureus, Escherichia coli, and Streptococcus, among others . The ability of spirochetes to adhere to eucaryotic cells and ECM molecules has also been reported ; . Several studies have demonstrated that the Lyme disease spirochete $B$. burgdorferi binds to a variety of mammalian cell types in vitro 
and to ECM components. For example, $B$. burgdorferi has been shown to express a 47kDa OMP called BBK32 and protein RevA which confer attachment to fibronectin , ErpX which interacts with host laminin and a GAGbinding adhesin termed Bgp . T. pallidum also interacts with ECM through the OMPs: Tp0155 and Tp0483 show specific binding to fibronectin and Tp0751 binds to a variety of laminin isoforms .

\section{Leptospiral adhesion to ECM}

Miller and colleagues (1966) reported for the first time the adhesion of Leptospira to cultured mammalian cells . Later, studies correlated the efficiency of leptospiral attachment to various cell types with bacterial virulence, since virulent organisms were more capable of attachment . Ito and Yanagawa (1987) were the first to describe the binding of $L$. interrogans to mouse fibroblast ECM, further correlating this ability to virulence. Their work corroborates previous findings that highly virulent leptospires attached more efficiently than non-virulent bacteria of the same serovar

These findings suggested that the binding capacity could be decreased or lost during virulence attenuation, and thus, could occur through differentially expressed protein constituents. Additionally, the leptospiral attachment was found to be heat inactivated, indicating the participation of protein-containing moieties in the interaction .

The interaction of Leptospira with Vero cells was shown to be inhibited by fibronectin competition, suggesting the leptospiral interaction with this ECM molecule. The direct attachment of $L$. interrogans to the ECM proteins laminin, collagen type I, collagen type IV, cellular and plasma fibronectin were first demonstrated by Barbosa and colleagues (2006), indicating the existence of multiple adhesion molecules. Leptospiral binding to elastin and its precursor, tropoelastin, was reported by Lin and colleagues (2009), further stressing the presence of a broad spectrum binding proteins. Moreover, the interaction of L. interrogans to the GAGs chondroitin sulfate and heparan sulfate was demonstrated by Breiner and colleagues.

\section{First leptospiral adhesin}

The first leptospiral adhesin was a $36-k \mathrm{Da}$ fibronectin-binding protein isolated from the outer sheath of a virulent variant of pathogenic leptospires. This adhesin was described to be expressed in virulent $L$. interrogans, totally lost during virulence attenuation and absent in the saprophytic strain L. biflexa serovar Patoc I. Evidence of surface-exposed localization of this $36-k D a$ protein was provided by proteinase $\mathrm{K}$ treatment, which abolished its fibronectinbinding activity, as assessed by Western blotting. Moreover, these studies revealed that the gelatin-binding domain of fibronectin was involved in the interaction. Unfortunately, the work did not identify the $36-\mathrm{kDa}$ protein with adhesive properties, and to date, it still remains unknown. Tables 1 and 2 depict features of the published ECM-binding proteins, and Figure 1 illustrates a model of leptospiral membrane architecture featuring the leptospiral adhesins described by our group. The drawing illustrates an outer membrane (OM), a cytoplasmic or inner membrane (IM) and the peptidoglycan (PG) cell wall closely associated with the IM.

\section{Lsa24/LfhA and related Len proteins}

The studies performed by Barbosa and colleagues (2006) reported the first leptospiral protein exhibiting attachment to purified ECM molecules. The protein encoded by the gene LIC12906 was named Lsa24 for leptospiral surface adhesin of $24 \mathrm{kDa}$. Lsa24 binds strongly to laminin in a specific, dosedependent and saturable fashion. Laminin sugar moieties appear to be involved in the interaction, since laminin oxidation by sodium metaperiodate reduces the Lsa24 adhesion. Complementary experiments showed that Lsa24 could partially block live leptospires from binding to immobilized laminin, evidencing the participation of this protein in attachment, but also implying the expression of other proteins involved in the interaction. The authors suggested that Lsa24 could mediate the adhesion of Leptospira to the host via laminin. In the same year, Verma and colleagues (2006) described this protein as a novel binding protein of both factor $\mathrm{H}$ - and factor $\mathrm{H}$ related protein 1 of $L$. interrogans, named $L f h A$ (leptospiral factor $\underline{\mathrm{H}}$-binding protein $\underline{\mathrm{A}}$ ) . Thus, it seems that Lsa24/LfhA/Len $\bar{A}$ is a multifunctional binding protein of Leptospira. Subsequently, Stevenson and colleagues (2007) reported that LIC12906 of $L$. interrogans possesses five paralogs, distributed among virulent leptospires and absent in non-pathogenic species . Because of their similarities to mammalian endostatins, these proteins called Len proteins. LenA protein (formerly called LfhA and Lsa24) and the additional homologs were named, LenB, LenC, LenD, LenE and LenF. LenB was found to bind human factor $\mathrm{H}$, and all Len proteins showed laminin-binding capacity. In addition, LenB, LenC, LenD, LenE and LenF exhibited 
affinity for fibronectin, as assessed by ligandblotting experiments.

LipL32

LipL32 is a subsurface lipoprotein found in pathogenic leptospires, expressed during mammalian infection and recognized by leptospirosis serum samples. It is the most abundant protein expressed by Leptospira, estimated at 38,000 copies per cell. Furthermore, LipL32 is highly conserved and restricted to pathogenic serovars, thus being absent in saprophytic ones and suggesting its role in pathogenesis. The ECM-binding capacity of LipL32 has been shown by independent studies. Hoke and colleagues (2008) showed that recombinant LipL32 selectively binds to the individual components laminin and collagens $\mathrm{I}$ and $\mathrm{V}$, where the carboxy-terminal is designated as the region binding . Hauk and colleagues (2008) observed that LipL32 interacts with collagen IV and plasma fibronectin, and confirmed that the carboxy-terminal portion was responsible for binding .

In addition to attachment to ECM molecules, LipL32 was shown to bind plasminogen, the precursor of the broad-spectrum serine protease plasmin. These studies indicated that LipL32 could interact simultaneously with plasminogen and plasma fibronectin, suggesting a dual binding activity. It has been speculated that one strategy for bacterial pathogenesis may be concomitant plasminogen/plasmin and ECM binding. Plasmin-associated bacteria could promote ECM degradation and consequently facilitate dissemination .

However, despite LipL32 abundance in bacterial cell and its presence limited to pathogenic species, mutagenesis experiments with mutants lacking the lipL32 gene surprisingly showed that this protein is not essential for the bacterial survival during acute or chronic infection of $L$. interrogans . Thus, although LipL32 is one of the most studied proteins, there is still controversy over its function in Leptospira.

\section{Leptospiral immunoglobulin-like (Lig) proteins}

Three proteins containing tandem repeats of the bacterial immunoglobulin-like (Big) domain, named LigA, LigB and LigC (for leptospiral immunoglobulin-like proteins), have been identified. The Big superfamily includes wellcharacterized virulence determinants that mediate pathogen attachment to host cells and tissues, such as intimin of enteropathogenic $E$. coli and invasin of Yersinia pseudotuberculosis. The L. interrogans Ligproteins are present only in pathogenic species, expressed during infection, absent after attenuation with culture passage, and upregulated under physiologic osmolarity stimuli. Based on this evidence, the Lig proteins were thought to be important for leptospirosis pathogenesis. The potential of the Lig proteins as vaccine candidates and diagnostic markers has also been proposed .

Choy and colleagues (2007) firstly described LigA and LigB as leptospiral ECM-binding proteins capable of interacting with fibronectin, laminin and collagen I and IV. The adhesive regions were attributed to the unique regions of each protein, instead of the shared Big repeats . Further studies by Choy and colleagues (2011) have also shown LigB to interact with collagen type III. The high affinity fibronectin binding region was identified and found to comprise amino acid residues from 1014 to1165. This portion includes part of the Big domain and a non-repeated region in the variable $\mathrm{C}$-terminal portion, which also binds laminin, but not collagen . Lin and colleagues, (2009) showed that Lig proteins also interact with elastin and its soluble precursor, tropoelastin. The binding sites are common to both molecules, and were identified as the $4^{\text {th }}$ Big repeat in the conserved domain between LigA and LigB, and to the regions comprising the $7^{\text {th }}-8^{\text {th }}, 9^{\text {th }}$ and $12^{\text {th }}$ Big repeats in the variable LigB portion. Therefore, the regions responsible for fibronectin and laminin binding seem to differ from that for elastin and tropoelastin, thus demosntrating the specificity and role of Big domains in ECM interactions. It is possible that the leptospiral interaction with elastin and its precursor involves other adhesins, still to be identified, since the LigA and LigB binding regions only partially inhibited $L$. interrogans attachment to elastin. Using the shotgun phage display technique, LigB was shown to further exhibit specific binding to heparin. The LigB portion that participates in the interaction includes the $12^{\text {th }}$ Big domain and the first 112 residues from the nonrepetitive carboxy-terminal, the same regions that interact with other ECM molecules already discussed.

\section{Outer membrane protein $A$ (OmpA)-like proteins}

Outer membrane protein $A(O m p A)$ is a major heat-modifiable surface-exposed protein in $E$. coli and is one of the best-characterized OMPs

The structure of OmpA and OmpA-like proteins is characterized by an amino-terminal 
domain that forms an eight-stranded, antiparallel $\beta$ barrel, embedded in the $\mathrm{OM}$, constituting a structural porin function . OmpA protein of $E$. coli and other enterobacteria have been reported to act as adhesin/invasin . OmpA-like proteins have also been described in other pathogens, including the Neisseria meningitidis RmpM , the flagellar motor proteins PomB and MotY of Vibrio alginolyticus and the peptidoglycan-associated lipoprotein (Pal) of Haemophilus influenza. Furthermore, it has been reported that OmpA-like proteins actively participate in pathogenesis process, such as adhesion, serum resistance, invasion and host cell activation .

The first protein identified in pathogenic Leptospira was a lipoprotein of $22 \mathrm{kDa}$ with a carboxy-terminal OmpA domain, named Loa22, 22-kDa Leptospira lipoprotein with OmpA domain. Subsequently, the proteins Omp52 and OmpA70 were identified in $L$. santarosai serovar Shermani and in $L$. interogans serovar Copenhageni, respectively . The OmpA-like protein Loa22 was reported to be essential for the leptospiral virulence, since mutants lacking Loa22 expression resulted in attenuated virulence in an animal model of acute infection. Thus, it is possible that OmpAlike proteins have a function in leptospiral pathogenesis. However, work performed in our laboratory showed that Loa22 does not interact with all ECM molecules tested: laminin, collagen I, collagen IV, cellular and plasma fibronectin . Hence, despite being a potential leptospiral virulence factor, Loa22 is not an ECM-interacting protein.

Oliveira et al. (2011) identified a novel leptospiral hypothetical protein, encoded by the gene LIC10258, which has a putative OmpAlike domain comprising 504 to 583 amino acid residues in the carboxy-terminal region. The recombinant protein, named Lsa66, showed laminin and plasma fibronectin binding properties. The interaction of Lsa66 to ECM components was determined to be specific, dose-dependent and saturable, with a $K_{\mathrm{D}}$ of $55.4+15.9 \mathrm{nM}$ and of $290.8+11.8 \mathrm{nM}$ for laminin and plasma fibronectin, respectively. Moreover, antibodies in serum samples of confirmed leptospirosis cases recognized Lsa66, suggesting its expression during infection. As expected, Lsa66 only partially inhibited adhesion of live $L$. interrogans to immobilized laminin and plasma fibronectin, taking into account the low copy number of this protein in leptospires (75 copies) and the existence of other adhesins. The presence of this protein in Leptospira, as a fibronectingligand binding, was further corroborated by the work of Pinne and colleagues (2012) using high-throughput microarray strategies . Lsa66 is also a plasminogen-plasmin -interacting protein. Collectively, these data suggest the involvement of Lsa66 in leptospiral pathogenesis.

\section{Laminin-binding adhesins}

Bioinformatics have predicted 184 coding sequences that appeared to be exported to the leptospiral surface, and thus, with the potential to participate in host-pathogen interactions . The majority of these proteins are annotated as hypothetical with no assigned function. By data mining this pool of sequences, our group has identified several novel leptospiral adhesins. Some of these proteins exhibited exclusive laminin-binding property when screened against several individual ECM components. These are: Lsa27, Lsa20, and Lsa25 and Lsa33. All these proteins are most probably surface-exposed, as assessed by indirect liquid phase immunofluorescence or proteinase $\mathrm{K}$ accessibility . The participation of the laminin sugar moieties in the interaction with the leptospiral proteins was tested for Lsa25 and Lsa33, and shown to be significant only for Lsa25 . In addition to mediating ECM interactions through laminin, Lsa33 and Lsa20 are also plasminogen-interacting proteins and, hence, may be possibly involved in leptospiral invasiveness and dissemination. Moreover, Lsa25 and Lsa33 are able to capture C4bp , a regulator of the classical pathway complement system, and may have a role in leptospiral immune evasion. The putative lipoprotein encoded by LIC12976, identified as an adhesin by shotgun phage-display approach, was also shown to have exclusive laminin-binding activity .

\section{Adhesins with multiple ECM-binding profile}

Several leptospiral adhesins with broader spectrum binding to ECM have been described. LipL53 and Lsa21 were reported to interact with laminin, collagen type IV, cellular and plasma fibronectin, and are thought to have roles in pathogenesis and virulence of leptospires . Lsa21 and LipL53 share some similarities with the Lig proteins and hence are virulence factor candidates: their protein expression seems to be restricted to highly virulent low-passage strains. It is well known that prolonged culture promotes attenuation of leptospiral virulence, and it has been suggested that expression of virulence factors may be downregulated upon sequential in vitro culture passages. Moreover, environmental factors such as osmolarity and temperature 
promote upregulation of Lsa21 expression at the transcriptional level, another characteristic this protein shares with Lig proteins. Osmotic control of gene expression and transition of temperatures, from ambient to mammalian body or higher during the febrile stage, have been correlated with changes in the expression of virulence determinants in many pathogens . Moreover, it has been demonstrated that $L$. interrogans also regulates protein synthesis in response to in vitro temperature and osmolarity changes. The gene encoding Lsa21 is present in pathogenic strains of $L$. interrogans and absent in the saprophytic $L$. biflexa . Although the gene for LipL53 is present in all pathogenic strains, its transcript was only detected in serovar Icterohaemorrhagiae under regular culture conditions. Furthermore, the adhesin Lsa21 has been shown to be present in liver and kidney tissues of human fatal cases of leptospirosis, and LipL53 is recognized by leptospirosis human serum samples, additionally suggesting the role of these adhesins in leptospirosis pathogenesis .

Proteomics studies of $L$. interrogans have identified a protein encoded by the gene LIC10314 that is differentially expressed under virulence conditions. The recombinant protein, named Lsa63, was characterized as an adhesin that binds strongly to laminin and collagen type IV . The protein Lsa63 is highly conserved among pathogenic strains and absent in $L$. biflexa. The protein sequence shows a p83/p100 conserved domain that seems to be largely distributed in spirochetes . Although the function of this domain is uncertain, p83/p100 containing proteins have been shown to elicit an immune response in hosts and are candidates for Lyme borreliosis serodiagnosis. This adhesin is probably expressed during infection because the protein is recognized by human leptospirosis serum samples, mostly at the convalescent phase of the disease. Lsa63 was found to partially inhibit the binding of intact $L$. interrogans to immobilized laminin and collagen IV. The inhibitory effect promoted by the recombinant protein was modest, and is it expected due to the presence of several L. interrogans ECMbinding proteins that would contribute to the leptospiral adherence to laminin and collagen IV .

The protein encoded by the gene LIC 11087 was genome annotated as hypothetical and predicted to be surface-exposed. We have evaluated the recombinant protein, named Lsa30, and shown that it is also an ECMinteracting protein with the ability to mediate attachment to laminin and plasma fibronectin, . This protein binds to laminin and plasma fibronectin in a dose-dependent and saturable manner, with dissociation equilibrium constants $\left(\mathrm{K}_{D}\right)$ of $292 \pm 24 \mathrm{nM}$ and $157 \pm 35 \mathrm{nM}$, respectively. Moreover, $\mathrm{Lsa30}^{-}$is a plasminogen receptor, capable of generating plasmin in the presence of activator. This protein may interfere with the complement cascade by interacting with $\mathrm{C} 4 \mathrm{bp}$ regulator. The Lsa30 is probably expressed during infection because antibodies present in serum samples of hamsters experimentally infected can recognize this protein. Thus, Lsa30 is another versatile leptospiral adhesin that may play a role in mediating adhesion to hosts.

OmpL1 is a $31 \mathrm{kDa}$ leptospiral transmembrane OMP, containing 320 amino acid residues, described by Haake and colleagues. Several studies have pointed out the importance of OmpL1 as a serological marker for the diagnosis of human leptospirosis and as a vaccine against the disease. Although the gene is restricted to pathogenic serovars of Leptospira, its function is uncertain. Analysis of recombinant OmpL1 immunogenicity in inoculated BALB/C mice showed that the protein has the capacity to promote humoral and cellular immune responses, as indicated by high antibody titers and proliferation of lymphocytes, strengthening its potential as a subunit vaccine. Fernandes and colleagues (2012) showed that OmpL1 has the ability to mediate attachment to laminin and plasma fibronectin, with a $K_{D}$ value of $2099.93 \pm$ $871.03 \mathrm{nM}$ and $1239.23 \pm 506.85 \mathrm{nM}$, respectively. Like previously described adhesins, OmpL1 inhibited the binding of live Leptospira to the same ECM components. In addition, OmpL1 mediates leptospiral binding to plasminogen/plasmin generation, characterizing this protein as multifunctional adhesin that possibly contributes to leptospiral infection and dissemination. Pinne et al. (2010) described the interaction of the protein OmpL37 (LIC12263) with the ECM components laminin, plasma fibronectin and elastin from aorta and human skin. However, intriguingly, recombinant OmpL37 did not impair leptospiral adhesion to elastin, and the presence of rabbit antiserum for OmpL37 acted as an enhancer in this interaction. The authors discuss that this effect may be due to a conformational alteration imposed by antibody binding or a stabilization of the ligand-adhesin complex by the antibodies. OmpL37, a protein present only in pathogenic serovars, could be involved in pathogenesis, facilitating the primary attachment of leptospires to human skin elastin and later promoting leptospiral binding to elastin-rich vascular structures . In the same study, OmpL47 (LIC13050) was 
described as binding weakly to laminin, collagen type III, fibronectin and elastin, but these interactions were not further characterized .

Lp95, an adhesin that activates cellular adhesion molecules (CAMs)

CAMs are surface receptors present in eukaryotic cells that mediate cell-cell or cellECM interactions. Several cells and extracellular molecules have been reported to use CAMs in host defense against infection. However, several microorganisms, including protozoa, fungi, bacteria and viruses are reported to employ CAMs during their pathogenesis. Mycobacterium tuberculosis, Yersinia spp., Shigella spp., and Neisseria spp., among others, are examples of bacteria that employ . Selectins, integrins, ICAM-1 (intercellular adhesion molecule 1) and VCAM (vascular cell adhesion molecule) are stimulated by $S$. aureus and their role suggested to be mitogenic with massive cytokine release. Protein activation of endothelial CAMs' has been described for the pathogenic spirochetes $L$. interrogans, Borrelia spp. and Treponema spp. The leptospiral proteins encoded by the genes LIC10365, LIC10507, LIC10508, LIC10509 have been shown to be present in cellular infiltrate of liver and kidney of hamsters experimentally infected with virulent $L$. interrogans serovar Copenhageni strain Fiocruz L1-130, suggesting that these proteins are expressed during infection. Most importantly, the recombinant proteins were capable of promoting the upregulation of ICAM-1 and Eselectin in human umbilical vein endothelial cells (HUVECs) . Subsequently, we demonstrated for the first time that virulent $L$. interrogans, but also the saprophyte $L$. biflexa, induced an upregulation of CAMs in HUVECs, although the virulent one was more effective on activation. Furthermore, the same work showed a novel leptospiral protein encoded by LIC12690, named Lp95 (leptospiral protein of $95 \mathrm{kDa}$ ) that is capable of specifically activate E-selectin in HUVECs. In addition to CAM induction, Lp95 binds to laminin and fibronectin, where the carboxy-terminal portion is responsible for the interaction. Thus, Lp95 with its dual activities could act as a protein that contributes to leptospiral attachment to ECM and cell receptors during Leptospira infection

\section{High-throughput screening microarrays}

In addition to in silico identification of putative surface proteins and their production, such as recombinant proteins for the characterization of leptospiral ECM-binding proteins, recent work has employed high-throughput microarray strategy to identify novel host ligand-binding proteins. These studies have employed OMP microarray containing 401 leptospiral proteins expressed in a cell-free expression system. These cited authors identified 15 candidates, as fibronectin-binding proteins: LIC13135, LIC11755, LIC11051, LIC11612, LIC13066, LIC10258, LIC11028, LIC13198, LIC12631, LIC11436, LIC12952, LIC10714, LIC10713, LIC10537 and LIC11893. Among them, only LIC10258, named Lsa66, had been previously characterized as a fibronectin adhesin. Western blotting only confirmed six proteins with fibronectin-binding capacities: LIC11612 (MFn1), LIC10714 (MFn2), LIC11051 (MFn6), LIC11436 (MFn7), LIC10258 (MFn8, Lsa66), and LIC10537 (MFn9). Some proteins previously characterized as fibronectin adhesins were not included in the assay: LIC12236 , LIC13143 (TlyC) and LIC10977 (LenB) . Previously assayed proteins that did not exhibit binding to plasma fibronectin were further confirmed as non-ligands; these are: LIC11834 (Lsa33) , LIC12253 (Lsa25) , LIC11469 (Lsa20) , LIC12895 (Lsa27) and LIC12906 (Lsa24/LenA) .

\section{Conclusions}

In recent years, major advances were made in the leptospiral field. Studies aimed at elucidating the pathogenesis of Leptospira on the basis of available genome sequences, proteomics and microarrays have been published and, the remarkable number of novel leptospiral ECM-interacting proteins (30) recognized demonstrates this progress. This work assembles the current knowledge of leptospiral adhesins and describes their characterizations. These ECM-binding proteins are capable of mediating the attachment of Leptospira to mammalian hosts and of starting the process of invasion/colonization. Several laminin- and plasma fibronectin- binding proteins were identified indicating that leptospires have a redundant repertoire of adhesion molecules that are probably part of their invasion strategies. Proteins with exclusive or larger ligand capacity for ECM were described. In addition, there are multifunctional proteins that exhibit binding activities towards a number of target proteins, such as plasminogen-plasmin and regulators of the complement system, and may have several tasks in leptospiral pathogenesis. 
However, there is a lack of understanding of the exact function of these ECM-interacting proteins, as most of the studies have been performed in vitro. These findings will have to be extended to suitable in vivo models to gain information on the precise mechanism of these ECM-binding proteins in leptospiral pathogenesis. The information on the molecular structure of these proteins should contribute to identifying a multicomponent acellular vaccine in addition to potential targets for antimicrobial therapy that may help fight leptospirosis.

Acknowledgements. This work was supported by FAPESP, CNPq and Fundacao Butantan, Brazil; MLV, MVA, RO, RFD, GHS, NMS, ARFT and LGF have scholarships from FAPESP and CAPES (Brazil). The funders had no role in study design, data collection and analysis, decision to publish, or preparation of the manuscript. We thank Dr. A. Leyva for helpful discussion and with English editing of the manuscript.

Declaration of Interest. The authors report that they have no declaration of interest.

\section{References}

ADLER, B.;DE LA PENA MOCTEZUMA, A. Leptospira and leptospirosis. Vet Microbiol, v. 140, p. 287-296, 2010.

ALBERTS, B., et al. The Extracellular Matrix of Animals. New York: Garland Science. 2007 (Molecular Biology of the Cell )

ATZINGEN, M. V., et al. Lsa21, a novel leptospiral protein binding adhesive matrix molecules and present during human infection. BMC Microbiol, v. 8, p. 70, 2008.

ATZINGEN, M. V., et al. Lp95, a novel leptospiral protein that binds extracellular matrix components and activates e-selectin on endothelial cells. J Infect, v. p. 2009.

BARBOSA, A. S., et al. A newly identified leptospiral adhesin mediates attachment to laminin. Infect Immun, v. 74, p. 6356-6364, 2006.

BLOM, A. M. Structural and functional studies of complement inhibitor $\mathrm{C} 4 \mathrm{~b}$-binding protein. Biochem Soc Trans, v. 30, p. 978-982, 2002.

BREINER, D. D., et al. Leptospira interrogans binds to human cell surface receptors including proteoglycans. Infect Immun, v. 77, p. 55285536, 2009.
CAMERON, C. E., et al. Treponema pallidum fibronectin-binding proteins. J Bacteriol, v. 186, p. 7019-7022, 2004.

CARVALHO, E., et al. Leptospiral TlyC is an extracellular matrix-binding protein and does not present hemolysin activity. FEBS Lett, v. 583, p. 1381-1385, 2009.

CHOU, L. F., et al. Sequence of Leptospira santarosai serovar Shermani genome and prediction of virulence-associated genes. Gene, v. 511, p. 364-370, 2012.

CONFER, A. W.;AYALEW, S. The OmpA family of proteins: roles in bacterial pathogenesis and immunity. Vet Microbiol, v. 163, p. 207-222, 2013.

DALEY, W. P.;PETERS, S. B.;LARSEN, M. Extracellular matrix dynamics in development and regenerative medicine. $J$ Cell Sci, v. 121, p. 255-264, 2008.

DRAMSI, S., et al. Epidemiologically and clinically relevant Group B Streptococcus isolates do not bind collagen but display enhanced binding to human fibrinogen. Microbes Infect, v. 14, p. 1044-1048, 2012.

EVANGELISTA, K. V.;COBURN, J. Leptospira as an emerging pathogen: a review of its biology, pathogenesis and host immune responses. Future Microbiol, v. 5, p. 1413-1425, 2010.

FAINE, S., et al. Leptospira and Leptospirosis. Melbourne, Australia: MediSci. 1999a. 259 p.

FAINE, S., et al. Leptospira and Leptospirosis. Melbourne, Australia MediSci. 1999b

FERNANDES, L. G., et al. OmpL1 Is an Extracellular Matrix- and PlasminogenInteracting Protein of Leptospira spp. Infect Immun, v. 80, p. 3679-3692, 2012.

FLICK, M. J., et al. Genetic elimination of the binding motif on fibrinogen for the $S$. aureus virulence factor ClfA improves host survival in septicemia. Blood, v. 121, p. 1783-1794, 2013.

FRANTZ, C.;STEWART, K. M.;WEAVER, V. $M$. The extracellular matrix at a glance. J Cell Sci, v. 123, p. 4195-4200, 2010.

GAMBERINI, M., et al. Whole-genome analysis of Leptospira interrogans to identify potential vaccine candidates against leptospirosis. FEMS Microbiol Lett, v. 244, p. 305-313, 2005. 
HAAKE, D. A., et al. The leptospiral major outer membrane protein LipL32 is a lipoprotein expressed during mammalian infection. Infect Immun, v. 68, p. 2276-2285, 2000.

HAAKE, D. A.;MATSUNAGA, J. Leptospira: a spirochaete with a hybrid outer membrane. Mol Microbiol, v. p. 2010.

HAYES, A. J., et al. Colocalization in vivo and association in vitro of perlecan and elastin. Histochem Cell Biol, v. 136, p. 437-454, 2011.

ITO, T.;YANAGAWA, R. Attachment of antigenic variants of leptospiras to mouse fibroblasts resisting inhibitory effect of antiparent antiserum. Jpn J Vet Res, v. 35, p. 251261, 1987.

KERR, J. R. Cell adhesion molecules in the pathogenesis of and host defence against microbial infection. Mol Pathol, v. 52, p. 220230, 1999.

KO, A. I.;GOARANT, C.;PICARDEAU, M. Leptospira: the dawn of the molecular genetics era for an emerging zoonotic pathogen. Nat Rev Microbiol, v. 7, p. 736-747, 2009.

KOBAYASHI, Y. Discovery of the causative organism of Weil's disease: historical view. J Infect Chemother, v. 7, p. 10-15, 2001.

LAHTEENMAKI,

K.;KUUSELA, P.;KORHONEN, T. K. Bacterial plasminogen activators and receptors. FEMS Microbiol Rev, v. 25, p. 531-552, 2001.

LEVETT, P. N. Leptospirosis. Clin Microbiol Rev, v. 14, p. 296-326, 2001.

LIMA, S. S., et al. Adhesin activity of Leptospira interrogans lipoprotein identified by in vivo and in vitro shotgun phage display. Biochem Biophys Res Commun, v. 431, p. 342-347, 2013.

LJUNGH, A.;WADSTROM, T. Interactions of bacterial adhesins with the extracellular matrix. Adv Exp Med Biol, v. 408, p. 129-140, 1996.

LODISH, H., et al. Molecular Cell Biology. New York: W. H. Freeman. 2000

LUO, Y., et al. Crystal structure of enteropathogenic Escherichia coli intiminreceptor complex. Nature, v. 405, p. 1073-1077, 2000.
MALMSTROM, J., et al. Proteome-wide cellular protein concentrations of the human pathogen Leptospira interrogans. Nature, v. 460, p. 762-765, 2009.

MATSUNAGA, J., et al. Osmolarity, a key environmental signal controlling expression of leptospiral proteins LigA and LigB and the extracellular release of LigA. Infect Immun, v. 73, p. 70-78, 2005.

MEKALANOS, J. J. Environmental signals controlling expression of virulence determinants in bacteria. J Bacteriol, v. 174, p. 1-7, 1992.

MILLER, R. E.;MILLER, N. G.;WHITE, R. J. Growth of Leptospira pomona and Its Effect on Various Tissue Culture Systems. J Bacteriol, v. 92, p. 502-509, 1966.

MUIZNIEKS, L. D.;WEISS, A. S.;KEELEY, F. W. Structural disorder and dynamics of elastin. Biochem Cell Biol, v. 88, p. 239-250, 2010.

PARSONS, L. M.;LIN, F.;ORBAN, J. Peptidoglycan recognition by Pal, an outer membrane lipoprotein. Biochemistry, v. 45, p. 2122-2128, 2006.

PARVEEN, N.;LEONG, J. M. Identification of a candidate glycosaminoglycan-binding adhesin of the Lyme disease spirochete Borrelia burgdorferi. Mol Microbiol, v. 35, p. 1220-1234, 2000.

PINNE, M.;MATSUNAGA, J.;HAAKE, D. A. Leptospiral outer membrane protein microarray, a novel approach to identification of host ligand-binding proteins. J Bacteriol, v. 194, p. 6074-6087, 2012.

PLANK, R.;DEAN, D. Overview of the epidemiology, microbiology, and pathogenesis of Leptospira spp. in humans. Microbes Infect, v. 2, p. 1265-1276, 2000.

SETTE, A.;RAPPUOLI, R. Reverse vaccinology: developing vaccines in the era of genomics. Immunity, v. 33, p. 530-541, 2010.

SMITH, S. G., et al. A molecular Swiss army knife: OmpA structure, function and expression. FEMS Microbiol Lett, v. 273, p. 1-11, 2007.

SUN, H. The interaction between pathogens and the host coagulation system. Physiology (Bethesda), v. 21, p. 281-288, 2006. 
THOMAS, D. D.;HIGBIE, L. M. In vitro association of leptospires with host cells. Infect Immun, v. 58, p. 581-585, 1990.

TOYOKAWA, T.;OHNISHI, M.;KOIZUMI, N. Diagnosis of acute leptospirosis. Expert Rev Anti Infect Ther, v. 9, p. 111-121, 2011.

VARKI, A., et al. Essentials of Glycobiology. New York: Cold Spring Harbor. 2009

VERMA, A., et al. LfhA, a novel factor Hbinding protein of Leptospira interrogans. Infect Immun, v. 74, p. 2659-2666, 2006.

VIEIRA, M. L., et al. In vitro identification of novel plasminogen-binding receptors of the pathogen Leptospira interrogans. PLoS One, v. 5, p. e11259, 2010.

VIEIRA, M. L., et al. Lsa63, a newly identified surface protein of Leptospira interrogans binds laminin and collagen IV. J Infect, v. 60, p. 52-64, 2010.

VIEIRA, M. L., et al. Plasminogen acquisition and activation at the surface of leptospira species lead to fibronectin degradation. Infect Immun, v. 77, p. 4092-4101, 2009.

VIEIRA, M. P., DC; DE MORAIS, ZM; VASCONCELLOS, SA; NASCIMENTO, ALTO. Proteome Analysis of Leptospira interrogans Virulent Strain. The Open Microbiology Journal, v. 3, p. 69-74, 2009.

VINETZ, J. M. Leptospirosis. Curr Opin Infect Dis, v. 14, p. 527-538, 2001.

WEISEL, J. W. Fibrinogen and fibrin. Adv Protein Chem, v. 70, p. 247-299, 2005.

WOODWARD, M. P.;YOUNG, W. W., JR.;BLOODGOOD, R. A. Detection of monoclonal antibodies specific for carbohydrate epitopes using periodate oxidation. J Immunol Methods, v. 78, p. 143-153, 1985.

\section{Legend to figure 1}

Figure 1. Schematic representation of the Leptospira cell membrane. The leptospiral membrane shares characteristics of both gram-negative and gram-positive bacteria. Depicted are outer membrane (OM), inner membrane (IM) and lipopolysaccharide (LPS). In the periplasmic space (PS), the peptidoglycan (PG) is found strongly associated with the (IM). In this diagram, the protoplasmic cylinder (PC) is also shown, containing the nucleoid. The endoflagela $(F)$, responsible for bacterial motility, are located in the (PS). Illustrated are the published adhesins, identified and characterized by our research group.

\section{Figure 01}

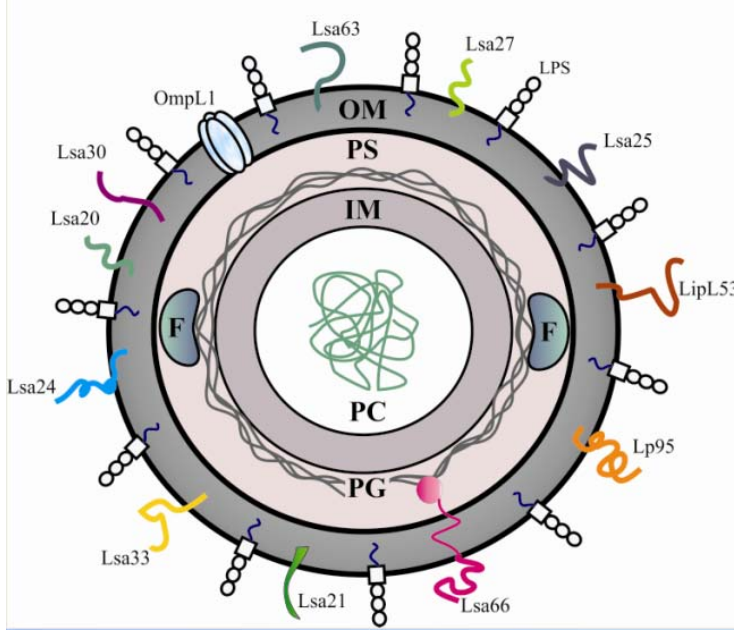


ANEXO A - Cromatogramas dos sequenciamentos das construções no vetor pAE contendo os insertos de DNA dos genes selecionados

\section{LIC10258}

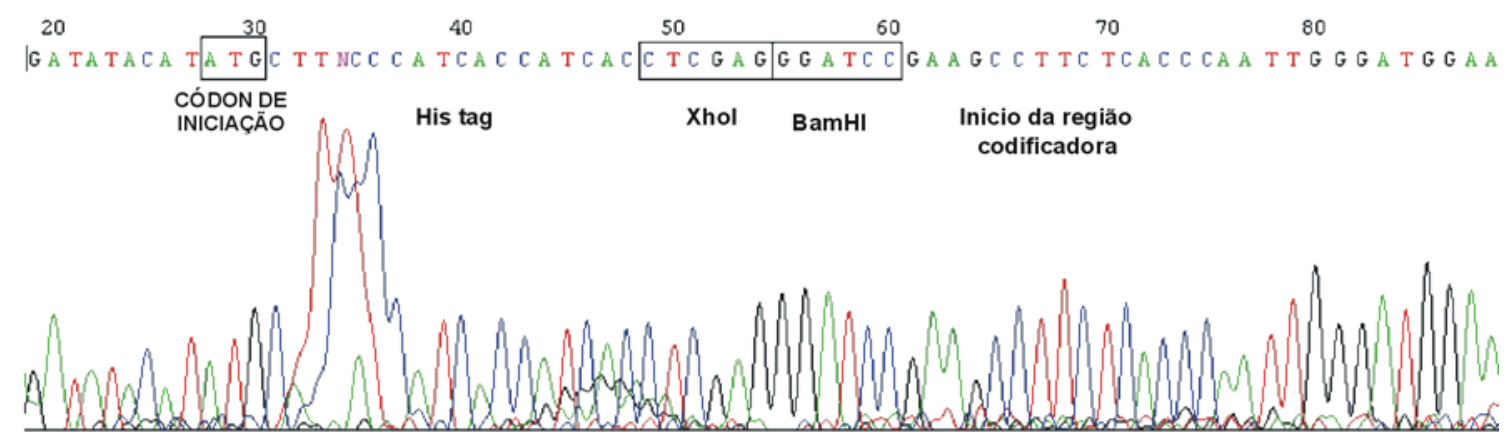

\section{LIC12880}

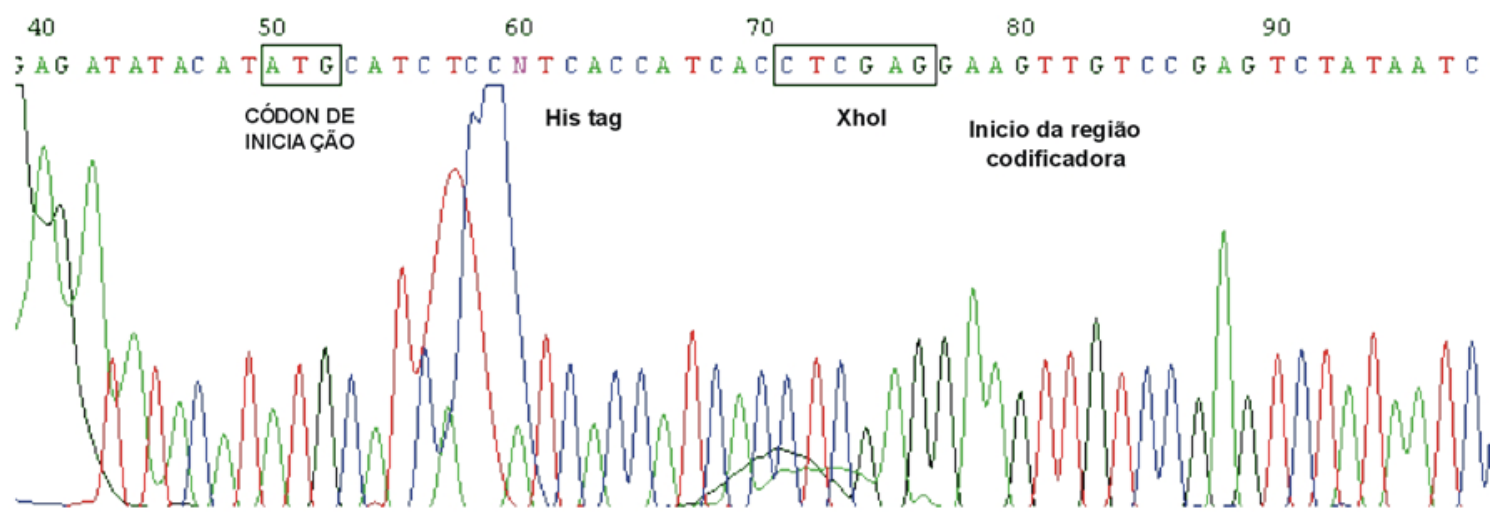

\section{LIC12238}

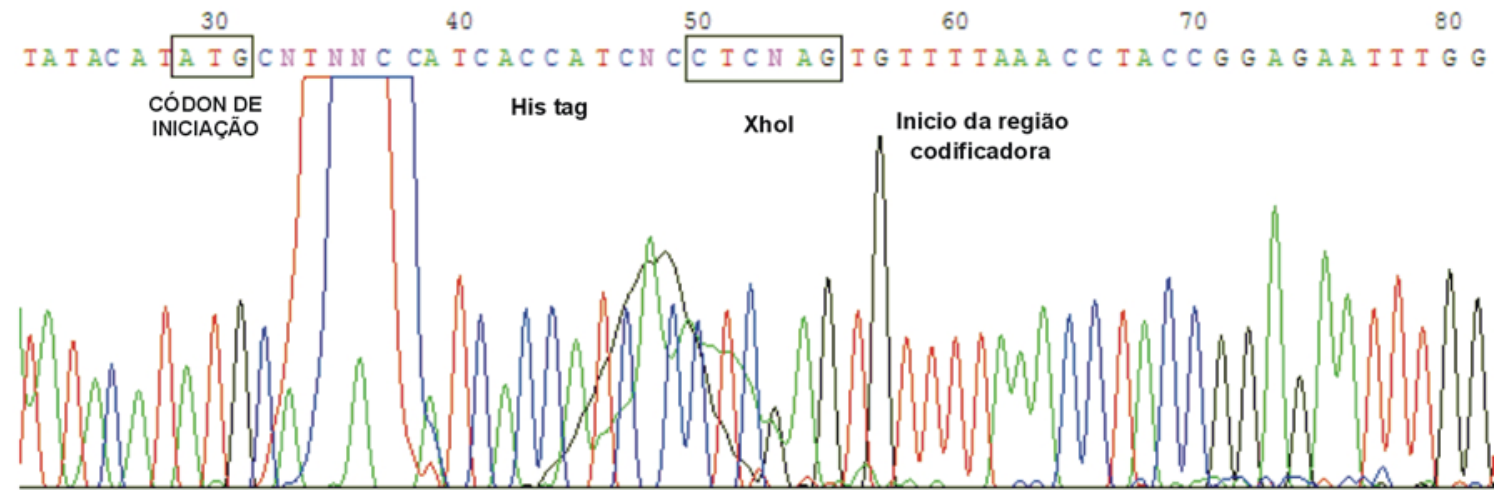


ANEXO B - Soro de pacientes diagnosticados com leptospirose empregados nos imunoensaios com as proteínas recombinantes rLIC10258, rLIC12880 e rLIC12238

\begin{tabular}{|c|c|c|c|}
\hline Amostra & Paciente & MAT & Sorovar (Título) \\
\hline 1 & 1 & negativo & 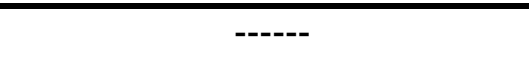 \\
\hline 2 & 1 & positivo & Copenhageni (1/800) \\
\hline 3 & 2 & negativo & ------ \\
\hline 4 & 2 & positivo & Icterohaemorrhagiae (1/3200) \\
\hline 5 & 3 & negativo & ----- \\
\hline 6 & 3 & positivo & Autmnalis $(1 / 1600)$ \\
\hline 7 & 4 & Negativo & ------ \\
\hline 8 & 4 & positivo & Icterohaemorrhagiae $(1 / 1600)$ \\
\hline 9 & 5 & Negativo & ----- \\
\hline 10 & 5 & Positivo & Icterohaemorrhagiae (1/800) \\
\hline 11 & 6 & Negativo & ------ \\
\hline 12 & 6 & Positivo & Copenhageni (1/3200) \\
\hline 13 & 7 & Negativo & ----- \\
\hline 14 & 7 & Positivo & Icterohaemorrhagiae $(1 / 6400)$ \\
\hline 15 & 8 & Negativo & ------ \\
\hline 16 & 8 & Positivo & Copenhageni $(1 / 1600)$ \\
\hline 17 & 9 & Negativo & ----- \\
\hline 18 & 9 & Positivo & Cynopteri (1/400) \\
\hline 19 & 10 & Negativo & ----- \\
\hline 20 & 10 & Positivo & Icterohaemorrhagiae (1/6400) \\
\hline
\end{tabular}


ANEXO C - Cromatogramas dos sequenciamentos das construções no vetor pAE contendo os insertos de DNA dos fragmentos do gene LIC10258

\section{N-terminal}

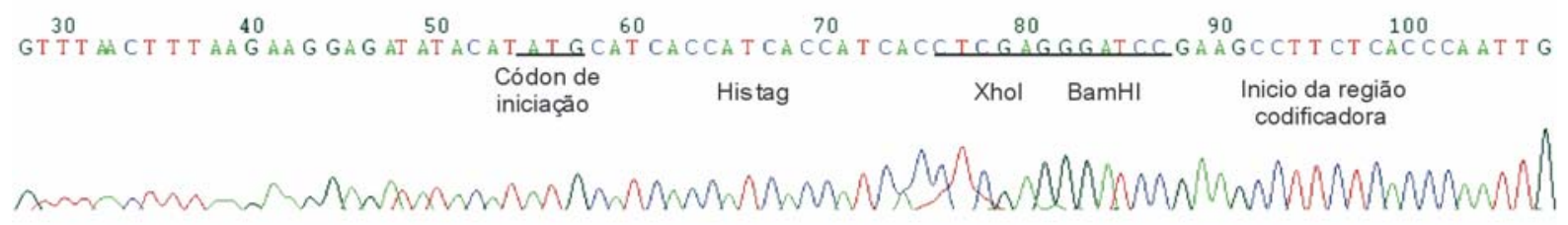

Intermediário

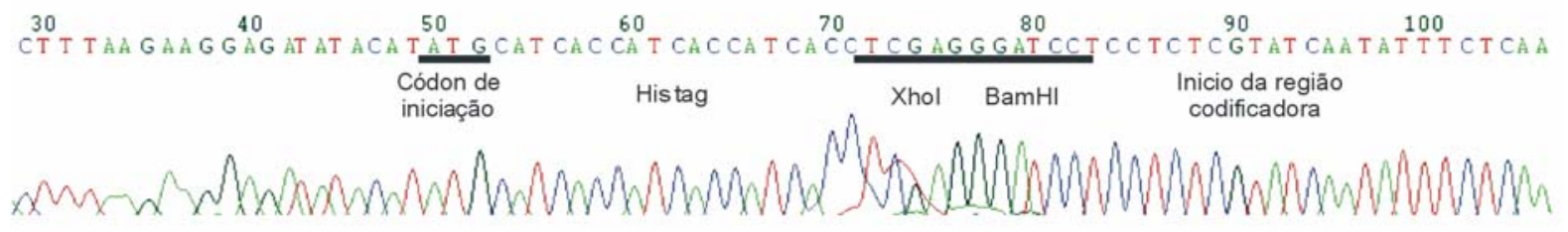

\section{C-terminal}

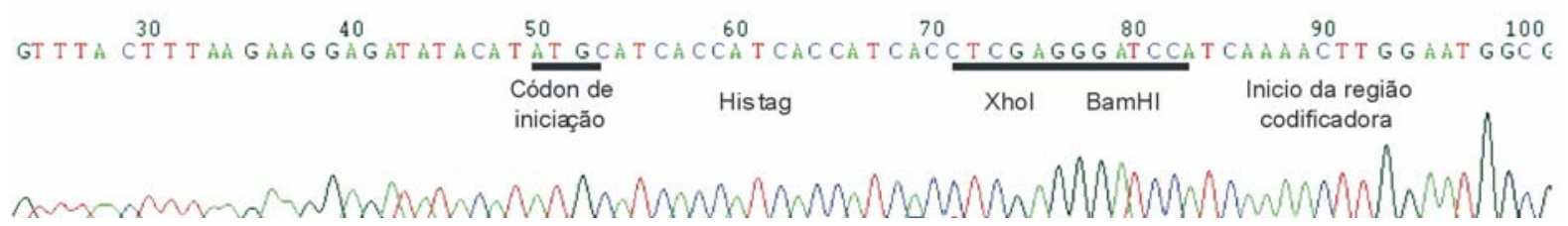




\section{ANEXO D - Soro de pacientes diagnosticados com leptospirose empregados}

nos imunoensaios com os fragmentos recombinantes do gene LIC10258

\begin{tabular}{|c|c|c|c|c|c|}
\hline Amostra & Paciente & MAT (Sorovar/Título) & Amostra & Paciente & MAT (Sorovar/Título) \\
\hline \multirow[t]{2}{*}{1} & 1 & negativo & 19 & 10 & negativo \\
\hline & & Positivo & & & Positivo \\
\hline 2 & 1 & $\begin{array}{l}\text { Icterohaemorrhagiae } \\
(1 / 1600)\end{array}$ & 20 & 10 & $\begin{array}{l}\text { Icterohaemorrhagiae } \\
(1 / 1600)\end{array}$ \\
\hline \multirow[t]{2}{*}{3} & 2 & negativo & 21 & 11 & negativo \\
\hline & & Positivo & & & Positivo \\
\hline 4 & 2 & $\begin{array}{l}\text { Icterohaemorrhagiae } \\
(1 / 400)\end{array}$ & 22 & 11 & $\begin{array}{c}\text { Icterohaemorrhagiae } \\
(1 / 25600)\end{array}$ \\
\hline \multirow[t]{2}{*}{5} & 3 & negativo & 23 & 12 & negativo \\
\hline & & Positivo & & & Positivo \\
\hline 6 & 3 & $\begin{array}{c}\text { Icterohaemorrhagiae } \\
(1 / 6400)\end{array}$ & 24 & 12 & $\begin{array}{c}\text { Icterohaemorrhagiae } \\
(1 / 51200)\end{array}$ \\
\hline \multirow[t]{2}{*}{7} & 4 & negativo & 25 & 13 & negativo \\
\hline & & Positivo & & & Positivo \\
\hline 8 & 4 & Hebdomadis (1/1600) & 26 & 13 & Bataviae(1/400) \\
\hline \multirow[t]{2}{*}{9} & 5 & negativo & 27 & 14 & negativo \\
\hline & & Positivo & & & Positivo \\
\hline 10 & 5 & Canicola $(1 / 6400)$ & 28 & 14 & Copenhageni(1/6400) \\
\hline \multirow[t]{2}{*}{11} & 6 & negativo & 29 & 15 & negativo \\
\hline & & Positivo & & & Positivo \\
\hline 12 & 6 & Australis $(1 / 3200)$ & 30 & 15 & Copenhageni $(1 / 800)$ \\
\hline \multirow[t]{2}{*}{13} & 7 & negativo & 31 & 16 & negativo \\
\hline & & Positivo & & & Positivo \\
\hline 14 & 7 & $\begin{array}{c}\text { Icterohaemorrhagiae } \\
(1 / 1600)\end{array}$ & 32 & 16 & Copenhageni(1/6400) \\
\hline \multirow[t]{2}{*}{15} & 8 & negativo & 33 & 17 & negativo \\
\hline & & Positivo & & & \\
\hline 16 & 8 & $\begin{array}{l}\text { Icterohaemorrhagiae } \\
\qquad(1 / 12800)\end{array}$ & 34 & 17 & $\begin{array}{c}\text { Positivo } \\
\text { Copenhageni (1/800) }\end{array}$ \\
\hline \multirow[t]{2}{*}{17} & 9 & negativo & 35 & 18 & negativo \\
\hline & & Positivo & & & Positivo \\
\hline 18 & 9 & $\begin{array}{l}\text { Icterohaemorrhagiae } \\
\qquad(1 / 12800)\end{array}$ & 36 & 18 & $\begin{array}{c}\text { Icterohaemorrhagiae } \\
(1 / 3200)\end{array}$ \\
\hline
\end{tabular}

